Juliana Justo B. Castello

\title{
LITIGÂNCIA DE MASSA: AÇÕES COLETIVAS E TÉCNICAS DE AGREGAÇÃO \\ (ESTUDO COMPARADO AO SISTEMA JURÍDICO ESTADUNIDENSE)
}

Tese de doutorado

Orientador: Professor Doutor Kazuo Watanabe

Faculdade de Direito da Universidade de São Paulo - USP

Departamento de Direito Processual

São Paulo - 2014 


\title{
LITIGÂNCIA DE MASSA: AÇÕES COLETIVAS E TÉCNICAS DE AGREGAÇÃO \\ (ESTUDO COMPARADO AO SISTEMA JURÍDICO ESTADUNIDENSE)
}

\begin{abstract}
Tese apresentada ao programa de pós-graduação stricto sensu da Faculdade de Direito da Universidade de São Paulo - USP, como requisito parcial para a obtenção do título de Doutor, sob a orientação do Professor Doutor Kazuo Watanabe.
\end{abstract}

Faculdade de Direito da Universidade de São Paulo - USP

Departamento de Direito Processual

São Paulo - 2014 


\section{LITIGÂNCIA DE MASSA: AÇÕES COLETIVAS E TÉCNICAS DE AGREGAÇÃO \\ (ESTUDO COMPARADO AO SISTEMA JURÍDICO ESTADUNIDENSE)}

Tese apresentada ao programa de pós-graduação stricto sensu da Faculdade de Direito da Universidade de São Paulo - USP, relativa à área de Direito Processual, como requisito parcial para a obtenção do título de Doutor, sob a orientação do Professor Doutor Kazuo Watanabe.

BANCA EXAMINADORA:

Prof. Dr. Kazuo Watanabe

Prof. Dr.

Prof. Dr.

Prof. Dr.

Prof. Dr.

São Paulo, de de 2014. 
A Deus. 


\section{AGRADECIMENTOS}

À minha família, meu pai Romulo e minha mãe Myrthes, que me ensinaram o significado de amor cristalino e incondicional e de união, sempre ao meu lado em todos os momentos da vida. Ao meu namorado, Pedro, pelo amor, pelo apoio e pela paciência com as longas horas de estudo.

Ao meu orientador e mestre Professor Kazuo Watanabe, pela honra e oportunidade de ter sido sua orientanda no programa de pós-graduação stricto sensu da Faculdade de Direito da Universidade de São Paulo - USP, bem como pelo apoio, pelos direcionamentos à tese e pelas inúmeras discussões acadêmicas travadas ao longo desses 3 anos do programa de doutorado.

À Professora Ada Pellegrini Grinover, por introduzir e incentivar o gosto pelo processo coletivo. É a ela a quem devo as primeiras e as mais profundas lições nessa temática, quando eu começava a vida acadêmica no programa de Mestrado da Faculdade de Direito de Vitória.

Ao Professor Samuel Meira Brasil, pelas inúmeras oportunidades abertas, pelas discussões acadêmicas e, mais ainda, por despertar o gosto pelo estudo da argumentação jurídica e por incentivar um espírito inquieto, sempre em busca de novos desafios acadêmicos e profissionais.

À Professora Susana Henriques da Costa, pelos comentários, pelas discussões e pelas inúmeras orientações dadas em vários momentos da realização desta tese e durante a qualificação.

Aos amigos e familiares, por sempre me ouvirem, me apoiarem e por não se esqueceram de mim durante a minha ausência, tão necessária à dedicação ao programa e à redação desta tese. 


\section{RESUMO}

Pretende-se abordar o tema da litigiosidade de massa e da agregação processual no sistema jurídico brasileiro, de forma comparada ao sistema jurídico estadunidense. Trata-se de apurar: qual é o nível ótimo de agregação processual, sem prejuízo à autonomia do indivíduo em contar a sua própria história? O que agregar e como agregar? Esse é o objetivo da presente investigação: aferir qual a extensão, necessária e adequada, da agregação processual nas controvérsias de massa e, ainda, seus respectivos limites no direito processual civil. A tese foi dividida em três seções fundamentais: (i) a primeira seção aborda a história da litigiosidade de massa e as técnicas (de larga escala) de agregação processual; (ii) a segunda seção enfrenta a temática da agregação processual à luz das controvérsias plurissubjetivas, diante dos diversos graus de interdependência substancial (grau de variância que se tolera entre os membros do grupo para admitir a agregação processual). O objetivo é que seja possível reconhecer as características dos interesses ou direitos que transcendem a esfera individual e; (iii) a terceira seção aborda o tema da representatividade adequada e das garantias constitucionais processuais, estabelecendo as premissas para a vinculação dos membros ausentes do grupo à questão comum decidida no procedimento agregado. E, por fim, examinam-se as técnicas de preclusão no sistema jurídico brasileiro e no sistema jurídico estadunidense, condicionando-as ao resultado da argumentação realizada no procedimento agregado e ao ônus ou carga da argumentação.

PALAVRAS CHAVES: Agregação processual. Otimização. Direito substancial. Preclusão. Ônus argumentativo. 


\begin{abstract}
In this work, we research the issue concerning mass disputes and aggregate litigation in the Brazilian legal system, compared to the U.S. legal system. The problem is to determine: what is the optimal level of aggregation, without prejudice to the individual autonomy? What is going to be aggregate? And how? That's the goal of this research: assessing the extent appropriate in aggregation of mass disputes and also their limits in civil proceedings. The thesis has been divided into three main sections: (i) the first section covers the history of mass disputes and the techniques (large-scale) of aggregate litigation, (ii) the second section faces the issue of aggregation in the light of various degrees of substantial interdependence: how much variance among class members' circumstances should courts tolerate. The aim is to be able to recognize the characteristics of rights that transcend the individual level, and (iii) the third section addresses the issue of adequate representation and procedural constitutional guarantees, establishing the premises for binding absent members of the group. And finally, it approaches the preclusion doctrine in the aggregate litigation, conditioning it to the result of the argument made in the aggregate procedure and the burden of persuasion (showing a good reason).
\end{abstract}

KEYWORDS: Aggregate litigation. Balancing. Substantial rights. Preclusion. Burden of persuasion. 


\section{RIASSUNTO}

In questa indagine, ricerchiamo il problema relativo al contenzioso di massa nel sistema giuridico brasiliano, quindi rispetto al sistema legale statunitense. Cerca di rispondere: qual è il livello ottimale di aggregazione, fatta salva l' autonomia individuale? Questo è l'obiettivo di questa ricerca: la valutazione della misura adeguata dell'aggregazione delle controversie di massa e anche i loro limiti nei procedimenti civili. La tesi è stata suddivisa in tre sezioni principali: (i) la prima sezione ripercorre la storia del contenzioso di massa e della tecniche (su larga scala) di aggregazione, (ii) la seconda sezione affronta il tema della aggregazione alla luce dei vari gradi di sostanziale interdipendenza: quanta varianza tra le circostanze dei membri della classe devono da tollerare. L'obiettivo è quello di essere in grado di riconoscere le caratteristiche di diritti che trascendono il livello individuale, e (iii) la terza sezione affronta la questione della rappresentanza adeguata e garanzia costituzionale, stabilisce le premesse per preclusione. E, infine, si avvicina la dottrina della preclusione nel contenzioso di massa, condizionata al risultato dell'argomento fatti nella procedura aggregato e l'onere della persuasione.

PAROLA-CHIAVE: Aggregazione. Ottimizzazione. Diritto sostanziale. Preclusione. L'onere della persuasione. 


\section{SUMÁRIO}

1 INTRODUÇÃO.

\section{SEÇÃO I - LITIGIOSIDADE DE MASSA E TÉCNICAS DE AGREGAÇÃO PROCESSUAL}

2 ANTECEDENTES HISTÓRICOS

2.1 APRESENTAÇÃO........................................................................................... 2

2.2 A RELAÇÃO DA COMUNIDADE E DO INDIVÍDUO.........................................................

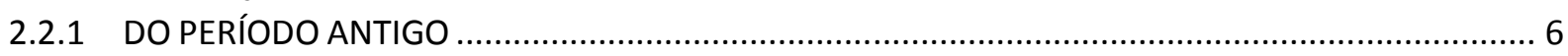

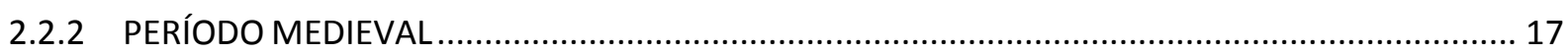

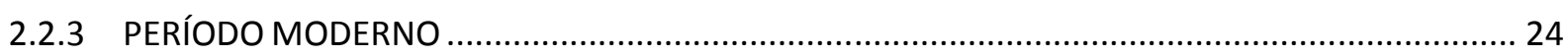

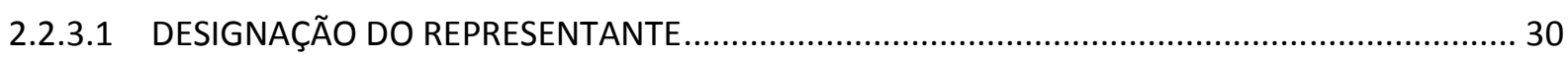

2.2.3.2 DOUTRINA DA NECESSARY PARTY E INDISPENSABLE PARTY E O LITISCONSÓRCIO................ 31

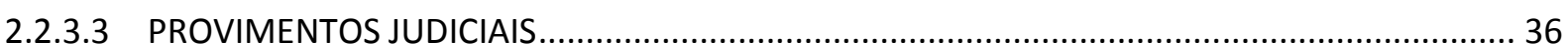

2.2.3.4 COISA JULGADA (CLAIM PRECLUSION) E PRECEDENTE...................................................... 40

2.2.3.5 TRANSIÇÃO: NOVO CONCEITO DE REPRESENTAÇÃO....................................................... 50

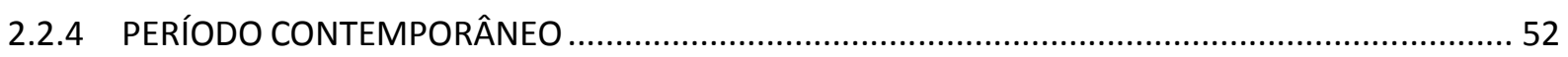

2.3 SÍNTESE PARCIAL ..........................................................................................

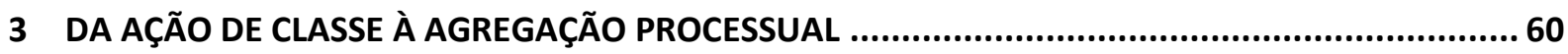

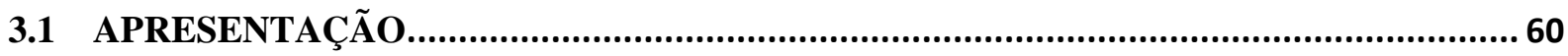

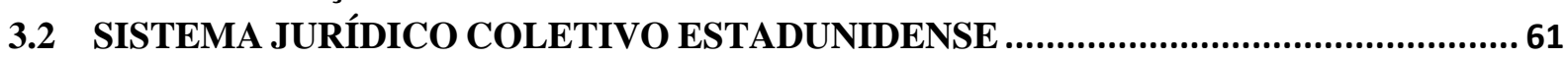

3.3 SISTEMA JURÍDICO COLETIVO BRASILEIRO ……………………………….......... 69

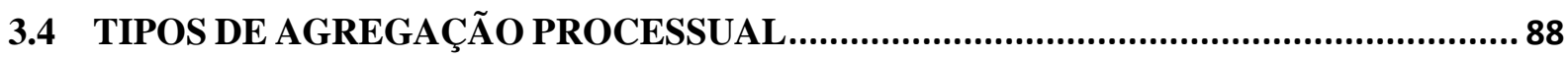

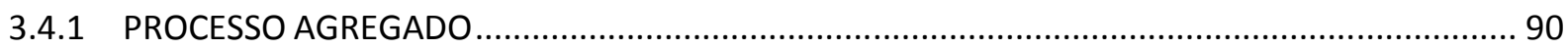

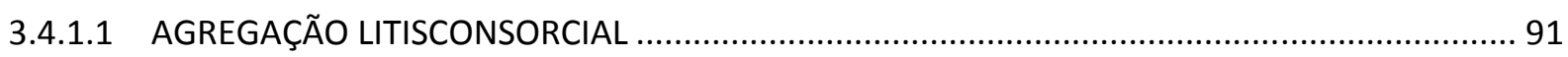

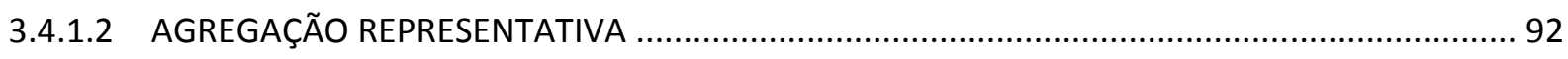

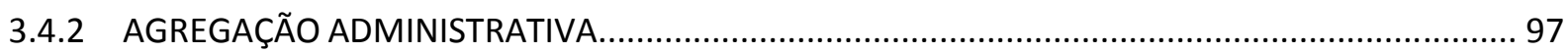

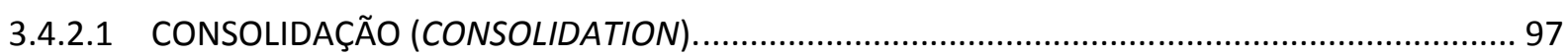

3.4.2.2 CONSOLIDAÇÃO MULTIDISTRITAL (MULTIDISTRICT LITIGATION - MDL) ........................... 105

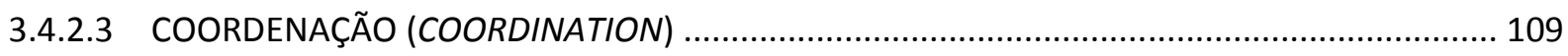

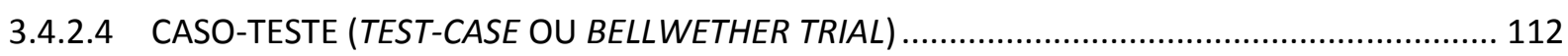

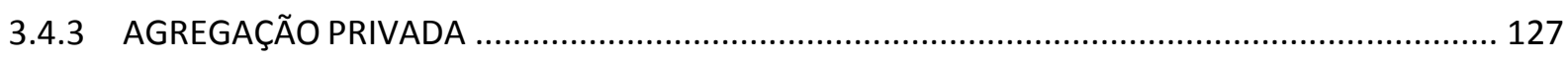

3.4.4 ESCOPOS E ASPECTOS COMUNS DAS TÉCNICAS DE AGREGAÇÃO ………………………...... 130

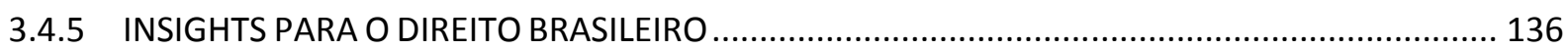

3.5 DESAFIOS DA AGREGAÇÃO PROCESSUAL: A AGREGAÇÃ̃o ÓTIMA …………..... 140

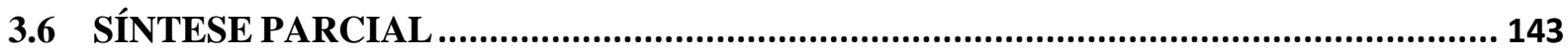




\section{SEÇÃO II - OTIMIZAÇÃO DAS TÉCNICAS DE AGREGAÇÃO PROCESSSUAL À LUZ DO DIREITO SUBSTANCIAL}

4 OBJETO DE PROTEÇÃO 145

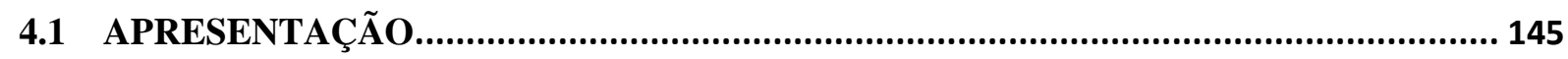

4.2 INTERESSES OU DIREITOS .................................................................................. 149

4.3 DICOTOMIA ENTRE O PÚBLICO E O PRIVADO …….............................................. 151

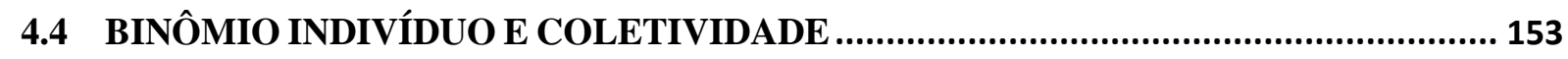

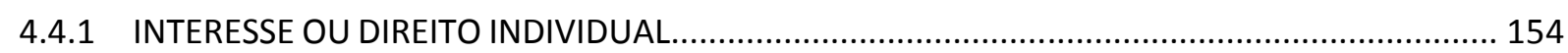

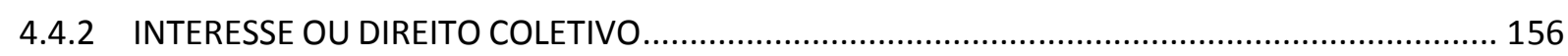

4.4.2.1 TEORIA DO INTERESSE PESSOAL OU INCORPORADO DO GRUPO ………………………....... 157

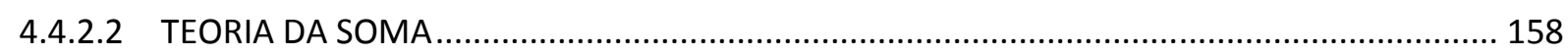

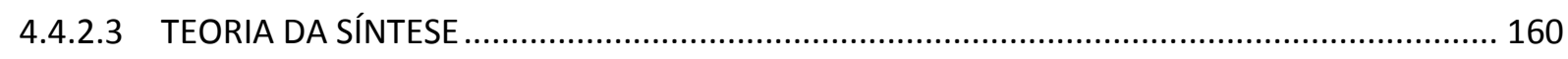

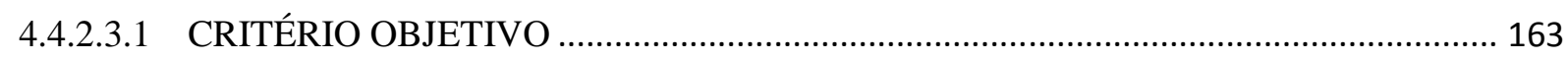

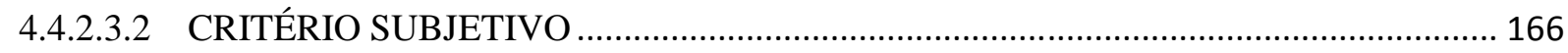

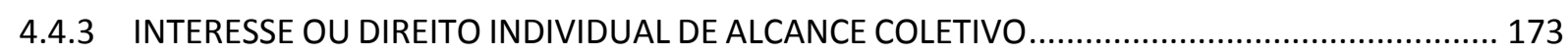

4.4.3.1 REFLEXOS EM RELAÇÃO SUBSTANCIAL INDIVISÍVEL E IMPESSOAL..................................... 178

4.4.3.2 REFLEXOS EM RELAÇÃO SUBSTANCIAL INDIVISÍVEL E POTENCIALMENTE IMPESSOAL........ 192

4.4.3.3 REFLEXOS EM RELAÇÃO SUBSTANCIAL PARITÁRIA E IMPESSOAL ....................................... 197

4.4.3.4 REFLEXOS EM RELAÇÃO SUBSTANCIAL POTENCIALMENTE PARITÁRIA E POTENCIALMENTE

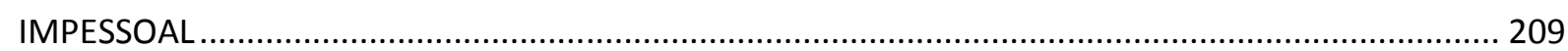

4.4.3.4.1 POTENCIALIDADE FORTE (FORÇA CENTRÍPETA) …………………………...... 210

4.4.3.4.2 POTENCIALIDADE FRACA (FORÇA CENTRÍFUGA) .............................................. 224

4.4.4 DIREITOS INDIVIDUAIS DE MASSA, HOMOGÊNEOS OU REPETITIVOS ........................................ 230

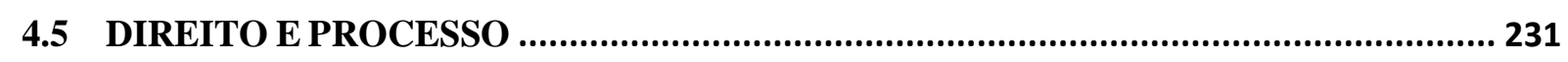

4.5.1 O CONCEITUALISMO NA CLASSIFICAÇÃO DOS DIREITOS.................................................... 233

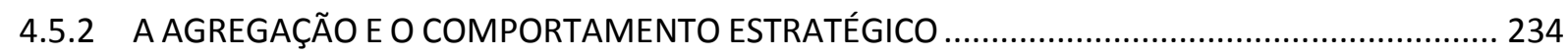

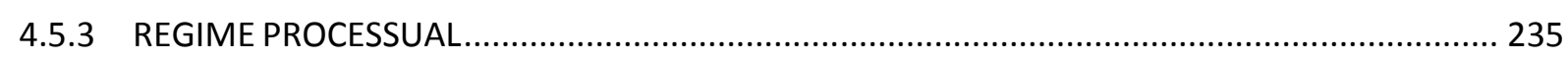

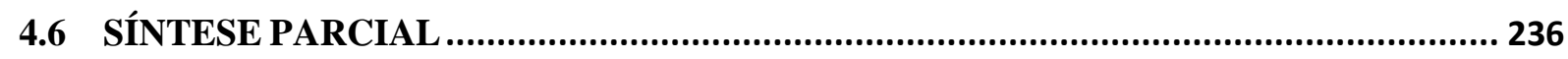

5 CRITÉRIOS SUBSTANCIAIS DE AGREGAÇÃO E REGIME PROCESSUAL ....................................... 238

5.1 APRESENTAÇÃO........................................................................................ 238

5.2 INTERESSES OU DIREITOS NO SISTEMA JURÍDICO ESTADUNIDENSE ................ 238

5.2.1 A INSUFICIÊNCIA DOS INSTRUMENTOS PROCESSUAIS TRADICIONAIS................................... 239

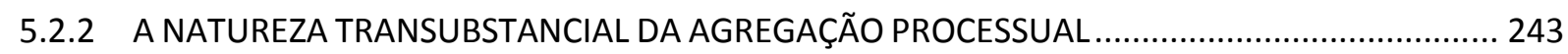

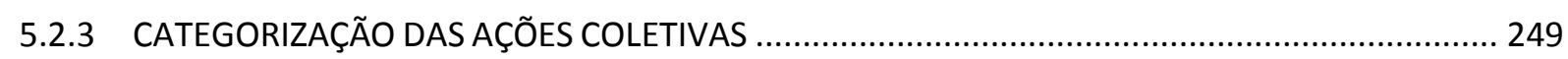

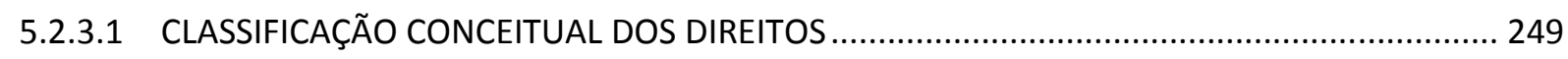

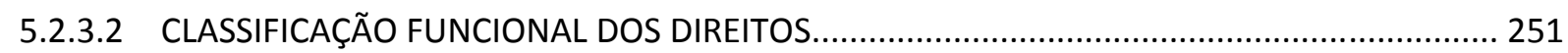

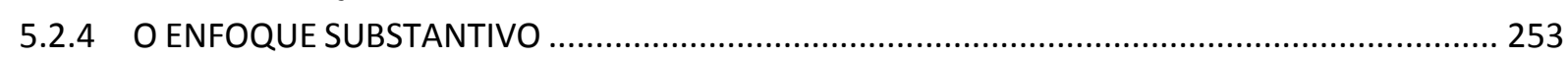

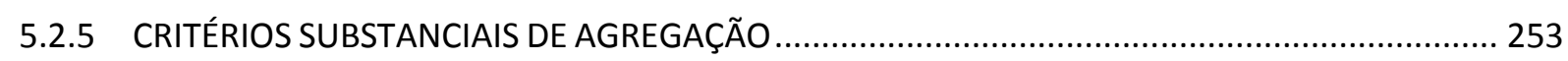

5.2.5.1 LITIGIOSIDADE PESSOAL E IMPESSOAL (PERSONAL LITIGATIVE AND IMPERSONAL

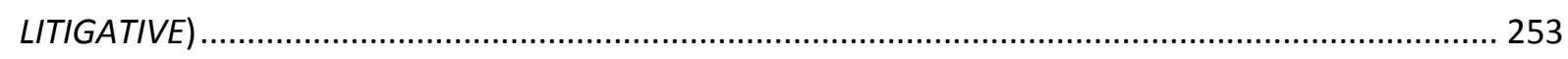


5.2.5.2 COMPENSAÇÃO DIVISÍVEL OU INDIVISÍVEL (DIVISIBLE AND INDIVISIBLE REMEDIES) ......... 258 5.2.5.3 CONTROVÉRSIA À MONTANTE OU À JUSANTE DO GRUPO (UPSTREAM DOWSTREAM AND

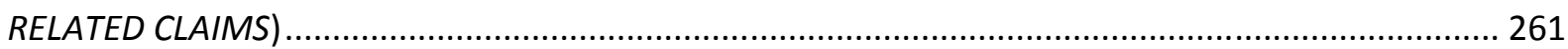

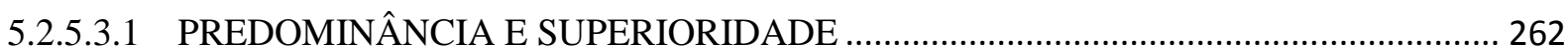

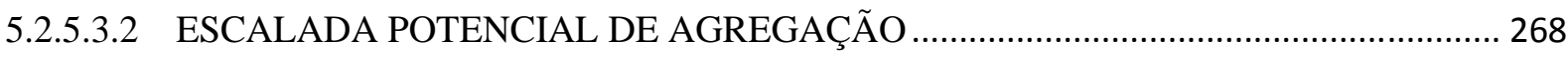

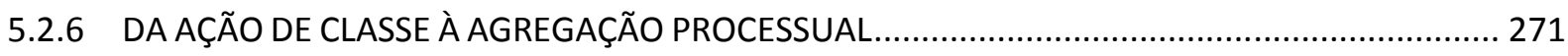

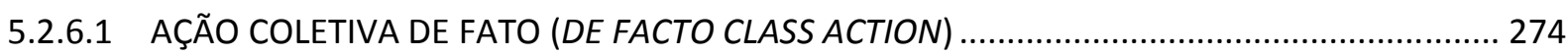

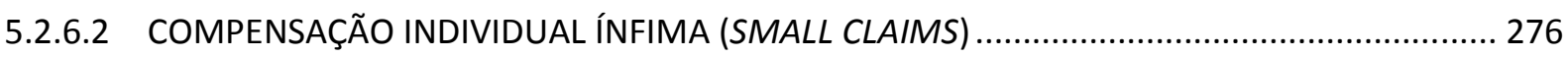

5.2.6.3 COMPENSAÇÃO INDIVIDUAL INCIDENTAL OU MERAMENTE ECONÔMICA (INCIDENTAL

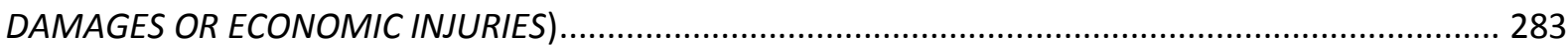

5.2.6.4 COMPENSAÇÃO INDIVIDUAL OBJETIVA - CONTAMINAÇÃO TÓXICA E MONITORAMENTO

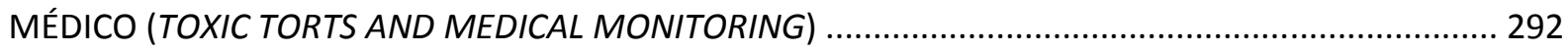

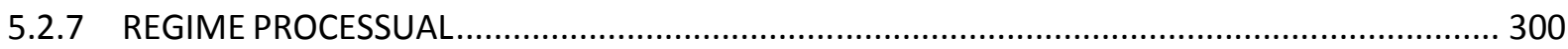

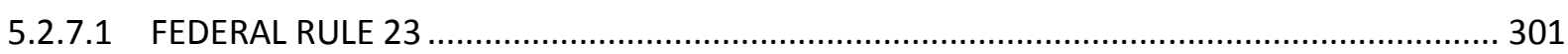

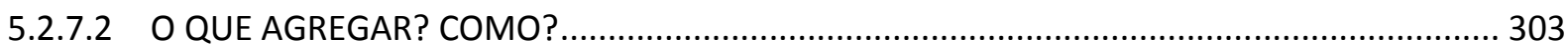

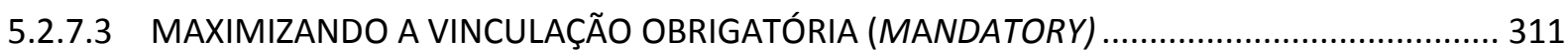

5.2.7.4 MINIMIZANDO A AUTOEXCLUSÃO E A NOTIFICAÇÃO (OPT OUT AND NOTICE) ................... 314

5.3 INTERESSES OU DIREITOS NO SISTEMA BRASILEIRO ............................................

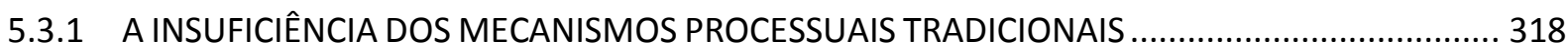

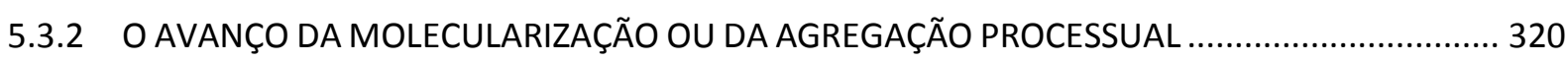

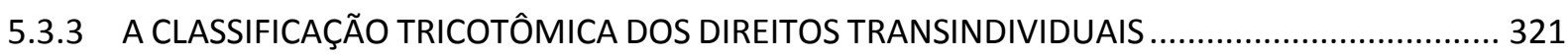

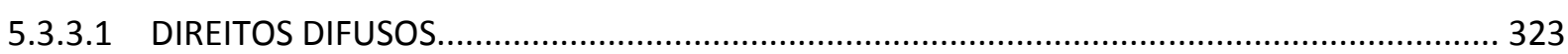

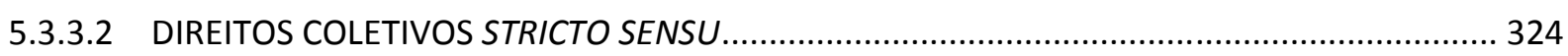

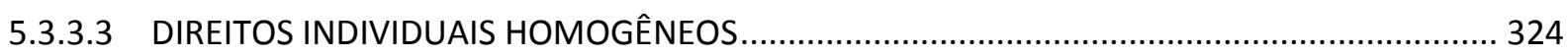

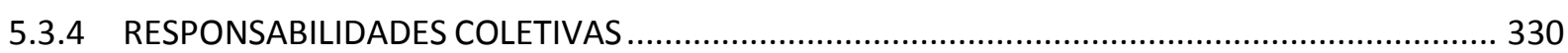

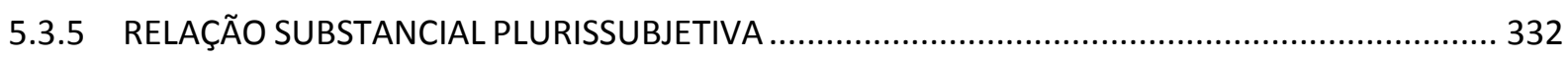

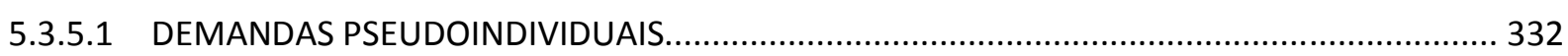

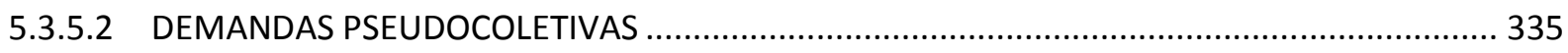

5.3.6 POR MAIS UM CRITÉRIO: A IMPESSOALIDADE .................................................................... 336

5.3.7 IDENTIFICAÇÃO DO INTERESSE OU DIREITO COLETIVO, DE ALCANCE COLETIVO E REPETITIVO E

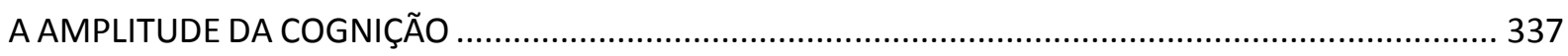

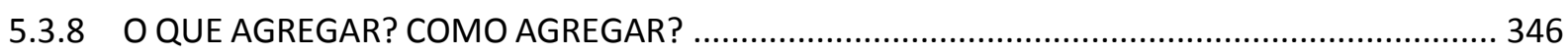

5.3.9 PROJETOS DE LEI E CASOS DE AGREGAÇÃO DE LEGE LATA .................................................... 347

5.3.9.1 ANTEPROJETO DE MODIFICAÇÃO DO CÓDIGO DE PROCESSO CIVIL DE 1985 ........................ 348

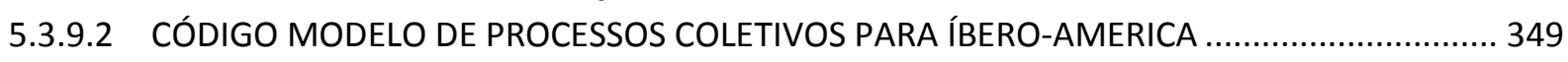

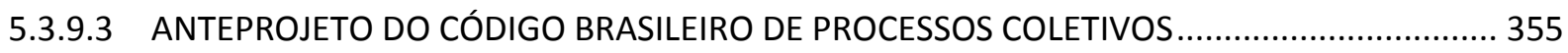

5.3.9.4 PROJETO DA NOVA LEI DA AÇÃO CIVIL PÚBLICA ............................................................. 356

5.3.9.5 PROJETO DE LEI SOBRE O CONTROLE JURISDICIONAL DE POLÍTICAS PÚBLICAS .................. 361

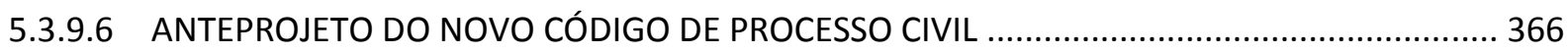

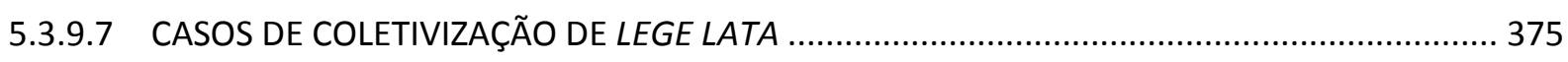

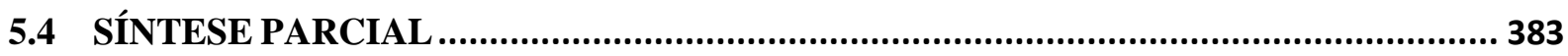

\section{SEÇÃO III - AGREGAÇÃo, PRECLUSÃo E ARGUMENTAÇÃo}


6.1 APRESENTAÇÃO............................................................................................. 385

6.2 TEORIAS DA REPRESENTAÇÃO .......................................................................... 387

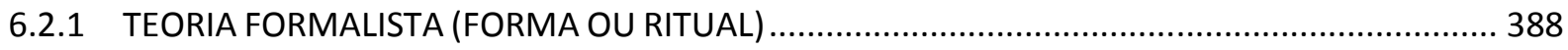

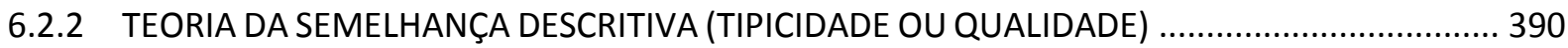

6.2.3 TEORIA DA IDENTIDADE DOS INTERESSES (SUBSTÂNCIA OU CONTEÚDO DA ATIVIDADE)...... 394

6.2.4 TEORIA DA REPRESENTAÇÃO VIRTUAL (PERFORMANCE OU RESULTADO) .............................. 398

6.2.4.1 ORIGENS E CONCEITO DE REPRESENTAÇÃO COMO PERFORMANCE OU RESULTADO ........ 402

6.2.4.2 A REPRESENTAÇÃO PROSPECTIVA E RETROSPECTIVA .................................................... 404

6.2.4.3 TÉCNICA PROCESSUAL: REPRESENTANTE ADEQUADO E AMOSTRA ADEQUADA ................ 405

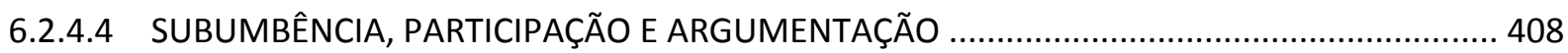

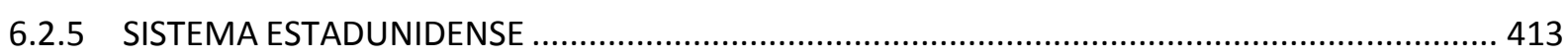

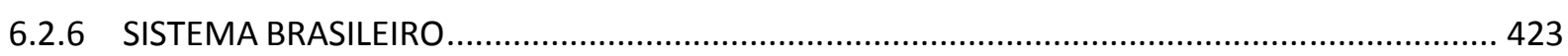

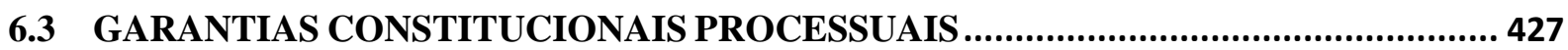

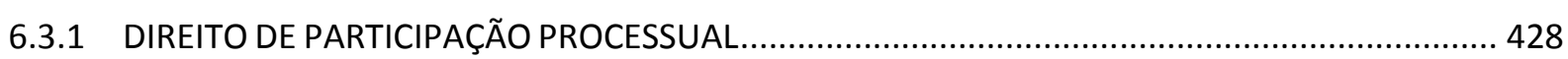

6.3.1.1 TEORIA DA PARTICIPAÇÃO ORIENTADA AO PROCESSO ..................................................... 429

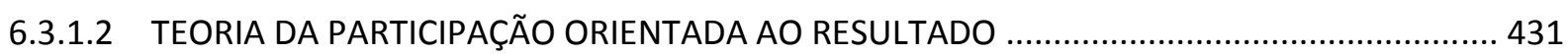

6.3.1.3 O CONTRADITÓRIO, AS TEORIAS DE PARTICIPAÇÃO E O DIREITO SUBSTANCIAL................. 433

6.3.1.4 O ABUSO PROCESSUAL E O ÔNUS/CARGA DE ARGUMENTAÇÃO ........................................ 437

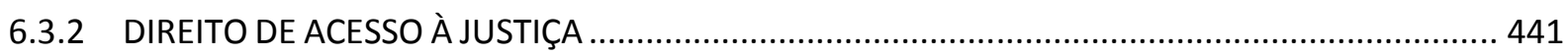

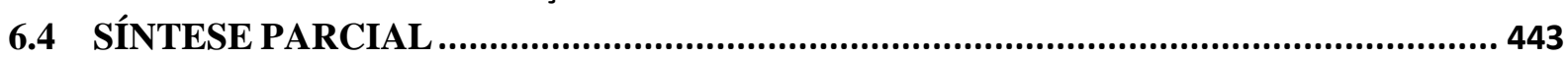

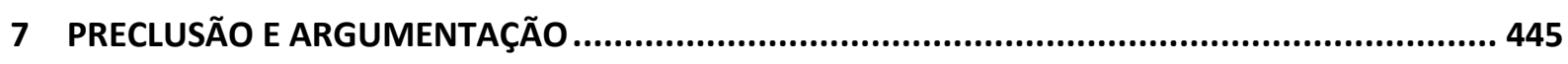

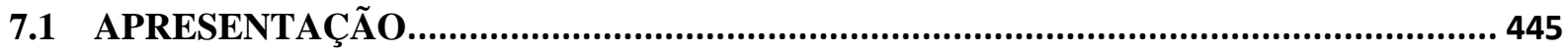

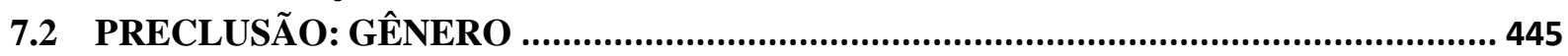

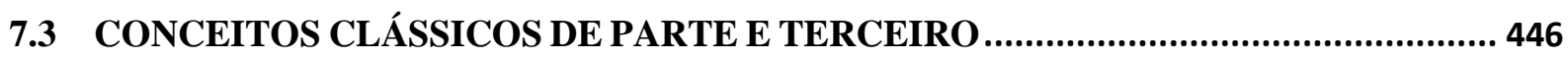

7.4 CONTROVÉRSIAS DE MASSA OU PLURISSUBJETIVAS: FUNGIBILIDADE DOS

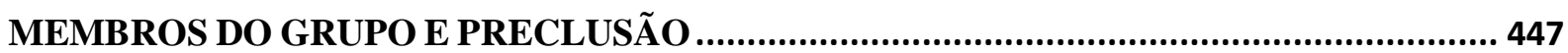

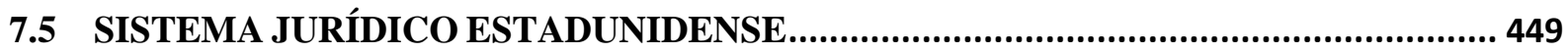

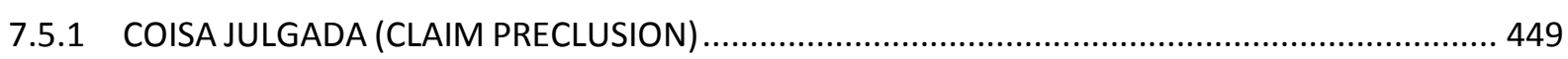

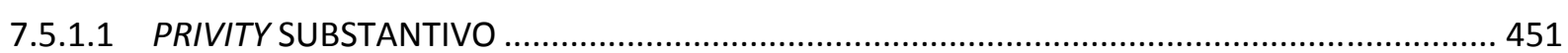

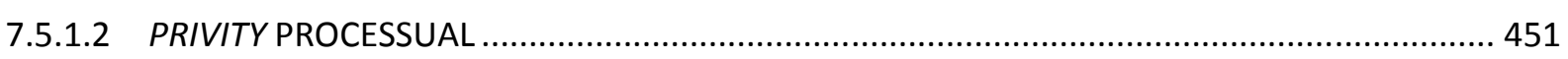

7.5.2 PRECLUSÃO DAS QUESTÕES DECIDIDAS (ISSUE PRECLUSION) .............................................. 453

7.5.2.1 IDENTIDADE E DIMENSÃO DA QUESTÃO: ARGUMENTAÇÃO E EVIDÊNCIA ......................... 454

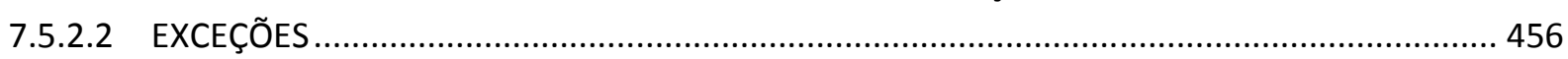

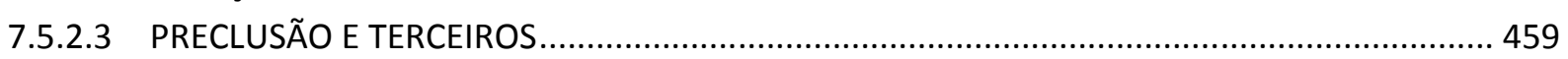

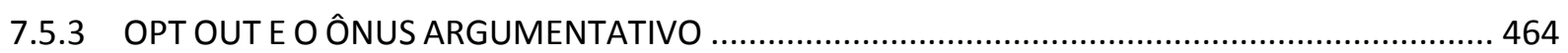

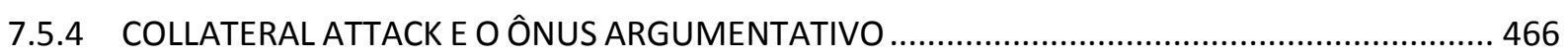

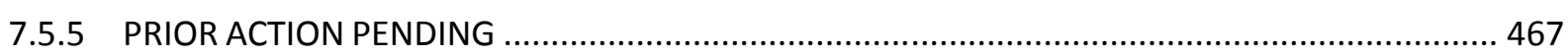

7.6 SISTEMA JURÍDICO BRASILEIROS: DIAGNÓSTICOS E PROPOSTAS DE LEGE

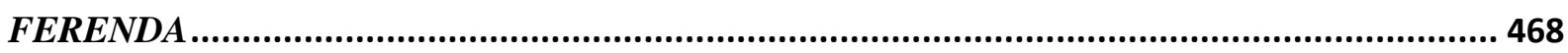

7.6.1 IDENTIFICAÇÃO DA DEMANDA: CONTROVÉRSIAS PLURISSUBJETIVAS OU DE MASSA ............ 471

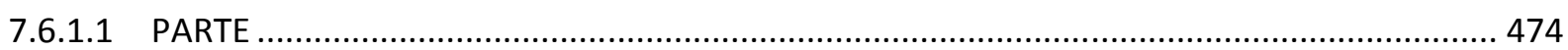


7.6.1.2 OBJETO LITIGIOSO: PEDIDO E CAUSA DE PEDIR.

7.6.2 COISA JULGADA COLETIVA SECUNDUM EVENTUM LITIS VEL PROBATIONIS, SECUNDUM PROBATIONEM E REBUS SIC STANTIBUS: DIREITOS DIFUSOS E COLETIVOS

7.6.3 COISA JULGADA COLETIVA SECUNDUM EVENTUM LITIS: DIREITOS HOMOGÊNEOS E ÔNUS ARGUMENTATIVO

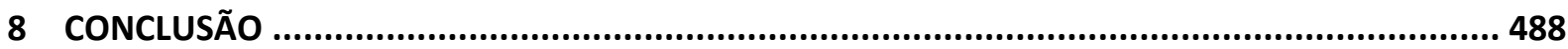

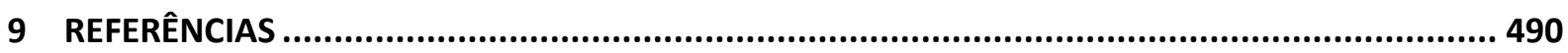




\section{INTRODUÇÃO}

O tema da litigiosidade de massa e da agregação processual - processamento e/ou resolução unitária de controvérsias plurissubjetivas - não foi, ainda, completamente, desenvolvido no sistema brasileiro. Trata-se de temática ambiciosa e para a qual não há, ainda, respostas definitivas. O escopo dessa investigação é, por isso, analisar esse tema, de forma comparada ao sistema jurídico estadunidense, buscando conhecer as possíveis respostas e os seus resultados.

Não obstante o pioneirismo do sistema jurídico brasileiro, que conta hoje com técnica processual coletiva inovadora e com produção acadêmica robusta sobre a temática, muitas são controvérsias de massa que ainda são resolvidas pelas ações individuais, sem atenção ao alcance coletivo do direito substancial. É preciso, pois, continuar refletindo sobre o sistema coletivo.

Para que essa simetria entre direito e processo possa ser melhor observada e aperfeiçoada, abordam-se, atualmente, técnicas de agregação processual. Além das ações coletivas, que podem ser, agora, compulsórias, discutem-se outras técnicas de reunião e de resolução unitária de demandas individuais e/ou coletivas. Destaca-se, nesse contexto, que o princípio da demanda não significa, necessariamente, o direito absoluto das partes em estruturar subjetivamente o procedimento da forma que melhor convier, sem atenção ao direito material controvertido. $\mathrm{O}$ design procedimental e o gerenciamento do processo tem também escopo público e social, de forma que esse design pode ser alterado em prol da resolução unitária da controvérsia de massa.

O sistema estadunidense, que já se destacava, historicamente, nas ações coletivas, continua a desenvolver a temática do processo coletivo, mas, agora, em um sentido mais amplo, que é o do agregação processual no bojo da litigiosidade de massa. Muitas dúvidas, ainda, ressoam e precisam ser respondidas, mesmo nesse sistema. Qual é o nível ótimo de agregação processual, sem prejuízo à autonomia do indivíduo em contar a sua própria história? O que e como agregar?

Esse é o objetivo da presente investigação: aferir qual a extensão, necessária e adequada, da agregação processual nas controvérsias de massa e os seus respectivos limites no processo civil. 


\section{SEÇÃO I}

\section{LITIGIOSIDADE DE MASSA E TÉCNICAS DE AGREGAÇÃo PROCESSUAL}

\section{ANTECEDENTES HISTÓRICOS}

A menção aos novos rumos da prestação jurisdicional coletiva é muito comum atualmente, não apenas pelas ações coletivas, mas também por outras técnicas de agregação. É, igualmente, comum a menção aos novos direitos coletivos ou de massa. A nossa investigação começa nesse ponto: será que as técnicas de agregação processual e os direitos coletivos são tão novos assim?

\subsection{APRESENTAÇÃO}

A litigiosidade de massa não é um fenômeno recente, embora, na atualidade, assuma dimensões, nuances e peculiaridades próprias; pode-se dizer que é um fenômeno recorrente na história.

Não se duvida que a massificação encontra-se na pauta do dia, tanto na rotina dos Tribunais, nos debates legislativos, na gestão administrativa e na vida privada. Contudo, mais do isso, ela é visível e sentida por todos, assumindo verdadeira notoriedade social. A massificação, na forma como conhecida hoje, é corriqueira e pode ser comprovada visualmente pela ocorrência das multidões, pela ocorrência da aglomeração ${ }^{1}$. Conforme Ortega y Gasset² ${ }^{2}$ a massificação é:

\footnotetext{
Simplicíssima de enunciar, ainda que não de analisar, eu a denomino o fato da aglomeração, do 'cheio'. As cidades estão cheias de gente. As casas cheias de inquilinos. Os hotéis cheios de hóspedes. Os trens cheios de viajantes. Os cafés cheios de consumidores. Os passeios cheios de transeuntes. As salas dos médicos famosos cheias de enfermos. Os espetáculos, desde que não sejam muito extemporâneos, cheios de espectadores. As praias cheias de banhistas. O que antes não era problema, começa a sê-lo quase de contínuo: encontrar lugar.
}

Se, nos dias de hoje, a massificação é visível e assume a proporção de grandes massas ou de multidões, não se afasta a ideia de que essa massificação já existia antes, em menores proporções, na sociedade gentílica romana, na vida comunal medieval, nas paróquias, nas associações mercantis. A vida social, política, econômica e jurídica foi, em períodos anteriores e por muito tempo na história, centrada no comum, nas coletividades ou nas comunidades.

1 GASSET, José Ortega y. A rebelião das massas. Tradução Herrera Filho. Rio de Janeiro: Ridendo Castigat Mores (www.jahr.org), 1959, p. 59.

2 Ibidem, p. 59. 
E, junto a essas coletividades ou comunidades, é uma obviedade - quase desnecessária - dizer que, com elas, também existiam as controvérsias ou os conflitos de massa. Trata-se de controvérsias que envolviam grupos e indivíduos, vinculados em torno dos mesmos interesses ou direitos, por vezes, agregados para fins de tratamento processual e julgamento unitário.

A fisionomia dos conflitos de massa é traçada, portanto, ao longo de séculos da história. Essa história não é, no entanto, linear ou constante. É, ao contrário, factual, complexa e contingente. O objetivo do presente capítulo é, nesse contexto, retomar as contingências na história da litigiosidade de massa e das técnicas de agregação processual. A partir disso, dialogar com o passado, verificar o que permanece e o que muda no tempo e as circunstâncias nas quais isso ocorreu e poderá ocorrer novamente ao longo da nossa historiografia.

É preciso, assim, retomar o passado e a história da litigiosidade de massa e da agregação processual, suas oscilações, continuidades e descontinuidades, com o fim de melhor esclarecer o presente, criticá-lo e também orientar a ação do processualista brasileiro rumo ao futuro.

\subsection{A RELAÇÃO DA COMUNIDADE E DO INDIVÍDUO}

A história da litigiosidade de massa e da agregação, como objeto de estudo, admite diversas perspectivas de investigação. Há aqueles que entendem a história como a marcha do tempo, isto é, como as narrativas dos eventos, datas e personalidades. Outros, no entanto, estudam a história como fonte de narrativas, as quais, a cada pesquisa, vão se revelando com o desvelamento das forças políticas, sociais e econômicas subjacentes aos acontecimentos e às instituições jurídicas.

A perspectiva de investigação, ora adotada, rechaça a primeira opção supracitada: que se trata de uma leitura - diga-se - romântica da história, como aquela marcada pelos grandes eventos, datas e personalidades ilustres que se seguem cronologicamente no calendário. ${ }^{3}$

3 É referência teórica, nesse aspecto, a obra de Reinhart Koselleck. Esse autor aduz que o historiador utiliza a cronologia dos eventos para organizar as suas narrativas. A mensuração do tempo na história não segue, no entanto, a cronologia do calendário. O tempo na história "está vinculado a unidades políticas e sociais de ação, a homens concretos que atuam e sofrem, a suas instituições e organizações" (Cf. KOSELLECK, Reinhart. Los extratos de tiempo. Estudios sobre la história. Barcelona: Paidós Ibérica, 2001, p. 68). 
Não importa, para efeito da investigação histórica realizada no presente trabalho, a data da entrada em vigor da ação popular, a cronologia do reconhecimento dos direitos coletivos no ordenamento jurídico brasileiro ou evento semelhante. Ao contrário, pretende-se analisar as estruturas subjacentes a esses acontecimentos, às organizações e às instituições jurídicas.

Logo, quando se diz que é preciso retomar o passado da litigiosidade de massa e da agregação processual, suas oscilações, continuidades e descontinuidades, o que se pretende é examinar as relações substanciais existentes entre a comunidade e o indivíduo. São essas relações a envolver uma pluralidade de sujeitos, interessados na solução de uma mesma controvérsia, que, ao longo do tempo, conduziram aos fenômenos da litigiosidade de massa e da agregação hoje abordados.

O modo pelo qual a comunidade e os indivíduos viviam, produziam, professavam a sua fé e, enfim, relacionavam-se, esclarece a forma pela qual os direitos do grupo e as demandas plurissubjetivas foram, em cada momento histórico, apreendidos pelo sistema jurídico e apresentados perante as Cortes de Justiça no caso de conflito. O direito segue, assim, a vida ${ }^{4}$.

As relações estabelecidas entre a comunidade e o indivíduo foram, portanto, deixando as suas marcas na história das instituições e dos conceitos jurídicos. Essas marcas não são, todavia, completamente varridas com a passagem do tempo - da antiguidade à contemporaneidade -, elas muitas vezes permanecem nos conceitos ainda hoje utilizados. E são esses conceitos que recontam a experiência da litigiosidade de massa e da agregação na história do processo civil.

O quadro histórico que se pretende examinar não é, como já enfatizado, constante ou linear no tempo. Nada obsta, todavia, que ele revele algumas recorrências que interessam ao processualista. Dessa forma, nesse contexto, percebe-se uma recorrência de preocupações teóricas e, até mesmo, uma recorrência de conceitos afetos à temática da litigiosidade de massa e da agregação, que desafiaram e desafiam, constantemente, a ciência processual.

\footnotetext{
4 José Rogério Cruz e Tucci e Luiz Carlos de Azevedo bem assinalam que, ao estudar a história do direito, é preciso se transportar para o local e tempo pesquisados, pois são os fatores internos e externos de uma sociedade que influenciam o direito positivo. O direito está vinculado a impulsos de ordem religiosa, moral, sociológica, cultural, ao sistema político, está jungido aos estamentos sociais e preso aos sucessivos fluxos e refluxos das novas ideias. Nesse estudo, deve-se atentar, principalmente, para os institutos de maior longevidade e estabilidade, pois foram eles que influenciaram o pensamento jurídico em maior profundidade e dimensão. (Cf. TUCCI, José Rogério Cruz e AZEVEDO, Luiz Carlos de. Lições da história do processo civil romano. 1. ed. 2. tir. São Paulo: Revista dos Tribunais, 2001, p.22).
} 
Em um primeiro plano, identifica-se uma permanência de preocupações teóricas, já em um segundo plano, uma recorrência de conceitos como a representatividade dos membros ausentes do grupo (indivíduos) e a extensão subjetiva da autoridade da coisa julgada. Quando se aborda a litigiosidade de massa e a estruturação agregada dessa espécie de controvérsia, preocupa-se, comumente, com as seguintes questões, que circundam os mesmos conceitos:

- $\quad$ Quando se investiga o direito de um grupo, trata-se de direito predominantemente coletivo ou de direitos predominantemente individuais, apenas reunidos sob um determinado título ou origem (consumidores, vítimas, moradores de um bairro, artesãos, paroquianos, acionistas, investidores do mercado de capitais etc.)?

- $\quad$ Admite-se a representação do grupo, no sentido de uma ou mais pessoas atuarem em seu próprio nome e em nome do grupo na defesa de interesses ou direitos comuns? Essa representação requer compromisso ou alguma condição de proteção aos ausentes? Se sim, sob quais condições admite-se a representação, considerando os direitos predominantemente coletivos ou predominantemente individuais?

- $\quad$ Admitida a representação, quais são os limites de vinculação dos indivíduos a um comando normativo, cunhado em um processo do qual não participaram?

Essas preocupações, reproduzidas na forma das questões supracitadas, são sentidas até hoje e acompanham o desenvolvimento de toda a presente investigação, como será visto mais adiante.

Mas, embora essas preocupações permaneçam na história, a resposta conferida à problemática se desloca, de tempos em tempos, como um pêndulo entre os planos individual e coletivo. Admite-se, assim, ora uma maior agregação ou molecularização da controvérsia, ora uma menor agregação ou molecularização dessa mesma controvérsia em juízo. Por qual razão?

Pode-se dizer que o debate sobre a agregação das controvérsias de massa deita suas raízes mais profundas nas relações plurissubjetivas estabelecidas entre a comunidade e o indivíduo. Avança-se no sentido de que é o grau de oposição ou de identidade entre o indivíduo e a comunidade a ele associado que oferece, ao longo da historiografia, diferentes respostas à problemática processual ora analisada na história, mas que mesmo na atualidade está presente. 
É válido, nesse sentido, recontar as experiências ocorridas em cada momento histórico, tendo em mente a forma pela qual essas preocupações foram sentidas e equacionadas, a partir do binômio comunidade e indivíduo. Didaticamente, adota-se a periodização da história do ocidente, dividindo-a em: período Antigo (753 a.C. a 476 d.C., com referência ao direito grego e romano), período Medieval (século V - Século XV), período Moderno (século XVI - século XVIII) e, por fim, período Contemporâneo (século XIX em diante).

\subsubsection{DO PERÍODO ANTIGO}

Na Grécia Antiga ou, mesmo, em Roma, a organização da vida social, política, econômica e jurídica era impregnada de individualismo. As suas organizações e instituições não se atrelavam, indissociavelmente, a uma comunidade ou a uma massa indistinta de sujeitos. ${ }^{5}$

Nesse período, não se localizam - a não ser excepcionalmente - registros do fenômeno da litigiosidade de massa, tampouco era, entre os juristas da época, comungada a ideia de agregação processual em torno dos mesmos interesses ou direitos, mediante representação.

A representação, embora não fosse completamente desconhecida como prática, não possuía uma clara correspondência teórica nesse período. A representação era, assim, apenas de fato.

Hanna Pitkin ${ }^{6}$ salienta a existência, na Grécia Antiga, de eleição de alguns oficiais e do envio de alguns embaixadores a outras regiões, o que - pode-se dizer - envolve alguma espécie de representação. Não se trata, no entanto, de representação de sujeitos na defesa de interesses ou direitos de grupos, acepção que, somente séculos mais tarde, tornou-se entre nós conhecida.

A palavra representação, ainda segundo Pitkin $^{7}$, tem origem latina, mas também não coincide com as instituições romanas. Essa noção teórica apresenta-se, apenas, no final do medievo.

5 É cediço que a forma de agricultura e a organização da propriedade romana tinham matizes essencialmente individuais. A tendência comunal, embora apareça em determinados momentos, é pontual entre os romanos. E, por isso, somente em algumas situações, houve, entre os romanos, a noção de interesses ou direitos atinentes à pluralidade romana, isto é, atinentes a todos os cidadãos romanos (Cf. VINOGRADOFF, Sir Paulo. Villainage in England: essays in english mediaeval history. Oxford: Clarendon Press, 1892, p.14).

6 PITKIN, Hanna Fenichel. The concept of representation. California: University of California Press, 1972, p.2.

7 Ibidem, p. 241. 
Os romanos conheciam a palavra representação para simbolizar a corporificação de um objeto inanimado, como ocorre na arte, por exemplo, ou para indicar a literal presença de algo, anteriormente ausente. Não a aplicavam no sentido de um sujeito representando outros sujeitos na defesa de interesses ou de direitos comuns a ele e a um grupo como um todo. ${ }^{8}$

Na experiência romana, a prática da representação em juízo - embora ainda não se usasse essa expressão - foi, em muito, limitada à ideia de mandato ou procuração, fundada no consentimento do interessado, bem como em procedimentos formais ou ritualísticos.

Para melhor situar o estudo, é importante destacar a periodização do direito processual romano, que se subdividiu em três: o período das ações da lei (legis actiones); o período formulário (per formulas), nos quais predominavam os juízos privados; e o período imperial ou a cognição extraordinária (extraordinaria cognitio), o qual ostentava caráter publicista.

No primeiro período da história do direito romano, relativo às ações da lei, sequer admitia-se a representação em juízo. José Rogério Cruz e Tucci e Luiz Carlos de Azevedo mencionam que, em famoso fragmento do Digesto, Ulpiano acentuava: "ninguém poderá agir em nome de outrem (D. 50.17.123, Ulpiano Libro XIV ad edictum: nemo alieno nomine lege agere potest)". Excepcionalmente, admitia-se a representação (frise-se - como prática apenas) nas causas entre tutor e curador, bem como nas ações populares (actio popularis), o que será analisado adiante. ${ }^{10}$

Mais tarde, a partir do processo formular, já era permitida a representação em juízo, mas ainda sem remissão a essa expressão. Admitia-se a representação em juízo por meio de terceiros (cognitores ou procuratores ${ }^{11}$ ), os quais figuravam no lugar das partes demandadas. A

8 PITKIN, 1972, p.241.

9 Nesse sentido: TUCCI, José Rogério Cruz e AZEVEDO, Luiz Carlos de. 2001, p. 55 e AZEVEDO, Luiz Carlos de. $O$ direito de ser citado: perfil histórico. São Paulo: Resenha Universitária - Fundação Instituto de Ensino para Osasco, 1980, p.102.

10 Outro fenômeno de pluralidade de partes (mas sem caráter representativo) também é encontrado nesse período: trata-se do litisconsórcio. Segundo Guilherme Estelita, um processo poderia ser constituído com pluralidade de autores ou réus, desde que os autores se coligassem a outros sujeitos, interessados na mesma relação substancial, para propor a ação ou se esta ação se dirigisse em relação a várias pessoas. Enrico Redenti, em texto seminal na Itália, também mencionava o fenômeno do litisconsórcio no direito processual romano. (CF. ESTELITA, Guilherme. Do litisconsórcio no direito brasileiro. Rio de Janeiro: Universidade do Brasil, 1954, p.71-74 e REDENTI, Enrico. Il giudizio civile com pluralità di parti. Milano: Società Editrice, 1911).

11 Os conceitos de cognitor e procurator são esclarecidos, no texto, a partir das obras de Vincenzo Arangio-Ruiz e Felippo Briguglio. Conferir: ARANGIO-RUIZ, Vincenzo. Il mandato in diritto romano: corso di lezioni svolto nell'università di Roma. Anno 1948-1949. Napoli: Casa Editrice Dott. Eugenio Jovene, 1965, p. 12 et seq. e BRIGUGLIO, Felippo. Studi sul procurator: l'acquisto del possesso e dela proprietà. Milano: Dott. A. Giuffrè Editore, 2007, p.4 et seq. 
constituição desses terceiros, para atuar na qualidade de parte, apresentava, por sua vez, a natureza de uma autorização solene. O interessado indicava, com o seu consentimento e mediante determinada solenidade, um terceiro para que esse figurasse em seu lugar na ação.

O cognitor era solenemente nomeado, na forma oral e na presença do adversário. O interessado substituído não mais possuía controle sob a atividade, sucessivamente, realizada pelo seu mandatário em juízo. O procurator ad litem era, por sua vez, uma espécie de encarregado ou de administrador dos negócios do interessado, sendo constituído, previamente, por mandato, para representá-lo em juízo. O mandato era lido no início do processo e os atos do procurador eram garantidos pelo aval de um garante (sponsor $)^{12}$.

É importante frisar, para os propósitos deste trabalho, que a preocupação em se conceder uma autorização solene - seja oral ou escrita - para fins de atuação de um terceiro, a figurar na posição de parte, identificava certa oposição entre a comunidade e o indivíduo dela integrante. Não havia - frise-se, ao menos, em regra - uma vinculação natural ou estreita entre os indivíduos e a sua respectiva comunidade, no tocante aos direitos pessoais ou individuais.

No tocante a esses direitos ditos pessoais ou individuais, as fontes clássicas revelam, de forma bastante coerente, uma preocupação em assegurar a atuação pessoal das partes ou dos procuradores autorizados a representá-las em juízo, bem como uma preocupação em afastar eventual proveito ou prejuízo àqueles que não estivessem reunidos no processo (terceiros). ${ }^{13}$

O comando normativo da sentença, em relação ao qual se atribuía a indiscutibilidade inerente à coisa julgada, não poderia alcançar sujeitos que não figurassem, formalmente, no processo. Como salienta Scialoja ${ }^{14}$, o alcance subjetivo era, em regra, inter partes, isto é, entre as partes ou entre os que ocupavam idêntica posição, como, por exemplo, o procurator e o cognitor.

12 Pelo aval do sponsor, esse garantidor assegurava a obrigação do mandante, ratificando a atuação do procurador em juízo e inviabilizando ulterior investida contra o réu. (Cf. TUCCI, José Rogério Cruz e AZEVEDO, Luiz Carlos de, 2001, p.82).

13 A máxima segundo a qual "C.7.56.3 é de evidentíssimo direito..., que não se pode prejudicar aqueles que não estiveram reunidos no processo" foi, inclusive, consolidada na Constituição dos Imperadores Diocleciano e Maximiano. De igual modo, no passo de Paulo (D. 20.4.16), afirmava-se que a "coisa julgada entre uns não costuma aproveitar nem prejudicar a outrem" (Cf. TUCCI, José Rogério Cruz e. Limites subjetivos da eficácia da sentença e da coisa julgada civil. São Paulo: Revista dos Tribunais, 2006, p.46).

14 SCIALOJA, Vittorio. L'exceptio rei iudicatae nelle azioni popolari: studio esegetico... Nabu Press, 2013 (reprint 1883), p.3 et seq. No mesmo sentido, TUCCI, 2006, p.45. 
José Rogério Cruz e Tucci ${ }^{15}$ esclarece que os juristas tinham consciência de que a sentença, sobre a qual se formava a coisa julgada, deveria aplicar-se apenas às partes e àqueles na mesma posição jurídica, sendo irrelevante para os terceiros, que não figuraram, formalmente, no processo. Igual preocupação não ocorria, porém, no direito barbárico-germânico do período.

O direito barbárico-germânico, ainda segundo Tucci ${ }^{16}$, não se preocupava com a extensão subjetiva da coisa julgada, uma vez que havia uma vinculação natural entre o indivíduo e o grupo. O grupo se reunia e participava de todos os atos processuais e a sentença, publicamente proferida, irradiava eficácia perante todos os membros do grupo, sendo praticamente impossível rediscuti-la em outras oportunidades. A eficácia subjetiva da coisa julgada era ultra partes.

Feita essa diferenciação, fica fácil compreender que: na experiência romana, diferentemente do direito barbárico-germânico, a vinculação do indivíduo à comunidade, no tocante aos direitos pessoais ou individuais, não era algo comum (talvez sequer existente). Esse fato se refletiu na prática solene de representação e na extensão subjetiva da coisa julgada apenas às partes. Em verdade, a extensão subjetiva da coisa julgada apenas às partes e a identificação das demandas idênticas foi preocupação marcante no direito romano, o que permanece até hoje no processo.

Mesmo assim, os romanos foram sensíveis a uma situação substancial plurissubjetiva: as hipóteses em que os interesses ou os direitos escapavam da esfera de apenas um indivíduo.

Ainda que a vinculação entre o indivíduo e a coletividade não fosse trivial, não se descuida de que ela, excepcionalmente, existia em relação a uma categoria de direitos substanciais. Em algumas situações, houve, entre os romanos, a noção de interesses ou direitos comuns atinentes à pluralidade romana, isto é, interesses ou direitos pertencentes a todos os cidadãos romanos.

A vinculação entre o indivíduo e a comunidade era intensa, no tocante à determinada categoria de direitos comuns, incidentes ${ }^{17}$ sobre bens ou interesses à disposição de todos (res sacrae, res

15 TUCCI, 2006, p. 46.

16 Ibidem, p. 49.

17 Apenas para esclarecer, quando se usa a expressão - direitos incidentes sobre coisas - trata-se de uma expressão contemporânea. Para ser fiel ao período retratado, é preciso dizer que os romanos não distinguiam a própria coisa do direito incidente sobre ela. Assim, dizia-se que a coisa era de alguém e não que alguém tinha um direito sobre a coisa (Cf. ALVES, José Carlos Moreira. Direito romano. 15. ed. Rio de Janeiro: Forense, 2012, p. 145). 
religiosae, res sanctae, res communes omnium, res publicae, res uniuersitatis) $)^{18}$. Esses interesses ou direitos comuns eram tuteláveis pelo próprio cidadão por meio da actio popularis.

O surgimento das ações populares, em um sistema de matiz individualista, se explica pela intensa vinculação existente entre os cidadãos romanos e pela comunhão de interesses ou direitos. Como bem descreve Mancuso $^{19}$, naquele tempo, a noção de Estado não possuía contornos bem definidos, o que favorecia a prevalência de uma vinculação natural entre o cidadão e a comunidade. A relação entre o cidadão e a coisa comum estava calcada na ideia de que essa última pertencia a cada um dos cidadãos e pertencia a todos eles ao mesmo tempo.

Nesse contexto, não é de se estranhar que, já a partir das ações da lei ${ }^{20}$, uma determinada categoria de interesses ou direitos comuns fosse tutelada em juízo pela actio popularis. Segundo essa ação ${ }^{21}$, um cidadão pleiteava, em nome próprio, a defesa de interesses ou direitos comuns, pertencentes a ele e a toda coletividade (populus) e, posteriormente, ao próprio ente público.

Enquanto as ações privadas dirigiam-se à defesa de interesses ou direitos pessoais do indivíduo, as ações populares voltavam-se à defesa de interesses ou direitos próprios do indivíduo, mas conexos à coletividade dos cidadãos. O indivíduo não era considerado na sua esfera pessoal ou singular, mas, sim, como participante de uma coletividade ou de uma comunidade de pessoas..$^{22}$

18 José Carlos Moreira Alves dispõe que essas coisas comuns e à disposição de todos são classificadas como extra commercium, isto é, insuscetíveis de alienação, dentre elas estavam as coisas sagradas (res sacrae), as coisas religiosas (res religiosae), as coisas santas (res sanctae), as coisas comuns a todos como o ar, os rios (res communes omnium), as coisas públicas como as praças, ruas, bibliotecas (res publicae) e as coisas coletivas (res uniuersitatis). Inicialmente, as coisas públicas e as coisas coletivas referiam-se aos mesmos bens da vida. Mas, com o avanço da noção e da distinção entre o Estado Romano e as cidades romanas, as coisas públicas tornam-se pertencentes ao Estado Romano e as coisas coletivas pertencentes às cidades (Cf. MOREIRA, 2012, p.151).

19 MANCUSO, Rodolfo de Camargo. Ação Popular: proteção do erário, do patrimônio público, da moralidade administrativa e do meio ambiente. 7. ed. rev. atual. São Paulo: Revista dos Tribunais, 2011, p. 47. No mesmo sentido, LEONEL, Ricardo de Barros. Manual do processo coletivo. São Paulo: Revista dos Tribunais, 2012 , p.41. 20 AZEVEDO, 1980, p. 102. TUCCI, AZEVEDO, 2001, p.55.

21 As ações populares, no processo romano, são variadas; algumas de natureza penal, outras de natureza civil. Não existe uma classificação exaustiva de todas as ações populares. Mas, o que deve ser destacado é que, inicialmente, quando Tício agia contra Mévio na defesa de uma via pública, por exemplo, ele não o fazia como representante do Estado, mas fazia valer um interesse próprio em conexão com os interesses de toda a coletividade. Somente com o surgimento do Estado, como entidade própria, surge a noção de um indivíduo atuando como substituto do oficial público, encarregado da defesa dos bens comuns pela administração estatal (Cf. CRISAFULLI, Vezio. Verbete "Azione popolare", in Nuovo Digesto Italiano II. Torino: Unione Tipografico, 1937, p. 138-143. PALADIN, Livio. Verbete "Azione popolare”, in Novissimo Digesto Italiano II, Torino: Unione Tipografico, 1957, p. 87-88). 22 SCIALOJA, Vittorio. Procedimiento civil romano: ejercicio y defesa de los derechos. Traducción de Santiago Sentis Melendo y Marino Ayerra Redin. Buenos Aires: Ejea, 1954, p. 342. Nesse sentido, conferir ainda: LOZANO Y CORBI, Enrique: La legitimación popular em el proceso romano clássico. Barcelona: Bosch, Casa Editorial, 1982, p.78. 
Logo, se o processo romano era, em regra, impregnado de individualismo, representado pela configuração antagônica de partes (Tício versus Caio) ${ }^{23}$, que impelia cada cidadão a deduzir o seu direito, em juízo, em nome próprio, a ação popular - por oposição - tinha ênfase coletiva.

Nesse mesmo contraponto, é preciso destacar que, não obstante a ênfase coletiva das ações populares, não havia discussão quanto à possibilidade de representação ou quanto à representatividade do cidadão romano, tampouco se exigia consentimento para qualquer fim.

É bem verdade que existem alguns passos do Digesto que aludem a temas como a idoneidade do autor na hipótese de concorrência de ações populares, bem como que se referem à extensão subjetiva da coisa julgada a toda a coletividade, que não participou formalmente do processo. Essas questões não foram, todavia, alcançadas por uma teoria compreensiva de representação.

A idoneidade do cidadão, no sentido de reputação e dedicação à vida pública, era objeto de referência apenas na hipótese em que mais de um cidadão ajuizasse ação popular. Era um critério de preferibilidade ou de eleição da ação popular do cidadão mais idôneo ${ }^{24}$. Essa idoneidade não excluía, tampouco limitava a legitimidade e a possibilidade de qualquer cidadão romano ajuizar a ação popular e também não era um critério válido para escolher a priori um representante adequado do povo romano. Todos os cidadãos romanos eram legitimados para tanto e, desse modo, não havia preocupação com a representatividade adequada dos cidadãos.

De maneira semelhante, a autoridade da coisa julgada vinculava terceiros, isto é, os demais cidadãos que não participaram do processo. Essa vinculação não é explicada por uma teoria de representação ou por qualquer coisa parecida. Scialoja ${ }^{25}$ esclarece que a vinculação é uma

23 Em sentido semelhante, MANCUSO, Rodolfo de Camargo. Jurisdição coletiva e coisa julgada: teoria geral das ações coletivas. 2. ed. rev. atual. amp. São Paulo: Revista dos Tribunais, 2007. p. 27.

24 SCIALOJA, 2013 (Reprint 1883), p. 5 et seq.

25 Cogliolo dizia que a autoridade da coisa julgada na ação popular romana não alcançava terceiros. Como não havia qualquer vínculo legal entre o terceiro e a parte na ação popular, a exceção de coisa julgada deveria ser afastada. Mesmo assim, Cogliolo dizia que não era admissível uma segunda ação popular idêntica. Segundo Cogliolo, o terceiro era obstado ao ajuizamento de uma segunda ação popular sucessiva, não por força da autoridade da coisa julgada, mas, sim, porque a sua pretensão já havia sido "consumida" anteriormente. Scialoja responde o argumento de Cogliolo e salienta que a ação popular romana não poderia ser renovada ao infinito, de modo que a autoridade da coisa julgada alcançava, sim, os terceiros, isto é, os demais cidadãos romanos. A razão para isso, segundo Scialoja, era que todos os cidadãos romanos se reportavam a um mesmo interesse ou direito geral, logo a mudança do autor não alterava substancialmente a demanda. Em suas palavras: "l'exceptio nell'azione popolare se aplica anche contro i terzi, ma ciò non è strano, perche ogni attore rappresenta coll'interesse generale anche dell'altro attore [...] non portando alcuna sostanziale modificazione il mutamento della persona" (Cf. SCIALOJA, 2013 (Reprint 1883), p. 7-8). 
decorrência do caráter impessoal da litigiosidade na ação popular, em razão da intensa vinculação entre o indivíduo e o povo romano. A vinculação não decorria, pois, da identidade das partes, mas da identidade da qualidade, da posição ou da situação jurídica dos indivíduos ${ }^{26}$.

Enfim, as fontes romanas não se dedicam a explicar a representação, as características do representante popular ou limitar essa representação a algumas pessoas eleitas, tampouco se preocupavam em limitar a autoridade da coisa julgada apenas às partes na ação popular. Afastase, com isso, nesse período histórico, apenas a teorização sobre a possibilidade de um sujeito exercer a proteção de seu direito e, ao mesmo tempo, representar outrem em juízo. ${ }^{27}$

Já que não há uma teoria de representação, é possível encontrar, no lugar disso, um rol descritivo das ações populares. Na falta de uma teoria, esse rol confere uma melhor ideia dos direitos passíveis de proteção coletiva e das espécies de ações populares possíveis no processo romano.

José Afonso da Silva ${ }^{28}$ elenca as seguintes espécies de ações populares: (i) sepulchro violato (concedida por violação do sepulcro, coisa santa ou religiosa), (ii) effusis et deiectis (concedida contra quem atirasse objetos em via pública), (iii) positis et suspensas (concedida contra quem mantivesse objetos na sacada ou na aba do telhado, com risco de queda), (iv) albo corrupto (concedida contra quem alterasse o album do pretor, isto é, o edito do pretor que declarava de que modo faria observar a lei e a administração da justiça), (v) a edilitio edicto et redhibitione et quanti minoris (cabível para evitar a introdução de animais perigosos a lugares públicos frequentados), (vi) termine moto (concedida contra quem retirasse as pedras demarcatórias de propriedade privada), (vii) tabulis (concedida contra quem abrisse testamento ou aceitasse herança, na hipótese em que os servos do de cujus ainda estavam sendo processados pela morte violenta de seu senhor), (viii) assertio in libertatem (concedida para lograr a liberdade de um parente), (ix) interdictum de homine libero exhibendo (concedida para lograr a liberdade de qualquer pessoa), (x) collusione detegenda (cabível quando escravos eram declarados livres em

26 No mesmo sentido, Miguel Seabra Fagundes defende a extensão subjetiva da coisa julgada coletiva aos demais cidadãos (terceiros) na ação popular, pois, embora não houvesse identidade da pessoa física, havia identidade da qualidade da parte (Cf. FAGUNDES, Miguel Seabra. Da ação popular. Revista de Direito Administrativo. Rio de Janeiro, 1946, V. VI, p.15).

27 Nesse sentido, Carlo Fadda relata que, em Roma, não se poderia falar em representação processual em nenhum modo, conceito que era completamente ignorado nessa época (Cf. FADDA, Carlo. L'azione popolare: studio di diritto romano ed attuale. Edição reproduzida (1894). Roma: L'erma, 1972 (Studia Juridica XXVI), p.371).

28 SILVA, José Afonso da. Ação popular constitucional: doutrina e processo. 2. ed. rev. amp. São Paulo: Malheiros, 2007, p.21-25. 
conluio com os seus donos), (xi) accusation suspecti tutoris (cabível para a destituição de tutor suspeito, para fins de defesa do patrimônio do menor), (xii) ações criadas por Justiniano para restituição de somas perdidas no jogo e para restituição do legado do pio, (xiii) vários interditos proibitórios e restituitórios, em defesa da res publicae e de outros bens comuns ou coletivos.

A classificação das ações populares não é, por sua vez, sedimentada na doutrina romanista. Todavia, é interessante notar a seguinte classificação proposta por Livio Paladin ${ }^{29}$ : existiam ações (i) com fundamento na origem da norma - ações legais e ações pretorianas, (ii) com fundamento no exercício da ação - ações populares e interditos populares e (iii) com fundamento no destinatário da soma da condenação - erário público, autor da ação e terceiros.

Por fim, a natureza da ação popular, se individual ou coletiva, se privada ou pública, é uma das matérias mais caras e controvertidas da doutrina romanista. Contudo, como é abordado, nesta tese, o binômio comunidade e indivíduo e as relações substanciais entre eles travadas, são questões que merecem ser, ao menos modestamente, enfrentadas na investigação desse período.

Miguel Seabra Fagundes ${ }^{30}$ destaca que existiam, dentro da categoria popular, tanto ações populares individuais com alcance coletivo, quanto ações populares propostas pelo indivíduo como substituto de um oficial público, encarregado da defesa das coisas comuns. Ricardo de Barros Leonel ${ }^{31}$ afirma, nesse mesmo sentido, a extraordinária amplitude das ações populares.

Essa amplitude extraordinária não deve surpreender. Isso é, aliás, consentâneo com a história do desenvolvimento do Estado como entidade própria em Roma. Como a noção de representação era, ao menos teoricamente, inconcebível entre os juristas romanos, não se distinguia, inicialmente, o cidadão e indivíduo do povo romano ou da coletividade de cidadãos.

Cabe lembrar que, inicialmente, o cidadão não era parte do povo, ele era o povo, no tocante à defesa da coisa comum. Logo, essa equivalência conceitual entre cidadão e povo (populus) não permitia distinguir o cidadão da coletividade a que ele estava associado. $\mathrm{O}$ direito comum do 
povo (populus), entendido como pluralidade dos cidadãos, identificava-se com o direito de cada um dos cidadãos romanos, autorizando-se a defesa individual dos interesses plurissubjetivos.

Aquele direito que era do povo, também era do cidadão. Aquele direito que era do indivíduo, na qualidade de cidadão ou membro do povo, era igual ao direito de toda a pluralidade de cidadãos. Por essa razão, eram possíveis ações individuais na defesa das coisas comuns. E, posteriormente, com desenvolvimento do Estado como entidade própria, o mesmo bem passa a ser defendido pelo indivíduo, mas agora em substituição ao magistrado ou ao oficial público.

Embora seja conhecida a dificuldade da doutrina em identificar a natureza desses direitos protegidos pela actio popularis romana, é possível dizer que a disciplina das ações populares situava-se em uma posição intermediária: sua natureza não era nem pública, nem privada, também não era nem exclusivamente individual, nem era exclusivamente do ente coletivo.

Para demonstrar isso, é válido realizar uma digressão sobre a doutrina do século XIX a respeito da ação popular romana.

Carl Georg Bruns, em texto escrito em 1864 e, posteriormente, traduzido por Vittorio Scialoja ${ }^{32}$, é um dos primeiros historiadores a intuir a natureza intermediária da actio popularis romana e a possibilidade de o cidadão atuar em nome próprio naquela actio, não na condição de indivíduo, mas na condição de membro de um grupo ou de uma comunidade.

A tese de Bruns ${ }^{33}$ era que a legitimidade conferida ao cidadão e o direito por ele protegido na ação popular representavam uma consequência necessária da estrutura gentílica da antiga comunidade romana, isto é, de uma vinculação natural entre o indivíduo e a gens romana.

Já se ressaltou, antes, que o Estado não constituía uma personalidade abstrata e diversa do cidadão. O cidadão era o povo e o povo era a pluralidade indistinta de cidadãos. Assim, aquele que agia no interesse comum do povo, alcançava um interesse que pertencia a ele como um partícipe daquela comunidade a que ele estava associado, ou seja, é um interesse impessoal.

32 BRUNS, Carl Georg. Le azioni popolari romane per Carlo Giorgio Bruns. Traduzione di Vittorio Scialoja, com prefazione e note del traduttore, in Studio Giuridici I, Roma, 1933, p.179-212.

33 Ibidem, p.179-212. 
Nessa linha de raciocínio, a ação popular romana não se prestava à defesa de um interesse de um ente público autônomo e apartado do cidadão, tampouco de um interesse estritamente privado. Tratava-se da defesa de um interesse ou direito próprio ao cidadão, direito esse, no entanto, comum à coletividade e que pertencia ao indivíduo enquanto membro daquele grupo. ${ }^{34}$

Tanto era assim que, segundo Bruns ${ }^{35}$, a fórmula processual (intentio e a condemnatio) continha, inicialmente, o nome do autor-cidadão e não o nome dominato (dominus). De igual modo, o proveito econômico da condenação era destinado em favor do cidadão e não do erário. Tratavase de um direito individual ou próprio, mas qualificado pelo pertencimento a uma coletividade.

O historiador italiano Carlo Fadda ${ }^{36}$, nos idos de 1894, vem, por sua vez, concluir o argumento de Bruns.

Fadda $^{37}$ expõe que essa ação popular, proposta em nome do cidadão, é, posteriormente, integrada por outra ação do cidadão. Tratava-se de uma segunda espécie de ação popular, proposta em nome do dominus, sendo a condenação revertida agora em favor do erário público.

Ao tempo dessa segunda espécie, a ideia de Estado como entidade própria já se encontrava mais desenvolvida e o cidadão agia na qualidade de substituto do magistrado ou do oficial, a quem se atribuía a tutela da coisa comum ou pública. Era evidente, portanto, que, nesse último caso, o valor da condenação reverteria, agora, em favor do erário ou da caixa pública. ${ }^{38}$

Essas espécies, continua Fadda ${ }^{39}$, não se seguem ou substituem, mas se acrescentam. Elas existem simultaneamente, conferindo unidade à categoria da actio popularis romana, na qual se perseguem direitos intermediários entre o privado e o público - pode-se dizer coletivos.

34 Vittorio Scialoja afirmou isso de forma bem clara, segundo o pensamento de Bruns. O direito defendido na ação popular é do povo, mas não se trata do povo orientado à ideia de Estado, mas sim, do povo orientado à ideia de um complexo de cidadãos. Assim, na ação popular, há uma gradação na relação indivíduo e coletividade, atenuando-se os elementos puramente pessoais do direito individual para transformá-lo em um direito do indivíduo, como membro da comunidade (Cf. SCIALOJA, 1954, p.345-346).

35 BRUNS, 1933, p.212.

36 FADDA, 1972 (reprint 1894), p.306 et seq.

37 Ibidem, p.320 et seq.

38 Ibidem, p.374.

39 Ibidem, p. 375. No mesmo sentido, Miguel Seabra Fagundes ressalta que as ações populares prestavam-se à defesa de direitos individuais com alcance coletivo (ex. defesa pessoal das vias públicas) e à defesa de direitos propriamente coletivos (ex. defesa da sepultura comum) (Cf. FAGUNDES, 1946, p.2) 
Nessa medida, os interesses ou direitos tutelados pela actio popularis não eram privados, nem públicos, constituíam uma terceira categoria ${ }^{40}$ - um interesse que coincidia, ao mesmo tempo, com o individual e com o coletivo. É, dessa forma, inapropriado dizer que as ações populares romanas defendiam direitos exclusivamente privados ou que defendiam direitos exclusivamente públicos, constituíam, assim, um meio termo ou um terceiro gênero.

Destaca-se que, na atualidade, a forma mais marcante e comentada pela doutrina para a identificação e diferenciação entre direitos individuais e direitos coletivos, é a natureza incindível ou indivisível do objeto substancial em relação a esses últimos. Essa diferenciação não foi feita na ação popular pelos romanistas ou, ao menos, isso não foi feito de forma clara.

O que se pode observar pela digressão realizada pela doutrina - o que aqui especialmente interessa - é a proteção pela ação popular romana tanto de direitos indivisíveis na prática, quanto de direitos individuais divisíveis, mas com alcance coletivo, em outras palavras, conectado à coletividade. $\mathrm{O}$ aspecto marcante na ação popular não era a propriedade do objeto, mas, sim, a qualidade impessoal com a qual o autor agia na demanda. Na ação popular, ora o autor cidadão defendia um direito individual qualificado pela coletividade, isto é, direito que lhe pertencia na qualidade de membro da comunidade, ora o autor cidadão defendia um direito titularizado pela própria comunidade, agindo na condição de substituto do oficial estatal. ${ }^{41}$

Veja, portanto, que: quão maior a identidade entre o indivíduo e a coletividade, maior a uniformidade substancial existente entre eles e, assim, maior a suscetibilidade de uma ação popular do primeiro tipo, a qual envolve a proteção do direito individual do cidadão, na qualidade de integrante da coletividade. Quão menor a identidade entre o indivíduo e a coletividade, entendendo-se essa coletividade como uma entidade jurídica autônoma, menor a

40 A tese intermediária é, segundo Iole Fargnoli, a dominante, o que também é acolhido por Vezio Crisafulli e Vittorio Scialoja (Cf. FARGNOLI, Iole. Studi sulla legittimazione ativa all'interdetto quod vi aut clam. Milano: Giuffrè, 1998, p.99).

$41 \mathrm{O}$ cidadão agia na qualidade de membro da comunidade. Não importava o destino da condenação, se para o erário, se para o autor ou se para terceiro, o que importava era o entrelaçamento dos interesses, o interesse geral com o interesse singular, o direito do povo com o direito do sujeito. Segundo Fadda: talchè ci sembra di potere com tutta sicurezza conchiudere, che la qualità di membro dela comunione dà a qualunque citadino il diritto e gli impone l'obbligo d'impedire e reprimere tutti quei fatti, che importano lesione dell'interesse generale. È come citadino, non come privato; come membro dela comunione, non come individuo isolato; come partecipe dela sovranità politica, come contitolare di questa, non come paterfamilias e nel suo interesse, che egli si presenta ed agisce. [...] Epperò, qualunque sia la destinazione dela condanna, nelle azioni proposte da ogni citadino como tale, si há um entreccio d'interessi respondente alle osservazioni fatte più sopra: l'interesse generale e l'interesse del singolo; il diritto del popolo e il diritto del singolo (Cf. FADDA, 1972 (reprint 1894), p.320) 
uniformidade substancial entre eles e maior a suscetibilidade de uma ação popular do segundo tipo, a qual envolve a defesa de um direito titularizado pela própria comunidade, que não se confunde com o direito pessoal ou particular de cada um dos indivíduos, membros do grupo ${ }^{42}$.

Em ambos os casos, todavia, verifica-se que o direito material, tutelável pela actio popularis, estabelecia sempre uma alusão ao plano coletivo. Essa alusão ao coletivo - que ocorre, ora quando se enfatiza o direito do indivíduo como partícipe da coletividade, ora quando se enfatiza o direito titularizado pela própria coletividade - dispensava maiores preocupações como uma teoria de representação ou com a qualidade do representante na controvérsia substancial.

Retomando-se a relação entre o indivíduo e a comunidade em Roma: pode-se dizer que, quando o plano coletivo predomina e quando o coletivo coincide com o individual, não há necessidade de acomodar particularidades e não há tamanha necessidade de proteger o indivíduo. Isso ocorre simplesmente porque o estritamente individual não mais faz parte dessa equação processual.

O cerne do interesse dos juristas, nessa hipótese, passa a ser o mérito da ação popular e, por conseguinte, a proteção do bem ou do interesse em comum. E, por essa mesma razão, a coisa julgada proferida na ação popular alcançava terceiros ${ }^{43}$, pois todos detinham a mesma posição jurídica na controvérsia, todos estavam atrelados a um mesmo interesse ou direito geral.

Foi de acordo com essa ênfase individual ou coletiva e com o grau de oposição ou de identidade entre o indivíduo e a coletividade que o processo romano se organizou. Ele estabeleceu, com isso, ações diferentes, sejam ações individuais ou pessoais, sejam ações populares ou impessoais, em que o indivíduo ora atuava como membro da coletividade, ora atuava como substituto do oficial da administração estatal - esse é o arremate para a compreensão do período.

\subsubsection{PERÍODO MEDIEVAL}

O panorama dos conflitos de massa começa a se transformar a partir dos influxos de uma nova ordem ideológica, social, econômica, política e jurídica, peculiar ao período medieval.

42 Em sentido similar, conferir: GIAGNORI, Michele. Brevi note in tema di azioni popolari. Disponível em: www.teoriaestoriadeldirittoprivato.com. Peer Reviewed Journal, ISSN 2036-2528. Acesso em 08 de junho de 2013.

43 SCIALOJA, 2013 (Reprint 1883), p. 7. 
Diferentemente da tradição romana, antes abordada, o período medieval exibe matiz essencialmente coletiva, marcada pela vinculação natural do indivíduo à comunidade a que estava associado. A primazia do coletivo permeia todos os aspectos da vida medieval e - é por essa ocasião - que se destacam os conflitos ou as controvérsias de massa que já precipitavam

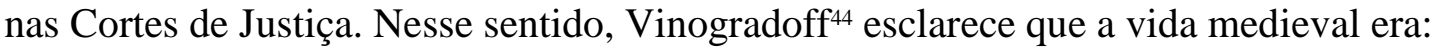

...evidentemente comunitária em sua própria essência. Cada característica que a torna estranha e inconveniente do ponto de vista do interesse individualista, torna-a altamente apropriada a um estado de coisas governado por tendências comunais ou coletivas. [Tradução nossa] ${ }^{45}$

Aldeias (villages), abadias (abbeys), conventos (convents), paróquias (parishes), corporações ou associações mercantis (guilds), burgos (boroughs), grupos de autopoliciamento coletivo (frankpledge's ${ }^{46}$ constituíam coletividades que se situavam no centro da vida econômica e social do sistema feudal. Esses grupos agiam como comunidades organizadas, isto é, uma pluralidade homogênea e $\operatorname{coesa}^{47}$, promovendo a agregação da controvérsia de massa e capitaneando demandas coletivas em seu nome e em favor de todos os seus integrantes.

Não era necessário, ao menos em regra, consentir para ser incluído em uma dada comunidade. O homem medieval nascia em uma aldeia, participava dos cultos religiosos e tinha obrigações com a sua paróquia, como o pagamento de dízimos, ofertas e a manutenção dos templos. Além disso, combinava com os outros aldeões a rotação de culturas para plantio, garantia a sua segurança em conjunto com os demais para atravessar as precárias estradas e, por fim, policiava a si mesmo e aos demais para que a ordem e a paz fossem mantidas. Noutros casos, mais limitados, a adesão ao grupo era espontânea ou voluntária, como nas corporações e burgos. ${ }^{48}$

44 VINOGRADOFF, 1892, p.400.

45 ...It is evidently communal in its very essence. Every trait that makes it strange and inconvenient from the point of view of individualistic interests renders it highly appropriate to a state of things ruled by communal conceptions (Cf. Ibidem, p.400)

46 Sistema medieval de policiamento e manutenção da paz, que estabelecia a responsabilidade mútua de um grupo de homens por suas ações e comportamentos, de forma a assegurar que o acusado de um crime fosse trazido a julgamento, sob pena de todo o grupo ser apenado com multa (Cf. FRANKPLEDGE. In: DICIONÁRIO jurídico. Merriam Webster: na enciclopaedia britannica company. Disponível em: http://www.merriam-webster.com/, acesso em 10 de julho de 2013).

47 Em sentido similar, essa menção à comunidade organizada ou à pluralidade homogênea e coesa é realizada em várias passagens do texto de Sir Paul Vinogradoff. Nesse sentido: VINOGRADOFF, 1982, p.359.

48 As peculiaridades do período medieval, período no qual se desenvolveram com maior intensidade as ações coletivas como método de agregação, são enumeradas por Stephen Yeazell, em uma das obras mais completas quanto à história da litigiosidade nos grupos até a moderna ação de classe estadunidense (Cf. YEAZELL, Stephen C. From medieval group litigation to the modern class action. New Haven: Yale, 1987). 
Essas circunstâncias não eram, no entanto, à época, digna de atenção entre os juristas medievais, tampouco estava presente em alguma teoria de representação. A explicação para isso é que, segundo Márcio Flávio Mafra Leal ${ }^{49}$, a oposição entre a comunidade e o indivíduo era praticamente nula na Idade Média. Não era possível discernir o indivíduo da comunidade a ele associada, uma vez que ambos compartilhavam os mesmos interesses e valores no seio social.

$\mathrm{Na}$ verdade, o pensamento medieval tem forte apelo ao coletivo. Não se pode negligenciar, conforme mencionou Otto Gierke ${ }^{50}$, que o pensamento, quando genuinamente medieval, começa a partir de um todo e, em seguida, atribui, de cima para baixo, o valor ou a importância às partes dele integrantes, incluindo-se aí, como parte, o próprio indivíduo.

A partir do medievo, surgem situações nas quais o grupo desempenha funções elementares na própria organização do modo de vida, enquanto os indivíduos operam apenas na qualidade de membros ou partícipes do grupo. O direito acompanha essa realidade do mundo medieval e, justamente por isso, os bens, os interesses, as instituições jurídicas como o casamento e, também, as obrigações e responsabilidades tornam-se, pois, coletivas ou plurissubjetivas.

Maitland ${ }^{51}$ observa, nesse sentido, que "tudo é coletivo, nem o crime, nem o débito, nem a propriedade, nem o casamento, nem a paternidade são atribuídos ao indivíduo. O grupo, o clã ou a família, somente eles, são sujeitos de direitos e deveres”. Não se separava, assim, ao menos no tocante ao costume ou ao modo de organização da vida societária ${ }^{52}$, aquilo que era de um e aquilo que era de todos. A coincidência entre o indivíduo e o grupo era coisa bastante trivial.

49 LEAL, Márcio Flávio Mafra. Ações coletivas: história, teoria e prática. Porto Alegre: Sergio Antonio Fabris Editor, 1998, p.26.

50 GIERKE, Otto. Political theories of the middle age. Translated by Frederic William Maitland. Cambridge: University Press, 1938, p.7.

51 “....all is 'collective'. Neither crime, nor debt, neither property nor marriage nor paternity can be ascribe to the individual. For rather the group itself, the clan or family, is the one and only subject of rights and duties" (MAITLAND, Frederic W. Township and borough. Volume II. London: Routledge/Thoemmes Press, 1997, p.20). 52 É preciso esclarecer que, quando se diz que tudo é coletivo, não se quer dizer que não existisse nenhum bem ou interesse privado, que se dividisse entre os membros da comunidade. O que ocorria era que o modo de organização da vida social, econômica e política e os costumes estabeleciam fortes laços de pertença do indivíduo à comunidade, impelindo-o à cooperação e à práxis coletiva. Um exemplo disso é a propriedade. Em várias passagens de Vinogradoff e Maitland (1892, p. 236 et seq, 1997, 26 et seq), relata-se a existência de ocupação individual de terras, de propriedade privada nas aldeias, bem como de sucessão hereditária. Ocorre que, por uma questão de princípio à época vigente, a concessão das terras cultiváveis aos aldeões deveria ser igual entre todos eles, assegurando acesso comum e paritário à água ou a terras férteis por todos os interessados. Por essa razão, a distribuição da terra arável aos ocupantes da aldeia era realizada em pequenas faixas de terra, que ficavam lado a lado das faixas de terra dos vizinhos e, a cada ano, esses quinhões eram submetidos a uma nova distribuição (sem mudar a quantidade de faixas por pessoa), para que ninguém ficasse muito tempo em um pedaço de terra mais fértil ou menos fértil, com água ou menos água que o outro. As culturas eram, por sua vez, costumeiramente submetidas a um planejamento comum entre os aldeões, para fins de subsistência. Nesse contexto, qualquer 
Vê-se logo que a consequência natural disso é agregação dos sujeitos em torno dos mesmos interesses ou direitos, por meio, principalmente, das ações coletivas. A coletividade, materializada em um ou mais indivíduos, defendia em uma demanda os interesses ou direitos comuns (os direitos de todos), os quais impactavam o indivíduo apenas como membro do grupo.

Justamente por isso, o que seria de se esperar é a presença de alguma espécie de teoria que justificasse a representação do grupo, por um ou mais indivíduos, em juízo. Paradoxalmente, porém, não há registros dela. Hanna Pitkin ${ }^{53}$, ao estudar a origem da representação, aponta que essa expressão - no sentido de sujeitos representando outros sujeitos na defesa de interesses ou direitos comuns - somente surge no final do medievo, já na transição para a modernidade.

Antes disso, a expressão representação significava apenas uma mística personificação. Exemplos: o papa não era o representante da igreja ou de Deus, ele era a corporificação de Deus. O rei não era o representante da Coroa ou do Reino, ele era a Coroa. O mesmo ocorria, inicialmente, com a comunidade, que era materializada ou corporificada por alguns sujeitos. ${ }^{54}$

De todo modo, é notável que, mesmo sem menção à representação e mesmo sem uma teoria sobre a representatividade do indivíduo no grupo que o autorizasse a agir em nome de todos, a agregação processual para defesa dos mesmos interesses ou direitos já era prática consolidada na vida jurídica medieval, mormente pelas ações coletivas inglesas.

Embora as controvérsias de massas se estendessem por toda a Europa, Yeazell ${ }^{55}$ adverte que são nos registros históricos ingleses, depois da conquista normanda, que se encontra material abundante sobre o aparecimento das ações coletivas, datadas há mais de oito séculos atrás ${ }^{56}$.

tratamento individualizado era secundário ou submetido à organização comunal da aldeia. Isso ocorria, até mesmo, por outras razões. A distância da autoridade central (rei), a limitação da comunicação e o perigo das estradas favoreciam a cooperação, a proximidade geográfica e a socialização dos sujeitos. Logo, pode-se dizer que a defesa do grupo e a deferência dada ao coletivo existiam, até mesmo, como forma de proteção dos próprios indivíduos, membros do grupo, e como forma de controle pelo poder central, que não tinha condições de impor obrigações individuais e de controlar, pessoalmente, a produção econômica e a ordem social do reino como um todo.

53 PITKIN, 1972, p.242.

54 Ibidem, p.242.

55 YEAZELL, 1987, p.21.

56 De fato, foi esse modelo teórico que, posteriormente introduzido no sistema jurídico estadunidense, veio a influenciar inúmeros outros sistemas jurídicos no mundo, inclusive o brasileiro. Esse fato até mesmo justifica o estudo comparado da agregação entre os sistemas brasileiro e estadunidense, proposto na presente investigação. 
A referência à conquista normanda, no presente texto, não é gratuita. Há uma razão para isso, a saber, a conquista normanda foi o marco que instaurou o regime feudal entre os ingleses, com a peculiaridade de que esse regime limitou-se na Inglaterra aos aspectos sociais e não políticos. Destaca-se que a Inglaterra, embora submetida a práticas sociais e econômicas comunais, típicas do regime feudal, mantinha uma tendência pela organização do poder real, enquanto o restante da Europa havia sucumbido aos interesses locais, privados e egoísticos ${ }^{57}$.

Helen $\mathrm{Cam}^{58}$ ressalta que a conquista normanda não se resumiu, por sua vez, à conquista militar. A conquista normanda foi um processo, segundo o qual o conquistador Duque William da Normandia, superando localismos e resistências, coordenou forças e ações no sentido de estabelecer sua autoridade central e de formar um sistema nacional na Inglaterra.

Para tanto, continua $\mathrm{Cam}^{59}$, ele controlou a violência, bem conhecida entre os bárbaros, bem como respeitou e conservou os direitos ingleses antes vigentes, reconhecendo outros novos. Recompensava com terras ou títulos de nobreza aqueles que lhe obedeciam e estabelecia, com eles, uma série de barganhas, como o fornecimento de cavaleiros em época de guerra, códigos de honra, regras de trabalho nas propriedades ou outras obrigações mútuas e recíprocas.

Enfim, por relações de subordinação e pela concessão de direitos e obrigações, a Inglaterra medieval, depois da conquista normanda, soube entrelaçar a pluralidade dos grupos a um poder monárquico central. Era possível notar que tanto a aristocracia, quanto as comunidades, se organizavam e se uniam, quer fosse para barganhar, quer for para litigar, mas respeitando nisso o direito costumeiro.

Se as aldeias e as comunidades dependiam de terras e de segurança para viver e produzir, o Rei e os senhores de terra também sabiam que nenhum plano, nenhuma campanha militar, nenhuma forma de produção ou de aplicação da justiça seria efetivamente observada, se não contassem

57 Nesse sentido, observa Vinogradoff (1892, p. 179), que acrescenta ainda: a Inglaterra se diferenciou da Alemanha, pois não se desagregou em tribos rivais, a competir com a ideia de uma unidade nacional. De igual modo, a Inglaterra se diferenciou da França, onde a organização do poder e sua unificação fora realizada egoisticamente na figura do rei, que lograva vantagens em relação aos grupos locais. Por fim, também estava à frente da Itália, território que sofria influência da situação tribal alemã, competia com a figura desagregadora e próxima da igreja (Papa) e, ainda, envolvia-se com o desenvolvimento das instituições municipais, que dificultavam a unificação nacional.

58 CAM, Helen Maud. England before Elizabeth. London: Hutchinson House University Library, 1950, p. 68.

59 Ibidem, p. 68-69. 
com a cooperação dos servos aldeões ${ }^{60}$. Nesse contexto, todos, inclusive o Rei, tinham seus direitos e obrigações recíprocos para com a comunidade a qual estavam vinculados. ${ }^{61}$

São, por sua vez, essas circunstâncias que explicam a atratividade da Inglaterra medieval pelas ações coletivas. As Cortes de Justiça e, por conseguinte, as demandas nela apresentadas, constituíam um reflexo dos direitos coletivos e das obrigações comunais daqueles tempos.

São muitos os exemplos disso: conflitos em que membros de uma paróquia litigavam com o pároco a respeito do pagamento das contribuições e dos serviços diários à igreja (Rector of Barkway v. Parishioners of Nuthamstead); conflitos em que alguns aldeões de Helpingham demandavam em face de toda a aldeia de Donington e de Bykere, alegando falha dos últimos em assistir os primeiros a reparar o dique local (villagers of Helpingham v. villagers of Donington and Bykere); conflitos em os burgueses pobres de Scarborough litigavam em face dos burgueses ricos (Emery Gegge and Robert Wawayn and poor burgesses of Scarborough $v$. Roger atte Cross, John Hughe'sson, Warin Draper and other rich burgesses of that town $)^{62}$; conflitos pela utilização das terras feudais e pela administração fiscal, em que litigavam o senhor feudal de terras em face dos aldeões diante da Coroa (Discart v. Otes) ${ }^{63}$ etc.

Essas demandas eram decididas com fundamento no direito substantivo: quem deveria consertar o dique, como seria o pagamento dos dízimos, como seria a distribuição das terras feudais etc. Não havia preocupação em nome de quem esse direito era litigado (portador

60 CAM, 1950, p.72.

$61 \mathrm{O}$ rei e os senhores de terra (lords) não tinham condições de controlar, individualmente, o modo de produção da terra e o policiamento. Por essa razão, estabeleciam responsabilidades coletivas às comunidades, como a agricultura coletiva (os aldeões trabalhavam em alguns dias da semana nas suas faixas de terra e, em outros dias da semana, nas faixas de terra dos lords) ou o sistema de mútua pacificação (frankpledge). A igreja (também titular de terras) não lograva, igualmente, estabelecer um controle estrito sobre as paróquias e sobre os conventos. Desse modo, estabelecia visitas regulares e impunha disciplina e sanções à comunidade como um todo, de forma a impelir o cumprimento das obrigações. As comunidades, por outro lado, como as aldeias, as paróquias e as corporações (guilds), também se organizavam para vários fins, dentre eles, (i) viabilizar um modo de produção que atendesse às suas necessidades básicas, (ii) cumprir suas obrigações e responsabilidades coletivas com o Rei e com os senhores de terra (lords) e (iii) apresentar suas queixas e apelos inicialmente às Cortes de Justiça e, posteriormente, ao Parlamento. Nesse último caso, um ou mais integrantes da comunidade eram chamados pelo Rei para receber as suas determinações e levá-las ao conhecimento da comunidade, como, por exemplo, a cobrança de novas taxas reais.Todavia, de igual modo, esses mesmos integrantes da comunidade, materializando-a ou personificando-a diante da Coroa, apresentavam ao Rei e aos senhores de terra as queixas e os apelos comuns da coletividade a ele associada. (Cf. CAM, Helen Maud. Liberties and Communities in Medieval England: collected studies in local administration and topography. Cambridge: University Press, 1944, p.224 et seq). 62 Todos os casos supracitados foram extraídos da obra de Stephen Yeazell (Cf. YEAZELL, 1987, p.38 et seq). 63 MARCIN, Raymond B. Searching for the Origin of Class Action. Catholic University Law Review, 1973-1974, Vol. 23:515-524p. 
ideológico dos interesses do grupo no processo ${ }^{64}$, tampouco havia preocupação com o consentimento e com a vinculação dos indivíduos do grupo ao resultado do julgamento ${ }^{65}$.

O grupo agia como uma categoria e não como um conjunto de indivíduos. O indivíduo, por sua vez, era visualizado apenas como membro de um grupo. Logo, para litigar uma controvérsia comum à categoria, bastava, como já se disse, a corporificação ou a materialização da coletividade em um ou mais sujeitos, como se eles fossem a própria entidade coletiva.

Não havia nenhuma condição ou compromisso com o indivíduo, integrante da coletividade, no intuito de defendê-lo das decisões e das estratégias do grupo. Isso porque havia uma coincidência conceitual entre a comunidade e os indivíduos. O indivíduo operava de forma impessoal, pelo status de pertencer a uma determinada comunidade. O comando normativo do julgado coletivo vinculava a toda comunidade, sendo comum até mesmo ações coletivas passivas, em que a coletividade, vinculada pelo julgado, era a própria parte ré da demanda.

A ação coletiva reportava-se a um mero incidente legal de status do grupo e não a interesses particularizados de alguém. O indivíduo atuava na demanda ou a ela resistia apenas como membro do grupo. Os direitos e as obrigações de todos esses indivíduos eram idênticos, já que eles fluíam de uma mesma relação substancial geral, aplicável, uniformemente, ao grupo todo. ${ }^{66}$

Aqui também - à semelhança da res publica - a identificação do direito material guarda referência ao binômio comunidade e indivíduo e à ênfase dada a cada um desses planos. No período medieval, todavia, a ênfase é dada com maior veemência à comunidade e ao modo de vida coletivo. O processo, por sua vez, acompanha pari passu essa dimensão substancial.

Adianta-se, por fim, que as rotas indispensáveis à transformação dessa conjuntura já são traçadas a partir do final do período medieval, caminhando-se, portanto, à modernidade.

64 Não havia um procedimento para a escolha do sujeito que representaria a comunidade em juízo, como a eleição, o consentimento ou a aferição judicial de representatividade adequada. Quando uma vila ou uma comunidade deveria comparecer em juízo, a Corte de Justiça apenas especificava as qualidades que o representante em juízo deveria ter, como ser o sujeito "o mais rico", o "mais prudente" ou o "soldado (Cf. YEAZELL, 1987, p.95).

65 YEAZELL, 1987, p. 5 e 94. No mesmo sentido, Márcio Flávio Mafra Leal (Cf. LEAL, 1998, p.27).

66 YEAZELL, op. cit., p. 57. 


\subsubsection{PERÍODO MODERNO}

No final da Idade Média e no início do período moderno (Século XVI), essa ideia de corporificação ou materialização do grupo começa ceder lugar à ideia de representação. ${ }^{67}$

Nessa última acepção, os interesses da comunidade são confiados a determinados indivíduos, mediante instruções e autorizações diretas. A partir desse momento, surgem representantes que passam a se reportar ou a consultar a comunidade que os designou para aquela função.

Helen $\mathrm{Cam}^{68}$ ressalta que, no século XVI, os representantes tornam-se agentes autorizados pela comunidade. Era comum eles realizarem uma consulta à comunidade antes de aceitar determinada imposição, como, por exemplo, a instituição de um novo tributo pelo Rei.

A mudança conceitual, como é possível perceber, é drástica. Nota-se, agora, a presença de indivíduos autorizando, instruindo ou sendo consultados por outros indivíduos a quem se denominou representantes e a quem os primeiros confiaram os seus interesses, coisa que não se observava antes, fosse nas ações populares romanas, fosse nas ações coletivas medievais.

O panorama em que se estabeleceu essa alteração conceitual foi marcado por uma série de acontecimentos, que vieram a suplantar o sistema feudal e a estabelecer um novo ethos social.

A essa altura, já é sabido que o Rei estabeleceu sua autoridade na Inglaterra medieval, mediante barganhas, o que implicou à organização tanto da aristocracia quanto das comunidades locais para efeito de negociação, bem como à instituição de um modo de vida comunal. Isso significava, por um lado, equilíbrio e paz para todos, mas, por outro lado, o fracionamento do poder real. Com a decadência do feudalismo, esse quadro veio a alterar-se substancialmente.

Com o fortalecimento do Estado, e das demais organizações sociais privadas, bem como com a intensificação do comércio e a redução dos perigos e da insegurança nas estradas, um sistema feudal como aquele caminhou- a toda evidência - à perda de sentido e ao absoluto abandono.

67 PITKIN, 1972, p.244-247.

68 CAM, 1944, p.232. 
Norbert Elias ${ }^{69}$ salienta que, no período medieval, as comunidades constituíam refúgios para os indivíduos, que estabeleciam relações de reciprocidade e cooperação nas famílias, nas aldeias, nas paróquias. A partir do período moderno, essa função passa a ser ocupada pelo Estado, que, ao instituir normas gerais e abstratas para regular as condutas dos indivíduos, torna-se o ponto de integração entre todos eles. É um processo denominado de "individualização em massa"70.

Com o poder concentrado no Estado, não há mais necessidade de barganha. O Estado não barganha mais com grupos, tampouco os grupos sentem a necessidade de se organizarem para barganhar com o Estado, pois a relação passa a ser direta, por meio da norma jurídica. As relações dos indivíduos entre si e a relação dos indivíduos com o Estado são introduzidas em uma norma jurídica, que é idêntica para todos. Nas palavras de Elias ${ }^{71}$, o Estado:

...elimina as diferenças entre as pessoas. Nos registros e órgãos estatais,
o indivíduo é basicamente despojado de sua personalidade característica.
Ele é um nome ligado a um número, um contribuinte ou, conforme o caso, uma
pessoa em busca de ajuda e proteção, que as autoridades estatais podem
conceder ou recusar. Mas, embora o aparelho de Estado assim
introduza o indivíduo numa rede de normas que é basicamente idêntica
para todos os cidadãos, a moderna organização estatal não se relaciona
com as pessoas como irmãs ou tios, como membros de um grupo familiar ou de uma
das outras formas pré-nacionais de integração, e sim com as pessoas
como indivíduos. No estado atual e mais recente de desenvolvimento, o
processo de formação das nações dá sua própria contribuição para um
novo avanço da individualização em massa.

Dito claramente: o indivíduo não mais se relaciona com o Estado como partícipe de uma comunidade. Ele não mais barganha como membro de um grupo, pleiteando um determinado direito ou uma determinada obrigação, que é comum a ele e a todos os demais interessados. Essa comunidade, no entanto, não deixa de existir. Ela é, por sua vez, de alguma forma, considerada pelo Estado em sua organização, mas, posteriormente, é ocultada dessa relação.

Vê-se que o Estado faz uma política de saúde e de distribuição de medicamentos, considerando os atributos de uma população ou de uma coletividade, contudo, em seguida, estabelece normas basicamente idênticas e diretas aos sujeitos dela integrantes. $\mathrm{O}$ mesmo raciocínio se aplica à

69 ELIAS, Norbert. A Sociedade dos Indivíduos. Tradução Vera Ribeiro. Revisão e notas Renato Janine Ribeiro. Rio de Janeiro: Jorge Zahar Editor, 1994, p.148-149.

70 Ibidem, p.149.

71 Ibidem, p.149. 
política educacional. O Estado faz uma política de educação, considerando os atributos de uma população ou de uma coletividade, todavia, logo depois, estabelece normas basicamente idênticas e diretas aos sujeitos dela integrantes. Por fim, ele aplica essas normas em relação ao indivíduo isolado, sem mais consideração ou referência àquela população ou coletividade.

O mesmo ocorre com os grupos, existentes no plano privado, que também sofrem um processo de "individualização em massa"72. Segundo Yeazell"73, no período medieval, o pequeno comércio existia em favor de um grupo (mercadores medievais), por força de barganhas estabelecidas com o rei. Esse acordo era, por sua vez, estabelecido, pessoalmente, com o rei, o que constituía um entrave ao crescimento do comércio, mormente nas relações internacionais.

Em razão da pessoalidade do acordo realizado com o rei para fins comerciais, os direitos alcançados pelo grupo eram, por vezes, questionados pela autoridade seguinte, que deveria confirmar ou não as ordens dadas pelos reis predecessores ${ }^{74}$. Isso implicava, por certo, razoável imprevisibilidade e insegurança nas relações comerciais entabuladas, principalmente, aquelas fora do território inglês e por força de um pujante monopólio comercial, que já se estabelecia.

Nesse contexto, percebeu-se a necessidade de reconhecimento formal de uma corporação, isto é, de uma pessoa distinta dos componentes do grupo, para garantir a esse grupo - que agora forma uma entidade ou pessoa fictícia ${ }^{75}$ - a segurança e a continuidade nas relações comerciais por ele travadas, bem como para permitir uma maior expansão do monopólio pela Europa ${ }^{76}$.

De igual modo, ainda segundo Yeazell ${ }^{77}$, a propriedade deixa de ser organizada sob a forma comunal. Uma agricultura mais rentável era algo que desafiava os grupos, mormente em razão do aumento populacional e da fome. Por essa razão, buscava-se criar maiores extensões de terra

72 ELIAS, 1994, p.149.

73 YEAZELL, 1987, p.106.

74 Ibidem, p.107.

75 Com a incorporação, um grupo informal de pessoas passa a existir sob a forma de uma entidade autônoma. Para a formação dessa entidade, por sua vez, os sujeitos do grupo manifestam adesão e, nessa medida, são formalmente agregados a outra unidade ou pessoa. O reconhecimento dessa corporação ocorria mediante a concessão (charter) da Coroa ou do Parlamento. A relação entre os indivíduos, membros do grupo, passa a ser regulada internamente pela própria corporação. (Cf. MAITLAND, 1997, p.18).

76 YEAZELL, op. cit., p.102

77 Ibidem, p. 102. Em sentido similar, Andrea Giussani (Cf. GIUSSANI, Andrea. Studi sulle class actions. Padova: CEDAM, 1996, p.7). 
aos indivíduos, nas quais fosse possível produzir em maiores quantidades. Os aldeões tornamse, assim, arrendatários e já não estavam mais vinculados ao modo de vida feudal.

É importante destacar, nesse ponto, que as práticas desses grupos, antes comunais, são abstraídas e concentradas em normas (leis ou precedentes ${ }^{78}$ ). E, com a consolidação dessas práticas em normas, não há mais necessidade de os sujeitos do grupo se cooperarem, basta aplicar a norma ao indivíduo isolado. A partir desse momento, tudo se torna questão de direito.

Quem adverte, nesse sentido, é John Pocock ${ }^{79}$. Ao analisar a formação da common law inglesa, ele salientou que os costumes medievais são particulares, remetem a fatos, pessoas e comunidades, são flexíveis e variáveis no tempo. Logo, quando esses costumes são abstraídos e consolidados em normas (leis ou precedentes), eles adquirem constância e autoridade. As práticas - inicialmente flexíveis e variáveis - são abstraídas do mundo dos fatos e concentradas nas normas jurídicas (leis ou precedentes), as quais, por sua vez, são aplicadas, diretamente, aos indivíduos e não mais aos grupos e, com isso, perde-se a essência costumeira do direito.

Se, antes, os sujeitos de um grupo cooperavam e definiam entre si a forma de estruturação e organização do modo de vida - como as faixas de terra seriam divididas? Como seria a rotação de culturas? Como seria o autopoliciamento? - de agora em diante, essas questões são consolidadas em normas, com as quais os indivíduos passam a se relacionar diretamente.

O resultado de tudo isso - tanto no espaço público quanto no espaço privado - é a valorização crescente da autonomia individual e a instauração de um ethos individualista ${ }^{80}$. O indivíduo e a

78 José Rogério Cruz e Tucci e Rodolfo de Camargo Mancuso salientam que o precedente judicial é uma decisão judicial, formada em um caso concreto, cujo comando normativo (ratio decidendi) constitui parâmetro universalizável para orientar a decisão de casos análogos no futuro. Não há necessidade de reiteração de julgados, como ocorre com a jurisprudência (Cf. TUCCI, José Rogério Cruz e. Precedente judicial como fonte do direito. São Paulo: Revista dos Tribunais, 2004, p.12 e MANCUSO, Rodolfo de Camargo. Divergência jurisprudencial e súmula vinculante. 3 ed. rev. atual. São Paulo: Revista dos Tribunais, 2007, p.35). Samuel Meira Brasil Jr ressalta, por sua vez, a força normativa do precedente vinculante (Cf. BRASIL JR, Samuel Meira. Precedentes vinculantes e jurisprudência dominante na solução das controvérsias. Tese. São Paulo: USP, 2010, p.31, no prelo).

79 POCOCK, John Greville Agard. The Ancient Constitution and the Feudal Law: a Study of English Historical Thought in the Seventeenth Century. Cambridge: Cambridge University Press, 1987, p.273. No mesmo sentido, Aleksander Peczenik aborda as transformações de fatos e de valores em norma jurídica, ocasião em que ocorre um salto (jump), isto é, surge uma razão suficiente que permita abstrair e transformar interesses, bens, vontades e necessidades em um direito (Cf. PECZENIK, Aleksander. The basis of legal justification. Lund: Infotryck AB. Distributed by Aleksander Peczenik, 1983, p.3-8).

80 Nesse sentido, Márcio Flávio Mafra Leal (Cf. LEAL, 1998, p.27). 
corporação (legal entity ou pessoa jurídica ou fictícia equiparável a um indivíduo) assumem a centralidade da vida social, econômica, política e jurídica do período moderno.

Algumas coletividades não foram, no entanto, prontamente reconhecidas pelo Estado no período moderno. Os grupos informais, como os paroquianos e os enfiteutas ou arrendatários, que não se incorporaram, foram paulatinamente escamoteados do sistema, tornando-se um fenômeno atípico e residual ${ }^{81}$. Reclamava-se, portanto, a partir desse momento, uma nova teoria que fundamentasse a representação dos indivíduos integrantes desses grupos remanescentes.

Frisa-se que essa atipicidade residual ocorre porque o grupo não é mais visto como uma comunidade homogênea, na qual os deveres e os direitos são coletivos. Não há mais senso de cooperação no grupo de forma a constituí-lo uma unidade diversa da soma das suas partes. $\mathrm{O}$ grupo passa a ser descrito como um simples conjunto de indivíduos, reunidos sob um determinado título ou origem. Os indivíduos são concebidos como seres autônomos ao grupo e deveriam, por consequência, autorizar ou consentir na hipótese de serem representados. ${ }^{82}$

Assim, quando não há mais predominância do coletivo, quando não há mais coincidência entre a comunidade e os indivíduos, o grupo não pode mais ser materializado por qualquer sujeito, a exemplo do que ocorria no período medieval. Exigia-se uma teoria que justificasse a representação do indivíduo e que estabelecesse as condições para essa representação em juízo.

Nesse contexto, a partir da modernidade, quando um grupo informal pretendia litigar um direito de massa, o sistema processual deparou-se, pela primeira vez, com uma perplexidade.

As ações coletivas e outras técnicas de agregação deixam, nesse período, de ser guiadas pelo mérito da demanda - qual é o direito? - e passam a se preocupar com um método estatal de resolução de controvérsias que assegura a autonomia individual - quem pode defender o direito? - e, com isso, o direito substancial sai de cena e entra o direito processual.

81 Stephen Yeazell salienta que persistiam, quase que como excentricidades, conflitos residuais de grupos no tocante aos direitos às terras feudais e aos deveres das paróquias, bem como no tocante aos grupos não formalmente incorporados, principalmente friendly societies e joint-stock companies (Cf. YEAZELL, 1987, p.138).

82 Ibidem, p.146-147. 
O processualista passa a se preocupar em proteger a autonomia do indivíduo, que não aderiu formalmente ao grupo, e em estabelecer com esse indivíduo algum tipo de compromisso que torna possível a resolução daquele lide, sem afetar a oportunidade de escolha individual. ${ }^{83}$

Segue-se, de todo modo, que, mesmo com as limitações supracitadas, as ações coletivas, no tocante aos grupos informais, subsistiram, ainda que, residualmente, na Inglaterra moderna.

No caso How v. Tenants of Bromsgrove ${ }^{84}$, do início do século XVII, o senhor Bromsgrove ingressou em face dos arrendatários das suas terras para que fosse reconhecido o seu direito de caçar animais naquela região. Os arrendatários resistiram à pretensão, pois o exercício do direito de caça pelo autor implicaria uma redução substancial das terras cultiváveis. Essa ação coletiva foi admitida, mas, segundo relatos da época, não mais com o escopo de atuar um direito substancial coletivo ou plurissubjetivo, mas, sim, para alcançar eficiência processual e obstar uma multiplicidade de demandas similares que, fatalmente, desaguariam nas Cortes de Justiça.

Desse modo, justamente em razão da autonomia individual supracitada, a resolução coletiva da controvérsia atinente a um grupo ou uma comunidade, quando excepcionalmente admitida, deveria ser, a partir de agora, restringida e justificada por novos objetivos do sistema processual, que não a mera aplicação do direito substancial coletivo ao caso concreto narrado pelas partes. ${ }^{85}$

Considerando que o direito substantivo era sempre individual e que o direito substantivo do grupo era a soma dos direitos individuais, a resolução coletiva da controvérsia de massa buscava apenas evitar a multiplicidade de demandas individuais similares e, com isso, alcançar a economia, a eficiência processual, a coerência e a uniformidade nos provimentos judiciais. ${ }^{86}$

83 No mesmo sentido, Michel C. Protos e Martin H. Redish salientam a preocupação das ações coletivas com a autonomia individual (Cf. PROTOS, Michel C. An epistemological approach to class certification: a classy understanding of the problems of class certification. Case Western Law Review, 1992, Vol. 42:1297-1338p e REDISH, Martin H. Wholesale justice: constitucional democracy and the problem of the class action lawsuit. Stanford: Stanford University Press, 2009).

84 YEAZELL, 1987, p. 132-133.

85 Raymond B. Marcin salienta que esses novos objetivos do sistema podem ser localizados no Bill of Peace. São eles aprimorar a eficiência das Cortes de Justiça, angariar economia processual, obstar a multiplicidade de demandas individuais similares ou repetitivas e reestabelecer a uniformidade do direito (Cf. MARCIN, 1974, p.518).

86 CHAFEE, Zechariah. Some Problems of Equity. Ann Harbor: University of Michigan Press, 1950, p.149. 
Os direitos atinentes a um grupo de pessoas são, nesta sorte, resolvidos coletivamente por razões de conveniência, eficiência, economia, coerência e uniformidade e, mesmo assim, nos limites em que respeitado o indivíduo e equacionada a questão de sua autonomia pessoal no processo.

Seguindo-se adiante, apontam-se quatro dos principais limites estabelecidos no período moderno que possibilitariam, em tese, a resolução coletiva dos direitos dos grupos e comunidades e, ainda, a proteção da autonomia e da oportunidade de escolha dos indivíduos:

- $\quad$ grupo escolhia o representante.

- $\quad$ Surge a doutrina da necessary parties e indispensable party, cujo escopo era a integração das partes à demanda e, assim, a resolução completa da controvérsia.

- Os provimentos das ações coletivas se restringiam, inicialmente, ao provimento declaratório e prospectivo, que regulasse a conduta da comunidade no futuro.

- Admitia-se, excepcionalmente, a vinculação do indivíduo ao resultado do julgamento, ainda que sem participação formal no processo. Isso ocorria por fundamentos oblíquos e não por força da coisa julgada formada coletivamente.

Encerrar-se-á o período moderno com um breve esboço sobre cada um dos referidos limites, inaugurados nesse momento histórico.

\subsubsection{DESIGNAÇÃO DO REPRESENTANTE}

Em primeiro lugar, o grupo passa a designar o seu próprio representante na ação coletiva, em homenagem à autonomia individual.

Raymond B. Marcin ${ }^{87}$ destaca que, nesse momento, o autor da ação propõe a demanda em face do grupo como um todo e não mais em nome de alguns indivíduos dele integrantes. E, cabe, agora, ao próprio grupo a escolha do seu representante, o que remete à noção de consentimento individual ou de autorização do indivíduo em relação ao representante a ser escolhido.

87 MARCIN, 1974, p. 515 
Um caso paradigmático do que se relata acima foi o precedente Brown v. Vermuden da Court of Chancery ${ }^{88}$.

Nesse precedente, segundo Hazard Jr. ${ }^{89}$, o reverendo Carrier ajuizou ação coletiva em face dos mineiros de sua paróquia (de todo o grupo), pleiteando o reconhecimento ao direito ao dízimo, incidente sobre todas as operações de mineração ocorridas em sua paróquia. O dízimo representava, essencialmente, um imposto sobre a terra, necessário para apoiar o bispado.

Os mineiros da paróquia, continua Hazard ${ }^{90}$, diferentemente do que se observava antes, nomearam quatro representantes para defendê-los na demanda, providência que era inédita em relação ao período medieval. Mas, ainda assim, o grupo sucumbiu e o reverendo Carrier logrou o provimento declaratório que vincularia o grupo e todos os seus integrantes (terceiros).

\subsubsection{DOUTRINA DA NECESSARY PARTY E INDISPENSABLE PARTY E O LITISCONSÓRCIO}

Em segundo lugar, desenvolveu-se, nesse período, a doutrina da necessary party e indispensable party.

Hazard Jr. ${ }^{91}$ explicita que, segundo a doutrina da necessary party, todos aqueles interessados na controvérsia de direito substancial são partes necessárias à demanda, de forma a possibilitar a resolução integral e plena daquela controvérsia em juízo. A integração dos indivíduos interessados é necessária, sob pena de não serem eles vinculados ao resultado do julgamento. Excetuavam-se apenas as hipóteses de representação, em que os indivíduos consentiam ou autorizavam o processamento coletivo da demanda, aderindo, assim, ao seu resultado.

88 Segundo Sergio Arenhart, o desenvolvimento do direito inglês apontou para uma gradual substituição das funções das Cortes locais (Manorial Courts) pela atuação das Cortes de Common Law e pela intervenção supletiva da Court of Chancery. O Chanceler, da Corte de Chancelaria (Court of Chancery), valendo-se de decisões anteriores - dado que suas decisões não eram fundadas apenas nas regras de direito, mas também na equity (regras de equidade) - solucionava as controvérsias coletivas, adaptando o sistema jurídico às dificuldades inerentes aos direitos de grupo e às ações coletivas (Cf. ARENHART, Sérgio Cruz. Perfis da tutela inibitória coletiva. São Paulo: Revista dos Tribunais, 2003, p. 140 (Coleção Temas Atuais de Direito Processual Civil V6).

89 HAZARD JR, Geoffrey C.et al. An historical analysis of the binding effect of class suits. University of Pennsylvania Law Review, 1998, V. 146: 1849-1948, p.1863.

90 Ibidem, p. 1863.

91 HAZARD JR, Geoffrey C. Indispensable party: the historical origin of a procedural phantom. Columbia Law Review, 1961, V. 61: 1254-1289, p.1255. 
A doutrina da indispensable party é, por sua vez, uma derivação da primeira, mas seu sentido é inverso. Segundo essa doutrina, continua Hazard $\mathrm{Jr}^{92}$, a integração dos interessados à demanda é indispensável, porque eles serão imperiosamente vinculados pelo resultado da ação coletiva. Sem a integração de todos, o processo deve ser extinto sem a resolução do mérito da controvérsia. Enfim, nesse caso, não se admite o processo, a não ser com pluralidade de partes.

As duas doutrinas compartilhavam um mesmo princípio: quem não figurou formalmente no processo na condição de parte, não deveria ser submetido à autoridade da coisa julgada. Assim, ao indivíduo, deveria ser conferida a oportunidade de consentir com o processamento coletivo da controvérsia ou de ser integrado ao processo, juntamente com todos os demais interessados.

Convêm trazer à baila, ainda, uma diferença crucial entre as duas doutrinas. A primeira doutrina, da necessary party, recomendava a integração das partes interessadas ou o consentimento ou a autorização individual para fins de representação em uma demanda. Mas, caso isso não fosse possível, era admissível a resolução da controvérsia de direito substancial por outro método, desde que fossem adotadas soluções criativas no tocante à estruturação subjetiva da relação processual (ex. ações coletivas) e fosse afastada a vinculação do indivíduo ao julgamento coletivo (res judicata). A segunda doutrina, da indispensable party, não admitia, por sua vez, soluções criativas. Assim, caso as partes não fossem integradas à demanda, o processo deveria ser extinto sem resolução de mérito, sem quaisquer outras alternativas. ${ }^{93}$

92 HAZARD JR, 1961, p.1271.

93 Inicialmente, a Corte de Chancelaria (Court of Chancery) adotava apenas a doutrina da necessary parties. Os primeiros precedentes relativos a essa doutrina surgiram entre 1673 a 1687, a exemplo dos casos Woodcock $v$. Mayne e Walley v. Walley. No primeiro precedente, um credor hipotecário secundário demandou o credor hipotecário principal. O Chanceler Lord Nottingham determinou a inclusão, como parte, dos herdeiros do devedor hipotecário, para que a resolução da controvérsia substancial fosse completa e eficiente. Caso não fosse possível a inclusão da parte necessária à demanda, in casu, os herdeiros do devedor hipotecário, eles não seriam vinculados pelo julgado e a questão controvertida seria suscetível à rediscussão posterior. No precedente Walley $v$ Walley, por sua vez, um avô estabeleceu um crédito em títulos em benefício do seu neto, sendo os bens e valores confiados à administração do seu filho, pai do menor. O pai quebrou seu dever fiduciário e vendeu os títulos a ele confiados. O beneficiário, por sua vez, ajuizou demanda em face dos compradores, para reaver os títulos vendidos. Os compradores argumentaram que o pai do beneficiário era parte necessária à demanda. Lord Nottingham superou essa preliminar e determinou o prosseguimento da demanda ao julgamento de mérito, sem a integração da parte necessária, pois, na ocasião, o pai do beneficiário estava em missão militar na Índia, razão pela qual era impraticável sua integração à demanda. Mais tarde, a doutrina da necessary party deu origem à doutrina da indispensabilidade por ocasião dos precedentes Lowe v. Morgan (1784) e Fell v. Brown (1787). Nesse último caso, não foi admitido que um credor hipotecário secundário prosseguisse em face do credor hipotecário principal, sem a integração dos herdeiros do devedor. Isso porque os herdeiros do devedor hipotecário estavam nos Estados Unidos e seria inviável, segundo o Chanceler Lord Thurlow, o pronunciamento judicial sobre a controvérsia sem a inclusão das partes indispensáveis à demanda, razão pela qual o Chanceler suspendeu o processo até que os herdeiros retornassem à Inglaterra (Cf. HAZARD JR, 1961, p.1256-1274. Em sentido semelhante, REED, John W. Compulsory joinder of parties in civil actions. Michigan Law Review, 1957, V. 55: 327-538p). 
É preciso destacar que essas doutrinas permanecem vigentes até hoje, inclusive no direito estadunidense, e foram desenvolvidas no bojo do instituto denominado joinder (compulsory joinder), o que se assemelha ao nosso litisconsórcio, nas modalidades unitário e necessário. ${ }^{94}$

Cândido Rangel Dinamarco ${ }^{95}$ assevera que, por força do litisconsórcio, admite-se, em juízo, um aglomerado de pessoas como demandantes ou demandados em razão da existência de fatos da vida, envolvendo uma pluralidade de interessados. Nesse caso, o esquema da relação jurídica de direito substancial supera o esquema processual tradicional, em que coexistem apenas duas pessoas. Esses fatos da vida são, por sua vez, direitos e obrigações compartilhadas por mais de uma pessoa, que se tornam, portanto, imediatamente interessadas na solução da crise de direito substancial. Isso, por sua vez, traz reflexos na relação de direito processual tradicional, que transita a passos largos de um caráter dualista para um caráter mais pluralista. A partir de então, admite-se a estruturação plurissubjetiva ou coletiva da controvérsia de direito substancial.

Nesse ponto, é preciso destacar que o fenômeno de direito substancial, que justificou, e ainda justifica, o litisconsórcio e as referidas doutrinas inglesas (necessary party/ indispensable party), é o mesmo fenômeno que originou, séculos antes, as ações populares romanas e as ações coletivas medievais. O que mudou, no período moderno, foi apenas o fundamento pelo qual as ações coletivas são agora admitidas e os objetivos que as justificam no sistema processual.

Todavia, antes de abordarmos a proximidade do regime jurídico aplicável às ações coletivas e ao litisconsórcio ou compulsory joinder sob esse aspecto substancial, é preciso retomar o raciocínio quanto ao desenvolvimento das referidas doutrinas inglesas até se chegar ao assunto.

Destaca-se que as doutrinas da necessary party e indispensable party foram aplicadas de forma vacilante no século XVII, não sendo examinadas de forma coerente ou sistemática pela Corte de Chancelaria. O mesmo ocorreu, anos mais tarde, no sistema jurídico dos Estados Unidos.

\footnotetext{
94 No sistema jurídico estadunidense, o precedente mais influente sobre o tema é Shields v. Barrow (1854), que também realizou a distinção entre partes necessárias e partes indispensáveis à demanda. Antes desse precedente, essa questão foi objeto de discussão em Russell v. Clarck's Executors, Cameron v. M'Roberts, Mallow v. Hinde e outros (Cf. REED, 1957, p.340 et seq).

95 DINAMARCO, Cândido Rangel. Instituições de Direito Processual Civil II. 6. ed. rev. atual. São Paulo: Malheiros, 2009, p. 349 et seq.
} 
Ora as Cortes de Justiça faziam menção a essas doutrinas, ora as ignoravam. A linha que as diferenciava era muito tênue e não raro ambas as doutrinas eram superadas e convenientemente abandonadas, mormente, nos casos envolvendo relações coletivas ou plurissubjetivas. ${ }^{96}$

A integração ou o consentimento dos interessados ao processamento coletivo de uma demanda eram necessários como regra geral. Mas, se a integração de todos os interessados ou o consentimento individual se tornassem impraticáveis, em razão do grande número de sujeitos envolvidos na controvérsia de direito substancial - plurissubjetiva ou coletiva - , as referidas doutrinas eram abandonadas e, no lugar, as ações coletivas passam a ser admitidas. ${ }^{97}$

Quando identificada uma relação de direito substantivo plurissubjetiva ou coletiva e sendo possível a participação direta dos interessados, impunha-se o joinder ou o litisconsórcio. Não obstante, quando identificada uma relação de direito substantiva plurissubjetiva ou coletiva e sendo impraticável a participação direta de todos os interessados, a agregação processual deveria ocorrer por outros instrumentos do sistema jurídico. Dentre eles, destacaram-se as ações coletivas, que foram - à moda desse período - excepcionalmente admitidas em juízo.

Pode-se dizer, assim, concluindo-se o raciocínio, que as doutrinas da necessary party e indispensable party têm a mesma origem das ações coletivas: a necessidade de agregação processual, na hipótese em que discutida uma mesma controvérsia de direito substancial, envolvendo uma pluralidade de interessados. O tratamento processual é o mero reflexo das relações substantivas que envolvem o indivíduo e a coletividade a que ele está associado.

Afirma-se, nesse sentido, que as doutrinas da necessary party e indispensable party nasceram, no período moderno, a partir de uma mutação do regime jurídico das ações coletivas ${ }^{98}$.

96 HAZARD JR et al, 1998, p.1859-1860.

97 A numerosidade (numerosity) e a impraticabilidade do litisconsórcio (joinder) de todos os interessados são premissas vigentes até hoje no sistema jurídico estadunidense para a admissão das ações de classe, segundo a Federal Rule 23 (Cf. HERR, David. Annotated Manual for Complex Litigation. 4. ed. Minneapolis: West, 2012, p.378).

98 Sergio Cruz Arenhart defende que, na realidade, as ações coletivas é que nasceram de uma mutação do regime do litisconsórcio (Cf. 2003, p.140-144). Essa divergência não é, no entanto, relevante em relação ao exposto acima, porque independentemente do que surgiu primeiro - se foram as ações coletivas ou se foi o litisconsórcio - o fato é que ambos se encontram no bojo de um mesmo regime jurídico. Arenhart sustenta que o litisconsórcio surgiu primeiro, pois ele considera o surgimento das ações coletivas apenas no século XVII com o Bill of Peace. Adotamos, no entanto, o raciocínio de que as ações coletivas existiam em Roma e durante toda a Idade Média. Isso justifica, portanto, a inversão da ordem mencionada, isto é, o litisconsórcio surgiu de uma mutação do coletivo. 
Lembra-se que, anteriormente, as relações substanciais plurissubjetivas ou coletivas dominavam o cenário medieval e, para tratar esse fenômeno, recorriam-se às ações coletivas, sem que isso fosse problematizado no âmbito processual. A preocupação era apenas resolver a crise de direito substancial, o que interessava à pluralidade de sujeitos de uma controvérsia.

Suplantada aquela ordem e inaugurado um novo ethos social, marcadamente individualista, a dualidade processual (Tício v. Caio) passa a ser regra. E, na melhor das hipóteses, exigia-se a integração compulsória das partes interessadas (necessary parties ou indispensable party) ou o consentimento e a autorização para fins de representação. Nesse contexto, a preocupação, mais do que resolver a crise de direito substancial, era estabelecer uma técnica processual hábil a tratar a pluralidade de interessados, preservando, porém, a autonomia individual ou pessoal.

Nada há de curioso nisso. Não causa estranheza essa orientação mais individualista do sistema processual para as controvérsias subjetivamente simples (Tício v. Caio) - que se tornam agora, no período moderno, um fenômeno bastante comum - e isso é, até mesmo, esperado como reação ao período medieval. O único problema é que os grupos não desapareceram de uma hora para outra. Eles ainda persistiam, mesmo que em proporções e em relevância bem menores.

Nesse contexto, considerando a persistência residual das controvérsias atinentes aos grupos ou às comunidades, que eram típicas do período medieval, considerando, ainda, a inviabilidade de proceder à integração de todos ou de obter o consentimento ou autorização individual de todos os interessados, a Court of Chancery passou a admitir, excepcionalmente, as ações coletivas, mas, sob determinados contornos, de forma a preservar a autonomia individual ou pessoal.

É interessante notar que quando as ações coletivas são admitidas, a Court of Chancery menciona essa admissão por razões de mera conveniência (artifact of convenience) ${ }^{99}$. $\mathrm{O}$ processamento coletivo teria relevantes objetivos a cumprir no sistema processual, como evitar a duplicidade de demandas individuais similares, alcançar eficiência, economia processual e uniformidade nos provimentos jurisdicionais. O direito substancial coletivo ou plurissubjetivo foi desacreditado pelas Cortes de Justiça, as quais se direcionaram à questão processual apenas.

99 YEAZELL, 1987, p.186. No mesmo sentido, HAZARD JR, 1961, p.1259. 
A Court of Chancery, ao mencionar a conveniência como fundamento para admissão das ações coletivas, deixa de lado - o que parece ter sido propositado pelo próprio panorama individualista da época - um dos fundamentos básicos do processo civil vigente hoje, a saber, o processo é um mero instrumento ou método de solução da crise de direito substancial. ${ }^{100}$

O processo visa à atuação do direito substancial. Na feliz assertiva de Giuseppe Chiovenda ${ }^{101}$, "o processo deve dar, tanto quando possível, a quem tem um direito, tudo aquilo e propriamente aquilo que ele tem o direito de conseguir" [tradução nossa]. Essa assertiva apresenta uma textura normativa aberta, alcançando tanto os direitos individuais, como também os direitos coletivos.

Logo, se a crise de direito substancial é coletiva, o processo também é coletivo ${ }^{102}$. Não se trata de mera conveniência, mas da atuação do próprio escopo jurídico do processo, o qual deve manter simetria ou correlação à crise de direito substancial que é, in casu, plural ou coletiva.

Isso - obviamente e como era de se esperar - não era claramente percebido no período moderno. As ações coletivas foram, sim, excepcionalmente aceitas. Mas, nota-se que quando admitida a ação coletiva, em exceção às doutrinas da necessary party e indispensable party, sua técnica foi, de certo modo, restringida, para equacionar a problemática da autonomia individual ou mesmo para camuflar essa problemática processual. Vamos avançar sobre essa temática.

\subsubsection{PROVIMENTOS JUDICIAIS}

100 Nesse sentido, José Roberto dos Santos Bedaque define o processo como instrumento ou método estatal de resolução de controvérsias de direito substancial (Cf. BEDAQUE, José Roberto dos Santos. Direito e Processo. 4 ed. rev. amp. São Paulo: Malheiros, 2006, passim). Samuel Meira Brasil Jr acrescenta ao conceito a perspectiva argumentativa do direito. Segundo Brasil Jr, a propriedade que define o processo não é o contraditório que anima o procedimento, mas, sim, sua estrutura argumentativa, que demonstra ser o processo apenas um método de argumentação (Cf. BRASIL JR, Samuel Meira. Justiça, Direito e Processo: a argumentação e o direito processual de resultados justos. São Paulo: Atlas, 2007, p.43).

101 CHIOVENDA, Giuseppe. Istituzioni di diritto processuale civile. V. 1. 2. ed. Napole: Jovene, 1960, p.40. 102 Mauro Cappelletti, Ada Pellegrini Grinover, Cândido Rangel Dinamarco e Antônio Carlos de Araújo Cintra já defenderam, em obras clássicas do processo civil, a necessidade de aprimoramento das técnicas do processo civil para conferir a um direito de massa um processo também de massa (Cf. CAPPELLETTI, Mauro. Appunti sulla tutela giurisdizionale di interessi collettivi o diffusi. Le azioni a tutela di interessi collettivi: atti del Convengo di studio (Pavia, 11-12 giugno 1974) Padova, CEDAM, 1976, p. 193 e CINTRA, Antônio Carlos de Araújo, GRINOVER, Ada Pellegrini e DINAMARCO, Cândido Rangel. Teoria Geral do Processo. 25 ed. rev. atual. São Paulo: Malheiros, 2009, p.51). 
Em contrariedade ao período medieval, em que todos os provimentos eram admissíveis em juízo, as ações coletivas da modernidade limitaram-se, inicialmente, aos provimentos judiciais declaratórios e mandamentais. Essa limitação teve uma função essencial no sistema inglês.

Ao se restringir o provimento, na forma realizada pela Court of Chancery, o escopo da demanda torna-se claramente prospectivo. Tratava-se tão somente de declarar um direito, decorrente de uma prática costumeira, ou de constituir uma obrigação em relação ao grupo como um todo. Os membros do grupo são, a partir de então, indiretamente vinculados pelo resultado do julgado coletivo. E, apenas no caso de esse provimento vir a ser inobservado, no futuro, que se tornava possível, em um segundo procedimento, o ressarcimento em pecúnia ou a condenação futura ${ }^{103}$

E, mais, tratando-se de questão de direito costumeiro- um mero incidente legal atinente ao status do grupo ${ }^{104}$ - o provimento judicial passa a regular a conduta futura de todos os membros do grupo, superando a preocupação com a autonomia individual. Com isso, torna-se possível proceder à resolução integral, econômica, uniforme e eficiente da controvérsia, sem os inconvenientes das doutrinas da necessary party e indispensable party, bem como se torna possível obstar a multiplicação de demandas individuais similares nas Cortes de Justiça.

A limitação aos provimentos declaratórios e mandamentais e a superação, nesses casos, das doutrinas supracitadas deitam suas raízes na concepção de direito e processo então vigente.

Quando a controvérsia se restringe à declaração de um direito ou à constituição de uma obrigação com fundamento aplicável ao grupo como um todo, o interesse ou direito do indivíduo tende a subsumir-se, com mais clareza, ao anonimato do grupo. A demanda coletiva torna-se uma forma impessoal de litigiosidade, para a qual não importam as características pessoais ou particulares do indivíduo, membro do grupo ou da comunidade. O indivíduo

103 Stephen Yeazell ressalta que, no início do período moderno, é impossível encontrar provimentos que não fossem declaratórios ou mandamentais, isto é, prospectivos. O escopo adjudicatório das ações coletivas consistia, apenas, em regular as condutas, comportamentos e obrigações do grupo ou da comunidade de forma ex ante ou para o futuro. Admitia-se, apenas, em um segundo procedimento, a condenação ao ressarcimento em pecúnia em razão do descumprimento da ordem judicial antes deferida. Em nenhuma demanda, todavia, houve provimento condenatório ao ressarcimento em pecúnia (money damages), em razão de fatos ilícitos pretéritos (Cf. YEAZELL, 1987, p.135).

104 Ibidem, p.136. 
apresenta-se como um anônimo, pois todos os membros do grupo comungam de um mesmo interesse ou direito e ocupam um status semelhante dentro grupo, em igual posição jurídica. ${ }^{105}$

Essa impessoalidade decorria da prática costumeira, antes vigente. Essa prática não era de apenas um indivíduo, ela se relacionava à organização de um grupo ou de uma comunidade como um todo. Assim, os interesses ou direitos, decorrentes dessa prática, quando declarados pelas Cortes de Justiça, atrelavam-se e vinculavam a todos os indivíduos membros dessas coletividades, pelo simples status de pertencer à categoria. Os interesses ou direitos individuais são, assim, "clones" ou "cognatos" dos direitos do grupo. Eles são impessoais e independentes dos atributos particulares, razão pela qual era facilmente dispensada a participação individual. ${ }^{106}$

Nessa medida, o provimento declaratório ou mandamental aplicável ao grupo, era, igualmente, aplicável aos indivíduos membros desse grupo, sem a necessidade de se postular a integração de todos à demanda, ou à autorização ou ao consentimento para fins de representação ${ }^{107}$. Do contrário, caso fosse possível a cada indivíduo litigar esse status impessoal, a controvérsia seria infinita. As Cortes de Justiça litigariam a mesma controvérsia a todo o momento, o que seria infactível. Foi sentida, portanto, a necessidade de vinculação dos indivíduos (terceiros).

Um exemplo disso ocorreu em Brown v. Vermuden, precedente antes mencionado. Lembra-se que o direito ao dízimo - incidente sobre as operações de mineração de uma paróquia - foi declarado em uma ação coletiva movida pelo reverendo Carrier. Não obstante, posteriormente, quando o dízimo passou a ser efetivamente exigido pelo sucessor do reverendo Carrier, a saber, pelo reverendo Brown, a coisa julgada coletiva (binding effect of res judicata) veio a ser questionada por Vermuden, um dos mineiros daquela paróquia, que não havia sido parte.

Vermuden não havia figurado, formalmente, na demanda coletiva na condição de parte. Ele era membro ausente do grupo, cuja controvérsia havia sido apreciada. A Court of Chancery resolveu a questão, aplicando à Vermuden, ao menos implicitamente, a autoridade da coisa julgada coletiva e obstando a rediscussão, na demanda individual, da matéria anteriormente

105 BONE, Robert G. Personal and impersonal litigative forms: reconceiving the history of adjudicative representation. Boston University Law Review, 1990, V. 70:213-307, p. 218.Nesse sentido: YEAZELL, 1987, p. 163.

107 BONE, op. cit., p.239. 
decidida de forma coletiva. Se do contrário fosse, disse a Corte de Justiça, a controvérsia tenderia ao infinito e seria impossível a sua conclusão, pois estaria sujeita à rediscussão. ${ }^{108}$

Veja, portanto, que a autoridade da coisa julgada, que se agregava ao provimento declaratório pronunciado em uma ação coletiva, vinculou Vermuden, que não era parte naquela demanda. Somente no final do período moderno e início do período contemporâneo, é que passam a ser admitidos, em juízo, além dos provimentos mandamentais e declaratórios, também os provimentos condenatórios ao ressarcimento em pecúnia, proferidos em uma ação coletiva. ${ }^{109}$

Mas, antes de continuarmos, um fato ainda merece ser destacado nesse período moderno: a prática costumeira do grupo ou da comunidade era, paulatinamente, transformada em direito.

O magistrado da Court of Chancery ${ }^{110}$ consolidava a questão fática - atinente a um costume e, por isso, flexível e variável no tempo e local - em um comando normativo concreto, aplicável, sucessivamente, aos integrantes do grupo, interessados na mesma controvérsia. A eficácia da coisa julgada coletiva era estendida, sucessivamente, aos indivíduos, frise-se, pois todos comungavam o mesmo interesse ou direito e ocupavam o mesmo status ou posição jurídica.

Mas, nem sempre isso foi assim entendido. Muitas vezes, a extensão subjetiva da coisa julgada coletiva foi confundida ou fundida com a doutrina do precedente, para efeito de vinculação dos indivíduos, membros do grupo. As Cortes de Justiça não poderiam admitir a constante substituição das partes, que litigariam sempre a mesma controvérsia impessoal de um grupo. Mas, em um sistema de orientação individualista, uma das marcas da modernidade, era

108 Nas palavras do Chanceler: "If the Defendant should not be bound, Suits of this Nature, as in case of Inclosures, Suit against the Inhabitants for Suit to a Mill, and the' like, would be infinite, and impossible to be ended. And declared, that the Defendant, though no Party nor privy, yet he may have a Bill of Review, because he is grieved by the Decree" (ENGLAND. Court of Chancery. Brown v Vermuden, 22 Eng. Rep. 796 (Ch. 1676)). No mesmo sentido, conferir: YEAZELL, 1987, p.155).

109 Somente, mais tarde, no final do período moderno e início do século XIX, torna-se comum a pretensão coletiva por ressarcimento em pecúnia, por atos ilícitos pretéritos praticados pela parte adversa. Isso ocorreu no precedente Adair v. New River Company a ser abordado adiante (Cf. YEAZELL, op. cit., p.149).

110 Essa prática já havia sido revelada, de uma forma geral, por John Pocock, ao analisar a história da common law, bem como por Aleksander Peczenik, ao analisar as transformações de ordens sociais e de valores em normas jurídicas. Stephen Yeazell, no entanto, diz, expressa e especificamente, que a Court of Chancery adotou essa prática nas ações coletivas, transformando práticas costumeiras dinâmicas e variadas em normas jurídicas uniformes. A estabilização do costume em norma (seja por lei, seja por precedente) conferiu maior segurança e previsibilidade para a expansão das práticas comerciais, erodiu as variedades regionais e favoreceu a centralização e formação de um modelo nacional. Em um período de rápidas mudanças econômicas, o sistema jurídico não mais poderia conviver com a insegurança e a imprevisibilidade dos costumes não registrados pelas Cortes de Justiça. A consequência disso foi remover o costume e o grupo da função de fonte do direito (Cf. YEAZELL, op.cit., p.151). 
extremamente improvável que se aceitasse, de forma expressa, a extensão subjetiva da coisa julgada a terceiros (membros ausentes do grupo) que não participaram do processo coletivo. ${ }^{111}$

Assim, o mesmo resultado - vinculação aos membros ausentes do grupo - foi, muitas vezes, obtido por vias oblíquas, a saber, pelo precedente, o que implicou algumas incongruências.

\subsubsection{COISA JULGADA (CLAIM PRECLUSION) E PRECEDENTE}

A jurisprudência foi bastante vacilante, no período moderno, em relação à extensão subjetiva da coisa julgada coletiva (claim preclusion) aos membros ausentes do grupo ou comunidade.

Por vezes, as doutrinas da coisa julgada e do precedente foram confundidas ou fundidas ${ }^{112}$, vinculando os membros ausentes do grupo ao resultado da demanda coletiva por força do precedente dela extraído e não por respeito à estabilidade do julgado coletivo (doutrina do former adjudication ou preclusion, da qual é espécie a res judicata ou claim preclusion $)^{113}$.

Na realidade, segundo a doutrina de representação vigente à época, no sentido de consentimento ou autorização pessoal do indivíduo à demanda coletiva, não seria possível - por razões óbvias - estender ao membro ausente do grupo a indiscutibilidade própria da coisa julgada, sem que todos tivessem consentido ou autorizado ao processamento coletivo da demanda, isto é, sido representados em juízo. De igual modo, considerando o grande número de interessados na controvérsia coletiva, não seria viável a integração de todos à demanda, segundo a doutrina da

111 Stephen Yeazell comenta que as doutrinas da coisa julgada e do precedente se imiscuíram nesse período, para o fim de vinculação dos membros ausentes do grupo. Era preciso limitar, de alguma forma, a constante substituição das partes, hábeis a litigar a mesma controvérsia. Caso não fosse limitada a rediscussão da controvérsia, no tocante aos membros ausentes do grupo, a demanda do grupo transformar-se-ia em um vasto e complicado monstro. Para que essa vinculação fosse, então, possível no período moderno, não foi raro o recurso ao precedente judicial, principalmente nas hipóteses de provimentos declaratórios e mandamentais (Cf. YEAZELL, 1987, p. 163 e 180). 112 Ibidem, p. 163.

113 No sistema estadunidense, a coisa julgada e outras formas de preclusão compõe a doutrina do former adjudication ou preclusion doctrine, ou seja, trata-se da doutrina da decisão prévia que estabiliza os resultados obtidos em uma demanda em relação aos processos futuros, nos quais se pretende rediscutir a mesma matéria já decidida em outra oportunidade. A coisa julgada (res judicata or claim preclusion) é apenas uma espécie dessa categoria de preclusão (Cf. SHAPIRO, David L. Civil procedure: preclusion in civil actions. New York: Foundation Press, 2001, p. 9-18; CASAD, Robert C. e CLERMONT, Kevin M. Res judicata: a handbook on its theory, doctrine, and practice. Durham: Carolina Academic Press, 2001, p. 13-22; CABRAL, Antônio Passo do. Coisa julgada e preclusões dinâmicas: entre continuidade, mudança e transição de posições processuais estáveis. Salvador: Editora Juspodium, 2013, p.180). 
necessary party e indispensable party. Não seria factível, ainda, convocar todos os indivíduos interessados, em juízo, para autorizar ou consentir com o processamento coletivo da demanda.

Mas, como as controvérsias multitudinárias de grupo ainda existiam no período moderno, era evidente e esperado que alguma espécie de efeito vinculante se fizesse necessário nesses casos. Recorda-se que a justificativa para isso não era a existência de um direito substancial plurissubjetivo ou coletivo, a exigir um processo de igual simetria, mas, sim, a conveniência do processamento agregado da controvérsia, de forma a alcançar eficiência e uniformidade.

A vinculação aos membros ausentes do grupo não poderia ocorrer, como já se disse, por força da representação dos indivíduos (ao menos, sob aquele conceito de autorização ou consentimento pessoal) ou pela integração dos interessados à ação coletiva, de forma a ensejar a extensão subjetiva da coisa julgada aos membros ausentes do grupo. Todavia, o fato é que essa vinculação ocorreu, em algumas vezes, não pela autoridade da coisa julgada, mas com fundamento no comando normativo (ratio decidendi) do precedente da demanda coletiva ${ }^{114}$.

Como é sabido, a participação ou a representação não são essenciais para efeito de vinculação pelo precedente ${ }^{115}$. A vinculação pelo precedente ocorre pela necessidade de coerência e uniformidade do sistema jurídico no tocante à questão de direito decidida e, por isso, alcança as demandas individuais similares. Não se trata, portanto, da autoridade da coisa julgada coletiva, que confere estabilidade ao julgado e obsta a contínua rediscussão da controvérsia.

114 Stephen Yeazell explicita a diferença. O respeito aos precedentes decorre da regra, segunda a qual decidida uma questão de direito em um determinado sentido no caso concreto, a Corte de Justiça deverá aderir a esse mesmo sentido (regra jurídica emanada do precedente) nos casos sucessivos similares. A autoridade da coisa julgada refere-se, no entanto, a uma noção similar, contudo mais estreita de vinculação, a saber, quando uma parte sofrer uma vitória ou uma derrota em dada demanda, ela não poderá rediscutir a questão decidida em outras oportunidades. As duas doutrinas, embora diversas, podem ser confundidas, no entanto, quando a controvérsia envolver a declaração de um direito, que expressa tanto estados de fato pretéritos quanto um regime a ser seguido no futuro. Quando a fonte normativa é um costume, a declaração de um costume passado, enquanto tecnicamente vincula as partes da demanda, também constituirá um precedente a ser seguido no futuro em outros casos similares. Assim, seguindo esse raciocínio, há coisa julgada em relação às partes, bem como há um precedente em relação aos casos similares no futuro. Quando a demanda é coletiva, todavia, uma ressalva deve ser feita. Pode-se dizer que os membros ausentes do grupo também são vinculados pela coisa julgada coletiva. Como os membros ausentes no grupo ocupam a mesma posição das partes e operam pelo status do grupo ou categoria, eles são vinculados pela coisa julgada coletiva e não pelo precedente. Essa matéria será abordada adiante (Cf. YEAZELL, 1987, p.180).

115 Aleksander Peczenik argumenta que o precedente é a decisão de um caso concreto que se transforma em um padrão normativo autorizado para orientar as futuras decisões das Cortes de Justiça. A razão para seguir um precedente é a manutenção da coerência do direito e da previsibilidade dos julgamentos. A vinculação à regra jurídica que emana do precedente (ratio decidendi) não ocorre, portanto, por força da representação ou participação das partes no processo (Cf. PECZENIK, Aleksander. On law and reason. Lund (Sweden): Springer, 2009, p.274). 
São técnicas processuais diferentes, portanto. Mas, o fato é que esse raciocínio - vinculação pelo precedente formado na demanda coletiva e não pela autoridade da coisa julgada coletiva foi aplicado no período moderno, a exemplo do caso Adair v. New River Company ${ }^{116}$, em 1805.

O caso em questão diz respeito a uma ação coletiva passiva, que envolvia a companhia New River, formalmente incorporada e responsável pelo fornecimento de água à cidade de Londres.

O Rei James I concedeu o status de corporação a essa companhia em troca de dividendos (parcela do lucro apurada pela empresa e dividida entre os acionistas). Posteriormente, seu filho, o Rei Charles cedeu os dividendos a Sir Hugh Midleton, recebendo em troca um aluguel de 500 libras esterlinas. Em seguida, depois da morte do Rei Charles, esse direito real (de recebimento do aluguel) foi transferido pela Coroa para William Adair. Enquanto isso, o direito de receber os dividendos da empresa (parte que originariamente cabia à Coroa e que, posteriormente, foi cedida a Sir Hugh Midleton) foi pulverizado e cedido, em parte, para a própria companhia e também para, pelos menos, 100 indivíduos, que não faziam parte da corporação. A relação substancial foi, em resumo, assim estabelecida ao final, de um lado estava William Adair que fazia jus a um aluguel em decorrência da cessão dos dividendos da companhia e, de outro lado, estava a corporação e, pelo menos, 100 indivíduos, a quem pertenciam os dividendos em questão, vinculados à obrigação do pagamento de aluguel em favor de William Adair.

O autor William Adair ingressou com uma demanda coletiva em face da companhia New River, bem como em face de oito indivíduos (dentre os 100 que compraram os dividendos), rediscutindo a forma de cálculo do valor do aluguel, que era devido pela companhia e pelos outros 92 indivíduos, que não figuravam, formalmente, na demanda. Ele pleiteou, em relação ao grupo, a correção da forma de cálculo do aluguel e as diferenças devidas. E, os demandados, por sua vez, argumentaram a necessidade de integração de todos os indivíduos ao polo passivo na demanda coletiva, por força da doutrina da necessary party e/ou indispensable party.

116 ENGLAND. Court of Chancery. Adair v. New River Co, 32 Eng. Rep. 1153 (Ch. 1805). 
$\mathrm{Na}$ ocasião, o Chanceler Lord Eldon afastou a doutrina da necessary party e/ou indispensable party, pois essa regra havia sido derrotada naquele caso concreto, sendo impraticável a integração de todos os interessados. A razão para a derrotabilidade daquela doutrina era que:117

\begin{abstract}
...uma petição (na jurisdição da equidade) é juntada pleiteando a declaração de um direito e não é necessário reunir todos os interessados. Por que? [...] ]as partes litigarão de forma justa e honesta um direito (legal right) entre elas, todas as outras pessoas e o autor. E, quando é estabelecido o direito segundo a lei, o remédio na jurisdição da equidade é muito simples: basta uma petição, afirmando que o direito foi estabelecido em um processo anterior e, com esse fundamento, a Corte de Equidade concederá ao autor a pretensão em face do réu no segundo processo, apenas representado por aqueles do primeiro [tradução nossa].
\end{abstract}

Segundo essa tese, não era preciso que todos os indivíduos figurassem na demanda coletiva ou com ela consentissem ou autorizassem. Isso seria, em primeiro lugar, impraticável e, em segundo lugar, desnecessário, pois é possível julgar apenas uma demanda e quando o direito for nela declarado e estabelecido em um precedente, o seu comando normativo (ratio decidendilis) será aplicável a todos os indivíduos interessados em uma segunda demanda.

Nota-se que algumas questões não podem passar despercebidas no precedente Adair $v$. New River Company: (i) há uma pretensão declaratória em relação à forma de cálculo do aluguel, mas também condenatória ao ressarcimento das diferenças, o que difere dos casos antes mencionados e (ii) as doutrinas do precedente e da coisa julgada coletiva aparecem teoricamente imbricadas nessa hipótese, sob o fundamento de que a questão era de direito.

117 ... a bill (in equity) is filed to establish that right, and it is not necessary to bring all the individuals: why? [...] they will fairly and honestly try the legal right between themselves, all other people, and plaintiff; and, when the legal right is so established at law, the remedy in equity is very simple: merely a bill, stating that the right has been established in such a proceeding, and upon that ground a Court of Equity will give the plaintiff relief against the Defendants in the second suit, only represented by those in the first (ENGLAND. Court of Chancery. Adair v. New River Co, 32 Eng. Rep. 1153 (Ch. 1805)).

118 Segundo Michele Taruffo, ratio decidendi é o comando normativo do julgado (regra jurídica posta como fundamento direto sobre os fatos relevantes e específicos do caso concreto), que se torna um critério de decisão para os casos similares no futuro. José Rogério Cruz e Tucci assinala, ainda, que a ratio decidendi é a 'norma legal' (abstraindo-a do caso) que poderá ou não decidir casos similares no futuro. Essa norma não é individuada pelo órgão julgador, no qual se formou o precedente, mas deverá ser extraída a partir dos elementos que compõe o caso concreto julgado, a saber, a) fatos relevantes, b) raciocínio lógico-jurídico e c) juízo decisório (Cf. TARUFFO, Michelle. Precedente e jurisprudência. Revista de Processo. V. 36. N. 199. São Paulo: Revista dos Tribunais, set. 2011, p. 141 e TUCCI, 2004, p.175). Nesse mesmo sentido, Samuel Meira Brasil Jr. ressalta a eficácia normativa da ratio decidendi (regra jurídica) constante no precedente, que é potencialmente vinculante aos demais casos no futuro (BRASIL JR, 2010, p.37). 
A conclusão levada a efeito, nesse caso, apresenta-se - isso é, ao menos, tecnicamente - de forma incongruente, pois não se tratava de simples questão de direito, a ser aplicada de forma coerente para todos os casos individuais, relativos aos membros ausentes daquele grupo.

O provimento pretendido por William Adair - declaratório quanto à forma de cálculo do valor do aluguel, bem como condenatório quanto ao ressarcimento das diferenças - vincularia os membros ausentes do grupo, não só porque o direito (o comando normativo do precedente), de uma forma geral, deve ser uniforme e coerente para todos os casos individuais similares, mas, sim, porque não é admissível que a forma de cálculo do valor aluguel seja diferente entre os indivíduos integrantes de um grupo, o qual apenas sucedeu o contratante anterior na relação negocial. A uniformidade é, aqui, mera decorrência da unidade presente na relação substancial.

Todos os indivíduos que adquiriram os dividendos antes pertencentes à Coroa Inglesa e à Sir Hugh Midleton, sucederam a eles na relação substancial estabelecida com William Adair. E são, agora, igualmente devedores do aluguel devido a esse último. Esse aluguel tem uma forma de cálculo una e objetiva, que se aplica ao grupo como um todo. O indivíduo, embora seja pessoalmente afetado pela alteração do método de cálculo, é um anônimo na relação substancial e comunga do mesmo interesse ou do mesmo direito do grupo como um todo. Enfim, se a forma de cálculo for alterada para o caso de um indivíduo, deve ser alterada para o caso de todos os demais indivíduos, pois eles atuam na qualidade de simples membros do grupo litigante.

Fica fácil compreender, desse modo, que: uma coisa é dizer que a regra jurídica cunhada em um caso concreto deve ser aplicada, potencialmente, para todos os casos similares no futuro. Por exemplo, se a responsabilidade omissiva do Estado é subjetiva, segundo entendimento do Superior Tribunal de Justiça aplicado em um caso concreto no Rio de Janeiro, esse mesmo entendimento deve ser aplicado para um caso similar de responsabilidade omissiva em Manaus, pois os parâmetros legais são os mesmos. Outra coisa é dizer que a relação substancial é incindível, paritária e impessoal, com fundamento aplicável ao grupo como todo. Nesse caso, a coisa julgada, formada na demanda coletiva, não pode ser rediscutida para os indivíduos, pois os indivíduos operam como membros do grupo, segundo o status jurídico da categoria.

Embora tenha sido vacilante a jurisprudência moderna, no aspecto supracitado, a vinculação dos membros ausentes do grupo não poderia ser imputada, de qualquer modo, ao precedente, 
mas, sim, à coisa julgada. Mas, para se alcançar essa conclusão, é preciso antes diferenciar o precedente e a coisa julgada coletiva. E, esta é, sem dúvida, a oportunidade ideal para isso.

Em primeiro lugar, quando um precedente é formado em um caso concreto, o julgador não conhece o universo de casos para o qual ele será aplicado no futuro. Mas, por razões de coerência e uniformidade da questão de direito decidida, o comando normativo (ratio decidendi) do precedente daquele caso paradigma deverá ser aplicado, por analogia, aos demais casos similares no futuro. A eficácia do precedente é contida, mas suscetível de extensão. ${ }^{119}$

Nas palavras de Michele Taruffo ${ }^{120}$, o comando normativo do precedente, cunhado em um caso concreto individual e compreendido, segundo essa fattispecie, é universalizável e aplicável de forma prescritiva e normativa, por analogia, aos casos sucessivos no futuro. A analogia não é, portanto, afirmada in re ipsa, mas pode ser afirmada ou excluída no caso concreto sucessivo.

Fato diverso ocorre nas controvérsias de massa ou coletivas. Quando uma questão é decidida em uma controvérsia de massa - em que os indivíduos do grupo se apresentam de forma impessoal e comungam dos mesmos interesses ou direitos - esse universo coletivo (fattispecie) da controvérsia passa a ser previamente considerado no processo de justificação e de decisão.

O julgador considera os interesses ou as questões comuns ao grupo, enfim, o status do grupo, no processo decisório. E, o indivíduo, ao integrar esse grupo ou universo coletivo, passa a ser submetido, por mera derivação lógica, à mesma norma jurídica. Não se trata mais, agora, de simples analogia aos casos individuais futuros. Isso porque o comando normativo do julgado não é apenas universalizável aos casos futuros, como ocorre no precedente, ele já foi universalizado ao considerar o grupo como um todo no processo de justificação e decisão coletiva. E, de igual modo, não se aplica aqui as técnicas de afastamento do precedente, como é o caso da distinção (distinguishing) e da superação (overruling), isso porque as eventuais variáveis já foram, em regra, consideradas para fins de identificação do universo coletivo.

119 Em sentido semelhante, Michele Taruffo salienta que a regra jurídica do precedente é um critério de decisão para os casos sucessivos no futuro, sendo passível de derrota por novas razões (Cf. TARUFFO, 2011, p.147). 120 Ibidem, p.141-145. No mesmo sentido, TUCCI, 2004, p.175. 
As práticas e as questões comuns de um grupo que foram, em um primeiro momento, investigadas e abstraídas pelas Cortes de Justiça em uma ação coletiva, transformaram-se, em um segundo momento, em um comando normativo, cuja autoridade se impõe diretamente ao indivíduo, membro do grupo ou comunidade, pois essa controvérsia já foi apreciada e julgada.

Ainda que se insista em se denominar isso de precedente vinculante, pode-se dizer que esse precedente, formado na ação coletiva ou por outra técnica de agregação, tem força diferente dos demais precedentes, formados nos casos individuais. Essa força assemelha-se ou confunde-se com a estabilidade ou a indiscutibilidade própria da coisa julgada, sendo menos derrotável.

Explica-se. Esse "precedente" seria menos derrotável ${ }^{121}$, pois, ao considerar os costumes e a prática comum de um grupo no processo de justificação e decisão, grupo na qual se insere o indivíduo, ele reduz as possibilidades de esse indivíduo afastar o comando normativo do julgado para o seu caso particular e proceder à rediscussão da questão controvertida. Essa redução poderá ser, até mesmo, integral, isto é, não sobrar nenhuma questão individual a ser discutida. Essa técnica processual aproxima-se, com isso, da estabilidade típica da coisa julgada.

Essa estabilidade ou indiscutibilidade do julgado, por sua vez, é exatamente uma das propriedades inerentes à coisa julgada coletiva, como uma das técnicas de preclusão.

A coisa julgada tem por escopo evitar a contínua rediscussão do thema decidendum (causa de pedir e pedido), estabelecido entre as mesmas partes ou entre aquelas que ocupam a mesma posição jurídica, como, por exemplo, ocorre com os membros ausentes do grupo nas ações coletivas. Ela se forma, por sua vez, depois do processamento e o julgamento definitivo das questões comuns ao grupo, sendo esse resultado qualificado pela estabilidade própria da coisa julgada. O escopo é conferir segurança e definitividade às relações jurídicas litigadas. ${ }^{122}$

121 Nesse sentido, Michele Taruffo explicita que o precedente é, em regra, derrotável (defeasible), isto é, ele pode ser afastado ou excluído nos casos futuros sucessivos (TARUFFO, 2011, p.147).

122 No sistema jurídico estadunidense, é válido conferir o artigo de Timothy J. Heinsz a respeito das diferenças conceituais entre o precedente e a coisa julgada (Cf. HEINSZ, Timothy J. Grieve it again: of stare decisis, res judicata and collateral estoppel in labor arbitration. Boston College Law Review. V. 38: 275-300, p. 277-280). No sistema jurídico brasileiro, há também obras de fôlego sobre o tema. Liebman, Ada Pellegrini Grinover, Barbosa Moreira e José Rogério Cruz e Tucci realizaram a análise evolutiva do conceito de coisa julgada (Cf. LIEBMAN, Enrico Tullio. Eficácia e autoridade da sentença e outros escritos sobre a coisa julgada. Tradução de Alfredo Buzaid e Benvindo Aires. Tradução dos textos posteriores à edição de 1945 de Ada Pellegrini Grinover. Notas de Ada Pellegrini Grinover. 4 ed. Rio de Janeiro: Forense, 2007; MOREIRA, José Carlos Barbosa. Direito Processual Civil (ensaios e pareceres): ainda e sempre a coisa julgada. Rio de Janeiro: Borsói, 1971; TUCCI, José Rogério Cruz. Limites subjetivos da eficácia da sentença e coisa julgada civil. São Paulo: Revista dos Tribunais, 2006). 
Em segundo lugar, o precedente difere da coisa julgada, pois o seu comando normativo (ratio decidendi) é aplicável a uma demanda substancialmente idêntica, depois da comparação dos fatos relevantes em cada caso concreto. A coisa julgada, por sua vez, não é uma regra jurídica potencialmente vinculante aos demais casos concretos, ela é a própria imutabilidade que se agrega à sentença do caso. Quando a coisa julgada é coletiva, os fatos relevantes à causa de pedir e pedido já foram analisados com fundamento aplicável ao grupo como um todo, enfim, a relação substancial analisada não é pessoal e exclusiva do indivíduo, mas plurissubjetiva.

Para finalizar essa distinção, é válido um exemplo. Imagine uma ação coletiva proposta pelo Ministério Público, pleiteando a anulação da questão n. 35 da prova objetiva de um concurso público para ingresso na magistratura do Estado de São Paulo. A anulação é pleiteada, uma vez que a questão da prova objetiva teria inobservado o conteúdo do edital. O bem da vida é paritário e impessoal para todos os candidatos, pois todos fazem jus à concorrência igualitária dos cargos públicos, segundo o edital do concurso. Essa ação é, todavia, julgada improcedente.

Imagine uma segunda ação sucessiva, agora proposta por uma Associação de Concurseiros, arguindo o mesmo pedido e a mesma causa de pedir. O que se aplica, nesse segundo caso, a eficácia vinculante do precedente da primeira ação ou a autoridade da coisa julgada? Não é possível aceitar, nesse caso, a aplicação do precedente. O que ocorre é a verdadeira indiscutibilidade que se agrega à sentença coletiva que apreciou a validade da prova objetiva e manteve o ato impugnado, o que se aplica para as partes e para todos os demais candidatos.

Veja com detalhe o raciocínio. A ratio decidendi do precedente seria uma regra jurídica abstrata redigida da seguinte maneira: é válida a questão de prova objetiva em concurso público, que exija conhecimento de matéria jurídica, devidamente elencada no edital do certame. Frisa-se que se trata de uma regra abstraída do caso concreto, não importando a prova ou a questão do concurso público analisada no julgamento (obiter dictum) ${ }^{123}$. O comando emergente da sentença, por sua vez, sobre o qual incide a indiscutibilidade da coisa julgada, é a regra jurídica

$123 \mathrm{Na}$ análise do precedente, exige-se cuidado com a identificação da ratio decidendi e do obiter dictum. Isso porque a vinculação decorre apenas da ratio decidendi, isto é, da tese jurídica ou do enunciado normativo geral. A obiter dictum é a mera descrição dos fatos, que são irrelevantes ou marginais para a tese jurídica. Exemplo: não importa se é a questão analisada da prova objetiva é a de número 35, 36 ou 37 (dicta), o que importa é que será válida a questão da prova objetiva que observar o conteúdo do edital do certame (ratio). A diferenciação entre ratio decidendi e obiter dictum devem ser conferidas em: BRASIL JR, Samuel Meira. Precedentes vinculantes e jurisprudência dominante na solução das controvérsias. Tese de Doutorado. USP. São Paulo, 2010. 
concreta que diz ser improcedente a pretensão de anular a questão n. 35 da prova objetiva, já que a questão era validamente exigível, segundo o edital do concurso público. Frisa-se que se trata de uma regra concreta e, portanto, importa a prova e o número da questão analisada. ${ }^{124}$

Por isso, a demanda sucessiva, que impugna a mesma questão, é alcançada pela autoridade da coisa julgada. Não se trata de simples analogia. A validade da questão impugnada já foi analisada, logo inadmissível as sucessivas investidas dos membros ausentes do grupo.

Deve-se enfatizar que as diferenças entre o precedente e a coisa julgada são, em verdade, bastante sutis, mormente quando a questão controvertida é realmente apenas de direito ${ }^{125}$.

Porém, o que importa ressaltar, nesse momento, é que essas sutilezas teóricas foram, de forma bem criativa, empregadas nas ações coletivas no período moderno. Logrou-se alcançar eficiência, evitando a multiplicidade de demandas individuais similares, bem como afastar a reunião compulsória de todos os integrantes do grupo (doutrina da necessary parties/indispensable party) ou a representação pelo consentimento ou autorização individual.

O fundamento, pelo qual se logrou esse resultado, negligencia, no entanto, as relações substantivas entre o grupo e o indivíduo e encerra, como já se comentou, confusões conceituais desconcertantes entre a teoria do precedente e a teoria da coisa julgada coletiva. Senão vejamos.

Não é uma mera coincidência o fato de um único precedente ter o condão de evitar uma multiplicidade de demandas similares individuais atinentes a um grupo, apenas porque o seu comando normativo decidiu uma questão de direito, assim extensível a todos os indivíduos.

Merece reflexão o que está subjacente a isso: a existência de indivíduos que operam pelo status, pelo status de pertencer a um grupo ou categoria. Na demanda Adair v. New River Company,

124 Trata-se do mesmo raciocínio da ação popular. Como diz Barbosa Moreira, se o pedido é acolhido e o ato anulado ou declarado nulo, a sentença prevalece em definitivo, perante todos os membros da coletividade. Se o pedido é rejeitado, por inexistência de fundamento para anular ou declarar nulo o ato, a eficácia é erga omnes, de sorte que a validade do ato não poderá ser rediscutida, por igual fundamento, em juízo novamente, ainda que por outro cidadão. Apenas se o pedido for rejeitado por insuficiência de provas, a questão poderá ser rediscutida em outra oportunidade por qualquer um dos legitimados, produzindo-se prova nova (Cf. MOREIRA, José Carlos Barbosa. A ação popular no direito brasileiro como instrumento de tutela jurisdicional dos chamados "interesses difusos”. Temas de Direito Processual. São Paulo: Saraiva, 1977, p.123).

125 YEAZELL, 1987, p.180 
por exemplo, não há uma história própria de cada indivíduo, a história controvertida é coletiva. Trata-se de uma prática comum aplicada, com fundamento em toda a categoria ou grupo.

Os direitos envolvidos, no conflito de interesses antes citado, eram sim apropriáveis pelos indivíduos isoladamente. Recorda-se que William Adair pretendia o retorno das diferenças financeiras (ressarcimento em pecúnia) em desfavor de cada um dos investidores, que constavam no polo passivo da demanda, em razão da discrepância na forma de cálculo do aluguel a ele devido. Esse direito não foi, no entanto, litigado em Adair v. New River Company, por razões estritamente particulares, mas, sim, por razões comuns à coletividade como todo.

Há uma unidade substancial, enfim, uma relação substantiva coletiva ou plurissubjetiva, em que todos os indivíduos também associados àquele grupo são imediatamente interessados. Os reflexos disso no processo - nas palavras de Shapiro ${ }^{126}$-é uma entidade coletiva litigante. ${ }^{127}$

Ainda que isso não seja reconhecido de forma plena no período moderno - como não foi em Adair v. New River Company - preferindo-se, por vezes, o recurso teórico ao precedente, de aplicação individual, o que se fez foi apenas camuflar uma técnica de agregação, in casu, a ação coletiva, bem como ocultar as relações substantivas existentes entre o indivíduo e o grupo.

Mas, como já se disse, a jurisprudência foi vacilante no final do período moderno no tocante à coisa julgada coletiva. Em alguns casos, recorreu-se ao precedente judicial para vincular os membros ausentes do grupo. Mas, em outros, revisitou-se a teoria de representação, para dispensar o consentimento ou a autorização individual dos membros ausentes do grupo e, assim, vinculá-los ao resultado do julgado. A partir desse momento, os membros do grupo são vinculados ao resultado do julgamento por força da coisa julgada coletiva. Ex. Chancey v. May.

126 SHAPIRO, David L. Class action: the class as party and client. Notre Dame Law Review, 1997-1998, V. 73:913-961, p. 919.

127 Em sentido semelhante, Frederic Calvert defende que a vinculação entre o grupo e o indivíduo ocorre pela coincidência de interesses e pela impessoalidade da posição da parte na controvérsia. $\mathrm{O}$ autor da demanda, ao litigar o seu interesse próprio, defende os interesses comuns a todo o grupo, pois ele age como mero guardião desse interesse (CALVERT, Frederic. A treatise upon the law respecting parties to suits in equity. New York: John S. Littell, 1837, p. 12). O argumento de Calvert realmente persuade, até porque, em momentos anteriores da história, as ações coletivas foram admitidas, sem qualquer preocupação com a representação. Isso ocorria porque havia uma equivalência conceitual entre o cidadão romano e povo, entre a comunidade medieval e qualquer de seus indivíduos. O que Calvert fez, na modernidade, foi apenas reconhecer uma nova espécie de equivalência, não uma equivalência conceitual de pessoas (equivalência até mesmo superada com o advento dos conceitos de Estado e de indivíduo), mas, sim, uma equivalência de interesses comuns aos indivíduos e aos grupos. 
O precedente Chancey v. May diz respeito a uma ação coletiva proposta pelos administradores, em nome de todos os demais proprietários de uma sociedade, em face dos antigos administradores e tesoureiros. A Court of Chancery rejeitou a aplicação da doutrina da necessary party à hipótese, já que o litisconsórcio era impraticável, à medida que envolvia centenas de acionistas. E, igualmente, concluiu que os membros ausentes do grupo de acionistas foram representados pelos autores que figuravam formalmente no processo. Os acionistas eram, para esse efeito, "quase-partes" na demanda coletiva, pois seus interesses foram representados.

É perceptível, portanto, que, a partir de agora, o processo caminha para uma nova teoria de representação, que se acrescenta à noção de consentimento ou autorização individual vigente.

\subsubsection{TRANSIÇÃO: NOVO CONCEITO DE REPRESENTAÇÃO}

Voltando ao precedente Chancey v. May, o representante atuou, nesse caso, em nome do grupo, não por força de um formal consentimento ou autorização expressa ao processamento coletivo da demanda, mas por promover, de forma substantiva, os interesses do grupo como todo. Surge, assim, como comentado, uma equivalência substancial entre os interesses do grupo e do indivíduo - equivalência que é recorrente na história, guardadas as suas devidas proporções.

Lembra-se que, na ação popular romana, o cidadão defendia direito próprio, mas qualificado pelo pertencimento a uma coletividade. No período medieval, o indivíduo operava por status. O grupo não era um conjunto de indivíduos, mas, sim, uma categoria própria. Há, desse modo, uma recorrência histórica à interligação de situações jurídico-substanciais plurissubjetivas.

Nessa ordem de ideias, não é mais preciso identificar todos os indivíduos integrantes do grupo, para fins de integração à demanda ou para fins de consentimento ou de autorização expressa ao processamento coletivo da controvérsia. O que é preciso identificar é a equivalência dos interesses substanciais, isto é, em que medida o indivíduo, ainda que em nome próprio, atua como membro do grupo ou de forma conectada, vinculada, entrelaçada a uma comunidade. ${ }^{128}$

A equivalência dos interesses entre o indivíduo e o grupo identifica as relações substantivas passíveis de serem resolvidas mediante a agregação processual. Os variáveis graus de 
intensidade de vinculação do indivíduo ao grupo manifestam-se nos diferentes regimes das ações coletivas, bem como nas diferentes técnicas de agregação presentes no sistema jurídico. ${ }^{129}$

É possível, por exemplo, a agregação da controvérsia de massa, em uma ação coletiva, mediante a atuação de um portador ideológico dos interesses do grupo em juízo, sem que se exija, necessariamente, a integração de todos os interessados ou o consentimento individual. O regime jurídico da ação coletiva varia conforme a intensidade da identificação do indivíduo e do grupo. De igual modo, é possível a adoção de outras técnicas de agregação, como é o caso do test-case ou bellwether trial (casos-teste), na forma prevista no sistema jurídico estadunidense.

Nessa última técnica, há seleção de uma amostra com um ou mais casos representativos da controvérsia, os quais apresentam as mesmas questões de fato e/ou de direito controvertidas no grupo. O comando normativo, formado no caso-teste, é, posteriormente, reproduzido nos casos sucessivos, com a eficácia preclusiva, própria da coisa julgada. Ou, em outras hipóteses, a técnica é utilizada apenas para melhor conhecer a controvérsia de massa, como se fosse um indicador/termômetro dos interesses ou direitos comuns que envolvem os membros do grupo. ${ }^{130}$

Só é preciso tomar cuidado para não confundir, agora, o caso-teste com a teoria do precedente. O caso-teste é uma técnica de agregação, assim como a ação coletiva, que visa à adjudicação unitária da controvérsia de massa, obstando a sua contínua rediscussão. Trata-se de instrumento processual que busca extrair uma amostra representativa da controvérsia do grupo, seja de fato, seja de direito. A vinculação pelo precedente, por sua vez, não esfria o debate da agregação, pois a teoria do precedente é uma categoria geral, aplicável tanto ao processo individual, quanto coletivo, é limitada à regra de direito e não visa alcançar uma amostra representativa do grupo.

Não se pode perder de vista, portanto, os aspectos subjacentes da agregação: (i) a necessidade de se investigar a relação substantiva do grupo, da qual se extraem as características

129 Em sentido similar: BONE, 1990, p.218.

130 Nos test cases ou bellwether trials, há uma preocupação em se colher uma amostra representativa do universo coletivo de casos semelhantes. A finalidade do julgamento do caso-teste pode ser preclusiva, para evitar a rediscussão das questões comuns controvertidas no grupo ou, ainda, pode ser informativa. Nesse último caso, o objetivo é melhor conhecer o universo coletivo do grupo. Depois do conhecimento e do julgamento levado a efeito no caso-teste, surge um indicador suficiente para informar os interesses e as questões comuns do grupo e, ainda, incentiva-se as partes à formulação de um acordo, já que agora elas já sabem o resultado de uma demanda relativa à mesma controvérsia (cf. NAGAREDA, Richard A. The law of class action and other aggregate litigation. New York: Foundation Press, 2009, p.542). 
homogêneas que o definem em abstrato; (ii) a necessidade de se analisar o grau de coesão entre o indivíduo e o grupo, a definir a técnica processual adequada e o seu regime jurídico.

Por fim, é importante salientar que as técnicas processuais de agregação dirigem-se ao processamento e à resolução unitária da controvérsia de massa e ao atendimento dos escopos do processo. Os instrumentos de agregação são variados e cada um deles tem seu espaço próprio no sistema, adaptando-se às diferentes situações da vida coletivas ou plurissubjetivas.

Discute-se hoje, no Brasil, por exemplo, um Novo Código de Processo Civil, em que instrumentos diversos de agregação, como a conversão de ações individuais em ações coletivas ou como o incidente de resolução de demandas repetitivas (que se aproxima da técnica do casoteste), são estudados e anunciados com entusiasmo pelos processualistas. Há espaço para todos.

Propostas como essa apenas reforçam a necessidade de se investigar o tema das ações coletivas e de outras técnicas de agregação, verificando em que circunstâncias elas são adequadas e necessárias à resolução da controvérsia de massa e, por fim, as possibilidades e os limites em se adotá-las no sistema brasileiro - é o que se pretende investigar no decorrer do trabalho.

Esses pontos serão retomados posteriormente. Por ora, o que é importante destacar é que essas questões, surgidas na modernidade, são ainda discutidas. E, reclamam, nessa medida, uma teoria que não foi plenamente desenvolvida e continua a merecer nossa atenção hoje.

\subsubsection{PERÍODO CONTEMPORÂNEO}

A existência de um grupo de interessados na mesma controvérsia de direito substancial não é nova. Está presente há muito tempo, na estrutura gentílica romana, nas aldeias medievais e, até mesmo, no próprio período moderno, segundo as possibilidades e os limites antes citados.

Isso ocorre em razão de um fato social incontornável, os homens cooperam. O indivíduo não nasce desprovido de qualquer laço com um grupo, tampouco ele escolhe todos os vínculos que forma na vida. Ele nasce em uma família, em um bairro, em uma economia, em um país, sob uma religião e, nada disso, foi por ele escolhido, tampouco houve manifestação de adesão. ${ }^{131}$

131 Em sentido semelhante, Michael Sandel salienta que não é possível pensar em um sujeito completamente desenraizado e sem qualquer referência coletiva. No mesmo sentido, Daniel Sarmento salienta que o indivíduo 
Muito embora o indivíduo seja livre para realizar suas escolhas pessoais e estabelecer o seu modo de vida, afastando-se dos grupos que não mais lhe interessam, mantém ainda, em maior ou menor grau, uma intercessão com os grupos nos quais optou conviver, bem como laços de cooperação, pertencimento, solidariedade e interesses compartilhados na sociedade, mormente nos casos de persecução de bens comuns, necessidades e vulnerabilidades semelhantes.

Ninguém escolhe ser lesado por uma droga, por um produto, por uma prática ou por uma política pública. Mas, quando isso ocorre de forma comum entre vários indivíduos, é possível que isso altere o curso das histórias individuais e os una por razões de solidariedade e reciprocidade, que eles jamais escolheram ou quiseram. Isso implica, por vezes, a formação de uma identidade no grupo, com a coesão dos interesses e com vínculos interindividuais. ${ }^{132}$

São esses interesses comuns e laços de pertencimento que se sucederam, no mundo jurídico, em direitos e obrigações, também comuns a uma pluralidade de pessoas. Logo, quando surgia uma controvérsia de massa, envolvendo esses direitos e obrigações, um processo, com igual dimensão, se fazia e, ainda, se faz necessário. É, nesse contexto, que o debate sobre a agregação processual assume maior relevância para atuação do direito substancial coletivo ou plural.

O fenômeno não é, portanto, contemporâneo. Mas, ao menos, pode-se dizer que a sua dimensão é. Globalização, conglomerados econômicos, mercados financeiros interligados, empresas transnacionais, avanços tecnológicos nas comunicações e na informática, redes sociais, tudo isso, segundo Daniel Sarmento ${ }^{133}$, encurtou as fronteiras e fragilizou o Estado, que, agora, tem menos condições de condicionar as forças presentes em seu território. O contraponto disso - do enfraquecimento estatal - é o fortalecimento, mais uma vez, na história das coletividades.

\footnotetext{
continua sendo 'a medida de todas as coisas', como dizia Protágoras, e sua autonomia está salvaguardada, mas não se pode esquecer que ele é um ser concreto, que se relaciona com outros sujeitos, mormente nos casos de fragilidades e carências (Cf. SANDEL, Michael. Liberalism and limits of justice. 2 ed. Cambridge: Cambridge University Press, 1998, p.121 e SARMENTO, Daniel. Livres e iguais: estudos de direito constitucional. Rio de Janeiro: Lumen Juris, 2006, p.65).

132 Nesse sentido, defende Elisabeth Chamblee Burch, que acrescenta, ainda, que a comunidade que se forma hoje não é mais geográfica, como ocorria entre as aldeias medievais ou com as comunidades tribais e religiosas, mas decorrentes de uma mesma prática, de um mesmo problema ou de uma mesma vitimização (Cf. BURCH, Elisabeth Chamblee. Group Consensus, Individual Consent. The George Washington Law Review, V. 79: 506541, p. 521-522. BURCH, Elisabeth Chamblee. Aggregation, community, and the line between. Kansas Law Review, 2010, V.58:889-916p).

133 SARMENTO, 2006, p. 46. No mesmo sentido, José Eduardo Faria (Cf. FARIA, José Eduardo. A definição do interesse público. In: SALLES, Carlos Alberto de (org.) Processo Civil e Interesse Público: o processo com o instrumento de defesa social. São Paulo: Revista dos Tribunais, 2003, p. 86).
} 
O fortalecimento dos grupos não deixou de ser percebido pelo direito. Superado o pavor de se retornar ao antigo regime medieval, cujas tendências comunais obstavam a autonomia e a competição dos indivíduos no mercado, surgem, agora, novas coletividades. De um lado, associações, sindicatos, partidos políticos, novas formas empresariais e, de outro lado, minorias e grupos submetidos às mesmas práticas ou às mesmas vulnerabilidades, como os consumidores, os afrodescendentes, os cortiçados. ${ }^{134}$ Surge, de novo, um pluralismo no direito.

As Constituições Federais, de uma forma geral, mormente depois das redemocratizações ocorridas na Europa e na América Latina, assimilaram esse pluralismo e, também, equacionaram, sob o ponto de vista jurídico, as relações substanciais entre o indivíduo e a comunidade - ao incorporar valores e princípios como solidariedade, justiça distributiva, igualdade, função social da propriedade, função social do contrato, os direitos coletivos. ${ }^{135}$

O indivíduo, que antes foi ícone da modernidade, continua com o seu espaço preservado, podendo orientar sua vida e suas escolhas. Mas, há, agora, o reconhecimento e a valorização de uma intersecção inerente entre os interesses desses indivíduos e de grupos, em razão de laços de pertencimento e cooperação. Se, antes, a relação era de tensão, agora se admite a convergência e a coordenação dos indivíduos em torno dos mesmos interesses ou direitos.

Para o processo civil, o reconhecimento dessa conexão ou interdependência no plano material, ensejou o aprimoramento dos instrumentos processuais, dentre eles, as técnicas de agregação.

Essas técnicas permitem a adoção de um processo com a mesma dimensão da controvérsia de direito substancial, restabelecendo a simetria entre substância e processo, com reflexos processuais relevantes na eficiência processual, na economia e na uniformidade dos resultados.

134 Nesse sentido, a Professora Ada Pellegrini Grinover, em um estudo seminal sobre os direitos coletivos no sistema jurídico brasileiro, apontou que, diante de uma violação de massa, o indivíduo lesado pode se encontrar em uma situação inadequada para reclamar contra o prejuízo pessoalmente sofrido. Nesse contexto, surgem os grupos ou os corpos intermediários, conscientes da comunhão de interesses e das fragilidades individuais que obstam a persecução pessoal do direito alegado. Multiplicam-se, assim, as associações de consumidores, de amigos do bairro, de pequenos investidores, que se unem para a proteção e defesa dos interesses ou direitos comuns. Nesse contexto, novos tipos de tutela hão de ser encontrados, não somente para esses grupos, mas também para as pessoas físicas envolvidas na mesma controvérsia de massa (Cf. GRINOVER, Ada Pellegrini. A tutela jurisdicional dos interesses difusos. Revista de Processo, V. 14-15, São Paulo: Revista dos Tribunais, abr/set.de 1979, p. 28-29). 135 Em sentido semelhante, Daniel Sarmento e Rodolfo de Camargo Mancuso revelam que a Constituição Federal Brasileira de 1988 deu guarida aos valores de solidariedade, cooperação, igualdade e democracia participativa (Cf. SARMENTO, 2006, p. 63; MANCUSO, 2011, p. 46). 
Os instrumentos de agregação, como as ações coletivas, o caso-teste e outras técnicas, ao adotarem a mesma dimensão da controvérsia de direito substancial, podem ensejar a compensação integral do dano, o desestímulo à prática ofensiva e, ainda, uma função redistributiva ${ }^{136}$, devolvendo ao grupo a força que antes foi pulverizada. Contribui, por fim, com os reflexos processuais antes mencionados na eficiência, na economia e na uniformidade.

Com o recente processo de massificação, de grandes proporções e até transnacional, nem o Estado, nem o mercado conseguiram mais concentrar forças e reger, integralmente, os comportamentos dos grupos sociais. Novas práticas sociais e econômicas surgem de forma dispersa e fragmentada, sem que sejam consideradas, por vezes, ex ante em uma norma. ${ }^{137}$

Se todos os indivíduos, prejudicados por essas práticas comuns, pleitearem, individualmente, será difícil verificar o impacto disso no plano coletivo, no sentido de restaurar a ordem violada e alterar a prática ofensiva ou lesiva para todos os afetados. Os indivíduos, no entanto, poderão maximizar, egoisticamente, os resultados da sua demanda. Dessa forma, é possível que cada um se aproprie individualmente de algo pensado a partir de um todo - o que não é adequado à exigência constitucional de igual respeito e consideração aos interessados de um mesmo grupo.

Por exemplo, uma política pública de saúde e um concurso público são pensados, em regra, de forma central e paritária para todos os interessados. Há uma tabela de medicamentos disponíveis e um edital de concurso, os quais são aplicáveis, de forma isonômica, a todos os pacientes da rede pública de saúde e a todos os candidatos do concurso público. Se essa tabela de medicamentos ou o edital do certame vierem a ser questionados, individualmente, pleiteandose, por exemplo, um medicamento de tecnologia mais avançada ou os pontos de uma questão

136 Carlos Alberto de Salles salienta, em boa hora, que a justiça corretiva tem por escopo restaurar a ordem violada, parcialmente destruída por uma ação injusta de outrem. A justiça distributiva, por sua vez, é aquela que define a ordem protegida pela justiça corretiva, isto é, como se realiza a alocação individual de recursos comuns ou como se realiza a alocação de benefícios e ônus entre as pessoas (Cf. SALLES, Carlos Alberto de. Entre eficiência e a equidade: bases conceituais para um Direito Processual Coletivo. In: FIGUEIREDO, Guilherme José Purvin e RODRIGUES, Marcelo Abelha (coords.). O Novo Processo Civil Coletivo. Rio de Janeiro: Lumen Juris, 2009, p. 65-66). Valendo-se disso, pode-se dizer que a agregação processual permite a manutenção da justiça corretiva em consonância com a justiça distributiva no tocante aos direitos substanciais coletivos, pois permite alocar, individualmente, recursos (corrigindo um direito violado), tendo em mente, ainda, a dimensão comum ou coletiva da distribuição desses recursos (ordem protegida pelo direito) na qual essa alocação será realizada.

137 José Eduardo Faria é preciso ao salientar a incompatibilidade entre a crise social e a crise do direito, pois a sociedade descola-se do direito e vai caminhando numa linha absolutamente inédita. O Estado é incapaz de criar, previamente, uma norma para regular cada segmento social, setor ou sistema diferenciado da sociedade brasileira e intervém por meio de princípios. A textura aberta dos princípios permite, por sua vez, a revitalização da livre negociação, do direito privado, do direito contratual, variáveis que não foram considerados no processo normativo (Cf. FARIA, 2003, p. 86). 
da prova objetiva que foi elaborada em discordância ao edital, e se isso for realizado sem a consideração ao alcance coletivo da controvérsia, a paridade originária existente entre os interessados, por força do direito substancial, poderá vir a sucumbir. A agregação, nessa hipótese, reinsere a controvérsia no plano coletivo, conferindo uma visão ampla de seus efeitos no grupo e tratando os interessados na controvérsia com igual respeito e igual consideração.

Do mesmo modo, se não houver interesse ou força para litigarem sozinhos, há o risco de a prática ofensiva permanecer sem reparação. Não houver interesse porque o dano fragmentado entre os indivíduos foi ínfimo. Não houver força porque o dano foi disperso, de forma a ser complexo, por exemplo, imputar o nexo de causalidade a um mesmo agente causador. Exemplo disso são os casos em que a etiologia de uma doença, como o câncer, é ainda desconhecida. Nessa hipótese, a causalidade somente é aferida em estudos epidemiológicos de grupo e não em casos clínicos individuais, sendo impraticável aferir o nexo de causalidade para o indivíduo.

A função redistributiva e os demais objetivos da agregação serão retomados no momento oportuno. É relevante, no entanto, consignar que a agregação, ao pensar sob o ponto de vista coletivo ou do status do grupo, fornece uma visão mais ampla da controvérsia e de seus impactos nos demais membros da coletividade. Com isso, permite otimizar, ou melhor, equacionar os interesses envolvidos e, ainda, realizar a reparação integral do dano causado.

Mas, depois de muita tinta gasta, da revalorização das relações substanciais entre o indivíduo e a coletividade e da elaboração de novos instrumentos de solução de conflitos, sobretudo técnicas processuais de agregação, alguns problemas teóricos e processuais ainda persistem.

Ainda é preciso estabelecer um link ou uma equivalência entre o indivíduo e a comunidade, de forma que a agregação seja a técnica necessária e adequada ao direito substancial coletivo ou plurissubjetivo, cujas controvérsias envolvem uma pluralidade de interessados. Essa agregação, de todo modo, não deverá impor gravames à autonomia individual, no sentido de ser o indivíduo um sujeito autônomo para litigar aquilo que lhe é próprio ou particular: a sua própria história.

O processo não pode se submeter integralmente à autonomia individual - no que se aproximaram os modernos - no sentido de tudo ser exclusivamente individual. Do contrário, tratar direitos e obrigações, que envolvem uma pluralidade de pessoas em um processo 
individual, seria tarefa árdua e, de todo modo, inadequada com relação à atuação do direito substancial coletivo e aos escopos do processo, como efetividade, economia e uniformidade.

O processo também não pode ceder, integralmente, ao apelo coletivista - no que se aproximaram os medievais - porque, do contrário, tratar as relações propriamente individuais em um processo coletivo poderia, por vezes, obstar o indíviduo de narrar a sua própria história, que pode não coincidir com os interesses ou direitos comuns ou ser contrária à história do grupo.

Nesse ínterim, o processo e as técnicas de agregação pendem entre os planos individual e coletivo, conforme o grau de oposição ou de identidade entre os interesses do indivíduo e do grupo ou, noutros termos, conforme se identifica uma relação substancial individual ou uma relação substancial plurissubjetiva ou coletiva, atinentes a uma pluralidade de interessados.

Assim, ora adota-se instrumentos mais consensuais, em que o próprio indivíduo opta ou consente com agregação processual, seja de forma expressa, seja de forma implícita, ora adotase instrumentos menos consensuais. No último caso, desde que seja identificada uma zona de convergência de interesses, em que o indivíduo atua na qualidade de membro do grupo, isto é, de forma impessoal e indiferenciada aos seus atributos particulares, singulares e específicos.

É preciso, então, investigar como os sistemas jurídicos processuais estabeleceram esse link entre o indivíduo e o grupo e, a partir disso, realizaram a correta identificação do direito substancial coletivo, de forma determinar a técnica de agregação aplicável e o seu regime jurídico.

Segue-se, adiante, com uma análise do sistema jurídico estadunidense e brasileiro. Nesse momento, o objetivo é examinar apenas o "estado da arte" desses sistemas, no tocante ao desenvolvimento das ações coletivas e de outras técnicas de agregação, bem como a relação desses instrumentos de agregação com os direitos substanciais coletivos ou plurissubjetivos. Essa comparação não para por aqui, muito pelo contrário, acompanha toda a investigação.

\subsection{SÍNTESE PARCIAL}

Foi possível constatar, depois a análise histórica da litigiosidade de massa e da agregação processual, a recorrência, ao longo do tempo, de controvérsias de massa e de situações do 
mundo da vida compartilhadas ou, em alguma medida, interligadas no plano do direito substancial. Os direitos coletivos ou plurissubjetivos não são tão novos como se poderia pensar.

E, de igual modo, os direitos substanciais coletivos ou plurissubjetivos não apresentaram, necessariamente e em todos os momentos históricos, um mesmo critério de identificação. Ora, adotava-se um critério subjetivo, isto é, a qualidade de quem defende esse direito em juízo, ora adotava-se um critério objetivo, a saber, a propriedade incindível do objeto controvertido.

$\mathrm{Na}$ ação popular romana, por exemplo, ora o direito substancial pertencia ao próprio indivíduo, na qualidade de membro de uma comunidade, e a ação proposta apresentava alcance coletivo, em favor de toda a comunidade associada, ora o indivíduo defendia um direito titularizado pela própria coletividade, a partir do momento em que melhor desenvolvida a noção de Estado como uma entidade própria. As duas modalidades de ação popular conviviam, pari passu, no sistema.

Nas ações medievais, embora predominasse com mais veemência o plano coletivo - não limitado apenas a uma determinada ação, como ocorria na ação popular romana- a identificação da relação jurídica de direito substancial também não apresentava sempre uma propriedade objetiva. O que era coletivo, não era algo que, necessariamente, tivesse uma propriedade inerente, como é o caso da indivisibilidade de um objeto, a que a todos pertencem e não é suscetível de apropriação exclusiva por alguém. Por vezes, o que era coletivo era, sim, cindível na prática, mas deveria, por força dos costumes da época, ser tratado, coletivamente, no grupo.

A propriedade era, por exemplo, dividida por quinhões de terra, todavia o alcance das ações que, porventura, discutissem esses quinhões de terras era necessariamente coletivo, por força, dos costumes e da organização paritária dessas comunidades. Não se poderia decidir a respeito da propriedade de um, sem que isso afetasse ou envolvesse as faixas de terra de todos os outros interessados daquela comunidade (aldeia). Logo, quando um aldeão litigava, ele o fazia indiferentemente às suas qualidades pessoais e de acordo com os atributos impessoais do grupo.

E, por muitas vezes, as Cortes de Justiça decidiram essas controvérsias de massa não apenas em favor dos sujeitos que figuravam formalmente no processo, mas de forma a alcançar também todos os demais interessados na mesma controvérsia de direito substancial, decidindo, com isso, a questão controvertida de modo homogêneo e vinculante para todos os membros do grupo. 
No período moderno, essas controvérsias ainda existiam, mas foram camufladas, por vezes, pela doutrina da necessary parties e indispensable party ou pela aplicação do precedente, de forma a disfarçar a autoridade da coisa julgada incidente sobre os membros ausentes do grupo.

Assim, ou propugnava-se pela inclusão ou consentimento de todos os interessados na demanda, ou admitia-se a ação coletiva, tratando a prática do grupo como questão de direito, e aplicando o precedente, formado no julgado coletivo, sucessivamente aos demais membros do grupo. Mas, mesmo quando a ação coletiva é admitida nesses moldes, isso ocorre por razões de conveniência, afastando-se a agregação fundamentada na natureza do direito substancial.

No período contemporâneo, há uma revalorização das relações substanciais que afetam uma pluralidade de interessados no plano do direito material. Mas, nem por isso, a relação indivíduo e comunidade foi plenamente resolvida. Admitem-se agora direitos coletivos e direitos individuais, mas o binômio individual e coletivo ainda não encontrou fórmula plenamente clara ou suficiente. Há ainda, nessa medida, uma incerteza quanto à amplitude dos direitos alegados.

Não é raro que se suceda nas Cortes de Justiça um vaivém entre os planos individual e coletivo, o que causa incerteza e, por conseguinte, erige obstáculos à solução molecularizada ou agregada da controvérsia de direito substancial. Enfatiza-se, por vezes, e ainda, a questão de quem poderá litigar um direito (processo) e não se o direito pretendido existe ou não existe (substância).

Mesmo que essa dicotomia seja superada, é preciso explicitar um fundamento pelo qual os interesses comuns de um indivíduo e de uma comunidade possam ser associados ou agregados para fins de serem litigados conjuntamente em juízo, sem prejuízo à autonomia individual, isto é, sem prejuízo de o indivíduo narrar as suas próprias peculiaridades, que podem coincidir ou não com os interesses do grupo como um todo ou podem, até mesmo, contrariar àqueles.

Esse é o cerne do presente trabalho - a agregação ótima. Consiste em investigar os pressupostos necessários e adequados ao manejo das técnicas de agregação processual, sem gravames à autonomia individual, a saber, o ponto em que o indivíduo é um anônimo no meio da massa. 


\section{DA AÇÃO DE CLASSE À AGREGAÇÃO PROCESSUAL}

O mecanismo mais clássico de agregação processual é o mecanismo representativo, a saber, a ação coletiva ou ação de classe. Mas, essa não é a única técnica de agregação. Abordam-se, cada vez mais, outras técnicas e instrumentos, cujos objetivos são reunir, processar e, por vezes, julgar, de forma unitária, a controvérsia de massa, evitando-se, assim, soluções fragmentadas.

A temática da agregação processual, bem mais ampla que a das ações coletivas, já é uma parte integrante e relevante do processo civil estadunidense. O mesmo tema também vem crescendo no sistema jurídico brasileiro, pela proposição e elaboração de novas técnicas e mecanismos de estruturação "molecular" 138 da controvérsia de massa, de forma simétrica ao direito substancial.

\subsection{APRESENTAÇÃO}

A litigância agregada é matéria, ainda, muito recente, que motivou, no sistema estadunidense, a elaboração de um projeto pelo American Law Institute, concluído em 2010. Trata-se dos "Princípios de direito: da litigância agregada" ${ }^{139}$, destacando-se, entre os seus principais autores, os juristas Samuel Issacharoff, Richard Nagareda, Charles Silver e Robert Klonoff.

O propósito desse projeto foi identificar técnicas e instrumentos processuais para lidar com a litigância agregada, bem como mecanismos de governança procedimental, de forma a promover a eficácia e a eficiência daquelas técnicas e instrumentos. De igual modo, a experiência demonstrou a necessidade de o design procedimental apresentar-se em consonância aos contornos do direito substancial, restabelecendo, com isso, a simetria entre direito e processo. ${ }^{140}$

Esse projeto não é o marco final da agregação, muito pelo contrário, é o marco inicial de inúmeras discussões acadêmicas e de congressos profissionais a respeito da temática ${ }^{141}$. A

138 WATANABE, Kazuo. Demandas coletivas e os problemas emergentes da práxis forense. Revista de Processo, v. 67, São Paulo: Revista dos Tribunais, jul./set. de 1992, p. 15.

139 UNITED STATES OF AMERICA. The American Law Institute. Principles of the law: aggregate litigation. St. Paul, MN: American Law Institute Publisher, 2010.

140 Ibidem, p. 1.

141 Roger H. Trangsrud relatoria congresso sobre a agregação processual no sistema estadunidense realizado em março de 2010, expondo as principais ideias dos artigos apresentados nos painéis (Cf. TRANGSRUD, Roger H. Aggregate litigation: critical perspectives. George Washington University Law School, 2011, V. 79:293-305p). 
matéria é, ainda, muito nova e objeto de intensos debates. O projeto, antes citado, veio apenas a consolidar as discussões então dispersas, bem como realizar propostas de aperfeiçoamento.

No sistema jurídico brasileiro, o desenvolvimento da temática da agregação não foi similar ao sistema jurídico estadunidense, mas pode-se dizer que foi convergente. Busca-se aqui, tanto quanto lá, técnicas e instrumentos para lidar com a litigiosidade de massa, permitindo-se a estruturação "molecular"142 da controvérsia. Sequer é possível dizer que essa discussão é nova, pois, sob o escólio de Kazuo Watanabe ${ }^{143}$, já é, há muito, apregoada a necessidade de agregação processual ou molecularização da controvérsia de massa, afastando-se das soluções atomizadas.

Atualmente, aqui, à semelhança do sistema jurídico estadunidense, existem muitos projetos de lei, no sentido de avançar e aperfeiçoar a estruturação "molecular" ${ }^{144}$ da controvérsia de massa.

Nesse ínterim, o escopo do presente capítulo é expor o estado da arte em que se encontram os dois sistemas coletivos, bem como traçar e sistematizar os tipos de técnicas e instrumentos de agregação de larga escala. O paradigma utilizado para tanto é o sistema jurídico estadunidense, pois, nesse sistema, já há uma categorização - inicial e exemplificativa - das referidas técnicas.

Começar-se-á, nesse momento, pelo estado da arte dos dois sistemas jurídicos. Trata-se do alicerce dogmático sobre o qual se desenvolve, hoje, a problemática da agregação processual.

\subsection{SISTEMA JURÍDICO COLETIVO ESTADUNIDENSE}

Segundo Stephen Yeazell ${ }^{145}$, as ações coletivas inglesas entraram em um estado de hibernação no século XIX. Mesmo assim, a teoria foi transportada para o sistema jurídico estadunidense, lá originando as class actions (ações de classe) e, ao lado delas, outras técnicas de agregação.

142 WATANABE, 1992, p. 15.

143 Ibidem, p. 15.

144 Ibidem, p. 15.

145 YEAZELL, 1987, p. 196. No mesmo sentido, Aluísio Gonçalves de Castro Mendes afirma que as ações de classe declinaram na Inglaterra entre os anos de 1750 e 1850, em razão da expressiva formalização das corporações como pessoas jurídicas e da adoção de soluções legislativas, elaboradas para a solução dos conflitos existentes entre os membros dessas corporações (Cf. MENDES, Aluísio de Castro. Ações Coletivas e Meios de Resolução Coletiva de Conflitos no Direito Comparado e Nacional. 3 ed. rev. atual. amp. São Paulo: Revista dos Tribunais, 2012, p. 51 (Temais Atuais de Direito Processual Civil, V. 4)). 
Embora as ações coletivas correspondam à técnica de agregação, existente no sistema jurídico estadunidense, mais conhecida entre nós, existe uma série de outros instrumentos processuais voltados à agregação. São técnicas de agregação: (i) o litisconsórcio (joinder); (ii) as hipóteses de intervenção de terceiros e de pluralidade de partes, quando há vários possíveis credores de um mesmo bem (intervention e interpleader); (iii) o caso-teste (test case ou bellwether trial); (iii) a consolidação ou reunião de demandas individuais (consolidation); (iv) a coordenação informal de demandas individuais (informal coordination); (v) a consolidação de demandas dispersas nos distritos da justiça federal (multidistrict litigation) e (vi) técnicas extrajudiciais de composição. Todas voltadas ao processamento, instrução e/ou resolução unitária da lide. ${ }^{146}$

A tendência hoje, no sistema jurídico estadunidense, é, no entanto, enfatizar a agregação processual de larga escala. Corrobora-se essa tendência, especialmente, naquelas hipóteses em que os instrumentos mais simples de pluralidade de partes, como o litisconsórcio e a intervenção de terceiros, configuram resposta jurisdicional insuficiente, dado o grande número de sujeitos interessados na controvérsia de direito substancial ${ }^{147}$. Para os propósitos do presente trabalho, são as técnicas de agregação de larga escala aquelas de maior interesse para fins de comparação.

Nesses casos, em que litigiosidade de massa assume foros de larga escala, o objetivo dos instrumentos processuais de agregação dirige-se a agregar as narrativas individuais, de forma a estabelecer uma única narrativa coletiva, seja pela atuação de um portador ideológico do grupo em juízo (class action), seja pela reunião das demandas (consolidation ou coordination), seja pelo julgamento de uma amostra representativa da controvérsia do grupo (test case ou bellwether trial). Com isso, alcança-se uma visão mais ampla da controvérsia e de seus impactos, melhorando o desempenho processual na atuação do direito substancial e na administração da justiça, mais eficiente, econômica e uniforme e, por isso, satisfatória às partes.

Mas, sem embargo dos nobres objetivos, o processo histórico, que culminou nessa tendência de agregação processual, é de evolução lenta. Destaca-se que a recepção da ação de classe inglesa em solo estadunidense foi, de início, bastante hesitante, repleta de idas e vindas.

146 Uma noção breve de cada uma dessas técnicas é encontrada em Manuais de Tutela Complexa (Manual for Complex Litigation) publicado nos Estados Unidos pelo Centro Judiciário Federal (Cf. FEDERAL JUDICIAL CENTER. Manual for Complex Litigation. 4 ed. Washington: Federal Judicial Center, 2004).

147 PACE, Nicholas M. Group and aggregate litigation in the United States. The ANNALS of the American Academy of Political and Social Science, 2009, V. 622: 32-40p. 
Foi preciso adaptar essa técnica de agregação a uma sociedade de massas, de maiores proporções, quando ainda se trabalhava com conceitos eminentemente individualistas. Houve um esforço da doutrina, da jurisprudência e da legislação nesse sentido, mas com alguns contratempos - é bem verdade - o que se descreverá adiante em um breve esboço da técnica. ${ }^{148}$

Um dos principais responsáveis pela introdução das ações coletivas no sistema jurídico estadunidense foi Joseph Story, cuja menção é unânime entre os processualistas estadunidenses.

A compreensão de Story sobre as ações coletivas era, no entanto, segundo Hazard Jr. ${ }^{149}$, muito limitada às hipóteses em que as ações coletivas beneficiavam o indivíduo, membro ausente do grupo. A hipótese clássica disso ocorria quando os danos pessoalmente sofridos eram ínfimos, razão pela qual os sujeitos não manifestavam interesse na persecução individual. Caso contrário, se o indivíduo viesse a ser prejudicado pelo resultado do julgamento coletivo, ele poderia rediscutir a mesma controvérsia de massa, agora em uma clássica demanda individual.

Nas ações coletivas, não era preciso - por óbvio - observar as doutrinas da necessary party e/ou indispensable party. As ações coletivas eram admissíveis, em exceção àquelas doutrinas. Mas, caso o indivíduo não se sentisse beneficiado pelo julgado coletivo e pretendesse impugná-lo em juízo, bastaria a propositura de uma ação própria para desvincular-se daquele resultado. Isso era, pois, a exceção da exceção. O litisconsórcio era excepcionado pela ação coletiva, caso fosse impraticável a reunião dos indivíduos em uma mesma demanda. Porém, em seguida, a ação coletiva também era excepcionada pela participação individual, caso sucumbente o indivíduo. ${ }^{150}$

A primeira codificação das ações de classe seguiu, por sua vez, esse raciocínio de Joseph Story. Ela ocorreu em 1842 pela Rule $48^{151}$ e era aplicável apenas à jurisdição da equidade (equity). A vinculação dos membros ausentes da classe (binding effect), por força da ação coletiva, foi vedada nesse momento. O resultado do julgado não poderia, pois, prejudicar quem não figurasse formalmente na demanda coletiva, sendo plenamente possível ao indivíduo, reacender o debate.

148 Um histórico detalhado de cada codificação pode ser conferido na obra de Robert H. Klonoff (Cf. KLONOFF, Robert H. Class actions and other multi-party litigation. Minneapolis: Thomson West, 2007, p.17-24).

149 HAZARD JR et al, 1998, p. 1879. No mesmo sentido é a crítica de Stephen Yeazell (Cf. YEAZELL, 1987, p.18-219).

150 HAZARD JR, 1998, p. 1879.

151 KLONOFF, 2007, p. 17. 
Posteriormente, a Suprema Corte admitiu a vinculação dos membros ausentes do grupo ao julgado coletivo no precedente Smith v. Swormsted $t^{152}$, mesmo sem amparo legal. Somente em 1912, essa vinculação foi admitida pela Rule 38, ainda na jurisdição de equidade. Essa alteração normativa suprimiu a vedação anteriormente contida na Rule 48, admitindo, implicitamente, a vinculação dos membros ausentes do grupo ao julgado coletivo, fosse ele favorável ou não. ${ }^{153}$

As Cortes de Justiça, apesar da supressão realizada pela Rule 38, continuaram vacilantes no tocante à vinculação dos membros ausentes da classe ${ }^{154}$. Apenas depois do precedente Supreme Tribe of Ben-Hur v. Cauble $e^{155}$, a questão foi consolidada. Na ocasião, os membros ausentes de uma organização beneficente ficaram vinculados ao pronunciamento judicial atinente ao controle e à disposição de fundos da instituição a qual estavam associados.

A codificação atual ocorreu pela Rule 23. Ela foi adotada em 1938, ocasião em que se unificaram as jurisdições comum e de equidade (common law e equity). ${ }^{156}$ Em seguida, sofreu uma alteração substancial em 1966, mormente no tocante às hipóteses de cabimento das ações coletivas (types of class action), questão que será retomada em capítulo posterior deste trabalho.

A Rule 23 sofreu, ainda, pequenas alterações, em 1987 (emendas de redação técnica), 1998 (emenda relativa à interposição imediata de recurso em face da decisão de certificação da ação coletiva), 2003 (emenda relativa ao tempo e à forma de certificação da ação coletiva, à notificação, à aprovação de acordo, à escolha de advogados e honorários) e 2007 (emendas de redação técnica) e também 2009 (emenda de alteração do prazo do recurso interposto em face

\footnotetext{
$152 \mathrm{O}$ precedente diz respeito à cisão da igreja metodista nos Estados Unidos, entre pregadores do sul e pregadores do norte do país, ocorrida durante a tensão pelo fim da escravidão nesse país. A controvérsia se estabeleceu em relação à administração de um fundo pecuniário formado com a venda de artigos religiosos pelos metodistas, cuja gestão havia sido confiada aos administradores da cidade de Cincinnati, norte dos Estados Unidos. Os administradores do fundo, que eram pregadores do norte do país, se recusaram a realizar a remessa dos valores devidos aos pregadores do sul. A decisão proferida pela Suprema Corte afirmou a vinculação de todos os membros ausentes do grupo de pregadores ao julgado coletivo (Cf. UNITED STATES OF AMERICA. Supreme Court of United States of America. Smith v. Swormstedt, 57 US (16 How) 303 (1853)).

153 KLONOFF, 2007, p.17.

154 YEAZELL, 1987, p.225.

$155 \mathrm{O}$ precedente diz respeito à reorganização de um fundo pecuniário de uma instituição beneficente, a saber, Supreme Tribe of Ben-Hur, a qual atravessava uma grave crise atuarial. Uma ação coletiva foi proposta inicialmente por um grupo de associados, os quais sucumbiram na demanda. Mais tarde, uma segunda ação foi proposta, agora por um segundo grupo de associados, formado por outros membros individuais. A Suprema Corte Americana reconheceu a eficácia vinculante da coisa julgada aos membros ausentes do grupo, na segunda demanda (Cf. UNITED STATES OF AMERICA. Supreme Court of United States of America. Supreme Tribe of Ben-Hur v. Cauble, 255 US 366 (1921)).

156 Em sentido semelhante, YEAZELL, 1987, p.225 e MENDES, 2012, p.68.
} 
da decisão de certificação, ampliado de 10 para 14 dias) ${ }^{157}$. Mas, foi em 2005, pelo $C A F A-$ Class Action Fairness Act, que nova alteração substancial foi realizada no tocante à federalização das ações coletivas e também sobre a aprovação de acordos de âmbito nacional.

Segundo o modelo atual, a ação de classe é o procedimento admissível nas hipóteses em que houver uma classe ou categoria identificável, a comunhão de interesses ou direitos, a tipicidade das pretensões e defesas, a numerosidade de interessados, bem como a representação adequada em relação à controvérsia de massa atinente ao grupo, de forma a se tornar impossível a integração de todos na mesma demanda (litisconsórcio) ou impraticável o ajuizamento de múltiplas demandas individuais. Esses requisitos gerais de admissibilidade estão previstos no dispositivo 23(a) (pré-requisitos da ação de classe) e se aplicam a todas as categorias de ação.

O resultado do julgamento vinculará a todos os interessados, seja ele favorável, seja ele desfavorável, basta que os interesses comuns ou compartilhados pelo grupo tenham sido adequadamente representados em juízo. Somente em limitadas circunstâncias, é permitida a exclusão (opt out) do indivíduo, membro do grupo, exigindo-se, para o exercício desse direito, uma notificação (notice), nos limites razoáveis, dos possíveis interessados na demanda coletiva.

Além dos requisitos gerais de admissibilidade supracitados, a ação coletiva deve ser classificada em uma das categorias previstas no dispositivo 23(b). Essa categorização define o regime jurídico aplicável à ação coletiva, como a existência do direito de autoexclusão e notificação.

Os critérios metodológicos adotados para fins de identificação das categorias (types of class action) em que são admitidas as ações coletivas, nesse sistema jurídico, são os seguintes ${ }^{158}$ :

157 UNITED STATES OF AMERICA. Rule 23. Federal Rules of Civil Procedure. Washington: US Government Printing Office, 2010.

158 [...] ((b) TYPES OF CLASS ACTIONS. A class action may be maintained if Rule 23(a) is satisfied and if: (1) prosecuting separate actions by or against individual class members would create a risk of: (A) inconsistent or varying adjudications with respect to individual class members that would establish incompatible standards of conduct for the party opposing the class; or (B) adjudications with respect to individual class members that, as a practical matter, would be dispositive of the interests of the other members not parties to the individual adjudications or would substantially impair or impede their ability to protect their interests; (2) the party opposing the class has acted or refused to act on grounds that apply generally to the class, so that final injunctive relief or corresponding declaratory relief is appropriate respecting the class as a whole; or (3) the court finds that the questions of law or fact common to class members predominate over any questions affecting only individual members, and that a class action is superior to other available methods for fairly and efficiently adjudicating the controversy. [...](Cf. UNITED STATES OF AMERICA. Rule 23. Federal Rules of Civil Procedure. Washington: U.S Government Print Office, 2010). 
- 23(b)(1)(A) Quando o processamento de ações individuais separadas criar o risco de pronunciamentos judiciais inconsistentes ou contraditórios, no tocante aos integrantes do grupo, estabelecendo o risco de padrões incompatíveis de conduta em relação à parte adversa. Denominada de incompatible standards class action (ação de classe por incompatibilidade de padrões). O regime jurídico aplicável é o de vinculação obrigatória dos membros ausentes, inexistindo direito de autoexclusão - mandatory class action.

- 23(b)(1)(B) Quando o processamento de ações individuais separadas criar o risco de o pronunciamento judicial em favor de um indivíduo, integrante do grupo, dispor dos interesses dos outros membros da classe, que não são partes na demanda, ou prejudicar e/ou impedir, substancialmente, a proteção desses mesmos interesses. Exemplo disso é a hipótese em que há fundos indenizatórios limitados ou insuficientes para o ressarcimento de todos os interessados. Essa categoria é denominada de limited fund class action ou prejudice class action. O regime jurídico é o de vinculação obrigatória dos membros ausentes, inexistindo direito de autoexclusão - mandatory class action.

- 23(b)(2) Quando a parte adversa à classe agir ou recusar-se a agir com fundamento aplicável à classe, tornando-se apropriado que o remédio jurídico final, provimento injuntivo (obrigação de fazer ou não fazer ou injunctive relief) ou provimento declaratório (declaratory relief), seja adotado para a classe como um todo. Essa categoria é denominada de injunctive class action ou declaratory class action. O regime jurídico aplicado a essa categoria é o de vinculação obrigatória dos membros ausentes do grupo, inexistindo direito de autoexclusão dos indivíduos- mandatory class action.

- 23(b)(3) Quando houver predominância de questões comuns de fato e/ou de direito em relação às questões individuais e a ação coletiva apresentar superioridade em relação aos demais instrumentos processuais disponíveis para o julgamento justo e eficiente da controvérsia. Somente, nessa última hipótese, há direito de autoexclusão do indivíduo (opt out) e, também, é obrigatória a notificação (notice) dos interessados, para fins de 
exercício daquele direito. É conhecida pelo nome de class action for damages. Essa modalidade de ação não é de vinculação obrigatória - not mandatory class action. ${ }^{159}$

É importante ressaltar que, nesse modelo, a representação adequada dos interesses do grupo assume relevância, pois é por meio da representação desses interesses por um portador ideológico que os membros ausentes do grupo são considerados e logram, portanto, a apreciação dos seus argumentos em juízo. Por meio da representação, busca-se influenciar a convicção do magistrado no tocante aos interesses coincidentes entre o indivíduo e o grupo. ${ }^{160}$

Essa é a principal diferença entre a ação coletiva e as hipóteses de litisconsórcio (joinder), pois esse último não é representativo, exigindo-se a participação direta das partes interessadas. $\mathrm{O}$ grupo ou a classe é, por sua vez, uma entidade própria e autônoma, diversa da mera reunião de demandas e/ou indivíduos, daí decorre a possibilidade de representação. É conhecida a menção de Shapiro à categoria como entidade própria. Nesse caso, a representação na ação coletiva é possível, porquanto a controvérsia diz respeito ao próprio grupo e não aos seus indivíduos. ${ }^{161}$

A representação, na ação coletiva, ocorre não porque o representante conhece as especificidades dos argumentos individuais. Ela ocorre porque não há, ao menos em parte (questão comum), especificidades, particularidades ou singularidades dos sujeitos interessados. $O$ indivíduo apresenta-se, assim, como membro do grupo ou da categoria. Os atributos individuais, objeto de uma ação coletiva, são aqueles que coincidem com os atributos comuns do grupo. $O$ centro de cognição da controvérsia é o próprio grupo.

De igual modo, a vinculação dos membros ausentes do grupo (binding effect) ocorre por força da adequada representação, que ensejou a consideração dos argumentos pertinentes ao grupo como um todo. Os membros ausentes tiveram, assim, o seu "day in court", pois seus argumentos

159 Somente nessa última categoria, há direito de autoexclusão e notificação dos membros ausentes do grupo. Nas categorias anteriores, a exclusão dos indivíduos, membros ausentes do grupo, e a notificação do grupo são facultativas, podendo ser deferidos, apenas por força de ordem judicial, considerando a necessidade e a adequação dessas medidas no caso concreto (Cf. HERR, 2012, p. 395).

160 BASSETT, Debra Lyn. Adequacy of class representation. Georgia Law Review, 2004, V. 38:927-989p.

161 SHAPIRO, 1997-1998, p. 917. Em sentido semelhante, Diane P. Hutchinson salienta que a ação de classe não é uma mera reunião de pessoas, agregadas por conveniência. Muito pelo contrário, se há a agregação processual, por um mecanismo representativo da controvérsia, isso ocorre em razão da própria comunhão ou congruência presente na relação substancial existente entre os indivíduos (Cf. HUTCHINSON, Diane Wood. Class action: representation or joinder? The Supreme Court Review, 1983, p. 482 et seq). 
já foram ouvidos, apreciados e julgados. Os atributos do indivíduo, na qualidade de membro do grupo - atributos esses coincidentes com as características do próprio grupo -, já foram considerados, por força da representação ocorrida na ação coletiva, não sendo possível a renovação da discussão, mesmo em sede individual, sobre o tema já decidido e estabilizado.

Caso os argumentos do indivíduo não sejam coincidentes aos do grupo (ausente a adequada representação) ou existam questões pessoais e singulares, o indivíduo pode ajuizar a sua demanda individual, afastando eventual julgado coletivo, em tese, a ele desfavorável. Nesse caso, é cabível o collateral attack, isto é, um mecanismo de impugnação incidental ao julgado. A existência ou não de preclusão torna-se, portanto, uma questão preliminar à ação sucessiva. ${ }^{162}$

O quadro acima sintetizado não é, todavia, estático. Essa ação suscitou reações favoráveis e desfavoráveis ${ }^{163}$ e novas propostas são continuamente elaboradas e aplicadas, muitas vezes informalmente, nas Cortes de Justiça. Estabelecem-se, com isso, novas tendências em matéria de ações coletivas e, modo geral, de agregação, com o intuito de aprimorar a prestação coletiva.

Ao lado das ações coletivas, outras técnicas de agregação foram desenvolvidas, como já antes se mencionou. É possível adotar, por exemplo, como método de solução unitária e agregada da controvérsia, a reunião de demandas individuais, segundo a técnica da consolidação ou segundo a técnica da informal coordenação, que serão apresentadas, mais tarde, no momento oportuno.

Mas, apenas a título de ilustração, é válido adiantar que, na consolidação, a Corte de Justiça profere uma ordem no sentido de estabelecer um processo mestre (master file), em que serão postuladas e instruídas as questões comuns do grupo. Somente se produzirá nos processos

162 Caso não tenha sido assegurada a adequada representação em juízo, é possível ao membro da classe realizar uma impugnação incidental à coisa julgada coletiva em momento posterior, por meio de uma ação sucessiva. Tratase do collateral attack. Nessa ocasião, o autor busca, preliminarmente, afastar a autoridade da coisa julgada coletiva e a sua eficácia preclusiva, de forma a ensejar a rediscussão da controvérsia para o seu caso individual, alegando não ter sido adequadamente representado no processo coletivo anterior. Por essa razão, ante a ausência de adequada representação, não haveria que se falar em coisa julgada para esse sujeito, autor da demanda individual (Cf. BUENO, Cássio Scarpinella. As class actions norte-americanas e as ações coletivas brasileiras: pontos para uma reflexão conjunta. Revista de Processo. São Paulo: Revista dos Tribunais, V. 82, abr.jun. de 1996).

163 Há quem denomine esse instrumento processual de chantagem legalizada ou de monstro Frankenstein, outros veem nele um benfazejo instrumento de reforma social e institucional. Nesse sentido, são exemplos os seguintes artigos: LANDERS, Jonathan M. Of legalized blackmail and legalized theft: consumer class actions and the substance-procedure dilemma southern. California Law Review, 1974, V. 47:842-900p.; MILLER, Arthur R. Of Frankenstein Monsters and shining knights: myth, reality and "the class action problem". Harvard Law Review, 1979, V. 92:664-694p.; WILTON, Timothy. The class action in social reform litigation: In whose interest? Boston University Law Review, 1983, V. 63:597-641p. 
individuais aquilo que for particular aos casos individuais. Nessa hipótese, a Corte de Justiça apontará um conselho ou um líder que representará a controvérsia comum do grupo em juízo. ${ }^{164}$

Nessa hipótese, não é permitida a exclusão dos indivíduos, mas, a vinculação dos interessados somente se aplica aos casos pendentes em juízo, que foram objeto de consolidação. Não há vinculação aos membros futuros do grupo, porventura envolvidos na mesma questão comum. ${ }^{165}$

A equivalência substancial de interesses entre o indivíduo e o grupo também enseja a agregação pelo caso-teste (test case ou bellwether trial). Nessa hipótese, é selecionada um ou mais casos individuais relativos à controvérsia de massa, a constituir uma amostra representativa da controvérsia, para o fim de orientar a resolução dos demais casos individuais.

Depois desse esboço, é possível perceber que, nessas hipóteses de agregação de larga escala, há sempre uma espécie de representação de interesses ou direitos comuns ao grupo, seja pela atuação de um portador ideológico do grupo, seja pela existência de uma amostra representativa dos interesses ou direitos comuns ao grupo, nos quais o indivíduo e a comunidade convergem.

Logo, para adoção das técnicas de agregação, é preciso compreender o fundamento pela qual é possível a representação dos interesses ou direitos do grupo e, por conseguinte, bem identificar as relações substantivas estabelecidas entre a pluralidade de interessados na controvérsia.

\subsection{SISTEMA JURÍDICO COLETIVO BRASILEIRO}

Os debates quanto à ação de classe estadunidense e o profícuo estudo comparado levado a efeito pelos processualistas italianos na década de 70 influenciaram, inicialmente, a escola processual brasileira. Essa última, posteriormente, construiu um modelo teórico próprio das ações coletivas e das técnicas de agregação processual, mais adequado e aderente a nossa realidade. Sem dúvida alguma, a posição assumida hoje pelo direito processual coletivo brasileiro é de vanguarda.

Mauro Cappelletti, Vittorio Denti, Andrea Proto Pisani, Vincenzo Vigoriti, Michele Taruffo e Nicolo Trockèr, dentre outros expoentes processualistas, capitanearam o movimento em

164 KLONOFF, 2007, p. 407-411. SULLIVAN, E. Thomas et al. Complex litigation. California: LexisNexis, 2009 , p. 381.

165 KLONOFF, op. cit., p. 407-411. SULLIVAN, op. cit., p. 381. 
direção à coletivização da tutela jurisdicional e à revalorização dos direitos materiais coletivos. Suas ideias protagonizaram o Congresso de Pavia em 1974, bem como prosperam até hoje. ${ }^{166}$

Entre nós, a perspectiva de novos instrumentos processuais, que superassem o esquema tradicional e individualista do processo, inaugurou-se pelos debates teóricos entabulados por processualistas de renome como Ada Pellegrini Grinover, Kazuo Watanabe, José Carlos Barbosa Moreira, Cândido R. Dinamarco e Waldemar Mariz de Oliveira. Expoentes, não apenas no campo acadêmico ${ }^{167}$, mas também responsáveis pelos primeiros resultados legislativos.

Conforme expõe Hugo Nigro Mazzilli168, o anteprojeto pioneiro para a defesa dos direitos transindividuais em juízo foi elaborado por Ada Pellegrini Grinover, Kazuo Watanabe, Cândido Rangel Dinamarco e Waldemar Mariz de Oliveira Júnior, os três primeiros são professores ligados ao Departamento de Direito Processual da Faculdade de Direito da Universidade de São Paulo -FADUSP e o último é professor ligado à Pontifícia Universidade Católica de São Paulo - PUC/SP. O anteprojeto foi, posteriormente, enriquecido com as contribuições do Professor José Carlos Barbosa Moreira, professor da Faculdade de Direito da Universidade Estadual do Rio de Janeiro - UERJ, e apresentado à Câmara dos Deputados pelo parlamentar paulista Flávio Bierrenbach (projeto $\mathrm{n}^{\circ}$ 3.034/84). Enquanto isso, as discussões quanto ao anteprojeto originário foram retomadas pelos Professores Antônio Augusto Mello de Camargo Ferraz, Édis Milaré e Nelson Nery Júnior, todos integrantes, à época, do Ministério Público do Estado de

\footnotetext{
166 Nesse sentido, são artigos seminais: CAPPELLETTI, Mauro. Appunti sulla tutela giurisdizionale di interessi collettivi o diffusi. Le azioni a tutela di interessi collettivi: atti del convengo di studio (Pavia, 11-12 giugno 1974) Padova, CEDAM, 1976; DENTI, Vittorio. Relazione Introduttiva. Le azioni a tutela di interessi collettivi: atti del convengo di studio (Pavia, 11-12 giugno 1974) Padova, CEDAM, 1976; PISANI, Andrea Proto. Appunti preliminari per uno studio sulla tutela giurisdizionale degli interessi collettivi (o più esattamente: superindividuali) innanzi al giudice civile ordinario. Le azioni a tutela di interessi collettivi: atti del convengo di studio (Pavia, 1112 giugno 1974) Padova, CEDAM, 1976; VIGORITI, Vincenzo. Interessi collettivi e processo: la legittimazione ad agire. Milano: Dott. A Giuffrè Editore, 1979; TARUFFO, Michele. I limiti soggettivi del giudicato e le "class actions”. Rivista di Diritto Processuale, Padova: CEDAM, volume XXIV (serie II), anno 1969, TROCKER, Nicolò. Gli interessi diffusi nell'opera della giurisprudenza. Rivista trimestrale di diritto e procedura civile. Ano XLI, N. 4, Milano: Dott. A. Giuffrè, dicembre 1987.

167 Nesse sentido, são trabalhos seminais: GRINOVER, Ada Pellegrini. A tutela jurisdicional dos interesses difusos. Revista de Processo, V. 14-15, São Paulo: Revista dos Tribunais, abr./set. de 1979; WATANABE, Kazuo. Demandas coletivas e os problemas emergentes da práxis forense. Revista de Processo, v. 67, São Paulo: Revista dos Tribunais, jul./set. de 1992; MOREIRA, José Carlos Barbosa. A ação popular no direito brasileiro como instrumento de tutela jurisdicional dos chamados "interesses difusos". Temas de Direito Processual. São Paulo: Saraiva, 1977; DINAMARCO, Cândido Rangel. Fundamentos do Processo Civil Moderno I. 6 ed. São Paulo: Malheiros, 2010; OLIVEIRA JR, Waldemar Mariz de. Tutela jurisdicional dos interesses coletivos. In: GRINOVER, Ada Pellegrini (coord.). A tutela dos interesses difusos. São Paulo: Max Limonad, 1984 (Série estudos jurídicos n. 1).

168 MAZZILI, Hugo Nigro. A Defesa dos Interesses Difusos em Juízo: meio ambiente, consumidor, patrimônio cultural, patrimônio público e outros interesses. 20 ed. rev. amp. atual. São Paulo: Saraiva, 2007, p. 115-116.
} 
São Paulo. Essa discussão, com a introdução de propostas e sugestões, originou um novo anteprojeto, o qual foi apresentado ao Governo Federal, por ele encampado e encaminhado ao Congresso Nacional, agora como anteprojeto do Poder Executivo. Esse último projeto foi sancionado e, em seguida, transformado na Lei da Ação Civil Pública de no 7.347/85.

A Lei da Ação Civil Pública foi um marco relevante para a proteção dos direitos transindividuais no direito processual civil brasileiro. Inicialmente, a sistematização trazida pela legislação a respeito dos instrumentos processuais para a defesa de direitos coletivos, em sentido lato, era esparsa e notoriamente insuficiente. A normatização existente referia-se, pontualmente, aos dissídios coletivos na Justiça do Trabalho e às ações populares (Lei $\mathrm{n}^{\circ}$ 4.717/65), limitadas, a essa ocasião, à defesa do patrimônio e também do erário público. ${ }^{169}$

A partir de 1977, com uma alteração no texto das ações populares, ampliou-se seu objeto, incluindo a proteção de bens de valor econômico, artístico, histórico, estético e turístico ${ }^{170}$. Em 1981, pela Lei $n^{\circ}$ 6.938/81, conferiu-se legitimidade ao Ministério Público para ações de responsabilidade por danos atentados contra o meio ambiente. Mas, foi mesmo em 1985, com a Lei da Ação Civil Pública (Lei $n^{\circ}$ 7.347/85), que os direitos substanciais coletivos ou plurissubjetivos encontraram um arcabouço técnico e mais amplo para a sua defesa em juízo. ${ }^{171}$

A Constituição Federal de 1988, por sua vez, ampliou o objeto dos direitos transindividuais e, por fim, o Código de Defesa do Consumidor estabeleceu novas regras e instrumentos processuais aplicáveis à tutela desses direitos de forma iterativa aos demais diplomas legislativos. Juntos, todos esses diplomas constituíram o tão difundido microssistema processual coletivo brasileiro ${ }^{172}$, que constitui, até hoje, o principal guia para os processualistas.

169 MOREIRA, 1977, p. 114. MANCUSO, 2011, p. 63-71. No mesmo sentido, ZUFELATO, Camilo. Coisa julgada Coletiva. São Paulo: Saraiva, 2011, p. 52.

170 MOREIRA, op. cit., p. 114. MANCUSO, op. cit., p. 63-71. ZUFELATO, op. cit., p. 52.

171 Em sentido similar: GRINOVER, Ada Pellegrini. Direito Processual Coletivo. In: GRINOVER, Ada Pellegrini, MENDES, Aluísio Gonçalves de Castro e WATANABE, Kazuo (coords.). Direito Processual Coletivo e o Anteprojeto de Código Brasileiro de Processos Coletivos. São Paulo: Revista dos Tribunais, 2007, p. 11; De igual modo, é válido conferir: LENZA, Pedro. Teoria Geral da Ação Civil Pública. 3 ed. rev. atual. amp. São Paulo: Revista dos Tribunais, 2008, p. 147-154.

172 GRINOVER, 2007, p. 11. 
Todavia, foi no campo das ideias que o desenvolvimento das técnicas de agregação processual ganhou corpo no sistema jurídico brasileiro. Um dos alicerces dogmáticos mais importantes foi revelado na feliz expressão “molecularização” cunhada, em boa hora, por Kazuo Watanabe ${ }^{173}$.

Com isso, o debate da agregação, presente no sistema jurídico estadunidense, revelou-se igualmente relevante e oportuno no sistema jurídico brasileiro, sendo aqui realizado sob a expressão: molecularização/estruturação molecular da controvérsia em oposição à atomização.

Kazuo Watanabe ${ }^{174}$ ressalta que é preciso fugir da estratégia tradicional de resolução de conflitos, que consiste na fragmentação da controvérsia de massa em demandas átomo. A resolução do conflito na dimensão molecular permite melhor atuar o direito material coletivo e conferir peso às ações destinadas à sua solução, evitando sua banalização. E, mais, permitirá um acesso à justiça qualitativo, isto é, mais fácil, mais barato e capaz de superar as barreiras socioculturais. Trata-se de um acesso diferenciado, conforme a natureza da relação substancial.

Essa valorização da dimensão molecular não implica, continua o processualista ${ }^{175}$, desprezo às ações individuais. Constitui, na realidade, uma forma paralela de resolução de conflitos, que deverá adequar-se à natureza da relação de direito substancial coletiva ou plurissubjetiva.

Mas, ao se adotar a estruturação molecular da controvérsia, isto é, a agregação processual, surge a outra face da moeda, qual seja, a possível vinculação dos membros ausentes do grupo que não figuraram formalmente na demanda coletiva. Agregada a controvérsia, por uma ação coletiva, ajuizada por um portador ideológico dos interesses do grupo, quais as consequências disso?

Em regra, em conformidade à teoria de Liebman ${ }^{176}$, há que se distinguir a autoridade da coisa julgada da eficácia natural da sentença. A sentença, como ato de poder do Estado, atinge a todos, mas a autoridade da coisa julgada - indiscutibilidade que se agrega ao comando emergente da sentença - só alcança as partes. Logo, terceiros, juridicamente interessados,

173 WATANABE, 1992, p. 15-23.

174 WATANABE, Kazuo. Do processo individual de defesa do consumidor. In: GRINOVER, Ada Pellegrini, WATANABE, Kazuo e NERY JR., Nelson (coords.). Código Brasileiro de Defesa do Consumidor Comentado pelos Autores do Anteprojeto II. 10 ed. rev. atual. reform. Rio de Janeiro: Forense, 2011, p. 4.

175 WATANABE, 2011, p. 4.

176 LIEBMAN, Enrico Tullio. Eficácia e autoridade da sentença e outros escritos sobre a coisa julgada. Tradução de Alfredo Buzaid e Benvindo Aires. Tradução dos textos posteriores à edição de 1945 de Ada Pellegrini Grinover. Notas e atualização de Ada Pellegrini Grinover. 4 ed. Forense: Rio de Janeiro, 2007, passim. 
podem opor-se, em demanda sucessiva, aos efeitos da sentença, sobre a qual formou-se a coisa julgada anterior, demonstrando a sua irresignação e a pretensão de serem ouvidos em juízo. ${ }^{177}$

É preciso destacar que, segundo Liebman ${ }^{178}$, se a sentença anterior for de improcedência, há interesse de os demais sujeitos interessados ajuizarem suas demandas individuais, para o fim de demonstrar o inconformismo. Se a sentença anterior for de procedência, não há interesse de os demais sujeitos interessados ajuizarem suas demandas individuais, pois houve o exaurimento dos interesses. Não se trata, nessa hipótese, da autoridade da coisa julgada, mas apenas da eficácia da sentença e do interesse em afastar ou não essa eficácia da esfera jurídica do terceiro.

Essa regra comporta, no entanto, exceções diante de situações da vida plurissubjetivas, que afetam uma pluralidade de sujeitos, todos interessados na solução da crise de direito substancial.

Ada Pellegrini Grinover ${ }^{179}$, ao abordar essa temática, ressalta a possibilidade de vinculação dos membros do grupo, na hipótese em que a cognição recair sobre objeto incindível e forem idênticas as situações jurídicas. Trata-se, simplesmente, de observar a natureza das coisas.

Assim, como ocorre no litisconsórcio facultativo unitário e no concurso subjetivo de ações, que versam sobre bens de natureza incindível, é impossível a formulação de regras jurídicas concretas diversas em relação àqueles indivíduos, membros do grupo, que não figuraram, formalmente, na demanda coletiva. Se o contrário fosse admitido, isso implicaria a falência da própria unitariedade, presente no direito substancial, unitariedade essa que deve ser atuada e concretizada - e não esfacelada ou destruída - pela prestação jurisdicional dada ao caso. ${ }^{180}$

177 Liebman dizia que a autoridade da coisa julgada formava-se no tocante à sentença e seus efeitos. José Carlos Barbosa Moreira salienta, no entanto, que Liebman não conseguiu desvincular, totalmente, o conceito de autoridade da coisa julgada do conceito de eficácia da sentença. Por essa razão, conferindo novos rumos à teoria da autoridade da coisa julgada e autonomizando essa teoria do conceito de eficácia, Barbosa Moreira ressaltou que a coisa julgada incide apenas sobre o comando normativo da sentença, não alcançando os seus efeitos. Os efeitos da sentença são mutáveis e podem ser provisórios, não se sujeitando à qualidade de imutabilidade. Exemplo: cônjuges, que hoje se divorciam, amanhã podem restabelecer o vínculo conjugal. (Cf. MOREIRA, José Carlos Barbosa. Ainda e sempre a coisa julgada. Direito Processual Civil (ensaios e pareceres). Borsói: Rio de Janeiro, 1971, p. 139).

178 LIEBMAN, 2011, passim.

179 GRINOVER, Ada Pellegrini. Coisa julgada erga omnes, secundum eventum litis e secundum probationem. Revista Forense, V. 380, jul./ago. de 2005, p. 4-6.

180 GRINOVER, 2005, p. 4-6. 
José Carlos Barbosa Moreira $^{181}$ salienta que, quando a relação jurídica substancial é plurissubjetiva, o resultado não pode deixar de produzir-se a um só tempo e de modo idêntico para todos os titulares em um mesmo polo da relação jurídica de direito processual, pois todas as posições jurídicas individuais se inserem, uniformemente, na situação global. O contrário não poderia ser admitido, sob pena de insubsistência da própria situação global ou coletiva.

Logo, o mestre carioca diz, enfaticamente, que a autoridade da coisa julgada estende-se, sim, aos terceiros, envolvidos na controvérsia plurissubjetiva, ainda que não tenham sido partes. ${ }^{182}$

Para tanto, o que deve ser levado em consideração, para apurar essa vinculação íntima entre os indivíduos, é a regra jurídica concreta sobre a qual incidirá a cognição do juiz. Essa regra concreta deve alcançar, necessariamente, todos os indivíduos que se situam em um mesmo polo da relação jurídica processual (unitariedade), sob pena de insubsistência prática da situação global. Esse raciocínio se aplica tanto para um único processo (litisconsortes virtuais litisconsórcio unitário facultativo), quanto para a hipótese de impugnações simultâneas ou sucessivas (ações concorrentes), com relação a um mesmo objeto incindível. O mesmo raciocínio também se aplica, por sua vez, para a tutela processual coletiva brasileira. ${ }^{183}$

Nesses casos, preconiza-se, em verdade, a extensão subjetiva da coisa julgada a quem não figurou formalmente como parte na relação processual e não apenas a extensão subjetiva da eficácia da sentença. O exemplo clássico disso é da ação de anulação da deliberação assemblear de uma sociedade anônima, por vários sócios, sendo idêntica a causa de pedir e o pedido. ${ }^{184}$

Cassio Scarpinella Bueno ${ }^{185}$ e Vincenzo Vigoriti ${ }^{186}$ bem ressaltam que essa ação de vários interessados, para impugnação de um mesmo ato, poderia, inclusive, ser recebida como uma ação coletiva, de forma que a decisão fosse vinculante para todos os interessados na controvérsia de massa. Frise-se que é "natureza das coisas" "187 que determina a vinculação.

181 MOREIRA, José Carlos Barbosa. Litisconsórcio unitário. Rio de Janeiro: Forense, 1972, p. 142-144, p. 2527 e p. 49.

182 Ibidem, p. 27.

183 Ibidem, p. 49.

184 Ibidem, p. 49.

185 BUENO, 1995, p.97.

186 VIGORITI, 1979, p.111-112.

187 GRINOVER, 2005, p.6. 
Em sentido semelhante, Proto Pisani ${ }^{188}$ assevera que a tendência da doutrina italiana em estender a autoridade da coisa julgada coletiva àqueles que não participaram formalmente no processo judicial (terceiros) é uma opção que foge ao individualismo oitocentista e adequa-se a uma nova realidade, na qual há um progressivo aumento do nexo de prejudicialidade-dependência existente entre as várias posições jurídicas individuais referentes à organização comunitária.

O próprio Liebman ${ }^{189}$, embora não tenha revisto o seu posicionamento, salientou que a doutrina processual não estava mais segura nessas hipóteses de relações substanciais plurissubjetivas. De igual modo, percebeu a tendência, já marcada naquele tempo, por um processo menos individualista. $\mathrm{O}$ homem não mais vive isolado na sociedade, aumentando a solidariedade social e a responsabilidade por seus atos, que, por vezes, impactam a esfera jurídica de outros sujeitos.

Veja que, aqui, mais uma vez na história, volta-se ao binômio indivíduo e coletividade. Quão maior a identidade das posições jurídicas ocupadas pelos indivíduos de um grupo, comunidade ou coletividade, maior a uniformidade substancial existente entre eles. Os indivíduos passam a operar pelo status ou pela categoria a eles comum. Valendo-se da metáfora de Kazuo Watanabe, os indivíduos atuam como uma molécula, isto é, como uma categoria, o que é mais do que um átomo ou do que um conjunto de átomos, em outras palavras, é mais do que a mera reunião.

No mesmo sentido, Arruda Alvim et al ${ }^{190}$ salienta a identidade e a autonomia do bem coletivo, pois, ainda que o bem coletivo seja composto de bens individuais, há, em sua composição, elementos valorativos inexistentes nos bens individuais, como a proteção da ordem social.

E, nesse sentido, quão maior a uniformidade substancial, maior a possibilidade de uma vinculação estreita do indivíduo ao grupo a ele correspondente, com a extensão da autoridade da coisa julgada aos membros ausentes daquela categoria. Como diz, peremptoriamente, Ada Pellegrini Grinover ${ }^{191}$, "não há como fugir. É da própria natureza das coisas - a indivisibilidade do objeto e a identidade das situações jurídicas - que dá resposta ao problema”, ora colocado.

188 PISANI, Andrea Proto. Appunti sui rapporti tra $i$ limiti soggettivi di efficacia della sentenza civile e la garanzia costituzionale del diritto di difesa. Rivista Trimestrale di Diritto e Procedura Civile, ano XXV, 1971, p. 239-1240.

189 LIEBMAN, 2007, p. 248.

190 ARRUDA ALVIM et al. Código de Defesa do Consumidor Comentado. 2 ed. rev. amp. SÃO PAULO: Revista dos Tribunais, 1995 , p. 366.

191 GRINOVER, 2005, p. 6. 
Para concluir, é preciso destacar que, desde a ação popular romana, já se levantam vozes na doutrina pela extensão da autoridade da coisa julgada coletiva aos membros ausentes do grupo. Scialoja ${ }^{192}$, em oposição a Cogliolo, defendia que o julgamento da ação popular não implicava o mero exaurimento ou consumação dos interesses dos demais cidadãos romanos, implicava, sim, a própria extensão da autoridade da coisa julgada aos membros ausentes daquela categoria.

A autoridade da coisa julgada era possível aos membros ausentes do grupo, segundo Scialoja ${ }^{193}$, pois tratando-se de um direito geral ao cidadão, a mudança da pessoa que o defende em juízo, não implica alteração substancial do direito, que refere-se ao sujeito na condição de cidadão.

Nota-se, portanto, que: embora o fenômeno das demandas coletivas e da autoridade da
coisa julgada sejam eminentemente processuais, é a situação substancial plurissubjetiva
que determina a necessidade e adequação da agregação processual e o regime
processual aplicável à hipótese. Isso porque o direito coletivo não é a mera reunião dos
direitos individuais, mas é um bem autônomo e identificável por critérios próprios.

Mas, como não poderia deixar de ser, ao se abordar essa questão, surge uma preocupação que é tipicamente contemporânea. Trata-se da autonomia individual, isto é, a possibilidade de o indivíduo narrar uma história que pode não coincidir ou, mesmo, contrariar a história do grupo.

A preocupação com a questão da autonomia individual está presente, como visto, no sistema jurídico estadunidense e também não é estranha ao direito brasileiro. A agregação processual, na medida em que desconsidera, inicialmente, particularidades individuais, em prol da unitariedade do grupo, deve discernir e equacionar as questões individuais, porventura presentes. É preciso aferir, portanto, como isso foi abordado e realizado pelo sistema brasileiro.

Conforme relata Ada Pellegrini Grinover ${ }^{194}$, o processo brasileiro inspirou-se, parcialmente, no sistema estadunidense, principalmente no tocante às class actions for damages (prevista na regra 23(b)(3)), mas afastou-se desse modelo em alguns aspectos relevantes. Senão vejamos.

192 SCIALOJA, 2013 (reprint 1883), p. 4.

193 Ibidem, p. 7-8.

194 GRINOVER, Ada Pellegrini. Relatório Geral - Civil Law: os Processos Coletivos nos países de Civil Law. In: GRINOVER, Ada Pellegrini, Watanabe, Kazuo e MULLENIX, Linda (coords). Os Processos Coletivos nos Países de Civil Law e Common Law: uma análise de direito comparado (XIII Congresso Mundial de Direito 
Diferentemente da classificação eminentemente prática dos Estados Unidos, os direitos substanciais coletivos ou plurissubjetivos foram conceituados em direitos difusos, direitos coletivos stricto sensu e direitos individuais homogêneos (art. 81 do Código de Defesa do Consumidor). A conceituação será objeto de capítulo específico, ocasião em que essa classificação será examinada com maior atenção. Por ora, é relevante dizer, que a partir desses conceitos, foi ponderada a relação do indivíduo e da comunidade, bem como revistos os esquemas processuais clássicos, dentre eles, a legitimação para agir e a coisa julgada coletiva.

Esses institutos - legitimidade e coisa julgada - são, na realidade, os pontos sensíveis de qualquer técnica de agregação. Eles permitem, aos processualistas e a todos aqueles que lidam com o processo, separar o que é individual e, por isso, deve ser tratado artesanalmente, do que é coletivo e, dessa forma, deve ser tratado de forma racionalizada, padronizada e impessoal, na mesma dimensão da controvérsia substancial. Façamos uma breve retrospectiva da legislação.

Em primeiro lugar, recorda-se que o direito de ação foi, ordinariamente, conferido a quem é titular de uma afirmada situação jurídica protegida ou posição de vantagem prevista na norma de direito material (art. $6^{\circ}$ do Código de Processo Civil). A exceção é para aquelas hipóteses em que a lei autoriza que outrem defenda, em nome próprio, direito alheio, o que ocorre, por sua vez, nos casos de substituição processual ou de legitimação processual extraordinária. ${ }^{195}$

Parte, por sua vez, já dizia Liebman ${ }^{196}$, é quem figura formalmente na relação jurídica de direito processual. A autoridade da coisa julgada, que se agrega ao conteúdo da sentença, vale, em regra, apenas entre as partes e não aos terceiros, que não figuraram formalmente na relação processual. Os efeitos da sentença, por sua vez, como ato de potestade, alcançam terceiros.

Pois bem. Esses conceitos clássicos e tradicionais do processo civil precisaram ser, ao menos em parte, revisitados ao transitar do paradigma processual individual para o paradigma coletivo.

Processual Salvador- Bahia, 16 a 22 de setembro de 2007 - Tema n. 5 - Novas Tendências em matéria de legitimação e coisa julgada nas ações coletivas). São Paulo: Revista dos Tribunais, 2008, p. 230. 195 Em sentido semelhante, LEONEL, 2013, p. 151 e ZAVASCKI, Teori Albino. Processo coletivo: tutela de direitos coletivos e tutela coletiva de direitos. 3. ed. rev. atual. amp. São Paulo: 2008, p. 77.

196 LIEBMAN, 2007, p. 50-52. 
Os direitos substanciais coletivos revelaram situações nas quais se postula, ao mesmo tempo, o que é próprio, mas também o que é alheio e comum, isto é, postulam-se interesses que são coligados ou interdependentes no plano do direito material para uma pluralidade de sujeitos. Pode-se dizer que essa interligação ou convergência material existe, em alguma medida, desde a ação popular romana, passando pelas ações medievais, o que permanece até os dias de hoje.

Há, assim, uma pertinência subjetiva do indivíduo à controvérsia, que é coincidente com a pertinência subjetiva de uma pluralidade de indivíduos ${ }^{197}$. Isso exigiu, por certo, uma ampliação dos esquemas de legitimidade para agir na defesa desses interesses e direitos coletivos ou plurissubjetivos, bem como uma concorrência de partes ideológicas ou de portadores adequados dos interesses do grupo em juízo, todos igualmente hábeis à promoção do direito substantivo.

O legislador brasileiro optou por identificar, em abstrato, quem são as partes ideológicas ou os adequados representantes do grupo, bem como os requisitos para que sejam admitidos em juízo. O nosso sistema, no entanto, não dispensou uma margem de apreciação judicial da representatividade adequada das partes ideológicas, o que é típico do sistema jurídico estadunidense. A aferição judicial da representatividade adequada é válida, mesmo quando previsto em abstrato os entes legitimados coletivos, seja para evitar conluio entre as partes, seja, até mesmo, para ampliar e assegurar a adequada proteção dos membros ausentes do grupo. ${ }^{198}$

\footnotetext{
197 Não se pode deixar de mencionar que, por força dessa comunhão de interesses, existe uma forte corrente doutrinária que reconhece a legitimidade ordinária de um ente, de uma organização ou de um órgão público, autorizados por lei para o ajuizamento da ação coletiva. Kazuo Watanabe menciona a situação de uma associação, que tenha por fim institucional a defesa dos interesses de um grupo. A legitimidade seria ordinária, nesse caso, pois continua existindo uma coincidência entre aquele que pleiteia o direito e aquele que afirma a titularidade da relação jurídica de direito substancial. A associação, que ingressa em juízo, atua em nome próprio na defesa dos seus próprios interesses institucionais, que constam nos fins estatutários daquela organização. Os interesses dos associados são também os interesses da associação, uma vez que esse ente se propôs a defendê-los. (Cf. WATANABE, Kazuo. Tutela jurisdicional dos interesses difusos: a legitimação para agir. In: GRINOVER, Ada Pellegrini (coord.). A tutela dos interesses difusos. São Paulo: Max Limonad, 1984, p. 94). Aluísio Gonçalves de Castro Mendes, nessa mesma linha de raciocínio, introduz a ideia de legitimidade ordinária composta, isto é, o autor coletivo defende um interesse próprio conjugado com o alheio (Cf. MENDES, 2012, p. 244). Embora esse não seja o entendimento que prevalece na jurisprudência, o argumento da legitimação ordinária realmente convence e, ao nosso ver, é inescapável. Convence, porque existe uma relação de comunhão que não pode ser desprezada, ou seja, o autor coletivo defende um interesse próprio e, ao mesmo tempo, um interesse dos demais membros ausentes do grupo. Convence, ainda, porque, em tempos de aferição judicial da representatividade adequada, se não houver uma tipicidade ou uma pertinência entre o interesse próprio do ente coletivo e os interesses dos indivíduos, membros ausentes do grupo, será difícil assegurar a adequada representação. A representatividade adequada, embora não seja reconhecida por lei, já é adotado pela doutrina e também está presente na jurisprudência (Pelo controle da representatividade: AgRg no REsp 901.936/RJ, Rel. Ministro LUIZ FUX, PRIMEIRA TURMA, julgado em 16/10/2008, DJe 16/03/2009).

198 GRINOVER, 2008, p. 236-238.
} 
O sistema jurídico brasileiro, atento a isso, previu, por exemplo, um sistema misto de legitimidade para as ações coletivas, atribuindo legitimidade a pessoas físicas - atualmente, apenas na ação popular -, mas também a associações, aos órgãos públicos e a instituições especializadas. Com isso, efetiva-se o anseio pela universalização da tutela jurisdicional. ${ }^{199}$

Previu, nessa mesma linha de raciocínio, uma legitimidade concorrente e disjuntiva, isto é, as partes credenciadas a servir em juízo como portadoras dos interesses ou direitos comuns a uma coletividade não se excluem entre si, mas concorrem, tampouco precisam atuar conjuntamente. Podem fazê-lo isoladamente ou, ainda, em litisconsórcio, mas sem a necessária participação de outro habilitado para fins de propositura da demanda coletiva e para a promoção dos direitos ${ }^{200}$.

A coisa julgada, por sua vez, guarda estreita correlação com o esquema de legitimidade anteriormente explicitado. Ada Pellegrini Grinover ${ }^{201}$ destaca essa estreita ligação entre os esquemas de legitimidade e da coisa julgada coletiva, pois quanto mais ampla a legitimação, mais amplas são as possibilidades de extensão a terceiros da coisa julgada coletiva, o que apenas corrobora a aferição judicial da representatividade adequada no sistema jurídico brasileiro.

Mas, antes de se abordar a coisa julgada coletiva no sistema jurídico brasileiro, é válido destacar que, a critério de política legislativa, várias são possibilidades em termos de coisa julgada - não há uma exigência genérica - o que importa é estabelecer um justo equilíbrio entre a agregação processual e a autonomia individual. Enfim, trata-se, apenas, de permitir que a história individual ou pessoal, que pode não coincidir ou ser contraria à história coletiva do grupo, possa vir a ser narrada isoladamente pelo indivíduo e também apreciada pelo Poder Judiciário.

Como já apontado, os instrumentos processuais que permitem a agregação, sem gravames à autonomia individual, variam entre instrumentos mais consensuais e menos consensuais.

Quão maior a equivalência de interesses, maior a uniformidade substancial entre o indivíduo e o grupo e, portanto, maior à tendência de vinculação à coisa julgada coletiva, mesmo sem

199 Ibidem, p. 236-238. Em sentido similar, MOREIRA, José Carlos Barbosa. La iniciativa em la defensa de los intereses difusos y colectivos (un aspecto de la experiência brasileña). Temas de Direito Processual Civil - Quinta Série. São Paulo: Saraiva, 1994, p. 164-165. LEONEL, 2013, p. 159. DIDIER, Fredie e ZANETTI JR, Hermes. Curso de Direito Processual Civil: processo coletivo. 3 ed. rev. atual. amp. Bahia: Juspodium, 2008, p. 217.

200 Em sentido semelhante, LEONEL, 2013, p. 159 e MANCUSO, 2011, p. 183.

201 GRINOVER, 2008, p. 238. 
consentimento. Afinal, se os argumentos são os mesmos ou coincidentes entre o indivíduo e o grupo, litigado para um indivíduo do grupo, litigado para todos os demais componentes do grupo. Há, no entanto, em algumas hipóteses, a previsão de uma válvula de escape, para que o indivíduo possa vir a juízo excluir-se da narrativa coletiva e narrar a sua história pessoal. Cada sistema jurídico adota e apregoa uma técnica processual diferente para essa mesma finalidade.

O sistema estadunidense, como já se viu, adotou a possibilidade de autoexclusão (opt out) na hipótese de ações coletivas em que os danos foram pessoalmente sofridos (tipo 23(b)(3)). O indivíduo, que não manifestar interesse na ação coletiva, poderá requerer sua exclusão, depois da notificação sobre a existência daquela, não se sujeitando à coisa julgada coletiva. Nas demais hipóteses de ação coletiva, não há direito de autoexclusão do grupo e, assim, todos os indivíduos deverão sujeitar-se à autoridade da coisa julgada coletiva, sem quaisquer temperamentos. ${ }^{202}$

Há, ainda, a possibilidade consistente na inclusão do indivíduo na demanda coletiva (opt in $)^{203}$. Nessa hipótese, a demanda coletiva é proposta e os indivíduos são notificados para nela se incluírem, sujeitando-se, nesse momento, à coisa julgada coletiva. É o que ocorre, por exemplo, no sistema jurídico inglês, o qual não foi alcançado pelo estudo comparado, aqui proposto, mas é válida a menção para se ter uma visão geral do instituto da coisa julgada coletiva, bem como conhecer uma das possibilidades de extensão subjetiva da coisa julgada.

O direito brasileiro, por sua vez, adotou a coisa julgada erga omnes e ultra partes, prot et contra, para os direitos difusos e coletivos stricto sensu, incidentes sobre objetos indivisíveis. A coisa julgada agrega-se ao comando da sentença, seja em caso de acolhimento, seja em caso de rejeição da demanda, impedindo a propositura de uma nova demanda por outro legitimado.

Conforme assevera Ada Pellegrini Grinover ${ }^{204}$, nos direitos difusos, por força da coisa julgada erga omnes, a sentença coletiva prevalece em definitivo perante todos os entes e pessoas

202 Não há direito à autoexclusão, mas, de acordo com as peculiaridades do caso concreto, o magistrado poderá determinar a exclusão de um ou mais indivíduos da ação coletiva, classificada nas categorias 23(b)(1) e 23(b)(2), para aprimorar a condução e o gerenciamento do processo coletivo (Cf. HERR, 2012, p. 395).

203 GRINOVER, 2008, p. 242. No mesmo sentido, ANDREWS, Neil. Multi-party proceedings in England: representative and group action. Duke Law Journal of Comparative and International Law, 2001, V. 11: 249-267p. p. 259.

204 GRINOVER, 2008, p. 240. No mesmo sentido, MANCUSO, 2007, p. 270. 
legitimadas à ação coletiva. Em caso de improcedência, não ficam preclusas as ações individuais, relativas aos interesses e direitos pertencentes pessoalmente aos indivíduos.

No direitos coletivos stricto sensu, por força da coisa julgada ultra partes, a sentença coletiva prevalece em definitivo em relação ao grupo, categoria ou classe. Mas, de qualquer modo, não fica preclusa a via da ação individual relativa aos interesses e direitos pertencentes pessoalmente aos indivíduos, membros do grupo, categoria ou classe de interessados. ${ }^{205}$

Nos dois casos supracitados, a coisa julgada erga omnes e ultra partes pode sofrer mitigação. Em caso de rejeição da demanda, por insuficiência de provas ou em caso de descoberta de novas provas a respeito do tema, a ação coletiva poderá ser reproposta com base nessas novas provas pelo mesmo legitimado da ação coletiva anterior ou também por qualquer outro legitimado. ${ }^{206}$

No tocante aos direitos individuais homogêneos, incidentes sobre objetos divisíveis, diferentemente do mecanismo de autoexclusão (opt out), bem como diferentemente do sistema de inclusão (opt in), adotou-se, no Brasil, a extensão subjetiva da coisa julgada secundum eventum littis ${ }^{207}$, só para beneficiar os membros ausentes do grupo e não prejudicá-los. No plano individual, a coisa julgada favorável é erga omnes e pode ser aproveitada - transportada in utilibus - em favor do indivíduo, encurtando-se, com isso, o caminho para a liquidação e para a execução da sentença que beneficiou os membros do grupo. Se desfavorável, não há óbice, ao menos em regra, à propositura das demandas individuais para o ressarcimento dos danos. ${ }^{208}$

A ação coletiva passiva, em que a coletividade ocupa o polo passivo da relação processual, não possui expressa previsão legal. Em que pese a ausência de previsão legal, essa modalidade é admitida no direito brasileiro. Nesse caso, os membros do grupo são alcançados pela autoridade da coisa julgada, tanto na sentença de procedência, quanto na sentença de improcedência. ${ }^{209}$

205 GRINOVER, 2008, p. 240.

206 GIDI, Antônio. Coisa julgada e litispendência em ações coletivas: mandado de segurança coletivo, ação coletiva de consumo, ação coletiva ambiental, ação civil pública e ação popular. São Paulo: Saraiva, 1995, p. 134. No mesmo sentido, pela coisa julgada secundum eventum probationem, a demanda poderá ser reproposta, ainda que a sentença tenha se embasado em prova suficiente, desde que o legitimado apresente prova nova. Sobrevindo novas provas, é sempre possível a renovação da ação coletiva para a defesa dos direitos transindividuais (Cf. MANCUSO, 2007, p. 302)

207 GRINOVER, 2005, p. 7-9.

208 GRINOVER, 2008, p. 244. MANCUSO, 2007, p. 270.

209 Pelo reconhecimento da ação coletiva passiva na doutrina: GRINOVER, Ada Pellegrini. Ações coletivas iberoamericanas: novas questões sobre a legitimidade e a coisa julgada. Revista Forense, V. 361, mai./jun. 2002, p. 312. MAIA, Diogo Campos Medina. Ação coletiva passiva. Rio de Janeiro: Lumen Juris, 2009, p. 142-143. 
Essas considerações são realizadas apenas para mostrar as categorias de conhecimento com as quais trabalha o direito brasileiro - o nosso estado da arte. A arte não é estática e continua em pleno desenvolvimento, pelos estudos dogmáticos, pela contribuição profícua da jurisprudência e por várias propostas legislativas, algumas ainda recentes e pendentes de apreciação.

Nesse momento, importa lembrar as seguintes propostas: o incidente de molecularização, recomendado por uma comissão de juristas, na qual se incluía o Professor Kazuo Watanabe, já nos idos de 1985210; o Código Modelo de Processos Coletivos para Ibero-América ${ }^{211}$; o Anteprojeto do Código Brasileiro de Processos Coletivos ${ }^{212}$; a proposta de Projeto da Lei que institui processo especial de intervenção e controle jurisdicional de políticas públicas ${ }^{213}$; o Projeto de lei relativo à Nova Lei da Ação Civil Pública ${ }^{214}$; e o Anteprojeto do Novo Código de Processo Civil Brasileiro ${ }^{215}$, esse último atualmente em trâmite na Câmara dos Deputados.

Essas propostas, especialmente o projeto de um Código Brasileiro de Processos Coletivos, buscam sistematizar, em um modelo único, não apenas o processo coletivo, mas também outras técnicas de agregação processual, como reunião de demandas, a suspensão de processos individuais, a liquidação coletiva, a coisa julgada e a litispendência coletiva e outras técnicas.

ZUFELATO, Camilo. Ação coletiva passiva no direito brasileiro: necessidade de regulamentação legal. In: GOZZOLI, Maria Clara et al (coords.) Em defesa de um novo sistema de processos coletivos: estudos em homenagem a Ada Pellegrini Grinover. São Paulo: Saraiva, 2010, p. 89-142. Pelo reconhecimento da ação coletiva passiva na jurisprudência, inclusive no tocante a direitos individuais homogêneos e na hipótese de sentença de procedência ao autor individual e contrária ao grupo: BRASIL. Tribunal de Justiça do Estado do Espírito Santo. Ação originária no 100070019698, Relator: Samuel Meira Brasil Jr. Disponível em: www.tjes.jus.br. Acesso 22 de outubro de 2013.

210 TEIXEIRA, Sálvio de Figueiredo. Apreciações sobre o Código de Processo Civil Anotado. 7 ed. Rio de Janeiro: Forense, 1986, 675-713p.).

211 GRINOVER, Ada Pellegrini e CALMON, Petrônio. Direito Processual Comparado XIII - World Congress of Procedural Law. Rio de Janeiro: Forense, 2008, p. 868-885p. GIDI, Antônio. MAC-GREGOR, Eduardo Ferrer (coords.). La tutela de los derechos difusos, colectivos e individuales homogéneos: hacia un código modelo para iberoamérica. Presentación Roberto O. Berizonce. Introducción Ada Pellegrini Grinover. 2 ed. Argentina: Editorial Porrúa, 2004.

212 GRINOVER, Ada Pellegrini, MENDES, Aluísio Gonçalves de Castro e WATANABE, Kazuo (coords.). Direito Processual Coletivo e o anteprojeto de Código Brasileiro de Processos Coletivos. São Paulo: Revista dos Tribunais, 2007.

213 BRASIL. CEBEPEJ. Projeto de lei que institui processo especial para o controle e intervenção em políticas públicas pelo Poder Judiciário e dá outras providências (no prelo).

214 BRASIL. Câmara dos Deputados. PL no 5.139/2009. Disponível em: http://www.camara.gov. br/proposicoes Web/fichadetramitacao?idProposicao=432485. Acesso em: 24 de outubro de 2013.

215 BRASIL. Congresso Nacional. Câmara dos Deputados. PL nº. 8.046/2010. Código de Processo Civil. Brasília: Câmara dos Deputados, Presidência, 2010. 
É, nesse momento, de inúmeros avanços e propostas, que uma abordagem a respeito da litigiosidade de massa e das técnicas de agregação processual no direito brasileiro se faz premente. Ainda há muito por dizer e não precisamos ir longe para demonstrar isso. A práxis dos juizados, fóruns e Tribunais revelam isso: a explosão de litigiosidade, a litigiosidade de massa e as inúmeras demandas repetitivas, que reclamam uma racionalização no seu tratamento.

O instrumental processual existente para tratar essas controvérsias de massa já é bastante vasto, mas a multiplicação de demandas persiste e os direitos substanciais coletivos ou plurissubjetivos - a razão primeira de tudo isso - por vezes soçobram, emaranhados em uma série de confusões, fragmentados, dispersos e sem lograr a resolução adequada de sua crise de direito e, senão, ainda pensado com as amarras e as restrições típicas dos processos individuais.

Marcelo MenezesVigliar ${ }^{216}$ adverte, valendo-se das lições de Kazuo Watanabe, que o sistema processual brasileiro passou da litigiosidade contida para a explosão da litigiosidade. $\mathrm{O}$ fenômeno inverteu-se, reclamando uma política de contingenciamento dessa mesma litigiosidade, isto é, uma política de "molecularização necessária" das controvérsias de massa.

São diversas as amarras, as restrições e as confusões envolvendo a tutela coletiva: não é difícil encontrar hipóteses de repetição de demandas coletivas por todo o Poder Judiciário sem solução unitária adequada. Enfrentam-se as restrições impostas pelo sistema, as incongruências jurisprudenciais e a imposição de obstáculos políticos, como o disposto na Lei nº 9.494/1997.

A referida lei conferiu uma nova disciplina aos limites subjetivos da coisa julgada coletiva, vinculando a autoridade da coisa julgada coletiva ao território sobre o qual verifica-se a competência do órgão prolator da sentença. Esse dispositivo, incluído no art. 16 da Lei $\mathrm{n}^{\circ}$ 7.347/85, peca pela atecnia, confundindo jurisdição e competência. E, de igual modo, contraria toda a sistemática da coisa julgada erga omnes, prevista no sistema brasileiro. Por fim, como cindir a autoridade da coisa julgada se o bem coletivo é, intrinsecamente, indivisível e unitário? Não é possível aplicar, em bom termo, o preceito legal, restando incongruente nesse aspecto. ${ }^{217}$

216 VIGLIAR, José Marcelo Menezes. Litigiosidade contida (e o contingenciamento da litigiosidade). In: SALLES, Carlos Alberto de. As grandes transformações do processo civil brasileiro: homenagem ao Professor Kazuo Watanabe. São Paulo: Quartier Latin do Brasil, 2009, p. 62-66. julgada nas ações coletivas: inconstitucionalidade. Revista dos Tribunais, Ano 86, V. 745, nov. de 1997, p. 71. 
De igual modo, são várias as hipóteses de demandas pseudocoletivas ${ }^{218}$ e pseudoindividuais ${ }^{219}$ tratadas de forma inadequada pelo sistema processual brasileiro, sem atenção à crise de direito substancial manifestada naqueles casos. De igual modo, lida-se com a resistência dos profissionais do direito, que, por vezes, se veem absolutamente perdidos ao conferir tratamento processual aos direitos substanciais coletivos ou plurissubjetivos. Tudo isso constitui campo bastante fértil e motivo suficiente para que se continue a avançar na discussão e na aplicação das técnicas processuais de agregação ou molecularização no direito processual coletivo.

Exemplo dessas confusões e amarras pode ser facilmente encontrado na jurisprudência. Não é raro, nesse contexto, encontrarmos precedentes dos Tribunais, confusos quanto aos direitos substanciais litigados e quanto aos instrumentos processuais adequados para a tutela jurisdicional. Continua, por vezes, um jogo de estica e puxa entre os planos individual e coletivo, sem que seja articulada claramente a categoria do direito ou o seu alcance coletivo.

No dia 25.06.2013, foi publicada a seguinte notícia no sítio do Superior Tribunal de Justiça: "Moradores de bairro carioca vão receber indenização por saneamento básico precário"220. Realizada a leitura dessa chamada, qual a primeira impressão havida pelo seu intérprete?

Parecia tratar-se de uma demanda, cujo escopo era atuar direitos substanciais coletivos ou plurissubjetivos, enfim, direitos que envolviam uma comunidade ou uma pluralidade de interessados de um bairro carioca em uma mesma controvérsia de direito substancial.

Essa primeira impressão desmoronou, por certo, com a leitura do inteiro teor da notícia e, posteriormente, com a leitura dos acórdãos mencionados naquela notícia. Senão vejamos.

A pretensão formulada por alguns moradores do bairro Anil, no Rio de Janeiro, em face do CEDAE (concessionária de serviço público) era que fossem providenciadas as obras de reparo da rede de esgoto daquele bairro e o ressarcimento por danos morais em razão do tratamento

218 ARAÚJO, Luiz Paulo da Silva. Ações Coletivas: a tutela jurisdicional dos direitos individuais homogêneos. Rio de Janeiro: Forense, 2000, p. 115.

219 WATANABE, Kazuo. Relação entre demanda coletiva e demandas individuais. In: GRINOVER, Ada Pellegrini, MENDES, Aluísio Gonçalves de Castro e WATANABE, Kazuo (coords.). Direito Processual Coletivo e o anteprojeto de Código Brasileiro de Processos Coletivos. São Paulo: Revista dos Tribunais, 2007, p. 156.

220 SUPERIOR TRIBUNAL DE JUSTIÇA. Disponível em: www.stj.jus.br/portal_stj/publicacao/enginewsp ?tmp.area $=398 \&$ tmp.texto=110167. Acesso em 25 de junho de 2013. 
inadequado do esgoto até aquele momento. Há - segundo entendemos - uma nítida interdependência no plano do direito substancial entre o indivíduo e a comunidade nesse caso.

Paradoxalmente, o Tribunal de Justiça do Estado do Rio de Janeiro ${ }^{221}$ asseverou que os interesses litigados eram exclusivamente individuais, pois afetavam a esfera individual dos moradores. A providência de melhoria da rede de esgoto avançaria a condição pessoal dos autores, os quais têm dificuldades de chegar a sua residência em dias de chuva e estão submetidos a diversas aflições e riscos à saúde, em razão da proliferação de insetos e doenças naquele local. A situação descrita na peça inicial encartar-se-ia, segundo acórdão, nos clássicos direitos individuais.

A CEDAE alegava, por sua vez, que o interesse era difuso e que, por isso, deveria ter sido postulado por um legitimado coletivo, a exemplo do Ministério Público, em Ação Civil Pública.

O argumento da empresa ré não persuadiu o Tribunal de Justiça do Estado do Rio de Janeiro, que disse ser o interesse ou direito litigado individual, tampouco logrou conhecimento no Superior Tribunal de Justiça. A Segunda Turma do STJ, à unanimidade, disse que a ré apenas alegou ser o direito difuso, mas não impugnou a existência concorrente do direito individual, o qual era diretamente defensável pelos moradores prejudicados do bairro, argumento esse que constava no acórdão do Tribunal de Justiça. Por essa razão, considerando a ausência de prequestionamento a respeito da tese do direito individual, o recurso especial foi inadmitido.

Veja, portanto, a perplexidade de quem leu aquela notícia: uma grande prestadora de serviço quer que se reconheça, na hipótese em tela, a violação de um direito difuso ao saneamento básico, cuja dimensão é muito mais grave, ampla e desastrosa para toda uma comunidade do Rio de Janeiro (Bairro Anil) e não apenas para o indivíduo. O Tribunal de Justiça, por sua vez, reconhece apenas o direito individual, que, em tese, interessa diretamente apenas aos moradores que são partes na demanda. Mas, em contrapartida, determina a realização de reparações na rede de esgoto e saneamento básico, bem que é incindível e beneficiará toda a comunidade.

Ao mencionarmos essa notícia, não se pretendeu questionar o mérito daquela decisão. Não se está dizendo que os reparos da rede esgoto não deveriam ter sido determinados em favor de toda a comunidade. Todavia, é forçoso convir que, em nome do indivíduo, fez-se para toda a

221 BRASIL. Tribunal de Justiça do Estado do Rio de Janeiro. Apelação Cível nº 00197220320098190001. Disponível em: www.tjrj.jus.br. Acesso em Ementa: 25 de junho de 2013. 
comunidade, mas insistia-se em frisar que a tutela era exclusivamente individual, apenas aos diretamente interessados, os quais tiveram o direito ao saneamento básico e à saúde violados.

O que se pondera, nesse caso, é se a solução adotada era realmente adequada e coerente para a hipótese. Será que era preciso insistir ser a tutela pretendida apenas individual, sem alcance coletivo, quando, ao final, beneficiou-se a todos? Não era possível dizer que o indivíduo constituía uma parte ideológica e, por isso, atuava para ele e também para toda a comunidade?

Em outro caso interessante, agora no Tribunal de Justiça do Estado do Espírito Santo ${ }^{222}$, os autores firmaram um pacto de adesão individual a um plano de saúde coletivo da empresa UNIMED. As cláusulas do contrato de plano de saúde foram negociadas coletivamente entre a UNIMED e a Associação Beneficente dos Trabalhadores e Servidores Públicos daquele Estado. Os indivíduos, associados, por sua vez, aderiram pessoalmente ao plano de saúde coletivo.

Ocorre que, no ano de 2011, o contrato coletivo do plano de saúde sofreu um reajuste de preço no percentual de 25,24\%, quando a Agência Nacional de Saúde - ANS havia sugerido índice de reajuste de apenas 7,69\% para os planos de saúde individuais, que poderiam ser contratados por todo e qualquer indivíduo, independentemente, de uma associação. Por essa razão, alguns contratantes ajuizaram demanda individual, alegando a abusividade do reajuste pretendido pela UNIMED no plano coletivo. Pleitearam a revisão do índice aplicado ao plano coletivo, utilizando como parâmetro o índice individual, bem como pleitearam a apuração das diferenças.

A sentença julgou procedente o pedido autoral individual. O Tribunal de Justiça do Estado do Espírito Santo, em recurso de Apelação Cível, reformou, todavia, essa sentença, dizendo que a base contratual do plano de saúde era coletiva, vantajosa para ambos os contratantes, e não poderia essa mesma base coletiva ser desvirtuada apenas em favor de alguns indivíduos.

O contrato coletivo, argumentou-se no acórdão, é vantajoso e permite a melhor discussão do preço para todos os contratantes, logo esse preço não poderia ser alterado unilateralmente para apenas alguns indivíduos. O recurso do Plano de Saúde UNIMED foi, em seguida, provido por unanimidade pelo colegiado e a pretensão autoral individual foi julgada improcedente.

222 BRASIL. Tribunal de Justiça do Estado do Espírito Santo. Apelação Cível no 28487-26.2011.8.08.0024. Disponível em: www.tjes.jus.br. Acesso em 25 de junho de 2013. 
Ao mencionarmos esse acórdão, não se pretendeu questionar o mérito da decisão, segundo o direito vigente. De fato, a base do contrato era mesmo coletiva. Essa coletividade deveria, sim, ser considerada para o reajuste de preço contratual, isso porque a questão não se restringe, tão somente, à aplicação do reajuste proposto pela Agência Nacional de Saúde - ANS, mas envolve também a manutenção do equilíbrio financeiro do contrato que, ao ser negociado coletivamente, tende a apresentar um preço mais vantajoso a ambos os contratantes, como consta no acórdão.

Mas, ao se julgar improcedente a pretensão autoral com esse fundamento, como fez o acórdão, a questão quanto à abusividade do índice estabelecido para o plano coletivo e quanto ao reajuste contratual - questão que interessa aos autores da demanda individual e a todos os demais segurados - não foi analisada sob nenhum ângulo, nem sob o individual, nem sob o coletivo.

Não havia mais alternativa para atuar esse direito substancial com alcance coletivo? Não era possível que um indivíduo atuasse em favor dele e em favor de toda a comunidade que com ele estava associada e, assim, lograsse o pronunciamento judicial em nome de todos? Nesse caso, a aplicação das técnicas de agregação processual conferiria - segundo entende-se - uma resposta mais adequada à controvérsia de direito substancial de alcance coletivo nesse caso. ${ }^{223}$

Muitas questões surgem, ainda, com essas hipóteses. Afinal, quais são os direitos envolvidos no conflito? E porque há esse jogo de estica e puxa entre os planos individual e coletivo?

223 A negociação é apenas, em tese, mais vantajosa. A Agência Nacional de Saúde - ANS somente fixa o índice de reajuste anual em relação aos planos individuais e não o faz em relação aos planos coletivos. A justificativa da agência para isso é a possibilidade de se alcançar, coletivamente, preços mais vantajosos para ambas as partes, tanto para o consumidor quanto para a operadora. O índice é fixado, todavia, nos contratos individuais, pois o consumidor individual não teria o grupo para protegê-lo e para barganhar melhores preços. Mas, o que tem se operado, na prática, é, muitas vezes, o inverso. Como não há limite de reajuste para os planos coletivos, as operadores têm negociado índices cada vez mais altos, sem que lhe seja imposto qualquer limite de preço pela agência. E, mais, veicula-se na imprensa a notícia de que os planos de saúde recusam, atualmente, a venda de planos individuais para pessoas físicas, pois como, nesse caso, há um limite de reajuste contratual, o negócio jurídico não seria interessante, pois a empresa correria o risco de o plano tornar-se deficitário ou pouco lucrativo, na hipótese de o reajuste fixado pela Agência Nacional de Saúde - ANS ficar aquém da avaliação das despesas. Esse risco não ocorre, portanto, nos contratos coletivos. A comercialização em massa de planos de saúde coletivo e a negativa da legitimidade individual prejudicariam, em muito, o acesso à justiça. Não se pode negar a legitimidade individual, quando o indivíduo é afetado pela prática abusiva em sua esfera jurídica. A resposta para essa questão passa, portanto, pela admissão da legitimidade individual, seguida, no entanto, da molecularização ou agregação necessária das demandas individuais, de forma a preservar a base coletiva do contrato e a paridade. Mantêm-se, com isso, em equilíbrio os dois valores: acesso à justiça e a paridade ou isonomia decorrente da base contratual coletiva (Cf. Planos de saúde recusam contratos individuais com pessoas físicas. Disponível http://g1.globo.com/jornal-nacional/noticia/2013/10/planos-de-saude-recusam-contratos-individuais-compessoas -fisicas.html. Acesso em: 1 de outubro de 2013). 
Vê-se que os casos antes citados não são, assim, tão diferentes daqueles enfrentados no passado. Os problemas parecem sempre os mesmos e a busca pela tutela jurisdicional adequada, se individual ou coletiva, desloca-se como se fosse um pêndulo entre esses dois planos.

Hoje, talvez, algumas comunhões entre o indivíduo e a coletividade não sejam claramente perceptíveis na vida em sociedade, como era a propriedade medieval. Mas, em compensação, no lugar das propriedades comunais em aldeias medievais, existem negociações coletivas de cláusulas contratuais, que implicam uma interligação ou uma convergência no plano substancial entre uma pluralidade de interessados. O plano de saúde coletivo, como antes mencionado, é um exemplo disso. É preciso entender a relação de direito substancial, para perceber que a concessão individual do reajuste seria inviável por frustrar a própria relação paritária e coletiva em que foi firmado o contrato de plano de saúde. O reajuste contratual deve ser, portanto, ainda que pleiteado individualmente, conferido a todo o grupo ou a toda coletividade de segurados.

Hoje, de igual modo, talvez, os indivíduos não mais litiguem, em regra, pelo status do grupo, mas, em compensação, vários litigam pretensões concorrentes, exatamente iguais ou similares, com relação a uma mesma controvérsia de direito substancial e a um mesmo bem incindível, de forma a beneficiar o grupo comum um todo. Esse foi o caso da demanda individual, pleiteando a melhoria da rede de esgoto e saneamento básico do bairro Anil, no Rio de Janeiro, o que se deu, necessariamente, em prol de toda a comunidade de interessados daquela região.

É, por essas e outras, que antes de se falar em agregação, é preciso saber primeiro o que agregar. Esse é o ponto fundamental das técnicas de agregação processual: compreender os contornos da relação substancial, extraindo-se, a partir daí, elementos informativos para a agregação.

Esse último tema será mais bem aprofundado na Seção II desta investigação. Por ora, é preciso retomar os tipos de instrumentos e técnicas de agregação processual de larga escala, utilizandose como paradigma a categorização já utilizada no sistema jurídico estadunidense. Segue-se.

\subsection{TIPOS DE AGREGAÇÃO PROCESSUAL}

A técnica de agregação processual consiste na reunião de demandas e de defesas de uma pluralidade de pessoas, envolvidas em uma crise de direito substancial plurissubjetiva ou 
coletiva, para fins de processamento e/ou resolução unitária da controvérsia de massa, seja pela prestação da tutela jurisdicional, seja por mecanismos alternativos de resolução de disputas. ${ }^{24}$

Trata-se, como já se disse, de fenômeno mais amplo que o das ações coletivas. Essa amplitude foi notada e comentada por Judith Resnik ${ }^{225}$, que salientou a mudança de posição do sistema estadunidense da resolução de "casos" para a resolução da "litigiosidade", o que representa uma tendência pela resolução unitária da controvérsia. Isso porque milhares de sujeitos passam a ser compreendidos de forma conjunta ou como uma unidade ou entidade litigante no processo.

Diversos tipos de técnicas e instrumentos de agregação já se consolidaram no sistema jurídico estadunidense. E, cada vez mais, novas variações surgem e são desenvolvidas naquele sistema, bem como em ordenamentos estrangeiros, orientados pela experiência coletiva - positiva ou negativa - dos Estados Unidos ${ }^{226}$. Não há uma categorização única ou exaustiva dessas técnicas, tampouco há uma preocupação estreita em catalogar os tipos de agregação processual presentes.

De qualquer modo, há, em alguns setores da doutrina estadunidense, uma categorização inicial e exemplificativa dessas técnicas e instrumentos de agregação processual. O intuito não é exaurir a tipologia, mas apenas estabelecer categorias funcionais, com finalidade informativa.

Aliás, o direito estadunidense é avesso a classificações formalistas, o que apenas reforça o caráter exemplificativo e descritivo das técnicas, sem abordagem minudente ou detalhada.

224 SHERMAN, Edward F. Aggregate disposition of related cases: the policy issue. Review of Litigation, 1991, V. 231:237-254p, p.237. NAGAREDA, 2009, p. 25-40. MARCUS, Richard L., SHERMAN, Edward F. and ERICHSON, Howard M. Complex litigation: cases and materials on advanced civil procedure. 5 ed. St. Paul: Thomson West, 2010, p. 9.

225 RESNIK, Judith. From “cases" to "litigation". Law and contemporary problems. 1991, V. 54: 6-67p, p. 25. 226 HODGES, Christopher. The reform of class and representative actions in European Legal Systems. A new framework for collective redress for Europe. Oregon: Hart Publishing, 2008. BACKHAUS, Jürgen G., CASSONE, Alberto and RAMELLO, Giovanni B. (editors). The law and economics of class actions in Europe: lessons from America. Massachusetts: Edward Elgar Publishing Limited, 2012. KOCH, Harald. Non-class group litigation under EU and German Law. Duke Journal of Comparative and International Law, 2001, V.11: 355-368p. BOGART, W. A. Questioning litigation role's: courts and class action in Canada. Indiana Law Journal, 1987, V. 62: 665-700p. ANDREWS, Neil. Multi-party proceedings in England: representative and group action. Duke Law Journal of Comparative and International Law, 2001, V. 11: 249-267p. TARUFFO, Michele. Some remarks on group litigation in comparative perspective. Duke Law Journal of Comparative and International Law, 2001, V. 11: 405-421p. WALTER, Gerhard. Mass tort litigation in Germany and Switzerland. Duke Law Journal of Comparative and International Law, 2001, V. 11: 369-379p. NORDH, Roberth. Group actions in Sweden: reflections on the purpose civil litigation, the need for reforms, and a forthcoming proposal. Duke Law Journal of Comparative and International Law, 2001, V. 11: 381-404p. FISCH, William B. European analogues of class action: group action in France and Germany. The American Journal of Comparative Law, 1979, V.27: 51-79p. 
Richard Nagareda ${ }^{227}$, por exemplo, classifica as técnicas de agregação processual em contratuais, não contratuais e intermediárias ou híbridas. Na modalidade contratual, ele inclui a agregação realizada pelos próprios escritórios de advocacia, que congregam clientes com causas semelhantes, bem como os mecanismos de resolução alternativa de conflitos. $\mathrm{Na}$ modalidade não-contratual, ele inclui a ação de classe, a consolidação e a coordenação informal de demandas individuais. E, por fim, nas técnicas híbridas, ele aborda o caso-teste. O caso-teste tanto pode ser utilizado para informar, ou melhor, modelar a resolução autocompositiva da controvérsia, quanto pode ser utilizado como uma amostra representativa da controvérsia de massa, com efeito preclusivo aos demais casos similares pendentes nas Cortes de Justiça.

Judith Resnik ${ }^{228}$, por sua vez, categoriza as técnicas de agregação em formais e informais. Dentre as formais, por exemplo, inclui a ação de classe e a consolidação, bem como outros mecanismos previstos na legislação federal. Dentre as informais, aborda as técnicas criadas por regras locais ou por criação dos magistrados, por oficiais da Corte de Justiça ou por advogados.

O American Law Institute ${ }^{229}$, nos princípios do contencioso agregado, propõe categorização diversa. As categorias são divididas em agregação representativa e litisconsorcial (processo agregado), agregação administrativa e agregação privada. A primeira categoria engloba as ações coletivas e o litisconsórcio. A segunda categoria abrange a consolidação, a coordenação de demandas individuais e o caso-teste. E, a última categoria alcança os mecanismos alternativos de resolução de disputas, sejam acordos coletivos, sejam métodos extrajudiciais.

A partir dessa última categorização, que aparenta maior amplitude, é que as técnicas e os instrumentos de agregação processual serão mais bem explicitados na presente investigação. De igual modo, essa categorização constitui um paradigma adequado para o estudo da temática.

\subsubsection{PROCESSO AGREGADO}

Trata-se das técnicas das ações representativas (representative actions) e do litisconsórcio (joinder). Consiste em uma única demanda, que abrange demandas e defesas de múltiplas partes ou de pessoas representadas - membros do grupo representados por um portador ideológico. ${ }^{230}$ 
Na hipótese do litisconsórcio, é possível a participação direta das partes interessadas, sendo que somente as partes são vinculadas pela autoridade da coisa julgada. Nas ações representativas, por sua vez, vincula-se os membros ausentes do grupo quando preenchidos os pressupostos legais, como a comunhão de interesses, a tipicidade, a representatividade adequada e outros.

\subsubsection{AGREGAÇÃO LITISCONSORCIAL}

A agregação litisconsorcial é a menos comum hoje no sistema jurídico estadunidense, pois insuficiente e inadequada para agregação de larga escala, comum na litigiosidade de massa.

Essa técnica também é conhecida pelos nomes de massive joinder ou mass actions. O CAFA, que expandiu a jurisdição federal naquele sistema, aplica-se tanto para as ações de classe quanto às hipóteses de litisconsórcio multitudinário ou de múltiplas ações individuais de massa, envolvendo 100 ou mais pessoas interessadas na resolução da crise de direito substancial. ${ }^{231}$

Estados que antes permitiam o litisconsórcio multitudinário, como Mississipi, restringiram essa possibilidade. Mas, muito embora vedado o litisconsórcio multitudinário, múltiplas demandas individuais, ajuizadas, por vezes, por um mesmo advogado, são encontradas no lugar. Isso ocorreu no precedente Spera v. Fleming Hovenkamp \& Grayson ${ }^{232}$, ocasião em que um mesmo escritório de advocacia ajuizou mais de 30.000 ações individuais em razão de danos pessoais à propriedade, decorrentes do sistema de encanamento, o qual utilizava tubos de polibutilenos.

Situação semelhante também ocorre no sistema jurídico brasileiro, o que já foi objeto de pesquisas empíricas. O problema da multiplicidade de demandas individuais, que, por vezes, quase conduziram à falência dos órgãos do Poder Judiciário, foi objeto de estudo de caso pelo $\mathrm{CEBEPEJ}^{233}$ no tocante à controvérsia atinente à assinatura da tarifa básica de telefonia.

Essa pesquisa relatou que, no ano de 2005, pendiam 95.000 ações individuais relativas a esse tema, apenas no Estado de São Paulo. O volume expressivo de ações tumultuou, inicialmente, os Juizados Especiais do Estado. Posteriormente, foram adotadas algumas medidas de gestão,

231 KLONOFF, 2007, p. 217.

232 AMERICAN LAW INSTITUTE, 2010, p. 17.

233 CEBEPEJ. A Tutela dos interesses metaindividuais - ações coletivas. Ministério da Justiça - Secretária de Reforma do Judiciário. Brasília, 2007. 
como dispensa de audiências de conciliação e instrução, dispensa da autuação e juntada das contrarrazões da ré, ficando os documentos disponíveis para consulta no site da empresa. Isso permitiu o processamento racional ou padronizado das múltiplas demandas individuais. ${ }^{234}$

\subsubsection{AGREGAÇÃO REPRESENTATIVA}

Dentre as ações representativas, a mais conhecida é a ação de classe ou coletiva, em que o membro do grupo propõe a ação coletiva em seu nome e em nome dos membros da classe. Essa modalidade, segundo Taruffo ${ }^{235}$, é conhecida como o modelo individualista altruísta.

$\mathrm{Na}$ ação de classe ou coletiva, o indivíduo atua não apenas na defesa de sua posição de vantagem, mas defesa da posição de vantagem atinente à categoria que integra. Trata-se de um mecanismo de promoção de direitos e interesses coletivos, bem como um mecanismo de pressão aos demais poderes - Legislativo e Executivo - pela proteção desses interesses ou direitos. ${ }^{236}$

O individualismo clássico não é esse, todavia. Tipicamente, o individualismo é egoístico, preocupado exclusivamente com os interesses pessoais. Assim, para preencher essa lacuna pois os indivíduos podem não agir altruisticamente - a proteção dos direitos coletivos ou plurissubjetivos também é conferida a outras entidades e não apenas ao indivíduo interessado. ${ }^{237}$

Nesse segundo caso de ações representativas, é crescente o número de associações e entes públicos que também propõem ações representativas na defesa dos seus próprios interesses e dos interesses do grupo ou da categoria. Embora essa categoria de ações representativas seja mais comum no sistema europeu, também estão presentes no sistema jurídico estadunidense nas ações associativas, nas ações de entes despersonalizados e nas ações parens patriae.

É preciso destacar que essas últimas espécies não se tratam de ação de classe, na forma prevista na Federal 23. São ações representativas, mas não são as ações coletivas, clássicas do sistema.

234 CEBEPEJ, 2007, p. 74.

235 TARUFFO, 2001, p. 418-419.

236 Ibidem, p. 418-419.

237 Ibidem, p. 420. 
As ações associativas e as ações de entes despersonalizados encontram maior resistência na jurisprudência estadunidense ${ }^{238}$. Por vezes, exige-se que a associação ou ente despersonalizado prove o prejuízo individual de alguns de seus membros, para justificar, concretamente, o ajuizamento da ação coletiva naquele caso, bem como atue em litisconsórcio com o indivíduo.

No precedente California Gas Retailers v. Regal Petroleum Corp, um dos indivíduos foi obrigado a integrar a demanda para que a ação coletiva fosse julgada. No precedente Greater Westchester Homeowners Association v. City of Los Angeles, a ação coletiva da associação foi extinta, pois não havia interesse dos membros componentes da classe. As duas decisões são passíveis de crítica no sistema estadunidense, pois, ainda, que a associação não tivesse interesse corporativo no conflito, há interesse próprio e institucional que possibilita a defesa vigorosa. ${ }^{239}$

Os entes públicos, por sua vez, podem ingressar com ações representativas (parens patriae) para a defesa dos interesses públicos soberanos ou quase soberanos. O primeiro diz respeito à atuação do ente público no cumprimento da lei e o segundo diz respeito à proteção da saúde e do bem estar dos cidadãos. O interesse defendido pela ação parens patriae não pode ser individual, mas deve ser um interesse geral, atinente a um segmento relevante dos cidadãos. ${ }^{240}$

Trata-se de ação representativa com origem inglesa medieval, que encontra o seu fundamento na prerrogativa real de proteger o território nacional, bem como de proteger, na qualidade de guardião, os cidadãos e incapazes ${ }^{241}$. No sistema estadunidense, as ações coletivas, propostas por entes públicos, dirigem-se principalmente ao ressarcimento governamental em razão de ilícitos de massa que causaram prejuízos aos cofres públicos (déficit nos programas de governo) e, além disso, com fundamento na perturbação da ordem pública e do bem-estar do cidadão.

238 Existe regra específica no direito estadunidense para a ação coletiva proposta por entes despersonalizados. Trata-se da Rule 23.2. As Cortes de Justiça identificam como entes despersonalizados a união de trabalhadores, a liga de atletas, os grupos políticos, as organizações estudantis etc. Embora algumas Cortes de Justiça tenham adotado uma visão restrita da Rule 23.2, outras admitem a invocação da Rule 23.2 mesmo quando tratar-se de associação incorporada, com capacidade de demandar e de ser demandada (Cf. KLONOFF, 2007, p. 354). 239 DEGNAN, Ronan E. Supreme Court of California 1970-1971 - foreword: adequacy of representation in class action. California Law Review, 1972, V. 60: 705-719p, p.713.

240 LEMOS, Margaret H. Aggregate litigation goes public: representative suits by state attorneys general. Harvard Law Review, 2012, V. 26: 486-549p.

241 FENTON, Richard L, HARTMAN, Kendra. Parens Patriae actions and the limits of State sovereignty. In: GREER, Marcy Hogan (editor). A practitioner's guide to class action. Illinois: ABA Publishing, 2010, p. 637. 
As ações de ressarcimento ocorrem, por exemplo, quando, depois de praticado um ilícito de massa, pretende-se o ressarcimento com os gastos públicos realizados. Um exemplo disso são as ações parens patriae, em face da indústria do tabaco para restituição das despesas com saúde pública, decorrentes do tratamento das doenças relacionadas ao cigarro, indevidamente causadas - é ao menos o que se alega - aos cidadãos. De igual modo, também são comuns as ações cuja pretensão é o reconhecimento da responsabilidade do réu em razão da prática atentatória à ordem pública e ao bem-estar do cidadão, a exemplo da degradação do ambiente. ${ }^{242}$

Exemplo dessa última modalidade é o precedente State v. Lead Industries Association, Inc, em que se argumenta a exposição tóxica dos residentes em Rhode Island, o que constituía um severo problema ambiental naquela localidade, ocasionando notória crise na saúde pública. ${ }^{243}$

Nessa categoria, diferentemente da ação de classe, não são necessárias a definição da classe e a certificação conforme as categorias de ação previstas na Rule 23(b). As ações coletivas mais comuns, propostas por entes públicos, pretendem provimentos declaratórios ou mandamentais. Não obstante, a partir do Clayton Act, editado pelo Congresso em 1976, autorizou-se ao Procurador-Geral a proposição de ações coletivas indenizatórias em razão dos prejuízos sofridos pelos cidadãos em sua propriedade em razão de qualquer violação ao Sherman Act. ${ }^{244}$

Por fim, é preciso destacar que a ações parens patriae são, em regra, consideradas método superior de resolução da controvérsia em relação às ações de classe, de forma que, caso proposta ação de classe privada, essa tende a não ser certificada. A primeira é considerada método superior, por tratar-se de procedimento mais simples. A representatividade do Procurador-geral é presumida e não há, ao menos em regra, direito de autoexclusão ou notificação sobre a ação ${ }^{245}$.

A situação supracitada ocorreu no precedente Commonwealth of Pennsylvania v. Budget Fuel Co. No mesmo dia do ajuizamento da referida demanda parens patriae, foi ajuizada uma ação de classe privada idêntica àquela. Essa última demanda não foi certificada como ação de classe

242 NAGAREDA, 2009, p. 590.

243 Ibidem, p. 598.

244 FENTON, HARTMAN, 2010, p. 638-639. Sherman Act diz respeito à legislação antitruste.

245 Wasserman assinala que as ações parens patriae são vinculantes aos indivíduos (City of Tacoma v. Taxpayers of Tacoma, 1958) (WASSERMAN, Rhonda. Procedural Due Process: a reference guide to the United States Constitution. Connecticut: Praeger, 2004, p. 190) 
ou coletiva em juízo, por não ser considerada método superior de resolução da controvérsia, uma vez que já pendia ação representativa parens patriae mais idônea à tutela coletiva pedida. ${ }^{246}$

Embora a ação parens patriae seja considerada método superior de resolução da controvérsia por algumas Cortes de Justiça, há, ainda, uma desconfiança doutrinária em relação à idoneidade do ente público na defesa da classe, pois a representatividade do ente público é presumida em juízo. Nagareda ${ }^{247}$ questiona se um ente público seria, de fato, mais adequado do que um experiente e capitalizado escritório advocatício, contratado pelo autor da ação de classe.

É curioso notar que igual preocupação não existe, com tanta intensidade, no direito brasileiro, cuja representatividade adequada também é presumida (determinada por lei) em relação aos vários legitimados coletivos. Exige-se, apenas, das associações a constituição há, pelo menos, um ano e a pertinência temática com os interesses ou direitos defendidos em juízo. O requisito da constituição prévia pode, todavia, ser dispensado, quando evidenciado o interesse social pela dimensão e pela característica do dano, bem como a relevância do bem jurídico a ser protegido.

E, não obstante a ausência de previsão expressa quanto à aferição judicial da representatividade adequada dos entes coletivos e públicos, a representatividade adequada já é apregoada pela doutrina, bem como aceita, majoritariamente, pela jurisprudência dos Tribunais Brasileiros ${ }^{248}$

Por fim, é preciso destacar, assim como fez Michele Taruffo ${ }^{249}$, que tanto as ações coletivas altruístas quanto aquelas ajuizadas por entes privados ou públicos devem ser vistas como complementares. Se o ente público ou privado não agir, agir de forma egoística, indiferente ou negligente na defesa dos interesses do grupo, é importante a intervenção individual. De igual modo, se a intervenção individual for egoística ou indiferente ao grupo, é de igual relevância a atuação subsidiária dos entes privados ou públicos na defesa dos interesses ou direitos coletivos.

No tocante às ações representativas, mais uma consideração se faz necessária: a ação representativa também pode revelar-se insuficiente à agregação ótima da controvérsia de massa.

246 FENTON, HARTMAN, 2010, p. 640.

247 NAGAREDA, 2009 , p. 589.

248 COSTA, Susana Henriques da. A representatividade adequada e litisconsórcio - o projeto de Lei $\mathrm{n}$. 5.139/2009. In: In: GOZZOLI, Maria Clara et al (coords.) Em defesa de um novo sistema de processos coletivos: estudos em homenagem a Ada Pellegrini Grinover. São Paulo: Saraiva, 2010, p. 630-631.

249 TARUFO, 2001, p. 420. 
Nem todos os indivíduos estão interessados em ajuizar uma ação de classe ou em realizar a agregação ótima da controvérsia de massa, mesmo quando diante de direitos coletivos. De igual modo, não é possível contar com a iniciativa dos entes públicos no ajuizamento de ações parens patriae, até porque pode não existir uma interesse que afete parcela substancial dos cidadãos. ${ }^{250}$

Por essa razão, aborda-se, hoje, a necessidade de conferir ao juízo a iniciativa de receber e certificar, compulsoriamente, como coletiva ação proposta pelo indivíduo, obstando, com isso, a fragmentação da controvérsia de massa e a repetição de demandas similares ou idênticas.

O caso Taylor v. Sturgell ${ }^{251}$ era, pois, um desses candidatos à agregação processual por iniciativa oficial. Taylor, presidente da Associação de Aviação Antiga - AAA, pretendia obter documentos técnicos sobre a construção do avião F-45, um modelo vintage produzido em 1930. Ocorre que essa não foi a primeira demanda proposta. Antes de Taylor, Greg Herrick, que também era membro daquela associação, sucumbiu em demanda individual anterior que pretendia a revelação dos referidos documentos. O pedido foi julgado improcedente em razão do reconhecimento do segredo comercial em relação a esse modelo. Os dois autores estavam representados pelo mesmo advogado e ajuizaram, em juízos diversos, demandas idênticas.

Nesse caso, a Suprema Corte estadunidense não reconheceu a autoridade da coisa julgada da primeira demanda em relação à segunda demanda individual, sob pena de transformar, retrospectivamente, uma demanda individual em coletiva. Não obstante, ainda que a preclusão não tenha sido reconhecida, é possível encontrar, hoje, no sistema estadunidense, quem defenda não a preclusão retrospectiva, mas, sim, a agregação compulsória da demanda individual.

A agregação compulsória era possível, segundo Samuel Issacharoff ${ }^{252}$, uma vez que o direito pleiteado em juízo era indiferenciado entre os membros individuais da classe. Não havia direito individual de Taylor ou de Herrick, tampouco a controvérsia referia-se aos aspectos pessoais dos autores. Logo, diante de um direito impessoal, com alcance coletivo, possível a agregação.

250 Sobre a atuação estratégica das partes e o comportamento oportunista, conferir: TIDMARSH, Jay, TRANGSRUD, Roger H. Complex litigation: problems in advanced civil procedure. New York: Foundation Press, 2002.

251 UNITED STATES. Supreme Court of United States. Taylor v. Sturgell. 128 S.Ct. 2161 (2008).

252 ISSACHAROFF, Samuel. Private claims, aggregate rights. New York University Public Law and Legal Theory Working Papers. Paper 93, 2008, p. 2. Disponível em http://lsr.nellco.org/nyu_plltwp/93. Acesso em 13 de junho de 2013. 
Para tanto, na certificação da ação individual como ação coletiva, deve-se atentar para o tipo de categoria em que enquadrada a demanda, bem como para os direitos substanciais controvertidos. Isso porque são os critérios dados pelo direito material que indicam a amplitude do conflito: se ele é impessoal e dotado de alcance coletivo e, por isso, passível de agregação.

É preciso destacar que sistemática similar também é ponderada no sistema jurídico brasileiro, bem como já consta em propostas e projetos de lei, os quais ainda serão objeto de abordagem.

\subsubsection{AGREGAÇÃO ADMINISTRATIVA}

Trata-se de técnicas de reunião e coordenação de demandas individuais, que são processadas sob supervisão judicial unitária. Enquadram-se, nessa categoria, a consolidação (consolidation), a coordenação informal (informal coordination) e o caso-teste (test case ou bellwether trial).

\subsubsection{CONSOLIDAÇÃO (CONSOLIDATION).}

Um dos aspectos mais marcantes da consolidação é a ausência de um representante formal. Essa técnica consiste na reunião das demandas individuais, para fins de processamento e/ou resolução unitária da controvérsia no tocante às questões comuns, de fato ou direito, desde que isso não implique dilação processual excessiva. Não há, pois, formação de demanda única. 253

A consolidação já existia no século XVIII, na Inglaterra, introduzida por Lord Mansfield. E, nos Estados Unidos, o conceito já constava no Federal Statute de 1813 e foi incorporado, pela primeira vez, pela Rule 42 de 1938, regra seguida de emenda em 1966 e $2007^{254}$. A consolidação é considerada um dos primeiros exemplos de gestão e de design procedimental e, também, um caso remoto de case management ${ }^{255}$, aspecto inseparável da autoridade das Cortes de Justiça.

253 Esse conceito pode ser extraído da leitura combinada dos seguintes autores: HERR, 2012, p. 181. SULLIVAN et al, 2009, p. 381. MARCUS, SHERMAN, ERICHSON, 2010, p. 107. NAGAREDA, 2009, p. 27. KLONOFF, 2007, p. 407-408. SILVER, Charles. Comparing class action and consolidations. The Review of Litigation, 1991, V. 10: 495-520p. MARCUS, Richard L. Confronting the consolidation conundrum. Brigham Young University Law Review, 1995, p. 880-924. MARCUS, Richard L. Still confronting the confronting the consolidation conundrum. Notre Dame Law Review, 2012, V. 88: 557-592p.

254 MARCUS, 1995, p. 882.

255 MEADOR, Daniel J. Inherent judicial authority in the conduct of civil litigation. Texas Law Review, 1995, V. 73: 1805-1817p. p. 1805-1806. 
Atualmente, a consolidação pode ser realizada para a resolução integral da controvérsia ou restrita a apenas algumas questões comuns de fato ou direito, pendentes, em regra, na mesma divisão da Corte de Justiça. Esse é o teor da Federal Rule $42^{256}$, que limita a técnica às ações individuais pendentes em face da mesma divisão da Corte de Justiça. Não alcança membros ausentes ou futuros do grupo, igualmente interessados na solução da crise de direito substancial.

Na consolidação, não há incorporação das ações individuais em uma única ação representativa. Os indivíduos continuam, em maior ou menor grau, com o controle das suas ações individuais. Por essa razão, não há aferição de representatividade adequada, tampouco é admitido o direito de autoexclusão dos membros do grupo ${ }^{257}$. Não há as proteções estruturais da ação coletiva.

O critério metodológico adotado para identificar as hipóteses suscetíveis de agregação é a identidade das questões controvertidas. Esse critério aproxima-se do requisito da comunhão, previsto para a admissão das ações de classe. Não é necessário que as ações refiram-se à mesma transação ou ocorrência, basta a existência de uma questão comum de fato ou de direito..$^{258}$

Segundo Marcus, Sherman e Erichson ${ }^{259}$, a agregação, mediante a consolidação de demandas individuais, coloca as mesmas questões e os mesmos desafios que existem no tocante à certificação da ação de classe: identificar o alcance coletivo ou plurissubjetivo da controvérsia.

E, mais, as próprias ações coletivas podem ser consolidadas com as ações individuais, daqueles indivíduos que optaram, na ação coletiva, por excluir-se da classe. ${ }^{260}$ Veja que o indivíduo exclui-se de uma técnica de agregação, in casu, a ação coletiva. Porém, se os contornos coletivos ou plurissubjetivos da relação substancial autorizarem, esse indivíduo pode ser novamente capturado por outra técnica de agregação, agora a consolidação das demandas.

256 (a) CONSOLIDATION. If actions before the court involve a common question of law or fact, the court may: (1) join for hearing or trial any or all matters at issue in the actions; (2) consolidate the actions; or (3) issue any other orders to avoid unnecessary cost or delay. (b) SEPARATE TRIALS. For convenience, to avoid prejudice, or to expedite and economize, the court may order a separate trial of one or more separate issues, claims, cross claims, counterclaims, or third-party claims. When ordering a separate trial, the court must preserve any federal right to a jury trial (Cf. UNITAD STATES OF AMERICA. Federal Rules of Civil Procedure. Washington: US Government Printing Office, 2010).

257 SILVER, 1991, p. 499. RESNIK, 1991, p. 5.

258 KLONOFF, 2007, p. 409. MARCUS, 2012, p. 562.

259 MARCUS, SHERMAN, ERICHSON, 2010, p. 118. MARCUS, op. cit., p. 562.

260 HERR, 2012, p. 181. 
É preciso destacar que os magistrados, do sistema jurídico estadunidense, têm amplos poderes para a estruturação da consolidação ${ }^{261}$. Por vezes, a consolidação é processada de forma similar às ações coletivas, isto é, as Cortes de Justiça podem processar a consolidação como uma entidade singular, a partir da adoção de algumas técnicas indiretas de agregação processual.

Dizem-se indiretas ${ }^{262}$, pois essas técnicas, por si só, não produzem a reunião de demandas. Mas, se aplicadas, elas facilitam o processamento e/ou resolução unitária das questões comuns, de fato ou de direito, presentes nas demandas individuais, objeto de consolidação naquela Corte.

Em primeiro lugar, a Corte de Justiça deve ordenar o estabelecimento de um processo mestre ${ }^{263}$, obstando a juntada de múltiplas petições e de documentos idênticos nesse processo, bem como obstando a juntada dessas petições e documentos nos demais processos individuais pendentes, salvo nas hipóteses em que essas informações digam respeito às questões singulares das partes.

Esse processo mestre, por englobar as questões comuns da categoria, pode ser considerado uma amostra representativa da controvérsia. A ação não é representativa, mas, considerando a reunião das questões comuns, sem duplicação ou redundância, há, ao menos, uma amostra. A parte perde, parcialmente, o controle individual sobre essa questão, objeto da consolidação. ${ }^{264}$

Em segundo lugar, a consolidação exige, na maioria das vezes, o apontamento de um conselho de advogados (lead counsel) e de um conselho administrativo (liaison counsel). Trata-se da seleção de um ou mais sujeitos, os quais são autorizados a manifestar-se sobre as questões comuns, objeto da consolidação. O magistrado pode convidar líderes, bem como realizar conferências para aferir a responsabilidade e a qualidade dos líderes selecionados para o caso. Igualmente, é possível estabelecer um comitê de autores e réus, para monitoramento da ação. ${ }^{265}$

A convocação de um comitê administrativo, de um comitê de advogados e de um comitê de autores e/ou réus, o que pode ser realizada de ofício pelo magistrado, é muito positiva. Essa convocação, além de permitir a simplificação do procedimento, evitando a multiplicação de

261 SILVER, 1991, p. 499.

262 TIDMARSH, TRANGSRUD, 2002, p. 27.

263 FEDERAL JUDICIAL CENTER, 2004, p. 33 e 218.

264 MARCUS, 1995, p. 890.

265 HERR, 2012, p. 46. FEDERAL JUDICIAL CENTER, 2004, p. 25 
petições de cada um dos indivíduos, confere credibilidade ao procedimento, bem como permite uma melhor fiscalização e monitoramento pelos advogados e, também, pelas partes.

O conselho administrativo é responsável por facilitar a comunicação entre a Corte de Justiça e as partes das ações individuais, bem como por advertir as partes sobre o desenvolvimento do procedimento, por agendar encontros e conferências, por facilitar a gestão dos documentos etc. Os líderes do conselho administrativo não precisam ser, necessariamente, advogados.

O conselho de advogados, por sua vez, exige, obviamente, a formação jurídica de seus líderes. Esse conselho deve apresentar, em juízo, as posições do grupo no tocante às questões comuns de natureza processual e substancial. O conselho pode apresentar argumentos e sugestões à Corte de Justiça, de igual modo, pode auxiliar a implementação do plano de julgamento da causa. O conselho de advogados pode compor um conselho de julgamento, para fins de participação oral na sessão de julgamento da controvérsia, que foi objeto de consolidação. ${ }^{266}$

Em terceiro lugar, a Corte de Justiça pode ordenar a emenda e a juntada de petições unitárias e uniformes ou consolidadas pelo conselho de advogados. Com isso, o processo mestre passa a ser constituído de petições únicas, evitando-se a duplicação de papéis e a formações de volumes expressivos de autos, de difícil manuseio. O manuseio de apenas um documento para todo o grupo simplifica a condução do processo mestre em juízo e facilita a prestação jurisdicional. ${ }^{267}$

Por ocasião da emenda e da elaboração da petição unitária, o conselho de advogados pode oferecer uma consolidation class action complaint ${ }^{268}$, ajuizada na Corte de Justiça cessionária, de forma a estabelecer a competência na localidade, pleiteando a certificação da ação de classe.

A exigência de alegações e petições unitárias ocorreu no precedente Katz v. Realty Equities Corp. of New York ${ }^{269}$. Nesse caso, o Segundo Circuito salientou que não há prejuízo ao indivíduo, pois as alegações singulares podem ser realizadas nos processos individuais pendentes. A exigência de petições uniformes não veda, portanto, requerimentos individuais.

266 HERR, 2012, p. 46. FEDERAL JUDICIAL CENTER, op. cit., p. 25.

267 MARCUS, SHERMAN, ERICHSON, 2010, p. 117.

268 FEDERAL JUDICIAL CENTER, 2004, p. 737.

269 UNITED STATES. Second Circuit. Katz v. Realty Equities Corp. of New York. 521 F. 2d 1354(1975). 
Por fim, lembra-se que a consolidação somente é admitida, pela Federal Rule 42, na hipótese de demandas individuais pendentes em uma mesma divisão da Corte de Justiça Federal. O número de juízes varia conforme o distrito. Por exemplo, há dois juízes no Distrito Leste de Oklahoma, 28 no Distrito Sul de Nova York e, por fim, 27 no Distrito Central da Califórnia. ${ }^{270}$

Nesse caso, as demandas individuais devem ser atribuídas ao mesmo magistrado de uma divisão do Distrito271. O mecanismo para tanto é denominado de "low numbering", isto é, quando a demanda é distribuída, ela recebe um registro. Por exemplo, a primeira demanda distribuída em 2010 tem o número 10-0001 e a centésima demanda daquele ano tem o número 10-0100. Ambos os processos são sorteados randomicamente entre os juízes distritais. Se o segundo caso for idêntico ou similar ao primeiro, ele será atribuído para o magistrado da primeira demanda, de numeração inferior ou low numbered, a quem competirá aferir a viabilidade da consolidação. ${ }^{272}$

Caso as demandas individuais estejam pendentes em divisões diversas da mesma Corte de Justiça, a Regra 28 U.S.C $§ 1404(b)^{273}$ autoriza a transferência (transfer - modificação da competência) para o juízo da primeira ação distribuída, seja por requerimento das partes, seja por iniciativa oficial do juiz, para fins de consolidação das múltiplas demandas individuais. Nesse caso, não existem requisitos específicos, basta a remessa para o juízo na forma citada.

Caso as demandas individuais estejam pendentes em distritos diferentes da jurisdição federal, a Regra 28 U.S.C §1404(a) ${ }^{274}$ autoriza a transferência (transfer - modificação da competência) para o juízo da primeira ação distribuída, em prol da conveniência das partes e testemunhas e

270 SULLIVAN et al. 2009, p. 380-381.

271 Algumas Cortes de Justiça dispõem de regras locais que determinam ao advogado, ao protocolar a sua petição, o dever de informar os dados gerais da demanda, bem como a existência de eventuais demandas similares ou, de qualquer modo, correlata àquela pendente (Cf. FEDERAL JUDICAIL CENTER, 2004, p. 232).

272 SULLIVAN, op. cit., p. 380-381.

273 “(b) Upon motion, consent or stipulation of all parties, any action, suit or proceeding of a civil nature or any motion or hearing thereof, may be transferred, in the discretion of the court, from the division in which pending to any other division in the same district. Transfer of proceedings in rem brought by or on behalf of the United States may be transferred under this section without the consent of the United States where all other parties request transfer. (c) A district court may order any civil action to be tried at any place within the division in which it is pending” (UNITED STATES OF AMERICA. Federal Rules of Civil Procedure. Washington: US Government Printing Office, 2010).

274 "(a) For the convenience of parties and witnesses, in the interest of justice, a district court may transfer any civil action to any other district or division where it might have been brought or to any district or division to which all parties have consented" (UNITED STATES OF AMERICA. Federal Rules of Civil Procedure. Washington: US Government Printing Office, 2010). 
do interesse da justiça em alcançar julgamento mais célere e uniforme, sob a forma agregada. Nesse caso, existem requisitos específicos a serem observados para fins de transferência.

Caso as demandas estejam pendentes em distritos diferentes da jurisdição federal, deve ser observada, em regra, a "first-filed rule"275. Em caso de modificação da competência, a primeira demanda individual distribuída adquire preferência, atraindo as demais demandas individuais.

No tocante à transferência entre distritos, com fundamento na Regra 28 U.S.C §1404(a) algumas limitações existem. A transferência somente pode ser realizada para outro distrito, em relação ao qual a demanda poderia, em tese, ter sido originariamente ajuizada. Isso é corroborado pelo precedente Hoffman v. Blaski ${ }^{276}$. A transferência pode ser pleiteada pelas partes ou pode ser ordenada de ofício, incluindo a fase instrutória e também a fase decisória. ${ }^{277}$

Por fim, uma última limitação: cada um dos juízes distritais, do local onde estão pendentes as demandas individuais, deve autorizar a transferência ${ }^{278}$. Exemplo: o réu realiza uma moção para a transferência das demandas distribuídas nos Distritos $\mathrm{X}, \mathrm{Y}, \mathrm{Z}$ para o Distrito A, no qual encontra-se a primeira demanda distribuída, todos os juízes envolvidos deverão aferir os requisitos e autorizar a transferência ao juiz do Distrito A. Essa limitação não existe na hipótese da Regra 28U.S.C §1407, relativa à consolidação multidistrital, a qual será abordada adiante.

Ainda, é preciso ressaltar que a transferência não é o único mecanismo para facilitar a agregação processual. As Cortes de Justiça, nas quais pendentes as demandas individuais distribuídas em segundo, terceiro, quarto, quinto lugar...podem suspender a tramitação dessas. Dessa forma, depois do julgamento da primeira demanda, objeto de consolidação, é possível aplicar a eficácia

275 SULLIVAN et al, 2009, p. 361 et seq.

$276 \mathrm{O}$ referido precedente esclarece que a demanda pode ser transferida apenas para o local competente, no qual poderia, em tese, ter sido originariamente ajuizada. Não é admissível afastar essa regra, mesmo se autor e réu concordarem no ajuizamento da demanda em novo fórum. Nesse sentido: "a) the phrase "where it might have been brought" in § 1404(a) cannot be interpreted to mean "where it may now be rebrought, with defendants' consent." Pp. 363 U. S. 342-343.(b) Under § 1404(a), the power of a district court to transfer an action to another district is made to depend not upon the wish or waiver of the defendant, but upon whether the transferee district is one in which the action "might have been brought" by the plaintiff. Pp. 363 U. S. 343-344" (Cf. UNITED STATES. Supreme Court of United States. Hoffman v. Blaski. 363 U.S. 365 (1960)). O precedente é criticado pela doutrina, mas não foi superado (overruled) (Cf. TIDMARSH, TRANGSRUD, 2002, p. 33).

277 KLONOFF, 2007, p. 416.

278 Ibidem, p. 418. 
positiva da coisa julgada em relação às demandas pendentes suspensas ou reconhecer a preclusão sobre a questão comum (fato ou direito) decidida por ocasião da consolidação. ${ }^{279}$

Jack B. Weinstein ${ }^{280}$ salienta que a suspensão das ações individuais é conhecida como "quasi consolidation", pois facilita a agregação de forma quase equivalente à consolidação de ações.

Essa modalidade de suspensão, antes mencionada, é denominada de self-stay ou kerotest stay. Nesse caso, as demandas subsequentes são suspensas pelo magistrado por elas responsável, por força de uma demanda originária, distribuída em primeiro lugar sob outra competência. ${ }^{281} \mathrm{O}$ próprio magistrado suspende a demanda, sob a sua gestão, em deferência à demanda originária.

Existe uma segunda modalidade de suspensão denominada de anti-suit injuction, em que um magistrado determina a outra Corte de Justiça ${ }^{282}$ ou às partes da própria demanda, para ele distribuída, a suspensão do processo subsequente e/ou a proibição de as partes de ajuizarem novas demandas ou demandas duplicadas em outras Cortes de Justiça. Nesse último caso, exerce-se autoridade sobre as partes, impedindo o ajuizamento de novas demandas de classe ou individuais em outras Cortes de Justiça. Isso é particularmente relevante nas ações de classe, pois a parte, que recebe a ordem proibitória, é própria classe e não o seu representante, obstando ações coletivas concorrentes. O objetivo da técnica é assegurar o exercício da competência, bem como assegurar a proteção e o cumprimento de eventual julgamento proferido pelo juiz. ${ }^{283}$

A regra da primeira demanda distribuída - "first-filed rule" - não é absoluta, todavia. Essa regra é excepcionada em casos especiais, como na hipótese de um dos interessados assumir conduta abusiva para ganhar, previamente, eventual corrida de interessados à Corte de Justiça. E, igualmente, a regra é excepcionada se o centro de gravidade da controvérsia estiver no distrito

279 SULLIVAN et al, 2009, p. 367.

280 WEINSTEIN, Jack B. Individual justice in mass tort litigation. Illinois: Northwestern University Press, 1995, p. 137.

281 TIDMARSH, TRANGSRUD, 2002, p. 30.

282 Uma Corte Federal pode determinar a suspensão de uma demanda em uma Corte Estadual, em nome de sua jurisdição, por força do All Writs Action - AWA. Mas, também é possível determinar a remoção, para fins de consolidação na Corte Federal (Cf. MILLER, Geoffrey P. Overlapping class action. New York University Law Review, 1996, V. 71:514-546p).

283 WEINSTEIN, Andrew S. Avoiding the race to res judicata: federal anti-suit injunctions of competing state class actions. New York University Law Review, 2000, V. 75: 1085-1120p. 
da segunda demanda distribuída. Para tanto, deve-se observar a residência das partes e das testemunhas, o melhor acesso às evidências e provas, o direito que irá governar a lide e outros. ${ }^{284}$

Por fim, a suspensão é a medida mais adequada quando não há maior antagonismo entre os membros da classe e existem questões comuns, a serem consolidadas, e questões individuais. A suspensão é decorrente da doutrina da abstenção ${ }^{285}$. Um juiz se abstém de julgar, pois a questão já se encontra judicializada, ao menos em parte, em outra demanda. Essa abstenção somente se justifica se houver pelo menos uma questão comum aos dois processos a ser resolvido primeiro e as partes interessadas estejam alinhadas no tocante aos seus argumentos. Resolvida a questão comum, resta apenas a resolução das questões individuais pendentes.

Se houver maior antagonismo entre os membros da classe, a medida mais adequada é a reunião, de forma a consolidar as causas de pedir e pedidos de todas essas ações individuais. Embora exista uma questão comum, essa questão pode ser objeto de maior divergência. Por essa razão, não é cabível a abstenção, mas, sim, a fusão das causas e argumentos das partes interessadas.

Apenas se as ações forem idênticas, a Corte de Justiça poderá extingui-las pela "prior pending action doctrine”, isto é, as mesmas partes, mesmo pedido e as mesmas questões controversas. Quando idênticas as ações, elas são referenciadas como imagens espelhadas uma da outra. ${ }^{286}$

Por fim, por ocasião da consolidação, eventuais questões individuais, presentes nas ações individuais, devem ser separadas das questões comuns do grupo. Apenas essas últimas devem ser objeto da técnica da consolidação. A Corte de Justiça pode separar o julgamento das

\footnotetext{
284 SULLIVAN, 2009, p. 366. As exceções à regra do "first-filed" foi mencionada no precedente Biolitec, Inc. v. Angiodynamics, Inc. (Cf. UNITED STATES OF AMERICA. District of Massachusetts. Biolitec, Inc. v. Angiodynamics, Inc 581 F. Supp. 2d 152 (2008)). No mesmo sentido, SHERMAN, Edward F. Class actions and duplicative litigation. Indiana Law Journal, 1987, V. 62:507-559p. p. 519.

285 TIDMARSH, TRANGSRUD, 2002, p. 58.

286 A Corte de Justiça tem o poder de extinguir demandas idênticas (mesmas partes, com relação ao mesmo pedido e mesmas questões controvertidas), por força da doutrina da prior pending action doctrine, similar à litispendência brasileira. Caso as demandas sejam parcialmente idênticas e persistam questões individuais, é possível a suspensão, para a consolidação da questão comum. Se houver causas de pedir diferentes ou um maior antagonismo entre os membros da classe, o ideal é reunião das demandas individuais. A reunião possibilita a agregação direta, enquanto os demais mecanismos são auxiliares ou indiretos à agregação. De igual modo, a reunião permitiria com maior facilidade, por exemplo, a formação de uma petição uniforme e unitária, que alcançasse a questão comum, de fato ou de direito, controvertida presente nas ações individuais. (Cf. Em sentido semelhante, conferir SULLIVAN et al, op. cit., p. 364. TIDMARSH, TRANSGSRUD, op. cit., p. 31).
} 
questões individuais e das questões comuns, bem como pode bifurcar o julgamento em duas fases: a primeira fase para a aferição da responsabilidade e a segunda para aferição dos danos. ${ }^{287}$

Existe uma segunda espécie de consolidação - multidistrital - a qual envolve aspectos específicos. Por essa razão, será abordada em separado no próximo tópico desta investigação.

\subsubsection{CONSOLIDAÇÃO MULTIDISTRITAL (MULTIDISTRICT LITIGATION - MDL)}

Os mecanismos antes mencionados são, notadamente, insuficientes na hipótese de demandas individuais com grande dispersão geográfica no sistema judiciário federal estadunidense.

A técnica de consolidação prevista na Rule 42 é insuficiente, pois somente aplicável às demandas individuais pendentes na mesma divisão da Corte de Justiça Federal. A Rule 28 U.S.C \$1404(a) também é insuficiente, pois cada juiz deverá autorizar a transferência das demandas individuais pendentes sob a sua relatoria. Nesse caso, será árduo o ônus das partes de protocolar milhares de moções de transferência em cada um dos processos individuais. E, de igual modo, o sucesso da técnica depende de 20, 30 ou 40 juízes, que, agindo de forma independente, reconheçam o preenchimento dos pressupostos legais e autorizem a transferência pleiteada. ${ }^{288}$

Essa insuficiência pode ser percebida no caso da conspiração para fixação dos preços dos equipamentos elétricos, os quais resultaram em uma avalanche de demandas individuais, dispersas em 35 diferentes distritos do sistema judiciário federal no início dos anos 60 . Considerando que não era possível o recurso à Regra 42 e à Regra 28 U.S.C §1404(a), as Cortes de Justiça desenvolveram, ad hoc, uma forma de cooperação para a resolução dessas demandas, a saber, foi criado um comitê, supervisionado por nove juízes federais, para a realização do saneamento e da instrução nacional dos casos individuais pendentes naqueles 35 distritos. ${ }^{289}$

A experiência, antes mencionada, inspirou a edição do Multidistrict Litigation Act, 28 U.S.C \$1407, que criou o Painel do Contencioso Multidistrital (Panel of multidistrict litigation) em 1968, o qual detém competência para transferir as demandas individuais para um mesmo juiz. A transferência é determinada pelo painel e não pelos juízes relatores das ações individuais. ${ }^{290}$ 
Os principais aspectos dessa transferência começam pela formação jurídica do painel. O painel é composto por sete juízes federais, nomeados pelo Ministro-Presidente do Tribunal Superior. Não há Tribunal ou sede para o painel, tampouco os juízes são afastados de suas funções regulares. Os juízes reúnem-se, quando necessário, para admitir a transferência pedida ou para discutir a conveniência em determinar a transferência das demandas individuais pulverizadas. ${ }^{291}$

O painel pode transferir as demandas individuais independentemente da regra de competência originária, bem como pode selecionar a Corte de Justiça mais apta e experiente para receber o quantitativo de processos determinados. De igual modo, pode designar um juiz específico, mais experiente, para compor aquela Corte Distrital, para onde são remetidas as demandas. ${ }^{292}$

A transferência é efetivada quando a decisão, concedendo a ordem de transferência, é distribuída na secretaria da Corte Distrital destinatária. Essa Corte de Justiça cessionária adquire jurisdição exclusiva, cessando, nesse momento, a jurisdição da Corte de Justiça cedente. ${ }^{293}$

Alguns parâmetros são utilizados para orientar a decisão pela transferência e a escolha do destino: (i) a finalidade da transferência é a consolidação, logo é necessária a existência de uma questão comum; (ii) a transferência deve promover a conveniência das partes, das testemunhas, bem como a justa e eficiente resolução da controvérsia; (iii) as partes das demandas individuais devem ser notificadas sobre a pretensão de transferência, bem como o painel deve conduzir uma audiência para determinar se a consolidação deve ser assegurada para a controvérsia em questão; (iv) são exigidas a numerosidade, a complexidade das demandas individuais e a insusceptibilidade de informal coordenação; e (v) o destino escolhido deve observar os distritos pelos quais estão pulverizadas as demandas individuais, o domicílio das partes, o domicílio das testemunhas, o local em que estão as evidências e, como já consignado, a experiência das Cortes Distritais e a de seus magistrados para o processamento do caso. É possível que o painel escolha como destino distrito diverso, que não possua competência territorial para a controvérsia ${ }^{294}$

291 SULLIVAN et al, 2009, p. 383.

292 TIDMARSH, TRANGSRUD, 2002, p. 35.

293 SULLIVAN et al, op. cit., 384.

294 HEYBURN II, John G. A view from the panel: part of solution. Tulane Law Review, 2008, V. 82: 22252244p. HEYBURN II, John G. Reflexions on the panel's work. ABA Section of Litigation Joint Committee's CLE Seminar, 2012. Em sentido semelhante, HERR, 2012, p. 322. 
São também objeto da transferência as demandas individuais ainda não ajuizadas. Caso novas demandas individuais sejam ajuizadas, elas são consideradas tag-along cases $^{295}$, isto é, as demandas ficam vinculadas à transferência e devem seguir para a Corte Distrital cessionária.

A negativa da transferência é irrecorrível e o deferimento da transferência é recorrível apenas pelo extraordinary writ, a teor da Regra 28 U.S.C $\$ 1651^{296}$. O writ deve ser julgado pelo Circuito Federal com competência para reexaminar as decisões da Corte de Justiça cessionária. Por fim, o writ em questão é um remédio excepcional e genérico e visa apenas assegurar o exercício da jurisdição de forma adequada, de acordo com os usos e os princípios de direito.

A transferência pode ser determinada pelo magistrado, bem como pleiteada por um das partes das demandas individuais. A regra 28 U.S.C $\$ 1407$ limita, todavia, esse mecanismo apenas para a fase de saneamento e instrutória (pre-trial). Ultrapassada essa fase, sem acordo ou julgamento sumário, as demandas devem ser remetidas para o juízo de origem para fins de julgamento.

Até 1998, o magistrado da Corte de Justiça cessionário utilizava o disposto na regra 28 U.S.C $\$ 1404(a)$, para lograr a transferência para efeito de julgamento. O Painel de MDL adotou, expressamente, regra, que permitia a transferência supracitada. Ocorre que, no precedente Lexecon Inc. v. Milberg Weiss Bershad Hynes \& Lerach, de 1998, a Suprema Corte dos Estados Unidos consolidou que a Corte de Justiça cessionária não tem autoridade para efetuar a transferência com fundamento na regra 28 U.S.C \$1404(a). Propostas para ampliar o escopo da transferência, incluindo o julgamento, são estudadas, mas não há, ainda, qualquer alteração. ${ }^{297}$

O Manual de Litigância Complexa ${ }^{298}$ oferece algumas medidas para contornar o precedente em Lexecon, dentre elas: (i) a realização de um caso-teste para facilitar a realização de acordos ou para o caso de as partes consentirem em se vincular ao resultado; (ii) as partes podem pleitear a extinção da demanda na Corte de Justiça cedente, ajuizando-a novamente na Corte de Justiça cessionária; (iii) a Corte de Justiça cedente, depois da devolução das demandas individuais para julgamento, pode novamente transferi-las à Corte de Justiça cessionária a teor da regra 28 U.S.C

295 HEYBURN II, 2008, p. 2233.

296 KLONOFF, 2007, p. 416.

297 NAGAREDA, 2009, p. 388.

298 FEDERAL JUDICIAL CENTER, 2004, p. 222. 
\$1404(a); e (iv) o magistrado da Corte de Justiça cessionária pode ser designado para atuar na Corte de Justiça cedente para fins de julgamento das demandas individuais antes consolidadas.

Grande parte dos casos, objeto de transferência, não chega a ser devolvido à Corte de Justiça de origem, pois são extintos ou pela realização de um acordo ou pelo julgamento antecipado da lide (summary judgment). O juiz cessionário tem todos os poderes relativos à fase de saneamento e instrução (pre-trial), como homologar acordos, extinguir a demanda e realizar o julgamento no estado do processo. Já houve recurso em face dessas decisões, mas a autoridade do Corte de Justiça cessionária, no tocante aos poderes do juiz no pre-trial, não foi negada. ${ }^{299}$

Um dos casos considerados bem-sucedidos de MDL é a controvérsia relativa ao implante de silicone $^{300}$. O Painel de MDL consolidou 78 casos individuais, pulverizados no sistema federal em 1992. Posteriormente, surgiram mais de 10.000 tag-along cases que também seguiram para a Corte de Justiça cessionária. O processo foi extinto por acordo no valor de $\mathrm{R} \$ 1$ bilhão.

Existem outros procedimentos que também permitem a consolidação multidistrital. Por exemplo, em 2002, o Congresso aprovou o Multiforum Trial Jurisdiction Act, que confere competência à Justiça Federal para as hipóteses de acidente de massa, superior a 75 mortes, (i) quando as partes forem cidadãos de estados diversos ou de um Estado Estrangeiro, (ii) quando o acidente ocorrer em localidade diversa do domicílio do réu ou (iii) quando dois ou mais réus possuírem domicílios em estados diversos e (iv) quando o acidente foi fragmentado por dois ou mais estados. A legislação também permite a remoção dos casos ajuizados na Justiça Estadual quando eles poderiam ter sido, originariamente, ajuizados também na Justiça Federal. ${ }^{301}$

Quando uma Corte de Justiça Distrital presidir questão relativa a esse ato normativo, deverá informar ao Painel de MDL, permitindo ao último aferir a viabilidade de consolidar as demandas pendentes nos vários distritos do sistema federal no tocante à fase do pre-trial. ${ }^{302}$

Um das técnicas mais poderosas de agregação supera, todavia, os limites da investigação do presente trabalho, mas é válida a sua menção. Trata-se da falência. A distribuição da moção de 
falência suspende, automaticamente, todas as demandas individuais na justiça federal e estadual e permite ao devedor paralisar qualquer procedimento que afete seu patrimônio. Depois da suspensão, as demandas individuais são consolidadas, para a distribuição pro rata dos créditos, em um mesmo juízo. Esse procedimento é mais raro, pois depende do ajuizamento de moção de falência. Esse é o único mecanismo que permite a agregação de demandas pendentes no sistema judiciário estadual e federal, muito embora seja restrito à falência. ${ }^{303}$

\subsubsection{COORDENAÇÃO (COORDINATION)}

Todas as técnicas de transferência e consolidação, com exceção da falência, aplicam-se, exclusivamente, ao sistema federal. Não há mecanismo de agregação direto para demandas individuais pulverizadas entre o sistema judiciário federal e estadual. Mesmo nas ações coletivas, há resistência à certificação de ações coletivas mandatórias ou de vinculação obrigatória (mandatory class action) quando existem demandas individuais e/ou coletivas duplicadas e essas demandas estão fragmentadas entre o sistema judiciário federal e estadual. ${ }^{304}$

Para essas hipóteses, incide, então, técnicas de coordenação informal das demandas individuais e coletivas pendentes, surgindo uma cooperação entre os magistrados e as Cortes de Justiça. ${ }^{305}$

Por vezes, há uma cooperação voluntária entre a Corte de Justiça Estadual e Federal, principalmente quando as demandas individuais estão pendentes em um mesmo Estado. Os juízes coordenam, entre si, a instrução, o apontamento do conselho de advogados e administrativo, o agendamento das fases do procedimento etc. E, mais, o Painel de MDL transfere, eventualmente, as demandas individuais para a Corte Distrital Federal, localizada no Estado com maior pendência de demandas individuais, para que surja essa cooperação. ${ }^{306}$

Em 1994, o American Law Institute ${ }^{307}$ realizou uma proposta robusta para possibilitar a agregação processual de demandas individuais pendentes em sistemas judiciários diversos. A

303 KLONOFF, 2007, p. 421.

304 SCHWARZER, William W. WEISS, Nancy E., HIRSH, Alan. Judicial federalism in action: coordination of litigation in state and federal courts. Virginia Law Review, 1992, V. 78: 1689-1751p. p. 1694.

305 HERR, 2012, p. 334. MARCUS, SHERMAN, ERICHSON, 2010, p. 172.

306 HERR, 2012, p. 335.

307 SULLIVAN et al, 2009, p. 438-439. KLONOFF, 2007, p. 428. No mesmo sentido: SCHWARZER, William W. Judicial federalism: a proposal to amend the multidistrict litigation statute to permit Discovery coordination of large-scale litigation pending in state and federal courts. Texas Law Review, 1995, V. 73: 1529-1568p. 
proposta consistia em permitir a remoção dos casos pendentes na Justiça Estadual para a Justiça Federal, quando as demandas fossem relativas à mesma transação ou ocorrência ou quando compartilhassem questões comuns de fato ou de direito. A remoção seria ordenada por um Painel de Contencioso Complexo, a quem caberia decidir a Corte Distrital Federal de destino. A lei aplicável deve ser uniforme, embora as demandas tenham surgido em Estados diferentes.

Essa proposta foi criticada, principalmente, em razão da preocupação com o federalismo e com a autonomia dos entes federados (Estados). Não foi, por isso, analisada pelo Congresso. Klonoff ${ }^{308}$ salienta, no entanto, que a proposta é séria e criativa e merecia uma melhor discussão.

Atualmente, o Manual do Contencioso Complexo ${ }^{309}$ confere algumas recomendações para auxiliar os magistrados a cooperar em prol da resolução agregada e unitária da controvérsia. A Corte de Justiça deve, em um primeiro momento, identificar as demandas pendentes em outras cortes e sistemas judiciários, bem como identificar o estágio do procedimento e o juiz responsável por essas demandas. A partir desse momento, os juízes devem entrar em contato uns com os outros, criando uma agenda de cooperação e práticas uniformes a serem adotadas.

De igual modo, é possível reuniões para discussões de preocupações comuns e sugestões a serem, eventualmente, adotadas. De igual modo, os magistrados podem designar um mesmo conselho administrativo e um mesmo conselho de advogados, bem como indicar um mesmo special master, isto é, espécie de perito investido de poderes para praticar alguns atos processuais, bem como para conduzir tratativas para a resolução alternativa da controvérsia. ${ }^{310}$

A coordenação não é o ideal. O ideal é a existência de técnicas mais previsíveis e formais de agregação ${ }^{311}$. Porém, na falta delas, o procedimento deve ser adequado aos contornos do direito substancial. Ainda que por força dos mecanismos de cooperação ou de colaboração das Cortes de Justiça, o método de resolução de controvérsias deve alcançar os seus escopos jurídicos.

308 KLONOFF, 2007, p. 429.

309 FEDERAL JUDICIAL CENTER, 2004, p. 227-228.

310 Ibidem, p. 227-228. No mesmo sentido, mencionado as técnicas de cooperação entre magistrados, conferir: MCGOVERN, Francis F. Rethinking coooperation among judges in mass tort litigation. UCLA Law Review, 1997, V. 44: 1851-1870.

311 Howard Erichson assinala que a controvérsia de massa atraí a agregação. Na falta de mecanismos formais de agregação, ela tende a acontecer de qualquer maneira. É importante atenção com a técnica de agregação informal, para que não se reúna o pior dos dois mundos, nem uma autonomia individual plena, nem uma agregação processual plena com a resolução unitária da controvérsia. (ERICHSON, Howard M. Informal aggregation: procedural and ethical implications of coordination among counsel in related lawsuits. Duke Law Journal, 2000, V. 50: 381-471, p. 467-469). 
Exemplos bem sucedidos de agregação informal entre o sistema judiciário federal e estadual podem ser encontrados nos seguintes casos, mencionados por SCHWARZER, WEISS e HIRSH ${ }^{312}$ :

(i) Federal Everglades air crash, relativo a acidente de avião que viajava de Nova York para Miami e que culminou no óbito de 96 passageiros e em grave lesão aos demais tripulantes. Nessa hipótese, foram ajuizadas demandas individuais nas Cortes Estadual e Federal da Flórida e na Corte Federal de Nova York. As demandas pendentes na Corte Estadual da Flórida foram atribuídas a um mesmo juiz, que cooperou com o magistrado responsável pelas demandas pendentes na Corte Federal da Flórida, lá centralizadas pelo Painel do Contencioso Multidistrital. Foram julgados dois casos-teste pendentes na Corte Federal, para fins de apuração da responsabilidade, sendo que as partes concordaram com a vinculação ao resultado obtido nos casos-teste. A quantificação dos danos foi, por sua vez, objeto de resolução individual, sem coordenação das demandas.

(ii) Beverly Hills Super Club fire, relativo a incêndio em um clube noturno de Kentucky, matando mais de 300 pessoas. Múltiplas demandas individuais foram ajuizadas tanto na Corte de Justiça Estadual (Kentucky State Court) quanto na Corte de Justiça Federal (States District Court for the Eastern District of Kentucky). Os dois juízes - federal e estadual - coordenaram entre si toda a fase de saneamento e instrução, evitando a duplicação de esforços, bem como dividiram as demandas em grupos para instrução. Os dois juízes procederam a certificação de uma ação coletiva estadual e outra federal.

(iii) A mesma espécie de coordenação, antes mencionada, ocorreu nos seguintes acidentes Chicago Air Crash, MGM Grand Hotel Fire, Hyatt Skywalk cases, L'ambience Plaza colapse, Sioux City Air Crash, Exxon Valdez oil spill e muitos outros.

As técnicas de coordenação mais comuns, aplicadas aos casos, foram aquelas antes citadas: saneamento e instrução cooperada, agenda compartilhada (designação de um mesmo perito, disponibilidade comum de documentos para os dois procedimentos), plano de gerenciamento comum da demanda, audiências comuns presididas pelos dois juízes (estadual e federal), 
programa comum de resolução alternativa da controvérsia e, por fim, julgamento conjunto, os dois juízes presidiriam o julgamento no mesmo dia, com um júri estadual e outro júri federal. ${ }^{313}$

\subsubsection{CASO-TESTE (TEST-CASE OU BELLWETHER TRIAL)}

O caso-teste responde por vários nomes no sistema jurídico estadunidense, dentre eles, testcase, trial by statistics, trial by sample, collective trial, bellwether trial e outros nomes. Tratase como, o próprio nome diz, de um caso-teste, líder, típico ou representativo do grupo, que orienta ou vincula o julgamento dos casos individuais similares, também pendentes em juízo.

Bellwether trial é um nome fantasia, que também caracteriza um caso como sendo líder e representativo do grupo. Esse nome deriva de uma antiga prática rural de se colocar um sino no pescoço de um carneiro, a quem incumbiria liderar o rebanho. O sucesso dessa prática depende de selecionar um carneiro que goze da confiança do rebanho, de forma que o rebanho passe a seguir o carneiro com o sino no pescoço por sentir segurança de que eles não irão se perder. ${ }^{314}$

A técnica do caso-teste consiste, à semelhança da situação do carneiro e do rebanho, em selecionar uma amostra representativa da controvérsia de um grupo de casos individuais similares. A partir dessa técnica, identificam-se elementos comuns entre vários casos individuais, previamente selecionados, segundo método estatístico, extrapolando a solução do caso representativo para os demais casos individuais, que compõe o mesmo universo coletivo. ${ }^{315}$

A técnica de agregação do caso-teste fundamenta-se na tipicidade das questões comuns a um grupo, bem como na fundamentação de probabilidade ou de verossimilhança das conclusões extraídas do caso representativo da controvérsia. Nesse momento, a atenção é dirigida às questões fáticas e jurídicas comuns, não há atenção para as questões particulares e individuais.

Segundo Alexandra D. Lahav ${ }^{316}$, o caso teste é, por excelência, técnica de agregação. A decisão é unitária em relação à questão comum, pois é baseada na tipicidade do grupo em juízo. Veja:

313 SCHWARZER, WEISS e HIRSH, 1992, p. 1700 et seq.

314 FALLON, Eldon, GRABILL, Jeremy T., WYNNE, Robert Pitard. Bellwether trials in multidistrict litigation. Tulane Law Review, V. 82: 2323-2367p, p. 2324.

315 TIDMARSH, TRANGSRUD, 2002, p. 262. FEDERAL JUDICIAL CENTER, 2004, p. 360.

316 LAHAV, Alexandra D. Bellwether Trials. The George Washington Law Review, 2008, V. 76: 576-638p., p. 597. 
O julgamento líder ou termômetro fundamenta-se na ideia de que os resultados de um conjunto de ensaios típicos (os casos "termômetro") podem ser extrapolados para muitos outros autores que não participaram e que não apresentaram a prova do nexo de causalidade e dos danos no seu caso particular. Porque o julgamento é baseado na tipicidade do grupo, esse procedimento não pode permitir que a maioria dos autores apresente determinadas provas particularizadas [Tradução nossa]. ${ }^{317}$

Para a agregação, segundo o caso-teste, os pressupostos a serem observados são bastante similares à ação coletiva. O grupo deve apresentar uma questão comum e homogênea, com um quantitativo determinado ou determinável de variáveis possíveis entre os casos constantes no universo coletivo, para que o método de inferência estatística seja validamente aplicável. ${ }^{318}$

Quão maior o número de variáveis e diferenças entre os casos individuais, menor a comunhão e a homogeneidade na classe. Quão menores as variáveis e as diferenças entre os casos individuais, maior a comunhão e a homogeneidade, ensejando a unitariedade da agregação. ${ }^{319}$

A metodologia dessa espécie de técnica de agregação é estatística. A conclusão do caso individual é, estatisticamente, inferida a partir de um caso representativo da controvérsia, selecionado, segundo esse mesmo método, do universo coletivo de casos individuais. ${ }^{320}$

A razão para a extrapolação de um caso individual para o universo de casos individuais reside, segundo a metodologia estatística, na seguinte assertiva: se um caso é típico e apresenta características similares ou idênticas às do universo investigado, é possível inferir que os resultados desse caso também devem ser típicos e comuns aos do universo investigado. Como a similaridade dos resultados é provável, os resultados do caso-teste podem ser extrapolados.

É interessante, então, abordar um pouco sobre a prova estatística ou por amostragem, que é o fundamento da aplicabilidade desta técnica de agregação. Segundo o Manual do Contencioso Complexo $^{321}$, o método estatístico pode aferir, em determinado nível, as características

317 [...] Bellwether trial rely on the idea that the findings of one set of typical trials (the "bellwether" cases) can be extrapolated to many other plaintiffs who did not participate and who have not presented proof of causation and damages in their particular case. Because bellwether trial are based on group typicality this procedure cannot allow the majority of plaintiffs to present particular evidence [...] (LAHVA, 2008, p. 597).

318 Ibidem, p. 605.

319 Ibidem, p. 605.

320 Ibidem, p. 597-602.

321 FEDERAL JUDICIAL CENTER, 2004, p. 102. 
específicas de uma população ou de um universo de casos semelhantes, apenas pela observação de uma amostra representativa dessa população ou universo. A produção da prova apenas no tocante à amostra pode representar substancial economia de tempo e de despesas, evitando, com isso, a produção de prova particularizada em relação a cada um dos casos individuais similares. A escolha do método estatístico irá, no entanto, depender do objetivo pretendido. Pode ser um método randômico (seleção por sorteio randômico ou aleatório) como também eletivo (seleção por eleição ou escolha). Nos dois casos, existem critérios gerais do método que devem ser observados: (i) a população ou universo deve ser definido; (ii) a amostra selecionada deve ser representativa; (iii) os dados gerados devem ser reportados com precisão; e (iv) os dados gerados devem ser aferidos e analisados segundo os princípios aceitos pela ciência estatística. ${ }^{322}$

As fases do método devem ser transparentes e apresentadas aos interessados, para que eventuais argumentos contrários à adequação da técnica sejam comunicados o mais rápido possível, sem desperdício de tempo e despesas. Não é admissível concluir a prova e somente depois apresentála à discussão das partes, pois os critérios podem ser impugnados, gerando um retrabalho. ${ }^{323}$

Nos casos de danos de massa, alguns cuidados adicionais devem ser tomados. Nesses casos, algumas variáveis devem ser observadas com atenção, a saber, a gravidade dos danos, as circunstâncias do vício ou da exposição ao produto ou acidente, os mecanismos de causalidade, os produtos e as pessoas consideradas responsáveis, as defesas afirmativas e a lei aplicável. ${ }^{324}$

A prova por estatística ou amostragem foi utilizada com sucesso no precedente Long $v$. Trans World Airlines ${ }^{325}$, relativo a uma ação de classe dos comissários de bordo em face do seu empregador em razão da negativa de emissão das cartas de direito e da realocação no emprego.

Na ocasião, foi ressaltada a legitimidade da apuração dos danos, segundo o método estatístico. Em casos de litígios de grupo multitudinários, é inviável a prova individualizada. Embora a prova por amostragem não apresente $100 \%$ de precisão, ela é adequada para as controvérsias

322 FEDERAL JUDICIAL CENTER, 2004, p. 103.

323 Ibidem, p. 103.

324 FEDERAL JUDICIAL CENTER, 2004, p. 361.

325 UNITED STATES OF AMERICA. United States District Court, N.D. Illinois, Long v. Trans World Airlines

E.D. 761 F.Supp. 1320 (1991). 
de massa, em que o ponto controvertido reside na própria questão comum ao grupo e não nas questões individuais. Não há prova individualizada, pois a controvérsia não é singularizada. ${ }^{326}$

O mesmo raciocínio é aplicado no caso-teste. Embora ele não se refira a uma controvérsia coletiva, veiculada em ação de classe, também apresenta um universo coletivo de casos individuais similares. Nesse caso, o julgamento é realizado por amostragem e o resultado do julgamento da amostra é extrapolado para as demais hipóteses pendentes naquele juízo.

Para o sucesso da técnica, alguns procedimentos prévios e técnicas devem ser utilizados. São inicialmente quatro etapas: (i) identificar e catalogar o universo de casos similares; (ii) definir o conjunto de possíveis casos-teste; (iii) realizar a instrução específica dos casos selecionados, abordando as variáveis que determinarão ou não a comunhão existente na categoria; (iv) realizar a seleção dos casos-teste, no conjunto pré-determinado dos possíveis casos-teste, para determinar aqueles que serão objeto de julgamento e, eventual, extrapolação às demais ações. ${ }^{327}$

De igual modo, o caso-teste apresenta, no sistema jurídico estadunidense, duas funções: (i) o caso-teste pode, em tese, implicar a preclusão dos demais casos individuais similares e (ii) o caso-teste pode exercer uma função informativa, principalmente naquelas controvérsias de massa, pouco amadurecidas ou novas, em que ainda é desconhecida a alegada homogeneidade dos casos individuais que compõe o universo coletivo do grupo (vítimas de vício do produto). ${ }^{328}$

Percebe-se que o caso-teste apresenta essa amplitude no sistema jurídico estadunidense, pois aplica-se às hipóteses em que há questões fáticas e/ou jurídicas controvertidas. Essa metodologia é muito utilizada para os casos de mass torts, em que há pedido condenatório ao ressarcimento em pecúnia por danos causados, hipótese em que é comum a controvérsia fática.

É óbvio que se a matéria controvertida for exclusivamente de direito, não exigindo prova sobre fatos ou sendo os fatos incontroversos, a seleção da amostra representativa da controvérsia tende a ser mais simples. Essa hipótese será abordada, após a exposição das etapas da técnica.

326 UNITED STATES OF AMERICA. United States District Court, N.D. Illinois, Long v. Trans World Airlines E.D. 761 F.Supp. 1320 (1991).

327 FALLON, GRABILL, WYNNE, 2008, p. 2342 et seq.

328 NAGAREDA, 2009, p. 541-542. 


\section{- IDENTIFICAÇÃO DO UNIVERSO COLETIVO E CATEGORIZAÇÃO}

Na identificação do universo de casos semelhante, é preciso catalogar e categorizar as variáveis relevantes para a apuração da controvérsia. Não é possível abordar essas variáveis em abstrato, pois, como o próprio nome diz, elas podem variar de um caso para o outro. Mas, como já consignado, nos casos de vício do produto, as variáveis mais comuns são aquelas relativas à identificação da lesão, da sua gravidade, do tipo de produto e do responsável causador do dano. Essas são as variáveis que, em regra, são relevantes nas controvérsias e nos danos de massa. ${ }^{329}$

São as variáveis que hão de determinar a tipicidade da questão comum ao grupo e objetividade de sua apuração, de forma permitir a extrapolação dos resultados aos casos individuais iguais.

A identificação do universo coletivo é importante para que não seja selecionado um caso anômalo, que não alcançará o escopo da técnica. Igualmente, a categorização das variáveis é importante para que o conjunto não fique caótico, ou seja, é preciso saber quais são os pontos de padronização e de diferença dentro do universo coletivo, aspecto determinante da análise. Alcançar uma amostra representativa da controvérsia é crucial a essa técnica de agregação. ${ }^{330}$

No caso Vioxx - medicamento objeto de milhares de ações individuais com relação ao vício do produto e objeto do Painel do Contencioso Multidistrital - as variáveis selecionadas foram as seguintes: tipo de dano (ataque cardíaco, acidente vascular cerebral), período de ingestão do medicamento (longo período, curto período), idade dos membros do grupo (mais novo ou mais velho que 65 anos), história de doenças cardíacas anteriores (história de doença preexistente ou não), data da injúria (antes ou depois da mudança do rótulo do medicamento em questão). ${ }^{331}$

\section{- DEFINIÇÃO DO CONJUNTO DE POSSÍVEIS CASOS-TESTE}

A primeira providência é determinar o tamanho do conjunto de possíveis casos-teste, objeto de análise, para fins de obtenção de uma inferência estatística relevante. A segunda providência é

329 FEDERAL JUDICIAL CENTER, 2004, 361.

330 SAKS, Michael J., BLANCK, Peter David. Justice improved: the unrecognized benefit of aggregation and sampling in the trial of mass torts. Stanford Law Review, 1992, V. 44:815-849p, p. 839-840.

331 FALLON, GRABILL, WYNNE, 2008, p. 2345. 
selecionar quem será o responsável por essa seleção. Essa seleção pode ser aleatória, pode ser realizada pela própria Corte de Justiça e pode ser realizada pelo conselho de advogados.

O tamanho do conjunto deve ser grande o suficiente para alcançar uma amostra adequada de todas as variáveis necessárias à controvérsia, mas pequena o suficiente para ser gerenciável, sem gasto desnecessário de tempo e ensejando economia das despesas processuais. Não há número certo ou definido, a Corte de Justiça deverá considerar o número total de casos pendentes, as variáveis existentes, bem como a forma de seleção para o julgamento (amostra de probabilidade/aleatória ou amostra resultante da eleição ou escolha do caso representativo). ${ }^{332}$

Casos como Vioxx demostram que é suficiente a seleção de 20 casos individuais para compor o conjunto de possíveis casos-teste, quando, ao final, pretende-se selecionar apenas seis casos para julgamento. Os casos escolhidos alcançaram de quatro a cinco das variáveis mais relevantes para as partes. Quão maior o número de variáveis, maior deve ser o conjunto de casos-teste definido. ${ }^{333}$

Como consignado, o conjunto de casos possíveis deve ser selecionado por um responsável. Esse responsável por ser a própria sorte ou probabilidade, isto é, um sorteio randômico ou aleatório dos casos. Esse método pode ser, no entanto, problemático. Na hipótese em que a controvérsia de massa é bem conhecida e amadurecida pelas Cortes de Justiça, não haverá, necessariamente, a escolha daqueles casos que já se sabe, de antemão, serem representativos do conflito. E, pela mesma razão, não é possível garantir que os casos selecionados contenham todas as variáveis. ${ }^{334}$

É possível, ainda, a seleção pela Corte de Justiça. Nesse caso, quando a controvérsia já está mais amadurecida, já foi objeto de vários julgamentos individuais anteriores, conta com farta instrução probatória, a Corte de Justiça pode conhecer quais são as variáveis mais relevantes, bem como quais são as questões de fato, quais são as questões de direito e quais são as estratégias da defesa que tornam um determinado caso individual um caso representativo da controvérsia. A Corte de Justiça deve - passe o truísmo - agir de forma imparcial, selecionando os casos pelas suas características típicas e não com fundamento no potencial de sucesso. ${ }^{335}$

332 SAKS, BLANCK, 1992, p. 840.

333 FALLON, GRABILL, WYNNE, 2008, p. 2347.

334 Ibidem, p. 2348.

335 FALLON, GRABILL, WYNNE, op. cit., p. 2348. 
Nas hipóteses em que pendem milhares de ações individuais repetitivas, algumas sequer ajuizadas na Corte de Justiça responsável pela instrução e julgamento do caso-teste, é possível que o magistrado não se sinta apto a selecionar as variáveis e os casos representativos da controvérsia. Nessas hipóteses, a seleção pelo juiz é considerada problemática e até inviável. 336

Por fim, é possível, ainda, a seleção do conjunto de casos-teste pelos advogados ou pelo conselho de advogados no caso do contencioso multidistrital. Os advogados são aqueles que, por vezes, estão na melhor posição para conhecer a representatividade ou não dos casos em julgamento. De qualquer modo, eles têm uma equipe, do próprio escritório, para desempenhar essa tarefa e orientar a escolha do caso-teste, sem implicar maior desgaste à Corte de Justiça. ${ }^{337}$

Quando o advogado escolhe, a primeira ideia que surge é que esse advogado escolherá o caso que vai conferir a vitória ao seu cliente e não, necessariamente, o caso mais representativo. Ainda que seja possível a escolha pelos advogados dos casos potencialmente mais bem sucedidos, há um incentivo para a escolha dos casos representativos. Isso porque, se o caso não for representativo, o procedimento será inútil para a orientação ou resolução dos demais casos semelhantes. Um caso vitorioso, mas anômalo, é imprestável para a agregação pelo caso-teste.

No caso de a escolha ser deferida aos advogados, três são as possibilidades: (i) o autor ou réu escolhem todos os casos que integrarão o conjunto de possíveis casos-teste; (ii) autor e réu escolhem juntos todos os casos que integrarão o conjunto de possíveis casos-teste; e (iii) a seleção é dividida, de forma igualitária, entre os advogados do autor e os advogados do réu. ${ }^{338}$

A racionalidade da primeira hipótese - determinar que apenas uma das partes escolha os casosteste - é a inferência de que, sucumbindo à parte no tocante ao caso-teste por ela escolhido, as suas alegações não seriam dotadas de verossimilhança ou, noutros termos, não haveria razões para acreditar que suas alegações encontrariam razão no mérito. $O$ ponto negativo dessa primeira hipótese é a possibilidade de o advogado escolher os seus casos favoritos ou menos representativos, ampliando, nesse contexto, o antagonismo existente na controvérsia. ${ }^{339}$

336 FALLON, GRABILL, WYNNE, 2008, p. 2349.

337 Ibidem, p. 2349.

338 Ibidem, p. 2349.

339 Ibidem, p. 2350. 
O mesmo problema - ausência de representatividade - é possível na segunda hipótese. Nesse caso, a escolha é dividida entre os advogados dos dois lados da controvérsia. Embora essa alternativa propicie uma maior igualdade entre as partes, os advogados podem ser tentados a escolher os casos potencialmente bem sucedidos e não aqueles representativos do conflito. ${ }^{340}$

Nessa segunda hipótese, corre-se o risco de inexistir um caso representativo da controvérsia. É possível que sejam selecionados 10 casos suscetíveis de vitória, escolhidos pelo autor, e 10 casos, possivelmente sucumbentes, escolhidos pelo réu. Isso ocorreu no precedente Chevron U.S.A., Inc ${ }^{341}$. Na ocasião, o magistrado consignou que não havia caso-teste ou representativo do conflito, mas, sim, 15 dos melhores casos e 15 dos piores casos do universo coletivo.

A terceira hipótese, por fim, é a que melhor alcançaria, em tese, a seleção dos casos representativos, pois os advogados devem decidir, conjuntamente, qual será o conjunto de possíveis casos-teste. É a melhor alternativa, mas também a mais difícil de ser alcançada, pois demanda que as partes adversas entrem em acordo no tocante o que é ou não é representativo. ${ }^{342}$

Nessa hipótese, é relevante a atuação do juiz para lembrar as partes que a seleção do caso-teste não visa a beneficiá-las ou prejudicá-las, mas apenas em verificar as repercussões concretas das alegações e defesas realizadas naquela controvérsia. Caberá ao juiz ou ao júri o julgamento das demandas individuais e a mera escolha do caso-teste não determina o resultado do julgado. ${ }^{343}$

Mais uma consideração se faz necessária, no tocante ao órgão responsável pela seleção do conjunto de possíveis casos-teste. A dificuldade de seleção pode variar conforme o amadurecimento ou conforme a novidade daquela controvérsia nas Cortes de Justiça.

Em controvérsias mais maduras, objeto de vários julgamentos individuais, com ampla instrução probatória e com a exaustão de argumentos, a Corte de Justiça tende a conhecer, em razão de sua própria experiência, as variáveis e, até mesmo, quais seriam os casos representativos da controvérsia. Já nas controvérsias novas ou pouco amadurecidas, há uma maior incerteza quanto

340 FALLON, GRABILL, WYNNE, 2008, p. 2350.

341 UNITED STATES OF AMERICA. United States Court of Appeals, Fifth Circuit. Chevron U.S.A., Inc. 109 F.3d 1016, 1019 (5th Cir. 1997).

342 FALLON, GRABILL, WYNNE, op. cit., p. 2350.

343 Ibidem, p. 2350. 
às variáveis ou quanto às questões comuns, típicas e representativas daquele universo. Nesse caso, é preciso observar com cuidado todas as fases da seleção da amostra, bem como é possível que a seleção aleatória ou o auxílio dos advogados seja fundamental para o sucesso da técnica.

Podem, ainda, ser utilizados dois mecanismos de seleção. Por exemplo, parte do conjunto dos possíveis casos-teste pode ser selecionada de forma aleatória e parte do conjunto pode ser objeto de indicação pelos advogados. Isso ocorreu no caso In re Bextra v. Celebrex Mktg. Sales practice and product liability litigation. Nesse caso, os autores e réus foram autorizados a selecionar 10 casos, cada um, de um conjunto de 45 casos-teste. Os outros 25 casos-teste seriam objetos de seleção randômica ou aleatória, independentemente da escolha dos advogados. ${ }^{344}$

Por fim, nessa seleção, é importante a atenção com os casos que realmente poderão ser objeto de julgamento. Por exemplo, no caso do contencioso multidistrital, a Corte de Justiça cessionária não pode proceder ao julgamento dos casos objeto de transferência interdistrital. Logo, as demandas ajuizadas em outros distritos e remetidas para a Corte de Justiça cessionária não devem compor o conjunto de possíveis casos-teste, pois essas demandas individuais não podem ser julgadas pela Corte de Justiça cessionária e não podem constituir um caso-teste.

De igual modo, os casos devem ser aptos para o julgamento de mérito da controvérsia. Os casos selecionados devem possuir a mais ampla prova pré-constituída, dispensando maior instrução probatória, que porventura seria exigida em outro caso individual, bem menos instruído. ${ }^{345}$

\section{- INSTRUÇÃO ESPECÍFICA DOS CASOS, SUAS VARIÁVEIS E O JULGAMENTO}

Uma vez selecionado o conjunto de possíveis casos-teste, é preciso, ainda, selecionar e instruir os próprios casos-teste. Aqui, a seleção pode ser feita da mesma forma antes mencionada: seleção aleatória, seleção pela Corte de Justiça, bem como seleção pelo conselho de advogados.

Na hipótese da seleção randômica, devem-se distinguir as variáveis e estabelecer diferentes conjuntos para a extração do caso representativo. Exemplo: se uma das variáveis disser respeito ao histórico de doenças cardíacas, se o conjunto de possíveis casos-teste for objeto de seleção

344 FALLON, GRABILL, WYNNE, 2008, p. 2348.

345 Ibidem, p. 2351. 
randômica, se na escolha do caso-teste, para efeito de instrução e julgamento, for novamente utilizada a seleção randômica e, por fim, se não for selecionado nenhum caso-teste que contenha a supracitada variável (histórico de doenças), o caso-teste pode não permitir uma inferência válida para os demais casos em que a preexistência da doença é matéria controvertida ${ }^{346}$.

Na seleção pela Corte de Justiça, com fundamento na sua experiência em demandas repetitivas, o julgador deve indicar a questões comuns de fato e/ou de direito e o motivo pelo qual aquele caso é representativo da controvérsia e deve ser selecionado. Esse mecanismo de seleção é positivo, uma vez que a Corte de Justiça deve fundamentar as variáveis, previamente conhecidas, bem como conferir tratamento igualitário aos dois lados da controvérsia. ${ }^{347}$

De igual modo, é possível deferir a seleção pelos advogados. Isso ocorreu, de forma bem sucedida, no caso dos medicamentos Vioxx e Propulsid. No caso Vioxx, cada lado escolhia um conjunto de casos-teste e tinha o direito de veto de dois casos escolhidos pela parte contrária. No caso Propulsid, a escolha dos casos-teste foi deferida, exclusivamente, à parte requerida. ${ }^{348}$

\section{- AMADURECIMENTO DA CONTROVÉRSIA}

Se a controvérsia de massa já está amadurecida e não há matéria fática controvertida, a seleção da amostra representativa do grupo é bem mais simples ${ }^{349}$. Não haverá, por exemplo, a necessidade de instrução dos casos-teste. A própria experiência das Cortes de Justiça tende a facilitar a identificação das variáveis e das questões jurídicas comuns, objeto de agregação.

Mas, de qualquer modo, é preciso atenção com o universo coletivo das demandas individuais pendentes. Não basta selecionar um caso, por exemplo, em que a controvérsia é relativa a uma cláusula abusiva de um contrato padrão, é preciso saber se essa cláusula varia por ano de contrato, por tipo de contrato, pela natureza do contratante, eventuais variáveis na hipótese.

346 SAKS, BLANCK, 1992, p. 842.

347 FALLON, GRABILL, WYNNE, 2008, p. 2363.

348 Ibidem, p. 2363-2364.

349 O conceito de controvérsia de massa madura foi introduzido por Francis E. McGovern, bem como aplicada por Peter Schuck para os danos de massa. Nas controvérsias maduras, pouco ou nenhuma prova é necessária (Cf. MCGOVERN, Francis E. Resolving mature mass tort litigation. Boston University Law Review, 1989, V. 69: 659-694p, passim. SCHUCK, Peter. Mass torts: an institutional evolutionist perspective. Cornell Law Review, 1995, V. 80: 941-989p., p. 949-950). 
De igual modo, depois de identificadas as variáveis comuns ao universo coletivo de demandas e a questão jurídica comum, é preciso que a Corte de Justiça efetivamente resolva, de forma unitária, a controvérsia que envolva essa questão jurídica comum. Não basta estabelecer os parâmetros normativos para a solução do caso concreto, é preciso que a variável seja resolvida.

Caso a Corte de Justiça apenas estabeleça os parâmetros normativos para a resolução da controvérsia, sem atenção aos elementos cambiantes das demandas, o escopo da agregação não será alcançado. Não haverá solução unitária da controvérsia, tampouco desincentivo ao ajuizamento de novas demandas individuais, pois cada julgador deverá aplicar aqueles parâmetros normativos aos casos individuais pendentes, o que poderá dar azo à subjetivação.

Imagine que a Corte de Justiça, ao julgar um caso-teste, afirme que o método da tabela price é inválido sempre que implicar vantagem manifestamente excessiva ao fornecedor. Resta claro, a partir deste julgado, que somente pode ser afastada a tabela price se houver uma vantagem manifestamente excessiva. Mas, o que é excessivo ou manifesto é variável, é cambiável, logo não há abreviação no julgamento das demandas individuais, pois cada juiz deverá apreciar, no seu caso concreto, o que deve ser considerado como vantagem excessiva para aquele fornecedor. De igual modo, esse caso-teste não desestimula o ajuizamento de novas demandas individuais, pois cada indivíduo pretenderá "testar" se o seu caso é ou não aquele referente à vantagem manifestamente excessiva. Embora os parâmetros dados no caso-teste possibilitem maior coerência na resolução das demandas individuais, não há solução agregada ou unitária.

Nesse aspecto, é interessante a abordagem realizada por Allan H. Erbsen ${ }^{350}$, que diz, no tocante à ação coletiva, que a Corte de Justiça deve abordar o critério da predominância das questões comuns, para fins de certificação da ação de classe na categoria 23(b)(3) - class actions for damages -, segundo o caráter da resolutividade. Segundo o caráter da resolutividade, a agregação deve propiciar a resolução da controvérsia, a abreviação das demandas individuais.

O mesmo raciocínio é aplicável ao caso-teste. Não basta conferir padrões normativos comuns a determinado conflito de interesses, padrões esses que podem ou não podem ser aplicados aos casos individuais. A Corte de Justiça, ao desenhar a solução da controvérsia, segundo o caso-

350 ERBSEN, Allan. From "predominance" to "resolvability": a new approach to regulating class action. Vanderbilt Law Review, 2005, V. 58:995-1081p. 
teste, deve conferir resolutividade às demandas individuais, solucionando as variáveis relevantes da controvérsia. Se as questões controvertidas no grupo permaneceram cambiantes, modificáveis, incertas, subjetivas, não será possível a estabilidade da solução agregada proferida no caso-teste, tampouco desestimulará o ajuizamento de novas demandas individuais. Nessa hipótese, o caso-teste constitui mero paliativo, não reduz o amontoado de processos.

Como diz a obra Princípios da Litigância Agregada, do American Law Institute ${ }^{351}$, a função da agregação processual é facilitar a adoção de decisão com função preclusiva. Não basta orientar a solução dos casos individuais, é forçosa a resolução unitária da lide, dotada de estabilidade.

Foi, por essa razão, que no primeiro capítulo desta investigação foi feita a diferenciação entre precedente e coisa julgada coletiva. O precedente é técnica de coerência e não necessariamente ele conduz à resolução agregada da controvérsia. O caso-teste é técnica de agregação, aplicável àquelas hipóteses em que presente a comunhão ou a unitariedade da relação substancial.

De igual modo, o caso-teste é aplicável in re ipsa, pois, a partir da amostra representativa da controvérsia, o resultado é extrapolado para os demais casos individuais. O precedente, como visto, não é aplicável in re ipsa, a analogia é postergada e pode ser afastada nos demais casos.

\section{- FUNÇÃO PRECLUSIVA DO CASO-TESTE}

A primeira abordagem do caso-teste, no sistema jurídico estadunidense, foi dotada de função preclusiva para os demais casos individuais pendentes. O caso-teste vinculava, formalmente, as outras demandas individuais, constituindo uma alternativa - muito próxima - à ação coletiva.

Mas, em razão da ausência de prévia certificação da classe, houve uma maior resistência da jurisprudência à função preclusiva, ao menos nos moldes em que praticada naquele tempo.

As Cortes de Justiça Distritais utilizavam a técnica, todavia, as Cortes de Apelação tendiam a reformá-la pela ausência de certificação da ação individual como ação de classe ou coletiva. ${ }^{352}$

351 AMERICAN LAW INSTITUTE, 2010, p. 119.

352 BARTON, R. Joseph. Utilizing statistics and bellwether trial in mass torts: what do the Constitution and Federal Rules of Civil Procedure permit? William \& Mary Bill of Rights Journal, 1999, V. 8: 199-240p. 
No caso Cimino v. Raymark ${ }^{353}$, por exemplo, o julgamento foi dividido em três fases: (i) a primeira fase destinava-se a resolver as questões comuns de fato e direito; (ii) a segunda fase dirigia-se à determinação dos locais de trabalho e períodos de tempo em que o produto viciado havia sido objeto de exposição, bem como à determinação de quais grupos haviam sido suficientemente expostos de forma a causar os danos e a ensejar o reconhecimento da responsabilidade do requerido; e (iii) a terceira fase voltava-se à quantificação dos danos.

Foi, por ocasião da terceira fase, que a técnica do caso-teste foi utilizada, com função preclusiva. Para tanto, as doenças sofridas pelos membros do grupo foram divididas em cinco categorias (câncer de pulmão, mesotelioma, outras espécies de câncer, doença pleural e asbestose). Para cada uma dessas variáveis, foi identificado o número total de casos por categoria, considerando um total de 2.298 casos individuais. Por exemplo, dos 2.298 casos individuais, 186 representavam câncer de pulmão, 1050 asbestosis, 972 doença pleural e assim por diante. ${ }^{354}$

Em seguida, foi selecionada uma amostra representativa para cada variável ou categoria de doença. Por exemplo, foi selecionada uma amostra com 26 casos de câncer de pulmão do total de 186 casos similares presentes no grupo de vítimas. No final, somando todas as categorias, a amostra total contava com 160 casos individuais, que formavam o conjunto de casos-teste. ${ }^{355}$

Esses 160 casos individuais foram julgados pelo júri e o resultado foi extrapolado para os demais casos individuais que não foram objeto da amostra. O Quinto Circuito reverteu a decisão, salientando que a causalidade é individual e não relativa aos grupos ou categorias. ${ }^{356}$

Em outro caso, Hilao v. State of $\operatorname{Marcos}^{357}$ a metodologia do caso-teste foi, por sua vez, aceita, com função preclusiva. Tratava-se de ação de classe contra o ditador das Filipinas Ferdinand Marcos. Por ocasião daquele regime ditatorial, muitos dos cidadãos forem presos e torturados. O ditador fugiu para o Havaí, ocasião em que foi ajuizada a ação de classe a ele contrária.

353 UNITED STATES OF AMERICA. United States District Court, E.D. Texas, Beaumont Division. Cimino v. Raymark. 751 F.Supp. 649 (1990).

354 Ibidem.

355 Ibidem.

356 Ibidem.

357 UNITED STATES OF AMERICA. United States Court of Appeals, Ninth Circuit. Hilao v. State of Marcos. 103 F.3d 767 (1996). 
A ação foi dividida em três fases, a saber, apuração da responsabilidade, apuração da indenização punitiva e apuração da indenização compensatória. Estavam pendentes 9.541 ações individuais. Em seguida, foi selecionada uma amostra de 137 casos individuais que constituíam o caso-teste. Os resultados, apurados pelo special master, foram extrapolados para os demais casos similares. Nesse caso, não houve reforma, a Corte de Apelação manteve a extrapolação.

Há, ainda, quem admita a preclusão por força do caso-teste, mas desde que as partes consintam com essa metodologia. Nessa hipótese, seria o consentimento com o procedimento do casoteste que autorizaria a preclusão. Recentemente, porém, novas tendências surgem nesse aspecto.

Alexandra Lahva ${ }^{358}$ defende, por exemplo, um caso-teste mandatório ou imperativo, com efeito preclusivo para os demais, independentemente do consentimento das partes interessadas.

Seria necessário, para tanto, uma fase de certificação formal da amostra representativa do grupo, bem como seria necessária a utilização de métodos estatísticos, com a orientação de um perito. A decisão pela agregação pelo caso-teste deve ser objeto de notificação coletiva aos interessados, bem como deve ser uma decisão fundamentada e transparente aos indivíduos. 359

Por fim, segundo Lahva ${ }^{360}$, admissível seria o opt out. O opt out não é necessário, para fins de exclusão. Mas, ele consiste em um mecanismo idôneo para aferir a eventual insatisfação das partes com a forma de condução do procedimento agregado, bem como constituiria um indicador relevante para que o juiz apure a representatividade da amostra selecionada. A quantidade de manifestações de exclusão pode relevar a insatisfação ou o erro no procedimento.

O opt out, sob essa perspectiva, pode ser interpretado como mecanismo de voz (voice) ${ }^{361}$ das partes, bem como forma de reorientação ou readequação do procedimento para melhor alcançar o escopo de agregação. Há aqueles que sustentam, ainda, que esse direito pode ser restringindo, quando o indivíduo não alegar nenhuma causa plausível ou pessoal para exclusão. Se o indivíduo exercer apenas uma estratégia para alcançar melhores resultados que o grupo, sem elencar uma causa pessoal ou uma nova dimensão da controvérsia, o direito de exclusão deve

358 LAHVA, 2008, p. 635.

359 Ibidem, p. 636-637.

360 Ibidem, p. 635-636

361 COFFEE JR, John C. Class action accountability: reconciling exit, voice and loyalty in representative litigation. Columbia Law Review, 2000, V. 100:370-439, p. 411. 
ser negado. De igual modo, esse direito deve ser negado na hipótese em que o caso-teste já houver sido julgado, pois não é possível adotar a prática "esperar para ver" ("wait and see"). ${ }^{362}$

Por fim, a função preclusiva não é determinada a priori pelo juiz que julgou o caso-teste. $\mathrm{O}$ magistrado deve se preocupar em selecionar uma amostra representativa da controvérsia. ${ }^{363}$

A preclusão é determinada ou não pelas Cortes de Justiça subsequentes, nas quais pendentes as demais demandas individuais. A questão quanto à preclusão consiste em uma preliminar das demandas individuais subsequentes. Assim, se apesar dos esforços em estabelecer uma amostra representativa de todo o universo coletivo, a amostra não se coadunar com as características de um determinado caso individual, pois esse caso é anômalo, não há preclusão a ser reconhecida. A amostra pereceria pela falta de representatividade, não sendo aplicável aos casos anômalos.

Nota-se que, na realidade, a função preclusiva do caso-teste é, ainda, objeto de muita divergência e propostas no sistema jurídico estadunidense ${ }^{364}$. No caso Cimino, a questão foi analisada à luz do direito estadual. No caso Hilao, a questão foi analisada à luz das circunstâncias extraordinárias do caso, que se referiam aos direitos civis fundamentais. Não há, portanto, ainda, uma regra uniforme e consolidada sobre a questão no sistema estadunidense.

\section{- FUNÇÃO INFORMATIVA DO CASO-TESTE}

O caso-teste pode apresentar uma função informativa. A seleção randômica dos casos e o julgamento por amostragem é realizado não para vincular, mas para melhor esclarecer a controvérsia, verificar quais são os argumentos fortes e fracos, quais são os pontos comuns de fato ou de direito, bem como para apurar receptividade do júri sobre a questão controversa. ${ }^{365}$

Essa função é adotada, sem maiores divergências, no sistema jurídico estadunidense, principalmente para definir os aspectos que autorizam a realização de um acordo entre as partes.

362 LAHVA, 2008, p. 635-636.

363 Esse é o fundamento da issue preclusion ou do collateral estopel, o qual é adotado pelos princípios do contencioso agregado (AMERICAN LAW INSTITUTE, 2010, p. 119). Nesse mesmo sentido: SAVAGE, Zachary B. Scaling up: implementing issue preclusion in mass tort litigation through bellwether trials. New York University Law Review, 2013, V. 88: 439-475p.

364 MARCUS, SHERMAN, ERICHSON, 2010, p. 774.

365 Ibidem, p. 774. 
O acordo não pode ser realizado no vácuo, principalmente tratando-se de uma matéria ainda nova e pouco esclarecida nas Cortes de Justiça. O caso-teste, nessa hipótese, pode informar os parâmetros para a realização do acordo, bem como para o pagamento das indenizações. ${ }^{366}$

Para fins informativos, o caso-teste exige o mesmo esforço e a mesma dedicação para a resolução unitária da controvérsia, que foram antes mencionados no tocante à função preclusiva. Isso porque ele orienta os termos sobre os quais incidirá a autocomposição.

O caso Vioxx, antes mencionado, foi resolvido de forma unitária por acordo, depois da realização do caso-teste. Em seguida ao julgamento do caso-teste, a empresa ré ofertou o valor de $\mathrm{R} \$ 4.85$ bilhões de dólares a ser administrado por um fundo destinado ao pagamento dos autores individuais. ${ }^{367}$

Esses são os principais aspectos do caso-teste, na forma prevista no sistema jurídico estadunidense, que fundamentam e esclarecem essa técnica de agregação processual.

\subsubsection{AGREGAÇÃO PRIVADA}

A agregação privada é uma das formas de agregação informal, que é realizada pelas partes e por seus advogados, sem supervisão ou controle oficial pelos órgãos do Poder Judiciário. ${ }^{368}$

Isso ocorre em função da concentração das causas similares e repetitivas em um mesmo escritório, da especialização dos escritórios de advocacia, que são contratados para essas demandas de massa, e dos contatos profissionais estabelecidos entre advogados, que encaminham causas e clientes para outro profissional, segundo o procedimento referral. ${ }^{369}$

Referral é um tipo de encaminhamento de clientes e demandas entre escritórios de advogados, que facilitam a concentração das demandas de massa sob o controle de um único escritório. ${ }^{370}$

366 MARCUS, SHERMAN, ERICHSON, 2010, p. 774.

367 SHERMAN, Edward F. The MDL model for resolving complex litigation if a class action is not possible. Tulane Law Review, 2008, V. 82: 1-29p. p. 17.

368 AMERICAN LAW INSTITUTE, 2010, p. 14.

369 Ibidem, p. 34-35.

370 AMERICAN LAW INSTITUTE, 2010, p. 34-35. 
Normalmente, as partes mais vulneráveis da controvérsia, como as vítimas ou os consumidores, apresentam maiores dificuldades de identificar o advogado mais especializado sobre aquela controvérsia. A técnica do referral cria incentivos para que os advogados menos experientes encaminhem seus clientes e causas para advogados mais experientes no tocante àquela controvérsia, facilitando, com isso, uma agregação informal de demandas sob o controle de um mesmo escritório. Cria-se, com isso, uma microestrutura para facilitar a resolução agregada. ${ }^{371}$

Ainda que não seja utilizada a técnica do referral, alguns escritórios de advocacia experientes, todos defendendo múltiplas demandas individuais, tendem a associar-se para, juntos, negociarem a resolução da controvérsia com o requerido e seus advogados. Práticas como essa podem originar, por força de contrato, um acordo coletivo extrajudicial, fora da ação coletiva.

De igual modo, tanto o referral quanto a associação de escritórios podem ser combinados com outras técnicas de agregação. Por exemplo, a coordenação ou a associação dos escritórios ou a reunião das causas sob a defesa de um único escritório facilita a formação de um conselho de advogados por ocasião do contencioso multidistrital, bem como possibilita o oferecimento de peças postulatórias e instrutórias unitárias para todas as partes das demandas individuais.

Ademais, é preciso destacar que, na agregação privada, o próprio modelo de resolução alternativa ou autocompositiva das controvérsias é, parcialmente, alterado. Nesse caso, a autocomposição não está subordinada à supervisão judicial. Igualmente, não se exigem os mesmos requisitos e a aprovação do acordo pelo magistrado, como ocorre nas ações coletivas.

Lembra-se que o acordo na ação de coletiva exige a prévia certificação da ação de classe, bem como a adoção, pelo juiz, de medidas de garantia ou de ressalva dos direitos dos membros ausentes da classe e dos membros futuros do grupo. Na ação coletiva, a aferição da representatividade adequada é realizada de forma estreita, considerando a potencial vinculação dos indivíduos, que não ingressaram em juízo e que não escolheram aquela representação. ${ }^{372}$

371 AMERICAN LAW INSTITUTE, 2010, p. 34-35.

372 Principalmente nos casos de danos causados por vício do produto, a resolução da controvérsia em uma ação de classe, mesmo por força de acordo entre as partes, é matéria complexa, uma vez que o magistrado deverá certificar a ação de classe como coletiva, bem como aferir a representatividade do autor coletivo em relação aos membros ausentes e futuros da classe. Todos os requisitos da ação de classe devem ser satisfeitos para fins de aprovação do acordo na ação de classe. Essa maior restrição e exigência das Cortes de Justiça é perceptível nos precedentes Amchem e Ortiz (Cf. UNITED STATES OF AMERICA. Supreme Court of United States. Amchem Products, Inc v. Windsor. 521 U.S. 591 (1997). UNITED STATES OF AMERICA. Supreme Court of United States. Ortiz v. Fibreboard Corp. 527 U.S 815 (1999). 
Igual preocupação é, em grande parte, afastada nas hipóteses de acordos coletivos realizados fora da ação de classe. Esses acordos coletivos podem ser realizados por ocasião da reunião de demandas individuais no contencioso multidistrital, bem como podem ser pré-processuais. As causas repetitivas podem estar concentradas nos mesmos escritórios de advocacia, os quais iniciam, junto à parte contrária, as tratativas do acordo coletivo em relação à controvérsia. ${ }^{373}$

O acordo coletivo fora da classe não suscita tantos problemas quanto ao acordo realizado na ação coletiva, pois, no primeiro caso, não há necessidade de certificação da ação de classe, tampouco vinculação dos membros ausentes e futuros do grupo. Os indivíduos alcançados pelo acordo são aqueles cujas demandas individuais pendem em juízo, bem como aqueles cujos advogados, por eles escolhidos, negociaram o acordo, considerando a situação dos clientes. ${ }^{374}$

Estudos dogmáticos sobre a agregação informal privada são mais difíceis, pois, como a agregação privada independe de aprovação da Corte de Justiça, esses casos não são reportados. É cediço, no entanto, que, por força do estatuto de ética profissional dos advogados, eventual acordo coletivo realizado pelo advogado, em seu portfólio de causas repetitivas, deve ser objeto de esclarecimento ao cliente, bem como de consentimento formal pelas partes interessadas. ${ }^{375}$

Uma solução híbrida, relativa à agregação privada, ocorreu no caso VIOXX. Nessa ocasião, foi negociado, em um contrato, um acordo coletivo entre a empresa ré e os escritórios advocatícios, responsáveis pelas demandas individuais que pendiam no sistema judiciário federal e estadual.

$\mathrm{O}$ acordo envolvia a formação de um fundo no valor de $\mathrm{R} \$ 4.85$ bilhões de dólares, que seria distribuído entre os autores individuais por um programa administrativo, que avaliaria os seguintes aspectos para a concessão da reparação: (i) comprovação médica de ataque cardíaco

373 AMERICAN LAW INSTITUTE, 2010, p. 188.

374 Em sentido semelhante, conferir: ERICHSON, Howard M. A typology of aggregate settlements. Notre Dame Law Review, 2005, V. 80: 1784-1792p. p. 1788.

375 Linda Mullenix é uma das críticas do acordo coletivo extrajudicial, na forma como realizado no sistema jurídico estadunidense, pois a Corte de Justiça não pode assegurar a observância das garantias processuais do devido processo legal. $\mathrm{O}$ acordo coletivo é transformado em um mero arranjo contratual realizado pelos advogados, que não necessariamente assegura os interesses das partes. Há um movimento na jurisprudência, no entanto, pelo reconhecimento da "quasi class action". Se houver assistência judicial e incentivos judiciais (nomeação de um special master, audiências) à formulação do acordo, como ocorre, por exemplo, no contencioso multidistrital, é possível reconhecer um grau de controle pelo Poder Judiciário, o que autorizaria a supervisão judicial sobre os termos e sobre a justiça do acordo para as partes. A doutrina da "quasi class action" foi enunciada no caso Zyprexa pelo magistrado Jack B. Weinstein (Cf. MULLENIX, Linda. Aggregate litigation and the death of democratic dispute resolution. Northwestern University Law Review, 2013, V. 107: 511-564p. p. 539-541). 
ou acidente vascular cerebral isquêmico; (ii) comprovação de receita médica, prescrevendo, ao menos, 30 pílulas de VIOXX e; (iii) proximidade da prescrição médica com o evento lesivo, que suporte a presunção de que o medicamento foi ingerido 14 dias antes da lesão alegada. ${ }^{376}$

Todos os escritórios de advocacia deveriam recomendar a 100\% dos seus clientes o ingresso no programa administrativo, ao menos aqueles que sofreram ataque cardíaco ou acidente vascular cerebral isquêmico. Caso o autor individual, representado por aquele escritório, não aceitasse a inscrição no programa, o escritório deveria renunciar a representação, encaminhando-o para outro profissional. Essa medida foi utilizada para evitar o cherry-picking, isto é, a atuação estratégica do advogado de recomendar para o programa apenas os casos individuais fracos, permanecendo com as causas individuais mais robustas e com melhores chances de vitória. ${ }^{377}$

O programa foi considerado vantajoso pelo comitê de partes, que atuava no contencioso distrital, pois a comprovação do nexo de causalidade específico era muito complexa, exigindo um processo longo e arrastado, que já pendia fazia mais de três anos nas Cortes de Justiça. ${ }^{378}$

Por todo o exposto, comenta-se, hoje, o fenômeno da hibridização ${ }^{379}$ da resolução das controvérsias de massa. As demandas individuais são iniciadas nas Cortes de Justiça, mas, posteriormente, resolvidas por mecanismos alternativos de resolução da controvérsia levado a efeito por sujeitos privados. A satisfação individual é assegurada, em regra, pela criação de um fundo administrativo, o qual, segundo os parâmetros negociados pelas partes, é responsável pelas indenizações devidas. O Poder Judiciário torna-se um dos veículos para autocomposição.

\subsubsection{ESCOPOS E ASPECTOS COMUNS DAS TÉCNICAS DE AGREGAÇÃO}

Depois dessa incursão nos mais variados tipos de agregação processual, do sistema jurídico estadunidense, alguns escopos e aspectos procedimentais comuns das técnicas se destacaram.

\section{- DECISÃO PELA AGREGAÇÃO OU COLETIVIZAÇÃO}

376 NAGAREDA, 2009, p. 553.

377 SHERMAN, 2008, p. 18.

378 NAGAREDA, 2009, p. 554.

379 VAIRO, Georgene. Why me? The role of private individuals in complex claims resolution. Stanford Law Review, 2005, V. 57: 1391-1428p. 
Todas as técnicas exigem uma decisão pela agregação ou pela certificação da ação de classe. A decisão pela agregação ou certificação - que possibilita a reunião ou coletivização de múltiplas demanda individuais em uma entidade litigante - é a decisão mais importante no gerenciamento da litigiosidade de massa. A partir da agregação, várias técnicas e instrumentos processuais encontram-se disponíveis para facilitar o processamento e a resolução unitária da controvérsia, com uniformidade no provimento judicial, economia processual e eficiência. ${ }^{380}$

Como visto, a agregação pode assumir diferentes tipos e formas. E, igualmente, diferentes técnicas e instrumentos processuais são oferecidos para o mesmo propósito, estabelecendo, por assim dizer, uma espécie de sistema único de agregação, com eventual combinação das técnicas.

Veja algumas das combinações possíveis: (i) a ação coletiva pode ser combinada à consolidação das demandas individuais, inclusive com as demandas individuais daqueles que se excluíram da ação de classe, isto é, que exerceram o opt out; (ii) consolidação multidistrital pode ensejar, posteriormente, o ajuizamento de uma ação de classe pelo conselho de advogados, no fenômeno denominado consolidated class action complaint; (iii) durante a consolidação, é possível a realização de um caso-teste com finalidade informativa, para instruir e orientar os termos de um acordo coletivo extrajudicial e; (iv) as demandas individuais podem ser reunidas ou coordenadas em um ou mais escritórios de advocacia, facilitando, com isso, a formação do conselho de advogado e do conselho de autores do contencioso multidistrital e assim por diante.

Nota-se, portanto, que as técnicas e instrumentos processuais de agregação podem ser combinados, de forma a ensejar a agregação processual e a resolução unitária das controvérsias.

O sistema único visa à otimização da agregação. Sempre que o intérprete estiver diante de uma situação de comunhão substancial, unitariedade ou de anonimato do indivíduo no grupo, a agregação é possível. Mesmo que a demanda individual escape de uma técnica de agregação, ela pode ser recapturada por outra técnica, permitindo, assim, a simetria entre direito e processo.

- VANTAGENS E DESVANTAGENS

380 HERR, 2012, p. 605. 
A agregação processual, por qualquer de seus tipos e técnicas, busca a maximização do gerenciamento da litigiosidade (case management) ${ }^{381}$, a minimização da repetição das demandas, a redução do custo e das dilações processuais indevidas, a promoção de resultados práticos consistentes e coerentes entre as várias demandas individuais. De igual modo, somente a agregação processual poderá conferir uma resposta jurisdicional adequada nas hipóteses em que não há interesse na persecução individual ou não há força para a persecução individual.

Por vezes, não há interesse na persecução individual de danos economicamente ínfimos. Sem a agregação processual, esses danos não seriam reparados ou permaneceriam irressarcidos. A agregação, ainda que não seja relevante sob o aspecto individual, enseja a compensação dos interessados, bem como confere um desestímulo à continuidade da prática abusiva ou lesiva.

De igual modo, nas situações de incerteza científica, em que os danos são latentes ou foram pulverizados, é improvável a comprovação do nexo de causalidade específico ou individual. Para essas hipóteses, a prova realizada no grupo ou na categoria é capaz de afastar a incerteza, possibilitando a verossimilhança quanto à causalidade dos danos em uma dada comunidade.

As desvantagens consistem na inexistência ou na redução da autonomia individual nos procedimentos agregados, bem como no acréscimo de complexidade e de tempo na tramitação das demandas individuais, depois de agregadas. Essas desvantagens devem, no entanto, ser ponderadas conforme os critérios metodológicos de agregação, à luz do direito substancial.

Conforme os contornos substanciais de uma controvérsia, a autonomia individual não só pode ser reduzida, como ela deve ser reduzida. Isso ocorre porque o centro de cognição da controvérsia não é o indivíduo, mas, sim, a própria categoria ou grupo de pessoas. Enfim, quando a história é coletiva e o indivíduo se insere como um anônimo no grupo, não existem peculiaridades individuais que justifique um procedimento com ampla autonomia individual.

381 Judith Resnik comenta que, hoje, não há mais gerenciamento do caso, mas, sim, gerenciamento da litigiosidade, a saber, da multiplicidade de casos individuais similares que devem agregados para fins gestão (Cf. RESNIK, 1991, p. 50). 
Aliás, esse é cerne da agregação processual e de suas técnicas: são os critérios de agregação, à luz do direito substancial, que definem o sucesso ou não dessa técnica de direito processual. Ante de agregar, é preciso saber o que agregar para alcançar as vantagens antes mencionadas.

\section{- MOMENTO PARA A TOMADA DE DECISÃO DA AGREGAÇÃO}

No sistema jurídico estadunidense, os juízes têm poder discricionário para definir o momento adequado para a agregação processual. Mas, algumas regras específicas orientam essa decisão.

Por exemplo, conforme a Regra 23, a certificação da ação coletiva deve ser adotada no momento mais cedo possível ou praticável. O contencioso multidistrital somente pode reunir as demandas que ainda esteja na fase de saneamento e instrução (pre-trial), pois, do contrário, não haveria propósito na agregação processual por essa técnica, que se restringe a essa fase processual. ${ }^{382}$

De qualquer modo, o tempo para tomada de decisão depende de um conjunto de informações confiáveis, que permitam ao juiz inferir a existência da comunhão ou do anonimato no grupo.

\section{- AMADURECIMENTO DA CONTROVÉRSIA DE MASSA}

Controvérsias que contam com muitas demandas individuais já julgadas e testadas pelas Cortes de Justiça, em que os autores individuais e réus já argumentaram à exaustão e testaram suas estratégicas e nas quais já houve ampla e farta instrução probatória tendem a facilitar a agregação. As Cortes de Justiça, por experiência própria, já reuniram informações suficientes sobre o universo coletivo da demanda e sobre a comunhão ou anonimato do indivíduo no grupo, o que facilita a decisão pela agregação processual, bem como pelo tipo de técnica a ser adotada.

Controvérsias cujas causas de pedir e pedido não foram, ainda, amadurecidos nas Cortes de Justiça tendem a rechaçar a agregação processual, todavia, isso não é uma regra absoluta. Muito pelo contrário, por vezes, as técnicas de agregação são aplicadas exatamente nessas hipóteses de pouco amadurecimento para reunir maiores e melhores informações sobre os contornos da controvérsia de massa. Esse é a hipótese do caso-teste e sua função informativa.

382 HERR, 2012, p. 606. 
A expressão maturidade da controvérsia é de Francis McGovern ${ }^{383}$, que, na década de 80, salientava a importância do amadurecimento da controvérsia para o sucesso da ação de classe. Como as controvérsias maduras exigem pouca ou nenhuma prova no tocante à matéria fática, não há necessidade de processamento pleno de todas as demandas individuais pendentes. Logo, é possível, com maior facilidade, a agregação processual dessas controvérsias em juízo.

O conceito, embora tenha sido muito aplicado para as ações coletivas, é hoje estendido para outras técnicas de agregação, como o caso-teste e para consolidação de demandas individuais.

\section{- GERENCIAMENTO}

$\mathrm{Na}$ agregação processual, é relevante a adoção de técnicas de gerenciamento do procedimento agregado. O juiz pode determinar que as partes ou um perito judicial (special master) identifiquem as principais características da controvérsia. É possível, também, autorizar o perito a praticar atos processuais no processo, bem como modelar a solução alternativa do conflito. ${ }^{384}$

É possível a formação de um conselho de advogados, um conselho administrativo e um conselho de autores e réus. O objetivo do conselho é ampliar a comunicação do juízo com as partes, bem como possibilitar o oferecimento de peças processuais unitárias e uniformes, evitando, assim, a multiplicação de documentos no procedimento objeto de agregação. ${ }^{385}$

De igual modo, é possível exigir um plano de julgamento (trial plan) ${ }^{386}$. O que significa isso? Significa que as partes deverão alegar, na petição inicial, as provas e evidências que demonstrarão em juízo as questões comuns de fato e de direito alegadas. Essa informação permite ao magistrado aferir se essa questão comum, alegada pelas partes, suporta ou não uma procedimento agregado ou, se pelo contrário, requer uma aferição individual. Algumas Cortes

383 MCGOVERN, 1989, p. 690.

384 Um special master é um perito a quem a Corte de Justiça delega a prática de atos de saneamento e instrutórios principalmente, principalmente nos mega-casos em que é o magistrado não possui recursos e tempo suficiente para atuar na resolução da controvérsia. Esse perito pode ser um advogado experiente, um juiz aposentado, um professor, normalmente especialistas na matéria objeto de julgamento. São remunerados por honorários, pois não são considerados servidores públicos. (BRAZIL, Wayne D. Special masters in the pre-trial development of big cases: potential and problems. In: BRAZIL, Wayne D., HAZARD JR., Geoffrey C., RICE, Paul R. Managing Complex Litigation: A practical guide to the use of special master. Chicago: American Bar Foundation Press, 1983, p.5-7).

385 FEDERAL JUDICIAL CENTER, 2004, p. 24-25.

386 Ibidem, p. 362. 
de Justiça, no sistema jurídico estadunidense, já rejeitaram a certificação da ação de classe, após o plano de julgamento revelar-se inábil a demonstrar a causalidade sob a forma agregada.

\section{- CRITÉRIOS METOdológicos DE AGREGAÇAO E O DIREITO SUBSTANCIAL}

As técnicas de agregação podem variar de forma mais ou menos intensa. Mas, como foi mencionado anteriormente, todas as técnicas circundam os mesmos ou, ao menos, similares critérios metodológicos de agregação: a comunhão das questões e a anonimato do indivíduo.

A agregação processual é, por certo, um fenômeno de direito processual, mas está, essencialmente, vinculado aos contornos da relação substancial. São os critérios, identificados na relação substancial, que orientam a decisão sobre o que agregar e sobre como agregar.

Como consigna o Manual do Contencioso Complexo ${ }^{387}$, o fator chave para decidir sobre a agregação é a existência de questões comuns ao grupo, categoria ou classe. Enfim, é unitariedade ou paridade presente no direito substancial que enseja a resolução unitária e uniforme da controvérsia de massa. Se a relação substancial revelar a heterogeneidade, a particularização e a necessidade de cognição artesanal, ela não deve ser objeto de agregação.

Esse é um dos temas mais caros e difíceis, no tocante à agregação processual, e também um dos assuntos menos explorados pela dogmática. Como bem salienta Erbsen ${ }^{388}$, muito se fala no sistema estadunidense em "quando", "onde", "quem" e "como" agregar. Mas, antes de tudo isso, é preciso compreender o que é individual e o que é coletivo e, portanto, passível de agregação processual. Somente quando avaliada o grau de similaridade ou de diferenças entre as situações jurídicas dos membros da classe, é possível decidir o que agregar e como agregar.

A forma, isto é, o método de agregação para fins de resolução da controvérsia, é apenas um instrumento de implantação das regras substanciais e dos seus escopos compensatórios, punitivos, pedagógicos e outros. Antes do processo, há que se analisar o direito substancial.

387FEDERAL JUDICIAL CENTER, 2004, p. 357.

388 ERBSEN, 2005, p. 5. 


\subsubsection{INSIGHTS PARA O DIREITO BRASILEIRO}

O direito processual brasileiro, embora possua um sistema coletivo de vanguarda, ainda não conta com um sistema de agregação processual, nos moldes do sistema jurídico estadunidense.

A exposição dos tipos de agregação processual e das técnicas e instrumentos de agregação foi realizada, anteriormente, com fundamento no direito estadunidense apenas. Mas, nem por isso, o direito processual brasileiro está inerte. Muito pelo contrário, embora não exista uma organização dogmática das técnicas de agregação processual, a exemplo do sistema jurídico estadunidense, a agregação ou a molecularização é, há muito, ponderada e refletida entre nós.

É claro que não há, ainda, uma explícita solução legislativa. E, há, em verdade, certa resistência política na reforma do microssistema processual coletivo brasileiro, o que obsta a potencialização da resolução unitária e uniforme dos conflitos, resistência essa injustificada!

A multiplicidade de demandas individuais repetitivas e, até mesmo a concorrência de ações coletivas, exigem a adoção de técnicas de agregação processual. Essa necessidade é corroborada pela jurisprudência e, principalmente, pela doutrina que se engaja nas discussões acadêmicas a respeito da molecularização, bem como na elaboração de projetos de reforma legislativa.

Justamente por isso, não há óbice a que a categorização presente no sistema jurídico estadunidense, no tocante aos tipos de agregação - processo agregado, agregação administrativa e agregação privada - seja também adotada, por analogia, na dogmática processual brasileira.

Como já abordado, várias das técnicas de agregação antes mencionadas já se encontram previstas em projetos de lei e em anteprojetos da reforma processual coletiva brasileira. É bem verdade - frise-se - que há uma maior resistência à formalização explícita dessas técnicas de agregação processual. Mas, a ausência de um sistema de agregação tipicamente brasileiro e a resistência política mencionada não nos impedem de traçar, desde já, alguns paralelismos entre as técnicas antes investigadas no sistema jurídico estadunidense e as propostas e os projetos já previstos e, que todavia seguem pendentes de apreciação pelo legislador brasileiro. 
Por exemplo, em 1985, foi proposto um "incidente de molecularização da controvérsia" 389 que apresenta uma grande semelhança ao caso-teste. $\mathrm{O}$ referido incidente referia-se, exclusivamente, à agregação da questão de direito comum, presente no universo coletivo de demandas individuais, e posicionava-se pela adoção da função preclusiva do caso-teste.

O Anteprojeto do Novo Código de Processo Civil Brasileiro 390 também prevê um "incidente de resolução de demandas repetitivas". Mas, a natureza desse procedimento não resta muita clara pelo texto do projeto, tampouco resta claro se possuiu ou não a função preclusiva de um casoteste. Seria um julgamento por amostragem ou não? Seria um precedente vinculante ou não?

Essas questões não foram suficientemente esclarecidas. Se for um julgamento por amostragem, seria necessário um melhor esclarecimento sobre a amostra representativa da controvérsia e sobre a preclusão processual, de forma a conferir uma resolução unitária à controvérsia de massa. Se for um precedente vinculante, não há necessariamente agregação processual da controvérsia de massa, pois as demandas individuais podem ser continuamente ajuizadas, com a pretensão de afastar o precedente por distinção ou superá-lo por outras razões jurídicas.

Igualmente, técnicas de conversão de demandas individuais em demandas coletivas coletivização de ofício - foram previstas no Projeto de Lei sobre um processo especial de controle jurisdicional de políticas públicas ${ }^{391}$, bem como nos substitutivos do Anteprojeto do Novo Código de Processo Civil Brasileiro ${ }^{392}$, ao lado do incidente de demandas repetitivas.

Nesse aspecto, assume relevância a identificação dos contornos da relação substancial, noutros termos, da comunhão entre os indivíduos que autorize a decisão pela coletivização das demandas. Como já salientado a partir do sistema estadunidense, o critério metodológico, aferível à luz do direito substancial, é o fator determinante e essencial à agregação processual.

389 BRASIL. Código de Processo Civil. 7 ed. Atualizador Sálvio de Figueiredo Teixeira. Rio de Janeiro: Forense, 1986, p. 682.

390 BRASIL. Congresso Nacional. Câmara dos Deputados. PL nº 8.046/2010. Código de Processo Civil: anteprojeto. Brasília: Câmara dos Deputados, Presidência, 2010.

391 BRASIL. CEBEPEJ. Projeto de lei que institui processo especial para o controle e intervenção em políticas públicas pelo Poder Judiciário e dá outras providências (no prelo).

392 BRASIL. Anteprojeto Substitutivo do Novo Código de Processo Civil. Exposição de motivos/Comissão de Juristas. Disponível em: http://www.direitoprocessual.org.br/index.php?substitutivo-elaborado-por-adapellegrini-grinover-carlos-alberto-carmona-cassio-scarpinella-bueno-e-paulo-henrique-dos-santos-lucon. Acesso em 5 de setembro de 2013. 
De igual modo, a consolidação ou reunião de demandas individuais é objeto de várias propostas. Apenas a título de exemplo, é válido ressaltar que o $\mathrm{CEBEPEJ}^{393}$, ao realizar pesquisa sobre a tutela dos direitos transindividuais, em 2007, consignou a necessidade de reunião e resolução conjunta de ações coletivas concorrentes, versando sobre um mesmo objeto controvertido.

Pedro Dinamarco ${ }^{394}$, abordando o mesmo tema, salientou que demandas coletivas ajuizadas por colegitimados diferentes deveriam ser reunidas e não extintas por força da litispendência.

O argumento é preciso. Mas, por força da análise comparada sobre a agregação processual, ora empreendida, a consolidação ou a reunião de demandas deve ocorrer não pelo fato de elas apresentarem diferentes colegitimados, mas, sim, pelo fato de a causa de pedir e o pedido - que identificam os contornos objetivos da relação substancial - referirem-se ao mesmo bem da vida controvertido. Não é a diferença das partes, mas, sim, é a diferença das causas e argumentos das partes com relação a um mesmo bem da vida que justificam, nesse caso, a reunião das demandas e não a litispendência. Se os argumentos forem iguais, se as peças processuais forem objetivamente idênticas, não há óbice ao reconhecimento da identidade e da litispendência.

É o direito material que determina, fundamentalmente, a agregação processual e não a relação processual estabelecida entre as partes. O processo pode, inclusive, ser adaptado ou flexibilizado, para adequar-se aos contornos da relação de direito substancial deduzida em juízo.

A coordenação informal de demandas, bem como a adoção de técnicas indiretas de agregação, como a suspensão obrigatória das demandas individuais, não está também distante da realidade brasileira. Muito pelo contrário, a agregação, de lege lata, já existe no direito brasileiro, em razão da adoção de práticas informais de agregação. Cita-se, como exemplo, a prática adotada pelos magistrados do Rio Grande do Sul, que procederam à suspensão compulsória das demandas individuais, enquanto pendente a apreciação de ação coletiva em processos repetitivos relativos ao reajuste da poupança. Após o julgamento da ação coletiva, as ações individuais foram convertidas, automaticamente, em liquidação individual da sentença. ${ }^{395}$

393 CEBEPEJ. A Tutela dos interesses metaindividuais - ações coletivas. Ministério da Justiça - Secretária de Reforma do Judiciário. Brasília, 2007.

394 DINAMARCO, Pedro da Silva. Competência, conexão e prevenção nas ações coletivas. In: Milaré, Edis (coord.) A ação civil pública após 20 anos: efetividade e desafios, São Paulo: RT, 2005, p. 513-515.

395 BRASIL. INNOVARE. Projeto Poupança. Disponível: www.premioinnovare.com.br/praticas/projetopoupanca-2208/. Acesso em: 21 de agosto de 2013. Esse entendimento foi mantido pelo Superior Tribunal de Justiça, em julgamento de recurso representativo da controvérsia (BRASIL. Superior Tribunal de Justiça. REsp. 
Uma segunda técnica adotada, no caso supracitado, foi a nomeação de um perito judicial, responsável por monitorar o cumprimento da tutela coletiva mandamental. Isso porque foi determinado às instituições financeiras o dever de depositar, em favor dos poupadores individuais, independentemente de habilitação, as diferenças reconhecidas na sentença coletiva.

No caso da assinatura telefônica, já antes mencionado, a pesquisa realizada pelo CEBEPEJ 396 informa que os Juizados Especiais de São Paulo também adotaram técnicas de agregação informal de demandas, como, por exemplo, a disponibilização de documentos comuns aos vários processos, a dispensação de numeração e autuação de peças processuais e outras.

O mesmo paralelismo entre o sistema jurídico estadunidense e o sistema jurídico brasileiro também é possível no tocante à agregação privada, mesmo que sem supervisão judicial.

Um projeto, desenvolvido por pesquisados da FGV e FADUSP ${ }^{397}$, abordou a aplicação no sistema jurídico brasileiro de um desenho de resolução alternativa de disputas. $\mathrm{Na}$ ocasião, embora tenham sido identificadas barreiras e desincentivos à resolução alternativa, foram abordados casos que lograram a resolução alternativa da disputa, como é o caso dos autistas. Não havia uma política pública educacional e de saúde para os autistas em São Paulo. Nessa hipótese, o próprio Município de São Paulo fixou um valor padrão, destinado à educação e à saúde dos autistas, bem como estabeleceu convênios com certas instituições especializadas.

Os projetos, superficialmente mencionados, serão recuperados em momento posterior da presente investigação. O aprofundamento reflexivo sobre essas questões devem ser realizadas depois de uma melhor investigação sobre os critérios metodológicos de agregação processual.

É preciso destacar, nesse momento, que foge ao escopo da presente investigação reformular o sistema coletivo brasileiro a partir das técnicas de agregação presentes no modelo estadunidense. O objetivo foi apenas realizar uma investigação do sistema jurídico

1.353.801/RS, Rel. Min. MAURO CAMPBELL MARQUES, PRIMEIRA SEÇÃO, DJe23.8.13).

396 CEBEPEJ. A Tutela dos interesses metaindividuais - ações coletivas. Ministério da Justiça - Secretária de Reforma do Judiciário. Brasília, 2007.

397 BRASIL. Ministério da Justiça. Secretária de Assuntos Legislativos. Série Pensando Direito nº 38/2010. O desenho de sistemas de resolução alternativa de disputas para conflitos de interesse público. GABBAY, Daniela Monteiro, CUNHA, Luciana Gross (coords.). Fundação Getúlio Vargas - FGV, 2010. 
estadunidense para dele extrair técnicas e critérios metodológicos de agregação processual, de forma a possibilitar a otimização da resolução das controvérsias de massa também entre nós.

A partir da investigação comparada, o que se pretende não é o transplante das técnicas daquele sistema jurídico para o sistema jurídico brasileiro. O que se pretende é apenas identificar insights que permitam a otimização da agregação processual ou da molecularização processual.

\subsection{DESAFIOS DA AGREGAÇÃO PROCESSUAL: A AGREGAÇÃO ÓTIMA}

O desafio da agregação processual, de uma maneira geral, é encontrar o ponto ótimo de agregação, isto é, quais são as circunstâncias dadas pelo direito material que tornam necessária e apropriada a técnica de agregação processual, de forma a evitar julgamentos repetitivos sobre a questão comum à categoria, sem implicar gravames à autonomia individual. O indivíduo deve poder narrar a sua história pessoal que pode não coincidir ou contrariar a história do grupo.

A agregação ótima, segundo Tidmarsh e Trangsrud ${ }^{398}$, é aquela que permite minimizar os custos futuros de novos processos individuais e coletivos repetitivos, bem como minimizar os custos atuais do saneamento, do julgamento e da satisfação dos múltiplos processos individuais e coletivos pendentes em juízo, os quais obstam à racionalização da administração da justiça.

De igual modo, no tocante ao escopo jurídico, a agregação ótima também visa a tratar casos iguais com igualdade. A agregação visa a garantir que os indivíduos recebam a sua parte na compensação a eles devida, bem como que essa parte seja equitativa ou paritária em relação aos demais indivíduos que, porventura, não são autores na referida demanda judicial. De igual modo, visa a evitar o conflito prático de decisões, quando a atuação de um indivíduo retira a eficácia do provimento pretendido por outro indivíduo, com relação ao bem controvertido. ${ }^{399}$

Para alcançar esse ponto ótimo, todas as técnicas de agregação antes mencionadas - se preenchidos os pressupostos legais - podem ser utilizadas para essa finalidade. Se uma situação de direito substancial, que é suscetível à agregação processual, escapar de uma das técnicas, ela

398 TIDMARSH, TRANGSRUD, 2002, p. 10.

399 Ibidem, p. 11 
pode ser recapturada por outra técnica de agregação, também aplicável, até alcançar um grau de ótimo de agregação no sistema jurídico. As técnicas podem ser combinadas, alternadas etc.

Não há prévia definição do grau ótimo de agregação, contudo, existem critérios que podem auxiliar o intérprete a aferir as hipóteses de agregação e a ensejar a otimização dessa técnica. Adianta-se que é a unitariedade ou paridade dada pelo direito substancial que permite identificar as hipóteses suscetíveis de agregação processual e as técnicas necessárias e idôneas para tanto.

Outro não é o entendimento no sistema jurídico brasileiro. São os contornos da relação jurídica de direito substancial que determinam os fenômenos de pluralidade de partes, do litisconsórcio, da intervenção de terceiros, do concurso subjetivo e, por fim, da tutela coletiva e agregada. $\mathrm{O}$ direito substancial define não só a necessidade da técnica, como a própria técnica adequada. ${ }^{400}$

A otimização, antes mencionada, faz, por sua vez, uma inequívoca remissão ao postulado da proporcionalidade e ao justo equilíbrio que vigem no direito processual civil brasileiro. A forma, isto é, a técnica processual, deve ser necessária e adequada para atingir os escopos do processo e, dentre eles, o escopo jurídico ${ }^{401}$, a saber, a atuação concreta e específica da norma de direito substancial, com eficiência, economia processual, uniformidade e coerência.

Segundo Samuel Meira Brasil $\mathrm{Jr}^{402}$, a instrumentalidade nada mais é do que sede material do princípio da proporcionalidade no direito brasileiro. Trata-se do reconhecimento da relação meio (processo) e fim (direitos) que orienta a aplicação das normas de direito processual. $\mathrm{O}$ importante é alcançar o escopo pretendido pelo processo, com o alcance dos resultados práticos postulados, sem prejuízo aos demais valores processuais concorrentes no sistema jurídico.

Em obra clássica do direito processual civil brasileiro, mencionada por Brasil $\mathrm{Jr}^{403}$, Ada Pellegrini Grinover, Antônio Carlos de Araújo Cintra e Cândido Rangel Dinamarco assinalam,

400 BEDAQUE, José Roberto dos Santos. Direito e Processo: influência do direito material sobre o processo. 4 ed. São Paulo: Malheiros, 2006, p. 108-109. No mesmo sentido, Liebman também aponta que é o direito substancial que determina a figura das ações concorrentes e sua disciplina jurídica. (Cf. LIEBMAN, 2007, p. 212). 401 Escopo jurídico, segundo Cândido Rangel Dinamarco, consiste na atuação da vontade concreta da lei, percebida essa última, no entanto, em conformidade à tendência de universalização da tutela jurisdicional e da adaptabilidade da técnica processual. Há que se observar uma interpretação dinâmica da lei, que não pode parar no tempo do legislador, com a manutenção do espírito individualista e arredio à molecularização do processo (Cf. DINAMARCO, Cândido Rangel. A instrumentalidade do processo. 8 ed. rev. atual. São Paulo: Malheiros, 2000, p. 217).

402 BRASIL JR, 2007, p. 100.

403 Ibidem, p. 101. 
com originalidade, a questão da necessidade e da adequação da técnica processual. O problema da forma processual somente se resolve pela resposta a duas questões. Vejamos quais são elas:

\footnotetext{
...problema das formas do próprio procedimento, o qual se desdobra em duas questões distintas: a) são necessárias as formas procedimentais? b) em caso de resposta afirmativa, qual a forma mais adequada para atingir o escopo do processo, em uma época determinada e segundo dadas condições? $?^{404}$
}

Marcelo José Magalhães Bonício ${ }^{405}$, a seu turno, ao estudar a proporcionalidade, salienta a correlação entre o princípio da proporcionalidade e da equidade processual. Trata-se da proteção da correta administração da justiça e da racionalidade de sua atuação concreta.

Carlos Alberto Alvaro de Oliveira ${ }^{406}$, também em obra específica sobre o tema, salienta a necessidade de se emprestar a maior efetividade possível ao direito processual no desempenho de sua tarefa básica de realização do direito material e outorga da justiça. A adequação da técnica processual às necessidades substanciais deve favorecer o grau máximo de efetividade.

Por fim, Carlos Alberto de Salles ${ }^{407}$ é preciso ao afirmar a necessidade de adaptação do design procedimental às necessidades e especificidades do direito material. $\mathrm{O}$ processo torna-se o ponto de chegada, após uma ponderação sobre as necessidades e as especificidades materiais.

No tocante à agregação processual, as assertivas, antes citadas, não são mais que verdadeiras. $\mathrm{Na}$ agregação processual, o processo é o ponto de chegada. Isso não quer dizer a liberdade total do método, a liberdade das formas, a atecnia processual. A forma não é livre, o que ocorre é que existem várias formas, várias técnicas e vários instrumentos processuais, possíveis e disponíveis para a resolução das controvérsias de massa. Justamente por isso é que são os contornos da relação de direito substancial que determinam a necessidade e a adequação de uma forma, técnica e instrumento processual, da combinação de formas, da alternância das formas.

404 CINTRA, GRINOVER, DINAMARCO, 2009, p. 285.

405 BONÍCIO, Marcelo José Magalhães. Proporcionalidade e processo: a garantia constitucional da proporcionalidade, a legitimação do processo civil e o controle das decisões judiciais. São Paulo: Atlas, 2006, p. 35 .

406 OLIVEIRA, Carlos Alberto Alvaro. Do formalismo no processo civil: proposta de um formalismo-valorativo. 3 ed. São Paulo: Saraiva, 2009, p. 134-135.

407 SALLES, Carlos Alberto de. Arbitragem em contratos administrativos. Rio de Janeiro: Forense, 2011, p. 25. 
No sistema jurídico estadunidense, Frederick Schauer ${ }^{408}$ ressalta que a forma é necessária para a previsibilidade do procedimento. Constitui, no entanto, uma mera presunção, que pode ser afastada ou adaptada quando inadequada ou desnecessária ao alcance dos escopos substanciais.

Muito bem. É, sob esse contexto, diga-se compartilhado entre os sistemas estadunidense e brasileiro, que se busca as hipóteses ou pontos ótimos em que a agregação constitui a técnica necessária e adequada à atuação do direito substancial, sem prejuízo à autonomia individual.

Esse ponto ótimo reside em equilibrar o que individual e o que é coletivo e, portanto, agregável. Por essa razão, esse será o objeto da próxima seção: a agregação à luz do direito substancial.

\subsection{SÍNTESE PARCIAL}

A representação, na ação coletiva, ocorre não porque o representante conhece as especificidades dos argumentos individuais. Ela ocorre porque não há, ao menos em parte (na questão comum), especificidades ou singularidades dos sujeitos interessados. O indivíduo apresenta-se, assim, como membro do grupo. O centro de cognição da controvérsia é o próprio grupo ou classe.

O mesmo ocorre nas demais técnicas de agregação, que envolvem a seleção de uma questão comum ao grupo. Essa questão comum ao grupo nada mais é do que uma amostra representativa da controvérsia de massa. De forma que, é possível perceber, nessas hipóteses de agregação de larga escala, sempre uma espécie de representação de interesses ou direitos comuns ao grupo, seja pela atuação de um portador ideológico do grupo em juízo, seja pela existência de uma amostra representativa dos interesses ou direitos comuns ao grupo, a ser resolvida.

As categorias de agregação processual são divididas em agregação representativa e litisconsorcial (processo agregado), agregação administrativa e agregação privada. A primeira categoria engloba as ações coletivas e o litisconsórcio. A segunda categoria abrange a consolidação, a coordenação de demandas individuais e o caso-teste. E, a última categoria alcança os mecanismos alternativos de resolução de disputas, como a arbitragem e a mediação.

408 SCHAUER, Frederick. Formalism. Yale Law Review, 1988, V.97: 509-548p. p. 547. 
No sistema jurídico estadunidense, pode-se dizer que a agregação processual já constitui um sistema único. Diante de um interesse substancial coletivo ou de alcance coletivo, o design procedimental pode ser reorganizado para conferir simetria entre direito e processo. Se um indivíduo exclui-se da ação coletiva, por exemplo, ele pode ser incluído em outras técnicas de agregação, como na consolidação, no caso teste, na coordenação informal de demandas, quando persiste a mesma natureza coletiva, objetiva, paritária e impessoal do direito substancial. 


\section{SEÇÃO II \\ OTIMIZAÇÃO DAS TÉCNICAS DE AGREGAÇÃO PROCESSUAL À LUZ DO DIREITO SUBSTANCIAL}

\section{OBJETO DE PROTEÇÃO}

Trata-se de um tema, ainda, pouco explorado na dogmática. O cerne da agregação processual reside na tensão e na convergência entre o que é individual e o que é coletivo ou plurissubjetivo. Qual o grau de variância que se tolera entre os membros do grupo para fins de agregação?

\subsection{APRESENTAÇÃO}

O presente capítulo tem por escopo enfatizar a relevância que a correta identificação das relações substanciais desempenha nas ações coletivas e em outras técnicas de agregação. Evidentemente, somente a partir dos parâmetros dados pelo direito material, será possível conferir um tratamento processual adequado à litigiosidade de massa e suas controvérsias.

Como é cediço, existem situações da vida que não se enquadram no arquétipo puro do direito subjetivo dualista. O processo não está adstrito sempre a duas pessoas (Tício e Caio), existem, ao contrário, situações plurissubjetivas. Situações da vida nas quais os interesses dos homens se entrelaçam, mesmo que esse destino não tenha sido por eles escolhido. A defesa de um coopera com os outros e as histórias individuais, por vezes, se imiscuem em uma só, coletiva.

Barbosa Moreira ${ }^{409}$ assinala que cresce, incessantemente, o número e o relevo de situações que envolvem coletividades de pessoas, as quais constituem o nascedouro de conflitos de interesses atinentes a uma pluralidade de indivíduos. A esses conflitos, o arsenal jurídico, herdado de outros tempos, não mais é capaz de processar, exigindo um esforço criativo para a tutela jurisdicional efetiva dos interesses que extravasam o quadro das relações interindividuais.

409 MOREIRA, 1977, p. 110. 
Essas situações plurissubjetivas, mencionadas por Barbosa Moreira, são, por sua vez, velhas conhecidas do direito processual civil. Hoje e sempre atormentam processualistas no mundo.

$\mathrm{Na}$ arena do processo tradicional, a expressão dessas situações plurissubjetivas encontrou guarida no litisconsórcio unitário, bem como no concurso subjetivo de ações, que possibilita, respectivamente, a atuação no processo de dois ou mais sujeitos em conjunto ou em ações simultâneas ou sucessivas. Esses sujeitos, por sua vez, comungam direitos ou obrigações, que compartilhadas "se inserem homogeneamente [...] na situação global" ${ }^{410}$, como ilustra o sempre mencionado caso de anulação de deliberação assemblear de uma sociedade anônima.

A técnica do litisconsórcio, bem como outras formas de intervenção de terceiros, já convivem - não sem tergiversação - no sistema jurídico brasileiro. A problemática da agregação surge ou, pelo menos, se acentua quando as situações da vida, que escapam ao quadro teórico dualista (Tício v Caio), refogem às fórmulas processuais tradicionais, em uma dimensão - muito mais explosiva e conflitiva - marcante na litigiosidade de massa do período contemporâneo.

É, nessa faixa, que se encontram os direitos substanciais coletivos em sentido amplo. Esses direitos apresentam - além de uma numerosidade de sujeitos interessados, o que impossibilita a participação direta de todos segundo as receitas processuais clássicas - uma maior conflitualidade, dispersão e fragmentação no seio social. Reclamam, por isso, novos instrumentos que estabeleçam formas de resolução molecular ou agregada da controvérsia. ${ }^{411}$

Contudo, antes de se adentrar a qualquer técnica de agregação, é preciso saber qual será o seu objeto material, noutros termos, é preciso bem identificar a natureza da relação jurídica de direito substancial, se a sua natureza é cindível ou particularizada e, portanto, não deve ser agregada, ou se a sua dimensão é incindível ou impessoal - isto é indiferente às características de cada um dos sujeitos interessados - e, portanto, suscetível à técnica de agregação processual.

410 MOREIRA, 1972, p. 145.

411 Nesse sentido, Ada Pellegrini Grinover, ao conceituar direitos difusos, chama a atenção do leitor para o caráter contingente e mutável desses interesses, vinculados apenas por circunstâncias fáticas, razão pela qual os rígidos esquemas do processo civil deveriam ser repensados para a sua tutela (Cf. GRINOVER, Ada Pellegrini. A tutela jurisdicional dos interesses difusos no sistema brasileiro. In: GRINOVER, Ada Pellegrini (coord.). A tutela dos interesses difusos. São Paulo: Max Limonad, 1984, p. 177-178 (Série Estudos Jurídicos N. 1)). Em uma das monografias mais completas sobre o tema dos interesses difusos, Rodolfo Camargo de Mancuso revela as áreas de conflitualidade propícias aos direitos difusos, bem como a sua intensa litigiosidade interna (Cf. MANCUSO, Rodolfo de Camargo. Interesses difusos: conceito e legitimação para agir. 7 ed. rev. atual. amp. São Paulo: Revista dos Tribunais, 2011). 
A compreensão e a identificação do direito substancial, objeto da agregação, é uma questão teórica de anterioridade lógica, além de ser um dos nós-górdios do processo civil moderno.

Essa advertência não é nova. Kazuo Watanabe ${ }^{412}$ já, há muito, menciona a necessidade de uma precisa identificação da relação jurídica de direito substancial. O problema, de aparente simplicidade, é objeto de grandes dificuldades práticas e isso, por vezes, implica a multiplicação de demandas substancialmente idênticas, veiculadas de forma atomizada no Poder Judiciário.

Nessa seara, continua o Professor Kazuo Watanabe ${ }^{413}$, é preciso atentar-se para os elementos objetivos da demanda, isto é, causa de pedir e pedido, para que seja feita a correta fixação da abrangência da demanda, sob pena de se comprometer o objetivo colimado pelo legislador no tocante à molecularização da controvérsia de direito substancial coletiva ou plurissubjetiva.

Um fato lesivo pode ensejar diferentes controvérsias, sejam elas de amplitude individual, sejam elas de amplitude plurissubjetivas ou coletivas, de acordo com a natureza da relação substancial.

Veja, por exemplo, o caso de uma indústria que polui. O fechamento da indústria, além de preservar o meio ambiente, direito por todos fruível, protegerá, reflexamente, a saúde de cada um dos indivíduos e de toda uma pluralidade de interessados, submetidos à poluição. Nessa hipótese, não é possível obstar que um indivíduo busque um provimento inibitório para a tutela de um interesse próprio com alcance coletivo - como, por exemplo, o fechamento da fábrica para proteção de sua saúde - quando a violação desse interesse apresentar reflexos individuais na sua saúde, na sua propriedade, no seu contrato e em outros direitos subjetivos clássicos. ${ }^{414}$

Mas, ainda que uma ação individual seja proposta, encartada em um direito individual clássico, como saúde, propriedade, contrato, se a relação jurídica substancial apresentar alcance coletivo,

412 Kazuo Watanabe ressalta a importância da compreensão da causa de pedir e do pedido no processo, pois, a partir desses elementos objetivos da demanda, decorre uma série de consequências processuais, como, por exemplo, o cabimento de ações coletivas, como o regime processual aplicável ao litisconsórcio, como a ocorrência de litispendência. Muitos erros têm sido cometidos na prática pela desatenção dos operadores do direito às particularidades da relação jurídica de direito substancial deduzida em juízo (Cf. WATANABE, 2007, p. 158). 413 Ibidem, p. 158.

414 Isso é chamado por parcela da doutrina de dano reflexo ou de ricochete. Nesse caso, no entanto, o indivíduo, ao invés de pleitear o ressarcimento pelos danos pessoalmente sofridos, realiza pretensão inibitória, qual seja, o fechamento da fábrica poluidora, também como forma de proteção de sua saúde (Cf. MILARÉ, Edis. A ação civil pública por dano ao meio ambiente. In: MILARE, Edis (coord.). Ação Civil Pública - Lei no 7.347/1984 - 15 anos. 2 ed. rev. atual. São Paulo: Revista dos Tribunais, 2002, p. 146 e LEITE, José Rubens Morato. Dano extrapatrimonial ou moral ambiental e sua perspectiva no direito brasileiro. In: MILARE, Edis (coord.). Ação Civil Pública - Lei $n^{\circ}$ 7.347/1984 - 15 anos. 2 ed. rev. atual. São Paulo: Revista dos Tribunais, 2002, p. 458-463). 
ou seja, incidir sobre bem da vida de natureza indivisível e impessoal, se o indivíduo atuar apenas na qualidade de membro de uma comunidade, for um mero anônimo no meio de uma multidão, essa demanda, apresentada pelo indivíduo, é uma forte candidata a sofrer agregação processual ou molecularização. Não importará o nome da demanda, mas apenas a essência.

De outro lado, se um indivíduo encarta sua pretensão em algum direito subjetivo clássico, como o contrato ou a propriedade, e se o bem da vida pretendido for suscetível de ser apropriado, na prática, por cada indivíduo isoladamente, isto é, se ele for divisível, há, ao que tudo indica, um direito individual. Esse seria, em tese, o caso em que se pretende a exclusão de uma tarifa abusivamente cobrada e o ressarcimento pelas diferenças financeiras decorrentes da cobrança ilícita. Todavia, o que poderia parecer, em um primeiro momento, um direito do indivíduo, apresenta, no plano substancial, uma relação impessoal, objetiva e incindível, em que a paridade entre todos os interessados na controvérsia deve ser, necessariamente, observada, sendo indiferentes as características de cada um dos sujeitos interessados. Isso ocorre, por exemplo, quando há uma exigência legal de que a cesta tarifária praticada por uma concessionária de serviço público seja uniforme, a exemplo da tarifa básica de telefonia. Trata-se, agora, de um direito individual com alcance coletivo. Nesse caso, não há que se obstar a persecução individual do direito, mas existe, novamente, um forte candidato às técnicas de agregação. ${ }^{415}$

Na realidade, a definição nominal do interesse ou direito (como meio ambiente, consumidor, propriedade, contrato, saúde), o nome da parte (como João, José, Fernanda, Juliana) ou a forma de sua persecução em juízo, por meio do indivíduo ou por um ente exponencial, não são os elementos determinantes para fins de aplicação das técnicas de agregação processual.

O que importa - é, ao menos, o que se põe para reflexão nesta investigação - é a dimensão ou o alcance coletivo da controvérsia de direito substancial. Se a controvérsia apresentar dimensão coletiva: incindível e superveniente à pessoa dos indivíduos, isto é, um tipo impessoal, padrão, objetivo e indiferente às características de cada um dos indivíduos, a agregação é, ao menos em tese, viável para a resolução plena da controvérsia substancial coletiva ou plurissubjetiva.

415 Kazuo Watanabe menciona que o caso da tarifa básica de telefonia como ação pseudoindividual, embora proposta por um indivíduo, revela objeto incindível, cujo tratamento deverá ser necessariamente igualitário (Cf. WATANABE, 2007, p. 159). De igual modo, o estudo do caso específico da tarifa básica de telefonia pode ser encontrado na pesquisa do CEBEPEJ, com dados estatísticos alarmantes sobre a repetição desse matéria (Cf. CEBEPEJ. A Tutela dos interesses metaindividuais - ações coletivas. Ministério da Justiça - Secretária de Reforma do Judiciário. Brasília, 2007). 
Sem a identificação da amplitude da controvérsia, há incerteza, possível oportunismo e estratégia. A penumbra conceitual quanto às posições do indivíduo e do grupo e, por conseguinte, o vaivém que se estabeleceria nas Cortes de Justiça entre os planos individual e coletivo poderia conduzir ao fatal esquecimento do direito material - a razão primeira e mais importante de tudo isso. $\mathrm{O}$ conceitualismo ${ }^{416}$ intransigente não tem, pois, mais lugar no sistema.

Já se adiantou suficientemente sobre o tema do capítulo. Mas, ainda faltam várias peças do quebra-cabeça. As premissas ora levantadas devem, portanto, ser demonstradas no decorrer da tese, a partir de uma perspectiva comparada entre os sistemas estadunidense e brasileiro.

Nesse capítulo, optou-se por não dividir os dois sistemas em tópicos separados. Os interesses ou direitos coletivos serão abordados em conjunto, de forma sistemática para os dois sistemas.

Para iniciar essa discussão, é preciso investigar o que são direitos ou interesses, bem como os critérios que permitam distinguir o alcance dos interesses ou direitos individuais do alcance coletivo. Essa é a base sobre a qual irão ou não incidir as técnicas processuais de agregação.

\subsection{INTERESSES OU DIREITOS}

O conceito de interesses não é de ordem exclusivamente jurídica, tampouco processual. A remissão à expressão interesses esteve presente, em alguma medida, no discurso sociológico, cultural, filosófico e político. E, o direito, por sua vez, não permaneceu inerte à essa realidade. ${ }^{417}$

Os interesses, de um modo geral, sofreram um processo de adequação ao fenômeno jurídico, de forma a viabilizar a sua proteção jurisdicional. Para isso, esses interesses foram conectados $\mathrm{ou}$ - pode-se dizer que - foram transformados (conceito de jump) (18 $^{418}$ em verdadeiros direitos.

\footnotetext{
416 O conceitualismo é também denunciado por Kazuo Watanabe e Elton Venturi (Cf. WATANABE, Kazuo. Da defesa do consumidor em juízo. In: GRINOVER, Ada Pellegrini, WATANABE, Kazuo e NERY JR., Nelson (coords.). Código Brasileiro de Defesa do Consumidor Comentado pelos Autores do Anteprojeto II. 10 ed. rev. atual. reform. Rio de Janeiro: Forense, 2011, p. 80 e VENTURI, Elton. Processo Civil Coletivo: a tutela jurisdicional dos direitos difusos, coletivos e individuais homogêneos no Brasil. Perspectivas de um Código Brasileiro de Processos Coletivos. São Paulo: Malheiros, 2007, p.84).

417 Em sentido semelhante: MANCUSO, 2011, p. 23-39. VENTURI, 2007, p. 43-45.

418 O conceito de jump é dado por Aleksander Peczenik, que esclarece que, a partir da observação das práticas humanas, dos fatos, dos valores e de outras normas, é possível inferir um interesse ou uma posição de vantagem a constituir um direito. $\mathrm{O}$ salto (jump) é a inferência que se estabelece entre o valor dos interesses para uma sociedade e a conclusão de que, a partir deles, existe um direito propriamente dito (Cf. PECZENIK, 1983, p. 8).
} 
Isso é o que explica Peczenik ${ }^{419}$. Um direito pode ser identificado a partir do momento em que certas práticas ou certas características da natureza humana destacam-se em interesses (vontades, desejos, necessidades e, enfim, posições de vantagem) considerados valiosos, que constituem uma razão suficiente à fundamentação ou à imputação de um dever a outrem. Os direitos nada mais são, nesse contexto, do que proposições derivadas ou inferidas de fatos, de práticas, de costumes, de outras normas existentes ou de valores, cujos interesses destacados são, por uma razão suficiente, qualificados juridicamente sob a forma de regras e de princípios.

Nessa linha de raciocínio, vários são os interesses, ou melhor, as aspirações, os desejos, as vontades, as necessidades, as vantagens, que existem no plano dos fatos, no mundo da vida real.

O direito surge quando um desses interesses, que constitui originariamente uma posição de vantagem, é extraído do mundo da vida e qualificado normativamente, apresentando, em seguida, um titular, um objeto de proteção jurídica e um terceiro a quem é oponível o objeto de proteção. O direito resultante dessa operação seria assim, nada mais, do que a medida de promoção e de defesa dos interesses, que dentre os vários possíveis, se sagraram vencedores. ${ }^{420}$

O nosso problema - aquele que é discutido no bojo do fenômeno da litigiosidade de massa e agregação - surgiu quando a expressão direito passou a ser imputada apenas aos interesses orientados, exclusivamente, aos indivíduos, em outras palavras, o titular do direito era um sujeito identificável. Não se pensava em direitos que transcendessem a esfera individual.

Assim, enquanto pendente essa incerteza ou, mesmo, vedação à existência de direitos transindividuais, a doutrina jurídica passou a nominá-los apenas de interesses, sejam interesses difusos, coletivos, legítimos, públicos, e, enfim, havia uma multiplicidade de termos, que designavam, em síntese, interesses que simplesmente ultrapassavam as esferas individuais. ${ }^{421}$

419 PECZENIK, 1983, p. 8.

420 Conceito de Rudolph Von Jhering, segundo o qual o direito é um interesse juridicamente protegido. Nesse sentido, conferir o verbete right em: BENN, Stanley, "Rights," Encyclopedia of Philosophy, ed. Paul Edwards, New York: Macmillan, 1967. Joseph Raz, por sua vez, também conceitua direito como sendo um interesse suficiente a estabelecer ou a justificar um dever imputado a outrem. Direito seria, assim, uma posição de vantagem de um sujeito ou de um grupo em relação a um objeto, que impõe uma obrigação a outrem (Cf. RAZ, Joseph. Morality of freedom. New York: Oxford University Press, 1988, p. 180-182).

421 Ada Pellegrini Grinover salienta que a admissão de direitos coletivos faz soçobrar o conceito clássico de direito subjetivo, centro de todo o sistema burguês, que investia apenas no indivíduo a titularidade da posição de vantagem prevista na norma jurídica. Os interesses que concerniam a toda a coletividade, denominados ora de simples, ora de legítimos, ora de públicos, estavam, portanto, aparentemente excluídos do conceito de direito subjetivo e, ainda, da tutela jurisdicional. (Cf. GRINOVER, 1984, p. 31). 
Hoje, no entanto, é possível encontrar, ordinariamente, muitos direitos que não promovem interesses de apenas um indivíduo ou titular. Alguns direitos são atribuídos de forma a beneficiar sujeitos que vão além do esquema dualista e cujo alcance de proteção transcende a esfera individual. Quando se avançam materialmente, os interesses de um, avançam-se os interesses de uma pluralidade de sujeitos, que se encontram, naturalmente, vinculados.

Existem prestigiosas teorias ${ }^{422}$ admitindo direitos coletivos, pertencentes, em uma primeiro plano ou como causa próxima, ao próprio grupo ou ente coletivo. Mas, nesse caso, o direito coletivo serviria, como causa remota, à proteção do próprio indivíduo, membro do grupo.

Paollo Commanducci ${ }^{423}$ fala, nesse sentido, que a titularidade de direitos pode ser de indivíduos, de pessoas jurídicas, de organizações, de coletividades, de grupos, de pessoas existentes e de novas gerações. Não seria um non sense falar, até mesmo, em direitos de animais, plantas e minerais, embora sejam esses interesses - passe o truísmo - tutelados apenas por pessoas.

Porém, para efeito prático, especialmente no tocante ao processo jurisdicional, a partir do momento em que os interesses coletivos, em sentido amplo, foram amparados pela legislação, não há mais sentido em diferenciar interesses ou direitos, que são, agora, apenas sinônimos.

Justamente por isso, Kazuo Watanabe ${ }^{424}$ consigna que os termos "interesses" e "direitos" foram utilizados como sinônimos no Código Brasileiro de Defesa do Consumidor, pois à medida que os interesses ganharam o status de direitos, desapareceu qualquer utilidade teórica ou prática em realizar a busca por uma diferenciação ontológica entre essas duas categorias.

\subsection{DICOTOMIA ENTRE O PÚBLICO E O PRIVADO}

422 A título de exemplo, vale citar Ronald Dworkin. Embora Dworkin não desenvolva especificamente a temática dos direitos de grupo, diferenciando-os dos direitos individuais, ele menciona tanto indivíduos quanto grupos como titulares de direitos (Cf. DWORKIN, Ronald. Levando os direitos a sério. São Paulo: Martins Fontes, 2007, p. 129). Na mesma linha, mas, desenvolvendo agora, com maior profundidade, o tema, cita-se Joseph Raz (Cf. RAZ, 1988, passim), Dwight Newman (Cf. NEWMAN, Dwight. Community and collective rights: a theoretical framework for rights held by groups. Oxford: Hart Publishing, 2011, passim), Peter Jones (Cf. JONES, Peter. Human rights, group rights, and people rights. Human Rights Quarterly, 1999, V. 21.1: 80-107p.) e muitos outros. 423 COMMANDUCCI, Paollo. Justice and rights: a conceptual analysis. In: PECZENIK, Aleksander; KARLSSON, Mikael (eds.) Law, justice and state I: essays on justice and rights. Stuttgart: Steiner,1995, p. 125. 424 WATANABE, 2011, p. 70. 
A tradicional dicotomia entre interesses ou direitos públicos e privados - a summa divisio sobre a qual se erigiu grande parte do pensamento jurídico ocidental e ainda está presente na nossa cultura manualística, já não mais se amolda ao fenômeno da litigiosidade de massa.

As diferenças entre público e privado, entre a autoridade estatal e sujeitos privados, já não mais explicam a dimensão dos novos conflitos, que envolvem a produção de massa, o consumo de massa, a tecnologia sem fronteiras, a globalização, o capital transnacional, os mercados apátridas, tornando-se incerta a manutenção dessa específica dicotomia nos tempos atuais.

Na realidade, é preciso destacar que a separação nítida entre público e privado, ainda hoje mencionada, ocorreu mesmo a partir daqueles momentos em que houve a concentração do poder real na história e a consolidação da autoridade estatal como entidade própria e autônoma, que se relaciona direta e exclusivamente com seu membro, o indivíduo ou o cidadão. ${ }^{425}$

Antes disso, como já foi abordado, a noção de Estado como entidade se confundiu, por vezes na história, com a noção de Estado como povo ou coletividade ${ }^{426}$. Isso ocorreu, inicialmente, entre os romanos, no tocante à defesa das coisas e interesses comuns, tuteláveis pela actio popularis. A esfera pública ou comum e a esfera privada se imiscuíam quando se abordavam interesses como a res publica, res communes omnium, res sanctae, res sacrae, res uniersitatis.

O mesmo ocorreu, no período medieval, em que as esferas privada e pública se imiscuíam, com maior veemência. Como diz Maitland ${ }^{427}$, "tudo aqui é coletivo, comum, nada é público, ou exclusivamente privado. A palavra na língua inglesa para res publica é commonwealth" [Tradução nossa].

E, agora, mais uma vez na história, as categorias de público e privado tornaram-se novamente nebulosas. Segundo Cappelletti ${ }^{428}$, a dicotomia entre o público e o privado é propriamente

425 José Reinaldo de Lima Lopes observou isso na realidade brasileira, a partir de uma pesquisa estatística. Percebeu-se que, quão maior a concentração de poder e a visão do Estado como algo diferente dos seus cidadãos, maior a separação entre o público e o privado e maior a desvinculação do indivíduo em relação ao Estado. O Estado é visto apenas como um garantidor social. E, nesse caso, o povo não se sente responsável pela coisa pública, que se torna incumbência exclusiva do Estado. O problema se torna, assim, do outro, do governo, da política e não mais meu ou seu, como membros do Estado, como cidadãos, como partes interessadas. (Cf. LOPES. José Reinaldo de Lima. A definição do interesse público. In: SALLES, Carlos Alberto de (org.). Processo civil e interesse público: o processo como instrumento de defesa social. São Paulo: RT, 2003, p. 92).

426 SCIALOJA, 1954, p. 352.

427 MAITLAND, 1997, p.32.

428 CAPPELLETTI, 1976, p. 191. 
superada diante do fenômeno de massa e de uma realidade muito mais complexa, que torna artificiosa aquela rigorosa dicotomia entre a autoridade pública e o cidadão ou o particular.

No mesmo sentido, a Professora Ada Pellegrini Grinover ${ }^{429}$, em estudo seminal sobre os direitos coletivos no Brasil, afirma que, com a valorização dos interesses comuns (meio ambiente, ordem pública, lisura financeira ou bancária etc) que todos compartilham, os conflitos não mais podem ser explicados segundo a perspectiva tradicional da autoridade estatal versus indivíduo.

Esses interesses comuns, continua Ada Pellegrini Grinover ${ }^{430}$, vão além da contraposição clássica indivíduo e autoridade, assumindo caráter transindividual, dada a sua intensa conflituosidade jurídica e fática. No mesmo sentido, Mirjan R. Damaška ${ }^{431}$ assevera que, sob a ótica do denominado public law litigation no sistema jurídico estadunidense, os interesses comuns não se tratam mais de interesses discerníveis do Estado, como entidade própria. A natureza dos bens é agora matéria de intensa controvérsia social entre homens e mulheres, negros e brancos, consumidores e fornecedores e entre todas as demais categorias na sociedade.

Diante desses direitos intermediários ou comuns, agora claramente reconhecidos, a preocupação contemporânea dirige-se, nesse momento, não mais a estabelecer um rígido pertencimento (autoridade ou indivíduo), mas a definir a amplitude ou espectro de atuação dos interesses ou direitos, se são exclusivamente individuais ou se são transindividuais e coletivos.

\subsection{BINÔMIO INDIVÍDUO E COLETIVIDADE}

Ultrapassada a summa diviso entre as categorias de público e privado, ressurge, mais uma vez, na história ocidental, o antigo e sempre presente binômio indivíduo versus coletividade.

Nesse passo, Gisele Citadino ${ }^{432}$ revela a presença desse binômio na Constituição Brasileira de 1988. O texto constitucional apresenta uma dimensão material comunitária, que atravessa toda

429 GRINOVER, 1979, p. 27.

430 Ibidem, p. 27.

431 DAMASKA, Mirjan R. The faces of justice and state authority: a comparative approach to the legal process. New Haven: Yale University Press, 1986, p. 238.

432 CITADINO, Gisele. Pluralismo, direito e justiça distributiva: elementos da filosofia constitucional contemporânea. 3. ed. Rio de Janeiro, Lúmen Juris, 2004, p. 11-44. Daniel Sarmento prefere referir-se à Constituição Federal como personalista e não comunitarista, isto é, continua-se afirmando a primazia da pessoa humana, mas o indivíduo não é mais visto de forma isolada ou metafísica no mundo. É preciso, portanto, 
a sua linguagem, quando faz remissão a direitos sociais, individuais e coletivos, à sociedade fraterna, pluralista e solidária, à democracia participativa, bem como apresenta uma dimensão processual comunitária, quando faz remissão ao mandado de segurança coletivo, à ação popular, à denúncia de irregularidades ao Tribunal de Contas por qualquer indivíduo etc.

Gregório Assagra de Almeida ${ }^{433}$ caminhou no mesmo sentido, ao postular a superação da summa divisio entre o público e privado pela summa divisio constitucionalizada, que é aquela estabelecida entre o direito coletivo e o direito individual, ambos autônomos e interdependentes. Mas, não é possível parar por aqui, há que se estabelecer parâmetros ou critérios pelos quais seja possível diferenciar interesse ou direitos individuais de interesses ou direitos coletivos.

É preciso destacar que, ao se aduzir esses critérios, não se afirma a existência de uma classificação plenamente satisfatória ou uma receita de bolo. Os critérios, ora aduzidos, tem por escopo ajudar o intérprete a identificar o alcance de uma determinada demanda, à luz do direito substancial, para fins de agregação, visando à resolução plena e integral da controvérsia.

A relação ou o binômio entre indivíduo e coletividade não é estanque ou esbatida, razão pela merece ser analisada com serenidade e isenção. Não há utilidade prática e teórica em dividir, de forma rigorosa, esses dois planos. Muito pelo contrário, o interesse é verificar a forma pela qual eles convergem no plano material, de forma a admitir agregação processual.

\subsubsection{INTERESSE OU DIREITO INDIVIDUAL}

Vamos começar por uma analogia, um interesse ou direito individual é como um belo terno, realizado por um alfaiate, ou como um vestido de noiva, desenhado por uma estilista e costurado e bordado à mão: é um produto artesanal, diferenciado, particularizado, pessoal, elaborado para um sujeito específico, para ser fruído por um indivíduo determinado ou determinável.

Um direito individual é, assim, um interesse ou uma posição de vantagem individual, que fundamenta um dever (objeto de proteção jurídica) a ser cumprido por outrem. O indivíduo é, nessa medida, uma razão suficiente para imputação desse dever. Por essa razão, surge a clássica

reconhecer a importância dos vínculos sociais que preexistem e que auxiliam a constituição da própria personalidade (Cf. SARMENTO, 2006, p. 69).

433 ALMEIDA, Gregório Assagra de. Direito material coletivo - superação da summa divisio direito público e direito privado por uma nova summa divisio constitucionalizada. Belo Horizonte: Del Rey, 2008, p. 22-57. 
equação: um direito é um interesse pertencente à alguém, incidente sobre certo objeto, que impõe uma obrigação a outra pessoa, que se encontra submetida, por sua vez, a um dever.

Joseph $\mathrm{Raz}^{434}$, nesse sentido, conceitua direito individual como aquele em que o indivíduo constitui uma razão para ser objeto de proteção jurídica. Ele foi afetado em sua esfera jurídica, merecendo proteção contra o Estado e contra outros indivíduos, estabelecendo-se, com isso, os limites da sua esfera privada. O indivíduo ganha, assim, o seu espaço de proteção jurídica. ${ }^{435}$

Há, assim, como se pode depreender, a partir da analogia e dos conceitos citados, dois critérios metodológicos necessários à identificação do interesse ou direito individual: um critério objetivo, orientado ao objeto ou bem da vida protegido, e um critério subjetivo, orientado à qualidade da pessoa ou à natureza particular e pessoal do conteúdo da relação substancial.

Os dois critérios, objetivo e subjetivo, são mencionados por Nicolò Trocker ${ }^{436}$, para fins de identificação da relação jurídica de direito material tratada no bojo dos direitos individuais.

Segundo o critério objetivo, o objeto do interesse ou direito individual é um bem fracionável e suscetível de fruição por um indivíduo ou sujeito isolado. Esse não é o único critério, que permite identificar um direito individual. É apenas um critério óbvio, mas insuficiente sozinho.

Até porque o bem pretendido em juízo pode ser, na prática, indivisível, mas continuar sendo individual. Exemplo: o direito de vizinhança de alguém. João é proprietário de uma fazenda, que faz divisa com uma fábrica poluidora, cuja construção irregular coloca em risco o seu prédio. $\mathrm{O}$ autor individual pleiteia o fechamento da fábrica, o que favorece os demais proprietários da região e a comunidade local, que também é afetada pelas atividades ilícitas e irregulares dessa mesma fábrica no ambiente. $\mathrm{O}$ bem tutelado, a segurança da propriedade de João, é indivisível, mas o direito continua sendo individual, pois a relação substancial deduzida

434 RAZ, Joseph. Rights and politcs. Indiana Law Journal, 1995, V. 71: 27-44p. 32.

435 Stefano Rodotà salienta que o componente individualista do direito surgiu, com maior força, em uma operação de reação e superação à sociedade medieval. O direito sofre um processo de isolamento em relação à classe ou comunidade, de forma a alcançar um espaço de proteção individual e próprio, um direito à propriedade solitária em reação à propriedade comunal. A propriedade deve ser, aqui, entendida em sentido amplo, como domínio próprio, seja o caso tratado o direito real de propriedade, seja o direito da personalidade, seja o direito de ação etc (Cf. RODOTÀ, Stefano. Le azioni civilistiche. Le azioni a tutela di interessi collettivi: atti del Convengo di studio (Pavia, 11-12 giugno 1974) Padua, CEDAM, 1976, p. 92).

436 TROCKER, Nicolò. Gli interessi diffusi nell'opera della giurisprudenza. Rivista trimestrale di diritto e procedura civile. Anno XLI, n. 4, dicembre de 1987, p. 1115. 
em juízo diz respeito exclusivamente à questão de vizinhança entre João e a fábrica. A controvérsia não diz respeito às demais propriedades vizinhas da região ou ao meio ambiente.

Logo, o direito individual não é identificado apenas pela divisibilidade do bem, assim, bens indivisíveis também podem ser individuais. É preciso continuar com o critério subjetivo.

Segundo esse critério, o interesse ou direito individual também pode ser identificado pela pessoalidade ou singularidade. Se o indivíduo constitui o centro de imputação normativa, argumenta de forma pessoal, narra a sua história peculiar e própria, segundo as suas particularidades e características pessoais, trata-se de um interesse ou direito individual. ${ }^{437}$

É importante, no critério subjetivo, atentar para o conteúdo da relação substancial deduzida em juízo e para a amplitude da cognição que será realizada para a solução da controvérsia. Se a controvérsia referir-se aos atributos pessoais do indivíduo, o direito é individual. No exemplo dado, o cerne da controvérsia é a propriedade específica de João e as interferências que essa propriedade sofre em razão da suposta irregularidade do prédio vizinho. O conteúdo da relação substancial é o direito de vizinhança de João e cognição a ser realizada limita-se à propriedade de João. A relação substancial deduzida em juízo não se refere, por vez, às demais propriedades da região ou ao meio ambiente natural, direito esse que é fruível por toda a comunidade.

Com os dois critérios, subjetivo e objetivo, é possível a melhor compreensão da relação substancial individual, isto é, se ela é artesanal, diferenciada, própria, pessoal, particularizada.

\subsubsection{INTERESSE OU DIREITO COLETIVO}

Os interesses ou direitos coletivos não são facilmente identificáveis. Há, ainda, muita controvérsia quanto à categorização, mas algumas teorias lançam luzes à compreensão do fenômeno, o que é especialmente importante quando se investiga a litigiosidade de massa.

437 Ressaltando a pessoalidade (critério subjetivo) como critério para a identificação do interesse ou direito individual, conferir Robert G. Bone (BONE, 1990, p. 218), Judith Resnik (RESNIK, 1991, p.6-8), Massimo Severo Giannini (GIANNINI, Massimo Severo. Interventi. Le azioni a tutela di interessi collettivi: atti del convengo di studio (Pavia, 11-12 giugno 1974) Padua, CEDAM, 1976, p. 353), Vincenzo Vigoriti (VIGORITI, 1979, p. 59). Ressaltando a cindibilidade (critério objetivo) como critério para a identificação da interesse ou direito individual, conferir Giorgio Costantino (COSTANTINO, Brevi note sulla tutela giurisdizionale degli interessi collettivi davanti al giudice civile. Le azioni a tutela di interessi collettivi: atti del Convengo di studio (Pavia, 11-12 giugno 1974) Padua, CEDAM, 1976, p. 231). 
Há, nesse sentido, basicamente, três teorias que justificam os interesses ou direitos coletivos em relação aos interesses ou direitos individuais. Trata-se (i) da teoria do interesse pessoal ou incorporado do grupo, (ii) da teoria da soma dos interesses individuais e (iii) da teoria da síntese a partir dos interesses individuais. Todas essas teorias - cada uma ao seu modo - buscam justificar os interesses ou direitos coletivos como uma categoria de conhecimento autônoma.

\subsubsection{TEORIA DO INTERESSE PESSOAL OU INCORPORADO DO GRUPO}

Rodolfo de Camargo Mancuso ${ }^{438}$, em uma das obras mais completas a respeito da temática dos interesses ou direitos coletivos, salienta que essa primeira teoria - teoria do interesse pessoal do grupo - tem conotação mais restritiva e refere-se ao interesse do grupo como organização própria ou como pessoa jurídica (legal entity), ou seja, como uma entidade autônoma. Cita, nessa hipótese, o exemplo de uma cooperativa de agricultores que tem interesse em elevar o capital social da cooperativa. Esse interesse é predominantemente da pessoa jurídica e não se confunde com os interesses dos agricultores ou dos demais cooperados considerados em si.

Essa teoria tem aplicação mais restritiva para adoção das técnicas de agregação processual, pois, em regra, a relação da pessoa jurídica com os seus membros é regulada de forma própria. Não há uma multiplicidade de pessoas, tendentes à resolução molecular ou agregada da controvérsia, mas apenas um ente legal (corporação), que não se confunde com seus membros.

Há, na legislação estadunidense, remissão específica à teoria do interesse ou direito pessoal da corporação. Trata-se da Rule 23.1 e da Rule $23.2^{439}$, as quais se referem às ações derivadas dos

438 MANCUSO, 2011, p. 54-55. No sistema estadunidense, o interesse pessoal da pessoa jurídica é denominado de interesse incorporado. Trata-se da teoria da corporate conception. É bem verdade que o conceito de corporate conception de Peter Jones é muito mais amplo, mas esse conceito se aplica tipicamente às pessoas jurídicas ou organizações sociais (JONES, 1999, 86).

439 Federal Rule 23.1 (a) PREREQUisites this rule applies when one or more shareholders or members of a corporation or an unincorporated association bring a derivative action to enforce a right that the corporation or association may properly assert but has failed to enforce. The derivative action may not be maintained if it appears that the plaintiff does not fairly and adequately represent the interests of shareholders or members who are similarly situated in enforcing the right of the corporation or association. Federal Rule 23.2 this rule applies to an action brought by or against the members of an unincorporated association as a class by naming certain members as representative parties. The action may be maintained only if it appears that those parties will fairly and adequately protect the interests of the association and its members. In conducting the action, the court may issue any appropriate orders corresponding with those in Rule 23(d), and the procedure for settlement, voluntary dismissal, or compromise must correspond with the procedure in Rule 23(e) (UNITED STATES OF AMERICA. Federal Rules of Civil Procedure. Washington: US Government Printing Office, 2010. Disponível em: 
acionistas e dos membros de associações informais (shareholder derivative suits and unincorporated associations). Nesses casos, uma ação de grupo é proposta pelos próprios acionistas e pelos membros de uma associação informal, em nome de todos os demais acionistas e associados, representando a própria entidade em juízo. Os indivíduos atuam, por sua vez, na defesa da própria pessoa jurídica ou da organização informal, na hipótese em que manifestada a omissão ou a negligência da entidade e dos seus administradores na sua defesa pessoal. ${ }^{40}$

Nesse caso, diz Klonoff ${ }^{441}$, o indivíduo atua apenas na qualidade de membro do grupo (acionista ou associado) e não segundo os seus atributos pessoais e particulares. E, mais, a ação de grupo, proposta pelo indivíduo, é denominada de ação derivada ou secundária, pois o interesse primário defendido por qualquer um dos seus membros é o interesse da própria corporação.

Essa teoria, como já se disse, é mais restrita, pois ela pressupõe um interesse incorporado, de uma pessoa jurídica ou de uma associação informal. A teoria da soma e a teoria da síntese são mais amplas, adequando-se a organizações e aos grupos não formalmente incorporados.

\subsubsection{TEORIA DA SOMA}

A teoria da soma postula que o interesse coletivo é o resultado da soma ou reunião das posições individuais preexistentes. $\mathrm{O}$ interesse coletivo pode ser reduzido ao conjunto dos interesses individuais, não apresentando uma distinção ontológica ou traços de autonomia conceitual.

Um interesse coletivo seria, nesse contexto, uma forma de avançar os interesses individuais, isto é, os interesses dos membros da comunidade, sem lhes acrescentar uma força própria ou

http://www.uscourts.gov/uscourts/rulesandpolicies/rules/2010\%20rules/civil\%20procedure.pdf. Acesso em: 13 de junho de 2013.

440 Trata-se de uma demanda similar a uma ação de classe (class action). O membro do grupo, nessa hipótese, deverá demonstrar ter sofrido um prejuízo em seus interesses - na qualidade de acionista ou de associado - como decorrência direta do prejuízo sofrido pela própria pessoa jurídica ou organização informal, cuja proteção foi negligenciada pelo corpo diretivo ou administrativo daquela entidade. Nessa hipótese, não há direito de autoexclusão dos membros ausentes do grupo. E, por fim, é preciso destacar que a demanda proposta pelo indivíduo, nesse caso, visa a proteger o interesse da própria pessoa jurídica ou organização. Não se refere a um interesse pessoal ou particularizado do acionista ou do associado, desvinculado dos interesses da própria corporação. Se esse fosse o caso, a ação seria apenas individual e não uma ação derivada ou secundária do grupo. Destaca-se que a linha que separa o pessoal do impessoal ou do corporativo é tênue. Mas, um teste tem sido bastante utilizado para auxiliar o intérprete a apurar a amplitude da controvérsia, a saber, trata-se de verificar se a cognição vai incidir sobre os atributos pessoais do indivíduo ou sobre os atributos da própria corporação (Cf. KIM, Susanna M. Conflicting ideologies of group litigation: who may challenge settlements in class actions and derivative suits. Tennesse Law Review, 1998, V. 66:88-135p.).

441 KLONOFF, 2007, p. 345-354. 
quaisquer propriedades e características específicas resultantes dessa coalizão de interesses individuais. Há, nesse caso, uma completa dependência do coletivo em relação ao individual.

Segundo essa teoria, os interesses coletivos são redutíveis e dependentes dos interesses individuais. As alterações que, porventura, ocorrerem no plano individual ou entre os membros componentes da coletividade implicaria, necessariamente, a alteração da fisionomia dos interesses coletivos. Os interesses coletivos seriam, assim, segundo Dwight Newman ${ }^{442}$, interesses voláteis, instáveis, sensíveis a quaisquer transformações no plano individual.

Essa teoria, ainda segundo Newman ${ }^{443}$, apresenta problemas teóricos graves, incorrendo no Arrow's Impossibility Theorem. Isso ocorre porque, explica o autor, os interesses coletivos seriam sempre transitórios e circunstanciais, não estabelecendo uma identidade e uma lógica consistente, o que tornaria a própria noção de interesses coletivos como algo problemático.

Vale lembrar que Carlos Alberto de Salles ${ }^{444}$ já fez menção à inadequação da teoria da soma, segundo o teorema de Arrow, criado por Kenneth J. Arrow na década de 60. Segundo essa teoria, se tomados hipoteticamente três indivíduos com poderes para adoção de uma decisão para o grupo como um todo e, considerando que cada um deles tem uma ordem diferente de preferências, o cruzamento matemático dessas preferências individuais, poderia induzir a decisões aleatórias, a depender dos fatores estruturais do processo de tomada de decisão.

Nesse sentido, sem uma permanência ou, pelos menos, sem uma estabilidade dos interesses coletivos, não seria possível falar deles como categoria jurídica de conhecimento autônoma.

No plano processual, a adoção da teoria da soma, para fins de justificação dos interesses coletivos, também colocaria os seus problemas. A decisão judicial que julgasse uma pretensão envolvendo interesses ou direitos coletivos não teria um núcleo mínimo de consistência e coerência. Logo, conforme aduz Carlos Alberto de Salles ${ }^{445}$, a adjudicação dos interesses ou direitos coletivos teria como único critério a competência da autoridade prolatora da decisão,

442 NEWMAN, 2011, p. 58-60.

443 Ibidem, p. 58-60.

444 SALLES, Carlos Alberto de. Processo civil de interesse público. In: SALLES, Carlos Alberto de (org.). Processo civil e interesse público: o processo como instrumento de defesa social. São Paulo: Revista dos Tribunais, 2003, p. 59.

445 SALLES, 2003, p. 59. 
sem um significado ou um conteúdo jurídico relevante ou necessário. Seria como se fosse uma verdadeira escolha política ou, mesmo arbitrária, realizada, todavia, por um órgão judicial.

O argumento de Salles persuade. Afinal, se o interesse coletivo fosse a mera soma dos interesses individuais, sempre que os indivíduos, que atuam em um processo, mudassem, com eles também mudaria o interesse coletivo e não seria possível alcançar um interesse ou bem comum aplicável com fundamento no grupo como um todo. Qualquer decisão seria uma escolha política e não seria possível extrair uma norma jurídica geral que congregasse a proteção desse direito.

A teoria da soma também não é compatível com as técnicas de agregação processual, nos moldes antes investigados. Seja nas ações coletivas, seja na consolidação, seja no caso-teste, há um representante ou há uma amostra representativa, e não um conjunto de indivíduos.

Vincenzo Vigoriti ${ }^{446}$, de igual modo, realizou duras críticas à teoria do interesse coletivo como soma dos interesses individuais, pois essa teoria negava qualquer autonomia ao plano coletivo. Interesses ou direitos coletivos não são e não devem ser, portanto, um mero subproduto das vontades individuais. Deve-se superar, pois, o conceito de interesses coletivos como soma.

\subsubsection{TEORIA DA SÍNTESE}

A teoria da síntese, por sua vez, postula a existência do interesse coletivo como bem comum, isto é, posição de vantagem compartilhada por um grupo, que é superveniente aos indivíduos ${ }^{447}$.

Os interesses coletivos não seriam, assim, uma mera soma dos interesses individuais, mas apresentam uma convergência ou uma interdependência no plano material, de forma que, ao mesmo tempo em que se avançam os interesses do grupo, avançam-se os interesses dos indivíduos em direção ao bem comum. O interesse coletivo, por sua vez, não se reduz a nenhum dos interesses individuais, mas é superveniente a eles, a saber, têm atributos próprios/peculiares.

446 VIGORITI, 1979, p. 44-48.

447 Bem comum (common good) ou bem moldura (framing good) são conceitos utilizados, respectivamente, por John Finnis e Joseph Raz para definir a relação de vinculação entre os indivíduos com relação aos bens da vida ou situações jurídicas, que são compartilhados por todos e estabelecem relações de colaboração, cooperação, comunhão e unidade entre os membros de um grupo (Cf. FINNIS, John. Natural law and natural rights. 2. ed. New York: Oxford University Press, 2011, p. 155 e RAZ, 1995, p. 37). 
Esse conceito de superveniência é dado por Dwight Newman. Segundo ele ${ }^{448}$, o indivíduo e a coletividade estão, assim, naturalmente vinculados ou interligados materialmente, de forma que a coletividade serve aos indivíduos, mas é superveniente a eles e não se reduz ao conjunto de indivíduos ou ao poder de suas vontades individuais. Existe, assim, uma identidade própria.

A coletividade existe, continua Newman ${ }^{449}$, ainda que os seus integrantes venham a se alterar. A coletividade é um conjunto de pessoas que mantém a sua identidade, ainda que essas pessoas venham a se alterar ao longo do tempo e novas gerações surjam, pois os critérios ou condições de adesão ao grupo continuam presentes e os seus membros ainda se identificam com eles.

Um exemplo disso é o direito à instituição de cotas raciais ou étnicas. É a existência de um grupo racial ou étnico, que fundamenta o reconhecimento ao direito às cotas. $\mathrm{O}$ direito do grupo às cotas não se resume ou se reduz ao direito de qualquer indivíduo, eventualmente beneficiado pela instituição das cotas. Tanto é assim, que é a história passada de discriminação enfrentada por um grupo racial ou étnico que justifica a instituição das cotas para os seus membros no momento presente, de forma a atenuar a histórica discriminação e a propiciar a inclusão social desse grupo. As cotas visam, assim, à coletividade como um todo, inclusive às gerações futuras e não a um indivíduo específico. Veja, portanto, que a coletividade não se reduz ao indivíduo, os membros desse grupo morrem, outros nascem, mas ainda há um grupo objeto de proteção. ${ }^{450}$

Outro exemplo é a instituição do direito de pesca, em uma região ambientalmente protegida. Autoriza-se, nesse caso, o direito de pesca em favor de uma comunidade ribeirinha de pescadores artesanais, para fins de proteção e subsistência do grupo. É o fato de existir uma população ribeirinha, dependente da pesca, que potencializa o reconhecimento do direito de pesca em favor do indivíduo, que integra a comunidade. O direito foi reconhecido em favor de um modo de vida comunal ou de uma organização produtiva, da qual os indivíduos extraem sua subsistência. Não se trata de pesca esportiva ou pesca profissional, para revenda ou comércio.

448 NEWMAN, 2011, p. 35-40.

449 Ibidem, p. 4.

450 Newman ressalta que o direito de grupo pode ser demonstrado, de uma foram geral, nas hipóteses de retificação de injustiças do passado pelo tratamento que é conferido ao grupo no momento presente. Há, nesse caso, uma conexão entre o grupo injustiçado no passado e o grupo existente no presente, conexão essa que pode ser explicitada a partir da ideia de que existe uma coletividade que mantém a mesma identidade ao longo do tempo (Cf. NEWMAN, 2011, p. 65). 
Um terceiro exemplo é a instituição do direito ao concurso público ou à licitação pública. $\mathrm{O}$ direito à assunção de um cargo público ou de um contrato administrativo não é deferido a nenhum indivíduo em particular. Todos os brasileiros (o grupo como um todo) têm direito. É exatamente, por essa razão, que é instituído um procedimento concorrencial e paritário entre todos os interessados, para que seja escolhido o melhor candidato ou a proposta mais vantajosa para a administração pública, segundo os requisitos previamente divulgados no edital do certame. Nenhum indivíduo tem o direito a uma vaga ou a um contrato administrativo, mas todos os indivíduos (o grupo como um todo) têm direito à observância de um procedimento paritário e isonômico, que lhes dê igual condição e oportunidade à realização dessa conquista.

É preciso destacar que, ao se mencionar esses exemplos, não se está dizendo que é impossível a um único indivíduo fundamentar sozinho um direito, inclusive às cotas, à pesca e ao concurso público. O que está se dizendo é que o grupo cria uma identidade e estabelece com os indivíduos relações de impessoalidade, paridade e unitariedade, de forma a potencializar os interesses ou direitos dos indivíduos, que são seus membros. Uma síntese de interesses pelo bem comum.

Uma coisa é postular que José deve ter o direito de pescar no lago. Outra coisa é postular que José, por ser membro de uma comunidade ribeirinha, que vive da pesca artesanal e, portanto, exerce uma atividade não degradante à natureza, deve ter o direito de pescar em uma região ambientalmente protegida, pois os dois valores - subsistência da comunidade e meio ambiente - convivem harmoniosamente. Novamente, uma coisa é postular que Felipe deve ter direito a uma cota no vestibular. Outra coisa é postular que Felipe, por ser afrodescendente, dificilmente seria integrado à sociedade se não houvesse um tratamento diferenciado, que lhe conferisse uma prerrogativa na disputa (uma cota às vagas da universidade). A existência da categoria potencializa o interesse ou direito individual de forma que o indivíduo passa a ser apresentado não mais como José ou Felipe, mas com os atributos do grupo (pescador ou afrodescendente).

Enfim, os traços característicos do grupo ou a identidade do grupo - que cria um vínculo entre seus membros - potencializa e avança a defesa dos interesses ou direitos individuais. Logo, o interesse ou direito coletivo não constitui a soma dos interesses ou direitos, mas a síntese. ${ }^{451}$

451 Celso Antônio Bandeira de Mello, ressalta, nesse sentido, que a lei pode, por exemplo, diferenciar pessoas sem violação ao princípio da isonomia, desde que o fator de discriminação seja correlato logicamente ao contexto objeto de apreciação (relação de pertinência lógica). Exemplo disso: é possível estabelecer uma restrição à participação de homens em um concurso público para provimento de vagas de agente penitenciário de um Presídio Feminino. Nessa hipótese, no entanto, a lei não poderia estabelecer um fator ou critério de discriminação que 
De qualquer modo, ainda que se reconheçam os interesses ou direitos coletivos como síntese, no contexto da teoria antes mencionada, ainda é preciso definir o que se caracteriza como bem comum ou posição de vantagem compartilhada, a estabelecer uma identidade ou um vínculo íntimo entre os seus membros e, com isso, a autorizar a possibilidade de agregação processual.

Para isso, alguns critérios são elencados pela doutrina. Dentre os critérios existentes ${ }^{452}$, dois se sobressaíram e se revelaram os mais relevantes para o propósito de identificar o bem comum ou interesse coletivo, a saber, trata-se do critério objetivo e do critério subjetivo de identificação, que permite a extração dos interesses autônomos e propriamente coletivos.

\subsection{CRITÉRIO OBJETIVO}

Segundo o critério objetivo, deve-se atentar para o bem ou objeto protegido para o fim de identificar o interesse ou direito coletivo. Um interesse ou direito é, assim, coletivo quando indivisível o bem da vida protegido, isto é, não pode ser apropriado exclusivamente por ninguém, sem perder a sua própria essência. Trata-se de conceito que perpassa a filosofia, a política, a economia, bem como os vários ramos do direito, como o direito civil, administrativo, empresarial, consumerista e, com efeito, também é mencionado no direito processual civil.

Esse bem ou objeto indivisível pode ser tanto recursos naturais, a saber, recursos que não foram criados por ninguém, eles simplesmente existem no mundo e são fruíveis por todos, como o ar, a água, as paisagens naturais, as florestas, bem como pode ser recursos humanos, isto é, recursos produzidos por uma multiplicidade de indivíduos e por todos eles fruíveis unitária ou

singularizasse ou individualizasse, no presente e definitivamente, o sujeito destinatário da lei. A lei não poderia estabelecer um regime peculiar para alguém de forma específica, sob pena de criar favoritismos. Esse critério de diferenciação, que se coaduna com o princípio da isonomia, deve se referir, portanto, a uma categoria de pessoas ou, então, a um indivíduo, mas desde que, nesse último caso, vise a um sujeito indeterminado ou indeterminável. É importante, então, que a situação de discriminação seja reproduzível, abarcando novos sujeitos, que pertençam ou se identifiquem com uma determinada categoria ou situação-tipo. Quem quer que se encontre naquela categoria ou situação-tipo, é membro ou partícipe da classe ou da categoria e faz jus ao tratamento diferenciado. Repete-se, portanto, o que se disse antes, o grupo potencializa o interesse ou direito do indivíduo, pois ele faz jus a um tratamento diferenciado não por ele ser o José ou o Felipe, mas por ele se enquadrar na categoria ou situação-tipo (Cf. MELlo, Celso Antônio Bandeira de. Conteúdo jurídico do princípio da igualdade. 3 ed. São Paulo: Malheiros, 2007, p. 23-28). No mesmo sentido, Mancur Olson ressalta a importância da formação de grupos na potencialização dos interesses ou direitos individuais (OLSON, Mancur. The logic of collective action: public goods and the theory of group. 12 ed. Massachusetts: Harvard University Press, 2002).

452 TROCKER, 1987, p. 1115. No mesmo sentido, José Carlos Barbosa Moreira ressalta o critério subjetivo (qualidade do sujeito) e objetivo (bem da vida protegido) como as duas notas essenciais à identificação do interesse ou direito coletivo (Cf. MOREIRA, José Carlos Barbosa. Temas de direito processual civil. $3^{\text {a }}$ Série. São Paulo: Saraiva, 1984, p. 183). 
paritariamente. Nessa última hipótese, encartam-se tanto empreendimentos comuns, como os encargos comuns (ex. seguro coletivo, um fundo financeiro comum a ser rateado pelos beneficiários), bem como os acervos comuns, como, por exemplo, diques de contenção de água, a língua nacional, os hospitais públicos, as praças públicas, as pontes e muitos outros bens em relação aos quais todos os indivíduos participam ou usufruem de forma unitária ou paritária. ${ }^{453}$

O critério objetivo é muito utilizado para definir interesses ou direitos coletivos no processo civil. A incindibilidade do bem pode ser, no entanto, tanto prática, quanto normativa ou jurídica.

Proto Pisani ${ }^{454}$, Ricardo Pardolese ${ }^{455}$, Vittorio Denti ${ }^{456}$ e Giorgio Costantino ${ }^{457}$, embora reconheçam a obscuridade do fenômeno e a dificuldade em se adotar um conceito rigoroso e estreito, são bons exemplos de autores que, já no Congresso de Pavia, na década de 70, conceituaram interesses ou direitos coletivos como interesses ou direitos de natureza indivisível e insuscetíveis de apropriação exclusiva. $\mathrm{O}$ interesse ou direito coletivo fundamenta-se e pertence à coletividade como um todo. Ele decorre da comunhão ou da unitariedade presente na relação de direito substancial, não se reportando a nenhum indivíduo ou sujeito isolado.

No sistema jurídico brasileiro, a incindibilidade também é mencionada para a caracterização dos interesses ou direitos coletivos, bem como consta no art. 81 do Código de Defesa do Consumidor, constituindo um dos critérios legais para definição dos interesses ou direitos difusos e coletivos em sentido estrito. Barbosa Moreira ${ }^{458}$, por sua vez, denomina esses interesses ou direitos de essencialmente coletivos, pois eles estabelecem uma unitariedade substancial. Trata-se de uma relação substancial incindível, que ou incide para todos, ou não incide para ninguém. É insuscetível de “decomposição num feixe de interesses individuais" 459 , não sendo possível discernir onde começa a quota de um indivíduo e acaba a quota de outro.

453 Em sentido semelhante, John Finnis (FINNIS, 2011, p. 155), Joseph Raz (RAZ, 1988, p. 207-209) José Reinaldo de Lima Lopes (LOPES, 2003, p. 94).

454 PISANI, 1976, p. 264.

455 PARDOLESE, Roberto. Il problema degli interessi collettivi e i problemi dei giuristi. Le azioni a tutela di interessi collettivi: atti del Convengo di studio (Pavia, 11-12 giugno 1974) Padua, CEDAM, 1976, p. 250.

456 DENTI, Vittorio. La giustizia civile. Bologna: Società Editrice il Mulino, 1989, p. 114.

457 COSTANTINO, 1976, p. 234.

458 Em contraposição aos interesses ou direitos essencialmente coletivos, Barbosa Moreira identifica outra categoria denominada de interesses acidentalmente coletivos. Nesse último caso, trata-se de direitos ou interesses individuais, apenas tutelados coletivamente por razões processuais. Essa categoria denominada direitos individuais homogêneos será abordada posteriormente (Cf. MOREIRA, 1984, p. 196).

459 MOREIRA, 1984, p. 195. 
Nem sempre, no entanto, a incindibilidade será sempre prática, isto é, aquelas hipóteses em que o bem da vida é insuscetível de, na prática, ser dividido ou decomposto em feixes individuais.

Por vezes, a incindibilidade pode ser considerada sob o aspecto normativo. Isso ocorre nas hipóteses em que distribuição de um bem ou a alocação dos recursos comuns é feita de forma paritária ou isonômica entre todos os membros de um grupo, estabelecendo uma relação necessária de paridade ou isonomia por força do direito substancial. Nesse caso, o bem é, sim, suscetível de sofrer, na prática, decomposição em feixes de interesses individuais. Mas esses feixes, embora suscetíveis de decomposição, devem andar juntos, em paridade ou isonomia, isto é, não podem se afastar um do outro, sob pena de falir a própria ordem jurídica isonômica e paritária antes determinada pelo direito substancial. O processo, a despeito de concretizar o direito substancial, não pode desconsiderar ou destruir a relação de paridade nele presente.

O exemplo clássico de incindibilidade normativa era a propriedade comunal medieval. Essa propriedade era suscetível de decomposição em faixas individuais, mas o modo de organização da propriedade, naquele tempo, era comunal e paritária. As faixas de terra, individualmente distribuídas, sofriam rotação, para que todos pudessem ter igual acesso às fontes de água e a terras férteis e as culturas eram combinadas, para que todos tivessem alimentos. Ainda que o bem fosse divisível, o direito à propriedade de cada indivíduo deveria seguir o mesmo destino do direito de propriedade do outro indivíduo, do contrário, o modo de produção feudal e comunal, que era a base dos costumes da sociedade daquele tempo, seria esfacelado.

Esse sentido é adotado por Kazuo Watanabe ${ }^{460}$, para quem é inadmissível a concessão de um tratamento diversificado a um interesse ou direito quando exigido for a concessão de um tratamento igualitário pelas peculiaridades da relação jurídica de direito substancial apreciada. Essa relação substancial igualitária reclama, igualmente às hipóteses de indivisibilidade prática, um tratamento incindível, uma solução global e uniforme para todos os componentes do grupo.

No direito estadunidense, embora não exista uma diferenciação ontológica, prevista em lei, para diferenciar interesses ou direitos individuais de interesses ou direitos coletivos, é preciso atentar, de igual modo, para o bem da vida ou para o objeto da relação de direito substancial.

460 WATANABE, 2007, p. 159. 
Nesse aspecto, no direito estadunidense, deve ser destacada tanto a indivisibilidade prática do bem, quanto a indivisibilidade normativa da relação substancial. A incindibilidade constitui critério comumente mencionado para fins de identificação da amplitude do interesse ou do direito controvertido. A categoria 23(b) da Federal Rule 23 é, por sua vez, um bom exemplo de incindibilidade normativa. Nesse caso, conhecido como limited fund class action, o direito de crédito pretendido, em face do devedor, pode ser, na prática, objeto de divisão e de satisfação individual em favor de cada um dos credores. Mas, como o fundo pecuniário do devedor é insuficiente ou limitado para o ressarcimento de todos os credores, deve ser observada a necessária paridade e isonomia entre os interessados, integrantes daquele grupo. ${ }^{461}$

A incindibilidade, no entanto, como já se disse antes, não é uma panaceia ou uma solução mágica, que identifica com precisão e definitividade a natureza da relação de direito substancial. Até porque existem bens da vida que, na prática, são incindíveis, mas que só interessam juridicamente a um indivíduo, a exemplo do direito de vizinhança mencionado no tópico dos direitos individuais. Assim, como o próprio Costantino ${ }^{462}$ defende, a indivisibilidade é, sim, um

critério prático, facilmente perceptível, que facilita ao processualista a identificação das relações substanciais coletivas. Mas, não é, necessariamente, o único e definitivo critério.

O critério da indivisibilidade influenciou, sobremaneira, a legislação brasileira de processos coletivos e, mais recentemente, também influenciou o direito estadunidense, o que será objeto de referência em capítulo específico sobre os critérios de agregação aplicados a cada sistema jurídico. Mas, agora, ao critério objetivo, deve ser acrescentado o critério subjetivo.

\subsection{CRITÉRIO SUBJETIVO}

O segundo critério é o subjetivo do interesse ou direito coletivo, que se refere à qualidade do sujeito que deduz a relação de direito substancial coletiva ou plurissubjetiva.

461 MULLENIX, Linda. General Report - common law. In: GRINOVER, Ada Pellegrini. WATANABE, Kazuo e MULLENIX, Linda. Os processos coletivos nos países de civil law e common law: uma análise de direito comparado. São Paulo: Revista dos Tribunais, 2008, p. 266.

462 COSTANTINO 1976, p. 276 (Il riferimento alla disciplina delle obbligazioni indivisibili non há esclusivamente la funzione di collocare il fenomeno degli interessi collettivi in categorie concettuali ma mira essenzialmente a risolvere i problemi pratici che tali fenomeni pongono all'interprete sul piano processuale). 
O critério subjetivo e a qualidade do sujeito são mencionados, por sua vez, pela doutrina, sob dois ângulos: pelo ângulo da titularidade da relação jurídica de direito substancial e pelo ângulo do conteúdo objetivo ou impessoal da controvérsia de direito substancial deduzida em juízo.

Segundo a noção de titularidade, um interesse ou um direito pode ser considerado coletivo, em sentido amplo, se a titularidade da relação de direito substancial for (i) indeterminada com relação a um grupo ocasional ou (ii) determinável com relação a uma categoria não ocasional (que apresenta uma relação jurídica base entre os seus membros). O primeiro é denominado de interesse ou direito difuso, pois o grupo, portador do direito, é circunstancial ou ocasional. $\mathrm{O}$ segundo é denominado de interesse ou direito coletivo em sentido estrito, pois o grupo, portador do direito, é um ente exponencial (uma associação, por exemplo) de um grupo não ocasional.

Nesse sentido, Nicolò Trocker ${ }^{463}$ salienta que um interesse ou um direito pode ser considerado coletivo, em sentido amplo, quando pertence, identicamente, a uma pluralidade de sujeitos, mais ou menos determinada ou determinável, pluralidade essa unificada de forma, mais ou menos estreita, em uma coletividade. A diferença entre interesse difuso ou coletivo não é, por sua vez, ontológica, mas refere-se apenas ao grau de agregação e à possibilidade de se delimitar, de forma específica ou jurídica, um grupo organizado. O interesse ou direito coletivo em sentido estrito, difere do difuso, pois seu portador é um ente exponencial de um grupo não ocasional.

Nesse mesmo sentido, Massimo Severo Giannini ${ }^{464}$ destaca o caráter anônimo da titularidade. O interesse ou direito coletivo, em sentido amplo, tanto o difuso, quanto o coletivo, detém titularidade anônima e o indivíduo apresenta-se como portador de um interesse ou direito, fruível por todo o grupo, seja um grupo ocasional e circunstancial, seja um grupo não ocasional.

Além da titularidade do interesse ou direito, o interesse ou direito coletivo pode ser identificado pelo conteúdo objetivo, impessoal ou indiferenciado da relação jurídica de direito substancial.

463 TROCKER, 1987, p. 1115.

464...l'ambito degli interessi collettivi non è determinato solo dalla natura oggettiva dell'interesse, ma è determinato precipuamente da una qualificazione normativa del suo portatore [...]gli interessi diffusi non sono però interessi né pubblici né collettivi: sono interessi adespoti, cioè interessi che non hanno un loro portatore [...] che gli interessi collettivi in particolare non sono caratterizzati, nel procedimento amministrativo, diversamente da come siano caraterizzati in altri settori dell'ordinamento positivo. Essi sono pertanto quegli interessi che, nell'ordinamento positivo, si individuano sulla base di um critério puramente soggettivo, che é quello del loro portatore: sono tali gli interessi che hanno come portatore (o centro di riferimento: in questa sede le due nozioni si equivalgono) um ente esponenziale di un grupo non occasionale (Cf. GIANNINI, 1976, p. 352-354). 
Um interesse ou um direito pode ser considerado coletivo, em sentido amplo, quando um indivíduo manifesta-se, segundo os atributos impessoais, objetivos e indiferenciados de um grupo, independentemente das suas características ou preferências pessoais. O interesse ou direito coletivo nasce do fato de o indivíduo ser membro de uma coletividade, a saber, esse interesse impacta a vida do indivíduo, não de forma pessoal, mas, sim, na medida em que esse indivíduo é membro de uma comunidade, um anônimo no grupo de interessados. Nessa hipótese, pode-se dizer que os membros do grupo são fungíveis ${ }^{465}$ entre si, pois a controvérsia é conhecida com fundamento aplicável ao grupo como um todo e não à pessoa do indivíduo. Não importa se o nome da parte é José, Felipe ou João, os indivíduos são fungíveis, pois todos operam como membros de um grupo e não segundo as suas qualidades pessoais ou particulares.

O critério substancial, com fundamento no conteúdo objetivo da relação de direito substancial, foi marcante na identificação dos interesses ou direitos coletivos na ação popular romana ou nas ações coletivas medievais. Como se viu antes, é frequente à remissão da doutrina ao autor popular ou ao autor coletivo como alguém que atuava, não na qualidade de pessoa ou de indivíduo, mas na qualidade de membro de grupo ou da categoria, isto é, de forma impessoal.

Vincenzo Vigoriti é um dos processualistas que bem explicita, na família civilista, o critério subjetivo, com fundamento no conteúdo impessoal da relação jurídica de direito substancial.

Vigoriti ${ }^{466}$ salienta a insuficiência da indivisibilidade como critério único na definição dos interesses ou direitos coletivos. Segundo ele, não se pode reduzir os interesses ou direitos coletivos à indivisibilidade de um bem comum. Deve ser observada, por sua vez, a existência de uma necessária coordenação das vontades individuais que dirija o destino organizacional da pluralidade de sujeitos, envolvidos na mesma relação substancial, a um bem ou fim comum.

Esse tipo de interesse, continua o autor, não designa uma posição de vantagem autônoma de qualidade particular, mas exprime uma valência coletiva a um conjunto de relações individuais solidárias, conjuntas, organizadas à satisfação de uma reinvindicação comum. Nesse sentido:

465 A fungilidade dos indivíduos, membros de um grupo, é destacada por Heather K. Gerken (GERKEN, Heather K. Understanding the right to an undiluted vote. Harvard Law Review, 2001, V. 114: 1665-1743p. p. 1724). 466 VIGORITI, 1979, p. 19 e 59. 
Todas essas qualificações de interesse (instrumental, final, incompatível, comum etc) não designa posição de vantagem autônoma de qualidade particular, mas designa o tipo de relação existente entre as várias posições de vantagem. Neste contexto, encaixa-se a expressão 'interesse coletivo': ela expressa a existência de uma relação entre os interesses de igual conteúdo, pertencentes a diferentes sujeitos, organizados para atingir o mesmo fim. O coletivo é o valor de uma determinada relação entre os interesses de natureza individual, não conflitantes, mas unidos, conjuntos e organizados para a satisfação de uma reivindicação comum [...]Fazer a indivisibilidade do bem o fundamento do coletivo significa reduzir o fenômeno a um mero evento objetivo, isso representa, em boa dose, negar que muitíssimos bens são coletivamente perseguíveis e, assim, implicitamente, excluir a possibilidade de detectar a dimensão superindividual em certos interesses [...] [tradução nossa] ${ }^{467}$

Na mesma linha de raciocínio, a Corte de Cassação Italiana, em 1978, no famoso caso da "Associazione Italia Nostra", que empolgou os processualistas italianos, já caracterizou o interesse coletivo como um interesse impessoal ou indiferenciado, que não diz respeito à pessoa do indivíduo, mas a sua qualidade de membro de um grupo. Ilustrativamente, cita-se trecho:

Aqueles que pela idoneidade do seu objeto hão de ser considerados no campo exclusivamente individual - a causa de sua natureza e o caráter normativo -, mas não se referem ao sujeito como indivíduo, mas sim como membro da uma coletividade, que mais ou menos ampla, coincide com a generalidade dos cidadãos, dando assim lugar a uma pluralidade de situações jurídicas análogas [tradução nossa]. ${ }^{468}$

No direito estadunidense, coube a Robert G. Bone ${ }^{469}$ e Judith Resnik ${ }^{470}$ qualificarem o interesse ou direito coletivo, em sentindo amplo, pelo aspecto da impessoalidade do indivíduo no grupo. O indivíduo, conforme o conteúdo da relação de direito substancial deduzida em juízo, tornase um mero anônimo no grupo, um sujeito impessoal e indistinto, igual aos demais membros.

467...tutte queste qualifiche dell'interesse (strumentale, finale, incompatible, comune, ecc) non designano posizioni di vantaggio autonome di qualità particolare, ma designano il tipo di relazione esistente fra le varie posizioni di vantaggio. In questo quadro si inserisce l'espressione interesse collettivo: essa esprime l'esistenza di una relazione fra interessi di uguale contenuto, facenti capo a soggetti diversi, organizzati per il raggiungimento del medesimo fine. Il collettivo è la valenza di una certa relazione fra interessi di natura individuale, non confliggenti, ma solidali, congiunti e organizzati per il soddisfacimento della pretesa comune [...] Fare dell'indivisibilità del bene il fondamento del collettivo significa ridurre il fenomeno ad un mero accadimento oggettivo, vuol dire in sostanza negare que moltissimo bene siano collettivamente perseguibili, e, quindi implicitamente escludere que possa mai rilevare la dimensione superindividuale di certi interessi (VIGORITI, 1979, p. 19 e 59).

468 [...] per interessi diffusi si possono intendere quegli interessi che per la inidoneità dell'oggetto - a causa della sua natura e del carattere della normative - ad essere considerati nell'ambito esclusivamente individuale, sono riferibili non al soggetto come indíviduo, ma come membro de una collettività piú o meno ampia, coincidente al limite con la generalità dei cittadini, dando cosí luogo ad una pluralità di situazioni giuridiche analoghe (Cf. Cass. Civ. sez. un, 8 maggio 1978, n.2207. POSTIGLIONE, Amedeo. Il rapporto diritto-ambiente nel quadro della tutela degli interessi diffusi e collettivi, il ruolo della Corte di Cassazione. In: Strumenti per la tutela degli interessi diffusi della collettività. Atti del convegno nacionale promosso dalla Sezione di Bologna di Italia Nostra (Bologna, 5 dicembre 1981). Bologna: Palazzo Pepoli, 1981, p. 69-70).

469 BONE, 1990, p. 218

470 RESNIK, 1991, p. 25. 
No mesmo sentido, diz Erbsen ${ }^{471}$ : que define a comunhão ou unitariedade entre os indivíduos do grupo não é a semelhança, mas a ausência de diferenças relevantes entre os sujeitos.

É o anonimato, a despersonalização, a objetividade, a indiferenciação, presentes na relação substancial, que determinam a agregação processual, mediante a representação por um portador ideológico dos interesses do grupo ou pela identificação de uma amostra representativa da controvérsia. Nesse caso, o centro da cognição e discussão são os atributos do próprio grupo. O indivíduo apresenta-se, nesse contexto e ao menos em parte, como membro de um grupo.

No direito brasileiro, Cândido Rangel Dinamarco ${ }^{472}$ também refere-se aos direitos transindividuais como aqueles caracterizados pela indivisibilidade, mas também pela impessoalidade. Em suas palavras, "os direitos difusos e os coletivos caracterizam-se por sua impessoalidade e indivisibilidade, não tendo como centro de imputação indivíduo algum, ou mesmo uma pessoa jurídica e não sendo suscetível de fragmentação ou partilha". ${ }^{473}$

De igual modo, em alguns precedentes do Superior Tribunal de Justiça, é possível verificar a remissão à expressão impessoalidade para caracterizar os interesses ou direitos coletivos em sentido amplo. Essa remissão, embora não seja acompanhada de uma roupagem conceitual que explicite o critério subjetivo, demonstra satisfatoriamente o conteúdo impessoal do direito. In verbis:

[...]4. A proteção a um grupo isolado de pessoas, ainda que consumidores, não se confunde com a defesa coletiva de seus interesses. Esta, ao contrário da primeira, é sempre impessoal e tem como objetivo beneficiar a sociedade em sentido amplo. Desse modo, não se aplica à hipótese o disposto nos artigos 81 e 82, I, do CDC. $[\ldots]^{474}[$ grifo nosso $]$

O critério da impessoalidade, segundo o conteúdo da relação de direito substancial deduzida em juízo, apresenta, ainda, uma vantagem em relação à noção de titularidade, antes mencionada.

471 ERBSEN, 2005, p. 9.

472 DINAMARCO, Cândido Rangel. Verbete "Direitos transindividuais, difusos, coletivos e individuais homogêneos - tutela coletiva”. Vocabulário do processo civil. São Paulo: Malheiros, 2009, p. 134.

473 Ibidem, p. 134.

474 BRASIL. Superior Tribunal de Justiça. REsp 1109335/SE. Rel. Ministro LUIS FELIPE SALOMÃO, QUARTA TURMA, julgado em 21/06/2011, DJe 01/08/2011. No mesmo sentido, BRASIL, Superior Tribunal de Justiça. AgRg no REsp 710.337/SP. Rel. Ministro SIDNEI BENETI, TERCEIRA TURMA, julgado em 15/12/2009, DJe 18/12/2009 e BRASIL, Superior Tribunal de Justiça. REsp 912.612/DF, Rel. Ministro ARNALDO ESTEVES LIMA, QUINTA TURMA, julgado em 12/08/2008, DJe 15/09/2008. 
Quando se diz que um interesse ou direito coletivo apresenta um portador indeterminado, pois trata-se de um bem que não pertence a ninguém, mas pertence a todos ao mesmo tempo, isso não diz muito ao intérprete sobre como diferenciar os interesses coletivos dos interesses individuais. Isso porque esses interesses pertencem, simultaneamente, ao grupo e ao indivíduo. O direito pertence ao grupo, mas não deixa de pertencer também ao indivíduo como membro do grupo, mormente nas hipóteses em que o indivíduo sofreu prejuízo em sua esfera jurídica.

A titularidade é mais adequada apenas para diferenciar os interesses coletivos em sentido amplo, dividindo-os em difusos ou coletivos em sentido estrito, conforme se refiram, respectivamente, a um portador de um grupo ocasional e ou de um grupo não ocasional.

Quando se diz, no entanto, que um interesse ou direito coletivo apresenta caráter impessoal e o indivíduo apresenta-se como um mero anônimo no grupo, isso permite uma melhor diferenciação dos interesses ou direitos coletivos dos interesses ou direitos individuais pelo aspecto da amplitude da cognição que deve ser realizada sobre a controvérsia deduzida. $\mathrm{O}$ coletivo é superveniente ao indivíduo, o indivíduo pode mudar, mas os atributos do grupo não.

No primeiro caso, dos interesses coletivos em sentido amplo, a cognição ${ }^{475}$ centra-se nos atributos ou nas características próprias de um grupo. Nesse caso, o membro do grupo é fungível, ele atua como um anônimo ou como um membro do grupo. No segundo caso, dos interesses ou direitos individuais, a cognição centra-se nos atributos ou características pessoais.

Lembra-se, agora, das técnicas de agregação, antes mencionadas. Naquela ocasião, já era possível perceber manifestações dessa fungibilidade, ora anunciada: (i) a demanda individual pode ser consolidada, sem direito de autoexclusão, com as demais demandas individuais semelhantes; (ii) o magistrado poderá determinar, na consolidação, o oferecimento de petições unitárias e uniformes; (iii) é admissível a prova por amostragem e um caso-tese, que nada mais é do que uma amostra representativa da controvérsia, extrapolada para os demais casos

475 Cognição - conforme argutamente observou Kazuo Watanabe - é "um ato de inteligência, consistente em considerar, analisar e valorar as alegações e provas produzidas pelas partes, vale dizer, as questões de fato e as de direito que são deduzidas no processo e cujo resultado é o alicerce, o fundamento do judicium, do julgamento do objeto litigioso do processo". Assim, a partir desse conceito, pode-se dizer que, nos interesses ou direitos coletivos, a cognição apresenta uma amplitude maior, pois é centrada no indivíduo, não como pessoa, mas como membro de um grupo ou categoria (Cf. WATANABE, Kazuo. A cognição no processo civil. São Paulo: Malheiros, 2012, p. $67)$. 
individuais; e (iv) o indivíduo, quando escapa de uma técnica, pode sofrer agregação por outra. Exemplo: ele exclui-se da ação coletiva, mas a sua ação individual é consolidada em juízo.

Nota-se, logo, que a impessoalidade é também um critério relevante, a ser conjugado com a incindibilidade. Se o bem da vida for, na prática, incindível ou se a relação substancial for necessariamente paritária, o intérprete deverá atentar-se ainda para o conteúdo impessoal ou objetivo da relação substancial deduzida em juízo para o fim de reconhecer os interesses ou direitos coletivos. Se o indivíduo argumentar, de forma impessoal, como membro do grupo, subsumindo-se ao anonimato ou às características da coletividade, surgirá, com maior força, o caráter ou a valência coletiva do direito material que se pretende identificar no caso concreto.

O interesse do indíviduo, quando opera pelo grupo, tem, conforme explana novamente Vigoriti ${ }^{476}$, uma valência ou uma força coletiva, que é diversa do interesse do indivíduo, quando ele opera fora do grupo, isto é, de forma pessoal. Frise-se, nesse sentido, que um interesse é coletivo à medida que nasce do fato de ser o indivíduo um membro de uma comunidade. $\mathrm{O}$ indivíduo apresenta um interesse ou direito com igual conteúdo dos demais membros do grupo.

O estabelecimento desses critérios é fundamental para a compreensão e identificação dos interesses ou direitos coletivos, como categoria própria, não redutível aos indivíduos, mas a serviço deles. De igual modo, esses critérios permitem ao intérprete saber o que agregar.

Somente depois de identificar a relação jurídica de direito substancial controvertida - e esse é um dos nós-górdios do processo civil contemporâneo - é possível a aplicação das técnicas de agregação processual às situações plurissubjetivas, que escapam ao esquema dualista clássico.

Mas, como já se afirmou anteriormente, ao se estabelecer esses critérios não se pretendeu estabelecer uma receita de bolo. Tanto o plano individual quanto o coletivo não existem de forma absolutamente desvinculada, o que torna difícil, senão impossível, pensar o direito material de forma estanque ou rigorosamente categorizada entre indivíduo e coletividade. $\mathrm{Na}$ realidade, os dois planos, embora possam ser abstratamente distinguidos e hoje possa-se falar até mesmo em novos direitos titularizados pelo próprio grupo- como é o caso, por exemplo, 
das cotas raciais, da higidez ambiental etc - destacam-se várias situações da vida em que uma pluralidade de interesses, individuais ou coletivos, se entrelaça substancialmente.

Para essas situações de entrelaçamento ou convergência material, não importa o nomen iuris do direito, se individual ou coletivo, o que importa é identificar a valência ou o alcance coletivo da controvérsia, ocasião em que serão identificados os candidatos à agregação processual.

Retomando-se: embora seja possível identificar nos interesses coletivos uma categoria conceitual autônoma, que persiste mesmo com a alteração dos membros da comunidade, como já foi consignado, esses interesses ou direitos coletivos podem ser coincidentes e incidentes sobre os mesmos bens e valores, que também são tutelados individualmente. Explicar-se-á.

\subsubsection{INTERESSE OU DIREITO INDIVIDUAL DE ALCANCE COLETIVO}

Ao lado dos interesses ou direitos individuais e dos interesses ou direitos coletivos, não é possível afastar as situações de plurissubjetividade, em que as histórias individual e coletiva se relacionam. A essas situações de plurissubjetividade, denominou-se, abstratamente, de interesses ou direitos individuais de alcance, de abrangência, de valência ou de força coletiva.

Esse fenômeno de interesses ou direitos individuais com alcance coletivo pode ser denominado de direitos pseudoindividuais, cujos reflexos no processo foram chamados, pelo Professor Kazuo Watanabe ${ }^{477}$, de demandas pseudoindividuais ou demandas de alcance coletivo. No sistema estadunidense $\mathrm{e}^{478}$, utiliza-se a expressão aggregate rights para fenômeno semelhante.

477 WATANABE, 2007, p. 156.

478 Alguns autores, no sistema jurídico estadunidense, utilizam a expressão aggregate rights (direitos individuais agregados) para designar fenômeno semelhante, isto é, direitos de titularidade individual, mas que são idênticos aos direitos de outros indivíduos, que ocupam a mesma situação ou posição jurídica. A identidade da situação jurídica é definida pelo conteúdo ou pela natureza agregativa ou pública da demanda, em que todos os indivíduos são igualmente interessados e indiferenciados, pois atuam pelo status do grupo. (ISSACHAROFF, 2008, p. 2). No mesmo sentido, Gerken denomina de aggregate right (direitos individuais agregados) o direito de titularidade individual, mas que encontra-se pulverizado entre vários indivíduos e somente pode ser concretizado ou eficazmente atuado se o indivíduo apresentar-se como membro de um grupo. Isso ocorre com muitas espécies de direitos - inclusive civil rights ou direitos públicos - mas a análise de Gerken se restringe ao direito de voto de grupos minoritários. Nas hipóteses de aggregate rights, os membros do grupo são fungíveis entre si, pois, embora afetados individualmente por uma prática abusiva ou lesiva, eles continuam a operar como membros de um grupo (referem-se ao status do grupo) e é, nessa medida, que surge a fungibilidade entre eles (GERKEN, 2001, p. 1724). 
A expressão utilizada pelo Professor Kazuo é precisa. Isso porque, por vezes, um interesse ou direito individual pode ser individual na sua titularidade, mas o conteúdo objetivo da relação de direito substancial deduzida em juízo e o bem controvertido são de amplitude coletiva.

Cada sistema jurídico, seja o brasileiro, seja o estadunidense, denominará essa espécie de uma forma, mas o fenômeno é semelhante. Trata-se de um direito cuja titularidade é individual, mas a natureza do bem pretendido e o conteúdo objetivo da relação jurídica de direito substancial deduzida em juízo são incindíveis, paritários e impessoais, isto é, são coletivos em senso amplo.

Não há surpresa nisso. A convergência entre interesses ou direitos coletivos e interesses ou direitos individuais não causa espanto. Muito pelo contrário, os interesses ou direitos coletivos são, em regra, interesses ou direitos moldura (framing $\operatorname{goods}^{479}$ ), a partir do qual se inserem vários interesses ou direitos individuais idênticos, em favor de uma pluralidade de sujeitos.

Joseph $\operatorname{Raz}^{480}$ assevera que determinados bens comuns (common goods) são suscetíveis de serem tutelados tanto por interesses ou direitos coletivos, quanto por interesses ou direitos individuais. Isso é denominado de framing goods, isto é, interesses ou bens molduras, que dão azo paralelamente a interesses ou direitos individuais idênticos. Logo, pode coincidir um direito individual e um direito coletivo sobre um mesmo bem. Essa situação de coincidência ou equivalência são, exatamente, aquelas situações plurissubjetivas, até agora mencionadas.

Aliás, Barbosa Moreira ${ }^{481}$, embora partindo de um caminho diverso, menciona o mesmo fenômeno, ao abordar o caso de uma situação substancial plurissubjetiva, que alcança duas ou mais posições jurídicas individuais, que devam se produzir a um só tempo e de modo igual para todos os titulares. Isso ocorre porque essas "posições jurídicas individuais se inserem na situação global”, inserção que deve ser uniforme sob pena de insubsistência da situação global.

E, de fato, uma posição de vantagem global reconhecida em favor do grupo, não tem, por vezes, o grupo como sujeito de imputação da norma. A essa posição de vantagem coletiva, se encartam idênticas posições de vantagens individuais, reflexas, derivadas ou secundárias à moldura coletiva, em que os indivíduos atuam, não pessoalmente, mas como membros do grupo.

479 RAZ, 1995, p. 37. No mesmo sentido, NEWMAN, 2011, p. 80. 480 RAZ, op. cit., p. 37.

481 MOREIRA, 1972, p. 142. 
Lembra-se dos direitos às cotas raciais. Um grupo étnico ou racial titulariza um direito coletivo às cotas raciais. Essas cotas servem ao grupo como uma categoria e não como um conjunto de pessoas. Mesmo que os membros do grupo mudem e novas gerações sobrevenham, o escopo das cotas consiste no mesmo, a saber, compensar uma discriminação passada e favorecer a inclusão social do grupo e não de um indivíduo específico. Esse direito, que introduz uma ação afirmativa, deve, assim, perdurar até que sobrevenha a integração social dessa coletividade.

Ocorre que, a partir do momento que a cotas são instituídas por uma lei, vários indivíduos, que preencham determinados requisitos raciais ou étnicos, passam a fazer jus à cota no momento presente. $\mathrm{O}$ indivíduo passa a ter um interesse juridicamente protegido por uma determinada lei que reconhece cotas no vestibular, no concurso público etc. Mas, essa posição individual de vantagem no direito material é derivada, secundária ou reflexa. Ela decorre do fato de o indivíduo ser membro de um grupo racial, cujo interesse coletivo sagrou-se vencedor. O direito às cotas de José é igual ao de João, pois ambos são membros do mesmo grupo racial ou étnico.

Lembra-se, agora, do direito de pesca de uma comunidade ribeirinha de pescadores artesanais, a ser exercido em uma região ambientalmente protegida. Foi o modo de produção artesanal e de organização comunal dessa população ribeirinha que potencializou o reconhecimento do direito de pesca em uma região ambientalmente protegida. Isso ocorre, pois os dois valores são compatíveis, a saber, a subsistência daquela comunidade, cujo modo de vida não é degradante, e a proteção ao meio ambiente. Ocorre que, a partir do momento em que o direito de pesca é instituído, todos os pescadores artesanais tem um direito individual à pesca, pois eles têm um interesse na sua sobrevivência, independentemente dos demais pescadores da comunidade.

Por fim, vamos retomar um último exemplo, o do concurso público que é um direito reconhecido a todos os brasileiros, para que todos tenham igual oportunidade de acessar um cargo público e para que a administração pública possa selecionar o candidato mais preparado. Ocorre que, a partir do momento em que uma prova objetiva de um concurso é realizada em inobservância ao seu edital (o edital estabelece as regras que garantem a todos os candidatos a concorrência em paridade), todos os candidatos, que erraram uma questão daquela prova, fazem jus a postular a pontuação dessa questão. Os candidatos, nesse caso, sofreram um prejuízo próprio, razão pela qual podem perseguir em juízo a posição de vantagem violada. Mas, o direito à pontuação, em razão da invalidade do edital, é igual para todos os candidatos. 
Enfim, veja que, em todos esses exemplos, existe um grupo ou uma categoria de pessoas, que independe dos seus membros individuais. O grupo racial ou étnico, a comunidade de pescadores e os concurseiros existem, independentemente de quem sejam seus membros individuais. Esse raciocínio permitiu concluir, em tópico anterior deste trabalho, pela existência de interesses ou direitos coletivos como síntese e não como mera soma dos interesses ou direitos individuais.

Mas, a partir do momento que um direito é instituído em favor dessa categoria, surgem várias posições de vantagem individuais, idênticas, relativas a um mesmo bem comum. No ponto, os indivíduos, embora possam ser prejudicados em sua esfera jurídica, não argumentam de forma pessoal, mas continuam argumentando como membros de um grupo ou de uma comunidade. ${ }^{482}$

Nesse contexto, é possível tanto a um ente exponencial como uma associação ou um órgão público (ex. associação dos afrodescendentes, associação dos pescadores, Ministério Público) atuar na defesa dos interesses ou direitos coletivos do grupo como um todo, como é possível o próprio indivíduo fazê-lo em seu nome, pois foi afetado, individualmente, pela prática lesiva.

Nesse último caso, no entanto, quando o indivíduo o faz em nome próprio, o conteúdo objetivo da relação de direito substancial e processual é o mesmo. João, Pedro, José deduzem uma causa de pedir e um pedido que não dizem respeito a eles pessoalmente, não dizem respeito aos seus atributos particulares, mas, sim, aos atributos que detêm como membros de um grupo, seja um grupo racial ou étnico, seja uma comunidade de pescadores, seja um grupo de concurseiros, os quais foram unitariamente afetados. Essa unidade existe porque a relação substancial é impessoal e o bem comum é materialmente incindível ou normativamente incindível (paritário) $^{483}$.

482 Nesse sentido, Joseph Raz reconhece o grupo como titular de um direito coletivo. Isso não restringe, no entanto, o indivíduo, que permanece com a possibilidade atuar individualmente, mas agora não com fundamento nos seus atributos pessoais, mas, sim, como membro do grupo (Cf. RAZ, 1988, p. 208).

483 As hipóteses materialmente incindíveis são aquelas em que o bem postulado é insuscetível de decomposição, ainda que em quotas ideais, como, por exemplo, é o caso do ar, dos rios, de uma praça pública, de uma ponte etc. As hipóteses normativamente incindíveis são aquelas em que a paridade ou a isonomia são exigidas pelo direito substancial, de forma a que a resolução de uma controvérsia dessa espécie deva ser realizada de forma unitária para todos. Nesse caso, o bem pode até ser, na prática, objeto de decomposição em feixes individuais, mas se isso for feito de forma a desequiparar os indivíduos, a própria natureza do direito passa a ser destruída ou esfacelada. Uma propriedade comunal que é dividida pelo Poder Judiciário em faixas desiguais deixa de ser comunal, um concurso público que é realizado sem observância da isonomia entre os candidatos, deixa de ser um procedimento de concorrência paritário destinado a selecionar o candidato mais preparado para o cargo e assim por diante. 
Pois bem. Esse fenômeno que se passa no direito material - que se denominou direitos individuais de alcance coletivo - tem reflexos no direito processual, implicando o fenômeno de repetição de demanda individuais objetivamente idênticas, assim denominadas demandas pseudoindividuais ou demandas individuais de alcance coletivo, sobre as quais já se adiantou.

Nessas hipóteses, o elemento que é modificado de uma demanda para outra é o elemento subjetivo. Esse elemento é, no entanto, fungível. Os membros do grupo são fungíveis entre si, já que a referência é realizada aos atributos do próprio grupo e não aos atributos pessoais ou particulares de um indivíduo em específico. Por essa mesma razão, o conteúdo objetivo da relação jurídica de direito processual deduzida em juízo, presente na causa de pedir e no pedido das demandas individuais repetitivas, é idêntico ou análogo para todas elas. Isso porque a controvérsia é deduzida com fundamento aplicável ao grupo como um todo e, nessa hipótese, o indivíduo apenas subsome-se ao anonimato da coletividade.

É, justamente para esses casos, que devem ser pensadas as técnicas de agregação processual. As técnicas clássicas de pluralidade de partes, como o litisconsórcio e a intervenção de terceiros, bem como a multiplicidade de demandas individuais em concurso tornaram-se instrumentos processuais insuficientes para assegurar a resolução unitária da controvérsia de massa.

Urge, então, desenvolver instrumentos de agregação processual de larga escala, estruturando de foram molecular a controvérsia de massa, sob pena de congestionar o sistema - se é que já não está congestionado - com uma multiplicidade de demandas-átomo, demandas-clone, demandas cognatas que concorrem entre si e que podem ser eventualmente idênticas a uma ação coletiva.

Mas, antes de se abordar a técnica de agregação propriamente, é preciso identificar o grau de agregação que existe na categoria denominada de direitos individuais de alcance coletivo. É esse grau de agregação que determinará, em regra, o design procedimental, os tipos de técnicas de agregação processual admissíveis e o regime processual aplicável a cada caso em análise.

Nesse sentido, Cândido Rangel Dinamarco ${ }^{484}$, ao analisar o litisconsórcio, salientou que existe uma escalada decrescente de vinculação entre causas, caminhando da hipótese de vinculação 
mais intensa (comunhão) à vinculação mais tênue (mera afinidade). Há uma diversidade de situações jurídicas nas quais uma pluralidade de sujeitos se entrelaçam. Esses variáveis graus de intensidade manifestam-se na diferença de tratamento processual que a lei endereça $\mathrm{a}^{485}$.

O raciocínio adotado aqui é semelhante ao do Professor Dinamarco. Porém, para identificar os direitos individuais de alcance coletivo, serão observados outros critérios e parâmetros.

Trata-se dos mesmos critérios - critério subjetivo e critério objetivo - que permitiram, anteriormente, identificar os interesses ou direitos coletivos em sentido amplo, a saber, a indivisibilidade do bem, a incindibilidade normativa (relação de paridade) e a impessoalidade.

Identificaram-se, nessa investigação, quatro espécies de direitos individuais com alcance coletivo. A tipologia não é exaustiva, tem por escopo apenas mostrar como os critérios substanciais (indivisibilidade, paridade e impessoalidade) se imiscuem nos direitos individuais, permitindo aferir o alcance coletivo da controvérsia e tornando-a candidata à agregação.

\subsubsection{REFLEXOS EM RELAÇÃO SUBSTANCIAL INDIVISÍVEL E IMPESSOAL}

Pode-se dizer, agora, sem temor, que alguns interesses ou direitos individuais apresentam-se como secundários, como um reflexo ou como uma derivação de um interesse ou direito coletivo. O mesmo interesse encontra expressão no direito coletivo do grupo, mas também encontra expressão no direito individual de um sujeito, na condição ou qualidade de membro do grupo.

Quando se diz reflexo, secundário, derivado, não se quer dizer menos importante. O indivíduo não só é relevante, como também é a razão última da admissão dos direitos coletivos, pois ao se avançar o direito da categoria, avança-se o direito do próprio indivíduo. ${ }^{486} \mathrm{Com}$ as expressões

\footnotetext{
concurso subjetivo de ações (Cf. ASSIS, Araken. Cumulação de ações. 4. ed. rev. atual. São Paulo: Revista dos Tribunais, 2002).

485 No mesmo sentido, Teresa Arruda Alvim Wambier assinala que a qualidade de terceiro em relação a um processo comporta diferentes níveis ou graus (Cf. WAMBIER. Teresa Arruda Alvim. Casos problemáticos: partes ou terceiros (análise de algumas situações complexas de direito material). In: WAMBIER, Teresa Arruda Alvim; WANBIER, Luiz Rodrigues. In: Aspectos polêmicos e atuais sobre terceiros no processo civil e assuntos afins. São Paulo: Revista dos Tribunais, 2004, p. 1043).

486 Essa advertência é realizada, no mesmo sentido, por Dwight Newman. O fato de se dizer que o grupo tem direitos não significa dizer que o grupo e não o indivíduo seja a unidade fundamental do mundo. Muito pelo contrário, por força do service principle (o princípio do grupo a serviço), o grupo está a serviço de avançar os interesses ou direitos individuais, à serviço do ser humano, da humanidade (Cf. NEWMAN, 2011, p. 69).
} 
secundário, reflexo ou derivado, quis se dizer apenas que o indivíduo encontra-se suscetível de sofrer uma ameaça ou uma lesão em sua esfera jurídica, na qualidade de membro do grupo e não de forma pessoal. A prática ilícita impacta o grupo, como causa próxima, e impacta o indivíduo, como membro do grupo ou causa remota, a exemplo do ricochetear de uma bala. ${ }^{487}$

Esse interesse ou direito é, por um lado, suscetível de ser considerado individual, pois o indivíduo sozinho poderá fundamentar um dever imputável a outrem. Mas, de outro lado, pode ser considerado um interesse ou direito de alcance coletivo. Isso porque, não obstante o interesse ou direito ser suscetível de persecução individual, a relação jurídica de direito substancial foi deduzida em juízo de modo impessoal e o seu objeto material é indivisível.

O indivíduo, ainda que em nome próprio, opera como membro de um grupo ou pelo status de uma coletividade, isto é, atua como um anônimo. Narra uma história coletiva, que é indiferente às suas particularidades individuais. E, nesse contexto, pretende um resultado, que é capaz de beneficiá-lo e, simultaneamente, beneficiar a todo o grupo ou a comunidade a ele associada.

Como afirma Vigoriti ${ }^{488}$, a valência desse direito individual incidente sobre uma relação substancial incindível e impessoal é diversa da valência de um direito individual ordinário. A vontade individual é capaz de influenciar o destino organizacional de uma pluralidade de sujeitos, de uma coletividade, igualmente interessada na relação jurídica de direito substancial.

Essa valência coletiva dos direitos individuais se manifesta, por sua vez, em diferentes graus de intensidade. A vinculação entre os indivíduos de um grupo pode ser estabelecer de uma forma mais intensa, alcançando, por vezes, uma situação de verdadeira comunhão de interesses.

Esse é o caso da categoria, ora abordada, em que os interesses ou direitos individuais dos membros do grupo compartilham, de forma reflexa, uma relação substancial

487 O dano de ricochete é mencionado por José Rubens Morato Leite e Edis Milaré, que sustentam as duas faces do dano ambiental ou ambivalência do dano ambiental, qual seja, danos causados ao ambiente e danos reflexos ou realizados por intermédio do meio ambiente (de ricochete) aos terceiros (Cf. MILARÉ, 2002, p. 146 e LEITE, 2002, p. 458-463).

488 VIGORITI, 1979, p. 19. 
plurissubjetiva ou de alcance coletivo, cujas notas essenciais são a indivisibilidade prática do bem e a impessoalidade. As ações individuais são objetivamente idênticas.

Nesse caso, a ÚNICA diferença entre as várias demandas individuais concorrentes é o nome da parte, isto é, a pessoa física que figura formalmente no polo ativo ou passivo de uma demanda. Considerando, no entanto, que o indivíduo, ao operar na qualidade de membro do grupo, é fungível aos demais integrantes da categoria, não se trata, na realidade, de uma distinção relevante, pois o centro da controvérsia não é a pessoa do indivíduo, mas os atributos do grupo.

A incindibilidade e a impessoalidade da relação substancial são, por sua vez, muito intensas na hipótese em que a tutela pretendida referir-se à inibição de uma conduta ou à remoção de um ilícito $^{489}$, que afeta, de forma unitária e impessoal, necessariamente todos os membros do grupo.

A incindibilidade é intensa, pois é impossível dividir, na prática, o objeto. Ou, inibe-se a conduta lesiva ou abusiva para todos os interessados, ou não se inibe para ninguém, ou removese o ilícito para todo mundo, ou não se remove o ilícito para ninguém. A impessoalidade é igualmente intensa, pois não há alternativas particulares. O sistema é binário, isto é, 0 ou 1, pois não é possível existir uma concepção pessoal ou personalizada da obrigação de não fazer. Só tem um jeito de não fazer uma coisa e esse jeito é simplesmente não fazendo essa coisa.

Imagine, por exemplo, uma lei municipal que institua cotas raciais para os cargos da Prefeitura Municipal de Vitória, Espírito Santo. Em relação a todos os cargos do Poder Executivo daquele Município, dever-se-á ser reservado o percentual de 5\% das vagas previstas, percentual que será destinado às cotas raciais. Suponha, no entanto, que o Município de Vitória publique um edital de um concurso público, omitindo qualquer referência à observância dessas cotas raciais.

489 Tutela inibitória ou de remoção do ilícito é uma ação cognitiva de natureza preventiva destinada a impedir a prática, a continuação ou repetição do ilícito. A inibição diz respeito à tutela pretendida, isto é, ao modo ou a técnica pela qual o direito processual soluciona os diversos casos conflitivos que são apresentados. Não se confunde a tutela com a eficácia do provimento ou da sentença, que pode ser condenatória, mandamental, constitutiva, declaratória ou executiva lato sensu. A sentença mandamental (coerção indireta que atua sobre a vontade do devedor para cumprir uma obrigação, sob pena de multa ou outra medida) pode veicular uma inibição, mas não é sinônimo dela, pois uma sentença mandamental também soluciona a tutela específica de uma obrigação de fazer, por exemplo (Cf. MARINONI, Luiz Guilherme. Técnica processual e tutela dos direitos. 3 ed. rev. atual. São Paulo: Revista dos Tribunais, 2010, p. 192). 
Nesse caso, um indivíduo poderia impetrar mandado de segurança, impugnando o edital, sob o argumento de ter direito líquido e certo à posição de vantagem, conferida por lei, a saber, uma das cotas no concurso público. E, por essa razão, pleitear-se-ia a anulação do edital do certame.

A mesma causa de pedir e o mesmo pedido, da demanda supracitada, poderiam ser formulados em uma ação coletiva, na defesa do direito do próprio grupo pelo Ministério Público ou por uma Associação de Afrodescendentes. E, de igual modo, uma multiplicidade de ações individuais concorrentes poderiam se seguir, sobre o mesmo objeto e com a narrativa impessoal.

Em todas essas demandas coletivas e individuais, mencionadas na ilustração supracitada, a impessoalidade e a incindibilidade da relação substancial plurissubjetiva são intensas, pois ou o edital é válido e o certame deve prosseguir para todos, ou o edital é inválido e não deve ser dada continuidade ao processo seletivo deflagrado por aquele edital. São duas opções antitéticas e binárias, que circundam, que entrelaçam e que vinculam todos os membros do grupo.

Outro exemplo é o caso de uma interferência negativa no meio ambiente por uma indústria poluidora. O meio ambiente é um bem natural comum, não é apropriável por ninguém e é fruível por todos. Uma indústria, no entanto, pode se apropriar do ar e realizar uma interferência negativa nesse bem comum, degradando-o. Ela poluiu o ar que é bem comum, coletivo e indivisível: é bem de todos. E, agora, o ar, que cada um dos indivíduos respira, está poluído. ${ }^{490}$

Pode-se dizer que essa indústria realizou, nesse caso, uma apropriação privada de um bem comum, mas de forma degradante, isto é, interferindo negativamente nas suas condições originárias. Ela causou danos ao bem comum, globalmente considerado, pois degradou o meio ambiente, tirando-o de suas condições naturais. Ao apropriar-se de um bem comum e degradálo, ela descumpriu um dever, resistiu à obrigação ambiental e causou prejuízos à coletividade. ${ }^{491}$

Mas, de igual modo, esse mesmo fato, essa mesma apropriação privada e danosa de um bem comum, pode ter ensejado riscos ou danos específicos à saúde dos indivíduos que respiraram aquele ar poluído ou à propriedade individual, submetida àquela interferência danosa.

490 José Reinaldo de Lima Lopes menciona que a interferência danosa no meio ambiente natural é uma forma de interferência e apropriação privada de um bem comum (Cf. LOPES, José Reinaldo de Lima Lopes. O aspecto distributivo do direito do consumidor. Revista de Direito Mercantil, Industrial, Econômico e Financeiro. Ano XL. V. 123. Malheiros: São Paulo, jul./set. 2001, p. 62).

491 LOPES, 2001, p. 62. 
O indivíduo pode, então, buscar a defesa de um interesse ou direito individual. Buscar-se-ia, nesse caso, a preservação da saúde ou da propriedade individual, que são objetos de proteção jurídica autônoma, independentemente da proteção conferida à coletividade. No entanto, ao deduzir essa controvérsia em juízo, o indivíduo não pretende a recomposição dos danos pessoalmente sofridos. O que o indivíduo pretende é a remoção da prática ilícita e a inibição da conduta lesiva praticada, de uma forma global, pela indústria poluidora, prevenindo os danos. ${ }^{492}$

É possível que o indivíduo pretenda, por exemplo, um provimento jurisdicional consistente no fechamento da indústria, para fins de proteção do seu direito à saúde ou à propriedade. Nessa hipótese, no entanto, o cerne da controvérsia não é centrado nos atributos particulares ou pessoais do indivíduo, mas passa incidir, de forma intensa, sobre um bem comum incindível e sobre uma relação substancial impessoal, a saber, sobre os atributos da coletividade que sofre os efeitos danosos daquela prática degradante no meio ambiente natural, por todos fruível.

O indivíduo percebe que não são as suas características peculiares que irão avançar a proteção plena dos seus interesses ou direitos em juízo. As suas características pessoais podem, sim, ser relevantes em um cenário em que há pedido de ressarcimento pelos danos pessoalmente sofridos. Mas, a mera restauração da ordem jurídica na sua esfera pessoal, isto é, o mero ressarcimento pelos prejuízos pessoalmente sofridos, pode ser considerado insuficiente por ele. O que o indivíduo pretende é que a própria interferência negativa realizada pela indústria no ambiente seja cessada, de forma a não mais advir reflexos daquela prática ilícita globalmente realizada na sua esfera pessoal, na sua saúde ou na sua propriedade. Avança-se o interesse ou direito coletivo, para, com isso, avançar o direito individual, na qualidade de membro do grupo.

Nessa hipótese, embora o indivíduo atue em nome de seu direito individual (saúde, propriedade, vizinhança e outros), esse direito é apresentado de forma secundária, reflexiva ou derivada, com

492 A proteção ou a exigência de um direito subjetivo pode ocorrer de várias formas. É possível uma proteção preventiva, uma proteção ressarcitória, uma proteção repressiva, uma compensação patrimonial etc. Com fundamento em um mesmo direito e diante de um mesmo fato lesivo, podem surgir diferentes interesses suscetíveis de serem exigidos por força da posição de vantagem substancial prevista na norma jurídica. $\mathrm{O}$ titular dessa posição de vantagem poderá, no entanto, pleitear no processo apenas um desses interesses substancialmente exigíveis. No caso de uma tutela inibitória, o indivíduo, embora sofra prejuízo pessoal na sua saúde ou propriedade, pode limitarse a exigir a remoção e a prevenção da prática lesiva, ao invés de ressarcimento em pecúnia. Nesse contexto, como diz Álvaro Vallery Mirra, um indíviduo poderá exigir a prevenção dos danos ambientais, que reflexamente atingem a sua esfera jurídica, pela correção da fonte, ou seja, pela supressão das atividades ou omissões degradadoras do meio ambiente, que se encontram na origem da situação ilícita ou lesiva que o alcança reflexamente (Cf. MIRRA, Álvaro Vallery. Ação Civil Pública ambiental e as tutelas jurisdicionais da prevenção e precaução. In: MILARÉ, Edis (coord.). Ação Civil Pública Ambiental após 25 anos. São Paulo: Revista dos Tribunais, 2010, p. 82). 
uma alcance inegavelmente coletivo. $\mathrm{O}$ interesse ou direito individual nasce do fato de o indivíduo ser membro de uma comunidade e ter sofrido os impactos individuais de uma violação global ou de uma interferência negativa em um bem, que é, por todos, comungado.

Sob a ótica desse indivíduo, aquele que ajuizou a ação pleiteando tutela inibitória, a melhor forma de avançar a proteção da sua saúde ou de sua propriedade é alterar o padrão pelo qual há uma interferência danosa ao meio ambiente. $\mathrm{O}$ indivíduo avança os seus interesses ou direitos individuais, à medida que avança os interesses de toda a coletividade a ele associada.

Nesse caso, o direito de titularidade individual - no, nosso exemplo, a defesa do direito individual à saúde ou à propriedade de um sujeito - incide, de forma reflexa ou derivada, sobre um mesmo bem incindível (o meio ambiente) e impessoal, em relação ao qual coletividade tem um interesse primário. Novamente, surge aqui um vínculo estreito entre os membros do grupo, pois o bem é incindível, na prática, de forma que todos os membros do grupo tem a mesma sorte. E, de igual modo, não existem concepções pessoais como centro de cognição da lide.

Muito bem. Esses direitos individuais derivados ou reflexos, de alcance coletivo e deduzidos em juízo nesse grau intenso ou estreito de indivisibilidade e impessoalidade, colocam alguns dos problemas teóricos mais graves enfrentados pelo processo civil da contemporaneidade.

Só para iniciar a enumeração desses problemas, é possível dizer que essa concorrência de demandas individuais, todas com alcance coletivo, implicaria um efeito carona invertido ou positivo. Como é cediço, no efeito carona, um indivíduo beneficia-se da iniciativa de outras pessoas na defesa de um bem coletivo em conflito, sem contribuir ou sem internalizar os custos da demanda judicial ${ }^{493}$. Na hipótese em tela, no entanto, o fenômeno do efeito carona é invertido. Por quê? Quanto mais ações individuais forem propostas, quão maior for a iniciativa individual dos membros do grupo em prol do bem comum, indivisível e impessoal, pleiteando o mesmo provimento jurisdicional, maiores as chances de sucesso. Lembra-se de que as partes são fungíveis, todos os indivíduos operam na qualidade de membros do grupo. Logo, se qualquer deles lograr êxito, também logrará êxito a coletividade como um todo, inclusive seus membros.

493 Os caronas ou free-riders são "aqueles que buscam se beneficiar da iniciativa de outras pessoas na defesa do bem comum em disputa, o qual, caso se concretize os abrangerá, sem qualquer custo ou compensação" (SALLES, Carlos Alberto de. Execução judicial em matéria ambiental. São Paulo: Revista dos Tribunais, 1998. p. 129). 
A coletividade como um todo e, com isso, também os seus membros individuais, aproveitamse, como se fosse carona, da proteção dos direitos ou interesses individuais de alcance coletivo realizado por outro indivíduo, pois há uma pluralidade de interessados na mesma controvérsia.

Em segundo lugar, sob o ponto de vista da parte adversa ao grupo, se admitida essa concorrência de demandas individuais idênticas, com alcance coletivo, sem o reconhecimento necessário da litispendência, da coisa julgada coletiva ou de uma técnica de agregação, seria ele uma eterna vítima, um eterno refém da coletividade, não lhe adiantando defesa alguma no processo. Se ele não sucumbir na primeira demanda, basta sucumbir na segunda, que todos serão beneficiados. Afinal, presente essa incindibilidade e essa impessoalidade tão intensas, de que se tratou nesse tópico, típica das tutelas inibitórias ou da obrigação de não fazer, é inviável excluir alguém, mesmo que sucumbente em demanda individual, do grupo de beneficiados.

Se um indivíduo ajuizar uma demanda, pleiteando a invalidade do edital de um concurso público que não reservou cota para afrodescendente, mesmo que pendente uma ação coletiva ou várias outras demandas individuais sobre a mesma controvérsia, qual seria o seu interesse em desistir da ação individual ou suspender a sua tramitação para aguardar o julgamento das demais demandas? A resposta é fácil: nenhum interesse esse indivíduo teria em fazer isso. Afinal, quão maiores forem as iniciativas individuais em alcançar a nulidade do edital, maiores as chances de o indivíduo lograr a vitória e, com ele, todo o grupo e todos os seus integrantes.

Mesmo que um indivíduo venha a sucumbir na sua demanda, o outro que lograr a invalidade do edital beneficiará, invariavelmente, o primeiro, como se o próprio fosse sagrado vencedor.

E, isso não é anedota. Quem dera fosse. Trata-se, na realidade ${ }^{494}$, de episódio frequente no Poder Judiciário, principalmente nessas hipóteses de concurso público. Passa-se à narração do caso.

Trata-se de uma ação coletiva em trâmite, proposta pelo Ministério Público, pleiteando a cessação do desvio funcional dos assessores comissionados da Procuradoria Municipal de Guarapari. O Ministério Público alega que os assessores exercem, no contencioso administrativo, as mesmas funções dos procuradores municipais concursados, o que viola a regra constitucional de provimento dos cargos públicos por concurso de provas e títulos. A

494 A relação do terceiro no processo é, especialmente, complexa, segundo Teresa Arruda Alvim, nos casos que envolvem controvérsias a respeito de concurso público (Cf. WAMBIER, 2004, p. 1040). 
partir do momento em que cessar o desvio funcional, o Município deverá proceder à nomeação dos candidatos concursados, segundo a ordem de classificação. Porém, além dessa ação coletiva, há várias demandas individuais idênticas, propostas pelos candidatos aprovados no último concurso para a Procuradoria Municipal de Guarapari, alegando os mesmos argumentos. Alega-se a preterição dos candidatos concursados e pleitea-se a cessação do desvio funcional dos assessores comissionados. Se qualquer uma dessas demandas for julgada procedente e os cargos em desvio de função forem desocupados, a administração municipal deverá proceder à nomeação dos candidatos, segundo a ordem de classificação. Logo, se um candidato sucumbir em sua demanda individual, a sucumbência não lhe prejudica necessariamente. A procedência de qualquer outra demanda individual concorrente ou a procedência da ação coletiva irá lhe aproveitar, pois a nomeação deverá observar sempre a ordem classificatória. Basta uma sentença favorável para que o grupo inteiro, inclusive o indivíduo sucumbente, seja beneficiado.

Todas essas demandas são idênticas, muda apenas o nome da parte. Todas buscam a cessação do desvio funcional dos assessores comissionados, sob o argumento de violação à regra constitucional do concurso público. Procedente uma demanda, a cessação da prática abusiva e a, consequente, restauração da regra constitucional do concurso público, alcançará todos os candidatos. E, a eventual nomeação para os cargos de Procuradores Municipais, agora vagos, deverá ser realizada observando a ordem de classificação no concurso público, o que inclui, invariavelmente, o candidato sucumbente na demanda individual, se classificado nessas vagas.

Kazuo Watanabe ${ }^{495}$ relata situação similar, agora em relação à cessação da poluição ambiental. O mesmo fato lesivo e a pretensão de cessação da poluição ambiental poderia ser, em tese, formulada em uma ação coletiva e em várias ações individuais concorrentes. Isso implicaria um verdadeiro bis in idem, bem como conflitos práticos, intoleráveis pelo sistema processual.

Em terceiro e último lugar da problemática posta nesse tópico, pode-se assegurar que essa situação é nefasta para o Poder Judiciário. São várias demandas atomizadas e dispersas, veiculando uma mesma controvérsia incindível e impessoal. Há possibilidade de conflito prático de julgados e corre-se o risco de o Poder Judiciário virar uma verdadeira casa de apostas. 
O indivíduo tenderá a propor a sua ação individual, ainda que outras demandas individuais e coletivas idênticas já tenham sido propostas, pois uma ação a mais, é uma chance a mais de vitória e, quem sabe, dessa vez a demanda não é distribuída para um juiz mais benevolente. $\mathrm{O}$ lema seria “vamos todos tentar a nossa sorte!". E, se você perder? Basta ligar para um colega do mesmo concurso público, basta ligar para um vizinho e pedir a ele para também ajuizar uma ação individual, pleiteando a cessação do desvio funcional, pleiteando a cessação da poluição ambiental etc e, pronto, a sua chance individual de tentar ganhar será, mais uma vez, renovada.

O problema de ordem processual está posto em uma situação em que o grau de entrelaçamento ou de vinculação entre os membros do grupo é, particularmente, intenso e forte, facilmente caracterizável, pois a única diferença entre as demandas é o nome da parte. A controvérsia deduzida em juízo incide sobre bem indivisível e ela é postulada de uma forma impessoal, em que o indivíduo é um mero anônimo e se encarta, integralmente, aos atributos comuns do grupo ou coletividade. Não existem atributos pessoais em discussão nessa categoria.

Como resolver esse problema de ordem processual, nessa hipótese em que há reflexos individuais em relação substancial de caráter plurissubjetivo, indivisível e impessoal? Várias são as soluções sugeridas pela doutrina e as propostas realizadas para essa mesma problemática.

Talvez, uma primeira solução a ser meditada seja negar a possibilidade de persecução individual desses direitos individuais de alcance coletivo. Essa solução, porventura aventada, deve ser, prontamente, colocada de lado. Não é possível obstar a persecução individual do direito, pois a titularidade do direito é individual, apenas o alcance da relação substancial é que é coletivo, indivisível e impessoal. O indivíduo sofreu prejuízos em sua esfera própria, logo deve ser objeto de proteção jurídica. Ocorre que esse indivíduo foi impactado, na qualidade de membro do grupo e não pessoalmente, daí inferir-se o alcance coletivo dessa controvérsia. ${ }^{496}$

\footnotetext{
496 Nesse sentido, pondera Bedaque: "O legislador infraconstitucional, que se refere a interesses coletivos e difusos, aparentemente restringiu a legitimidade apenas àquele rol do art. 82. Mas essa limitação não pode chegar ao ponto de um interesse coletivo ou difuso com reflexo na esfera individual da pessoa, impedir ou obstar que essa pessoa venha buscar perante o Poder Judiciário a tutela do seu interesse individual, muito embora isso vá ter repercussão na esfera do interesse indivisível coletivo ou difuso. Estamos aqui diante da garantia constitucional ampla à inafastabilidade da Justiça" (BEDAQUE, José Roberto dos Santos. Legitimidade processual e legitimidade política. In: SALLES, Carlos Alberto de. Processo civil e interesse público: o processo como instrumento de defesa social. São Paulo: Revista dos Tribunais, 2003, p. 111).
} 
Uma segunda solução pensada seria restringir as espécies de provimento, não se permitindo ao indivíduo postular, por exemplo, uma tutela inibitória, mas apenas compensatória ou ressarcitória dos danos pessoalmente sofridos. Essa proposta é, ainda, inviável. Não é possível, aceitar a limitação dos provimentos deferidos aos indivíduos às hipóteses ressarcitórias. $\mathrm{O}$ indivíduo poderá pleitear a tutela que melhor se coaduna com a atuação do direito substancial, seja a eficácia do provimento jurisdicional declaratório, mandamental, constitutivo ou condenatório, seja a tutela inibitória, preventiva, repressiva ou compensatória pelos danos. ${ }^{497}$

Uma terceira solução seria identificar o direito com a pretensão. Ao invés de se abordar o direito como difuso, como coletivo, adotar-se-ia a expressão pretensão difusa, pretensão coletiva. Logo, o tipo de direito seria identificado pelo tipo de pretensão ou provimento jurisdicional pedido. Nesse ínterim, sempre que a pretensão fosse coletiva, a demanda também seria coletiva.

Novamente, essa solução não se apresente técnica, pois, como já consignou José Roberto dos Santos Bedaque ${ }^{498}$, o direito existe antes do processo. Não é possível falar em pretensão difusa, coletiva ou individual, mas apenas em direito difuso, coletivo ou individual. Se o direito fosse identificado pela pretensão, seria o mesmo que admitir que o direito substancial existe apenas e por ocasião do processo, restaurada a antiga e velhaca fórmula remedies precedes rights.

\footnotetext{
497 É inadmissível limitar a tutela jurisdicional de acordo com eficácia do provimento pretendido - declaratório, mandamental, constitutivo ou condenatório. Na realidade, a sentença será declaratória, constitutiva, condenatória ou mandamental de acordo com as circunstâncias da vida deduzidas em juízo, a respeito das quais se instaurou a controvérsia e pleiteia-se a proteção jurisdicional. (Cf. BEDAQUE, 2006, p. 31, MARINONI, 2010, p. 113, ARENHART, Sérgio Cruz. A tutela inibitória da vida privada. São Paulo: Revista dos Tribunais, 2000, p. 40 (Coleção Temas Atuais de Direito Processual Civil V. 2).

498 José Roberto dos Santos Bedaque salienta que há quem sustente que a distinção entre determinadas categorias de direito deve ser feita em função do tipo de tutela pleiteada. A qualidade individual, coletivo, difuso depende da pretensão, isto é, do tipo de tutela jurisdicional pretendida. Assim, um mesmo fato poderia originar uma pretensão difusa, coletiva e individual. Mas, isso é uma anomalia, continua Bedaque. De fato, interesses exigíveis diversos poderão advir do mesmo fato, no entanto o que caracteriza do direito como difuso, coletivo ou individual não é a pretensão, mas, sim, a unitariedade ou indivisibilidade prevista no direito substancial. É o tipo de direito que determinará o tipo de tutela. Há tutelas preventivas e reparatórias para todos os tipos de direito ou interesses. Tudo vai depender das circunstâncias concretas do caso. Se não fosse assim, chegar-se-ia ao absurdo de dizer que inexistem direitos difusos, coletivos ou individuais fora, ou antes, do processo. Eles surgiriam apenas com a formulação da pretensão pela tutela jurisdicional. O interesse é difuso, coletivo ou individual, independentemente do processo. Kazuo Watanabe, aliás, enfatiza que é a existência de direitos coletivos que implica um processo coletivo. O que vai determinar a tutela é a correta fixação do objeto litigioso do processo, isto é, o fundamento e os termos em que formulado o pedido e causa de pedir. Enfim, são as notas características dos direitos individuais e coletivos que vão determinar a espécie de tutela jurisdicional adequada (Cf. BEDAQUE, 2006, p. 40 e WATANABE, Kazuo. Do objeto litigioso das ações coletivas: cuidados necessários para sua correta fixação. In: MILARÉ, Edis (coord.). Ação Civil Pública Ambiental após 25 anos. São Paulo: Revista dos Tribunais, 2010).
} 
Ultrapassadas todas essas possíveis propostas, a solução que se apresenta mais adequada ao direito substancial deduzido nessa categoria- isso é ao menos o que se defende - seria a agregação processual ou molecularização compulsória das demandas individuais idênticas, incidentes sobre uma mesma relação substancial plurissubjetiva, indivisível e impessoal.

Se o interesse ou direito é de titularidade do indivíduo, não é devido afastar a legitimidade do indivíduo. Contudo, considerando que o conteúdo da controvérsia é objetivo e impessoal, sendo o membro do grupo fungível, a estruturação subjetiva da demanda pode ser alterada, pois não importa a identidade física do indivíduo para fins de resolução da controvérsia e adjudicação.

Eis aí a agregação ótima: identificado o alcance coletivo no direito substancial, o sistema único de agregação deve, por um de seus instrumentos, permitir a agregação processual dessa demanda, ainda que ela não tenha sido, originariamente, veiculada sob a forma coletiva. Tratase apenas de reconhecer, jurídica e formalmente, o alcance coletivo já presente na substância.

O pronunciamento judicial deve ser único e uniforme, pois o bem da vida protegido é único e impessoal. O indivíduo é objeto de proteção jurídica de per si, mas o processo deve ser necessariamente coletivo, evitando-se a multiplicidade de demandas idênticas concorrentes.

Situações substanciais como essa, que envolvem uma pluralidade de interessados em uma mesma relação incindível e impessoal, já justificam, atualmente, o litisconsórcio unitário e o concurso subjetivo de ações individuais. Ocorre que, agora, diante da nova dimensão das controvérsias de massa, novos instrumentos processuais devem ser pensados, sob pena de se incorrer nos problemas antes citados. Giuseppe Chiovenda ${ }^{499}$ já observara isso, ao afirmar que, a partir modelo do litisconsórcio unitário, poderia ser pensado o modelo da tutela coletiva.

É possível refletir, assim, em uma certificação de ofício dessas ações individuais como coletiva, buscando, dessa forma, uma agregação ótima da controvérsia de direito substancial. A agregação constituirá a técnica processual necessária (com menor restrição ou gravame à autonomia individual) e adequada (mais idônea) ao direito substancial deduzido. A participação direta das partes interessadas, além de impraticável, não seria uma providência necessária, dada

499 CHIOVENDA, Giuseppe. Instituições de Direito Processual Civil. V.1. Tradutor Paolo Capitanio. Anotações de Enrico Tullio Liebman. São Paulo: Bookseller, 1998. 
a impessoalidade da relação substancial por todos comungada. Enquanto os indivíduos forem anônimos e a relação substancial não disser respeito aos atributos pessoais ou particulares dos sujeitos, os membros do grupo são fungíveis entre si, pois todos farão referência ao status do grupo, aos atributos e as características compartilhadas pelo grupo, sem gravames pessoais.

A participação individual é exigível quando o direito também é pessoal, pois ninguém melhor do que o indivíduo para deduzir a controvérsia que diga respeito à sua pessoa. Recorda-se da metáfora do vestido de noiva. O direito individual é como um vestido de noiva, feito por um estilista. Se o vestido é feito sob medida, ninguém melhor do que o indivíduo para vesti-lo.

O direito individual de alcance coletivo, ora abordado, não se equipara a um terno ou a um vestido de noiva estilizado. Não é mais produto artesanal. Agora, estamos diante de um direito derivado ou reflexo. Esse novo enfoque substancial permite, portanto, conferir uma maior racionalidade ao tratamento do direito individual de alcance coletivo, sem que isso represente um prejuízo ao indivíduo, que não mais aparece nesse cenário de forma pessoal ou particular.

Como se argumentou, ainda que seja possível reconhecer o direito coletivo como categoria própria, esse direito não permanece desvinculado dos interesses ou direitos individuais. São situações plurissubjetivas que sempre existiram no processo e foram inicialmente tratadas na ação popular, nas ações medievais e, no período moderno, foram, em muito, tratadas pelo litisconsórcio. Mas, hoje, diante da dimensão das controvérsias de massa, não é mais factível impor o litisconsórcio a todas as situações unitárias, não é possível litisconsorciar a sociedade.

A regra do litisconsórcio e a regra das ações individuais concorrentes podem e devem ser derrotadas quando impraticáveis em dado caso concreto, quando infactíveis e, até mesmo, quando desnecessária for a participação de todos os interessados. Por essa razão, é que podem ser pensados em outros instrumentos para a molecularização da controvérsia ou agregação.

Frise-se que a participação direta somente é, realmente, necessária, sob o ponto de vista constitucional, quando cada indivíduo tem o condão de influenciar o magistrado com argumentos pessoais, com fundamento nas suas características peculiares. Esse não é o caso do interesse ou direito individual de alcance coletivo, de que se tratou acima, pois esse direito incide sobre bem de natureza indivisível, que impacta o sujeito de forma impessoal, como membro da comunidade. As partes operam pelo status do grupo, de forma anônima, logo se os 
seus nomes forem substituídos na demanda, isso não teria o condão de influenciar a convicção do magistrado, que deverá conhecer os argumentos comuns e aplicáveis à categoria como toda.

De qualquer forma, a partir do momento em que a ação individual for coletivizada, o Ministério Público atuaria nessa hipótese, obrigatoriamente, como custus legis, a quem incumbe a defesa da ordem jurídica, do regime democrático e dos interesses sociais e individuais indisponíveis.

A participação ministerial afastaria eventuais riscos de conluio entre as partes, bem como, em caso de desistência da demanda pelo indivíduo, o Ministério Público poderia assumir, subsidiariamente, a condição de parte, conduzindo esse processo de interesse público. ${ }^{500}$

Por fim, tratando-se de demanda individual com alcance coletivo, os institutos da coisa julgada e da litispendência operariam de forma similar à ação popular, alcançando todos os membros do grupo, de forma a não advir aquele efeito carona que se denominou de invertido ou positivo.

A partir do momento em que ação individual é coletivizada, o regime aplicável a essa ação, originariamente individual, será necessariamente o mesmo daquele das ações populares e das ações coletivas para direitos difusos. Mantém, pois, o mesmo regime processual hoje aplicável.

Aliás, já existem prestigiosas doutrinas processuais, pugnando pela litispendência e pela coisa julgada erga omnes e prot et contra nas hipóteses de litisconsórcio unitário e concurso subjetivo de ações. Barbosa Moreira ${ }^{501}$, Ada Pellegrini Grinover ${ }^{502}$ e Kazuo Watanabe ${ }^{503}$ já salientaram,

\footnotetext{
500 Nessa hipótese, é ponderável uma espécie de ação civil pública subsidiária. O Ministério Público ou qualquer outro legitimado coletivo poderia ter agido, com primazia, em defesa de uma relação substancial incindível e impessoal, mas não o fez. O indivíduo ajuizou a ação individual com alcance coletivo e essa ação individual, por força da relação substancial controvertida, foi coletivizada. Se o indivíduo desistir da ação, morrer e os seus herdeiros não tiverem interesse em se habilitar ou surgir qualquer outra causa extintiva com fundamento subjetivo (inadequação ou negligência da parte), o Ministério Público poderia retomar a titularidade da ação. Mas, de qualquer forma, sendo ele titular ou não da demanda, a sua participação já seria, invariavelmente, assegurada como custus legis, como já salientado no corpo do texto. E, por fim, se o Ministério Público propuser, diretamente, a ação coletiva nessa hipótese, sendo obstadas as demandas individuais idênticas, o mesmo raciocínio se aplica. É preciso, igualmente, de uma medida para resguardar o indivíduo, pois o membro do Ministério Público também é suscetível de ser negligente ou omisso (perder o prazo de um recurso, por exemplo). Nesse caso, poderia ser formado um comitê com outros legitimados coletivos e também por alguns dos indivíduos interessados na demanda para fins de monitorá-la. De igual modo, poderiam ser realizadas audiências públicas para que os indivíduos se manifestem sobre o conflito de interesses. E, ainda, caso sobrevenha uma negligência ministerial, esse comitê seria intimado para suprir a falta ou manifestar a sua ausência de interesse na causa ou na prática desse ato processual.
}

501 MOREIRA, 1972, p. 138.

502 GRINOVER, 2005, p. 6.

503 WATANABE, 2007, p. 159-160. 
lembrando lição de Chiovenda ${ }^{504}$, que a identidade da qualidade (o indivíduo opera como membro do grupo) ocupa o lugar da identidade da pessoa. Se a autoridade da coisa julgada se forma em relação a um, exclui-se a ação dos outros, sob pena de conflito prático de julgados.

O raciocínio aqui é o mesmo. O pedido é acolhido, a sentença prevalece em definitivo para todos os membros do grupo. O pedido é rejeitado, o objeto incindível e a relação substancial impessoal não poderão mais ser rediscutidos em juízo. Em caso de demandas individuais objetivamente idênticas - suscetíveis de coletivização - aplicar-se-á a coisa julgada coletiva e a litispendência coletiva. Assim sendo, frisa-se que o regime é o mesmo das ações coletivas.

Essa mesma lição já estava presente no direito romano, no direito costumeiro medieval e foi, apenas, camuflada no direito moderno. Agora, na contemporaneidade, está de volta com força, para permitir o processamento das controvérsias de massa que abarrotam o Poder Judiciário. E, como diz Ada Pellegrini Grinover ${ }^{505}$, não há como fugir disso, é a natureza das coisas. Noutros termos, é direito substancial que segue determinado a forma processual necessária e adequada. Por fim, mais uma consideração deve ser realizada nesse tópico. Tratou-se aqui de uma espécie de vinculação intensa entre os membros do grupo, pois as demandas individuais apresentam alcance coletivo, com reflexos em uma relação substancial incindível e impessoal. Disse, ainda, que essa incindibilidade e impessoalidade são intensas, principalmente, nas tutelas inibitórias.

Mas, é bom não confundir, quando se disse que essa comunhão é marcante nas tutelas inibitórias, não se está restringindo a unitariedade a essa espécie de tutela ou à sentença mandamental. O que se disse é que, quando a relação substancial individual é deduzida nesse grau de incindibilidade e impessoalidade, em que não há sequer antagonismos na classe, como ocorre nas hipóteses de inibição, a identificação da unitariedade é marcante. É fácil de ser percebida. Não tem como cessar algo, anular alguma coisa, remover um ilícito, cumprir uma obrigação de não fazer de uma forma diferente para cada indivíduo. O sistema é binário, ou cessa para todo mundo, ou não cessa para ninguém, ou inibe para todo mundo, ou para ninguém.

A caracterização da incindibilidade ou da impessoalidade é muito simples nesse caso. Como salienta os Princípios do Litigância Agregada ${ }^{506}$, uma ordem inibitória ou proibitória 
(prohibitory injunctions) se encaixa, com perfeição, ao tipo de indivisibilidade e impessoalidade ideal aqui tratada. A categorização desse direito individual de alcance coletivo não requer tanto a atenção do julgador, pois identificação do objeto litigioso é, por vezes, óbvia.

Mas, é preciso continuar, agora, o raciocínio relativo aos diferentes graus de vinculação existentes entre os membros do grupo em uma relação substancial plurissubjetiva. Outras relações unitárias existem, não só aquelas do tipo indivisível e impessoal antes mencionadas.

\subsubsection{REFLEXOS EM RELAÇÃO SUBSTANCIAL INDIVISÍVEL $\quad \mathrm{E}$ POTENCIALMENTE IMPESSOAL}

A identificação do direito individual de alcance coletivo não é tão simples quanto foi citado no tópico anterior. Há hipóteses em que há dúvidas, há antagonismos, há controvérsia na classe.

Em alguns casos, um direito individual incide sobre um bem da vida de natureza indivisível e, de igual modo, a relação jurídica de direito substancial é deduzida em juízo de forma impessoal.

Noutros casos, todavia, embora o direito individual continue apresentando reflexos em um bem de natureza indivisível, a forma pela qual essa relação jurídica substancial é deduzida em juízo é apenas potencialmente impessoal. Explica-se. A impessoalidade deve ser alcançada da mesma forma que ocorreu no tópico anterior dessa investigação, mas há um risco maior de antagonismo entre indivíduos ou entre subgrupos presentes na comunidade ou na coletividade social.

A comunhão e a unitariedade não são menores aqui. Os indivíduos continuam operando como membros de uma coletividade. Mas é possível que surja, entre eles, diferentes concepções sobre a forma de proteção jurídica a ser conferida ao grupo naquela hipótese concreta. O destino organizacional do grupo é matéria de intensa conflituosidade, ainda que, ao final, apenas uma solução uniforme, unitária, incindível, global e impessoal deva ser adotada para todos em igual.

Mais um exemplo: imagine uma situação em que o autor de uma demanda individual pleiteia uma tutela específica de uma obrigação consistente na reestruturação do sistema de saneamento básico do seu bairro. As frequentes enchentes no bairro colocam em risco a sua saúde, bem como ensejam prejuízos à sua propriedade. E, por essa razão, o autor deduz, em juízo, a 
pretensão de reparação da rede de esgoto e drenagem do bairro, para que seja providenciada a limpeza dos bueiros daquela localidade, de forma a facilitar o escoamento das águas da chuva.

A relação jurídica substancial deduzida nessa demanda incide sobre bem indivisível e é potencialmente impessoal, pois a rede de saneamento e esgoto é a mesma para toda a comunidade. Mas, a solução a ser adotada nesse caso não é mais binária, entre 0 e 1 . Cada membro da comunidade pode ter uma concepção diferente sobre como deve ser reformulado o sistema de saneamento básico. Um vizinho pode entender que basta a limpeza dos bueiros, outro vizinho pode pleitear a dragagem de um pequeno córrego próximo a comunidade etc.

Quando há a necessidade de implementação de uma alteração estrutural em um objeto ou em serviço indiviso, como a reestruturação do sistema de esgoto e drenagem de uma comunidade, podem surgir diferentes concepções sobre como fazê-lo (enforcement) entre os indivíduos ou os grupos da coletividade, que identificam meios diferentes para a implementação pretendida.

Nesse caso, em que se postula uma tutela específica da obrigação ou, na forma denominada pelo sistema estadunidense, uma afirmative injunction ou strutural injunction, a agregação continua sendo uma técnica necessária, pois todas as posições individuais devem confluir para a mesma situação substancial de natureza indivisível, isto é, apresentam um alcance coletivo. ${ }^{507}$

Nesse contexto, os direitos individuais apresentam-se como reflexos dos direitos coletivos e o indivíduo, ainda, opera como membro da coletividade. Ocorre que os indivíduos e eventuais subgrupos revelam concepções diferentes sobre a proteção jurídica devida. Embora muitos sejam os fundamentos para a reestruturação do bem, não é possível estabelecer uma rede de esgoto para cada um dos indivíduos ou subgrupos. Todos usufruem juntos do mesmo bem.

Como assevera Owen Fiss ${ }^{508}$, na afirmative ou strutural injunction alega-se a presença de uma ilegalidade ou de uma inconstitucionalidade que residiria na própria ordem ou estrutura do bem ou objeto indiviso. Pleiteia-se, por isso, um novo desenho, uma nova estruturação a ser conferida a esse objeto, que embora preexistente, deve agora ser reformulado dentro dos padrões legais ou constitucionais, em tese, aplicáveis ao caso narrado pelos interessados.

507 AMERICAN LAW INSTITUTE, 2010, p. 119.

508 FISS, Owen M. The civil rights injunction. Bloomington: Indiana University Press, 1978, p. 11. 
Ainda, segundo Fiss ${ }^{509}$, os pronunciamentos judiciais, nessa hipótese, tendem a ser mais específicos, mas ainda são potencialmente impessoais. No caso da segregação escolar nos Estados Unidos, por exemplo, não bastava dizer que o sistema escolar não poderia estabelecer discriminação mediante a separação de pessoas de raças diferentes em escolas diferentes. Era preciso dizer como transformar um sistema escolar dual em um sistema unitário e não discriminatório de ensino. Nesse momento, surge uma maior controvérsia entre os indivíduos do grupo ou entre os eventuais subgrupos no tocante à proteção jurídica a ser conferida a eles, enquanto membros do grupo racial. Mas, de qualquer modo, ainda que surja um antagonismo, a controvérsia não se estabelece em relação às particularidades de um indivíduo ou de um conjunto de indivíduos, mas, sim, em relação ao próprio grupo racial. Não são as características pessoais do indivíduo que definirão os contornos do sistema escolar unitário. O que definirá o novo sistema escolar, unitário e não discriminatório, são considerações potencialmente impessoais sobre os atributos do grupo e sobre a forma de se promover a sua inclusão no ensino.

Para a caracterização do direito mencionado nesse tópico, há que se atentar - passe o truísmo para a caracterização da natureza indivisível e potencialmente impessoal da situação de direito substancial. Nos exemplos anteriormente dados, existem bens de natureza indivisível que impactam os indivíduos de forma impessoal, como é o caso a rede de esgoto e drenagem de um bairro, bem como é o caso da reestruturação do sistema escolar. Embora a questão controvertida possa ser objeto de antagonismo dentro do grupo, o bem continua a apresentar natureza indivisível e potencialmente impessoal, ou seja, a proteção jurídica deve superar as concepções individuais, porventura existentes, para angariar uma concepção comum ou coletiva, definindo o destino organizacional de um bem ou de serviço que afeta toda uma comunidade.

Caso interessante sobre essa categoria ocorreu no sistema jurídico estadunidense. No precedente Ayers v. Thompson ${ }^{510}$, uma ação coletiva foi proposta pelos afrodescendentes do Mississipi, em face do Governador do Estado e do Conselho Educacional de Ensino Superior, pretendendo a reestruturação igualitária do sistema universitário. O sistema educacional do

509 FISS, 1978, p. 13-15 (The beneficiary of the typical civil right injunction is not a individual, or even a collection of identifiable individuals, rather it is a social group -the blacks. The contours of the benefited group are determined not by their personal characteristics of the person who happens to be the named plaintiff, but rather by considerations of who should - as a matter of fairness, efficacy and equal protection theory - receive the benefit).

510 RENDLEMAN, Doug. Complex litigation: injunctions, structural remedies and contempt. New York: Thomson Reuters, 2010, p. 508 et seq. 
Mississipi contava com cinco universidades para brancos e três universidades para negros. Essa ação de classe foi certificação na categoria 23(b), que não admite a autoexclusão dos indivíduos.

$\mathrm{Na}$ ocasião, foi realizado um acordo, formando um fundo de US\$ 500 milhões de dólares para iniciar a reestruturação do sistema universitário, segundo o planejamento elaborado. A Corte Distrital aprovou o acordo. Vários litigantes individuais recorreram, todavia, para que o acordo fosse revertido e para que fossem excluídos da demanda e, assim, pudessem litigar de forma autônoma a controvérsia. Eles não estavam satisfeitos com a extensão das medidas adotadas.

É preciso destacar que foi feito um plano para eliminar a segregação racial existente no sistema educacional, plano esse considerado adequado e razoável pela Corte de Justiça. O plano envolvia novos critérios admissionais nas Universidades, programas acadêmicos adicionais, bem como oferta de novos cursos em algumas universidades. Os indivíduos recorrentes estavam, no entanto, insatisfeitos pelo fato de não terem sido oferecidos, por exemplo, os programas de Direito e de Farmácia na Jackson State University, bem como insatisfeitos com outras medidas adotadas. Mesmo diante dessa insatisfação, não foi admitida a exclusão dos membros da classe, pois não era possível existir demandas pessoais sobre a controvérsia. $\mathrm{O}$ sistema educacional era único e era preciso alcançar uma concepção impessoal para a reestruturação desse sistema, independentemente das concepções próprias de cada um do grupo.

John Bronsteen e Owen Fiss ${ }^{511}$ salientam que, em alguns casos, é possível o exercício abusivo do direito de autoexclusão (opt out) pelo indivíduo, o que deve ser negado. O indivíduo pretende, por vezes, a exclusão da classe exatamente para buscar, no futuro, a "second bite at the apple" ${ }_{512}$, isto é, uma segunda mordida na maçã, uma nova chance de litigar uma controvérsia idêntica, ou seja, incindível e potencialmente impessoal. Se o indivíduo excluir-se da ação de classe e esta for vitoriosa, ele se beneficia. Se o indivíduo excluir-se da ação de classe e a classe sucumbir, ele (e toda a classe) tem uma segunda chance de alcançar a mesma medida pretendida anteriormente pelo grupo, bem como alcançar outras providências que ele julgar necessárias e, de fato, lograr obtê-las com um segundo juiz, mais simpático à causa.

511 BRONSTEEN, John, FISS, Owen M. The class action rule. Notre Dame Law Review, 2003, V. 78: 14191454p. p. 1443.

512 Ibidem, p. 1443. 
Se cada indivíduo pretender alcançar a sua concepção do que é melhor para o grupo, a controvérsia será eterna e o sistema, a ser reestruturado, ficará instável, suscetível a modificações casuísticas. Por isso, deve ser alcançado o senso do que constitui o bem comum e impessoal ao grupo. O que é comum e impessoal será matéria, porém, de intensa controvérsia.

Independentemente dos antagonismos presentes no grupo, a agregação processual - como a coletivização das ações individuais - é tão necessária e adequada quanto na categoria anterior. A agregação é medida que se impõe, pois, do contrário, a controvérsia seria infinita, não acabaria nunca, pois cada indivíduo, pertencente ao grupo, poderia pretender litigar a sua concepção própria a respeito da proteção jurídica devida a ele e a todos os demais membros do grupo. A agregação é, assim, medida imposta pelo direito substancial. E, mais uma vez, Fiss ${ }^{513}$ arremata esse argumento ao dizer que a técnica de agregação não é aqui mera roupagem processual, mas exigência da dimensão coletiva do direito substancial. É "forma que segue a substância" ${ }^{14}$.

O instrumento de agregação escolhido deve, por sua vez, ser adequado às peculiaridades dessa relação substancial e, com isso, preocupado em extrair da comunidade os vários argumentos possíveis e potencialmente impessoais (suscetíveis de abstração para todo o grupo) para conferir a proteção jurídica pretendida. $\mathrm{Na}$ ação coletiva estadunidense, apenas para ilustrar, um mecanismo bastante utilizado para isso é a formação de subclasses no processo, de acordo com as concepções e os eventuais antagonismos surgidos dentro da coletividade. De igual modo, é possível ponderar a oferta de contraditório coletivo, como audiências públicas e intervenção de amicus curiae e a participação de comitê popular para o monitoramento do programa adotado.

$\mathrm{Na}$ fase de implementação da tutela específica, poderá ser nomeado um perito do juízo (special master), para zelar pelo cumprimento da sentença, elaborando relatórios sobre o cumprimento da obrigação e prestando informações ao magistrado sobre o andamento dos trabalhos e, de igual modo, para manter atualizados um comitê popular de monitoramento do programa.

Caso existam ações individuais pendentes relativas à controvérsia incindível e potencialmente impessoal, essa demandas individuais poderiam ser consolidadas. Nas demandas individuais 
pendentes, é possível que os autores tenham deduzido argumentos e concepções diferentes atinentes à própria categoria. Esses argumentos - que nada mais são do que o exercício coletivo do contraditório - devem ser reunidos por uma técnica de agregação. Assim, por força da consolidação, uma dessas demandas individuais seria selecionada como processo mestre e as questões comuns, presentes nas demais demandas individuais pendentes, poderiam ser trazidas ao bojo do processo mestre. Por fim, à semelhança do sistema estadunidense, poderia ser formado um conselho de advogados, um comitê de autores e réus, bem como determinada a apresentação de petições unitárias e uniformes no processo mestre, evitando o retrabalho.

Veja que, nessa hipótese, há uma maior preocupação com a instrução da ação coletiva e com a reunião dos interesses representativos do grupo $^{515}$. O magistrado, a quem pertence a defining function $^{516}$ no processo, deve conhecer o grupo cujos interesses foram submetidos à apreciação jurisdicional, buscando alcançar, além da solução da controvérsia, o escopo de pacificação.

\subsubsection{REFLEXOS EM RELAÇÃO SUBSTANCIAL PARITÁRIA E IMPESSOAL}

A primeira hipótese de direitos individuais, com alcance coletivo mencionado, diz respeito à demanda individual incidente sobre relação substancial indivisível, deduzida de modo impessoal. O indivíduo defende o seu interesse ou direito e, simultaneamente, defende o interesse ou direito da coletividade, pois opera como membro do grupo ou da coletividade.

A segunda hipótese, por sua vez, diz respeito à demanda incidente sobre bem de natureza indivisível, deduzida de modo potencialmente impessoal. Embora surjam diferentes concepções sobre a proteção devida a um mesmo interesse ou direito, a implementação desse último deve superar as concepções individuais para angariar uma concepção comum ou coletiva, definindo as características e o destino do bem de natureza incindível, igualmente para todo o grupo.

As duas categorias, acima citadas, tratam de um objeto que, na prática, é insuscetível de divisão.

515 Susan Sturm ressalta que há uma maior demanda por participação nas hipóteses em que é possível influenciar o convencimento do juiz na implementação do remédio jurídico, como ocorreu no caso de segregação escolar. (Cf. STURM, Susan. The promisse of participation. Iowa Law Review, 1993, V. 78, p. 981).

516 A defining function é poder-dever do magistrado de realizar a correta identificação do direito coletivo controvertido, de forma a aferir a comunhão de interesses, a homogeneidade do grupo, a representação adequada, bem como determinar as diligências necessárias a suprir eventuais vícios ou, até mesmo, negar a certificação coletiva para que a causa prossiga como ação individual apenas. (Cf. VIGORITI, 1979, p. 269). 
Mas, o coletivo não se limita à indivisibilidade prática. É possível identificar um direito individual de alcance coletivo, mesmo nas hipóteses em que o bem da vida pretendido for, na prática, divisível entre os indivíduos ${ }^{517}$. Isso, por sua vez, merece uma explicação detalhada.

O objeto de uma relação substancial plurissubjetiva pode ser divisível ou fragmentável entre os indivíduos. Mas, ainda que esse objeto seja, na prática, fragmentável entre os sujeitos interessados, o direito substancial exige, necessariamente, a observância da paridade, objetividade e impessoalidade entre todos os membros de um grupo de interessados.

O fundamento do direito substancial é, necessariamente, paritário e impessoal, aplicável ao grupo como todo. Nessa hipótese, o indivíduo, ainda que possa lograr, na prática, um benefício somente para si, deve operar, por força de exigência normativa, como membro de um grupo.

Na categoria ora abordada, essa paridade e impessoalidade são induvidosas. A exigência da paridade e da impessoalidade depreende-se das próprias peculiaridades do direito substancial. Contudo, mais do que isso, há um comando normativo expresso e específico no sentido exigido.

O exemplo mais clássico é a massa falida. O direito substancial exige, por força de um comando normativo expresso e específico dirigido à falência, a observância da paridade e da impessoalidade no grupo de credores. E, não só, o direito processual também estabelece um procedimento específico e diferenciado para o concurso de credores na hipótese de falência, de forma a conferir aos membros do grupo um tratamento obrigatoriamente paritário e impessoal.

Esse exemplo é mencionado por John Finnis ${ }^{518}$, como hipótese ideal de justiça distributiva, na qual se estabelece uma ordem de alocação de ônus e recursos comuns à coletividade. Finnis ${ }^{519}$ desenvolve essa hipótese com fundamento no direito inglês, mas a analogia é válida aqui.

Finnis $^{520}$ salienta que o direito material exigível pelos credores na falência estabelece uma ordem paritária incidente sobre os fundos do devedor insolvente, que deve ser observada por todos. Os credores do devedor insolvente fazem jus ao respeito dessa ordem paritária, em que

517 VIGORITI, 1979, p. 21.

518 FINNIS, John. Natural law and natural rights. 2 ed. New York: Oxford University Press, 2011, p. 188-192. No mesmo sentido, LOPES, 2001, p. 64.

519 FINNIS, op. cit., p. 188-192.

520 FINNIS, op. cit., p. 188-192. 
a apropriação do fundo pecuniário, embora divisível, deve ser realizada de forma objetiva e igualitária, com fundamento no grupo como um todo. Por essa razão, esse fundo, de interesse de todos os credores, é objeto de um procedimento específico que irá culminar com a repartição proporcional ou igualitária dos recursos segundo as ordens de créditos e de classes de credores.

Essa regra da falência veio substituir outro procedimento. Segundo Finnis ${ }^{521}$, antes da falência, qualquer credor poderia pleitear a prisão do insolvente, para que a obrigação fosse cumprida por coerção. Ocorre que a prisão do insolvente não permitia, ao devedor, adotar qualquer providência no sentido de melhorar a sua situação financeira e adimplir a obrigação. E, de igual modo, essa forma de cumprimento da obrigação era prejudicial aos interesses dos demais credores, pois o crédito, insuficiente para pagar a todos, ficaria com aquele que primeiro tomasse a iniciativa para a ação. $\mathrm{O}$ direito de crédito dos demais credores restaria frustrado.

A falência, nesse contexto, teve por escopo realizar duas espécies de justiça: a justiça comutativa, corretiva ou redistributiva, que visa a devolver, corrigir ou restaurar a ordem violada, permitindo a satisfação do direito de crédito de um indivíduo, bem como a justiça distributiva, que visa a estabelecer uma ordem de alocação dos recursos comuns entre todos os interessados do grupo. Os benefícios são distribuídos entre todos e o risco é diluído para todos.

Assim, para que um credor obtenha, no processo, a satisfação do seu crédito em face do devedor insolvente, ele deverá propiciar com a sua ação a satisfação equitativa de todos os demais credores. O direito substancial reconhece uma ordem paritária ou comum ao grupo, bem como estabelece prioridades entre determinadas categorias, elementos que devem ser observados no processo que visa ao rateio proporcional dos fundos financeiros do devedor insolvente.

O objeto de proteção é, assim, fragmentável em direitos individuais, gerando um direito de crédito para cada um dos indivíduos. Forma-se, assim, um feixe de interesses ou direitos individuais. Mas, esses interesses ou direitos não podem se dispersar, pois eles devem andar ou caminhar juntos, já que ninguém pode correr na frente do outro ${ }^{522}$. São feixes fragmentáveis,

521 FINNIS, op.cit., p. 188.

522 Em regra, diz Nagareda, é possível que um crédito corra na frente do outro, pois não há empecilho para que outro credor também obtenha o adimplemento da sua obrigação para com o devedor em momento posterior. A situação, no entanto, se modifica diante de um fundo limitado. Nesse caso, o "direito de correr" de um indivíduo conflita com o direito de adimplemento do outro. Por essa razão, todos devem receber o seu crédito de uma forma paritária, pois a ninguém é dado exaurir o crédito, apenas porque agiu primeiro. Nessa hipótese, não é possível exclusão do indivíduo do grupo de credores, pois uma exclusão equivaleria a conceder uma prerrogativa a esse 
mas, por razões substanciais, caminham emparelhados, partindo todos de um mesmo ponto de igualdade no sistema jurídico. A relação substancial é, portanto, incindível normativamente.

A incindibilidade, nesse caso, não decorre da natureza de um bem comum ou coletivo, isto é, da impossibilidade física de um bem ser fruível ou apropriável por apenas um indivíduo. A incindibilidade decorre do caráter paritário e impessoal da posição de vantagem prevista na norma jurídica de direito substancial, que se fundamenta no grupo como um todo e não no indivíduo. Como a alocação dos ônus e recursos é pensada sob a dimensão coletiva, na hora da distribuição desses recursos, essa dimensão coletiva, paritária e impessoal, deve ser observada.

No caso da massa falida, não pode ser negada a compensação de um indivíduo apenas porque outro agiu primeiro, exaurindo o fundo comum. A paridade deve ser observada no processo de rateio do fundo. E, mais uma vez, o processo apenas acompanha a natureza da substância.

A massa falida é um caso muito simples e facilmente identificável nessa categoria de direitos individuais incidentes sobre relação substancial impessoal e paritária. Todos os indivíduos devem respeito à igual posição de vantagem do outro indivíduo do grupo, sem furar a fila. $\mathrm{O}$ próprio legislador impede o fenômeno do fura-fila, estabelecendo o processo de rateio do fundo.

Há hipóteses, no entanto, em que o direito substancial estabelece uma ordem distributiva, paritária e impessoal dos recursos comuns, aplicável com fundamento no grupo como um todo. Mas, no entanto, não se estabelece, de forma correlata, um processo diferenciado de rateio, que propicie conferir esse tratamento paritário aos membros do grupo na mesma dimensão do direito substancial. Recorre-se, portanto, aos instrumentos processuais atípicos de agregação.

Se a controvérsia envolver poucos interessados, os instrumentos processuais clássicos de agregação, já previstos no sistema jurídico, como o litisconsórcio e a conexão, conferem uma resposta adequada. $\mathrm{O}$ mesmo não se pode dizer para as controvérsias de massa multitudinárias.

São vários os exemplos em que o direito substancial estabelece expressamente uma ordem distributiva paritária e impessoal, de grande escala. Imagine uma questão envolvendo um

indivíduo do cobrar o seu crédito sozinho e na frente dos demais interessados, o que não é admissível pela ordem determinada pelo direito substancial (Cf. NAGAREDA. Richard. The preexistence principle and the structure of class action. Columbia Law Review, 2003, V. 103: 149-242p. p. 229-230). 
reajuste de um seguro coletivo de vida, de um plano de saúde coletivo, um concurso público, uma licitação com muitos candidatos, uma política pública, a tarifação de um serviço público.

Para todos esses casos, não existe procedimento molecular diferenciado ou típico, o que faz com que os profissionais do direito lancem mão dos instrumentos processuais tradicionais de agregação, os quais são, notoriamente, insuficientes. Nesse caso, é preciso realizar a agregação ótima: manejar uma técnica processual que seja necessária e adequada à tutela do direito substancial que, embora individual, assume alcance coletivo e contornos multitudinários.

E, para essas controvérsias multitudinárias, em que as demandas individuais incidem, reflexamente, em uma relação substancial paritária e impessoal, o manejo das técnicas agregação, de larga escala, como as ações coletivas, o caso-teste, a consolidação de demandas individuais, é medida que se impõe, sendo despicienda a participação direta de todos os indivíduos, membros do grupo. E isso ocorre por uma razão muito simples, os indivíduos são meros anônimos no grupo. Eles se subsomem aos atributos da coletividade, não litigam os seus atributos pessoais e, nessa medida, são fungíveis. Isso porque - frise-se - o direito substancial estabeleceu uma ordem paritária e impessoal de alocação dos ônus e recursos comuns, logo a posição de vantagem de um indivíduo está atrelada à posição do outro membro do grupo.

Pouco importa, assim, a divisibilidade prática do bem nessa categoria. A propriedade no período medieval era, por exemplo, fragmentável, mas o direito costumeiro exigia um tratamento paritário e impessoal aos membros do grupo. Quando surgia uma controvérsia, o método de resolução aplicado pela Corte de Justiça era a ação coletiva, que deveria considerar a dimensão plurissubjetiva do conflito. O indivíduo atuava como membro de uma coletividade e não de forma pessoal. Aliás, não só a propriedade seguia esse esquema, mas os sistemas de policiamento, de agricultura e de responsabilidade civil eram, predominantemente, coletivos.

As técnicas tradicionais continuam aplicáveis para as hipóteses de pluralidade de partes. Mas, quando inviáveis forem as técnicas tradicionais, autoriza-se a adoção de outro método de agregação, não litisconsorcial, isto é, um método que não demande a participação direta.

É preciso destacar que, quão maior a coesão da classe e a impessoalidade da demanda, menor a necessidade de participação direta do indivíduo, uma vez que a questão deixa de ser pessoal e particular. Tratando-se de demanda individual incidente, reflexamente, em relação substancial 
de ordem paritária, deduzida em juízo de modo impessoal, os indivíduos, membros do grupo, são fungíveis. A partir do momento em que a narrativa torna-se coletiva, paritária e impessoal, o que importa é a compreensão e o julgamento dos argumentos que são comuns ao grupo.

É preciso adentrar, agora, em alguns casos mais complexos. O primeiro a ser abordado é o caso de um concurso público em que o autor individual não pleiteia a anulação de uma questão da prova objetiva, ele pleiteia os pontos da questão, o que, segundo ele, seria fragmentável. O segundo caso a ser abordado é a hipótese em que o autor individual pleiteia a declaração de abusividade do reajuste aplicado em plano de saúde coletivo e o ressarcimento das diferenças.

É cediço que o concurso público instaura uma ordem paritária entre os candidatos ${ }^{523}$. Mas, em algumas demandas individuais, em que o autor impugna uma questão da prova objetiva, o candidato não pleiteia a anulação da questão, de forma a manter a paridade entre todos. Sua pretensão é o prosseguimento no certame, com o deferimento dos pontos de determinadas questões, que, segundo ele, estariam supostamente em desacordo com o edital. É possível perceber que muitos advogados usam "meias palavras" ou "jogos de linguagem", para evitar os inconvenientes do litisconsórcio, bem como para lograr os pontos (em tese fragmentável) somente para o seu cliente e, com isso, melhorar a classificação geral do candidato no certame.

Se a pretensão fosse claramente anulatória, cujo objeto detém natureza, na prática, incindível, seria mais perceptível o alcance coletivo da controvérsia e a interferência na classificação dos demais candidatos do certame, o que poderia conduzir o magistrado a determinar, por exemplo, um litisconsórcio. Se o autor da demanda, candidato do concurso, pleiteia apenas os pontos da questão, isso poderia soar, ao juiz, como uma pretensão individual, sem alcance coletivo.

523 Além da massa falida, que institui um procedimento concorrencial igualitário, o mesmo ocorre com o concurso público. Várias hipóteses de direitos substanciais, que instauram uma ordem paritária e impessoal entre os membros do grupo, são mencionados por José Reinaldo de Lima Lopes em obra citada (Cf. LOPES, 2001, p. 64). 
Trata-se de uma estratégia ${ }^{524}$. Prestigiosas doutrinas processuais ${ }^{525}$ são distorcidas dando azo à anormalidade supracitada. $\mathrm{O}$ autor individual deduz, na causa de pedir, a invalidade da questão da prova objetiva em face do edital, mas, no pedido, requer a concessão individual de pontos, que, nada mais é do que o resultado prático da invalidade e da anulação da questão contrária ao edital. Mas, como a invalidade é aduzida, incidentar tantum, o autor sustenta que não há comunhão a atrair a agregação pelo litisconsórcio necessário, com a participação dos demais candidatos, tampouco tratar-se-ia de litisconsórcio unitário, pois os pontos são divisíveis ${ }^{526}$.

Mas, como já apontado, o direito substancial plurissubjetivo ou coletivo não é identificado pela eficácia do provimento pretendido, se declaratório, constitutivo, condenatório ou mandamental.

Não é a pretensão que define o direito substancial. Se o direito estabelece uma ordem paritária e impessoal, ainda que o objeto seja suscetível de fragmentação na prática, essa dimensão coletiva deve ser observada. Enfim, ainda, que se possa pensar que os pontos de uma prova objetiva de um concurso público possam ser dados para um dos candidatos (autor individual de uma demanda) e não para os outros. Não é possível esquecer que todos os candidatos tem direito a aplicação paritária, objetiva e impessoal das regras do edital. Logo, a (in)validade a todos aproveita. Os feixes de interesses podem se dividir, mas não podem se dispersar uns dos outros.

524 São várias as demandas individuais com essa argumentação. Isso ocorreu no MS 13.237/DF, no Superior Tribunal de Justiça, em relação a um concurso de Procurador da Fazenda Nacional. A candidata requerente, que impetrou mandado de segurança contra a questão n. 28 da prova objetiva, argumentou a invalidade dessa questão na causa de pedir, mas, no pedido, a pretensão foi a concessão individual dos pontos apenas para ela e não a anulação da questão (BRASIL. SUPERIOR TRIBUNAL DE JUSTIÇA. MS 13.237/DF. Rel. Ministro MARCO AURÉLIO BELLIZZE, TERCEIRA SEÇÃO, julgado em 12/12/2012, DJe 24/04/2013).

525 Arruda Alvim adverte, por exemplo, que muitas demandas buscam camuflar a identidade jurídica existente entre elas, justamente no intuito de evitar a litispendência (ARRUDA ALVIM, José M. Ensaio sobre a litispendência no Direito Processual Civil II. São Paulo: Revista dos Tribunais, 1970, p. 102).

526 É preciso destacar, novamente, que não é o pedido que determina se um direito tem ou não tem alcance coletivo, é a natureza da relação substancial. No caso do concurso público, é a natureza paritária (incindível normativamente) e impessoal da relação substancial plurissubjetiva é que determinam o alcance coletivo. O objeto não é indivisível na prática. Muito pelo contrário, os objetos são divisíveis, os pontos da prova, os vagas dos cargos públicos, tudo isso é divisível. O que é indivisível é o direito a um procedimento concorrencial igualitário, em que todos os candidatos estão em pé de igualdade. Se isso for inobservado e as posições individuais não mais se subsumirem à posição global, o direito ao concurso público restará esfacelado e não cumprirá mais a sua função de selecionar o candidato mais preparado. Enfim, o eixo de referência prática, a que faz remissão Dinamarco para identificar a incindibilidade, não é o pedido deduzido na petição inicial, mas, sim, a relação de direito substancial deduzida em juízo. A leitura a ser dada à expressão "eixo de referência” é verificar se a relação substancial permite ou não a viabilidade de decisões divergentes, à luz da norma jurídica e das peculiaridades da relação substancial controvertida. (Cf. DINAMARCO, 2009, p. 357). 
Importa ressaltar que se os pontos forem "dados", judicialmente, para alguns candidatos, mas não forem dados para outros, que realizaram a mesma prova e integraram a mesma lista de classificação, esses últimos candidatos não serão os únicos a serem prejudicados na história. $\mathrm{O}$ próprio direito ao concurso público - direito de todos à seleção dos candidatos mais preparados para o serviço público - tornar-se-á insubsistente sob o ponto de vista global. Os candidatos, nesse caso, não mais concorrerão em paridade de condições, sendo incerta a seleção daquele mais preparado. A questão se torna de "sorte". Um candidato teve a sorte de conseguir os pontos no Poder Judiciário, outro candidato não teve a mesma sorte e, quem sabe, a coletividade terá a sorte de que seja escolhido, ao final, o melhor candidato ao cargo público.

O fenômeno do fura-fila não pode ser institucionalizado pelo Poder Judiciário, sob pena de se pôr a perder a própria ordem material. A pretexto de se proteger o indivíduo, não se pode botar a perder o direito substancial ou, na expressão popular, jogar o bebê fora com a água do banho.

Lembra-se que a posição de vantagem individual é, por vezes, mero reflexo do direito coletivo primário ao concurso público. O concurso público foi reconhecido como direito constitucional, deferido a todos os brasileiros que preencham os requisitos da lei e aos estrangeiros na forma da lei, ou seja, ao grupo como um todo. É uma forma de alocação paritária e impessoal dos cargos, empregos e funções públicas. O indivíduo, preenchendo os requisitos da lei, tem direito individual de participar do concurso e também de impugná-lo em caso de ilicitude, mas a ordem distributiva e paritária presente no direito substancial não pode ser frustrada. Assim, para manter os dois valores - a defesa da posição de vantagem individual e a preservação da ordem impessoal ou paritária - a agregação parece ser, segundo entendemos, a melhor resposta para alcançar esse resultado. Não se trata de impedir a judicialização da controvérsia individual, mas de tratá-la como exige o direito substancial, isto é, tratá-la como se coletiva fosse desde o início.

Presente uma demanda individual, impugnando uma questão da prova objetiva supostamente contrária ao edital, essa demanda deve ser coletivizada, pois o edital deve ser aplicado a todos de modo impessoal e paritário. Suponha-se, no entanto, que existam várias demandas individuais, com causas de pedir e pedidos diferentes, cada uma impugnado, por exemplo, vários pontos do edital ou várias questões da prova objetiva. Todas essas demandas, mesmo que com causas de pedir diversas ou com pedidos diversos, continuam sendo de alcance coletivo. Todas devem ser coletivizadas, pois não é possível diferenciar os candidatos. Se um ponto for concedido em uma dessas demandas, deve ser concedido para todos os demais 
candidatos. Exemplo: o candidato João pede os pontos da questão 21 da prova objetiva de analista do Tribunal de Justiça de São Paulo, pois essa questão contraria o edital do certame, José pede os pontos da questão 32 da mesma prova objetiva, pois essa questão também contraria o edital do certame. Na hipótese de serem essas questões consideradas inválidas pelo Poder Judiciário nas referidas demandas individuais, mas de alcance coletivo, os pontos da questão 21 e os pontos da questão 32 daquele concurso devem ser concedidos a todos os candidatos. ${ }^{527}$

O tratamento processual a ser conferido a essas demandas individuais, no entanto, vai depender da identidade configurada no caso concreto. Lembra-se, aqui, da técnica de consolidação.

Se a identidade das demandas individuais for total, à exceção das partes, é possível ponderar o reconhecimento da litispendência. Até, porque, à medida que essas demandas individuais forem coletivizadas, todas serão demandas coletivas, suscetíveis à litispendência coletiva. Não há necessidade de reunião nesse caso, pois os elementos objetivos da demanda são idênticos. Eventual participação aos candidatos individuais poderá ser oferecida na demanda coletiva, com a formação de um comitê de candidatos, com audiências públicas, amicus curiae e outros.

É possível existir uma situação de identidade parcial da causa de pedir e pedido entre as várias demandas individuais, remanescendo questões individuais específicas. Exemplo disso é: João pede os pontos da questão 21 e 22, por contrariar o edital. João pede, ainda, indenização por danos morais, pois foi impedido de ir ao banheiro durante as provas. José pede dos pontos da questão 21, 22, por contrariar o edital. José pede, ainda, a realização de novo exame psicológico, pois, na data do exame, havia sofrido um acidente. Nesse caso, é possível coletivizar e consolidar os pontos controvertidos em comum dessas duas demandas individuais, estabelecendo um processo mestre. Os processos individuais remanescem para a discussão das questões controvertidas especificas e singulares. A sentença do processo mestre será única, analisando a validade das questões 21,22 da prova objetiva em prol de todos os candidatos.

Se não houver identidade, nem mesmo parcial, nos elementos objetivos das demandas individuais. Exemplo: João impugna a questão 21, porque contraria ao edital. José impugna a

527 O mesmo raciocínio se aplica na hipótese de validade das questões do concurso. Se reconhecida a validade da questão 21 e 32 e se uma demanda individual posterior vier a questionar essa validade, impugnando novamente o edital de forma idêntica, essa segunda demanda será coletivizada e sobre ela incidirá a autoridade da coisa julgada coletiva, que se agregou à sentença anterior, pois o Poder Judiciário já se pronunciou sobre essa mesma controvérsia com definitividade, não sendo suscetíveis a sucessivas investidas. 
questão 21, porque apresentava erro de digitação. Fernando impugna a questão 33, porque não havia nenhuma resposta certa entre as alternativas. Enfim, se os candidatos impugnarem questões diferentes ou questões iguais, mas por fundamentos diversos, as demandas individuais também devem ser coletivizadas, pois todos os candidatos estão em situação de paridade e impessoalidade. Depois de coletivizadas, essas demandas, agora coletivas, devem ser reunidas ou consolidadas em um mesmo órgão julgador, para a resolução integral, uniforme e objetiva da controvérsia em relação a todos os candidatos do concurso público. A sentença do processo mestre deverá analisar a validade da questão 21 e 33 da prova objetiva, conforme cada um dos fundamentos elencados nas demandas reunidas, em prol de todos os candidatos do certame.

Por fim, há ainda, um segundo exemplo que pode ser citado como um direito substancial paritário ou impessoal: a negociação de reajuste de preço de um plano de saúde coletivo.

A teoria da base objetiva do negócio jurídico ${ }^{528}$ exige que eventual revisão de uma negociação contratual coletiva seja realizada nos mesmos moldes ou sob as mesmas circunstâncias da contratação, a saber, de forma objetiva, paritária ou coletiva. O objetivo disso é manter as bases atuariais do contrato. Uma negociação coletiva permite, em tese, uma melhor negociação do preço, pois são várias pessoas contratando, ao mesmo tempo, o serviço de uma das partes. Se essa negociação coletiva fosse revista, casuisticamente, para o indivíduo, o equilíbrio contratual poderia ser afetado, pois o preço globalmente fixado seria, pouco a pouco, mais amofinado.

A dimensão coletiva deve, portanto, ser obrigatoriamente considerada na hipótese de surgir uma pretensão individual impugnando o reajuste do preço do contrato, negociado coletivamente. Para tanto, a demanda individual que incida, reflexamente, em uma relação substancial paritária e impessoal (ex. reajuste tarifário de um plano de saúde coletivo), deve ser agregada ou molecularizada, resolvendo a controvérsia de uma forma uniforme para todos os interessados.

\footnotetext{
528 Em relações paritárias, como plano de saúde coletivo, seguro coletivo, vige a teoria da base objetiva do negócio jurídico, isto é, as circunstâncias externas do negócio, fundamentais para o seu equilíbrio, não podem ser alteradas. Esse entendimento já foi adotado pela Ministra Nancy Andrighi ao examinar caso de plano de saúde coletivo. Em suas palavras: "a teoria da base objetiva do negócio (Lehre von der objektiven Geschäftsgrundlagen), estruturada pela doutrina alemã. Segundo essa concepção, as obrigações recíprocas dos contratantes são fixadas sob determinada realidade fática, que assegura a equivalência e a finalidade do contrato. Se essas circunstâncias forem substancialmente modificadas, é permitida a revisão, rescisão ou resilição do contrato ( $\$ 31$ do BGB - código civil alemão). A teoria da base objetiva do negócio diferencia-se da teoria da imprevisão, porque na teoria da base do negócio não há o advento de vantagem exagerada em prol de uma das partes do contrato (HARKE, Jan Dirk. Allgemeines Schuldrecht. Heidelberg: Springer Verlag, 2010, p. 93 e ss". (Cf. SUPERIOR TRIBUNAL DE JUSTIÇA. REsp 1119370/PE, Rel. Ministra NANCY ANDRIGHI, TERCEIRA TURMA, julgado em 07/12/2010, DJe 17/12/2010).
} 
A pretexto de realizar um direito substancial individual, o magistrado não poderia frustrar o escopo coletivo do contrato, isto é, o direito coletivo de todos os envolvidos na demanda à ordem paritária e impessoal. Aliás, já diz o ditado estadunidense, there's no free lunch, ou seja, não existe almoço grátis. Alguém paga a conta. Se o indivíduo sagrar-se vitorioso em uma ação individual e vier a lograr uma prestação menor pelos serviços de saúde só para ele, é bem possível que o equilíbrio financeiro do contrato coletivo não mais se mantenha em termos atuariais e é evidente que alguém pagará essa conta. Ou pagará a empresa, com a redução momentânea dos lucros, ou pagarão os outros associados, que permaneceram com o reajuste negociado coletivamente, e, ainda, correm o risco de, no próximo ano, sofrerem novo reajuste ainda maior, em razão da redistribuição dos prejuízos. O direito de um, portanto, interfere ou perturba a posição de vantagem dos outros. E, na pior das hipóteses, se um significativo número de demandas individuais lograr o reajuste individual do contrato e não for mais possível redistribuir os prejuízos aos demais indivíduos, o próprio contrato coletivo poderá ser frustrado. Se as posições individuais não se inserirem na situação global, a situação global será esfacelada.

Nesse caso, o magistrado deve ter em mente que o direito substancial envolvido na demanda não é um direito individual puro, mas, sim, um direito individual de alcance coletivo. Uma sentença de procedência ao indivíduo o transformaria, fatalmente, em um carona, um predador, um oportunista, um fura-fila no mau sentido ${ }^{529}$. Todos vão continuar pagando o custo da negociação coletiva, menos o indivíduo que logrou sagrar-se vencedor naquela demanda.

Essa alternativa não é, portanto, viável. Por outro lado, também não é possível obstar o indivíduo de realizar a persecução do seu direito individual, muito embora esse direito apresente alcance coletivo. Se o reajuste é abusivo e se o indivíduo é prejudicado, ele foi afetado em sua esfera jurídica. Não se trata, portanto, de impedir o acesso à justiça, mas, sim, de reconhecer que, nessa hipótese, o acesso à justiça deverá ser realizado sob a forma agregada ou coletiva. $\mathrm{O}$ alcance coletivo não veda a persecução individual, apenas exige a adequação do design procedimental à amplitude coletiva e plurissubjetiva da relação substancial controvertida.

Se o magistrado negar a legitimidade ao indivíduo ou julgar improcedente a demanda individual, em razão de a negociação ter sido coletiva, sem ao menos investigar a causa de 
pedir, isto é, a abusividade do reajuste do plano de saúde coletivo, o que se fez foi deixar o indivíduo e a todos os todos interessados do grupo sem proteção jurisdicional pleiteada.

A preocupação com a justeza processual do indivíduo que figura na demanda é tão grande que, por vezes, incorre-se o risco de esquecer o próprio direito substancial: (i) ou a pretensão individual é julgada, pondo-se a perder o próprio escopo coletivo do contrato. E, assim, à pretexto de atuar o direito substancial, destrói-se a ordem paritária e impessoal por ele instituída e (ii) ou a pretensão individual não é julgada, esquecendo-se do próprio direito substancial. E, assim, a posição de vantagem substancial, a saber, o interesse ou direito do indivíduo e de todos os demais interessados em afastar a suposta abusividade do reajuste não é apreciada em juízo.

Não é factível manter esse vaivém entre os planos individual e coletivo, o que se propõe é reconhecer o entrelaçamento, a convergência do individual com o coletivo, a admitir a agregação processual das demandas individuais. A agregação é necessária ou obrigatória.

A necessidade de agregação, nessas hipóteses, não é uma novidade. Essa necessidade já foi sentida, tanto é assim que o litisconsórcio é manejado em grande parte desses casos. Ocorre que o litisconsórcio e a participação direta podem não ser praticáveis, tampouco necessários em cenário em que a controvérsia não apresenta as características pessoais e únicas de alguém.

Outras hipóteses, também podem ser encartadas nessa mesma categoria de direitos individuais de alcance coletivo. Lembra-se (i) da hipótese do questionamento das tarifas de assinatura telefônica, em que a estrutura tarifária é igual para todos; (ii) os casos de regularização fundiária, com demarcação urbanística e legitimação coletiva da posse em assentamentos de baixa renda, (iii) controvérsias envolvendo os participantes de licitação multitudinária, que envolvam muitos participantes e seja inviável o litisconsórcio. A casuística é inesgotável.

No sistema estadunidense, constitui também exemplo de direitos individuais de alcance coletivo, marcado pela paridade e impessoalidade, a hipótese de fundo limitado (limited fund). A noção de limited fund consiste na distribuição pro rata dos recursos comuns de um grupo, estabelecendo justiça e equidade entre todos os interessados, isto é, todos devem estar em pé de 
igualdade (equal footing). A agregação no limited fund, afirma Nagareda ${ }^{530}$, é mera decorrência da natureza da demanda à luz do comando normativo preexistente de direito substancial.

O critério de distribuição e alocação dos recursos comuns, nas relações substanciais impessoais e paritárias, é dado pelo próprio direito material preexistente. O processo é, nesse contexto, constrangido à necessária agregação, no sentido de conferir um rateio, impessoal e paritário, aos recursos comuns nos termos exigidos pelo direito substancial que preexiste ao conflito.

Para finalizar, conclui-se que essa terceira categoria de direitos individuais de alcance coletivo refere-se à hipótese em que o indivíduo defende uma posição de vantagem individual, cujo objeto de proteção é, na prática, fragmentável. No entanto, o direito substantivo exige, expressa e especificamente, um tratamento paritário e impessoal aos membros do grupo. Como não existe procedimento diferenciado para isso, como ocorre na falência, por exemplo, é preciso lançar mão das técnicas processuais atípicas de agregação. A agregação é obrigatória, diante da unitariedade presente no direito substancial. Os feixes de interesses individuais podem se fragmentar, mas não podem se dispersar, devem andar juntos, emparelhados uns aos outros. Mas, é preciso, ainda, acrescentar uma última situação em que surge a plurissubjetividade. Trata-se de hipótese cujo nível de complexidade é um pouco maior, mas não é possível furtarse à possível agregação nesse caso e, desse modo, merece igualmente ser objeto de reflexão.

\subsubsection{REFLEXOS EM RELAÇÃO SUBSTANCIAL POTENCIALMENTE PARITÁRIA E POTENCIALMENTE IMPESSOAL}

É cediço que os mecanismos de agregação, como as ações coletivas, são muitas vezes percebida pelos profissionais do direito como, exclusivamente, processuais, isto é, desvinculados do direito substancial. A coletividade é, por vezes, compreendida como um mero conjunto de pessoas, que são agregadas por razões de conveniência e apenas para se alcançar escopos processuais, como a uniformidade dos julgados, a eficiência e a economia processual.

Essa visão estritamente processual já foi, parcialmente, superada conforme a argumentação até agora realizada. As técnicas de agregação, embora alcancem escopos processuais, tem a sua

530 NAGAREDA, 2003, p. 228 et seq. No mesmo sentido, NAGAREDA, Richard A. Mass torts in a world of settlements. Chicago: The University of Chicago Press, 2007, p. 131. 
razão de ser na atuação do direito substancial. São, muitas vezes, elementos do direito substancial que exigem a prestação jurisdicional sob a forma agregada ou molecularizada.

Há casos, no entanto, em que o direito substancial controvertido em juízo não incide em bem de natureza indivisível, tampouco existe um comando normativo que exija, clara, específica e expressamente, um tratamento paritário e impessoal entre os interessados de uma categoria. Pela mesma razão, também não existe um processo diferenciado para conferir um tratamento processual agregado ou paritário ao direito afirmado. Mesmo assim, alguns indivíduos continuam deduzindo a relação jurídica de direito material de forma impessoal e paritária em juízo e operando segundo o status do grupo. A referência ao grupo continua sendo necessária, pois, por vezes, é apenas essa referência que tem o condão de avançar a proteção individual.

Nesse caso, a paridade ou a impessoalidade, em uma categoria, decorre apenas das peculiaridades da relação substancial deduzida em juízo. Não existe um padrão normativo expresso que claramente estabeleça a incindibilidade, a impessoalidade ou a paridade entre os indivíduos, isto é, que estabeleça induvidosamente o alcance coletivo da controvérsia posta.

A incerteza, em maior ou menor grau, impera. Nem por isso, as técnicas de agregação podem ser, de plano, afastadas na resolução da controvérsia. O indivíduo, ainda que desprovido de um comando normativo específico, subsome-se como um anônimo ao grupo, para alcançar a proteção do direito por ele alegado. E, essa relação substancial, afirmada em juízo de forma impessoal e paritária, poderá sujeitar-se, igualmente, às técnicas de agregação. Trata-se de espécie de impessoalidade e de paridade potenciais, ora mais fortes, ora mais fracas.

\subsection{POTENCIALIDADE FORTE (FORÇA CENTRÍPETA)}

O direito deduzido em juízo apresenta reflexos em relação substancial impessoal e paritária, de forma potencialmente forte, quando a controvérsia incidir sobre os atributos do próprio grupo. O indivíduo continua atuando como membro do grupo, um anônimo. E, mais, a compensação individual é paritária ou proporcional segundo fórmula única e fixa, aplicável a todo o grupo.

Trata-se de uma força centrípeta, em que os indivíduos são atraídos a litigar como membros do grupo, isto é, há uma tendência ou uma força centrípeta de agregação das partes em direção ao 
grupo. A controvérsia é resolvida com fundamento no grupo, estabelecendo a metodologia de distribuição individual dos benefícios e essa compensação segue fórmula unitária e uniforme.

No sistema estadunidense, segundo Samuel Issacharoff, ${ }^{531}$ esse fenômeno é denominado de upstream, isto é, a controvérsia está à montante do grupo, os indivíduos atuam com referência ou com origem no grupo. A controvérsia é deduzida em relação aos atributos do grupo e os indivíduos operam como membros desse grupo. E, mais, a solução da controvérsia do grupo implica a satisfação ou a compensação individual, segundo fórmula padrão, paritária ou pro rata. O raciocínio jurídico é, assim, focado naquilo que é superveniente aos indivíduos, mas que avança materialmente não só a proteção, bem como a satisfação dos interesses ou dos direitos de cada um dos indivíduos envolvidos na controvérsia de direito substancial deduzida.

De igual modo, segundo o American Law Institute ${ }^{532}$, que recentemente (em 2010) publicou os Princípios da Litigância Agregada (aggregate litigation), o direito substantivo pode apresentar determinadas situações da vida em que, na prática, a solução da questão comum ao grupo importa tanto a solução da responsabilidade imputada a outrem, quanto o método de compensação ou de distribuição dos danos pessoalmente sofridos pelos membros do grupo.

É preciso destacar que, nessa categoria, diferentemente do tópico anterior, não há um comando normativo que estabeleça direta, especificamente e expressamente a impessoalidade e a paridade entre os membros do grupo. Mas, as noções de impessoalidade e de paridade podem ser extraídas, de forma potencialmente forte, das próprias peculiaridades do direito substancial. Nesses casos, a agregação é medida processual igualmente relevante, para atuar um direito substancial que também apresenta um alcance coletivo, embora a hipótese seja mais complexa.

A comunhão é intensa entre os membros do grupo, mas a caracterização dessa comunhão ou a categorização do direito como sendo de alcance coletivo apresenta outro nível de complexidade.

531 ISSACHAROFF, Samuel. Class action conflicts. University California Davis Law Review, 1997, V. 30:805833p, p. 832.

532 AMERICAN LAW INSTITUTE, 2010, p. 104-105. 
Novamente, alguns exemplos podem ajudar a melhor ilustrar e esclarecer essa categoria em que o direito individual apresenta reflexos potencialmente fortes em uma relação substancial impessoal e paritária. É, segundo expressão de Issacharoff ${ }^{533}$, conflito upstream, do grupo.

Não é possível olvidar que o Estado Contemporâneo não acompanha, por muitas vezes, as práticas sociais e econômicas. Novas carências e vulnerabilidades surgem a todo momento, sem que essas situações sejam, por vezes, previamente consideradas em abstrato em uma norma jurídica. É compreensível, portanto, que existam situações da vida, envolvendo indivíduos e grupos que sejam impessoais e objetivas, mas que ainda não entraram na agenda do Poder Legislativo ou do Poder Executivo. Essas situações, quando conflituosas, podem ser, por sua vez, judicializadas e caberá ao Poder Judiciário estabelecer mecanismos processuais para lidar com essa realidade no processo, sem, no entanto, contar com um parâmetro normativo específico, claro ou óbvio para isso. Esses são os denominados casos difíceis (hard cases) de Dworkin ${ }^{534}$, em que não há regra específica direcionada uma situação da vida plurissubjetiva.

Apesar da complexidade acima mencionada, as situações da vida em que ela surge são corriqueiras. Nada tem de extraordinário. São casos em que o prejuízo individual afirmado e a proteção jurídica pretendida pelo indivíduo - objeto da controvérsia deduzida em juízo - não podem ser processadas e julgadas, com êxito, sem referência à coletividade como um todo.

Veja, por exemplo, a hipótese dada pelo Professor José Reinaldo de Lima Lopes, a saber, o caso dos moradores de um cortiço (moradia coletiva). A preocupação exposta é a seguinte:

\footnotetext{
Qual a situação dos cortiçados em juízo? Tratada individualmente como se fosse uma relação de locação ordinária, não qualificada pela concretude do seu status? Pior ainda: dada a violência física que de fato impera nos cortiços, pois em inúmeros os casos o 'dono do cortiço' ou pensão mora com os locatários e está no dia-a-dia a ameaça-los de arma em punho, existe de fato a possibilidade de acesso à justiça? [...] Quantas leis de inquilinato se fizeram tendo como modelo a relação individual que se estabelece entre indivíduos padrão classe média, a quem resta sempre alguma alternativa de escolha do imóvel... ${ }^{535}$
}

Se os cortiçados litigarem sozinhos e de forma pessoal, a relação individual será entendida como uma típica locação ordinária. É necessário, então, litigar pelo status do grupo, de forma 
impessoal, com referência à situação substancial daqueles que vivem em uma moradia coletiva. O problema é que não existe um comando normativo específico, claramente dirigido a essa situação substancial especial de inquilinato de baixa renda, que amplie a abrangência da demanda. A lei de inquilinato pensou, como destinatária, a classe média e não os cortiçados. ${ }^{536}$

Mesmo assim, não é difícil imaginar a hipótese de uma ação coletiva ser proposta por um ente exponencial em defesa dos moradores do cortiço, bem como a hipótese de um ou vários cortiçados ajuizarem uma ou mais ações individuais em face do proprietário da moradia coletiva, pretendendo a declaração da abusividade do reajuste do valor do aluguel e a abusividade do valor do rateio das despesas comuns, pretendendo a devolução das diferenças pagas. Nessa hipótese, ao invés de uma típica locação, os cortiçados vão narrar as práticas comuns nas quais um integrante de um cortiço é submetido: a insegurança, a insalubridade das áreas comuns (banheiros, área de serviço e cozinha), os aluguéis exorbitantes, a inexistência de contrato escrito, a ausência de uma justificativa atuarial para a forma de rateio das despesas comuns e para os reajustes contratuais realizados, as cobranças constrangedoras no cortiço etc.

Embora os direitos dos cortiçados sejam individuais - o indivíduo é uma razão suficiente para imputação de um dever ao dono da moradia, independentemente da coletividade - e embora as demandas, eventualmente propostas, possam ser veiculadas pelos indivíduos prejudicados, os cortiçados operam, em tese, como membros de um grupo, segundo o status da categoria.

Justamente por isso, pelo fato de os cortiçados operarem em juízo como membros de um grupo e não de forma pessoal ou individual, o pronunciamento judicial nesse caso deve considerar o alcance ou abrangência coletiva da relação jurídica de direito substancial afirmada em juízo.

O pronunciamento judicial, a ser conferido nesse caso, no tocante às regras de rateio das despesas comuns e ao reajuste do valor do aluguel, não pode alcançar apenas o indivíduo, autor de uma demanda, mas deve considerar a dimensão da comunidade. Não existe rateio de um só,

536 A lei de inquilinato não se aplica de forma integral ou adequada a essa realidade. Em São Paulo, por sua vez, existe a Lei Moura de ${ }^{\circ}$ 10.928/91, que dispõe sobre as condições de habitação do cortiço, a qual estabelece, por exemplo, o padrão de construção dessa moradia. Não existe, no entanto, previstos critérios para a solução de um conflito de interesses entre os moradores do cortiço no tocante à moradia comum. Conforme informaç̃̃es obtidas no site da Prefeitura de São Paulo, existem na Capital existem 23.688 imóveis "encortiçados", onde vivem 160.841 famílias (dado Fipe, 1993). Na Subprefeitura da Sé são 1.288 cortiços onde vivem 15.102 famílias e na Subprefeitura da Mooca são 523 cortiços onde vivem 4.156 famílias (SECRETARIA MUNICIPAL DE HABILITAÇÃO. Programa cortiços. Disponível em: http://www.prefeitura.sp.gov.br/cidade/secretarias/habita cao/programas/. Acesso em: 13 de junho de 2013). 
rateio pressupõe outros sujeitos. Não é possível, por exemplo, excluir um morador - o autor de uma demanda individual - do rateio das despesas comuns ou diminuir o valor do reajuste do aluguel somente para ele e deixar para todos os demais o pagamento integral do valor do aluguel e do valor exigido pelo proprietário do cortiço para fins de pagamento dos custos de água, de energia e de outras despesas das áreas comuns. Isso seria institucionalizar a figura do carona. Enfim, não é possível alocar ou distribuir os benefícios ou os ônus da moradia coletiva entre alguns moradores, excluindo outros da mesma residência. Em um quarto da casa, a despesa do cortiçado seria mais barata, em outro quarto da casa, a despesa de outro cortiçado mais cara.

Mas, também não é possível deixar o indivíduo que acessou ao Poder Judiciário sem uma resposta jurisdicional adequada. É preciso, novamente, voltar os olhos ao direito substancial.

A tarefa não será fácil. Não há um referencial normativo específico, tampouco um contrato coletivo, que disponha sobre a distribuição e a alocação impessoal e paritária dos recursos comuns da moradia coletiva. A lei de locação, embora preveja a habitação multifamiliar, foi pensada para uma realidade de classe média, uma relação entre particulares em que há contrato escrito, regras para uso das dependências comuns, regras de rateio das despesas comuns, ela não foi pensada para uma forma de habitação coletiva precária de aluguel, como é o caso do cortiço. É preciso destacar que o sistema jurídico e constitucional brasileiro alcança, sim, a proteção dos cortiços e da população de baixa renda que nele vive, pois a lei não excluirá da apreciação do Poder Judiciário lesão ou ameaça de lesão, mas o modo ou a forma de como fazer isso, nesse caso concreto, não constitui uma providência fácil ou pré-concebida pelo julgador. Mesmo diante dessas dificuldades e da inexistência de uma previsão normativa específica, pode-se dizer que, nesse caso, a agregação das demandas dos cortiçados, por uma ação coletiva ou por outra técnica de agregação, não seria uma mera conveniência do sistema processual, para evitar a multiplicidade de demandas similares, mas uma decorrência do direito substancial.

Existe um enfoque substantivo, pois, quando visualiza-se a dimensão coletiva, essa dimensão amplia o acesso à justiça ao indivíduo, fortalece os seus argumentos e, até mesmo, modifica a percepção que se tem dele: o magistrado, ao inserir o indivíduo na categoria que ele alega fazer parte, transforma-o de locatário à cortiçado e transforma sua moradia de habitação individual à habitação coletiva. A proteção individual avança à medida que o indivíduo refere-se à categoria que pertence e não às suas características pessoais. Os atributos da controvérsia que serão objeto de cognição são do grupo e do indivíduo na qualidade de membro do grupo de cortiçados. 
Uma ação coletiva proposta por um ente exponencial, antecedida por um inquérito civil ou por outro mecanismo investigatório, seria adequada nesse caso, para que as dimensões da controvérsia fossem percebidas de modo mais abstrato e impessoal. Mas, não se pode afastar a possibilidade de múltiplas ações individuais serem ajuizadas pelos próprios cortiçados, defendendo um argumento com base no status do grupo. E, nesse caso, também é possível recorrer às técnicas de agregação, como a coletivização da demanda individual em demanda coletiva, como a consolidação das demandas individuais, como o julgamento por amostragem dos casos similares, para se delimitar, por exemplo, as propriedades comuns desse grupo. A agregação será determinada, assim, com fundamento nas particularidades do direito substancial.

Nesse caso, no entanto, as técnicas extrajudiciais de resolução de conflitos são as mais indicadas $^{537}$. Meios alternativos de solução devem ser oportunizados, pelo Poder Judiciário, antes do procedimento judicial. A designação de uma audiência de mediação prévia, com uma comissão do grupo de cortiçados e com o proprietário da moradia coletiva poderia ser institucionalizada, com o propósito de estabelecer uma negociação coletiva do contrato de aluguel da moradia multifamiliar. Nessa audiência, poderiam ser convocados, ainda, órgãos representativos, no caso de São Paulo, por exemplo, a Secretária de Habitação e Desenvolvimento Municipal, bem como a Defensoria Pública e as associações de moradores. ${ }^{538}$

A situação é, aqui, é de uma comunhão intensa entre os cortiçados. Não existe contrato coletivo, não existe relação de condomínio para fins de rateio das despesas comuns, mas a relação substancial apresenta um ordem potencialmente forte de paridade e impessoalidade. Há uma

537 Ada Pellegrini Grinover salienta que o método contencioso não é o mais apropriado para certos tipos de conflito em que se faz necessário atentar-se para os problemas de relacionamento que estão à base da litigiosidade. Os métodos alternativos podem recuperar certas controvérsias que permaneceriam sem solução na sociedade contemporânea, diante da inadequação da técnica processual para a solução de questões que envolvam, por exemplo, relações comunitárias ou de vizinhança (Cf. GRINOVER, Ada Pellegrini. Os fundamentos da justiça conciliativa. In: GRINOVER, Ada Pellegrini, WATANABE, Kazuo e LAGRASTA NETO, Caetano. Mediação e gerenciamento do processo: revolução na prestação jurisdicional. São Paulo: Atlas, 2007, p. 2-4).

538 A Lei Moura de São Paulo (art. $8^{\circ}$ da no 10.928/91) estabelece que o Município criará programas específicos de melhoria dos cortiços, mediante contratos coletivos entre as entidades representativas dos moradores e o proprietário (“Art. $8^{\circ}$ - O Executivo poderá criar programas específicos, voltados para a melhoria dos cortiços e sua adequação aos parâmetros previstos nesta lei, por meio de financiamentos, assistência técnica e outras formas, mediante contratos coletivos firmados entre as entidades representativas dos moradores e o proprietário, garantindo sempre a permanência dos primeiros por prazo a ser ajustado em função do investimento previsto"). Em caso de judicialização da controvérsia, uma audiência prévia pode ser convocada pelo magistrado, para cumprir o art. $8^{\circ}$ da referida lei, na tentativa de alcançar um contrato coletivo que regule as relações plurissubjetivas do cortiço. 
força centrípeta em que a posição de vantagem de um indivíduo interfere na posição do outro e as posições individuais se subsomem às características homogêneas do grupo como um todo.

A hipótese, ora retratada, é mais complexa, pois pende a incerteza. Não existe comando normativo específico que possa orientar a alocação impessoal e paritária dos recursos comuns ao grupo, embora o destino organizacional da moradia coletiva deva ser o mesmo para todos.

Não há pretensão de esgotar todas as possibilidades postas pelo direito substancial. O que se pretende esclarecer é, mesmo sem um comando normativo específico, o direito substancial afirmado, em juízo, continua a exigir, pelas suas peculiaridades, um tratamento impessoal e paritário, com alcance coletivo a todos os membros de um grupo, de forma a atrair a agregação.

Outro caso interessante, mas também mais complexo, é a suposta contaminação tóxica que se sucedeu no bairro Barretos, no Município de Triunfo ${ }^{539}$, no Rio Grande do Sul. O Poder Executivo Municipal, a FEPAM - Fundação Estadual de Proteção Ambiental e o Ministério Público Estadual investigam a contaminação do solo, dos lençóis freáticos e, provavelmente, do Rio Taquari, causada por uma usina de postes de eletricidade, instalada no local na década de 60 e que lá permaneceu até 2005, quando foi desativada. Essa contaminação química, já constatada e admitida pela própria empresa (CEEE e AES-Sul), ocorreu por uma falha no processo de conservação, tratamento e impermeabilização da madeira destinada à fabricação de postes de eletricidade na região, que culminou no despejo de produtos tóxicos como pentaclorofenal, creosoto e CCA, um composto de cobre, cromo e arsênio no meio ambiente. Além disso, foram encontrados toneis do produto tóxico, sem acondicionamento adequado, enterrados próximo ao Rio Taquari, prática proibida. E, esse mesmo fato lesivo tem sido objeto de demandas individuais movidas pelos moradores do bairro Barretos e de uma ação coletiva.

Há várias ações individuais ajuizadas, propostas pelos moradores da região, argumentando a violação à incolumidade física e a ocorrência de danos à saúde, principalmente casos de câncer. Além das múltiplas ações individuais propostas, o Ministério Público ajuizou, por sua vez, Ação

539 Notícias sobre esse acidente podem ser encontradas em: RIO GRANDE DO SUL. Governo do Rio Grande do Sul. Notícias. FEPAM organiza retirada de focos de contaminação em distrito de Triunfo. Disponível em: http://www.rs.gov.br/noticias/1/97780. Acesso em: 14 de junho de 2013; BRASIL. IG. Saúde. Alta taxa de mortes por câncer faz comunidade do RS ser monitorada. Disponível em: http://saude.ig.com.br/minhasaude/alta-taxa-demortes-por-cancer-faz-comunidade-do-rs-ser-monitora/n1597609884357.html. Acesso em: 14 de junho de 2013. 
Civil Pública em face das empresas CEEE e AES-Sul, pleiteando, além da reparação ambiental, a formação de um fundo no valor de $\mathrm{R} \$ 6.000 .000,00$ (seis milhões de reais), a título de danos morais coletivos. Por fim, em uma pesquisa realizada no Diário de Justiça do Tribunal de Justiça do Rio Grande do Sul, foi possível perceber a suspensão dos processos individuais ${ }^{540}$ até a conclusão da prova pericial realizada no bojo da ação coletiva ambiental, cujo escopo é aferição do dano ambiental. O processo coletivo, por sua vez, encontra-se na fase instrutória e a reparação ambiental já é objeto de tutela de urgência, para a retirada do material contaminado ${ }^{541}$.

A questão da saúde das vítimas, que é dano reflexo ambiental, não foi, por sua vez, objeto da ação coletiva e o nexo de causalidade específico individual é negado pelas empresas requeridas. Por essa razão, essas demandas individuais continuam pendentes, para que caso ultrapassada a questão ambiental, a questão quanto à saúde individual dos moradores do bairro seja apreciada.

O que é interessante notar, para os propósitos deste trabalho, é que, embora o direito ao meio ambiente seja o direito coletivo primário, surgem em casos como esse - contaminação tóxica em acidente ambiental - direitos individuais secundários, de alcance coletivo, quanto à saúde.

Para desenvolver esse raciocínio vamos continuar trabalhando com o exemplo da comunidade de Barretos, do Rio Grande do Sul, mas agora de forma meramente ilustrativa. Imagine que aquela ação coletiva proposta pelo Ministério Público Estadual seja julgada procedente reconhecendo o dano ambiental, que é o dano primário. Nesse caso, as múltiplas demandas individuais persistiriam quanto aos danos individuais à saúde. Mas, nessa hipótese, imagine que os indivíduos, autores das demandas, ao invés de procederem à liquidação da ação coletiva e à prova do nexo de causalidade específico, continuassem com as suas demandas individuais e continuassem a atuar como se um vínculo existisse entre eles como membros da comunidade.

Todos os indivíduos, nas suas demandas individuais, pleiteiariam, por exemplo, uma prova estatística e epidemiológica a respeito do grau de risco que aquela contaminação tóxica causou à saúde pública da comunidade de Barretos, do Município de Triunfo, em comparação ao

540 Exemplo de ação individual suspensa. TRIBUNAL DE JUSTIÇA DO RIO GRANDE DO SUL. Comarca de Triunfo. Ação no 139/1.09.0000.1950-1 ou CNJ 0019501-37.2009.8.21.0139. Juiz Ivan Fernando de Medeiros Chaves.

541 Ação Civil Pública no ${ }^{\circ}$ 1.08.0000360-3. A tutela de urgência foi, no entanto, deferida em grau recursal. TRIBUNAL DE JUSTIÇA DO RIO GRANDE DO SUL. Agravo de Instrumento No 70046163093, Primeira Câmara Cível, Tribunal de Justiça do RS, Relator: Carlos Roberto Lofego Canibal, Julgado em 21/03/2012. 
restante do Estado. A cognição, quanto aos riscos à saúde pública, não foi realizada na ação coletiva, tampouco foi realizada a prova epidemiológica, pois a ação coletiva dizia respeito aos danos diretos ao meio ambiente. Logo, a cognição realizada naquele momento dizia respeito, exclusivamente, à extensão da contaminação e às medidas reparatórias e preventivas a serem aplicadas ao meio ambiente, não dizia respeito à saúde pública ou às doenças investigadas.

Nesse caso, a impessoalidade da controvérsia e a paridade presente entre os membros do grupo - moradores do bairro Barreto - seria marcante mesmo que o pedido das demandas individuais se referisse ao ressarcimento em pecúnia. Isso porque uma mesma vitimização e a exposição comum ao risco de uma contaminação prejudicial à saúde pode ensejar uma situação de comunhão de interesses entre os indivíduos, de modo que a argumentação seja impessoal e a compensação individual seja paritária ou proporcional aos riscos objetivos imputados ao grupo.

\section{Explica-se.}

O indivíduo continua a operar na condição de membro de um grupo. A razão para isso é muito simples: a referência ao grupo é necessária, pois é o grupo - a comunidade de Barretos - que apresenta os impactos decorrentes da exposição de risco à saúde. Os atributos e as propriedades da controvérsia litigada são primeiro do grupo e, depois, do indivíduo membro do grupo.

Os impactos à saúde do grupo, por sua vez, podem ser medidos, estatisticamente, estabelecendo um padrão lesivo, como, por exemplo, um leque de doença determinadas, uma maior taxa de mortalidade na região, comparado com o padrão regular do Estado. Nenhum indivíduo sozinho lograria demonstrar esse padrão, que é de grupo, populacional e não individual ou pessoal.

A impessoalidade seria, nessa hipótese, óbvia, pois os indivíduos deduzem a sua causa de pedir e pedidos como membros da comunidade de Barretos. Reportam-se, por exemplo, aos dados estatísticos daquela comunidade, como o fato de a incidência de câncer nessa comunidade (bairro de Barretos) ser superior a 50\% à média do Município de Triunfo (probabilidade elevada) e o fato de as doenças apresentarem certa padronização (intensidade elevada de um ou alguns determinados tipos de doença ou a afetação de determinado órgão do corpo humano). $\mathrm{O}$ indivíduo torna-se mero anônimo, que se subsume aos atributos da coletividade como um todo. 
A posição do indivíduo, em relação ao grupo, é reforçada pela dificuldade prática de se comprovar a etiologia de algumas doenças, em exames clínicos individuais. A etiologia de determinadas doenças, como câncer, é, ainda, incerta. Mesmo a medicina, não logrou, ainda, comprovar se um determinado agente carcinogênico (câncer hazard) é a causa específica da doença manifestada em um sujeito em particular. O nexo causal é aferido, por essa razão, não em relação a um indivíduo específico, mas em relação a uma comunidade, igualmente submetida ou exposta ao agente carcinogênico. A causalidade é, assim, mensurada por uma comparação de grupos, entre o grupo exposto e o grupo não exposto à contaminação. De igual modo, por exames epidemiológicos e evidências estatísticas, é estimada a dose intolerável de exposição ao agente carcinogênico a caracterizar o risco de desenvolvimento de determinadas doença (cancer risk) na comunidade exposta, o que é extrapolado para os casos individuais. ${ }^{542}$

O IARC - Internacional Agency for Research on Cancer ${ }^{543}$, em ensaio monográfico, já salientou que a caracterização do risco de câncer, isto é, o nexo de causalidade é verificável, de forma intensa, quando há aumento de uma doença em determinado sítio anatômico e quando as taxas desse aumento forem diversas entre grupos expostos e não expostos ao agente carcinogênico.

Não é possível dizer, com certeza, que José, que vive na Comunidade de Barretos, tem leucemia em razão daquela contaminação ambiental, pois existem possíveis concausas a essa doença. Mas, é possível dizer, com certeza, que José foi exposto a um risco 50\% maior àquela doença, apenas porque José era um membro da comunidade, que foi ilicitamente afetada pelo acidente.

Falou-se, apenas, da impessoalidade. Mas, a paridade também é forte. Isso porque fixados os riscos, incidentes por classes de doenças e também pela gravidade, surge uma fórmula fixa, unitária, padronizada, uniforme que se aplica, igualmente, a todos os membros da comunidade. Dois indivíduos com leucemia, com igual gravidade de risco, receberão compensação individual igual, pois as posições individuais apenas se inseriram na posição de risco global.

Nesses casos, portanto, em que há uma contaminação tóxica por acidente ambiental e a etiologia das doenças, decorrentes da exposição, é incerta, a comprovação do nexo de causalidade

542 BRENNAN, Troyen A. Causal chains and statistical links: the role of scientific uncertainty in hazardous substance litigation. Cornell Law Review, 1998, V. 73:469-533p.

543 WORLD HEALTH ORGANIZATION. IARC Monographs on the evaluation of carcinogenic risks to human. V. 84. France, Lyon: IARC Press, 2004. 
específico em uma ação individual é inviável ${ }^{544}$. Por essa razão, surge uma força centrípeta que impele os indivíduos à agregação, à realização de uma referência necessária ao status do grupo.

O direito individual seria, assim, de alcance coletivo, pois os membros do grupo passam a ser reportar, reflexamente, de forma forte, a uma relação substancial impessoal e paritária (risco).

A impessoalidade e a paridade dos indivíduos são elementos potencialmente fortes, pois ainda que os danos sejam pessoais e possam assumir montantes de alto valor, a compensação individual pode não ser viável. O risco criado pela atividade perigosa e o nexo de causalidade específico não são suscetíveis, em regra, de aferição pela mera apreciação clínica dos sintomas individuais, é preciso inserir o indivíduo no grupo e avaliá-lo como membro da comunidade afetada, isto é, uma aggregative valuation ${ }^{545}$, uma cognição agregada das ações individuais.

Para que isso seja aprimorado, tanto o direito substancial, quanto o direito processual estão se desenvolvendo no sentido de admitir um direito agregado pelo risco e um processo agregado.

Pondera-se, hoje, em vários sistemas jurídicos, a existência de uma responsabilidade decorrente do risco da exposição, a que toda a comunidade foi submetida. A responsabilidade pelo risco visa alcançar a atuação do direito substancial e de seus escopos: a compensação pelos danos causados à saúde dos indivíduos que, do contrário, permaneceriam irressarcidos individualmente (compensatory policies), e o desincentivo à prática abusiva (deterrence). ${ }^{546}$

No sistema jurídico estadunidense, esse fenômeno é compreendido nas demandas conhecidas como risk-based-claims, casos em que a responsabilidade não se dirige aos danos, mas à exposição dos riscos. Os riscos a que submetidos os indivíduos não são compensados na forma convencional, mas podem ensejar uma espécie de seguro coletivo ou de uma tutela específica. ${ }^{547}$

$\mathrm{Na}$ hipótese de os danos materiais já terem se manifestado, esse danos poderão ser quantificados, ao menos em tese, de forma impessoal e paritária entre os membros do grupo,

544 WORLD HEALTH ORGANIZATION, 2004, p. 14. No mesmo sentido, BRENNAN, 1998, p. 475.

545 ABRAHAM, Kenneth S., ROBINSON, Glen O. Aggregative valuation of mass torts claims. Law and contemporary problems Law Review. V. 53:137-157p.

546 JONES, Craig. Theory of class action. Toronto: Irwin Law, 2003, p. 9-38.

547 BEN-SHAHAR, Omri. Causation and multiple tortfeasors. In: FAURE, Michael (org.). Tort law and economics. V. 1. 2 ed. Massachussetts: Edward Elgar Publishing Limited, 2009, p. 96. 
conforme o padrão lesivo apurado. Há um fórmula unitária, que considera a replicabilidade da doença, a probabilidade de sua incidência e a gravidade do prejuízo (morte, perda de membro, etc), estabelecendo uma metodologia de distribuição individual dos valores indenizatórios.

Na hipótese de inexistir danos e a tutela ser preventiva à saúde, é possível adotar uma programa coletivo, composto por medidas assecuratórias ou mitigatória dos riscos. Ex. programa coletivo de advertência da comunidade sobre os riscos e a forma de prevenção, programa de monitoramento médico e preventivo de doenças, exames periódicos de saúde e outros.

Admitida essa hipótese, a técnica processual também seria agregada. David Rosenberg ${ }^{548}$ pondera que, nesses casos, de exposição ao risco, o Poder Judiciário poderia aferir, em uma ação coletiva ou em outra técnica de agregação, a responsabilidade do réu e, ainda, realizar a compensação proporcional dos danos individuais, conforme a fórmula de riscos do grupo. Isso é denominado de damage scheduling ${ }^{549}$ a saber, a compensação individual é realizada, não com base nas características pessoais ou particulares do sujeito ou com fundamento no nexo de causalidade específico, mas com base nas características da categoria que o indivíduo integra.

O mesmo raciocínio, relativo à responsabilidade pelo risco, foi sustentado no sistema jurídico brasileiro por Giselda Hironaka ${ }^{550}$, a partir do art. 927 do Código Civil Brasileiro. Trata-se de uma responsabilidade pelo risco, que é denominado, por ela, de responsabilidade pressuposta.

Segundo a responsabilidade pressuposta, o fundamento da responsabilidade é o mise em danger ou a exposição ao risco como critério geral de justificação do dever de reparação, que supera a mera identificação causal do dano. A responsabilidade é fundada, portanto, em um critério padrão de imputação. Atualmente, explica Hironaka ${ }^{551}$, existem situações danosas, mormente, nos casos de contaminação com produtos químicos, cujos resultados lesivos ainda são desconhecidos na ciência, não sendo mais possível garantir a reparação dos danos às vítimas. Nesse caso, a responsabilidade decorreria da própria atividade, envolvendo substâncias perigosas, que causam riscos. A responsabilidade surgiria pelo risco da atividade e pela

548 ROSENBERG, David. Individual justice and collectivizing risk-based claims in mass exposure cases. New York Law Review,1996, V. 71: 210-257p.

549 Rosenberg explicita que damage scheduling é uma fórmula unitária que fixa valores indenizatórios considerando o tipo e a gravidade de lesões por determinadas categorias de risco (ROSENBERG, 1996, p. 223). 550 HIRONAKA, Giselda Maria F. Novaes. Responsabilidade pressuposta. Belo Horizonte: Del Rey, 2005, p. 338. 551HIRONAKA, 2005, p. 338 et seq. 
caracterização concreta do risco. O risco concreto, por sua vez, é caracterizado pela probabilidade geral do dano e pelo elevado índice de ocorrências de certo tipo de doença.

O risco concreto é, por sua vez, medido coletivamente e não em casos individuais. Ainda que apenas um indivíduo seja afetado, o risco é da comunidade afetada e não do indivíduo em si.

Ainda que a responsabilidade por riscos não seja adotada na forma pressuposta, como prescreve a Professora Hironaka, o mesmo raciocínio pode ser realizado no processo sob o ponto de vista da teoria da redução do módulo da prova ${ }^{552}$. Não há prova robusta do risco ou do nexo de causalidade específico em relação ao indivíduo isoladamente, mas o julgador pode aferir a verossimilhança de sua alegação por provas indiciárias que digam respeito à comunidade.

A partir de toda essa exposição, o que se pretendeu demonstrar é que, seguindo a linha de raciocínio desenvolvida, é forçoso reconhecer um direito individual de alcance coletivo, vez que há uma referência necessária à comunidade que o indivíduo integra. Para essas hipóteses, a agregação processual é medida que se impõe, pois existiriam múltiplas ações individuais referindo-se a uma mesma relação substancial impessoal e paritária em que os atributos do grupo é que serão objeto de cognição e, igualmente, em que os meios de prova serão coletivos.

A participação do indivíduo, nessa hipótese, também não seria essencial. O indivíduo atuaria como anônimo, como membro do grupo que pretende demonstrar o risco à saúde da coletividade. Todos os indivíduos se inserem na controvérsia como membros do grupo de risco.

Os danos, embora pessoalmente sofridos, poderiam ser calculados segundo uma fórmula padrão e paritária ao grupo, bastando ao indivíduo provar a sua qualidade de membro daquela categoria. Os impactos individuais são decorrentes, portanto, dos impactos à saúde do grupo.

552 Pela teoria da redução do módulo da prova, a prova é aferida não fundamento em um juízo de certeza, mas com fundamento em um juízo da verossimilhança, colhido das provas indiciárias, na hipótese em que a prova necessária for impossível ou inviável nas peculiaridades do caso concreto. Ainda que o legislador não adote o nome de responsabilidade pressuposta (que excluiu a causalidade específica), construção semelhante pode ser inferida do sistema a partir da responsabilidade pelo risco (que consta no código, mas sem os critérios concretos para a sua aferição) e a partir da redução do módulo da prova, que, em alguns casos, admite a causalidade hipotética ou verossímil, quando o direito material impuser essa redução (Cf. WALTER, Gerhard. Livre Apreciación de la Prueba. Bogotá: Temis, 1985, p. 211). 
Ademais, agregada a controvérsia em uma ação coletiva ou em um caso-teste, por exemplo, não seriam admitidas ações individuais concorrentes. Isso porque a controvérsia é em relação ao grupo e só existe um único padrão de risco, aplicável com fundamento ao grupo como um todo. A concorrência de demandas individuais deve ser possível apenas na hipótese de existir uma causa pessoal ou singular do indivíduo, bem como na hipótese de uma nova dimensão do conflito que afete o contraditório coletivo (ex. um antagonismo e a existência de um subgrupo).

Uma ação individual poderia, portanto, ser ajuizada se o indivíduo alegasse um dano pessoal, distinto do grupo. Nesse caso, o direito é individual, artesanal, pessoal do indivíduo. Não é derivado, nem reflexo de uma relação substancial impessoal e paritária. Aqui, a demanda é individual, sem alcance coletivo e não existe mais referência ao grupo. O status do grupo não prejudica, nem beneficia o indivíduo. Um exemplo disso é o caso de um funcionário da fábrica que não foi contaminado pelo acidente ambiental, ele foi contaminado pelo produto tóxico, porque era obrigada a utilizar esse produto sem equipamento de proteção adequada - EPI.

Se pela natureza da relação substancial, decorrente da paridade e da impessoalidade da relação deduzida, for alcançada fórmula unitária para o grupo como um todo, não é admissível sucessivas e idênticas investidas dos membros do grupo em relação à parte contrária, pois o Poder Judiciário já decidiu, com definitividade, essa controvérsia aplicável com fundamento no grupo. Assim, controvérsia idêntica não deve ser novamente apreciada, sob pena de abuso. É claro que se houver uma demanda individual, pessoal, particularizada, artesanal entre os indivíduos, membros do grupo, como já mencionado, não há qualquer óbice à demanda.

Por fim, um terceiro exemplo de conflito upstream, em que surge uma força centrípeta de agregação, aplica-se às ações coletivas ínfimas ou small class action. Nesses casos, os danos individuais são, em regra, ínfimos e proibitivos à persecução individual, de forma que a controvérsia deduzida em juízo é impessoal. É a mera narração da prática lesiva que, no plano macro, causou danos consideráveis, embora pessoalmente sejam eles desimportantes. E, de igual modo, a compensação individual dos danos tende a ser paritária, objetiva ou proporcional.

Nessa categoria, em regra, o prejuízo sofrido pelo indivíduo tende a ser meramente econômico, isto é, diferenças financeiras ou perdas decorrentes de uma prática abusiva global. Por essa 
razão, a compensação individual tende também a ser calculada por uma fórmula uniforme ou unitária, sem particularidade ou pessoalidade e aplicável a todos os membros do grupo ${ }^{553}$

Uma advertência se faz necessária nesse ponto: é importante identificar a existência de um padrão no grupo ou da impessoalidade - que é característica do direito individual de alcance coletivo, afirmado na inicial - e avançar a resolução da controvérsia de direito material em favor de todos, de forma a possibilitar um tratamento paritário e uniforme ao grupo no final.

Se a comunhão, apesar de afirmada na inicial de uma ação coletiva, não vier a ser demonstrada, a demanda deverá - passe o truísmo - ser julgada improcedente, a exemplo do que já ocorre. Se a ação coletiva for julgada procedente, por exemplo, isso somente vai postergar o problema para as liquidações, que se aproximarão a verdadeiras ações individuais e o Poder Judiciário, muito provavelmente, será levado a atuar de forma artesanal e não impessoal. A sentença coletiva, nessa hipótese, seria um engodo, pois não haveria comunhão ou direito coletivo. ${ }^{554}$

De qualquer modo, para fins de conclusão, repete-se: alguns direitos individuais apresentam uma potencialidade forte para agregação ou uma força centrípeta, em que a referência ao status do grupo é, em alguns casos, cogente para avançar a proteção individual. Nesses casos, denominados potencialmente fortes, a agregação é necessária não apenas para apuração da questão comum ao grupo, mas também para avançar a compensação individual dos prejuízos.

\subsection{POTENCIALIDADE FRACA (FORÇA CENTRÍFUGA)}

O direito deduzido em juízo apresenta reflexos em relação substancial impessoal e paritária, de forma potencialmente mais fraca, quando a resolução da questão controvertida, comum ao grupo, avançar a proteção de cada indivíduo isoladamente, remanescendo, no entanto, questões individuais a serem solucionadas pessoalmente ou artesanalmente pelo Poder Judiciário.

553 AMERICAN LAW INSTITUTE, 2010, p. 105.

554 Sempre que não houver um padrão impessoal e paritário entre os membros do grupo, a liquidação assume foros de verdadeira ação cognitiva individual. Isso pode ser percebido no caso dos autistas, em ação civil pública proposta pelo Ministério Público do Estado de São Paulo, recomenda-se a leitura da pesquisa "Pensando o direito" (Cf. BRASIL. Ministério da Justiça. O desenho de sistema de resolução alternativa de disputas para conflitos de interesse público. Série Pensando o Direito 038/2010. São Paulo, 2010). 
Segundo Samuel Issacharoff ${ }^{555}$, esse fenômeno é denominado de downstream, isto é, à jusante do grupo. Nesse caso, ao se discutir e solucionar a questão comum ao grupo, avança-se a solução da controvérsia em favor de seus membros. Esse raciocínio jurídico não dispensa, no entanto, a apreciação posterior da situação pessoal de cada um dos indivíduos do grupo.

Trata-se de uma força centrífuga. Os indivíduos, membros do grupo, operam inicialmente como membros do grupo, isto é, de forma paritária e impessoal para resolver, parcialmente, a controvérsia. Remanescem, em seguida, questões individuais, que devem ser apreciadas segundo os atributos do indivíduo e não mais de forma unitária, com referência ao grupo todo.

De igual modo, segundo o American Law Institute ${ }^{556}$, o direito substantivo pode apresentar determinadas situações da vida em que a solução da questão comum ao grupo avança materialmente a solução da controvérsia de cada um dos indivíduos. Essa questão comum deve constituir o núcleo da controvérsia ou o ponto central da disputa (the core of dispute), remanescendo, por sua vez, questões particulares, que são autônomas ou independentes em relação ao núcleo comum. Essas questões particulares devem ser apuradas, em uma segunda fase, em relação a cada um dos interessados, sem rediscussão do decidido anteriormente.

O direito substantivo, nesse caso, não é, na prática, incindível e não estabelece direta e especificamente a impessoalidade e a paridade entre os membros do grupo. Mas, o vínculo substancial entre os membros do grupo persiste, de forma potencialmente mais fraca. Solucionada a questão comum, remanescem questões individuais a serem decididas em isolado.

Nesses casos, afirmada a existência desse núcleo comum da controvérsia de abrangência coletiva, pode-se dizer que a agregação é, ainda, uma medida possível e atrativa para o processo.

Novamente, alguns exemplos podem ajudar a ilustrar melhor e esclarecer essa categoria, que foi denominada no sistema estadunidense, segundo Issacharoff ${ }^{557}$, de conflito downstream.

Imagine, por exemplo, um contrato de compra e venda de um apartamento, em que ficasse acordado, verbalmente, que a comissão de corretagem é devida pelo comprador e já estaria 
inclusa no preço final do bem. Assim, caberia à empresa vendedora fazer o pagamento ao seu corretor, que é funcionário da empresa. Essa informação não fora registrada, porém, no contrato escrito. Em momento posterior, abusivamente, o corretor de imóveis realiza a cobrança da corretagem, valor que já teria, em tese, sido anteriormente incluído no preço final do bem.

Essa prática abusiva (a empresa, ao vender, diz que aquele é o preço final do bem, incluindo a corretagem, mas depois realiza cobrança por intermédio do corretor) não ocorreu apenas com um comprador. Mas, tratou-se de uma prática abusiva aplicada contra todos os compradores de um empreendimento imobiliário. E, nenhum dos compradores tem prova escrita do negócio.

Nesse caso, é cediço que o pagamento se demonstra por prova escrita a quem alega tê-lo feito. Mas, os indivíduos ajuízam, cada um, a sua demanda, pretendendo demonstrar a prática abusiva da empresa vendedora. Há uma questão comum, de valência coletiva, pois todos os indivíduos, operam como membros de um grupo e, mais, a referência ao grupo é capaz de demonstrar a prática abusiva. Essas múltiplas demandas individuais devem ser agregadas, pois a centro da controvérsia (the core of dispute) são os atributos do grupo e não pessoais dos indivíduos.

Provada a prática abusiva, ainda que o indivíduo não possua a prova escrita do pagamento, é possível inferir que a comissão de corretagem já estava inclusa no preço final do bem, cabendo à empresa o pagamento ao corretor. Posteriormente, será analisado o contrato de cada indivíduo, para verificar se, de fato, naquele contrato não há cláusula expressa quanto à corretagem.

Outro exemplo, muito citado como downstream ou, como denominamos, de força centrífuga, é a hipótese de danos pessoalmente sofridos $^{558}$, em razão de vício ou defeito do produto ${ }^{559}$. Não se trata mais de responsabilidade pressuposta pelo risco, mas de responsabilidade pelos prejuízos decorrentes do produto defeituoso. Nesses casos, para fins de agregação, é preciso identificar um núcleo comum ou central da controvérsia, que avance a solução daquela em favor de cada um dos indivíduos interessados, como, por exemplo, a questão da responsabilidade pela

558 ISSACHAROFF, 1997 p. 832.

559 O caso do vício do produto é distinto da hipótese de contaminação tóxica ambiental, tratada anteriormente. Ada Pellegrini Grinover já abordou as dificuldades inerentes às demandas por vício do produto, ressaltando que: "a existência dos requisitos da prevalência e da superioridade tem sido reconhecida, até com facilidade, em campos que não são o dos danos provocados por vício do produto: em matéria de desastres ambientais, de acidentes aéreos, de desmoronamento de obras, de prejuízos aos trabalhadores, muitas são as ações de classe reparatórias de danos individuais em que houve não só a certification, mas também o juízo posterior, chegando-se à sentença final" (Cf. GRINOVER, Ada Pellegrini. Da class action for damages à ação de classe brasileira: os requisitos de admissibilidade. Revista Forense, V. 352, out./nov./dez. de 2000, p. 6). 
fabricação do produto e a existência do defeito. Mas, mesmo que essa questão comum seja decidida, cada indivíduo deverá demonstrar a sua inserção na categoria comum, isto é, que fizeram uso daquele produto e que sofreram pessoalmente ou particularmente os prejuízos.

Nesses casos, conforme explicita o American Law Institute ${ }^{560}$, é importante analisar, com atenção, o direito substantivo e verificar se a questão comum, relativa à responsabilidade civil por exemplo, encontra-se apartada da questão da distribuição dos danos ou da compensação individual. É importante que a questão comum e as questões particulares estejam separadas ou que não estejam entrelaçadas conceitualmente, pois, do contrário, a questão comum será rediscutida ou reconsiderada para cada indivíduo, na fase posterior relativa à liquidação dos danos, o que não se coaduna com o tratamento unitário e uniforme das técnicas de agregação.

O reconhecimento da responsabilidade, nessa hipótese, deve ser o núcleo da controvérsia (the core of dispute) e avançar, materialmente, o direito dos indivíduos, de forma que ela seja insuscetível de rediscussão por ocasião da liquidação. Do contrário, a agregação processual será inadequada para a resolução dessa controvérsia e não prevenirá a duplicação de demandas.

No sistema brasileiro, Ada Pellegrini Grinover ${ }^{561}$ já se dedicou a essa questão, salientando que em determinados casos, por exemplo, existe uma questão comum central que avança as controvérsias individuais, como, por exemplo, responsabilidade pelo pagamento de diferenças devidas pela Previdência Social, pela devolução das mensalidades escolares pagas em excesso pelo consumidor, pela aplicação de índices de correção monetária, bem como vários outros.

Em outros casos, continua Ada Pellegrini Grinover ${ }^{562}$, não há uma questão comum ou coletiva central. Nessas hipóteses, uma sentença condenatória genérica, formada em uma ação de coletiva, constituiria uma verdadeira falácia, pois ainda que ela seja favorável, não aproveitaria às demandas individuais. Todos os pontos controvertidos, comuns e individuais, deverão ser provados na liquidação individual, restando duvidosa a utilidade da técnica da ação coletiva.

Isso ocorre porque, em regra, quando a questão da responsabilidade não se separa da questão da compensação individual, não é possível centrar a controvérsia no âmbito coletivo. Nesse

560 AMERICAN LAW INSTITUTE, 2010, p. 105.

561 GRINOVER, 2000, p. 11.

562 Ibidem, p. 11. 
caso, a responsabilidade pode ser até ser provada genericamente, mas isso pode não avançar a comprovação do nexo de causalidade específico e individual, o qual, segundo as peculiaridades do caso, torna-se o cerne da controvérsia, sendo inócua, portanto, aquela sentença coletiva. ${ }^{563}$

Exemplo: em um caso, há uma fundada dúvida sobre o vício de um produto e sobre a própria existência desse vício. A sentença coletiva, que reconheça o vício do produto e o nexo de causalidade geral, avançará a controvérsia individual, sendo desnecessário renovar a discussão sobre o vício do produto na liquidação individual. Em outro caso, não existe dúvida quanto ao vício, a controvérsia é sobre os efeitos desse vício no indivíduo. A sentença coletiva, que reconheça o vício e o nexo causal, não avança a controvérsia individual, pois cada sujeito deverá demonstrar os efeitos danosos daquele vício para si, ainda que o próprio vício seja induvidoso.

O cerne para distinguir as hipóteses supracitadas fundamenta-se no direito substancial. A questão comum ao grupo deve se autonomizar, à luz do direito substancial, em relação às questões individuais ou pessoais, de forma que a discussão da primeira encerre a controvérsia em relação a cada um dos indivíduos interessados, abreviando, assim, o procedimento.

Nesses casos, em que a questão comum se autonomiza em relação às individuais é possível a agregação, pois o direito individual apresenta reflexos em uma relação potencialmente impessoal e paritária: enfim, ainda existe um núcleo comum que congrega os sujeitos.

Mas, é preciso advertir que não há, em regra, vinculação obrigatória ao julgado coletivo. Os indivíduos podem propor suas ações individuais. Isso porque, aqui, há uma divisão: parte da controvérsia tem alcance coletivo, parte da controvérsia é simplesmente individual, pessoal.

Como se verá adiante, aqui, surge o direito de opt out no sistema estadunidense e a coisa julgada secundum eventum litis brasileira. Noutros termos, no primeiro caso, o indivíduo pode se excluir da ação coletiva e, no segundo caso, o indivíduo não pode ser prejudicado pela ação coletiva.

Propõe-se, no entanto, ponderar para o seguinte, ainda que o indivíduo possa propor a sua ação individual, ele deve cumprir um ônus argumentativo, a saber, ele deve (i) elencar uma nova

563 Segundo Grinover, a prova do nexo causal pode ser tão complexa, no caso concreto, que tornará praticamente ineficaz a sentença condenatória genérica do art. 95, a qual só reconhece a existência do dano geral (Cf. GRINOVER, 2000, p. 11). 
dimensão da controvérsia coletiva (novas circunstâncias de fato ou de direito) ou (ii) argumentar de forma pessoal, isto é, deve demonstrar que a controvérsia é pessoal ou singular.

Por quê? Imagine que, naquele caso do apartamento, uma demanda individual é coletivizada para o fim de demonstrar a prática abusiva da empresa vendedora. E, depois de ampla instrução, conclui-se que não há prática abusiva alguma, sendo que a sentença transita em julgado com esse conteúdo normativo. Em seguida, surge uma multiplicidade de demandas individuais, em que os indivíduos novamente controvertem em juízo sobre a existência de uma prática abusiva adotada pelo vendedor. Os indivíduos continuam argumentando de forma impessoal, como membros do grupo, com referência a uma prática que todos sofreram igual, paritariamente.

As múltiplas demandas individuais, propostas depois de transitada a ação coletiva, é, essencialmente, a mesma entre todos os indivíduos. Eles não deduzem nenhuma nova dimensão da controvérsia, tampouco deduzem uma causa pessoal, particularizada. Muito pelo contrário, a demanda é padrão, objetiva, impessoal e paritária (igual à demanda coletiva anterior).

Nesse caso, essas demandas individuais, se idênticas, poderiam ser novamente objeto de agregação processual, por uma ação coletiva ou pelo caso-teste. Isso porque todos os indivíduos continuam operando de forma impessoal e a respeito de objeto paritário ao grupo (prática abusiva). Mas, uma vez novamente agregadas essas demandas individuais, surgirá, por consequência lógica, uma inconsistência com o resultado do primeiro provimento. Isso ocorreria por uma razão óbvia: os fatos permaneceriam (que dizem respeito ao grupo) os mesmos. Caso se tratasse de uma nova ação coletiva, por exemplo, a coisa julgada coletiva da primeira demanda incidiria sobre essa segunda demanda individual, objeto de agregação.

Esse ponto será retomado em momento oportuno, mas o que se quer dizer, com isso, é que o indivíduo, por força do opt out ou da coisa julgada secundum eventum litis, tem a prerrogativa de ajuizar uma demanda individual. Uma demanda individual não se define apenas pela titularidade do direito. Além da titularidade, ela deve ter uma causa de pedir e um pedido individualizado, pessoal ou particular, exigindo uma cognição artesanal do Poder Judiciário. ${ }^{564}$

564 Essa é a diferença entre um direito individual e um direito individual homogêneo. O direito individual homogêneo concentra-se no acolhimento de uma tese geral, referente a determinados fatos, que aproveitam a muitas pessoas. O que é completamente diferente de se apresentar inúmeras pretensões individualizadas, especificamente verificadas em relação a cada um dos titulares (ARAÚJO, p. 114. 2000). Essa impessoalidade, que determinada a homogeneidade do direito individual, também é orientada pela relação de direito substancial. 
Se algum indivíduo, ao invés de propor a demanda individual, naqueles termos, resolver ajuizar demanda com alcance coletivo, essa demanda é suscetível de nova agregação e, pode ser coletivizada. E, se já houver outra demanda coletiva idêntica pendente ou se já houver coisa julgada coletiva, será forçoso reconhecer, portanto, a litispendência e a preclusão da questão.

Por isso, o indivíduo deve cumprir um ônus argumentativo, pois o opt out e a coisa julgada secundum eventum littis oportunizam ao indivíduo a possibilidade de ajuizar uma demanda individual e essa individualidade deve ser afirmada e demonstrada na petição inicial da ação. No caso do apartamento, por exemplo, o indivíduo não poderia mais argumentar a existência de prática abusiva coletiva, mas poderiam alegar vício de consentimento pessoal no contrato.

Enfim, essas considerações serão retomadas, posteriormente, conclui-se dizendo que: nessa categoria, denominada no sistema jurídico estadunidense de downstream e, para nós, de controvérsia coletiva potencialmente fraca ou de força centrífuga, há ainda uma valência coletiva. O indivíduo pode excluir-se da controvérsia e o seu direito individual não será prejudicado, mas deverá ele cumprir um ônus argumentativo demonstrando essa pessoalidade.

\subsubsection{DIREITOS INDIVIDUAIS DE MASSA, HOMOGÊNEOS OU REPETITIVOS}

Nessa categoria, diferentemente das anteriores, não há valência coletiva, tampouco há referência necessária ao grupo. Pode-se dizer que permanece, no entanto, a impessoalidade na categoria. São direitos individuais, mas cognatos, em decorrência de uma produção de massa e de um consumo de massa, que emergiram de uma decisão central de uma empresa, de um contrato bancário padrão, de uma mesma política econômica e financeira do poder público etc.

O indivíduo não precisa mais se relacionar ou se vincular com um grupo para avançar a proteção individual. Isso porque cada indivíduo sozinho reúne, em si, todos os atributos ou todas as propriedades para litigar a sua controvérsia. Os atributos do indivíduo são iguais aos atributos de toda a coletividade ou grupo. São demanda clones, cognatas, repetitivas e, enfim, de massa. 
Esse fenômeno lembra muito aquilo que, no período moderno, foi denominado por Elias Norbert "individualização em massa" ${ }^{565}$. Os Estados e, de uma forma geral, os mercados, deixam de barganhar com grupos e passam a se relacionar diretamente com o indivíduo por meio da norma jurídica. A norma é aplicável a todos, que podem exigir a posição de vantagem.

Nas palavras de Ruy Zoch Rodrigues ${ }^{566}$, direitos homogêneos decorrem de um fenômeno de "emergência de direitos individuais vinculados às relações jurídicas que se formam na cadeia de produção e consumo em massa de bens e serviços”. É, nessa categoria que ocorrem, em juízo, a grande maioria das ações repetitivas. Não há identidade de causas aqui ou, ao menos, essa identidade é sutil, pois é possível uma variação das situações fáticas entre os indivíduos.

Barbosa Moreira ${ }^{567}$ denominou essa categoria de acidentalmente coletiva. A eventual agregação dessa demanda cumpriria outro papel no sistema, além de atuação do direito substancial. Cumpriria alcançar escopos processuais como a uniformidade das decisões, a economia processual e a eficiência processual. A disciplina unitária não deriva de uma necessidade intrínseca do direito material. Mas, por motivos processuais, estende-se essa disciplina aqui.

Muito bem. Embora essa categoria não apresente a mesma valência coletiva que as anteriores, é preciso destacar que esses direitos individuais de massa, homogêneos ou repetitivos se distinguem dos demais direitos individuais. Os primeiros são padronizados, são impessoais, de cognição padronizada, talvez com sutis diferenças de uma demanda para a outra, mas o segundo é pessoalizado, particularizado, singularizado e exige cognição artesanal em juízo.

Aqui, as técnicas de agregação também são aplicáveis, principalmente a consolidação e os casos-teste. Isso porque cunhada a solução jurídica em um dado caso concreto, essa mesma solução pode ser aplicada aos casos posteriores, com relação à controvérsia de massa. Em sede de liquidação ou em processos individuais, a questão individual será apreciada em separado.

\subsection{DIREITO E PROCESSO}

565 ELIAS, 1994, p.148-149.

566 RODRIGUES, Ruy Zoch. Ações repetitivas: casos de antecipação da tutela sem o requisite de urgência. São Paulo: Revista dos Tribunais, 2010, p. 31.

567 MOREIRA, 1984, p. 195-197. 
Após toda essa exposição, forçoso convir que embora seja possível identificar os planos individual e coletivo em abstrato, eles não estão completamente desvinculados. Existe um número muito grande de situações plurissubjetivas, que envolvem um aglomerado de interessados em uma controvérsia. O que importa é identificar a convergência ou entrelaçamento de interesses comuns, de forma a admitir a aplicação das técnicas de agregação.

Existem direitos coletivos e pseudoindividuais, esse último dotado de uma valência coletiva diferente dos direitos subjetivos clássicos, pois confluem em uma dimensão global ou coletiva e, por essa razão, são suscetíveis à agregação. Ao lado desses, convivem os direitos individuais homogêneos, de massa ou repetitivos, que são agregados por força da individualização de massa das relações jurídicas. Por fim, existem os direitos individuais puros, pessoais e artesanais.

Essa amplitude já foi demonstrada anteriormente, visualizando-se uma escalada de coletivização. Destacam-se os casos em que há, em maior ou menor grau, reflexos em bem de natureza indivisível e impessoal ou em uma relação substancial impessoal e paritária (incindível normativamente), operando o indivíduo com referência ao status do grupo a que faz parte.

Não houve, aqui, a pretensão de exaurir a tipologia ou a amplitude dos direitos substanciais, se individuais, coletivos, individuais de alcance coletivo ou de massa, já que como afirma Barbosa Moreira, "a passagem de um a outro se faz, com frequência, por graus insensíveis, e que a riqueza policrômica das situações da vida em sociedade não se deixa aprisionar num espectro intencionalmente esquemático" ${ }_{568}$. A tipologia não é, portanto, exaustiva, mas exemplificativa.

O que se fez, a todo o momento, foi apenas revelar alguns critérios, que permitirão aferir se a controvérsia é coletiva ou detém predominância coletiva, com fundamento no direito substantivo: são os critérios da indivisibilidade, paridade, impessoalidade e homogeneidade que indicam a amplitude das situações plurissubjetivas, a admitir as técnicas de agregação.

Esses critérios são extraídos do direito substancial e são eles que autorizam ou não a agregação. A técnica processual é, assim, determinada pela situação da vida plurissubjetiva. São os elementos da relação de direito material que determinam o objeto da agregação e o método de 
solução da controvérsia. Citam-se, nesse sentido, as palavras de José Roberto dos Santos Bedaque $^{569}$ :

\begin{abstract}
A complexidade das relações jurídicas de direito material acaba produzindo reflexos no processo. Se são vários os integrantes da situação da vida regida pelas normas substanciais e trazida para o exame do juiz, surge o fenômeno da pluralidade de partes no processo. A admissibilidade ou obrigatoriedade do litisconsórcio, a necessidade ou não de regulamentação uniforme das situações de cada um dos litisconsortes, a possibilidade de a tutela jurisdicional atingir terceiros, ainda que indiretamente, a correção do polo passivo no curso do processo, dedução de pretensões incidentais versando direito de regresso ou responsabilidade solidária, são questões processuais cuja solução deve ser encontrada segundo dados da relação material.
\end{abstract}

O mesmo raciocínio se aplica, portanto, para as técnicas processuais de agregação de uma forma geral. A necessidade da agregação para a tutela de dada situação da vida e o instrumento processual idôneo para esse escopo são aferidos a partir da relação de direito substancial.

De igual modo, o grau de variância ou de convergência tolerado entre os membros do grupo, para fins de agregação, constituem uma combinação de possíveis cenários, em que os critérios dados pelo direito substancial se imiscuem: de um situação mais intensa de indivisibilidade e impessoalidade ou uma situação mais fluída de paridade e impessoalidade ou, ao menos, a impessoalidade ou equidistância do indivíduo em relação ao bem (individualização em massa).

\title{
4.5.1 O CONCEITUALISMO NA CLASSIFICAÇÃO DOS DIREITOS
}

A exemplificação dos direitos individuais, coletivos, individuais de alcance coletivo e homogêneos teve por objetivo apenas esclarecer ou ilustrar os direitos suscetíveis de agregação.

Não importa o nomen iuris dado ao direito, o que importa é a caracterização da situação da vida plurissubjetiva ou massificada, segundo os critérios mencionados, que estabelecem parâmetros pragmáticos para fins de agregação processual - sempre à luz do direito substancial, é claro!

O pano de fundo é o mesmo nos dois casos citados: se o direito é coletivo, se o direito é individual com alcance coletivo ou se é o direito de massa, a agregação é possível, pois há uma valência coletiva ou, ao menos, uma individualização de massa das relações jurídicas. Apenas, 
se o direito deduzido em juízo for pessoal, particularizado e exigir cognição artesanal, é que a agregação deverá ser considerada, em um primeiro plano, inidônea como método de solução.

O conceitualismo entre individual e coletivo já é, na realidade, bastante criticado no direito brasileiro, pois como destaca Elton Venturi ${ }^{570}$, a incompreensão das categorias do direito coletivo e do direito individual e a rígida categorização entre eles acarretam, por vezes, a inefetividade do sistema de tutela jurisdicional coletiva. E, isso não ocorre sem uma razão.

Ainda segundo o referido autor, seja pela herança individualista que inibe o reconhecimento de direitos coletivos, seja pela insensibilidade daqueles que inadmitem a tutela coletiva para direitos patrimoniais e disponíveis, o fato é que teses resistentes à tutela coletiva tem se apropriado da penumbra conceitual em que estão inseridos os direitos supraindividuais.

A agregação busca-se, de forma pragmática, superar o conceitualismo no tocante à natureza dos direitos. Isso porque a rígida separação entre individual e coletivo, além de suprimir inúmeras situações da vida plurissubjetivas existentes nesse medium, estabelece a incerteza processual e incentiva o comportamento estratégico das partes no processo, que estabelecem um jogo de estica e puxa entre os planos coletivo e individual, quando assim lhes é interessante.

\subsubsection{A AGREGAÇÃO E O COMPORTAMENTO ESTRATÉGICO}

Não é raro encontrar situações nas quais uma empresa, requerida em uma demanda individual, argumenta ser o direito alegado pelo autor um direito difuso ou coletivo e não individual. E, por vezes, nesse caso, o magistrado afirma que o direito é individual e não coletivo, mas, ao julgar procedente essa pretensão, beneficia toda a comunidade a que o indivíduo faz parte.

Lembra-se da controvérsia relativa ao saneamento básico do bairro Anil no Rio de Janeiro, citada no início do segundo capítulo. A CEDAE - concessionária de serviço público - alegava que a demanda individual era inadequada, para lograr a reparação da rede de saneamento básico do bairro, pois o direito era coletivo e o pedido se adequaria a uma Ação Civil Pública. 
O Poder Judiciário, na ocasião, consignou que o direito era individual, pois visava à melhoria da condição pessoal de cada um dos moradores do bairro. Não obstante, ao reconhecer o direito e julgar procedente a pretensão autoral, determinou a reparação da rede de esgoto, o que beneficiaria não apenas o indivíduo, autor da demanda, mas a todo o bairro referenciado.

O que se quer dizer com esse exemplo? Quer se dizer que a rígida distinção entre individual e coletivo provoca um jogo de estica e puxa entre esses planos, quando assim interessa.

A empresa diz que o direito é coletivo, para extinguir a demanda individual, pois, em tese, a titularidade do direito é indeterminada. O Poder Judiciário admite a demanda individual, uma vez que o direito também é do indivíduo, mas o resultado se estende para toda a comunidade. No caso, admitindo-se a ação individual, há ensejo ao bis in idem e conflito prático de julgados.

É preciso superar essa dicotomia, pois ela não é um retrato fiel das controvérsias possíveis no mundo da vida. O mundo da vida não se divide, esquematicamente, em individual e coletivo. Existem tanto direitos individuais, com valência coletiva e de massa, como existem direitos coletivos, que são supervenientes aos indivíduos e que afetam profundamente suas vidas.

Nesses casos, seja o direito nomeadamente individual, porque o indivíduo é uma razão suficiente para a proteção jurídica, seja o direito nomeadamente coletivo, porque titularizado coletivamente, o que importa para fins de agregação é caracterização da valência coletiva ou, ao menos, tratar-se de um direito individual massificado ou homogêneo. O processo deve ser coletivo ou agregado sempre que o direito apresentar alcance coletivo ou massificado.

\subsubsection{REGIME PROCESSUAL}

Para afastar esse conceitualismo e o comportamento estratégico e, por vezes, até abusivo das partes, a agregação processual não se vincula ao tipo de direito, mas sim ao seu alcance.

O que identifica os direitos são os critérios substanciais, antes mencionados, incindibilidade, paridade (incindibilidade normativa), impessoalidade e homogeneidade (massificação social). Não é o nome, a titularidade ou o tipo de direito (saúde, propriedade) que os identificam. 
Em todos esses casos em que há uma abrangência coletiva ou de massa, a agregação é possível. Os variáveis graus de vinculação que existe entre os planos individual e coletivo manifestamse, por sua vez, apenas na forma de tratamento ou nos instrumentos de agregação processual.

A intensidade com que as situações jurídico-substanciais de uma pluralidade de sujeitos se entrelaçam ou refletem de forma impessoal, indivisível ou paritária uns nos outros - reflexos que foram ponto a ponto explicitados e exemplificados no tópico anterior - determinam não a agregação em si, mas o tratamento processual ou o regime processual da agregação.

Existem regimes de vinculação obrigatória, na qual não se admite a exclusão do indivíduo e será ele, eventualmente, prejudicado pelo resultado do procedimento agregado. Existem regimes de vinculação não obrigatória, na qual se admite a exclusão do indivíduo e não será ele prejudicado por eventual improcedência do resultado decisório do procedimento agregado.

Pondera-se, apenas, que mesmo nos regimes de vinculação não obrigatória, seja admitida a instituição de um ônus argumentativo às partes, para evitar abusos ou sucessivas investidas de indivíduos ao Poder Judiciário, deduzindo uma mesma controvérsia coletiva em juízo. Esse tema será recuperado, todavia, no último capítulo, quando abordado o ônus argumentativo.

O panorama estabelecido, até agora, teve por escopo identificar, teoricamente, os critérios que diferenciam e identificam os planos individual e coletivo. É preciso verificar a forma como esses critérios foram, em concreto, previstos nos sistemas jurídicos brasileiro e estadunidense, bem como o tratamento ou o regime processual a eles conferido, bem como as tendências.

\subsection{SÍNTESE PARCIAL}

Os interesses coletivos não são uma mera soma dos interesses individuais, mas apresentam uma convergência ou uma interdependência no plano material, de forma que, ao mesmo tempo em que se avançam os interesses do grupo, avançam-se os interesses dos indivíduos em direção ao bem comum. O interesse coletivo, por sua vez, não se reduz a nenhum dos interesses individuais, mas é superveniente e independente, a saber, têm atributos próprios/peculiares. 
Para tanto, a identificação dos atributos próprios dos interesses ou direitos coletivos vincula-se a dois critérios: critério objetivo e critério subjetivo. É a indivisibilidade e/ou paridade e a impessoalidade, presentes na relação substancial, que determinam a agregação processual, mediante a representação por um portador ideológico dos interesses do grupo ou pela identificação de uma amostra representativa da controvérsia. Nesse caso, o centro da cognição e discussão são os atributos do próprio grupo. O indivíduo apresenta-se, nesse contexto e ao menos em parte, como membro fungível de um grupo, sem apresentar atributos pessoais.

O grau de variância ou de convergência tolerado entre os membros do grupo, para fins de agregação, constituem uma combinação de possíveis cenários, em que os critérios dados pelo direito substancial se imiscuem: de um situação mais intensa de indivisibilidade e impessoalidade ou uma situação mais fluída de paridade e impessoalidade ou, ao menos, a impessoalidade ou equidistância do indivíduo em relação ao bem (individualização em massa). 


\section{CRITÉRIOS SUBSTANCIAIS DE AGREGAÇÃO E REGIME PROCESSUAL}

\subsection{APRESENTAÇÃO}

No capítulo anterior, foi descrito um panorama geral dos interesses ou direitos, suscetíveis de agregação, com remissão aos critérios subjetivo e objetivo de identificação e categorização. $\mathrm{O}$ escopo do presente capítulo é demonstrar a aplicação prática desses critérios substanciais, antes mencionados apenas teoricamente, no sistema jurídico estadunidense e no sistema jurídico brasileiro, bem como os regimes processuais e as tendências recentes de agregação processual.

\subsection{INTERESSES OU DIREITOS NO SISTEMA JURÍDICO ESTADUNIDENSE}

Como já mencionado, a principal regra do sistema jurídico estadunidense que se dirige ao fenômeno da litigiosidade de massa é a Federal Rule 23, que introduziu as ações coletivas.

Existem outras regras que também instituíram técnicas de agregação processual. Há técnicas de agregação voluntária, como as hipóteses de intervenção de terceiros (intervention - Rule 24) e de litisconsórcio facultativo (permissive joinder-Rule 20), em que há participação espontânea, direta e individual na demanda. Há técnicas de agregação involuntária, em que há forçosa participação direta e individual na demanda, como ocorre no litisconsórcio involuntário (involuntary joinder - necessary parties e indispensable party - Rule 19) e na técnica do terceiro interveniente (interpleader - Rule 22). E, por fim, há técnicas de agregação involuntária de larga escala, como ocorre nas ações coletivas (class action - Rule 23), na consolidação e na coordenação de demandas (consolidation e coordination - Rule 42) e nos casos-teste (testcase), nas ações derivadas de acionistas ou membros de associações informais (shareholder's derivative suits e unincorporated association's derivative suits - Rule 23.1 e 23.2), hipóteses nas quais a agregação tende a ser involuntária e a participação individual bastante mitigada. ${ }^{571}$

Essas últimas técnicas, denominadas de larga escala, são as mais adequadas ao fenômeno da litigiosidade de massa, em que surgem relações coletivas ou plurissubjetivas multitudinárias.

571 TIDMARSH, TRANSGRUD, 2002, p. 87. No mesmo sentido, cf. NOTE. Developments in the law: multiparty litigation. Harvard Law Review, 1958, V. 71: 874-998p. 
E, como visto, até mesmo historicamente, foi no bojo das ações de classe que o problema das relações substanciais coletivas ou plurissubjetivas recebeu, em sua ultima ratio, uma maior dedicação por parte do legislador estadunidense e também uma maior sistematização jurídicoconceitual. Por essa razão, adota-se a metodologia de abordar os critérios substanciais de agregação previstos na Federal Rule 23, com remissões recorrentes às demais legislações.

\subsubsection{A INSUFICIÊNCIA DOS INSTRUMENTOS PROCESSUAIS TRADICIONAIS}

Como já é cediço, as ações coletivas já existem há muitos séculos, mas, no período moderno, com o esfacelamento dos grupos medievais, esse mecanismo foi, por vezes, suplantado pelas doutrinas da necessary parties ou indispensable party, como reação ao regime coletivo anterior.

Para relembrar, segundo a doutrina da necessary parties, todos aqueles interessados na controvérsia de direito substancial são partes necessárias à demanda, de forma a possibilitar a resolução integral daquele conflito. A integração desses interessados é necessária. Mas, caso isso não seja possível, o indivíduo ausente não seria prejudicado pelo resultado do julgamento.

A doutrina da indispensable party é derivada da primeira, mas seu sentido é inverso. Segundo essa doutrina, a integração dos interessados é indispensável porque eles serão imperiosamente prejudicados ou vinculados pelo resultado da ação coletiva. Sem a integração de todos, não é possível alcançar o julgamento de mérito na demanda, sendo imperiosa a sua extinção.

Conforme assevera Hazard $\mathrm{Jr}^{572}$, a doutrina da necessary parties admite exceções, caso venha a se tornar inconveniente ou impraticável. Por exemplo, na hipótese em que seja necessária a integração de uma multiplicidade de sujeitos, de forma a tumultuar a condução do processo, admitem-se exceções àquela doutrina, estabelecendo soluções criativas para que os indivíduos não sejam prejudicados, como, por exemplo, a ação coletiva. A doutrina da indispensable party, que foi uma derivação da primeira doutrina, não admitia, no entanto, outra solução, que não fosse a integração da parte ausente à demanda, sob pena de extinção. Se o provimento não fosse pleno e integral a todos os sujeitos interessados, então nenhum provimento seria proferido.

572 HAZARD JR, 1961, 1256-1274. 
No momento atual, as doutrinas supracitadas são, paulatinamente, percebidas como insuficientes e limitadas, principalmente diante de relações substanciais coletivas ou plurissubjetivas multitudinárias. E, o pior, muitas vezes, são invocadas pelas partes apenas para lograr a extinção do processo e não para propiciar a efetiva agregação processual dos sujeitos.

Como os conceitos de parte necessária e parte indispensável (necessary parties and indispensable party) são bastante tênues e os parâmetros para distinguir uma doutrina da outra não são suficientemente claros, não é difícil imaginar situações nas quais a doutrina da indispensable party é invocada, com o fim estratégico de extinguir o processo judicial. ${ }^{573}$

Alguns exemplos são explorados por Jay Tidmarsh e Roger Trangsrud ${ }^{574}$, como o precedente Eldredge v. Carpenters 46 Northern California Counties Joint Apprenticeship and Training Committee. Nesse caso, dois autores ajuizaram uma demanda em face do comitê gestor do programa de treinamento e aprendizagem profissional, alegando discriminação sexual. O programa somente admitia indivíduos que já tiveram um primeiro emprego e os cadastrava no sistema. Os empregadores eram, por sua vez, obrigados, por um acordo trabalhista, a contratar um determinando número de aprendizes daquele sistema. Era perceptível, no entanto, a pouca representatividade de mulheres cadastradas no programa de aprendizagem assim organizado.

Em sua resposta, o comitê alegou que os profissionais treinados eram aqueles que já foram contratados por alguma empresa, razão pela qual alegou que 4.500 empregadores e 60 uniões sindicais constituíam partes necessárias à demanda. A District Court determinou a inclusão das partes ausentes. Os autores consideraram impossível a condução da demanda como se fosse um "widespread joinder" ou um litisconsórcio difuso. A District Court argumentou, por sua vez, que não era admissível o exame da pretensão autoral sem a integração das partes indispensáveis à demanda e, por conseguinte, extinguiu o processo prematuramente, sem resolução de mérito.

A Court of Appeals (Tribunal de Apelação), posteriormente, reformou a decisão. Argumentou que a discriminação realizada pelo programa é independente da discriminação realizada pelos

573 Mary Kay Kane, embora afirme a distinção, ressalta a sutileza conceitual. Segundo Kane, a parte necessária é aquela que pode ser afetada pelo julgamento, razão pela qual é relevante a sua integração à demanda e a parte indispensável é aquela que, inevitavelmente, será afetada pelo julgamento, razão pela qual é indispensável a integração à demanda (Cf. KANE, Mary Kay. Civil procedure. Minneapolis: Thomson West, 2007, p. 112 e, NOTE. Developments in the law: multiparty litigation. Havard Law Review, 1958, V. 71: 874-998p, p. 113).

574 TIDMARSH, TRANSGRUD, 2002, p. 89-90. 
empregadores. Ainda que a modificação do programa não altere integralmente a discriminação dos empregadores e das uniões sindicais contra as mulheres, o programa era, por si só, discriminatório e, por essa razão, merecia análise independente por aquela Corte de Justiça.

A partir desse precedente, é possível perceber tanto as sutilezas que existem nas doutrinas da necessary party e da indispensable party, como o uso estratégico da doutrina da indispensable party, para extinguir a demanda. Mas, mesmo que essas doutrinas não sejam usadas estrategicamente, elas ainda seriam inadequadas para os contornos multitudinários de um caso concreto. Como salienta Tidmarsh e Transgrud ${ }^{575,}$ as referidas técnicas não promoveriam a agregação ótima, noutros termos, a agregação necessária e adequada ao direito substancial.

O mesmo ocorreu no precedente Makah Indian Tribe $v$. Verity, também citado por Jay Tidmarsh e Roger Trangsrud ${ }^{576}$. Nessa hipótese, 24 tribos indígenas do noroeste pacífico gozavam de direitos, presentes em tratados indígenas, que lhes autorizavam a pescar salmão no Rio Columbia. Outras pessoas também pescavam na mesma área, como o pescador comercial e o esportista, o que resultou em um declínio da população de salmão naquela região. Para preservar a espécie, mas, ao mesmo tempo honrar as obrigações do tratado indígena, foi um estabelecido um regime administrativo de pesca, na qual um conselho deliberava, a cada ano, uma cota de pesca para cada uma das tribos. A tribo Makah ajuizou uma demanda em face do Secretário de Comércio, alegando que a Secretaria de Comércio violou a legislação federal na elaboração do regime administrativo e que fazia jus a uma cota maior de pesca, em razão de sua dimensão.

O Nono Circuito (Ninth Circuit) alegou que não havia a necessidade de incluir as tribos ausentes à demanda no tocante à revisão do regime administrativo, pois a questão atinente à observância ou não da legislação federal na elaboração daquele regime não afetaria os demais interessados. No entanto, não era possível realocar ou redistribuir as cotas de pesca, conferindo uma cota maior à Tribo Makah, sem que as demais tribos fossem integradas à controvérsia como partes. Cada tribo seria afetada pela decisão quanto às cotas, constituindo, portanto, partes indispensáveis à demanda. Esse é um caso clássico de paridade, em que a doutrina da indispensable party torna-se perversa, pois a multiplicidade de interessados torna, praticamente inviável a litigância da controvérsia. O segundo pedido, a saber, o pedido de majoração da cota de pesca, realizada pela tribo Makah Indian Tribe não foi sequer apreciado em juízo. 
O mesmo raciocínio se aplica à técnica do terceiro interveniente (rule interpleader). Segundo essa técnica, se um sujeito estiver exposto a pretensões individuais múltiplas, relativas ao mesmo objeto, em hipóteses nas quais o fundo para ressarcimento dessas pretensões seja limitado ou que haja risco de pronunciamentos judiciais inconsistentes ou contraditórios à parte, esse sujeito pode convocar, obrigatoriamente, como intervenientes todos os demais indivíduos interessados, de forma a alcançar a resolução integral e definitiva da controvérsia para todos. ${ }^{577}$

Esse mecanismo tem sido, muitas vezes, considerado inadequado, pois o poder de realizar a estruturação molecular da controvérsia está nas mãos do devedor, que cabe realizar a intervenção compulsória. Normalmente, esse mecanismo somente é utilizado pelo devedor quando considerado por ele vantajoso, a exemplo de pretender a limitação da sua responsabilidade. O uso da técnica pelo devedor é, portanto, estratégico, não lhe interessando quando não houver uma vantagem pessoal. Não há, assim, em regra, o escopo de alcançar o método necessário ou mais idôneo à atuação do direito substancial e a solução do conflito. ${ }^{578}$

As formas de agregação voluntária são, com mais razão, inaptas a tratar do fenômeno da litigiosidade de massa. Isso porque, em razão da espontaneidade, não há uma juízo de adequação e/ou de necessidade da agregação processual em relação à controvérsia substancial.

Enfim, o que se percebe é que esses mecanismos processuais, seja a necessary parties, seja a indispensable party, seja o interpleader, perderam o fôlego para o tratamento de determinadas controvérsias de direito substancial coletivas ou plurissubjetivas, que acabaram se tornando multitudinárias no período contemporâneo. Por essa razão, outras técnicas de agregação, como as ações coletivas, são ponderadas para esses mesmos casos, sendo que os critérios substanciais a autorizar o manejo de uma ou de outra técnica são bastante similares no plano legislativo ${ }^{579}$. 
Os critérios substanciais presentes no litisconsórcio involuntário ${ }^{580}$ e na técnica do terceiro interveniente ${ }^{581}$ são muito próximos daqueles critérios adotados na ação de classe ${ }^{582}$. Mas, diante da inviabilidade prática de se admitir a participação direta de todos os interessados e, até mesmo, diante da desnecessidade de participação direta de todos, as ações coletivas, bem como outras técnicas de agregação foram aceitas no sistema estadunidense e já são triviais. O processo segue, assim, flexível e adaptável às necessidades e às circunstâncias do direito substancial.

\subsubsection{A NATUREZA TRANSUBSTANCIAL DA AGREGAÇÃO PROCESSUAL}

Dizer que o processo deve adequar-se ao direito substancial não é tão simples quanto parece, mormente, no tocante à tutela de situações da vida coletivas ou plurissubjetivas, como se verá.

É cediço que a primeira classificação das ações coletivas, introduzida pela Rule 23, em 1938, apresentava uma classificação conceitual ou abstrata dos direitos, que admitiriam a agregação processual mediante as ações coletivas. Somente a determinadas categorias de direitos, ontologicamente definidos na legislação federal, que o regime processual dado seria coletivo.

580 [... a a) Persons ReQuired to Be JoIned IF FeAsible.(1) Required Party. A person who is subject to service of process and whose joinder will not deprive the court of subject-matter jurisdiction must be joined as a party if:(A) in that person's absence, the court cannot accord complete relief among existing parties; or (B) that person claims an interest relating to the subject of the action and is so situated that disposing of the action in the person's absence may:(i) as a practical matter impair or impede the person's ability to protect the interest; or(ii) leave an existing party subject to a substantial risk of ncurring double, multiple, or otherwise inconsistent obligations because of the interest (Cf. UNITAD STATES OF AMERICA. Federal Rules of Civil Procedure. Washington: US Government Printing Office, 2010).

581 [...] (1) By a Plaintiff. Persons with claims that may expose a plaintiff to double or multiple liability may be joined as defendants and required to interplead. Joinder for interpleader is proper even though:(A) the claims of the several claimants, or the titles on which their claims depend, lack a common origin or are adverse and independent rather than identical; or(B) the plaintiff denies liability in whole or in part to any or all of the claimants.(2) By a Defendant. A defendant exposed to similar liability may seek interpleader through a cross claim or counterclaim (Cf. Cf. UNITED STATES OF AMERICA. Federal Rules of Civil Procedure. Washington: US Government Printing Office, 2010).

582[...] ((b) TYPES OF CLASS ACTIONS. A class action may be maintained if Rule 23(a) is satisfied and if: (1) prosecuting separate actions by or against individual class members would create a risk of: (A) inconsistent or varying adjudications with respect to individual class members that would establish incompatible standards of conduct for the party opposing the class; or (B) adjudications with respect to individual class members that, as a practical matter, would be dispositive of the interests of the other members not parties to the individual adjudications or would substantially impair or impede their ability to protect their interests; (2) the party opposing the class has acted or refused to act on grounds that apply generally to the class, so that final injunctive relief or corresponding declaratory relief is appropriate respecting the class as a whole; or (3) the court finds that the questions of law or fact common to class members predominate over any questions affecting only individual members, and that a class action is superior to other available methods for fairly and efficiently adjudicating the controversy. [...](Cf. UNITED STATES OF AMERICA. Federal Rules of Civil Procedure. Rule 23. Washington: U.S Government Print Office, 2010). 
Essa definição ontológica dos direitos, a admitir tratamento agregado, implicava grande confusão e controvérsia doutrinária e jurisprudencial. A classificação era considerada, por demais, técnica e abstrata com fundamento nas características do direito substancial (character of the right), dando azo à incerteza na aplicação da técnica. Noutros termos, era complexo identificar, em concreto, de qual direito se tratava e qual seria o regime processual aplicável. ${ }^{583}$

Por essa razão, em 1966, em sede de reforma normativa, o Federal Rule Advisory Committee rejeitou a classificação prevista na antiga Federal Rule 23 e estipulou uma nova classificação, mas pragmática e funcional, das hipóteses a admitir o tratamento processual agregado. Ao invés de referir-se ontologicamente aos direitos, o texto referiu-se às hipóteses práticas atinentes a situações da vida coletivas ou plurissubjetivas, as quais admitiriam a agregação. E, mais, fez menção à tutela processual correspondente à categoria-tipo, se injuntiva, se declaratória etc..$^{584}$

Essas sucessivas alterações normativas, ocorridas desde 1938, devem ser compreendidas segundo uma nova mentalidade que permeava todo o direito processual, mormente, a sua relação com o direito substancial. Surgia, cada vez mais forte, o nexo entre direito e processo.

De uma forma geral, percebeu-se que a elaboração de regras e instrumentos processuais rígidos, relativos a determinadas categorias de direitos substanciais, implicava, certo formalismo ${ }^{585} \mathrm{ou}$, em inglês, adversarialness ou gamesmanship, isto é, um abuso das formas e das sutilezas processuais para que o direito substancial não fosse atuado e o processo, por sua vez, não alcançasse os seus resultados. Dada a rigidez e a multiplicidade das técnicas processuais, vigorava a incerteza quanto à justeza das posições das partes em relação à técnica processual adotada e a possibilidade de alcançar o mérito de demanda tornava-se uma atividade cada vez mais intrincada, complexa e insatisfatória para as partes no tocante aos resultados almejados. ${ }^{586}$

583 Essa crítica é realizada por KLONOFF, 2007, p. 19; CHAFEE, 1950, p. 245-247; KAPLAN, Benjamin. Continuing work of the civil committee: 1966 amendments of the federal rule of civil procedure. Harvard Law Review, 1968, V. 81:356-416p. p. 376-380.

584 KAPLAN, op. cit., p. 386. No mesmo sentido, BONE, 1990, p. 280.

585 Frederick Schauer explora o tema formalismo no sistema estadunidense, salientando o sentido pejorativo que se imprime a essa expressão. Posteriormente, de forma positiva, Schauer busca recuperar a noção de forma como regra, isto é, o dever de se levar à sério a regra (in casu, forma ou técnica) e não ficar aprisionado ou escravizado por ela. Uma regra (forma ou técnica) pode ser afastada ou derrotada, por exemplo, se o escopo pretendido por ela não for alcançado (Cf. SCHAUER, Frederick. Formalism. Yale Law Review, 1988, V.97: 509-548p. p. 547).

586 POUND, Roscoe. The causes of popular dissatisfaction with the administration of justice. Presented at the annual convention of American Bar Association in 1906. 
Segundo Stephen N. Subrim ${ }^{587}$, que realizou análise da relação entre direito e processo na história do sistema anglo-americano, percebeu-se que era preciso simplificar e flexibilizar as formas processuais, para alcançar justiça substancial. Isso se aplicava a vários campos desde os atos postulatórios e instrutórios aos provimentos e às hipóteses de demandas plurissubjetivas.

No mesmo sentido, Judith Resnik ${ }^{588}$ ressalta, que em 1901, nos Estados Unidos, não havia um acesso plausível às Cortes de Justiça e poucos eram os direitos correntemente reconhecidos. Com as Federal Rules of Civil Procedure, publicadas em 1938, uma nova gama de normas, de leis e de práticas permitiam o recurso às Cortes Federais para exigir e fazer cumprir os direitos.

Importa destacar que essa mentalidade processual, que já se firmava a partir do início do século XX, no sistema jurídico estadunidense, mormente com a promulgação das Federal Rules of Civil Procedure ${ }^{589}$, foi inicialmente motivada pela necessidade de unificar os juízos de equidade e os juízos de common law, pois, para cada situação substancial, estabelecia-se um procedimento distinto, o que, por vezes, ensejava a rigidez processual, o abuso das formas. ${ }^{590}$

A partir desse momento, como assinala Hazard $\mathrm{Jr}^{591}$, a simplificação e a flexibilização da forma processual, além de permitir a unificação dos juízos de equidade e common law, ensejou a tutela de situações substanciais não previamente consideradas pelo legislador processual. Novos direitos, como os direitos públicos sociais nos Estados Unidos, foram judicialmente tutelados, sem que essa situação substancial fosse antevista pelo legislador processual de forma a estabelecer um procedimento abstrato, prévio e diferenciado a essa espécie de direito. A atipicidade procedimental tem servido, portanto, ao longo do tempo, para a tutela de novos

587 SUBRIN, Stephn. How equity conquered common law: the federal rules of civil procedure in historical perspective, 1987, V. 135:909-1002p. p. 910.

588 RESNIK, Judith. Compared to what? ALI Aggregation and the shifting contours of due process and of lawyer's powers. The George Washington Law Review, 2011, V. 79: 628-699p., p. 637.

589 Ibidem, p. 910.

590 Antonio Gidi explicita que as Federal Rules of Civil Procedure não são uma lei, no sentido de norma jurídica emanada do poder legislativo (statute), também não se trata de um código no sentido de um sistema legal coerente e completo. Trata-se apenas de um conjunto de regras emitido pela Suprema Corte Estadunidense, por meio de uma delegação do Poder Legislativo. Em 1934, o Congresso promulgou uma lei, a Rules Enabling Act, delegando a Suprema Corte a tarefa de promulgar normas processuais para regular o processo na Justiça Federal. O único limite era a vedação de que essas regras processuais implicassem o aumento, a modificação ou a redução dos direitos substanciais (Cf. GIDI, Antônio. A class action como instrumento de tutela coletiva dos direitos: as ações coletivas sob uma perspectiva comparada. São Paulo: Revista dos Tribunais, 2007, p. 46).

591 HAZARD JR, George. Discovery vices and trans-substantive virtues in the Federal Rules of Civil Procedure. University of Pennsylvania Law Review. 1989, V. 137: 2237-2247p, p. 2246 
direitos. Em linguagem figurada, trata-se de pôr "novo vinho em velhas garrafas" 592 , de forma que as modificações substanciais sejam suportadas pelo esquema procedimental então vigente.

O sistema estadunidense descobriu o valor da atipicidade processual, sem, com isso, desmerecer a tutela diferenciada. Nada impede, assim, que, em determinadas situações, o processo também se diferencie em abstrato. Tanto que, em alguns casos, o procedimento permanece diferenciado, à luz da situação substancial, como, por exemplo, ocorre na falência (bankruptcy), já abordada.

De igual modo, o profundo relacionamento entre direito e processo também exsurge. Segundo Bone ${ }^{593}$, é incontroverso que a função adjudicatória do processo civil consiste em fazer cumprir o direito substancial, produzindo resultados que atendam aos direitos substantivos das partes.

Essa qualidade ou virtude da atipicidade processual recebeu, todavia, no sistema estadunidense, a denominação de escopo transubstancial do processo (trans-substantive scope of procedure $)^{594}$, isto é, o procedimento deve ser flexível, de forma a adaptar-se às necessidades do direito material, sem, no entanto, ser rigidamente confinado por ele. O sistema processual não pode ser estabelecido de forma tão previsível e predicável, como se existisse um procedimento específico para cada controvérsia. Muitas vezes, a lei não pode prever tudo e o procedimento deve apresentar uma abertura normativa para adequar-se às diversas situações jurídicasubstanciais do mundo da vida ainda não previamente consideradas pelo legislador. Isso já foi é vantajoso em vários momentos da história, como ocorreu com a tutela dos direitos sociais.

Como salienta Hazard $\mathrm{Jr}^{595}$, não é possível um design procedimental para cada tipo de controvérsia substancial. Nesse contexto, foi preciso estabelecer um processo com uma textura normativa mais aberta ou elástica, mas sem abrir mão da técnica ou da sofisticação tipicamente processual. A finalidade transubstantiva do processo facilita o acesso à justiça de controvérsias, que talvez não fossem judicializadas. Isso porque reduz as barreiras que um procedimento rigidamente definido, a partir de determinado direito material, estabeleceria nessa hipótese.

592 HAZARD JR, 1989, p. 2247.

593 BONE, Robert G. Securing the normative foundations. Boston University Law Review, 2006, V. 86:11551170 p., p. 1161.

594 COVER, Robert M. For James Mm Moore: some reflections on a reading of the rules. Yale Law Review, 1975, V. 84: 718-740p, p. 718.

595 HAZARD JR, op. cit, p. 2247 
Embora o nome transubstancial possa dar azo a equívocos, a qualidade transubstancial do processo não implica nem o abandono da técnica processual, tampouco significa desvinculação das exigências do direito substancial. $\mathrm{O}$ fato de o procedimento ser atípico não elimina a sofisticação do processo, tampouco o nexo estabelecido com o direito substancial: a finalidade de atuá-lo. Embora transubstancial, o processo continua a ser orientado pelo direito substancial.

Quer se dizer apenas que processo deve superar uma cartilha procedimental rigidamente estabelecida na hipótese em que essa não favorecer a administração da justiça substancial. Isso não significava, porém, jogar essa cartilha fora. Trata-se de correlacionar técnica com resultado.

A atipicidade processual tinha, portanto, por escopo, superar o processo como fetiche e permitir que fosse ele pensado como método de administração da justiça. Essa mentalidade permitiria relevar vícios processuais quando esses não afetassem a resolução da controvérsia de direito substancial ${ }^{596}$, bem como permitiria ampliar as hipóteses de tutela jurisdicional, mediante o recurso a esquemas procedimentais normativamente mais abertos e orientado à substância.

Com isso, pode-se dizer que, embora o processo possa constituir um procedimento indiferenciado a um determinado tipo de direito, ele é, ao mesmo tempo, adaptável às necessidades do direito substancial. É um juízo, portanto, de adequação à substância e não de confinamento a ela - essa é a virtude transubstancial do direito processual antes referida.

Roberto Cover ${ }^{597}$ salienta que existe um valor em admitir um conjunto de regras processuais aplicável independentemente da natureza do direito substancial deduzido, em outras palavras, a atipicidade processual tem o seu valor. Reconhecer essa atipicidade não diminui o valor das Federal Rules of Civil Procedure, que a adotou, não nega a relação entre direito substancial e processo, bem como não afasta o fato de o processo ser sensitivo e adaptável à substância. ${ }^{598}$

596 Para Robert Cover, a regra que institui a forma ou a técnica processual deve ser compreendida à luz do direito substancial. Cita, como exemplo, o caso Eisen. Nesse caso, a notificação da ação coletiva ao membro ausente do grupo superava o valor da compensação individual. Por essa razão, a técnica, que determinava a melhor comunicação possível deveria ser orientada às peculiaridades da relação substancial, como o fato de o dano ser ínfimo e desinteressante à persecução individual. A técnica processual deveria ser, portanto, adaptada à necessidade e fins do direito substancial, sob pena de não alcançar resultados (Cf. COVER, 1975, p. 738-739). 597 Ibidem, 1975, p. 718 e 752.

598 Essa afirmação não descumpre a Rules Enabling Act, que veda a criação, a modificação ou a redução de direitos substanciais. O processo é orientado pelo direito substancial, ele não cria, reduz ou modifica o direito substancial. Aliás, se o processo não fosse orientado pelo direito substancial, nenhum valor teria em se adotar um procedimento flexível, que seria congelado sempre a uma mesma forma. $\mathrm{O}$ direito processual deve ser impactado 
Mas, o que essa relação entre direito e processo tem a ver com a agregação processual, especialmente com a Rule 23 que introduziu a ação coletiva no sistema estadunidense?

Em 1938, foi admitida uma classificação das ações coletivas, que embora unificasse a equity e a common law, ainda fazia remissão a direitos substanciais em abstrato, o que prejudicava a compreensão da norma naquele momento. Em 1966, por ocasião de reforma legislativa, a classificação das espécies de ação coletiva foi alterada. No lugar da classificação abstrata de direitos, foi estabelecido um critério pragmático ou funcional, sem menção à espécie de direito.

Nesse ínterim, sustentou-se -e há ainda quem o sustente ${ }^{599}$ - que essa alteração legislativa revelou a inexistência de um enfoque substantivo nas ações de classe, isto é, os direitos coletivos, os direitos de abrangência coletiva e os direitos de massa nada mais seriam do que os típicos direitos individuais, apenas convenientemente agregados para fins exclusivamente processuais. O processo ganharia um valor em si, para o atingimento dos seus próprios escopos, como se o processo fosse neutro ou indiferente a qualquer manifestação no direito substancial.

Por tudo o que foi investigado até agora, essa crítica não deve prevalecer. Talvez, o nome transubstancial assuste ou cause confusões. Mas, Kaplan ${ }^{600}$, um dos juristas que participaram da redação da Federal Rule 23, disse que a regra da ação de classe "não é neutra, não escapou a atenção naquele momento em que ela iria abrir o caminho para a afirmação de muitas, muitas reivindicações que de outra forma não seriam pressionadas contra o réu" [tradução nossa]. Enfim, a atipicidade se justificava, naquele momento, para conferir um maior acesso à justiça.

Há, hoje, forte doutrina sustentando a permanência do enfoque substantivo, mesmo que sem abrir mão da atipicidade. Ainda que novas tutelas diferenciadas surjam, a atipicidade tem valor como cláusula de escape no sistema jurídico e desde que a orientada à relação substancial. ${ }^{601}$

pelo direito substancial e vice-versa, mas sempre de forma conectada aos escopos ou ao valor do direito substancial (COVER, 1975, p. 734-735).

599 REDISH, 2009, p. 10, 16 e 22.

600 KAPLAN, Benjamin. Comment on Carrington. University of Pennsylvania Law Review, 1989, V. 137: $2125-$ $2127 \mathrm{p}$.

601 Segundo Carlos Alberto de Salles, a estratégia legislativa dirigida à elaboração de um processo atípico, transubstancial ou não diferenciado, não está incorreta. Não há outra saída, senão caminhar no sentido de uma norma de maior generalidade, que possa abarcar um maior número de situações. Não é preciso, ainda, moldar os procedimentos a um tipo de direito, o que se deve esperar do processualista é a sua capacidade de moldar ou construir arranjos ou desenhos procedimentais aptos a atender às necessidades de grande especificidade (Cf. SALLES, Carlos Alberto de. Arbitragem em contratos administrativos. Rio de Janeiro: Forense, 2011, p. 23-24). 
O processo - e passe o truísmo o processo coletivo - foi apenas direcionado à atipicidade. A atipicidade processual, por sua vez, não nega as diferenciações, porventura, presentes no direito substancial. Muito pelo contrário, a atipicidade é justamente a forma de tutelar as distintas necessidades substanciais, sem vincular-se a um tipo substancial em abstrato. Logo, o processo coletivo tem uma orientação do direito substancial: de um direito coletivo ou plurissubjetivo.

De igual modo, mesmo uma classificação pragmática ou funcional das ações coletivas - que é aquela hoje prevista - não dispensa o enfoque substancial: são os critérios substanciais, subjacentes a essa classificação, que permitem compreender e tutelar as situações da vida plurissubjetivas já existentes e aquelas que, porventura, ainda estão por vir. Senão vejamos.

\subsubsection{CATEGORIZAÇÃO DAS AÇÕES COLETIVAS}

As duas formas de classificação da tutela coletiva, previstas na Federal Rule 23, serão abordadas nesse tópico, para que a problemática supracitada seja visualizada com clareza.

\subsubsection{CLASSIFICAÇÃO CONCEITUAL DOS DIREITOS}

A classificação, presente na Federal Rule 23 de 1938, buscou estabelecer diferentes categorias de ações coletivas, identificadas pelo caráter do direito (character of right ${ }^{602}$. Trata-se de uma definição abstrata, conceitual ou ontológica, cuja identificação, no caso concreto, era necessária para fins de prestação da tutela jurisdicional. O regime processual aplicado alterava-se a partir da identificação da relação substancial coletiva plurissubjetiva estabelecida em cada categoria.

A legislação anterior, a saber, a Equity Rule 38, dizia apenas que: quando a questão controvertida for comum ou de interesse geral a uma ou mais pessoas, de forma a constituir uma classe tão numerosa e cuja reunião seja impraticável em juízo, uma delas poderá agir ou proteger o interesse em nome de todas as outras. Nesse caso, enfatizava-se apenas a generalidade do direito deduzido em juízo e a existência de uma questão comum ao grupo. ${ }^{603}$

602 LESAR, Hiram H. Class suits and the federal rule. Minnesota Law Review, 1938, V. 22: 34-59p, p. 40. 603 MOORE, James Wm; COHN, Marcus. Federal class action. Illinois Law Review, 1938, V. 32: 307-325p., p.310. 
Essa assertiva foi substituída em 1938 pela Federal Rule 23. E, no lugar, as ações coletivas foram classificadas em três categorias: (i) true class action (ação coletiva genuína, autêntica ou pura), (ii) hybrid class action (ação coletiva híbrida ou mista) e (iii) spurious class action (ação coletiva espúria ou por mera conveniência). Essa classificação foi proposta, originariamente, pelo Prof. James Moore e, ainda, foi apresentada ao Conselho Consultivo para Normas do Processo Civil Federal (Advisory Committee on Federal Rules of Civil Procedure). ${ }^{604}$

Segundo James Moore e Marcus Cohn ${ }^{605}$, a ação coletiva seria: (i) true sempre que o caráter do direito a ser protegido fosse comum, unitário, conjunto ou secundário entre vários indivíduos, o que ocorria quando o titular do direito primário agia de forma negligente na persecução daquele direito, o que ensejava a atuação do titular do direito secundário ou concorrente. Nessa espécie, havia uma unidade ou comunhão necessária entre os membros do grupo. O principal exemplo dessa categoria são as ações derivadas de acionistas. (ii) hybrid sempre que o caráter do direito a ser protegido fosse separado ou independente, mas afetasse uma propriedade específica ou um fundo comum à controvérsia, a que a muitos indivíduos interessava. $\mathrm{O}$ principal exemplo é hipótese de créditos concorrentes em relação a um fundo pecuniário limitado; e (iii) spurious sempre que o caráter do direito fosse separado ou independente, mas existissem questões comuns de fato ou direito e um remédio comum. O principal exemplo é uma espécie de litisconsórcio voluntário. Essa categorização, presente na proposta preliminar de Moore, foi, em seguida e em parte, acolhida pelo Advisory Committee on Federal Rules.

Ainda segundo Moore e $\mathrm{Cohn}^{606}$, o regime processual conferido à tutela coletiva era distinto conforme a categorização supramencionada, principalmente no tocante à coisa julgada. Se a ação coletiva fosse true, a coisa julgada alcançaria todo o grupo, inclusive os membros ausentes. Se a ação coletiva fosse hybrid, a coisa julgada alcançaria as partes e também todos os demais afetados pela propriedade controvertida em juízo, ainda que não figurassem formalmente na demanda, uma vez que consumado o interesse dos membros ausentes pela divisão do bem. Se a ação coletiva fosse spurious, a coisa julgada afetaria apenas as partes, ou seja, aqueles que figuraram formalmente na demanda ou que nela intervieram. Segundo a jurisprudência, no entanto, os membros ausentes do grupo seriam beneficiados, caso o pronunciamento judicial

604 MOORE, COHN, 1938, p. 314. MOORE, James Wm. Federal Rules of Civil Procedure: some problems raised by the preliminary draft. Georgetown Law Review, 1937, V. 25: 551-576p, p. 572.

605 MOORE, James Wm; COHN, Marcus, op. cit., p. 310. MOORE, James Wm., op. cit., p. 572.

606 MOORE, James Wm., op. cit., p. 571. 
fosse favorável ao grupo, manifestando sua intervenção posteriormente à sentença, o que ficou conhecido como one way intervention. Essa segunda categorização, também proposta por James Moore, não foi acolhida na Federal Rule 23, embora fosse aplicada pela jurisprudência. ${ }^{607}$

Essa classificação foi considerada sofisticada, complexa e excessivamente abstrata, não sendo possível identificar, com clareza, em cada caso concreto, qual era o caráter do direito deduzido.

E, por vezes, determinadas situações tornavam-se especialmente confusas, por exemplo, quando se pretendia uma tutela inibitória ${ }^{608}$ em razão de uma prática discriminatória, o julgado em favor de um indivíduo discriminado favoreceria a todos os demais igualmente, mas esse direito não era facilmente categorizado nas definições abstratas de true, several ou hybrid class.

É possível perceber, nessa categorização, a existência de um entrelaçamento de interesses ou direitos de vários sujeitos. Moore soube reconhecer a orientação substancial da técnica processual $^{609}$. No entanto, essa definição ontológica e excessivamente abstrata do caráter desses direitos não facilitou a prestação jurisdicional coletiva no sistema jurídico estadunidense.

\subsubsection{CLASSIFICAÇÃO FUNCIONAL DOS DIREITOS}

Conforme asseverou Kaplan ${ }^{610}$, não obstante fosse confusa a classificação abstrata dos direitos tuteláveis pela ação coletiva, já era perceptível a existência de uma vinculação natural ou necessária entre vários sujeitos em dada controvérsia, a exigir uma adjudicação unitária.

O problema que enfrentou o Advisory Committee, em 1966, data em que aquelas categorias foram objeto de reforma, era, ainda segundo Kaplan ${ }^{611}$, como elaborar isso sem incorrer nas mesmas armadilhas de categorização abstrata, antes presente. Por essa razão, adotou-se uma categorização funcional ou pragmática, que relacionasse os interesses dos sujeitos, sem vinculá-

607 LESAR, 1938, p. 54.

608 NOTE. Developments in the law - multiparty litigation in the Federal Courts. Harvard Law Review, 1958 V. 71:874-998p, p. 935.

609 Em sentido semelhante, Robert Cover afirma isso, ao dizer que Moore sempre se mostrou contrário à primazia da forma sobre a substância (Cf. COVER, 1975, p. 740).

610 KAPLAN, Benjamin. Continuing work of civil committee: 1966 amendments of Federal Rules of Civil Procedure. Harvard Law Review, 1968, V. 81:356-416p., p. 386.

611 KAPLAN, 1968, p. 394. 
los a um tipo substancial em abstrato. Esse é a regra que vigora até hoje no sistema. Essas categorias já foram mencionadas no período contemporâneo, é preciso apenas rememorar.

Além dos pré-requisitos da ação de classe, que são a numerosidade e inviabilidade do litisconsórcio, a representação adequada, a existência de uma classe identificável, a existência de questões comuns de fato ou de direito e a tipicidade das pretensões e defesas, surgem agora quatro categorias de ações coletivas e são elas autorizadas quando: (i) houver risco de pronunciamentos judiciais inconsistentes ou contraditórios, no tocante aos integrantes da classe, estabelecendo padrões incompatíveis de conduta para a parte adversa, (incompatible standards class action); (ii) houver risco de pronunciamentos judiciais, em benefício de alguns indivíduos membros da classe, os quais, estariam, na prática, dispondo dos interesses de outros integrantes da classe, que não são partes na demanda, prejudicando-os, substancialmente, ou obstando a possibilidade de sua proteção (limited fund class action or prejudice class action); (iii) a parte adversa à classe tiver agido ou recusar-se a agir, com fundamento aplicável, em geral, ao grupo, tornando-se apropriado que o remédio jurídico final, da condenação de fazer ou não fazer ou da correspondente sentença declaratória, seja adotado para o grupo como um todo (injunctive class action or declaratory class action), acompanhada ou não de pedido incidental de ressarcimento em pecúnia; e (iv) questões comuns, de fato ou direito, aos membros da classe predominarem em relação às individuais, sendo a ação coletiva método superior aos demais métodos disponíveis para a solução justa e eficiente da controvérsia substancial (damage class action). ${ }^{612}$

Na Federal Rules of Civil Procedure, na reforma de 1966, também foram criadas as ações derivadas de acionistas e membros de associações informais (shareholder's derivative suits $e$ unincorporated association's derivative suits). São demandas coletivas que parecem com as ações de classe, mas apresentam requisitos diferenciados, a saber, não é preciso de numerosidade e existem pré-requisitos especiais para a propositura da ação (pleading), como, por exemplo, ser acionista ou membro da classe no momento da transação reclamada e outros. ${ }^{613}$

Mesmo a categorização supracitada, que não se fundamenta de forma abstrata no direito substancial, deve adequar-se a determinados critérios substanciais para ser compreendida.

612 UNITED STATES OF AMERICA. Federal Rules of Civil Procedure. Washington: US Government Printing Office, 2010.

613 KAPLAN, 1968, p. 387. 


\subsubsection{O ENFOQUE SUBSTANTIVO}

Em 1975, a Harvard Law Review ${ }^{614}$ já tratou da relação direito e processo no tocante às ações coletivas, mencionado o enfoque ou o caráter substantivo apresentado pela Federal Rule 23.

Em que consiste esse enfoque substantivo? Significa que, mesmo diante de uma classificação pragmática ou funcional, aquelas categorias processuais referem-se, implicitamente, a situações de impessoalidade e incindibilidade presentes no direito substancial. E, assim, para estabelecer, em determinado caso, qual é a tutela jurisdicional adequada, é preciso analisar essas exigências do direito substancial e os escopos substantivos a serem concretizados no caso concreto. ${ }^{615}$

O conceito de aggregate right ${ }^{616}$, já mencionado anteriormente, também permite aferir essa orientação substancial das ações coletivas, a saber, a necessidade de o indivíduo, operar na qualidade de membro do grupo, para nele inserir-se e avançar a proteção individual. Se há agregação, é porque o objeto substancial já tem ínsito a objetividade e a despersonalização.

\subsubsection{CRITÉRIOS SUBSTANCIAIS DE AGREGAÇÃO}

Os critérios para se aferir esses enfoque substantivo são aqueles já mencionados, como a impessoalidade, a indivisibilidade, paridade e individualização de massa da relação substancial.

Esses critérios são comuns aos dois sistemas jurídicos investigados, não são, portanto, exclusivos. Por essa razão, eles foram abordados e analisados de forma conjunta, anteriormente, quando abordados os direitos e/ou interesses, objeto de proteção, todavia, agora serão mencionados em concreto no sistema estadunidense, com referência a esse regime processual.

\subsubsection{LITIGIOSIDADE PESSOAL E IMPESSOAL (PERSONAL LITIGATIVE AND IMPERSONAL LITIGATIVE)}

614 NOTE. Developments in the law: class action. Harvard Law Review, 1976, V. 89: 1319-1517p, p. 1353. 615 A ação de classe deve ser justificada por razões substanciais, não sendo admissível a aplicação mecânica. Cabe ao magistrado estabelecer um design do procedimento adotado para atender as necessidades substanciais. A regra da ação de classe é regra atípica, que deve ser adequada conforme as peculiaridades do direito litigado (Cf. NOTE, 1976, p. 1366).

616 ISSACHAROFF, 2008, p. 2. GERKEN, 2001, p. 1682. 
Segundo Robert G. Bone ${ }^{617}$, o ponto central da agregação, na história, é a existência de formas impessoais de litigiosidade, que não se focalizam no indivíduo, mas, ao contrário, subsome o indivíduo ao anonimato de um grupo ou de uma categoria impessoal, padronizada e objetiva.

Existe, assim, segundo Bone ${ }^{618}$, uma dicotomia entre litigiosidade impessoal e pessoal. A litigiosidade impessoal refere-se à dedução em juízo de uma relação substancial atinente ao status legal de um grupo, cuja referência central é a categoria, atuando o indivíduo como membro dessa categoria. A litigiosidade pessoal refere-se à dedução em juízo de uma relação substancial particular, cuja referência central são os atributos ou características pessoais.

Embora a coesão ou a unidade entre os membros do grupo também constitua um critério substancial para agregação, Bone ${ }^{619}$ ressalta que, em determinados litígios, mais do que a coesão, o que se destaca é o anonimato individual, isto é, relações substanciais deduzidas em juízo nas quais o indivíduo é mero anônimo, não constitui o "elemento normativo central". ${ }^{620}$

Os tipos de ações de classe, previstas na Federal Rule 23, demonstram implicitamente essa dicotomia entre a litigiosidade pessoal e impessoal. Isso porque, como já apontado, ainda que a categorização seja prática ou funcional, ela continua a referir-se ao direito substancial.

Bone $^{621}$ assinala que, embora essa questão não seja inteiramente clara e pacífica, o Advisory Committee, ao investigar a homogeneidade ou a solidariedade no grupo, também ponderava em termos de quando o pronunciamento seria focalizado no grupo ou classe como conjunto (litigiosidade impessoal) ou nos membros da classe como indivíduos (litigiosidade pessoal). Mais do que a coesão ou convergência, o comitê investigava as situações de anonimato.

A impessoalidade é, por exemplo, muito marcante nas duas primeiras categorias da Federal Rule 23, a saber, (i) quando ações independentes ensejarem o risco de pronunciamentos judiciais inconsistentes ou contraditórios no tocante aos membros do grupo, estabelecendo padrões de conduta incompatíveis à parte adversa (incompatible standards); e (ii) quando ações

617 BONE, 1990, p. 218.

618 Ibidem, p. 233.

619 Ibidem, p. 297.

620 Ibidem, p. 297.

621 Ibidem, p. 297. 
independentes ensejarem o risco de pronunciamentos judiciais que prejudiquem substancialmente ou obstem a proteção de outros membros do grupo (limited fund class action or prejudice class action). Nesses casos, a adjudicação não é centralizada nos atributos pessoais dos sujeitos. Ao contrário, tende-se a enfrentar, de forma objetiva, a controvérsia em relação à pluralidade de interessados, de forma a que não surja conflito prático de julgados, bem como prejuízo em relação aos demais membros, que não figuraram formalmente na demanda. ${ }^{622}$

Como já se disse, isso ocorre porque a relação substancial deduzida em juízo é, por vezes, decorrente de um mesmo status legal compartilhado por um grupo, a estabelecer direitos individuais que se apresentam como reflexos ou secundários em relação à coletividade.

Nos antecedentes históricos da litigiosidade de massa, já foi possível perceber como isso ocorria com os direitos costumeiros ${ }^{623}$. O costume, quando discutido em juízo, vinculava-se à prática de uma comunidade ou de grupo e não ao indivíduo. Embora o indivíduo fosse afetado por essa prática e pudesse ser judicialmente protegido, eventual pronunciamento das Cortes de Justiça comprometeria, necessariamente, os demais membros da comunidade, submetidos à mesma prática. As ações coletivas afastavam, portanto, o risco de inconsistência ou contradição no tocante à prática comunitária, bem como o risco de prejuízo aos demais membros do grupo.

Lembra-se que Frederic Calvert ${ }^{624}$ já havia explicitado essa questão, ao salientar que, para fins de agregação, era preciso considerar os impactos objetivos ou impessoais da relação substancial

622 BONE, 1990, p. 297-300.

623 “...The general right, as we have seen, was a single right that spawned distinct but identical individual rights or duties, the general right was an impersonal right. Its content derived from a source of law that was largely independent of the individual wills of the particular persons who happened to benefitted or burdened by the right. Customary right, for example, derived from longstanding community practice, not from contract. Moreover, at least in theory, individuals had no power to alter the legal incidents of a customary right; they could only choose whether or not to occupy the particular status. This impersonal quality helped assure that the declaration of the single general right would also determine each of the distinct individual rights or duties associated with it individuals did not voluntarily 'choose' to become group members; all persons with the requisite status who lived in the proper location were automatically members sharing in the group's privileges and obligations and in its social network. All such rights or duties were in effect clones of the general right, and thus all were identical in form. As a result, the separate actions at law, when viewed from the perspective of the rights or duties at stake, were simply "multiples" of one prototypical lawsuit. In other words, they were a 'multiplicity of suits'. The decree declaring a general right focused on the legal incidents of an impersonal status, not on the legal rights of individual status occupants." (Cf. BONE, 1990, p. 249).

624 “...persons may be required as parties, either on account of something personal, as for instance, having done certain acts of fraud or collusion,...or else because they are the owner or guardians of certain interests which the suit will affect. Upon grounds of the first nature, they must appear in their own persons if the proceedings concern the individual responsible for the fraud...they cannot be equally well conducted in the presence of some other person appearing on his behalf. On the other hand, if the general rule requires a person to be present, merely as the 
no grupo. Nos casos em que esses impactos fossem subjetivos ou pessoais, aquele tratamento processual não seria adequado. Calvert enunciou, assim, um critério geral de agregação, pouco percebido ao seu tempo, a partir da impessoalidade ou da pessoalidade do direito substancial.

Esse raciocínio, embora não conste na Federal Rule 23, persiste ainda hoje, seja nas hipóteses em que se discutem direitos públicos, seja nas hipóteses em que se discutem direitos privados. Isso porque o critério substancial de agregação não se vincula à natureza jurídica do bem. ${ }^{625}$

Nota-se que os casos clássicos de impessoalidade, citados na manualística estadunidense, são tanto de direito público, quanto de direito privado: (i) ação proposta por contribuinte para invalidar ato municipal lesivo ao patrimônio público ou ação de investidores para compelir a sociedade à declaração dos dividendos. São casos elencados como exemplos de incompatible class action $^{626}$ e (ii) ação proposta por um investidor para compelir à sociedade a indenizá-lo pelo direito a um dividendo, quando um direito idêntico surge para outros investidores da sociedade, potencialmente afetados pela ação independente do primeiro, ou ação na qual se pretende à gestão ou distribuição de um fundo fiduciário, situações nas quais os indivíduos devem ser tratados com paridade. É o caso do limited fund ou prejudice class action. ${ }^{627}$

Ultrapassadas essas questões, há que se prosseguir com a análise da terceira categoria injunctive class action ou declaratory class action. Essa categoria aplica-se quando a parte adversa à classe tiver agido ou recusar-se a agir, com fundamento, em geral, aplicável ao grupo, tornandose, portanto, apropriado que o remédio jurídico final, da condenação de fazer ou de não fazer ou da correspondente sentença declaratória, seja adotado para o grupo com um todo.

owner of and protector of a certain interest then the proceedings may take place with an equal prospect of justice, it that interest receives an effective protection from others" (Cf. CALVERT, 1837, p. 12).

625 “...Although no longer referred to by the appellation 'general right' those late nineteenth and early twentieth century representative suits that bound all class members combined both the impersonal quality and the strong reasons forbidding nonparties that characterized the earlier general right suit. For example, the decree in a taxpayer representative suit challenging unlawful municipal action normally bound all taxpayers Representative suits with res judicata effect were not confined to the public law arena. Private law also assigned rights and duties to classes of persons on the basis of shared status, thereby creating impersonal forms of litigation whenever the remedy determined the legal incidents of that status. Due to the categorical nature of its estate system, for example, the law of property generated a number of representative suits of this kind. The represented class embraced all persons sharing in a single estate or encumbrance, such as a remainder estate or a mortgage lien, and the remedy determined rights attaching to the particular estate or encumbrance and thus to all class members as a matter of law" (Cf. BONE, 1990, p. 274).

626 MARCUS, Richard L., SHERMAN, Edward F., ERICHSON, Howard M. Complex litigation: cases and materials on advanced civil procedure. 5 ed. St. Paul: Thomson West, 2010, p. 288.

627 TIDMARSH, 2002, 131. 
Semelhante ao raciocínio anterior, essa categoria também é marcada pela impessoalidade. É a categoria aplicável, principalmente, aos civil rights ou ao public interest litigation, mas apresenta uma peculiaridade. Embora o resultado ou provimento final deva ser impessoal, isto é, dirigido à classe como um todo e não à pessoa do indivíduo. Os sujeitos tendem a ter concepções particulares sobre as formas de concretização dos direitos de interesse público, mormente os direitos sociais. Isso ocorre porque esses direitos contam, por vezes, com apenas um patamar normativo geral, que pode ser objeto de concretização por diferentes formas.

Como já comentado, o caso clássico citado é o da desagregação escolar no sistema escolar estadunidense, no sentido de transformar um sistema educativo dual e discriminatório em um sistema unitário e igualitário entre brancos e afrodescendentes. O risco de conflitos dentro da classe é potencialmente maior, pois cada pessoa pode ter uma concepção diferente de como deveria ser o sistema escolar. Contudo, de qualquer modo, a impessoalidade deve ser alcançada, pois a parte adversa deve agir com fundamento, em geral, aplicável ao grupo como um todo. ${ }^{628}$

Por fim, a última categoria é a mais complexa (damage class action). Trata-se da hipótese em que, em regra, pretende-se indenização compensatória pelos danos sofridos por um indivíduo. Assim, se questões comuns, de fato ou de direito, predominarem no grupo e a ação coletiva constituir método superior de resolução da controvérsia, a agregação é, em tese, admissível.

Esse caso, embora se refira a danos sofridos por um indivíduo e a ele seja atribuída a compensação, estabelece diferentes graus de impessoalidade. Na realidade, o que determina o grau de impessoalidade não é a eficácia condenatória da sentença, mas o direito. A controvérsia poderá centrar tanto nas características gerais de um grupo de vítimas, quanto nas características individuais, estabelecendo, assim, uma escalada potencial de agregação no processo civil. Dada a especificidade dessa última categoria de classe, ela será abordada em tópico apartado da tese.

Por fim, o critério da impessoalidade encontra-se presente em outras técnicas de agregação, bem como em outras regras do processo civil federal. A Federal Rule 23 foi utilizada como parâmetro, mas o critério da impessoalidade também é encontrado, por exemplo, em outras regras, como nas doutrinas do necessary party e indispensable party. A Federal Rule 19, que

628 FISS, 1978, p. 11. No mesmo sentido, CHAYES, Abram. The role of the judge in public law litigation. 1976. V. 89:1281-1316p. p. 1284. 
introduziu aquelas doutrinas, reproduz, aliás, com bastante semelhança as hipóteses de incompatible standards class action (23 (b)(1)(A)) e limited fund class action (23 (b)(1)(B)).

De igual modo, na shareholder's derivative suits e na unincorporated associations derivative suits (ações derivadas propostas por acionistas e ações derivadas propostas por indivíduos, membros de associações informais ou sem personalidade jurídica), o critério da impessoalidade encontra-se previsto expressamente na Federal Rule 23.1 e na Federal Rule 23.2629

Segundo a Federal Rule 23.1, o investidor ou associado age na qualidade de membro do grupo e na defesa dos interesses próprios da empresa ou da associação, isto é, de forma impessoal. A impessoalidade é, nesse caso, bastante clara, pois, conforme já mencionado na teoria do interesse pessoal do grupo, é induvidosa a existência de interesses próprios da pessoa jurídica ou associação informal, que não se confundem com interesses pessoais dos indivíduos do grupo.

Para concluir esse tópico, é importante destacar que a autonomia e a participação individual na demanda são exigidas, com mais força normativa, nas hipóteses em que a litigiosidade é centrada nos atributos pessoais de um sujeito. Logo, quão maior a impessoalidade, maior a tendência de a litigiosidade centrar-se nos aspectos coletivos ou do próprio grupo, a admitir a fungibilidade do seu membro e a concessão de tratamento processual agregado à controvérsia ${ }^{630}$.

\subsubsection{COMPENSAÇÃO DIVISÍVEL OU INDIVISÍVEL (DIVISIBLE AND INDIVISIBLE REMEDIES)}

Outro critério substancial de agregação - esse bem mais comentado que o anterior - trata-se de aferir a divisibilidade ou a indivisibilidade da reparação pretendida pelo interessado em juízo.

Como já abordado, o direito ou interesse coletivo diz respeito a um bem comum incindível. Esse bem pode referir-se tanto a recursos naturais, que pertencem a todos e não são apropriáveis

629 Ações derivadas devem ser distinguidas das ações diretas. Acionistas que sofrem uma lesão em seus interesses pessoais podem propor ações individuais diretas, independentemente do grupo. São apenas os acionistas que sofrem uma lesão como resultado de uma lesão sofrida pela própria corporação é que podem propor as ações derivadas (Cf. KIM, 1998, p. 102).

630 “...the personal-impersonal dichotomy, as we have seen, supposes that litigant autonomy and individual participation make their strongest normative claims when state adjudicative power focuses directly on personal attributes of an individual rather than on aggregative characteristics of a group" (Cf. BONE, 1990, p. 292). No mesmo sentido: CALVERT, 1837, p. 19-20. 
exclusivamente por ninguém, quanto a recursos humanos, como encargos, fundos, empreendimentos e acervos comuns, que, embora possam ser apropriados individualmente por alguém, quando o são, essa apropriação deve ser realizada de forma equitativa ou paritária.

Veja, portanto, que a incindibilidade pode decorrer tanto de uma incindibilidade prática, quanto de uma incindibilidade normativa, decorrente de uma teoria substantiva paritária ou equitativa.

Richard Nagareda ${ }^{631}$ estabelece, nessa linha, que as categorias incompatible standards, injunctive class action e limited fund aludem a hipóteses de reparação indivisível, a admitir a agregação processual. Essa indivisibilidade, todavia, apresenta fundamentos diversos.

Nas duas primeiras categorias, a reparação conferida a um sujeito enseja, na prática, a reparação dos demais membros do grupo. Todos têm a mesma sorte, pois há uma coesão ou uma interdependência no direito substancial que, na prática, determina a unitariedade, seja porque a parte adversa à classe deve adotar conduta uniforme em relação às partes, seja porque a parte adversa age ou recusa-se a agir com fundamento, em geral, aplicável à classe, tornando-se apropriado que o remédio jurídico final (injuntivo ou declaratório) seja adotado, para todos.

Na terceira categoria, por sua vez, a reparação conferida a um sujeito deve ser idêntica à reparação conferida a outro membro do grupo, não por razões práticas, mas por força de um direito substancial comum (common theory of recovery) ${ }^{632}$, que exige, especificamente, uma distribuição equitativa ou pro rata de um fundo, de um ativo, de uma propriedade do grupo. ${ }^{633}$

Novamente, Nagareda ${ }^{634}$, conclui dizendo que, nos três casos, há uma unidade, uma interdependência preexistente entre os membros da classe, que circunda o direito substancial.

631 ".....would the affording of compensatory damages to a given plaintiff affect the application or availability of the same remedy as to others. In this respect, the limited-fund scenario presents a specialized instance of the broader category of indivisible remedies" (Cf. NAGAREDA, Richard. Embedded aggregation in civil litigation. Cornell Law Review, 2010, V. 95: 1105- 1119p, p. 1119).

632 UNITED STATES OF AMERICA. United States Supreme Court. Ortiz et al v. Fibreboard Corp et al. 527 U.S. 815 (1999). No mesmo sentido, MULLENIX, Linda. Aggregate litigation and the death of democratic dispute resolution. Northwestern University Law Review, 2013, V. 107:511-564p. p. 525.

633 NAGAREDA, 2010, p. 1119.

634 Ibidem, p. 1118. 
Por fim, a última categoria, qual seja, damage class action, é o caso clássico em que se pretende indenização compensatória em razão de danos pessoalmente sofridos pelo indivíduo. Essa hipótese é, em regra, considerada como hipótese de reparação individual. Porém, em razão de uma predominância de questões comuns, de fato ou de direito, a vários indivíduos, a reparação decorrente da lesão de massa pode ser pleiteada sob a forma agregada em uma ação coletiva.

A divisibilidade ocorre, porque, em regra, a perda injustamente sofrida por um autor em particular pode ser pretendida em face de um determinado réu, a quem competirá indenizar àquele autor, sem prejuízo da indenização compensatória, eventualmente pretendida, por outros indivíduos em situação semelhante. As ações individuais seriam, em regra, independentes. ${ }^{635}$

Mas, mesmo nessa hipótese, é preciso destacar que também há graus de incindibilidade, pois, em determinadas situações, é ainda necessária a referência ao grupo, bem como surgem situações de paridade e impessoalidade. A incindibilidade não é mais prática, mas potencial. Ela existe em razão da coordenação das vontades dos indivíduos, que deduzem, em juízo, a controvérsia atinente aos atributos do próprio grupo, o que é paritário para todos do grupo. E, uma vez deduzida a controvérsia do grupo, a cognição é impessoal e não pessoal ou particular. ${ }^{636}$

Vale lembrar que a eficácia condenatória da sentença ao ressarcimento em pecúnia não muda a natureza do direito. Assim, é possível uma situação de incindibilidade ou paridade, à luz do direito substancial, mesmo que a pretensão, no caso, diga respeito ao ressarcimento em pecúnia.

Na realidade, os dois critérios gerais - a impessoalidade, a indivisibilidade e/ou paridade - são ângulos de um mesmo fenômeno: da valência coletiva ou plurissubjetiva da relação substancial controvertida. Ambos os critérios interagem e auxiliam o intérprete a alcançar uma compreensão mais ampla do direito, objeto da controvérsia, a admitir agregação processual.

635 Nagareda diz que, nessa hipótese, o cálculo do valor indenizatório é individual, mas a apuração da responsabilidade em determinadas áreas do direito substancial é paritário por excelência e estabelece um método de distribuição dos danos. Valendo-se desse conceito, pode-se dizer que o crédito de um é diferente e independente do crédito do outro, pois não se trata de um fundo limitado. Mas, a fórmula necessária para se alcançar o quantum é igual para todos e impessoal (NAGAREDA, 2010, p. 1133).

636 Aliás, Vigoriti já mencionava essa característica, ao salientar que, no exercício de certas liberdades e na reação a atos discriminatórios, os indivíduos podem pretender a perseguição coletiva desse interesse ou direito, de forma que o legislador pode conferir relevância autônoma a essas hipóteses, ainda que o bem não seja indivisível. Isso porque, embora possível o exercício individual, o exercício coletivo do direito é mais adequada. (VIGORITI, 1979, p. 59-60). 
Essa interação já foi objeto de demonstração no capítulo anterior, é preciso prosseguir demonstrando a existência e aplicabilidade prática desses critérios no sistema estadunidense.

\subsubsection{CONTROVÉRSIA À MONTANTE OU À JUSANTE DO GRUPO (UPSTREAM DOWSTREAM AND RELATED CLAIMS)}

Nesse contexto, uma categoria tem merecido especial atenção no sistema jurídico estadunidense, pelas dificuldades práticas e teóricas que enseja. Trata-se da class action for damages, isto é, ação coletiva por danos pessoalmente sofridos pelos membros de um grupo grupo de vítimas, de consumidores, de cidadãos, igualmente interessados na controvérsia.

Lembra-se que toda a categorização presente na Federal Rule 23 é funcional ou prática. Por essa razão, ao enunciar a class action for damages, o texto normativo não enunciou o direito substancial a ser tutelado, mas enunciou que sempre que predominarem questões, de fato ou de direito, em relação às questões individuais e a ação coletiva constituir método superior em relação aos demais disponíveis, a ação coletiva será cabível como forma de resolução da controvérsia. É preciso, portanto, aferir a presença dos requisitos da predominância e da superioridade, para o fim de estabelecer o cabimento dessa categoria de ação coletiva.

O Advisory Committee $^{637}$, ao mencionar essa categoria em nota técnica, afirmou que o tratamento coletivo em situações como essa não é um método tão claro quanto nas categorias anteriores. Mas, de qualquer forma, a agregação pode ser conveniente, dependendo das circunstâncias particulares do caso concreto. Nessa hipótese, a ação coletiva visaria, segundo o comitê, principalmente, à promoção de economia de tempo, esforços e despesas, eficiência processual e uniformidade nos provimentos jurisdicionais, relativos a sujeitos em situação semelhante, sem impor, todavia, o sacrifício das garantias processuais e constitucionais.

Ocorre que, ao mencionar a agregação por uma questão de mera conveniência, o Advisory Committe $^{638}$ não enunciou, no tex to normativo, qual seria o parâmetro adequado para aferir os

637 "...In the situations to which this subdivision relates, class-action treatment is not as clearly called for as in those described above, but it may nevertheless be convenient and desirable depending upon the particular facts. Subdivision (b)(3) encompasses those cases in which a class action would achieve economies of time, effort, and expense, and promote, uniformity of decision as to persons similarly situated, without sacrificing procedural fairness or bringing about other undesirable results" (Cf. UNITED STATES OF AMERICA. Federal Rules of Civil Procedure. Washington: US Government Printing Office, 2010).

638 Isso se depreende da própria leitura da nota do Conselho Consultivo de 1966, que não definiu a predominância em termos abstratos, apenas exemplificou esse critério, deixando para o intérprete a função de extrair desses 
requisitos da predominância e da superioridade no caso concreto. Limitou-se a enunciar que a ação coletiva é cabível quando, realmente, for possível alcançar a economia processual.

Hoje, no entanto, a doutrina estadunidense já aponta para a indispensabilidade da análise do direito substancial, como parâmetro para aferição da predominância e da superioridade.

\subsection{PREDOMINÂNCIA E SUPERIORIDADE}

Mesmo que, no sistema estadunidense, a conveniência da ação coletiva por danos (class action for damages) - conveniência no sentido de uma apropriada reunião de indivíduos para o atingimento de escopos processuais - continue como referência, é possível afirmar que essa conveniência não se refere, tampouco se mensura por um mero juízo de eficiência, uniformidade dos provimentos ou economia processual. A compatibilidade da ação coletiva à dada situação da vida é orientada por razões de direito substancial e não apenas processual.

Na realidade, conforme o já mencionado enfoque substantivo das ações coletivas, aferir, no caso concreto, o que significa o requisito da predominância e da superioridade, requer uma análise do direito substancial e não dos demais escopos do processo, como poderia transparecer.

Nesse sentido, o corpo editorial da Harvard Law Review ${ }^{639}$ já salientou que, embora essa questão não seja imediatamente aparente pela letra da Federal Rule 23, o parâmetro para aferição da predominância e da superioridade não se vincula ao alcance de um escopo

exemplos a norma concreta, a orientar os casos sucessivos no futuro. Diante da omissão do Conselho Consultivo, Rachael Mulheron revelou, por sua vez, as dificuldades em se definir o critério da predominância no caso concreto, o que implicou a multiplicação de métodos na jurisprudência, os quais configuraram uma tentativa de lograr essa definição em abstrato (número de questões comuns em relação ao número de questões individuais, tempo despendido para análise da questão comum em relação ao tempo para análise da questão comum etc). No mesmo sentido, o corpo editorial da Harvard Law Review salientou a dificuldade prática em se alcançar um conceito de predominância, considerando apenas os escopos processuais mencionados pelo Conselho Consultivo, como eficiência, economia, duração do processo e outros. É preciso, para isso, verificar as diferentes espécies de comunhão existentes no direito substancial, para aferir o critério da predominância (Cf. MULHERON, Rachael. The class action: in a common law legal systems - a comparative perspective. Oregon: Hart Publishing, 2006, p. 199-210; NOTE, 1976, p. 1504).

639 “...the importance of predomination analysis, and its relevance to the substantive theory of class action, is not immediately apparent from the surface of class action doctrine as it has developed under rule 23 [...] If the content of predomination doctrine as it has developed under rule 23 thus does not explicitly reveal the kind of approach which a substantive theory of class action would suggest, practice under rule 23 nonetheless conforms rather closely to the substantive model. Before a court can judge whether common questions are more 'significant' than individual questions, it must first determine which elements of cause may in fact be litigated in common and which elements will require separately showings by each class members" (NOTE, 1976, p. 1504-1506). 
processual. Seria inviável, por exemplo, mensurar a adequação da ação de classe em relação a uma situação da vida, utilizando como parâmetro a probabilidade de se alcançar economia.

O parâmetro para se aferir a predominância não se trata, portanto, de medir o tempo despendido em cada uma das questões controvertidas comuns ou individuais, tampouco de enumerar as questões comuns em relação às questões individuais. Trata-se, sim, de aferir se agregação avançará, materialmente, a resolução da controvérsia de massa como um todo, à luz do direito substancial controvertido. A paridade ou a comunhão de um grupo é determinada pelo direito substancial, de forma que a questão comum não venha, posteriormente, a ser rediscutida em relação aos indivíduos, que apenas se subsomem ao grupo nesse aspecto. O objetivo é, assim, a preclusão, isto é, obstar a rediscussão da controvérsia coletiva em relação aos indivíduos. ${ }^{640}$

A superioridade, por sua vez, é um juízo que diz respeito à efetividade e ao adequado gerenciamento do processo coletivo, sem desperdício de tempo e de recursos judiciais. $\mathrm{O}$ parâmetro para se aferir a superioridade também é dado pelo direito substancial, a saber, é preciso identificar se algum instrumento de agregação, enquanto um design procedimental possível, possibilitará alcançar, com idoneidade e menor restrição possível às partes, os escopos do direito substancial, como a compensação pelos danos em massa sofridos pelas partes (compensatory policies) e o desestímulo à prática lesiva ou abusiva (deterrence policies). ${ }^{641}$

Nesse ínterim, para aferir a superioridade, é preciso estabelecer qual será o instrumento mais idôneo e com menor restrição possível para o tratamento agregado da controvérsia. Há que se

640 “...there's no point to the aggregate treatment of common issues in litigation if such treatment will not alleviate, as a practical matter, the need to revisit the same issues in other proceedings" (Cf. AMERICAN LAW INSTITUTE, 2010, p. 90).

641 Muitas vezes, a doutrina tem tratado o critério de superioridade como um critério de utilidade processual (custo v. benefício) da ação de classe. Sob esse aspecto, a ação coletiva não constitui método superior para a solução da controvérsia se o quantitativo de informações aduzido na demanda implicar o colapso do gerenciamento do processo ou se os custos do processo, com a notificação dos membros ausentes do grupo, por exemplo, for superior a compensação pretendida. Mas, não é bem assim, a superioridade também é um critério que requer a análise do direito substancial. O benefício a ser pensado, para fins de aferição da superioridade, é o alcance dos escopos substantivos do processo (escopo jurídico do processo para Dinamarco), isto é, se a conduta abusiva será descontinuada, se os membros da classe serão recompensados etc. Presente a necessidade de atuação do direito substancial, as eventuais dificuldades processuais devem ser contornadas, modelando-se, para tanto, o procedimento, como, por exemplo, reduzir o tamanho da classe para níveis possíveis de gerenciamento, instituir subclasses, realizar uma notificação coletiva dos membros ausentes da classe. Enfim, em primeiro lugar, é preciso analisar o grau de vinculação existente entre os membros da classe, isto é, a relação substancial plurissubjetiva ou coletiva. Em segundo lugar, é preciso analisar os possíveis procedimentos e técnicas processuais disponíveis que poderão ser usados para superar eventuais dificuldades na condução do processo coletivo. E, em terceiro lugar, é possível afirmar a superioridade do método de resolução da controvérsia. Pode ser dizer que a aferição do critério da superioridade converge para a questão da congruência do procedimento da ação de classe (pode-se dizer procedimento de agregação de um modo geral) com o direito substantivo (Cf. NOTE, 1976, p. 1503). 
estabelecer, assim, uma comparação entre a ação de classe e outros instrumentos de agregação e individuais disponíveis, bem como verificar qual desses instrumentos mais se adequa às peculiaridades do direito substancial naquele caso, de forma a atuar seus escopos ou fins.

Um exemplo, dado em nota pela Harvard Law Review ${ }^{642}$, é esclarecedor sobre a aferição concreta dos requisitos da predominância e superioridade da class action for damages.

Trata-se de ações coletivas envolvendo situações de franquia. Os franqueados alegavam que, como pré-condição para aquisição dos direitos sobre a marca franqueada e sobre os processos do franqueador, eram obrigados a adquirir também equipamentos, suprimentos, locações de imóveis para a sede da loja etc, o que caracterizaria, ao menos em tese, venda casada (tying).

No precedente Siegel v Chicken Delight, Inc ${ }^{643}$, por exemplo, o contrato de franquia padrão já previa a venda de suprimentos pelo franqueador. As questões controvertidas naquele caso eram, desse modo, principalmente duas: (i) aferir se a comercialização daqueles suprimentos era uma medida necessária para fins de assegurar o controle de qualidade sobre as atividades do franqueado pelo franqueador ou (ii) se o contrato padrão de franquia instituiu, ilegalmente, uma venda casada (tying) entre as partes, ao instituir a comercialização dos suprimentos. Nesse caso, não houve controvérsia quanto à compatibilidade da ação de classe à situação deduzida em juízo, pois não havia a necessidade de aferir questões pessoais dos franqueados, bastava avaliar a prática comercial, em tese abusiva, prevista no contrato padrão do franqueador, contrato esse que era manejado em relação a todo o grupo de franqueados. A ação de classe foi certificada, sem maiores controvérsias, e os franqueados lograram êxito em afastar a prática abusiva. Posteriormente, o montante indenizatório individual (relativo à venda casada) foi objeto de procedimentos individuais, pois não foi uma questão alcançada pela ação de classe ou coletiva.

Aliás, é preciso ponderar que essa demanda, em muito, se assemelha à categoria, trabalhada anteriormente, denominada de direitos homogêneos, de massa ou repetitivos ou, em inglês, related claims $^{644}$, decorrentes do fenômeno da individualização de massa. Um contrato abusivo padrão foi pactuado com cada franqueado. Mas, todos eles em estão em igual situação frente 
ao franqueador, pois foram objeto de uma padronização contratual e, em seguida, as relações jurídicas decorrentes desse contrato padrão foram pulverizadas pelo franqueador. Assim, cada indivíduo, isoladamente, poderia litigar em face do franqueador, instituindo uma demanda repetitiva ou relacionada (related claim), bastando ao magistrado aferir a alegada prática abusiva a partir da leitura do contrato individual. Um franqueado não depende do outro franqueado. No entanto, as demandas individuais são clones ou cognatas umas das outras.

Sem embargo, a técnica processual aplicável à controvérsia deve ser a técnica de agregação, em razão das peculiaridades de massa da relação substancial. Esse direito não é um direito individual puro, no qual cada indivíduo tem uma história pessoal, particularizada para deduzir em juízo. É um direito de um grupo (franqueados) que foi padronizado e pulverizado pelo franqueador para a massa e, por isso, demanda um tratamento na mesma simetria e medida.

Até porque não é possível desconsiderar que o franqueador, em sua atividade econômica, possa ter mensurado um lucro global, que obteria com a prática abusiva - venda casada de produtos. Assim, se cada indivíduo postular individualmente, ele poderá ser ressarcido, mas não haverá necessariamente o desestimulo da prática abusiva (deterrence). Para que todos os escopos do direito substancial sejam cumpridos, inclusive o desestímulo da prática, a agregação foi nesse caso e é, em geral, método mais adequado de resolução dessa espécie de controvérsia de massa.

A agregação é o método mais adequado de solução da controvérsia à luz do direito substancial ${ }^{645}$ Muito bem. Mas, a história da franquia não termina por aí. Na esteira do precedente supracitado, muitos franqueadores modificaram seus contratos padrões, removendo qualquer remissão expressa à prática abusiva da venda casada. Os franqueados, no entanto, continuavam a ajuizar ações coletivas, argumentando a persistência daquela prática abusiva, mas agora insidiosa. ${ }^{646}$

Essa segunda geração de ações coletivas ensejou, a seu turno, diversas controvérsias judiciais, no tocante à adequação da técnica de agregação: houve aqueles que afirmaram a necessidade de analisar a relação particularizada estabelecida entre o franqueador e cada um dos franqueados, para aferir a existência ou não da venda casada em cada um dos casos. A pessoalidade, supostamente, presente na relação substancial tornava, portanto, duvidosa a congruência da ação de classe ao caso narrado. Dada a ausência de uma cláusula contratual 
padrão a respeito da venda casada aplicada ao grupo, apostava-se que cada franqueado teria uma história diferente com o franqueador, o que inviabilizaria a ação coletiva na espécie. ${ }^{647}$

E não foram poucas as Cortes de Justiça que realmente decidiram nesse sentido. Posteriormente, isso foi revisto. No precedente Ungar v. Dunkin Donuts, Inc, ${ }^{648} \mathrm{o}$ entendimento quanto à incompatibilidade da ação de classe foi superado para hipóteses como essa, admitindo-se a agregação processual mesmo na hipótese de inexistência de contrato padrão de franquia.

Não existia contrato padrão de franquia, que expressamente indicasse a ocorrência da venda casada. Mas, mesmo assim, não era preciso que cada indivíduo provasse, pessoalmente, a venda casada em seu caso concreto. A inferência da venda casada poderia ser demonstrada coletivamente: seja comprovando a existência de uma prática ou política abusiva comum aplicada pelo franqueador contra o grupo como um todo, no sentido de exigir do franqueado a exclusividade na compra de determinados suprimentos, seja comprovando a presença de um grande número de franqueados que adquiriram, "estranhamente", produtos mais onerosos do franqueador em relação aos menores preços praticados mercado, submetendo-se a um contrato de franquia, por si só, antieconômico em relação aos preços concorrentes, por exemplo. ${ }^{649}$

Na realidade, nesse último caso, a técnica de agregação, in casu, a ação coletiva, demonstrou ser ainda mais necessária. Essa necessariedade merece explicação mais detida nesse ponto.

Nos casos em que inexiste um contrato padrão de franquia, prevendo expressamente a venda casada, o objeto da controvérsia passa a ser a prática aplicada contra o próprio grupo de franqueados. A inferência causal dessa prática em relação a cada um dos franqueados se fundamenta coletivamente e o indivíduo torna-se um mero anônimo. Provada a existência de uma prática globalmente realizada pelo franqueador, prova-se a situação individual: que é apenas uma parte (posição de vantagem individual) encartada no todo (posição global).

É justamente a referência à situação semelhante ou idêntica do outro franqueado que fortalece o argumento de que existe uma prática abusiva global de venda casada, silenciosamente

647 NOTE, 1976, p. 1509.

648 Ibidem, p. 1509.

649 Ibidem, p. 1509. Esse entendimento foi acolhido pela District Court, o julgamento foi, posteriormente, reformado pela Court of Appeal, mas não houve discordância quanto à abordagem substantiva da predominância, a discordância restringiu-se às especificidades do caso narrado (Cf. NOTE, 1976, p. 1511). 
aplicada, em relação a cada um dos franqueados. Isso estabelece uma inferência estatística relevante para o grupo como um todo: se em 50\%, 60\%, 90\% dos casos investigados, os franqueados adquiriram produtos do franqueador em preços superiores ao mercado, por exemplo, é possível inferir se houve a aplicação de uma prática abusiva comum de venda casada em relação ao grupo dos franqueados. O magistrado, diante desse quantitativo, pode formar a sua convicção de que existe uma prática abusiva velada aplicada contra todo o grupo. Enfim, o franqueador vinculava, ilegalmente, a concessão da franquia à aquisição dos seus suprimentos.

Quão maior o número de casos semelhantes, maior a probabilidade e a segurança do magistrado em afirmar a existência da prática abusiva, silenciosamente, aplicada em relação ao grupo dos franqueados como um todo. Essa ilação permite concluir - objetivamente - pela existência de uma prática abusiva aplicada contra o grupo do fraqueados, sem que a situação de cada indivíduo deva ser analisada pelo Poder Judiciário. Até porque a prática foi pulverizada e a controvérsia de cada indivíduo diz respeito aos atributos do grupo e não uma história pessoal. ${ }^{650}$

As questões individuais tornam-se relevante, apenas em um segundo momento, quando o procedimento seguirá para a quantificação dos danos. Cada indivíduo deverá demonstrar o quantitativo de suprimentos, adquiridos do franqueador, por força da venda casada, a ser objeto de ressarcimento. Se esse quantitativo também for padrão, seria possível nesse caso, até mesmo, a liquidação coletiva. A relação substancial seria integralmente impessoal e paritária, sem análise individual, pois o cálculo dos danos derivaria de uma fórmula padrão aplicável a todos.

Esse é o típico caso de downstream e upstream, em que não existe um comando normativo determinando a paridade e a impessoalidade entre os membros do grupo, mas os contornos substanciais da controvérsia demonstram essa comunhão, avançando a defesa individual. Se a controvérsia não for agregada, cada indivíduo buscará comprovar a prática abusiva a que foi submetido todo o grupo. Seguir-se-á uma repetição inaceitável de demandas, pois cada um dos indivíduos postulará a cognição sobre os atributos do grupo e não sobre os atributos pessoais.

A relevância da agregação processual na espécie é até mesmo óbvia. Além disso, a situação de cada indivíduo não é clara, até que esse indivíduo seja visualizado dentro de um grupo de afetados, submetidos a uma mesma prática. Caso essa prática abusiva permaneça pulverizada, 
silenciosamente, dentro do grupo, o direito substancial de cada indivíduo pode não ser atuado. Por isso, é preciso voltar os olhos ao grupo, para que o direito substancial coletivo seja atuado.

Justamente por isso, o requisito da predominância e da superioridade deve ser considerado à luz da atuação do direito substancial. Esse é o enfoque substantivo (substantive theory) de que se tratou antes e se repete agora. Se a ação coletiva for capaz de avançar a controvérsia do grupo como um todo, restando caracterizada a predominância da questão comum, e se ação coletiva constituir método superior de resolução da controvérsia, restando caracterizada a superioridade do processamento coletivo da demanda, a agregação - por uma ação coletiva -, será cabível ainda que remanesçam questões individuais a serem, em seguida, discutidas no caso concreto.

Lembra-se que na class action for damages, não existe, em regra, uma interdependência específica no direito substancial determinada expressamente por um texto normativo, como ocorre, por exemplo, nos casos de falência ou no concurso público, cujo texto normativo exige expressamente o tratamento impessoal e paritário entre os credores ou candidatos.

Mesmo assim, as demandas compensatórias apresentam, por vezes, situações nas quais a referência ao grupo torna-se imperativa e isso ocorre quando o direito substancial apresenta uma situação de coesão ou comunhão dos interesses dos membros de um grupo e a impessoalidade ou o anonimato do indivíduo no grupo, ainda que não expressamente.

Como já abordado antes, quando mencionados os interesses ou direitos, objeto de proteção, a impessoalidade e a paridade são potenciais na class action for damages (ação coletiva por danos pessoalmente sofridos): trata-se de uma comunhão potencial, ora mais forte, ora mais fraca.

\subsection{ESCALADA POTENCIAL DE AGREGAÇÃO}

Segue-se, nesse tópico, uma diferenciação importante na class action for damages. Nota-se, que, nessa categoria, a controvérsia poderá centrar tanto nas características gerais de um grupo, como nas características individuais dos seus membros, estabelecendo, assim, uma escala potencial de agregação no processo civil: do upstream (à montante) ao downstream (à jusante).

De igual modo, nessa mesma categoria, existe as related claims ou repeated litigation. Nesse caso, não existe mais um alcance coletivo inerente ao direito substancial. Os indivíduos não 
mais fazem remissão, nem mesmo parcial, aos atributos do grupo. Isso ocorre porque os atributos do grupo coincidem, de forma nuclear ou essencial, com os atributos individuais. ${ }^{651}$

Nessa espécie, existe uma fattispecie padrão, que não é, em regra, controvertida, a qual é reproduzida por todas as demandas individuais. Todas essas demandas individuais padronizadas - requerem uma idêntica ou similar solução jurisdicional. No capítulo anterior, isso foi denominado de individualização em massa, em que surgem demandas individuais clones ou cognatas, que são independentes entre si, mas o resultado pretendido é similar.

Apesar de essa diferenciação - upstream, downstream and related/repeated claims - não ser mencionada na Federal Rule 23, ela surge na doutrina como um ponto fundamental para a identificação das hipóteses substanciais em que a técnica processual de agregação é necessária e adequada ao caso concreto. Em todas as hipóteses, o norte é sempre o direito substancial ${ }^{652}$

Upstream são aquelas situações em que a controvérsia é centrada integralmente nos atributos do grupo, de forma que até mesmo a satisfação individual pode ser mecanicamente calculada, a partir da sentença genérica em favor do grupo. Como diz Issacharoff ${ }^{653}$, os casos de upstream ocorrem quando o dano alegado pelo grupo diz respeito a um curso uniforme de conduta adotada pelo réu, a partir do qual tanto a proteção do direito, quanto a sua satisfação individual se seguem. A satisfação individual segue fórmula padrão, que independe dos atributos pessoais.

Normalmente, nesses casos, a indenização compensatória pelos danos individualmente sofridos pode ser calculada administrativa ou ministerialmente, a partir de critérios objetivos ou de uma fórmula rígida ou matemática, com cada autor recebendo uma compensação proporcional ou paritária (pro rata sharing) ao montante indenizatório sobre o qual o grupo sagrou-se vencedor.

Downstream são aquelas situações em que a controvérsia é centrada, parcialmente, nos atributos do grupo. Apesar de apresentar uma questão comum relevante ao grupo, remanescem questões individuais, que requerem cognição particularizada. Nessa hipótese, é essencial que, à luz do

651 “...multiple civil claims nonetheless are appropriately described as 'related claims' when they exhibit overlapping legal and factual features that give rise to a common nucleus of operative fact (Cf. AMERICAN LAW INSTITUTE, 2010, p. 79)

652 “...the content of substantive law influences the decision whether to afford aggregate treatment. Substantive law defines the relationships among legal and factual issues - sometimes intertwining them and sometimes separating them cleanly so as to create a 'joint' at which aggregate treatment may carve." (Cf. Ibidem, p. 89).

653 ISSACHAROFF, 1997, p. 832. 
direito substancial, a questão comum ao grupo seja autônoma ou independente das questões individuais e avance a resolução da controvérsia em relação a todos os interessados. Assim, a questão comum não deve ser substancialmente reconsiderada no exame individual. A agregação processual é útil, na medida em que for capaz de propiciar definitividade (preclusão) ao julgamento da questão comum, sem reapreciação da questão comum nos casos individuais. ${ }^{654}$

Embora esse temática já tenha sido abordada de uma forma genérica no capítulo terceiro, é preciso, agora, situá-la no sistema jurídico estadunidense, apresentando exemplos concretos.

Tem sido apontados como hipóteses de upstream casos relativos a: (i) danos de pequena monta, cuja compensação individual é ínfima e meramente econômica (small class actions); (ii) danos cuja compensação individual é meramente econômica e calculada segundo fórmula padrão aplicável com fundamento no grupo como um todo (economic injuries); (iii) casos de exposição ao risco por contaminação tóxica (toxic exposure tort ou risk-based claims), que que admitem extrapolação estatística da responsabilidade e da compensação individual sem exame pessoal de cada um dos membros do grupo; e (iv) casos de discriminação racial ou de gênero (discrimination pattern) e casos de políticas públicas no tocante a direitos sociais (welfare rights), os quais admitem distribuição do montante indenizatório de forma incidental à sentença declaratória ou injuntiva, isto é, segundo fórmula aplicável com fundamento ao grupo. ${ }^{655}$

Hipótese de downstream, por sua vez, são aqueles em que existe uma questão comum ao grupo, capaz de avançar a resolução da controvérsia como um todo, mas cuja compensação individual deve ser relegada a uma fase posterior do procedimento no qual proceder-se-á à quantificação dos danos individuais. Um exemplo disso é a franquia, mencionada anteriormente. Recorda-se que, nessa hipótese, a responsabilidade quanto à prática da venda casada foi aferida coletivamente, mas a quantificação dos danos foi mensurada, posteriormente, em relação a cada um dos indivíduos, sem que fosse rediscutida à questão da prática abusiva antes provada.

Novamente, nos deparamos com o direito substancial. É o direito substancial que guia a identificação das hipóteses de downstream. Para o processamento coletivo ou agregado da controvérsia do tipo downstream, é preciso que o direito substancial separe a questão da responsabilidade do réu em relação à questão da reparação, da distribuição ou da compensação 
da indenização individual. No tocante à venda casada, antes apreciada, a responsabilidade pela venda casada era independente e autônoma da mensuração dos danos individuais de alguém. ${ }^{656}$

Por fim, nessa categoria, também se encartam as hipóteses de responsabilidade pessoal (personal liability). A experiência prática estadunidense revela, no entanto, especial dificuldade em agregarem-se demandas relativas à responsabilidade por danos pessoais decorrentes de vícios do produto, como, por exemplo, decorrente do uso de medicamentos, álcool e cigarros. ${ }^{657}$

Mas, se não é impossível, tende a ser excepcional, pois as hipóteses de vício do produto exigem, usualmente, análise e prova particularizada de cada um dos indivíduos afetados, independentemente do resultado da sentença genérica coletiva. Isso quer dizer que, ainda que a sentença genérica reconheça, por exemplo, a responsabilidade do réu pelo fornecimento de um produto viciado (ex. medicamento com efeitos colaterais não previstos na bula farmacêutica), ainda assim é preciso que o indivíduo demonstre o nexo de causalidade específico, isto é, deve demonstrar ter sofrido, pessoalmente, os efeitos danosos do uso do produto viciado, bem como afastar eventuais concausas relativas à ocorrência dos danos causados, para a procedência. ${ }^{658}$

Daí falar-se em escalada potencial de agregação. Há situações em que a impessoalidade e a paridade são fortes entre os membros do grupo. Há outras situações em que a impessoalidade e a paridade entre os membros do grupo é mais fraca, uma mera afinidade, que tende a desaparecer em uma multiplicidade de situações pessoais e particularizadas dos indivíduos.

Não é fácil certificar essas hipóteses de direito substancial dentro das categorias previstas na Federal Rule 23, pois os regimes processuais aplicáveis às categorias são diferentes. Por essa razão é forçoso convir pela necessidade de reduzir as diferenças entre esses regimes e, com isso, reduzir a incerteza na categorização e no tratamento processual deferido às ações de classe.

\subsubsection{DA AÇÃO DE CLASSE À AGREGAÇÃO PROCESSUAL}

656 AMERICAN LAW INSTITUTE, 2010, p. 106.

657 ISSACHAROFF, 1997, p. 832.

658 Ada Pellegrini Grinover realiza profundo estudo sobre a class action for damages estadunidense, para as hipóteses de vício do produto. Relata as dificuldades encontradas por aquele sistema na certificação de demandas dessa espécie, para ultrapassar os critérios da predominância e superioridade (Cf. GRINOVER, 2000, p. 7). 
É cediço que a definição da categoria na qual se encarta a ação coletiva é relevante, pois os regimes processuais de agregação diferenciam-se, mormente, a partir da certificação da ação.

Nos casos de incompatibilidade de conduta (incompatible standards), de prejuízo aos interesses do grupo (prejudice class action or limited fund class action) e de conduta ilícita e uniforme do réu (injunctive or declaratory class action), o regime processual aplicável adota a vinculação compulsória de todos os membros do grupo (mandatory class action), a notificação facultativa dos membros ausentes (notice) e a vedação à exclusão dos indivíduos. Excepcionalmente essa exclusão é admitida pelo juiz em limitadas hipóteses, para o gerenciamento da demanda. ${ }^{659}$

Nas hipóteses de ação de classe por danos pessoalmente sofridos, em que há uma questão comum predominante em relação às questões individuais, o regime processual é diverso. Em regra, os indivíduos devem ser obrigatoriamente notificados (notice) a respeito da ação coletiva, detém direito ao exercício da autoexclusão (opt out) da ação de classe e a vinculação ao julgado coletivo não é compulsória (non-mandatory class action). Os membros do grupo, notificados da ação coletiva, podem optar por excluir-se daquela demanda, afastando a vinculação ao julgado coletivo ou, noutros termos, afastando a própria autoridade da coisa julgada coletiva.

Isso não é nenhuma novidade e já consta na Federal Rule 23. As hipóteses admissíveis de ação de classe e o regime processual de agregação, a ela conferida, estão expressamente previstos.

A novidade que deve ser apontada, nesse momento, é a insuficiência desse texto normativo, se desacompanhado dos critérios substanciais de agregação antes mencionados. O texto normativo, por si só, com remissão à tutela processual pretendida (declaratória, injuntiva e condenatória ao ressarcimento por danos), é deveras insuficiente para a identificação da categoria de interesses ou direitos a ser objeto de agregação e para a incidência do regime processual de agregação, se compulsório (mandatory) ou não compulsório (non-mandatory).

Não basta dizer, por exemplo, que o pedido é a declaração da ilegalidade da conduta ilícita e uniforme do réu para que a ação seja certificada na categoria 23(b)(2) e, assim, para que se siga o regime processual de vinculação compulsória. Não basta dizer que o pedido é a condenação

659 SERENKA JR, Robert L. Annotation: propriety of allowing class member to opt out in class action certified under subsections $(b)(1)$ and $(b)(2)$ of Rule 23 of Federal Rules of Civil Procedure. American Law Reports Federal, 563 (2009). 
ao ressarcimento pecuniário por danos sofridos para que a ação seja certificada na categoria 23(b)(3) e para que se siga o regime processual de vinculação não compulsória dos indivíduos.

Enfim, não basta remissão ao pedido ou à eficácia do provimento. É preciso analisar o grau de impessoalidade, de indivisibilidade e de paridade da relação substancial deduzida em juízo para fins de certificação da ação de classe ou, de modo geral, para a agregação processual de ações. ${ }^{660}$

E, mais, por força desses critérios substanciais de agregação, a temática das ações coletivas tem sido convertida para a temática da agregação processual, que é mais ampla e mais geral que a primeira. A partir da agregação, o procedimento deve ser modelado, a partir das exigências do direito substancial. Não se trata de abandonar a técnica, mas de adaptá-la ao seu escopo. ${ }^{661}$

Há hipóteses em que demandas, classicamente encartadas em uma categoria e sob um regime processual, são agora categorizadas em classe diversa e sob um regime processual diferenciado.

Esse é o caso, principalmente, das hipóteses de upstream, categorizadas como class action for damages, as quais são, agora, identificadas nas categorias anteriores como espécies híbridas. $\mathrm{O}$ efeito prático disso é obstar, em regra, a autoexclusão dos indivíduos, favorecendo a adjudicação unitária e uniforme de uma controvérsia de direito substancial de alcance coletivo.

E, mais, muitas demandas individuais (sem pedido de certificação coletiva) são consideradas ações coletivas de fato, suscetíveis, portanto, de serem objeto de agregação processual. Assim, uma demanda individual pode ser coletivizada ou agregada, por iniciativa da Corte de Justiça,

660 "...the point is that the degree of class cohesion - not the type of the suit or even the relief sought - is the essential feature in determining when class certification is proper. [...] This is not to say that the kind of relief sought is irrelevant to the issue of class cohesion, it is only to say that the relief sought is not the exclusive factor to consider in addressing the issue of cohesion within a putative class. For example, relief by an injunction, instead of damages is often a useful, although rough, proxy for the degree of class cohesion". (Cf. LILLY, Graham C. Modeling class action: the representative suit as an analytic tool. Nebraska Law Review, 2003, V. 81: 1008-1055p. p. 1024-1025). No mesmo sentido: WOOD, Diane P. Adjudicatory jurisdiction and class action. Indiana Law Review, 1987, V. 62:597-624, p. 623.

661 John C. McCoid revela a necessidade de desenvolvimento de mecanismos de packaging (agregação) para alcançar uma adjudicação unitária da controvérsia com múltiplos interessados. Dentre esses mecanismos, destacam-se técnicas de preclusão (vinculação obrigatória ao julgado) e técnicas de consolidação (reunião obrigatória de demandas ou pessoas) (Cf. MCCOID, John C. A single package for multiparty disputes. Stanford Law Review, 1976, V. 28: 707-728, p. 708). A viragem metodológica da ação de classe pela agregação processual é também objeto de estudo por Roger Transgrud (Cf. TRANGSRUD, Roger H. Aggregate litigation: critical perspectives. George Washington University Law School, 2011, V. 79:293-305p). 
considerando a sua intrínseca natureza coletiva ou plurissubjetiva. Essas demandas são, assim, candidatas naturais à agregação processual do sistema jurídico. Cabe ao processo apenas reconhecer juridicamente e formalizar essa situação jurídica que já existe substancialmente.

É preciso destacar que todo esse debate da agregação é, ainda, muito novo no sistema jurídico estadunidense. Mas, além da teoria, já existem casos específicos na jurisprudência estadunidense, adotando a flexibilização da técnica processual conforme o direito substancial. É preciso demonstrar alguns desses casos, para ilustrar essa orientação substancial da técnica.

\subsubsection{AÇÃO COLETIVA DE FATO (DE FACTO CLASS ACTION)}

Segundo Richard Nagareda ${ }^{662}$, o sistema estadunidense convive com ações coletivas de fato (de facto class action). São demandas propostas por indivíduos, sem pedido de certificação coletiva, mas que são necessariamente unitárias. Ainda que o indivíduo deduza, em juízo, uma controvérsia de direito substancial sob a forma individual e em seu próprio nome, o conteúdo da controvérsia e o provimento pretendido irá alcançar, necessariamente, os membros ausentes do grupo, como se fosse uma ação de classe judicialmente certificada (de jure class action).

Esse é o caso, principalmente, das hipóteses em que a controvérsia deduzida em juízo diz respeito à relação substancial impessoal e indivisível ou paritária, critérios típicos das categorias 23(b)(1)(A), 23(b)(1)(B) e 23(b)(2). São hipóteses em que a compensação de um dos interessados implica a compensação simultânea dos demais ou afeta a disponibilidade de essa mesma compensação ser deferida em relação aos outros sujeitos, membros ausentes da coletividade. Todos os indivíduos apresentam uma vinculação íntima, todos têm a mesma sorte.

Nessa hipótese, se existir uma ou várias demandas individuais, que deduzam relação substancial impessoal e indivisível ou paritária, a Corte de Justiça poderá conferir um tratamento agregado na forma de uma ação coletiva. O regime aplicável será o mesmo de uma ação de classe certificada nas categorias 23 (b)(1)(A), 23(b)(1)(B) e 23(b)(2), ou seja, regime de vinculação compulsória (mandatory), sem possibilidade de autoexclusão pelos membros da coletividade.

662 NAGAREDA, 2010, p. 1123. 
Isso é o que diz o American Law Institute ${ }^{663}$, em seu Manuel de Litigância Agregada. Não seria possível afastar a agregação nessas hipóteses, pois trata-se apenas de reconhecer a interpendência preexistente entre os membros da coletividade, o que torna infactível a exclusão de qualquer indivíduo. Esse raciocínio se aplica tanto para as hipóteses de indivisibilidade prática do objeto pretendido, quanto nas hipóteses de paridade, em que o direito de um reduz ou prejudica o direito de outro indivíduo, que compartilha da mesma condição ou qualidade.

Outro argumento justifica essa conclusão. Se a agregação não for realizada por uma ação coletiva, por iniciativa ou ordem da Corte de Justiça, o mesmo resultado será alcançado em qualquer ação individual. Por exemplo, a declaração de ilegalidade da prática discriminatória de uma empresa ou a ordem que determine a cessação dessa prática alcançará necessariamente todos os membros ausentes do grupo (empregados da empresa submetidos à discriminação).

Ademais, a agregação, nesse caso, além de manter simetria à unitariedade presente na relação substancial, facilitaria a formação de um fórum de discussão sobre a prática abusiva, ampliando a instrução da controvérsia, bem como evitaria decisões inconsistentes ou contraditórias. ${ }^{664}$

Nessa hipótese, repita-se - a proposta realizada pela doutrina ${ }^{665}$ - é a vinculação compulsória dos membros da classe, sem direito de autoexclusão. Os membros ausentes da classe se sujeitariam à autoridade da coisa julgada coletiva, sendo ela favorável ou desfavorável. O raciocínio é, portanto, o mesmo das categorias 23 (b)(1)(A), 23(b)(1)(B) e 23(b)(2), já citadas.

Essa mesma razão, por fim, também consta no precedente Allen v. Int'l Truck \& Engine Corp. ${ }^{666}$ Nesse precedente, a Corte Recursal do Sétimo Circuito (Court of Appeal of Seventh Circuit) reformou a decisão da Corte Distrital (District Court) e certificou como ação de classe na categoria - 23(b)(2) - injunctive or declaratory relief - uma controvérsia relativa à prática de discriminação racial no ambiente de trabalho. Essa certificação foi realizada mesmo com pedido incidental de indenização pecuniária por danos individuais decorrentes da citada discriminação.

663 AMERICAN LAW INSTITUTE, 2010, p. 155.

664 Ibidem, p. 155.

665 Ibidem, p. 155.

666 UNITED STATES OF AMERICA. United States Court of Appeals, Seventh Circuit. Allen v. Int'l Truck \& Engine Corp. 358 F.3d 469 (2004). 
A razão para certificar essa ação como coletiva, segundo o Sétimo Circuito, é que não haveria diferença prática na cognição de uma ação coletiva e na cognição de 27 ações individuais idênticas (números dos autores individuais nomeados na demanda coletiva), que se seguiriam.

Caso aquela primeira ação não fosse certificada como coletiva, todos os 27 autores individuais postulariam, em juízo, a mesma controvérsia atinente ao grupo, isto é, buscariam demonstrar a prática ilícita e uniforme do réu no tocante à discriminação racial praticada contra o grupo, ensejando uma multiplicidade desnecessária de demandas individuais. E, mais, ainda que essas ações prosseguissem como individuais, não seria possível, de qualquer modo, estabelecer uma tutela inibitória (injunction) que fosse restrita aos autores individuais e que não alcançassem, necessariamente, os membros ausentes da classe (323 membros ausentes da classe). Se qualquer demanda individual fosse julgada, todas as demais seriam alcançados por força da preclusão da questão nela decidida, que é unitária por força do direito substancial deduzido em juízo. ${ }^{667}$

A certificação formal da ação de classe, nesse caso, é mera decorrência da situação de fato, que vincula os membros do grupo à mesma sorte substancial. O Sétimo Circuito asseverou, por sua vez, que, no tocante à indenização pelos danos, a matéria deveria retornar para a Corte Distrital, para que fosse aferida a certificação da ação de classe sob esse aspecto dos danos também ${ }^{668}$.

Por fim, a agregação processual não se limita às essas hipóteses - até mesmo óbvias - de impessoalidade, de indivisibilidade prática ou de paridade (incindibilidade normativa). A agregação processual é possível nas hipóteses potenciais de impessoalidade e indivisibilidade.

\subsubsection{COMPENSAÇÃO INDIVIDUAL ÍNFIMA (SMALL CLAIMS)}

667 "....How is it feasible to draft and enforce an injunction that will bear on these 27 plaintiffs alone, and not on the other 323 black employees? Unless it is possible to prepare such relief - and we do not see how it could be, or why a court should try — then the equitable aspects of the litigation are class-wide whether the judge certifies a class action or not. (The need for, if not inevitability of, class-wide treatment when injunctive relief is at stake is what Rule 23(b)(2) is about.) Formal certification has two benefits over the informal approach: first, class certification obliges counsel (and the representative plaintiffs) to proceed as fiduciaries for all 350 employees, rather than try to maximize the outcome for these 27 at the potential expense of the other 323 ; second, certification will entitle counsel to attorneys' fees representing the gains (if any) achieved by all employees, and not just the named plaintiffs." (Cf. UNITED STATES OF AMERICA. United States Court of Appeals, Seventh Circuit. Allen v. Int'l Truck \& Engine Corp. 358 F.3d 469 (2004)).

668 "...The order of the district court is vacated, and the case is remanded with instructions to certify a class under Rule 23(b)(2) for equitable matters and to reconsider the extent to which damages matters also could benefit from class treatment" (Cf. Ibidem). 
Nas demandas nas quais o interesse individual em obter a compensação pelos danos sofridos é mínimo (small claims), o elemento normativo que destaca não é a pessoalidade, como normalmente ocorre nas class action for damages (ou ações coletivas por danos sofridos).

Muito pelo contrário, nessas hipóteses em que o montante indenizatório é mínimo ou ínfimo e que os danos, sob a perspectiva individual, são de bagatela, os sujeitos não têm, em regra, interesse no ajuizamento de demandas individuais. Muitas vezes, o valor a ser recuperado, em razão de um comportamento abusivo do réu, sequer compensa as despesas prévias do indivíduo na demanda judicial, como os honorários advocatícios, as custas e as despesas processuais. ${ }^{669}$

Nesse caso, o elemento normativo que se destaca na ação coletiva, portanto, não é a pessoalidade presente na relação substancial, mas, sim, a impessoalidade ou o anonimato ${ }^{670}$ do indivíduo no grupo. Somente se considerados os danos, sob uma perspectiva global ou macro do grupo, é que a controvérsia e a prática abusiva demonstrará todo o seu potencial lesivo.

Por exemplo, um dano individualmente considerado de US\$3,00 (três dólares), cobrados a mais na tarifa de telefonia da TIM, é irrisório ao indivíduo. Mas, se esse valor for considerado globalmente em relação a todos os clientes dessa operadora de telefonia, a prática abusiva ganha relevância social e econômica, bem como revela a perpetuação desse ilícito. Afinal, se a empresa não for devidamente sancionada, ela continuará a se beneficiar da sua prática abusiva.

Esses danos ínfimos ou de pequena monta raramente levantam antagonismos entre os indivíduos, membros do grupo (ex. clientes da operadora de telefonia). A relação substancial tende a ser impessoal e os membros do grupo tendem a comungar dos mesmos interesses, qual seja a atuação do direito substancial e o desestímulo à prática lesiva ou abusiva do réu.

O que importa, nessa espécie, não é tanto a recuperação ou a reparação dos danos sofridos, embora esse seja também um dos escopos do processo coletivo, mas, sim, a modificação prospectiva da conduta ou da prática lesiva ou abusiva levada a efeito pela empresa ré.

669 No sistema estadunidense, ressalta-se comumente o valor negativo (negative value) das ações ínfimas, valor esse que obsta, na prática, a persecução individual do direito (ISSACHAROFF, Samuel. Preclusion, due process and the right to opt out of class action. Notre Dame Law Review, 2002, V.77: 1057-1082p, p. 1059).

670 BONE, 1990, p. 218. 
Nesse sentido, Kalven e Rosenfield ${ }^{671}$, em texto seminal sobre a função da ação de classe no sistema jurídico estadunidense, são enfáticos ao mencionar que as small claims, se processadas coletivamente, propiciariam a atuação do direito substancial e o desestímulo à prática abusiva ou lesiva (deterrence) praticada pelo réu, prática que, do contrário, permaneceria irreparada.

Para justificar esse raciocínio, aqueles autores ${ }^{672}$ fazem uma comparação entre ações derivadas e as ações por danos ínfimos. No primeiro caso, os investidores ou acionistas defendem um direito pertencente à própria pessoa jurídica, o que os afeta indiretamente ou de forma derivada. Nas ações por danos ínfimos, à semelhança das ações derivadas, a compensação pretendida pelo indivíduo é secundária e inviável à persecução individual. A lesão individual é mera decorrência de uma prática lesiva primária e global perpetrada contra a própria coletividade e, em seguida, pulverizada ou fragmentada entre os indivíduos. De igual modo, a quantificação do montante indenizatório nas ações ínfimas tende a decorrer de mero cálculo, obtido por fórmula padrão, aplicada à coletividade ou por cálculo administrativo. Há, assim, uma objetividade na quantificação dos danos, não sendo, em regra, necessária a análise particular.

Guardadas as devidas proporções - pois, no caso da compensação individual ínfima, os interesses ou direitos controvertidos não necessariamente pertencem à própria pessoa jurídica - a comparação realizada por Kalven e Rosenfield não poderia ter sido mais feliz. Ela revelou a impessoalidade e a paridade que estão potencialmente presentes nas ações ínfimas (small claims), a exemplo do que já ocorre com as ações derivadas dos acionistas e de membros de associações informais e também com as outras categorias das ações de classe americanas, como a incompatible standards, a limited fund class action e injunctive or declaratory class action.

É interessante notar que nas small claims a impessoalidade e a ausência de antagonismo entre os indivíduos do grupo são, porventura, até mesmo superiores às hipóteses em que a pretensão refere-se à obrigação de fazer ou não fazer ou à provimento declaratório aplicável ao grupo como um todo. A reestruturação do sistema escolar ou prisional podem ser muito mais controvertida e gerar maiores antagonismos no grupo que as ações de danos de pequeno valor. ${ }^{673}$

671 KALVEN JR, Harry, ROSENFIELD, Maurice. The contemporary function of the class suit. The University of Chicago Law Review, 1941, V. 8: 684-721p, p. 691. 692. 
Mas, em que essa impessoalidade e essa paridade potenciais, agora identificadas, importam na certificação coletiva das ações por danos ínfimos?

A impessoalidade importa, pois, nesses casos, o regime processual mais rígido previsto para a class action for damages, que exige a notificação individualizada e obrigatória aos membros da classe identificáveis, poderia ser facilmente flexibilizada para a hipótese de small claims, sem prejuízo aos indivíduos. Admitir-se-ia, por exemplo, uma notificação por amostragem de alguns indivíduos, bem como uma notificação coletiva, a exemplo daquelas hipóteses em que os réus já possuem meios de comunicação com os indivíduos, como contas de cobrança pela prestação de serviços (contas de luz, telefone, água), publicações em jornais ou revistas especializadas. ${ }^{674}$

Recorda-se, nesse sentido, do precedente Eisen v. Carlisle \& Jacquelin, em que proposta uma ação coletiva em nome de seis milhões de pequenos investidores da bolsa de valores de Nova York. A Suprema Corte decidiu que a notificação individualizada era necessária aos investidores que pudessem ser identificados. Ocorre que, nesse caso, as despesas com a notificação individualizada dos membros da classe alcançaria um custo de US\$225.000,00 (duzentos e vinte e cinco mil dólares), quando o valor discutido individualmente não ultrapassava US\$ 70,00 (setenta dólares), valor desinteressante à persecução individual. ${ }^{675}$

O esquema rígido de notificação da ação classe tornou-se, nesse caso, proibitivo ao acesso à justiça, bem como obstou a atuação do direito substancial, quando, na realidade, sequer haveria uma razão suficiente para que essa modalidade de notificação assim fosse exigida. Era preciso, portanto, que a técnica fosse orientada a essa controvérsia substancial de valor ínfimo. ${ }^{676}$

Por esse motivo, muitos Estados americanos, em suas legislações específicas, optaram por não seguir o processo civil federal nesse aspecto, estabelecendo maior flexibilidade à notificação.

674 As várias modalidades de notificação são comentadas por Rachael Mulheron, sob a perspectiva comparada entre os sistemas estadunidense, australiano, canadense e inglês. Dentre as modalidades, cita: propaganda no rádio e televisão, jornais de circulação diária, telefonemas toll-free, revistas especializadas de um segmento ou categoria, notificação reproduzida em fatura de cobrança, em caixas de leite, nos contracheques ou ordens de pagamento etc (Cf. MULHERON, 2004, p. 352-353).

675 UNITED STATES OF AMERICA. Supreme Court of United States. Eisen v. Carlisle \& Jacquelin. 417 U.S. 156 (1974).

676 COVER, 1975, p. 739. 
Em Illinois ${ }^{677}$, por exemplo, a Corte de Justiça poderá ordenar a notificação na medida em que necessário para a proteção dos interesses da classe e dos membros ausentes. Não há exigência de notificação individualizada mesmo nas class actions for damages regulares e não ínfimas.

Em Iowa ${ }^{678}$, por sua vez, a notificação individualizada aos membros facilmente identificáveis da classe somente é exigida se os danos individuais superarem o valor de US\$100,00 (cem dólares). Em Oregon ${ }^{679}$, a notificação pode ser dada a todos ou alguns indivíduos, de acordo com a proteção exigida aos membros ausentes da coletividade em determinado caso concreto.

Igualmente, já houve proposta de emenda à Federal Rule 23, realizada pelo ABA - American Bar Association' ${ }^{680}$, que previa a realização de uma notificação apropriada, conforme a proteção ao indivíduo exigida no caso concreto, mormente para as hipóteses de small claims.

677 “.... Notice in class cases. Upon a determination that an action may be maintained as a class action, or at any time during the conduct of the action, the court in its discretion may order such notice that it deems necessary to protect the interests of the class and the parties. An order entered under subsection (a) of Section 2-802 of this Act, determining that an action may be maintained as a class action, may be conditioned upon the giving of such notice as the court deems appropriate" (ILLINOIS. Code of Civil Procedure. Part. 8. Class action. Disponível em: http://www.ilga.gov/legislation/ilcs/ilcs3.asp?ActID=2017\&ChapterID=56.Acesso em: 24 de outubro de 2013). 678 “...1.266(4) Each member of the class, not a representative party, whose potential monetary recovery or liability is estimated to exceed $\$ 100$ shall be given personal or mailed notice if that member's identity and whereabouts can be ascertained by the exercise of reasonable diligence. 1.266(5) for members of the class not given personal or mailed notice under rule 1.266(4), the court shall provide, as a minimum, a means of notice reasonably calculated to apprise the members of the class of the pendency of the action. Techniques calculated to ensure effective communication of information concerning commencement of the action shall be used. The techniques may include personal or mailed notice, notification by means of newspaper, television, radio, posting in public or other places, and distribution through trade, union, public interest, or other appropriate groups. (IOWA. Rules of Civil Procedure. Rule 1.266. Disponível em: https://www.legis.iowa.gov/DOCS/ACO/CR/LINC/08-282013.chapter.1.pdf. Acesso em: 24 de outubro de 2013).

679 “...F(1) When ordering that an action be maintained as a class action under this rule, the court shall direct that notice be given to some or all members of the class under subsection $\mathrm{E}(2)$ of this rule, shall determine when and how this notice should be given and shall determine whether, when, how, and under what conditions putative members may elect to be excluded from the class" (OREGON. Rules 32 of Civil Procedure. Disponível em: http://www.oregonlegislature.gov/bills_laws/Pages/orcp.aspx. Acesso em: 24 de outubro de 2013).

680 Sobre a proposta realizada pelo ABA, conferir: BONE, Robert G. Rule 23 redux: Empowering the federal class action. The Review of litigation, 1994, V. 14: 79-112p. p. 111). 
Robert G. Bone ${ }^{681}$, Jay Tidmarsh e David Betson ${ }^{682}$ vão muito além da referida proposta, salientando que também o direito de autoexclusão seria inviável nas ações coletivas por danos de valor ínfimo (small claims). O principal escopo dessa ação não é a compensação individual ou a economia processual, mas a atuação do direito substancial e o desestímulo à prática abusiva. Nesse caso, a possibilidade de exclusão da classe poderia, até mesmo, encorajar comportamentos oportunistas de advogados, que excluiriam seus clientes da ação de classe para propor outra ação, com o objetivo de competir pelos honorários advocatícios devidos no caso.

O argumento é persuasivo, pois, em hipóteses como essas, realmente é possível pensar em um uso abusivo do opt out. O indivíduo pleitearia a exclusão da classe não por considerar mais adequada a persecução individual do direito - até porque, em regra, não existe interesse sob o ângulo do custo v. benefício - mas para alcançar algum fim estratégico na demanda judicial.

No entanto, em hipóteses como essa, a negativa prima facie do opt out não deve prevalecer. A presunção não deve ser pelo abuso processual, mas a presunção deve ser pela boa-fé. Assim, é preferível adotar um opt out argumentativo. Com isso, mantém-se, presumidamente, a possibilidade de um indivíduo exercitar a autoexclusão, presunção que pode vir a ser afastada.

Essa presunção de opt out é importante até mesmo para que haja oportunidade de o indivíduo apontar, por exemplo, um advogado desleal no processamento da demanda coletiva ou a existência de conluio entre as partes. Essa presunção é, no entanto, relativa ou derrotável. ${ }^{683}$

\footnotetext{
681 A ação de classe por danos ínfimos nada tem a ver com a economia processual para ser certificada como class action for damages, pois essa ação coletiva surge quando não há interesse algum na propositura de demandas individuais. Não há, portanto, uma multiplicidade de demandas individuais que justifique uma suposta economia processual na ação coletiva por danos ínfimos. De igual modo, essa ação de classe nada tem a ver com compensação individual, pois o indivíduo sozinho receberá uma compensação financeira ínfima. A principal razão dessa ação coletiva por danos ínfimos é obstar a conduta lesiva do réu (deterrence). Nessa hipótese, não haveria razão para o exercício do opt out. O opt out, nessas circunstância, é, na verdade, estratégico, pois muitas vezes a autoexclusão de um interessado ocorre em razão da concorrência de advogados pelos honorários (Cf. BONE, 1994, p. 100).

682 Segundo Tidmarsh e Betson, poucos são os indivíduos que exercem o direito de autoexclusão da ação de classe. Todavia, quando o fazem, normalmente é por razões estratégicas (Cf. TIDMARSH, Jay, BETSON, David. Optimal class size, opt-out rights and 'indivisible' remedies. The George Washington Law Review, 2011, V. 79 : 542-576p, p. 544).

683 A ideia de um opt out condicionado já está presente há muito tempo no direito estadunidense. Linda Mullenix já abordava, em 1986, a necessidade de se condicionar o exercício do direito de autoexclusão, devendo o indivíduo assumir o ônus argumentativo (burden of persuasion) para lograr a exclusão da classe, alegando as razões, de fato e/ou de direito, que justificassem a persecução individual da causa (Cf. MULLENIX, Linda S. Class resolution of the mass tort case: a proposed federal procedure act. Texas Law Review, 1986, V. 64: 1039-1099p. p. 1073).
} 
O indivíduo deverá justificar a razão pela qual pretende a exclusão do grupo. Se a razão disser respeito ao design procedimental ou à ausência de alguns dos pré-requisitos da ação de classe, como a representatividade adequada, o magistrado poderá corrigir a demanda, negando o opt out do indivíduo, por ausência de interesse superveniente. De igual modo, o opt out deverá ser negado, se o indivíduo não alegar uma causa particular ou pessoal, para justificar a persecução individual de uma ação com valor ínfimo. Isso porque não é admissível que o indivíduo se exclua da ação de classe para propor demanda individual idêntica à ação coletiva, de forma abusiva ou por razão meramente estratégica (ex. disputa entre advogados por honorários).

O direito de autoexclusão da ação de classe (opt out) deverá ser deferido, por sua vez, apenas nas hipóteses em que surgir uma causa particular ou pessoal do indivíduo que justifique a participação direta na demanda judicial ou nas hipóteses em que não for possível suprir o vício da ação de classe (ex. defeito de representação) em relação ao indivíduo. A exclusão do indivíduo, nesse caso, deveria ser, até mesmo, de ofício, pois se não houver adequação, o indivíduo poderá realizar, no futuro, um collateral attack, isto é, o indivíduo sucumbente poderá pretender afastar a autoridade da coisa julgada coletiva em procedimento futuro por ausência de representatividade adequada. Para evitar isso, é melhor a exclusão logo no curso da ação.

O opt out argumentativo favorece a agregação ótima (necessária e adequada) em uma ação de classe, sem causar gravames à autonomia individual e sem abusos. Assim, há a possibilidade de o indivíduo narrar a sua história pessoal, particularizada, que pode não coincidir ou contrariar a história do grupo. O processo adapta-se, portanto, aos contornos substanciais da controvérsia.

Por fim, destaca-se que as ações que reivindicam compensação individual ínfima raramente requerem análise pessoal dos membros do grupo. E, muitas vezes, a compensação individual é meramente econômica, sendo calculada segundo um critério objetivo ou uma fórmula padrão do grupo, o que apenas reforça a impessoalidade potencialmente presente nessa hipótese.

Veja que, na realidade, não há necessidade de criar uma nova categoria de ação classe, aplicável especificamente para as hipóteses de danos ínfimos. O que se pretendeu demonstrar, nesse tópico, é que a própria categoria da class action for damages revela, em alguns casos, como nas hipóteses de danos ínfimos, situações de upstream, isto é, situações da vida dotadas das mesmas características substanciais da impessoalidade e da indivisibilidade ou paridade, que já estão presentes nas demais categorias da Federal Rule 23. A técnica deve apenas seguir a substância. 
Por essa razão, a diferenciação estabelecida no regime processual não poderia ser tão rígida e inflexível. Há que se admitir maior adaptabilidade ao direito substancial, conforme o que denominamos de critérios substanciais de agregação. Sempre que a situação da vida apresentar os critérios substanciais da impessoalidade e paridade ou indivisibilidade, a controvérsia deve ser agregada e o regime jurídico processual de agregação orientado ao direito substancial.

Como é cediço, a divisão mais conhecida do regime processual é assim estabelecida: (i) na hipótese de tutelas declaratórias, constitutivas ou mandamentais, a ação coletiva é de vinculação obrigatória aos membros ausentes da classe, a notificação e a exclusão dos membros ausentes da classe são facultativas e excepcionais (mandatory class action) e (ii) na hipótese de tutela condenatória por danos, a ação coletiva é de vinculação não compulsória aos membros ausentes, a notificação é obrigatória e a exclusão do indivíduo é admitida (non-mandatory class action). ${ }^{64}$

O que se deve refletir é que o regime processual (coisa julgada, notificação e direito de autoexclusão) não deve estar vinculado à eficácia do provimento (declaratória, constitutiva ou mandamental), mas, sim, a presença dos mencionados critérios substanciais de agregação.

Isso será retomado ainda neste capítulo da tese. Mas, é preciso caminhar agora para uma segunda espécie de casos upstream: os casos de compensação incidental ou econômica.

\subsubsection{COMPENSAÇÃO INDIVIDUAL INCIDENTAL OU MERAMENTE ECONÔMICA (INCIDENTAL DAMAGES OR ECONOMIC INJURIES)}

É cediço que as pretensões mandamentais (injuntivas) e declaratórias, aplicáveis, em geral, com fundamento no grupo como um todo, são comumente certificadas na categoria 23(b)(2).

São casos, por exemplo, de discriminação racial ou de gênero, em que se alega um padrão de conduta ilícito, discriminatório e uniforme aplicável contra toda a classe, por exemplo, contra toda a classe de afrodescendentes, de latinos ou de mulheres, que são vulneráveis na hipótese.

684 TIDMARSH, BETSON, 2011, p. 542. 
E, na mesma categoria, incluíram-se demandas de civil rights, principalmente aquelas que discutem direitos sociais, em que o Estado age ou recusa-se a agir, com base em fundamento aplicável à classe. Exemplo disso é a reestruturação do sistema escolar e da política prisional.

Nesse ponto, algumas questões interessantes de upstream surgem. O sistema jurídico depara, por várias vezes, com situações em que, ao lado das pretensões mandamentais e declaratórias, o autor coletivo também deduz, em juízo, pretensões indenizatórias incidentais ou econômicas.

Essas situações são desafiadoras na certificação da ação coletiva, pois se forem certificadas na categoria 23 (b)(2) - injunctive or declaratory class action, o regime jurídico de agregação não admitirá, por exemplo, o direito de autoexclusão e os membros ausentes serão, necessariamente, vinculados pela autoridade da coisa julgada formada na demanda coletiva.

Se a pretensão indenizatória for, todavia, considerada predominante ou o elemento de maior relevância no caso concreto, a ação de classe será certificada na categoria 23 (b)(3) - class action for damages - e o regime jurídico de agregação admitirá, por exemplo, o direito de autoexclusão dos indivíduos e os membros ausentes da classe somente serão vinculados pela coisa julgada formada na demanda coletiva, se forem adequadamente representados pelo autor coletivo e caso não exercitem o direito de autoexclusão (opt out) no momento oportuno.

Ocorre que, nos típicos casos de upstream, as pretensões indenizatórias tendem a ser meramente incidentais ou meramente econômicas, isto é, a compensação individual é calculada segundo um critério objetivo ou segundo uma fórmula matemática ou padrão aplicável ao grupo como um todo. O cálculo é considerado administrativo ou ministerial ${ }^{685}$, independentemente de aferição posterior dos atributos pessoais de um indivíduo. A compensação, a reparação ou a distribuição do montante indenizatório, por sua vez, tende a ser proporcional ou paritário entre os membros do grupo (pro rata sharing), constituindo mera decorrência do cumprimento do pronunciamento judicial mandamental (injuntivo) ou declaratório antes mencionado.

Nesse caso, embora a pretensão também seja condenatória ao ressarcimento em pecúnia, a relação substancial deduzida em juízo é potencialmente impessoal, pois não demanda análise 
particular dos indivíduos do grupo, e é potencialmente paritária entre os membros do grupo, pois a compensação individual é mera decorrência da aplicação de um critério ou fórmula.

É preciso destacar que a ação coletiva que envolve danos incidentais ou meramente econômicos goza dos mesmos requisitos de paridade e de impessoalidade presente nas categorias 23(b)(1) e 23(b)(2). Nesse contexto, o próprio Advisory Committee ${ }^{686}$ em 1966 assegurou a essa hipótese a certificação segundo o regime de vinculação compulsória (mandatory), típica das categorias anteriores. Esse entendimento não é, todavia, aplicável se a questão disser respeito exclusivo ou predominante ao ressarcimento em pecúnia por danos pessoalmente sofridos pelo indivíduo.

Uma crítica merece ser feita à terminologia utilizada. Como já disse antes, não é a eficácia do provimento que deveria definir o regime processual (se vinculante ou não), mas, sim, os critérios substanciais de agregação. Pouco importa se a pretensão é o ressarcimento pecuniário incidental/econômico ou se a pretensão é o ressarcimento pecuniário predominante, o que importa é se a relação substancial deduzida em juízo é impessoal e indivisível ou paritária.

A eficácia do provimento pretendido é apenas um indício que permite identificar essa relação substancial. Exemplo: se a pretensão é mandamental, há um indício forte de que a relação substancial é indivisível ou coletiva, a ensejar a certificação na categoria 23(b)(1) ou 23(b)(2), cujo regime é de vinculação obrigatória. Mas, não basta observar a indivisibilidade, é preciso aferir a impessoalidade, ou seja, se essa pretensão é aplicável com fundamento no grupo como um todo. Se não for aplicável ao grupo como um todo, mas disser respeito apenas ao indivíduo, isto é, for pessoal, de cognição artesanal, trata-se, ao final, de relação substancial individual.

Outro exemplo é o da pretensão condenatória. Se a pretensão é condenatória ao ressarcimento em pecúnia por danos sofridos pelo indivíduo, há um indício forte de que a relação substancial é divisível e individual, a ensejar a certificação na categoria 23(b)(3), cujo regime é de vinculação não compulsória (admite autoexclusão). Mas, não basta observar a divisibilidade, é

686 “...This subdivision is intended to reach situations where a party has taken action or refused to take action with respect to a class, and final relief of an injunctive nature or of a corresponding declaratory nature, settling the legality of the behavior with respect to the class as a whole, is appropriate. Declaratory relief "corresponds" to injunctive relief when as a practical matter it affords injunctive relief or serves as a basis for later injunctive relief. The subdivision does not extend to cases in which the appropriate final relief relates exclusively or predominantly to money damages. Action or inaction is directed to a class within the meaning of this subdivision even if it has taken effect or is threatened only as to one or a few members of the class, provided it is based on grounds which have general application to the class." [grifo nosso] (Cf. UNITED STATES OF AMERICA. Federal Rules of Civil Procedure. Washington: US Government Printing Office, 2010). 
preciso aferir a impessoalidade, isto é, se o ressarcimento é aplicável com fundamento no grupo como um todo. Se for aplicável ao grupo como um todo (mera restituição de salário dos últimos meses, parcialmente retido por uma prática uniforme de conduta da ré) e não ao indivíduo, a relação substancial é coletiva, admitindo certificação na categoria 23(b)(1) ou 23(b)(2).

Justamente em razão do problema terminológico antes mencionado, o sistema jurídico estadunidense encontra dificuldades e muitas divergências para definir o que é ressarcimento pecuniário incidental ou econômico ou o que é ressarcimento pecuniário predominante.

Nesse ponto, não se conta ainda com uma jurisprudência consolidada. As Cortes de Justiça apresentaram-se hesitantes quando o assunto é certificar as situações de upstream e os "testes" para se identificar que essas situações variam de um circuito federal para outro circuito federal.

Algumas cortes têm certificado a ação coletiva, em que há compensação indenizatória incidental ou meramente econômica, segundo o regime aplicável à injunctive or declaratory class action, isto é, segundo o regime de vinculação obrigatória ao julgado (mandatory class action) e sem a possibilidade de exclusão dos membros ausentes da classe (opt out).

Isso é possível - repita-se - sem que sobrevenha prejuízo aos membros ausentes da classe, pois a pretensão indenizatória não requer análise pessoal ou artesanal. E, igualmente, não faria sentido admitir a exclusão do indivíduo. Afinal, como admitir a exclusão do indivíduo em relação à pretensão indenizatória, quando o critério ou a forma de cálculo da compensação individual é mera decorrência lógica do pronunciamento judicial mandamental ou declaratório, em relação a qual, por força da regra processual, não seria admitido o direito de autoexclusão.

Essas hipóteses são denominadas de hybrid class action, pois a pretensão é composta ou mista. A pretensão deduzida em juízo tanto é mandamental ou declaratória, na forma prevista na categoria 23(b)(2), quanto indenizatória, na forma prevista na categoria 23(b)(3). A certificação, se admitida essa modalidade híbrida, é realizada em regra na categoria 23(b)(2). ${ }^{687}$

De fato, a pretensão é mista ou híbrida, pois se encarta em duas categorias autônomas. Mas, segundo compreendemos, o fenômeno no direito substancial é o mesmo. Os critérios 
substanciais de agregação, isto é, a impessoalidade e a paridade estão presentes tanto na categoria 23(b)(2), como potencialmente na categoria 23(b)(3). Logo, esse hibridismo tende a ocorrer com frequência, mas isso ocorre por força da relação substancial deduzida em juízo.

Lembra-se que não é a pretensão que define o direito substancial discutido na tutela coletiva. Logo, quando se busca classificar o direito substancial em categorias fundamentadas no tipo de pretensão deduzida, o hibridismo tende a ocorrer e será necessário unificar o tratamento processual, pois as características substanciais das duas categorias são, no fundo, as mesmas.

Para identificar essas situações de hibridismo, em que a pretensão indenizatória pode ser certificada junto à categoria 23(b)(2), que é típica dos provimentos mandamentais ou declaratórios, o Quinto Circuito (Fifth Circuit) no precedente Allison v. Citgo Petroleum Corp, estabeleceu o teste de identificação denominado "danos incidentais" (incidental damages). ${ }^{688}$

Em Allison, os autores pleitearam a certificação da ação de classe na categoria 23(b)(2) e/ou 23(b)(3), em nome de todos os empregados afrodescendentes ou interessados em um emprego, alegando que a empresa Citgo realizou prática discriminatória aplicável em relação à classe como um todo com relação às contratações, promoções, compensações e/ou treinamento.

Para certificar essa ação de classe, o Quinto Circuito salientou que, para fins de certificação na categoria 23(b)(2), a pretensão indenizatória não deveria predominar. Para aferir isso, adotou o seguinte teste: se a pretensão indenizatória for incidental à pretensão mandamental ou declaratória, a certificação em 23(b)(2) é autorizada. A pretensão indenizatória é, por sua vez, incidental, sempre que a compensação individual decorrer ou fluir diretamente da responsabilidade reconhecida em favor da classe como um todo em um provimento base do tipo mandamental (injuntivo) ou declaratório ${ }^{689}$. Esse teste foi, por sua vez, acompanhado pelo Quarto, Sexto, Sétimo e Décimo Primeiro Circuito da Justiça Federal estadunidense. ${ }^{690}$

688 UNITED STATES OF AMERICA. Court of Appeals, Fifth Circuit. Allison v. Citgo Petroleum Corp. 151 F.3d 402 (1998).

689 “... By incidental, we mean damages that flow directly from liability to the class as a whole on the claims forming the basis of the injunctive or declaratory relief. See Fed.R.Civ.P. 23(b)(2) (referring only to relief appropriate "with respect to the class as a whole"). Ideally, incidental damages should be only those to which class members automatically would be entitled once liability to the class (or subclass) as a whole is established" (Ibidem) 690 GRANTHAM, BODDEN, 2010, p.351-361. 
Como em Allison o grupo não preenchia os parâmetros supracitados, pois envolvia intensa análise pessoal dos membros do grupo para a quantificação da compensação individual, não decorrendo essa incidentalmente do provimento mandamental ou declaratório pretendido na demanda, a ação de coletiva foi certificada na categoria 23(b)(3) e não na categoria 23(b)(2).

Atualmente, o Quinto Circuito estabeleceu mais um requisito para fins de certificação na categoria 23(b)(2) no precedente Maldonado v. Ochsner Clinic Foundation ${ }^{691}$. Agora, além do teste Allison, é preciso que o grupo afirme a existência de danos futuros em razão da conduta praticada pela parte contrária, para que a certificação na categoria 23(b)(2) seja apropriada. ${ }^{692}$

No caso Maldonado, os autores alegavam que a clínica médica Ochsner praticava taxas não razoáveis pelos serviços médicos prestados a pacientes sem seguro saúde, razão pela qual pleitearam a alteração da taxa aos parâmetros adequados e o reembolso das diferenças devidas. Ocorre que, quando o Corte de Justiça veio a decidir a respeito da certificação da ação, a clínica já havia espontaneamente alterado sua política de preços para os pacientes sem seguro saúde. Nesse caso, disse a Corte, não havia mais interesse no provimento mandamental, embora ainda presente o interesse pela pretensão indenizatória incidental, a ação não poderia ser certificada na categoria 23(b)(2), pois a classe não estava ameaçada de sofrer danos futuros (future harm).

É interessante notar, no entanto, que o direito substancial não mudou em razão da ausência superveniente do interesse de agir na pretensão mandamental. Os danos, ditos incidentais, continuam sendo impessoais e paritários, enfim, eles decorreram de uma conduta uniforme praticada pela parte ré (política abusiva de preços) e a compensação individual é paritária ou proporcional, segundo critério objetivo e paritário: o cálculo devido é mera diferença de preços.

Assim, não é possível entender, portanto, o porquê de o tratamento processual aplicável antes da alteração da política de preços ser o regime de vinculação compulsória (mandatory) e o

691 "Rule 23(b)(2) certification is also inappropriate when the majority of the class does not face future harm. See Bolin, 231 F.3d at 978. Before suit was filed, Ochsner instituted an automatic thirty-five percent discount to uninsured patients, on top of the numerous other discounts already provided to uninsured patients. An injunction prohibiting Ochsner from charging the "full" charge master rate in the future would be meaningless, while an injunction requiring Ochsner to afford the discount that it has instituted serves no purpose. This situation leaves monetary claims for retrospective damages predominant in the case. Therefore, the "declaratory relief [Appellants] seek serves only to facilitate the award of damages," and Rule 23(b)(2) certification is improper" (UNITED STATES. Court of Appeals, Fifth Circuit. Maldonado v. Ochsner Clinic Foundation 493 F.3d 521 (2007)). 692 GRANTHAM, BODDEN, 2010, p. 353. 
porquê de o tratamento processual aplicável posteriormente a alteração da política de preços ser o regime de vinculação não compulsória (non-mandatory), se o direito continua o mesmo.

O Segundo Circuito (Second Circuit) superou, por sua vez, o parâmetro fixado em Allison, e sequer considerou a alteração realizada em Maldonado. No precedente Robinson v. MetroNorth Commuter Railroad, adotou parâmetro diverso, consistente no teste denominado de "balanceamento ad hoc" (ad hoc balancing). Esse teste é, por sua vez, considerado menos rígido que o anterior, mas também é bastante criticado por ser muito menos claro ou preciso. ${ }^{693}$

Em Robinson ${ }^{694}$, o Segundo Circuito salientou que a certificação da ação de classe pode ser realizada na categoria 23(b)(2) quando a pretensão indenizatória não for predominante. Mas, para tanto, é preciso atentar-se para o seguinte: a pretensão não é predominante quando (i) consideradas as peculiaridades da evidência apresentada, a compensação individual não é o elemento que se destaca na controvérsia; (ii) a pretensão mandamental ou declaratória predomina, ainda que presente a pretensão compensatória; e (iii) o tratamento coletivo dessa controvérsia será eficiente e suscetível de gerenciamento, de forma a alcançar economia.

Nesse caso, não é preciso que a compensação individual seja mais incidental ou meramente econômica. O importante seria aferir, nas circunstâncias do caso concreto, se a pretensão mandamental ou declaratória é relevante e realmente avançará a solução da controvérsia em relação ao grupo como um todo, sendo, por isso, necessária e apropriada para que os argumentos dos membros do grupo tenham real chance de prevalecer no julgamento de mérito da demanda.

O Nono Circuito (Ninth Circuit) adotou, inicialmente, o teste Robinson. Mas, no caso Dukes v. Wal Mart Stores Inc ${ }^{695}$ superou aquele entendimento e adotou teste diverso. Nesse último teste,

693 ISSACHAROFF, 2002, p. 114.

694 "...Rather, we hold that when presented with a motion for (b)(2) class certification of a claim seeking both injunctive relief and non-incidental monetary damages, a district court must "consider[] the evidence presented at a class certification hearing and the arguments of counsel," and then assess whether (b)(2) certification is appropriate in light of "the relative importance of the remedies sought, given all of the facts and circumstances of the case." Hoffman, 191 F.R.D. at 536. The district court may allow (b)(2) certification if it finds in its "informed, sound judicial discretion" that (1) "the positive weight or value [to the plaintiffs] of the injunctive or declaratory relief sought is predominant even though compensatory or punitive damages are also claimed," Allison, 151 F.3d at 430 (Dennis, $J$., dissenting), and (2) class treatment would be efficient and manageable, thereby achieving an appreciable measure of judicial economy" (UNITED STATES OF AMERICA. Robinson v. Metro-North Commuter Railroad. Second Circuit. August Term, 2000267 F.3d 147 (2001)).

695 "...to determine whether monetary relief predominates, a district court should consider, on a case-by-case basis, the objective "effect of the relief sought" on the litigation. See Allison, 151 F.3d at 416. Factors such as whether the monetary relief sought determines the key procedures that will be used, whether it introduces new and 
é preciso avaliar os seguintes fatores: (i) se a demanda introduz questões controvertidas novas e fáticas em relação aos membros do grupo; (ii) se serão necessárias audiências individuais; e (iii) se o tamanho e a natureza do grupo, medidos pela compensação individual pretendida, suscitará preocupações com o devido processo legal e com o gerenciamento do processo, não prevalecendo, assim, fator que seja determinante ou aplicável para toda a classe como um todo.

Esse teste foi chamado de "balanceamento multifatorial ou multifacetado" (multi faceted balancing test). Ele é útil para determinar se a pretensão individual indenizatória é predominante ou não, para fins de certificação da ação de classe na categoria 23(b)(2) injunctive or declaratory class action. Esse teste é considerado seguro, por ofertar fatores claros de distinção, bem como é considerado menos rígido que os demais testes antes referenciados. ${ }^{696}$

É menos rígido, obviamente, pois não se trata mais de averiguar se a compensação individual é incidental ou meramente econômica (teste Allison), tampouco de se aferir se a pretensão mandamental ou declaratória é necessária e apropriada para a proteção dos membros do grupo (teste Robinson), a questão central para a certificação da ação coletiva na categoria 23(b)(2) consiste em saber se é preciso ou não análise pessoal dos indivíduos, membros do grupo.

Em verdade, quando o Quinto Circuito disse, em Allison, que a compensação individual é incidental ou meramente econômica (mera restituição financeira, pagamento retroativo de salários), o objetivo já era afastar análise pessoal ou particularizada dos membros do grupo. De igual modo, quando o Segundo Circuito disse, em Robinson, que é preciso avaliar se a pretensão mandamental ou declaratória é fundamental para definir a proteção do grupo, o objetivo também era afastar a análise pessoal ou particularizada dos membros. O que o Nono Circuito fez em Duke foi apenas revelar diretamente esse critério, qual seja, a necessidade de se afastar análise pessoal ou particularizada dos membros do grupo para fins de certificação na categoria 23(b)(2), cujo regime processual é de vinculação obrigatória (mandatory class) ao julgado.

E, mais, é possível ponderar até mesmo em um avanço nesse raciocínio realizado em Dukes. Os danos, ditos incidentais ou meramente econômicos, poderiam ser suscetíveis de certificação

significant legal and factual issues, whether it requires individualized hearings, and whether its size and nature as measured by recovery per class member - raise particular due process and manageability concerns would all be relevant, though no single factor would be determinative." (UNITED STATES OF AMERICA. Dukes v. Wal Mart Stores Inc. Ninth Circuit. 603 F.3d 571 (2010)).

696 GRANTHAM, BODDEN, 2010, p. 367. 
em qualquer categoria de vinculação obrigatória (mandatory class action), até mesmo na hipótese de tutela condenatória repressiva ou retrospectiva. Isso porque os critérios substanciais são os mesmos, independentemente de essa pretensão indenizatória vir expressamente cumulada com a pretensão mandamental (injuntiva) ou declaratória pelos membros do grupo.

Mas, agora, voltando aos precedentes dos Circuitos da Justiça Federal estadunidense, é preciso destacar que alguns Circuitos não adotaram qualquer parâmetro claro para as hybrid classes. Esse é o caso do Primeiro, Terceiro, Oitavo, Décimo Circuito e o Circuito do Distrito de Columbia. ${ }^{697}$ As District Courts adotaram, por vezes, alguns dos testes supramencionados, mas mencioná-las aqui estaria fora dos propósitos da presente investigação. Por ora, o importante é apenas destacar os critérios substanciais de agregação, que circundam a certificação da ação.

A certificação da hybrid classes na categoria 23(b)(2) obsta, em regra, a autoexclusão, favorecendo a agregação ótima (necessária e adequada) da controvérsia na ação de classe, sem causar gravames à autonomia individual. Não há gravame à autonomia individual, pois o direito substancial, objeto da controvérsia, é impessoal e paritário e não pessoal ou artesanal.

Repete-se, aqui, o mesmo que se comentou em relação às demandas por danos ínfimos: parece que as Cortes de Justiça do sistema jurídico estadunidense estão sempre a dar voltas em torno dos mesmos critérios substanciais de agregação. Volta-se sempre à impessoalidade e à paridade ou indivisibilidade da relação substancial deduzida em juízo, para, assim, decidir a categoria na qual a ação de classe será certificada e o regime processual de agregação a ela aplicável.

Muito mais fácil seria se, ao invés de simplesmente certificar uma pretensão indenizatória na categoria mandamental ou declaratória, fosse explicitada a razão para isso, isto é, os critérios substanciais de agregação que autorizam o tratamento unitário daquela controvérsia em juízo.

Frisa-se - mais uma vez - que as class action for damages apresentam, de forma potencial, a impessoalidade e a paridade ou indivisibilidade presente nas categorias anteriores, mormente nos casos upstream. Logo, não faz sentido adotar regimes processuais que diferenciem essas categorias de forma muito rígida, sob pena de serem elas, eventualmente, combinadas ou misturadas os casos ditos híbridos, o que, como já se viu, acontece com muita frequência.

697 GRANTHAM, BODDEN, 2010, p. 367- 375. 


\subsubsection{COMPENSAÇÃO INDIVIDUAL OBJETIVA - CONTAMINAÇÃO TÓXICA E MONITORAMENTO MÉDICO (TOXIC TORTS AND MEDICAL MONITORING)}

Por último, é preciso abordar as hipóteses de contaminação tóxica ou de monitoramento médico, hipóteses que envolvem, igualmente, exposição a substâncias consideradas de risco.

Não é novidade que, nos dias de hoje, o desenvolvimento de novas tecnologias e o uso de novas substâncias e componentes químicos implicaram um aumento das lesões de massa. Muitas vezes, os efeitos desses novos componentes e de seus processos de fabricação sequer são integralmente conhecidos, tampouco a ciência poderia afirmar peremptoriamente, em um caso clínico e individual, a etiologia ou origem causal de doença, provocada por essas substâncias.

Lembra-se, como já antes abordado, que a causalidade nas ciências médicas é aferida, nesses casos, por prova epidemiológica realizada no grupo, mediante comparação entre o grupo de afetados e o grupo de não afetados. Isso ocorre porque, nas hipóteses de exposição ou contaminação tóxica, não há, em regra, evidência física e individual do agente causador do dano e sua relação com uma determinada doença manifestada. $\mathrm{O}$ que pode ser aferido é o grau de risco causado por um agente químico, em relação ao universo de afetados ou a comunidade. ${ }^{698}$

Por essa razão, há uma tendência em se abandonar, nesses casos de risco e de incerteza endógena ${ }^{699}$, a responsabilidade pelos danos causados, isto é, a responsabilidade tudo ou nada (all or nothing criterion $)^{700}$. Segundo esse critério, ou há certeza quanto à causalidade e quanto aos danos e a responsabilidade é afirmada, ou não há certeza quanto à causalidade e quanto aos danos causados e a responsabilidade é afastada, sem qualquer compensação individual.

698 “...in an individual case, epidemiology cannot conclusively prove causation, at best it can establish only a certain probability that a randomly selected case of disease was one that would not have occurred absent exposure, or the 'relative risk' of the exposed population. Toxic tort litigation, therefore, involves inference on causation derived from group-based information, rather than specific conclusions regarding causation in the individual case" (GOLD, Steve. Causation in toxic tort: burdens of proof, standards of persuasion and statistical evidence. The Yale Law Journal, 1986, V. 96: 376-402p, p. 380).

699 Quando menciona-se a incerteza endógena refere-se ao próprio fato, que somente poderia ser aferido estatisticamente. Não se trata da verossimilhança da alegação, isto é, do grau ou da probabilidade de algo ser real ou ter ocorrido, noutros termos, o grau de persuasão a respeito do fato (belief probability). Trata-se, sim, da probabilidade do próprio fato investigado, como, por exemplo, o ato de tirar a sorte com uma moeda para iniciar um jogo de futebol, no qual a probabilidade é inerente ao fato (fact probability). Nas hipóteses em que o próprio fato é uma probabilidade, não é possível dizer se ele realmente ocorreu ou não ocorreu, o que é possível dizer é que, na maioria dos casos, em determinadas condições, esse fato poderia ocorrer. Isso é o que acontece com as hipóteses de contaminação química. Não é possível dizer que o agente químico causou ou não o dano, mas é possível dizer que, em determinadas condições, um grupo de indivíduos foi submetido aos riscos de um dano (Cf. GOLD, 1986, p. 381-382).

700 ROSENBERG, 1996, p. 247. GOLD, 1986, p. 397. 
Embora esse ponto já tenha sido comentado, quando abordados os direitos de alcance coletivo, é preciso situar, agora, o desenvolvimento dessa questão no sistema jurídico estadunidense.

Nos casos de incerteza e de risco, há uma tendência em se abordar a responsabilidade pelo critério da proporcionalidade (proportional liability criterion). Segundo esse critério, quando existe probabilidade de a lesão ter sido causado por vários réus, a responsabilidade é a eles imputada, mas, posteriormente reduzida proporcionalmente. A forma mais comum de efetuar essa redução é observar a fatia de mercado (market share) ${ }^{701}$ dominada por cada um dos réus. Essa abordagem tornou-se comum nos anos 80, quando houve explosão da mass torts (dano de massa) e, ilustrativamente, consta no precedente Sindell v. Abbot Laboratories. ${ }^{702}$

No referido caso, que envolve o medicamento DES, cada fabricante foi considerado proporcionalmente responsável por uma fração dos danos causados às vítimas, sendo essa proporcionalidade estabelecida pela fatia de mercado (market share) do fabricante da droga.

Uma segunda abordagem, bem mais ousada que a anterior, tem sido levantada por civilistas e processualistas. Consiste na redução mais intensa do nexo de causalidade nas hipóteses de risco. Sob esse regime, a responsabilidade é proporcional, não aos danos causados, mas ao próprio risco imputado (risk-based) às vítimas ${ }^{703}$. Essa responsabilidade é, por sua vez, voltada, principalmente, às hipóteses de exposição ou contaminação tóxica em acidentes de massa.

701 "...the second approach to resolving uncertainty over causation is the proportional liability criterion. Under this approach, whenever there is a positive probability that the defendant caused the injury, liability will be imposed, but its magnitude will be reduced proportionally to account for the uncertainty. The most common proportional rule, known as the 'market share' approach, sets the defendant's liability equal to the actual harm multiplied by the probability that the defendant caused the injury. Traditionally, the law of torts has been governed by the first approach of all-or-nothing. [...] However, beginning in the 1980's, and coming as a response to the onslaught of mass exposure or catastrophic injury torts, American courts have been more willing to apply the second approach" (Cf. SHAHAR, 2009, p. 91-92).

702 “...the 'market share' thesis may be paraphrased. Plaintiffs have been hurt by someone who made DES. Because of the lapse of time no one can prove who made it. Perhaps it was not the named defendants who made it, but they did make some. Although DES was apparently safe at the time it was used, it was subsequently proven unsafe as to some daughters of some users. Plaintiffs have suffered injury and defendants are wealthy. There should be a remedy. Strict products liability is unavailable because the element of causation is lacking. Strike that requirement and label what remains "alternative" liability, "industry-wide" liability, or "market share" liability, proving thereby that if you hit the square peg hard and often enough the round holes will really become square, although you may splinter the board in the process (UNITED STATES OF AMERICA. Supreme Court of California. Sindell v. Abbot Laboratories. 26 Cal.3d 588 (1980)607 P.2d 924163 Cal. Rptr. 132).

703 A responsabilidade é baseada na causalidade provável. A responsabilidade é proporcional não ao dano, mas ao risco causado. Essa responsabilidade se estabelece na hipótese de já existir a manifestação concreta dos danos ou na hipótese de não existir essa manifestação, mas apenas a majoração do risco (Cf. SHAHAR, op. cit, p. 96). 
Como é cediço, a regra geral, no tocante à causalidade, é a necessidade de demonstração do nexo de causalidade geral, que diz respeito ao potencial danoso do agente químico, bem como o nexo de causalidade específico, que diz respeito à distinção do caso individual em relação à incidência regular da doença e a atribuição dessa doença à exposição individual ${ }^{704}$. No caso da contaminação tóxica, a causalidade específica é inviável de ser comprovada individualmente. Essa causalidade decorre apenas do fato de o indivíduo ser membro da comunidade exposta.

Diante disso, vê-se, logo, que a justificativa para a abordagem da responsabilidade pelo risco é desestimular a prática abusiva ou lesiva, incentivando os causadores do risco a adotar parâmetros mais seguros de prevenção de acidentes, bem como permitir a compensação das vítimas, que raramente logram a reparação dos danos. Isso porque, nessas hipóteses, a incerteza quanto à etiologia da doença é severa e raramente a causa pode ser aferida individualmente.

A adoção dessa abordagem decorre, segundo Steve Gold ${ }^{705}$, da impossibilidade em se realizar análise individual da causalidade nas hipóteses de exposição ou contaminação tóxica. E, é essa impossibilidade que difere esse caso das demais hipóteses de responsabilidade por danos pessoalmente sofridos. Nesse contexto, a prova epidemiológica e estatística, bem como a referência ao grupo ou à comunidade de vítimas são essências à resolução da controvérsia.

Samuel Issacharoff ${ }^{706}$ salienta que a relação substancial que se estabelece na hipótese de responsabilidade pelo risco é de natureza plurissubjetiva ou coletiva, pois o risco é aplicável com fundamento no grupo como todo e ele é calculado de forma paritária entre os membros.

Segundo Richard Nagareda ${ }^{707}$, a responsabilidade civil de massa passa, assim, por uma reorientação, sendo-lhe conferida, cada vez, mais uma perspectiva regulatória, isto é, alcançar o desestímulo da prática abusiva ou lesiva e a compensação ótima ou proporcional das vítimas.

704 SHAHAR, 2009, p. 83.

705 GOLD, 1986, p. 380-381. No mesmo sentido: BRENNAN, 1988, p. 50.

706 “...instead of the plaintiff being an identifiable individual whose harms may be greater than immediately apparent, the probabilities attach certain number of individuals among the some future date. As should be evident from the nature of epidemiological proof, there is no difference among affected class members in terms of proof of harm. All affected individual become the basis of the same probalistic risk of harm. The key, however, is that there is no effort to provide compensation to the affected group of individuals - only to detect and forestall adverse consequences from the toxic exposure" (Cf. ISSACHAROFF, 2002, p. 119).

707 Richard Nagareda explicitou a reorientação da responsabilidade civil nos Estados Unidos, bem como enumerou as tendências em termos de responsabilidade de massa. Em seguida, por força da simetria entre direito e processo, ele enumera as transformações processuais no tocante à litigiosidade de massa (Cf. NAGAREDA, 2007, p. 4-9). 
O processo, por sua vez, tem acompanhado esse processo de reorientação do direito substancial, para também tornar um procedimento de agregação ótima - adequado e necessário ao conflito.

É bem verdade que não existem, ainda, linhas ou parâmetros seguros no tocante a essas questões, tampouco a jurisprudência estadunidense consolidou algum posicionamento.

Mesmo assim, é nesse contexto, quando surgem controvérsias relativas à contaminação química, que a agregação processual e a prova epidemiológica e estatística surgem como tendências e são animadamente discutidas como métodos de resolução dos conflitos de massa.

A técnica de agregação tem se destacado nessa seara, pois constitui o campo ideal para aferição coletiva da responsabilidade pelo risco e da própria causalidade individual. Isso ocorre porque, no tocante ao risco, a relação substancial tende a ser igualmente impessoal e paritária entre os membros do grupo. As características individuais ou pessoais não são, a priori, essenciais no caso concreto, pois o objeto de investigação são as características ou atributos do próprio grupo.

É preciso destacar, todavia, que agregação processual já passou por um boom no sistema estadunidense na década de 80 . À época, houve uma maior resistência à técnica, principalmente pela contínua exigência, pelas Cortes de Justiça, do nexo de causalidade específico e do diagnóstico individual das doenças, ainda que provada a existência do risco na comunidade..$^{708}$

Atualmente, pode-se dizer que houve um avanço nesse aspecto e a questão volta a ser discutida com maior força. Isso se deve, principalmente, à epidemiologia, que tem logrado estabelecer melhores evidências do pertencimento do indivíduo ao grupo de vítimas. ${ }^{709}$ Trata-se do desenvolvimento de pesquisas genéticas (toxicogenomics), bem como de estudos subcelulares a que foi submetido o indivíduo (T-CELL e molecular epidemiologic), membro do grupo..$^{710}$

708 STUNDTNER, Elizabeth A. Proving causation in toxic tort cases: T-cell studies and as epidemiological and particularistic evidence. Environmental Affairs, 1993, V. 20:335-370.

709 Ibidem, passim.

$710 \mathrm{O}$ estudo de T-cell e o estudo epidemiológico foram utilizados nos seguintes precedentes para estabelecer a causalidade do grupo e a inserção do indivíduo no grupo. Não se tratam de ações coletivas, mas de ações individuais consolidadas: UNITED STATES OF AMERICA. Missouri Court of Appeal. Elam v. Alcolac, Inc. 765 S.W.2d 42 (1988) e UNITED STATS OF AMERICA. United States District Court, D. Utah, C.D. Allen v. United States. 588 F.Supp. 247 (1984). 
Esses estudos permitem aferir a presença de biomarcadores genéticos, de modificações subcelulares e de alterações no sistema imune do indivíduo, em decorrência do contato com o agente químico. As alterações genéticas e subcelulares são, assim, tão-somente pegadas ou digitais da contaminação química, as quais, se associadas à prova epidemiológica realizada no tocante à comunidade das vítimas, podem ser esclarecedoras para permitir a subsunção do indivíduo no grupo ou na comunidade afetada pelo risco ilícito e uniforme criado pela ré.

Essa prova não é, todavia, conclusiva, ou seja, ela não afasta necessariamente outras possíveis concausas para uma mesma doença. Ainda não se trata, portanto, de provar o dano ou nexo de causalidade específico do indivíduo. Mas, de qualquer modo, ela facilita a inserção da posição individual no panorama global do risco, aplicável com fundamento no grupo como todo.

A prova epidemiológica já é capaz de estabelecer, por exemplo, que, em determinada comunidade, submetida a um agente químico, surgiria um risco de desenvolvimento de determinadas doenças, superior ao dobro do risco base existente em relação ao restante da população não exposta. Essa constatação já era considerada, por muitos, suficientes para aferição da responsabilidade pelo risco. Agora, seria possível também aferir a inserção do indivíduo nessa comunidade exposta ao risco, estabelecendo, assim, a responsabilidade civil.

Nesse contexto, a extrapolação estatística é o leitmotiv da responsabilidade pelo risco. É inerente ao conceito de risco a sua aferição em relação ao grupo ou comunidade como um todo e a extensão do resultado ao indivíduo, apenas na qualidade de membro do grupo. A amostragem estatística é, nesse sentido, considerada suficiente por muitas Cortes de Justiça no sistema estadunidense para provar tanto a responsabilidade coletiva quanto os danos sofridos.

Isso foi mencionado no precedente Long v. Trans World Airlines ${ }^{711}$. Nesse caso, foi ressaltada a possibilidade de reconhecimento da responsabilidade e também dos danos sob a forma coletiva, isto é, sem análise individual dos membros do grupo. O uso da amostragem estatística constitui um dos métodos de prova que poderia ser utilizado para essa finalidade no processo. O mesmo raciocínio foi aplicado, ainda, no precedente Bell v. Farmers Insurance Exchange.

711 "...thus, courts have approved various methods of discovering and determining damages in class actions on the basis of classwide, rather than individualized proof of damages, and the use of statistics and representative samples are one such legitimate method" (UNITED STATES OF AMERICA. United States District Court, N.D. Illinois, E.D. Long v. Trans World Airlines. 761 F.Supp. 1320 (1991)). 
Segundo a Corte Recursal da Califórnia, não há dispensa da prova dos danos. A amostragem estatística apenas oferece um diferente método, qual seja, o dano é inferido a partir da integração do indivíduo a uma comunidade, substituindo a necessidade de análise e prova individualizada.

No tocante às hipóteses de responsabilidade pelo risco, essa assertiva firma-se com maior força argumentativa nos dias de hoje. Isso porque, a partir de agora, com a possibilidade de o indivíduo demonstrar a presença do antígeno no seu organismo, aliada à prova epidemiológica clássica, há um reforço à tese da responsabilidade pelo risco. Facilita-se tanto a aferição do risco substancial presente na coletividade como um todo, quanto a inclusão do indivíduo no grupo ou na comunidade das vítimas a serem compensadas pela majoração do risco criado.

Por fim, a extrapolação estatística, tanto da responsabilidade coletiva, como também da compensação individual, constituem uma tendência já caracterizada no sistema jurídico estadunidense. Embora essa extrapolação estatística tenha sido, nessa ocasião, endereçada à hipótese de contaminação química, esse mecanismo também é manejado em casos envolvendo práticas discriminatórias, danos econômicos, fraude consumerista e outras hipóteses. ${ }^{712}$

Nesse aspecto, a questão é muito similar às demais class actions for damages do tipo upstream. Trata-se da possibilidade de estabelecer uma compensação objetiva pelos riscos causados, segundo determinados parâmetros ou critérios padronizados em relação ao grupo como um todo. Esses parâmetros podem ser os tipos de danos suscetíveis em razão de eventual manifestação concreta dos riscos, a intensidade e a variedade de doenças ou lesões possíveis.

David Rosenberg ${ }^{713}$ foi um dos autores que sustentou essa linha de raciocínio na década de 80 e até hoje é comentado no tocante à tese da responsabilidade pelo risco e sua relação com as ações coletivas. Esse autor sustentou, ainda, o damage schedule, a indenização pelos riscos causados aferida por uma fórmula padrão que considera o tipo de lesão possível, a sua gravidade e, até mesmo, manifestações concretas da doença ocorridas até aquele momento no caso. ${ }^{714}$

712 ANTONICCI, Peter A. Statistical sampling as a basis for extrapolating liability and/or damages. In: GREER, Marcy Hogan (org.). A practitioner's guide to class action. Chicago: ABA Publishing, 2010, p. 496.

713 ROSENBERG, 1996, p. 223. No mesmo sentido, ABRAHAM, ROBINSON, 1992, p. 1493.

714 É preciso destacar que a responsabilidade pelo risco não afasta a responsabilidade pelos danos, pois são demandas com causas de pedir diferentes e com fundamentos legais diferentes. $\mathrm{O}$ indivíduo, se possuir uma história pessoal e elementos de convicção que permitam concluir pelo nexo de causalidade específico, poderá deduzir em juízo uma demanda individual, pleiteando a responsabilidade pelos danos causados. Nessa hipótese, no entanto, por tratar-se de uma história pessoal e particularizada, é obrigatória e inafastável a prova do nexo de causalidade específico. O nexo de causalidade específico nada mais é do que subjetivação da responsabilidade. De 
O campo de maior desenvolvimento, até agora, das técnicas de agregação referenciadas tem sido as hipótese de contaminação ambiental. Nas hipóteses de acidentes ambientais, em que há o despejo de dejetos tóxicos e a degradação do meio ambiente natural, alcança-se, reflexamente, a saúde de indivíduos presentes em determinada área geográfica e em dado período de tempo. ${ }^{715}$

O mesmo raciocínio, traçado nas linhas anteriores, não tem sido aplicado pela jurisprudência americana nas hipóteses de vício do produto, principalmente em razão da variação no período de tempo, na localidade e na gravidade, que requerem, em regra, análise individualizada. ${ }^{716}$

Para finalizar, uma outra consideração deve ser feita no tocante à exposição de risco. Quando não há qualquer manifestação concreta dos riscos, mas mera latência de lesão, as Cortes de Justiça tem deparado com pretensões de apenas monitoramento médico (medical monitoring).

Monitoramento médico, segundo Greer e Fischer ${ }^{717}$, consiste em instituir um programa que oferta exames e serviços médicos para detectar eventuais doenças, ainda latentes, decorrentes da exposição a substâncias de risco, bem como para minimizar o surgimento dessas no futuro.

\footnotetext{
igual modo, o réu poderá afastar a caracterização desse nexo, demonstrando a existência de concausas suficientes para a manifestação isolada dos danos individuais alegados. Nessa hipótese, caso o indivíduo já tenha recebido, por exemplo, a indenização pelos riscos (independentemente dos danos terem sido causados ou não pela atividade do réu, é possível que o réu, com sua atividade, tenha majorado, substancialmente, os riscos de uma doença e, por isso, foi condenado a indenizar), esse valor deverá ser abatido do montante indenizatório eventualmente fixado a título de indenização por danos pessoais na ação individual. Isso porque a indenização pelos riscos é uma indenização média (um valor fundamental para fazer frente à majoração do risco), que foi fixada sem análise da das particularidades do caso. É um minus em relação aos danos sofridos. Assim, se mesmo diante das dificuldades antes mencionadas, o indivíduo lograr provar os danos pessoalmente sofridos, o minus (que é a indenização pelo risco) deve ser deduzido do montante indenizatório final fixados para os danos pessoais sofridos, para que não haja excessos. Guardadas as devidas proporções, isso é o que ocorre no Brasil, por exemplo, com o seguro DPVAT, que é um mínimo fundamental para casos de acidentes de trânsito, que deve ser posteriormente deduzido em caso de procedência de uma demanda com pretensão indenizatória. (Sobre a subjetivação dos danos, conferir ABRAHAM, ROBINSON, 1992, p. 1485, Sobre a preclusão ISSACHAROFF, 2002, p. 124 e, ainda, UNITED STATES OF AMERICA. District Court for the southern District of Illinois. Leib et al v. Rex Energy Operating Corp. No. 06-cv-802-JPG-CJP "A judgment on that claim would not prevent a class member from later bringing a personal injury lawsuit seeking damages, although the class member may be bound by issues actually determined in the class action and may be unable to recover for services received from the medical monitoring fund").

715 Nesse sentido, Jack B. Weinstein identifica os tipos de desastres ou acidentes de massa, suscetíveis de agregação (Cf. WEINSTEIN, Jack B. Individual justice in mass tort litigation. Illinois: Northwestern University Press, 1995, p. 16-19).

716 MARK, Richard W., STRAUCH WEISS. Exposure torts. In: GREER, Marcy Hogan (org). A practitioner's guide to class action. Chicago: ABA Publishing, 2010, p. 429.

717 GREER, Marcy Hogan, FISCHER, Madeleine. Medical monitoring classes. In: GREER, Marcy Hogan (org.). A practitioner's guide to class action. Chicago: ABA Publishing, 2010, p. 377.
} 
No precedente Friends for all children, Inc v. Lockheed Aircraft Corporation ${ }^{718}$, esclarece-se, com simplicidade, a pretensão por monitoramento médico e sua receptividade no sistema. $\mathrm{O}$ caso diz respeito a um acidente aéreo em que houve a descompressão da aeronave, com falta de oxigênio. Entre os passageiros, estavam crianças órfãs vietnamitas que estavam sendo conduzidas para adoção nos Estados Unidos em uma operação denominada "Operation Babylift". Depois do resgate de 149 crianças, foi ajuizada uma ação coletiva, pleiteando o monitoramento médico em razão do risco de possíveis danos neurológicos no desenvolvimento dos menores, devido à falta de oxigenação num dado período de tempo. A questão controvertida era saber se a legislação civil admitia essa espécie de responsabilidade, sem a prova dos danos.

O Circuito do Distrito de Columbia ${ }^{719}$, para explicitar a pretensão mandamental formulada na ocasião, exemplificou a questão como se fosse um caso individual, para depois enquadrá-la na relação substancial coletiva examinada, que é mais complexa. Citou a hipótese de um pedestre de nome Jones que é atropelado por uma motocicleta, quando essa ultrapassa o semáforo vermelho. Jones bate a cabeça no acidente. Muito abalado, o pedestre é conduzido ao Hospital, quando os médicos realizam uma bateria de exames, diagnosticando, ao final, a inexistência de danos físicos. Por esse exemplo, diz a Corte, pode-se concluir, sem dúvida, pela responsabilidade do motorista pela negligência na condução do veículo, devendo aquele responder pelos custos dos exames médicos, ainda que o evento não tenha culminado em danos.

O mesmo raciocínio deve ser aplicado nas hipóteses de demandas plurissubjetivas, permitindo a reparação ou a tutela específica da obrigação, com a concessão do próprio tratamento médico.

Esse entendimento não é, todavia, pacífico. Muitas Cortes de Justiça rejeitam a responsabilidade nessa hipótese em razão da ausência de sintomas físicos. Outras Cortes de Justiça aceitam a tese da responsabilidade pelo monitoramento médico, independentemente da pretensão (se injuntiva ou condenatória ao ressarcimento pecuniário das despesas realizadas).

718 UNITED STATES OF AMERICA. Court of Appeals, District of Columbia Circuit. Friends for all children, Inc v. Lockheed Aircraft Corporation. 725 F.2d 1392 (1984).

719 "...to aid our analysis of whether tort law should encompass a cause of action for diagnostic examinations without proof of actual injury, it is useful to step back from the complex, multi-party setting of the present case and hypothesize a simple, everyday accident involving two individuals, whom we shall identify simply as Smith and Jones: Jones is knocked down by a motorbike which Smith is riding through a red light. Jones lands on his head with some force. Understandably shaken, Jones enters a hospital where doctors recommend that he undergo a battery of tests to determine whether he has suffered any internal head injuries. The tests prove negative, but Jones sues Smith solely for what turns out to be the substantial cost of the diagnostic examinations. From our example, it is clear that even in the absence of physical injury Jones ought to be able to recover the cost for the various diagnostic examinations proximately caused by Smith's negligent action" (Cf. Ibidem). 
Enquanto outras Cortes admitem a responsabilidade, mas desde que a pretensão do autor seja mandamental, constituindo um programa uniforme e único de monitoramento médico. ${ }^{720}$

Em razão dessas divergências, a certificação da ação de classe por monitoramento médico requer atenção. Nesses casos, no entanto, é preciso avaliar a intensidade e a variação das situações individuais. Essa dúvida tem sido superada, no maior parte das vezes, quando a pretensão é exclusivamente mandamental e a ação de classe é certificada na categoria 23(b)(2). Esse tem sido, novamente segundo Greer e Fischer ${ }^{721}$, a maioria dos casos em que ações coletivas de monitoramento médico tem sido certificadas no sistema jurídico estadunidense.

Na hipótese de existir também pretensão indenizatória, as Cortes de Justiça tem utilizado os testes antes já mencionados em Allison, Robinson e Duke, ou seja, tem aferido se a compensação individual será meramente econômica ou incidental ou se ela será predominante e, nesse último caso, deverá a demanda ser certificada na categoria das class action for damages $23(\mathrm{~b})(3) .{ }^{722}$

Nesse ponto, recorda-se das dificuldades inerentes à certificação das ações de classe do tipo upstream e ao regime processual de agregação aplicável a essas hipóteses. É preciso abordar, em seguida, quais as razões justificam essas distinções de regime processual, bem como as tendências da técnica de agregação, atualmente vigentes, no sistema jurídico estadunidense.

\subsubsection{REGIME PROCESSUAL}

Nota-se que as relações substanciais, até agora mencionadas, apresentam diferentes graus de entrelaçamento ou vinculação entre os membros do grupo. Esses diferentes graus de

720 GREER, FISCHER, 2010, p.380-381.

721 "...plaintiffs have had most consistent success in obtaining class certification when they seek a Courtadministered fund and the fund is categorized as injunctive relief" (Cf. Ibidem, p. 391).

722 Nesse caso, deve ser ponderado o seguinte: ainda que o pedido seja indenizatório, por exemplo, o indivíduo pretende obter um valor indenizatório para custear o tratamento com o médico de sua preferência, o tratamento entre os membros do grupo deveria ser paritário e impessoal. Do contrário, um indivíduo buscará o tratamento médico no Hospital Sírio Libanês e outro indivíduo se submeterá a simples exames laboratoriais no laboratório de uma esquina qualquer de São Paulo. Enfim, mesmo nessa hipótese, é preciso uma padronização de valores, pois o risco a que todos foram submetidos é o mesmo. Excepciona-se esse raciocínio, apenas, se houver uma hipótese pessoal ou particularizada, que mereça tratamento individualizado. Exemplo, o indivíduo tem uma doença rara e o risco à saúde a que foi submetido agrava potencialmente o quadro médico daquela doença (circunstância pessoal) e requer, por isso, um acompanhamento médico diferenciado. Nesse caso, a controvérsia é artesanal e poderia ser pretendida em uma demanda individual ou, ainda, em uma subclasse na ação coletiva, se houver outros em situação similar. 
impessoalidade, indivisibilidade ou paridade se manifestam, por sua vez, no tratamento coletivo ou no regime processual de agregação, conforme cada uma das situações da vida apresentadas.

Essa distinção do regime processual se atém a três aspectos fundamentais: (i) vinculação obrigatória dos membros ausentes do grupo ou, noutros termos, coisa julgada; (ii) dever de notificação dos membros ausentes; e (iii) direito de autoexclusão dos membros ausentes.

\subsubsection{FEDERAL RULE 23}

Para rememorar, segundo a Federal Rule 23, o autor coletivo (ideological plaintiff) deve preencher os requisitos de admissibilidade previstos no dispositivo 23(a), a saber, a numerosidade, a impraticabilidade do litisconsórcio, a inviabilidade de múltiplas ações individuais similares, a representatividade adequada, a tipicidade das pretensões e das defesas e, por fim, a comunhão de direitos ou interesses (questões comuns de fato e/ou direito).

A autorização para o processamento coletivo da demanda não se limita, todavia, ao preenchimento dos requisitos de admissibilidade supracitados. O grupo deve, ainda, ser inserido em alguma das categorias de ação de classe antes mencionadas, a saber, as categorias relativas aos padrões incompatíveis de conduta imputados ao réu $(23(b)(1)(A))$, ao prejuízo imputado aos demais membros da classe ou ao fundo limitado (23 (b)(1)(B)), à conduta uniforme e abusiva do réu com fundamento, aplicável ao grupo como um todo (23(b)(2)) e, por fim, às questões comuns predominantes de fato e/ou direito e a superioridade ação de classe (23(b)(3)).

Essa categorização, como já visto, tem a sua especial relevância no sistema jurídico estadunidense. Isso porque é com fundamento nela que se distinguem dois regimes jurídicos de agregação processual. Um tratamento processual é dado às hipóteses 23(b)(1)(A), 23(b)(1)(B) e 23(b)(2) e, a seu turno, outro tratamento processual é conferido à última hipótese 23(b)(3).

As categorias do tipo (b)(1) e b(2) são consideradas mandatory class action, isto é, a vinculação ao julgado coletivo é obrigatória aos membros ausentes do grupo e não há direito de autoexclusão e de notificação obrigatória e/ou individualizada dos seus integrantes. A 
autoexclusão (opt out $)^{723}$ e a notificação (notice) ${ }^{724}$ podem ser autorizadas, excepcionalmente, pelo magistrado, quando for necessário ao gerenciamento e ao processamento coletivo.

Excepcionalmente, no curso do gerenciamento do processo coletivo nas categorias (b)(1) ou (b)(2), podem surgir situações particularizadas que não se coadunam com o tratamento aplicável à classe como um todo. Essa situação, ao demandar análise particularizada, não seria, de qualquer forma, alcançada pela eficácia vinculante do julgado coletivo, pois refere-se à causa de pedir distinta, individualizada ou pessoal. Mas, para que não sobrevenha maior incerteza quanto à inclusão ou não desse indivíduo no grupo, autoriza-se o magistrado a expressamente excluir esse indivíduo da definição ou identificação abstrata dada ao grupo como um todo. ${ }^{725}$

Enquanto isso, a categoria (b)(3) é considerada non-mandatory class action, isto é, a vinculação ao julgado coletivo não é imperativa aos membros ausentes do grupo. A vinculação se perfaz caso o indivíduo permaneça inerte e não requeira a sua exclusão da classe. Trata-se de uma espécie de consentimento implícito ao prosseguimento da ação processada pelo autor coletivo.

Nessa categoria, surge o direito à autoexclusão (opt out), bem como à notificação obrigatória (notice) $)^{726}$ dos membros ausentes do grupo. Excepcionalmente, todavia, como já se viu, nas demandas de compensação incidental ou objetiva, a exclusão dos membros ausentes da classe não têm sido admitidas, pois a demanda pode ser certificada na categoria 23(b)(2). De igual modo, nesses casos, a notificação adotada não tem sido individualizada, sendo direcionada a uma amostra do grupo ou por meios coletivos, como jornais, revistas, faturas telefônicas etc.

723 Rule 23(b)(1) e Rule 23(b)(2) não autorizam a exclusão dos membros ausentes. Mas, o magistrado no exercício dos seus poderes de gestão do processo, previstos na Rule 23(d)(5), pode autorizar a exclusão. Essa autorização é concedida, principalmente, se houver um pedido individualizado cumulado (principalmente ressarcimento em pecúnia) ou grave antagonismo entre os membros da classe (Cf. KLONOFF, 2007, p. 172-173).

724 Nas categorias 23(b)(1) e 23(b)(2) é possível a notificação dos membros ausentes do grupo, a critério do magistrado. O método de notificação será aquele considerado apropriado para as circunstâncias do caso. Trata-se de um padrão mais flexível. A notificação, nesse aspecto, não tem por escopo oportunizar a exclusão da classe, mas, sim, ampliar o monitoramento sobre a condução da ação (Cf. HERR, 2012, p.460).

725 A exclusão pode ser admitida para afastar um antagonismo grave oposto por um indivíduo. Como a divergência é relativa à apenas um indivíduo e não há numerosidade para formar uma subclasse na ação coletiva, é possível admitir a sua exclusão, afastando esse antagonismo prejudicial ao desenvolvimento da ação de classe (Cf. UNITED STATES OF AMERICA. Fifth Circuit. Penson v. Terminal Transport Co. 643 F.2d 989 (1981)).

726 A notificação na categoria 23(b)(3) é mais controversa. O modo e a extensão da notificação variam muito na jurisprudência estadunidense. No entanto, a notificação individual é considerada preferível, pois deve ser alcançada a melhor notificação possível. Mas, há uma verdadeira campanha doutrinária por uma abordagem mais eficiente ou mais restrita da notificação nessa categoria, a partir das peculiaridades da relação substancial (HERR, 2012, p. 464). 
Enfim, o regime processual de agregação é diferenciado entre dois grupos, mandatory e nonmandatory de acordo com a categoria das ações de classe. Mas, por vezes, essas categorias se imiscuem. Por isso, ora, permite-se, excepcionalmente, a exclusão e a notificação nas categorias b(1) e b(2), ora não mais se admite a exclusão e a notificação individualizada à categoria b(3).

Vê-se logo, portanto, quão importante é a identificação da categoria da ação coletiva e do regime jurídico a ela aplicável. Mas, acima de tudo, revela-se importante entender qual é o critério pelo qual é realizada aquela categorização e por qual razão os regimes processuais foram definidos em regra, segundo a forma mandatory e non-mandatory class action.

Os insights para essa conclusão já foram adiantados, mas é bom repetir: embora a categorização da Rule 23 seja prática, são os critérios extraídos do direito substancial que permitem a identificação daquelas categorias e o seu regime processual. Isso foi denominado no presente capítulo de critérios substancias de agregação processual. São esses critérios que definem os casos candidatos à técnica de agregação e, ainda, definem o regime processual a eles aplicável.

Em função desses critérios substanciais de agregação, é possível perceber, cada vez, mais uma tendência pela redução das diferenças entre os regimes processuais. O contraditório coletivo é ampliado nas categorias (b)(1) e (b)(2) ${ }^{727}$ e a participação individual, quando abusiva, repetitiva, impessoal, meramente estratégica, é vedada na categoria $b(3)^{728}$, conforme os exemplos dados.

\subsubsection{O QUE AGREGAR? COMO?}

727 Pela notificação coletiva, pelo monitoramento da ação coletiva, pela participação de um amicus curiae: em todas essas hipóteses há uma ampliação do contraditório coletivo (Cf. KLONOFF, 2007, p. 407).

728 São várias limitações: ou exige-se uma justa causa para fins de exclusão da classe, ou proíbe-se o ajuizamento de uma ação individual idêntica nos aspectos objetivos à ação coletiva, ou admite-se a ação individual, mas vedase o aproveitamento pelo autor individual da sentença favorável conferida na ação coletiva. Nesse último sentido, no precedente Premier Electrical Construction Co. v. National Electrical Contractors Association, foi anunciada uma regra imperativa contra o uso do offensive collateral estoppel pelos indivíduos que se excluíram da ação de classe. Com isso, pretende-se evitar que os indivíduos que se excluíram aleguem, posteriormente, a incidência favorável da preclusão sobre a questão comum, de fato ou de direito, que foi julgada na ação coletiva. A técnica mencionada trata-se do issue preclusion, a saber, um método de estabilização das questões decididas em um processo em relação a um segundo processo, evitando a rediscussão dessa questão. Offensive, por sua vez, significa que a preclusão é oposta por um terceiro (autor de uma nova demanda individual) em face do réu da ação coletiva, que sucumbiu em um processo anterior (Cf. UNITED STATES OF AMERICA. Premier Electrical Construction Co. v. National Electrical. Contractors Association, 814 F.2d 358 (7th Cir. 1987)). 
Como bem explicita Richard Nagareda ${ }^{729}$, o que permite a agregação e define o regime jurídico aplicável é o direito substancial preexistente (preexistente principle), isto é, as relações de interdependência ou comunhão preexistentes no grupo em relação ao direito substancial.

A agregação, segundo Nagareda ${ }^{730}$, não se presta a ampliar a posição de vantagem das partes, tampouco a alcançar a conveniência do sistema processual. Visa, sim, a estruturar a controvérsia em consonância à natureza do direito substancial. Em algumas hipóteses, a situação da vida controvertida já revela a existência de uma ação coletiva de fato. Nesses casos, o que o processo faz é apenas incorporar a classe em juízo, visando à adjudicação unitária da controvérsia.

É bom lembrar, apenas, que quando se diz direito preexistente, isso não se quer dizer texto expresso. A norma - e passe o truísmo - de direito substancial não se resume ao texto normativo em abstrato, mas corresponde à construção de significado do dever-se. A norma é o significado construído a partir da interpretação e da argumentação de um ou vários textos ou comandos normativos, a depender da complexidade do caso concreto. O legislador não prevê, necessariamente, um tex to normativo para cada caso concreto, até porque isso não seria factível.

Com isso, duas situações se apresentam: ou a indivisibilidade (paridade) e a impessoalidade presentes em uma relação substancial são práticas (insuscetíveis de divisão) ou são elas determinadas por um texto normativo específico (a própria norma instaura uma ordem paritária e normativamente incindível). Nesses dois casos, não há dúvida quanto à unitariedade e uniformidade da situação jurídica. Noutros casos, porém, não há nenhum texto normativo específico, determinando a paridade na ordem substancial. Mas nem por isso é possível afastar, de plano, a indivisibilidade e a impessoalidade da controvérsia. Essas características podem decorrer, sim, dos contornos da relação substancial deduzida, suscetível, assim, de agregação.

A importância do direito substancial e dos critérios supracitados são, por sua vez, destacados pelo Projeto do American Law Institute, endereçado aos princípios da Litigância Agregada. ${ }^{731}$

729 NAGAREDA, 2003, p. 181 et seq. 
Destaca-se que, em 2010, o American Law Institute - $A L I^{332}$ publicou os princípios da litigância agregada. Os juristas relatores do projeto, responsáveis pelo desenvolvimento dos princípios, fundamentos e regras de agregação processual, foram Samuel Issacharoff (relator principal), Robert H. Klonoff, Richard A. Nagareda e Charles Silver (relatores associados). De igual modo, funcionaram como conselheiros os seguintes juristas e profissionais do direito: Edward F. Cooper, Kenneth R. Feinberg, Geoffrey C. Hazard Jr, Deborah R. Hensler, Mary Kay Kane, Arthur R. Miller, Judith Resnik, Jack B. Weinstein, Howard M. Erichson, Diane P. Wood, William B. Rubinstein, Elisabeth J. Cabraser, Geoffrey P. Miller e muitos outros juristas.

A obra é, de todo, respeitável por consolidar a temática da agregação, que já estava presente de forma esparsa na manualística, bem como em precedentes dispersos do sistema jurídico estadunidense. Mas, além de consolidar, a obra inova, introduzindo ou aperfeiçoando as técnicas processuais de agregação e auxiliando os profissionais no gerenciamento e processamento de causas complexas, relacionadas às demandas coletivas ou plurissubjetivas.

No tocante ao tema, o projeto ALI (ALI's project), como ficou conhecido, ressalta a importância do direito substancial para a definição do objeto da agregação. Essa abordagem não é exclusiva do projeto. Outros doutrinadores já estabeleceram a relação direito e processo no sistema jurídico estadunidense, inclusive no processo coletivo, muito antes desse projeto de agregação.

Mas, o que é interessante notar é que o projeto reuniu, sob a forma de regras, quais são as hipóteses materiais de agregação, segundo critérios, que denominamos, no decorrer desta investigação, de critérios substanciais de agregação - impessoalidade e indivisibilidade ou paridade. Não há nenhuma surpresa aqui, pois esses critérios já foram enfrentados no decorrer deste texto. Mas, é válido conferir, nesse momento, a apresentação dessas regras de agregação.

Antes de adentrar nesse aspecto, é preciso ressaltar que não houve uma sistematização dessas regras no projeto. Elas encontram-se esparsas na obra. Uma proposta de sistematização dos direitos de alcance coletivo e dos direitos individuais de massa, sob o ponto de vista teórico, já foi realizado em capítulo anterior desta investigação. Naquela ocasião, reuniram-se informações tanto do sistema jurídico estadunidense como um todo, quanto do sistema jurídico brasileiro, apresentando-se as teorias e a escalada de coletivização a partir do direito 
substancial. Neste tópico, apresentam-se, a seu turno, apenas as regras na forma como estabelecida pelo projeto ALI.

O que agregar, segundo o ALI's Project?

O primeiro passo é identificar o objeto material ou o escopo do tratamento agregado. Isso consta na regra $\$ 2.02(\mathrm{e})^{733}$. Para tanto, a Corte de Justiça deverá identificar as questões substantivas, objeto do tratamento agregado, e explicitar de que forma esse tratamento avançará a resolução da controvérsia como todo. Identificadas essas questões, a Corte poderá autorizar a agregação.

A autorização para agregação é dada considerando as seguintes categorias ou critérios substanciais: em primeiro lugar, são candidatos à agregação os direitos de caráter indivisível (para efeito prático) ou paritário (por força normativa), aplicável com fundamento no grupo como um todo (impessoal). Se o bem for divisível, a agregação é possível nas situações de upstream e downstream. Nesse último caso, o requisito predominante é a impessoalidade e o "sameness" 734 (igualdade), que permite avançar a resolução da controvérsia comum entre os membros do grupo, no tocante à responsabilidade e/ou à reparação individual dos danos.

A regra $\$ 2.04^{735}$ diferencia, por sua vez, as hipóteses de compensação divisível e indivisível. Compensação divisível é aquela que enseja a distribuição da reparação a um ou mais reclamantes individuais, sem obstar ou prejudicar a mesma reparação para outros reclamantes. Compensação indivisível é aquela em que a distribuição da reparação para um reclamante obsta, para efeito prático, a concessão ou a disponibilidade do mesmo bem para outros reclamantes.

733 “...the court should (1) identify the issue encompassed by aggregate treatment and (2) explain how aggregation will resolve fairly and efficiently the common issue identified and materially advance the resolution of any remaining issues or claims" (Cf. AMERICAN LAW INSTITUTE, 2010, p. 83).

734 TIDMARSH, BETSON, 2011, p. 275.

735 “...indivisible remedies versus divisible remedies (a) divisible remedies are those that entail the distribution of relief to one or more claimants individually, without determining in practical effect the application or availability of the same remedy to any other claimant, (b) indivisible remedies are those such that the distribution of relief to any claimant as a practical matter determines the application or availability of the same remedy to other claimants, (c) the court may authorize aggregate treatment of common issues concerning an indivisible remedy by way of class action, with no requirement under $\$ 2.07$ that the claimants must be afforded an opportunity to exclude themselves from such treatment. Aggregate treatment as to an indivisible remedy may be appropriate even though additional divisible remedies are also available that warrant individual treatment or aggregate treatment with the opportunity of claimants to exclude themselves as to divisible remedies, as specified in $\$ 2.07$ " (Cf. AMERICAN LAW INSTITUTE, 2010, p. 116). 


A agregacão é possível tanto nas hipóteses de divisibilidade, quanto nas hipóteses de
indivisibilidade. A diferenca reside apenas no tratamento ou no regime processual que
será abordado mais adiante. É importante ressaltar que a agregacão é questão distinta
do regime processual. É passível de agregacão não apenas aquelas relações substanciais
indivisíveis, mas também as divisíveis. O que varia é, frise-se, o regime processual.

Se a relação substancial for divisível, é preciso atentar para um segundo conceito. Trata-se da diferença entre upstream e downstream. Segundo a regra $\$ 2.03^{736}$ a Corte de Justiça pode autorizar o tratamento agregado apenas da questão comum da responsabilidade do grupo, mas, desde que o direito substancial separe a questão da reponsabilidade das questões individuais remanescentes, atinentes à escolha e à distribuição da compensação individual (downstream ou à jusante do grupo). A Corte de Justiça pode, ainda, autorizar o tratamento agregado tanto da questão comum de responsabilidade do grupo quanto da questão da compensação individual pretendida. Isso ocorre quando a resolução da responsabilidade implicar também a resolução, o método de escolha e a distribuição da compensação individual. A distribuição da compensação individual, no último caso, segue um padrão ou fórmula matemática, de aplicação mecânica, administrativa ou ministerial ao caso individual (upstream ou à montante do grupo).

As múltiplas demandas individuais, por acaso existentes, também são suscetíveis de agregação, segundo os mesmos critérios antes mencionados. Conforme a regra $\$ 2.07^{737}$, para a agregação de demandas individuais, são necessárias, mormente, a ausência de conflito de interesses entre os membros da classe e a possibilidade de autoexclusão e notificação. O direito de autoexclusão pode ser minimizado em algumas hipóteses, o que será mencionado a partir do tópico seguinte.

736 "...the court (a) may authorize aggregate treatment of a common issue concerning liability by way of class action when substantive law separates that issue from the choice and distribution of appropriate remedies and from other issues concerning liability; and (b) may authorize aggregate treatment of both common issues of liability and individual issues of remedy by way of a class action when resolution of the liability issues in claimants' favor will, in practical effect, determine both the choice of remedy and the method for its distribution on a individual basis" (Cf. AMERICAN LAW INSTITUTE, 2010, p. 104).

737 “[...] Individual rights in aggregation of related claims (a) as necessary conditions to the aggregate treatment of related claims by way of a class action, the court shall (1) determine that there are no conflicts of interest (A) between the named parties and other claimants and the lawyer who would represent claimants on an aggregate basis, which may include deficiencies specific to the lawyers seeking aggregate treatment or (B) among the claimants themselves that would present a significant risk that the lawyers for claimants might skew systematically the conduct of the litigation so as to favor some claimants over their respective claims or to disfavor claimants generally vis-à-vis the lawyers themselves. (2) provide claimants the opportunity to avoid preclusive effect of any determination made on an aggregate basis, absent the exception recognized in subsection (c); and (3) provide claimants appropriate notice of the opportunity to participate in the aggregate proceeding and, if applicable, to avoid its preclusive effect under subsection (a)(2) [...]" (Cf. AMERICAN LAW INSTITUTE, 2010, p. 147). 
Enfim, quão maior a impessoalidade e a incindibilidade ou a paridade presentes no direito substancial deduzido em juízo, maior a oportunidade conferida para a agregação processual. Demandas individuais cognatas, derivadas de um mesmo direito, são assim boas candidatas.

Por fim, uma consideração se faz ainda necessária. Como já abordado em capítulo anterior, nesses casos mais complexos, em que não há texto normativo específico aplicável, surge uma maior incerteza quanto à relação substancial existente entre os membros do grupo. Pode não restar facilmente caracterizada, a priori, uma controvérsia do tipo upstream ou dowstream.

Isso não obsta, no entanto, o processamento agregado dessa relação substancial mediante uma ação coletiva ou por qualquer outra técnica de agregação. A agregação processual é viável, conforme a situação de direito substancial afirmada na petição inicial. Se, posteriormente, restar provada a inexistência da indivisibilidade (paridade) e da impessoalidade na relação substancial afirmada na inicial, ação de classe deverá ser julgada, portanto, improcedente no mérito.

Diante dessa incerteza, não se nega a possibilidade do surgimento de demandas temerárias, com fins especulativos (fishing expedition ${ }^{738}$ ), de forma a estabelecer um estado de ameaça ou de barganha entre as partes. Para obstar isso, outras técnicas processuais relativas à forma dos atos postulatórios são adotadas, como, por exemplo, a exigência de um plano de julgamento (trial $\operatorname{plan}^{739}$ ) sob o encargo do autor coletivo, para aferir a viabilidade inicial da demanda coletiva.

O autor coletivo, ao afirmar na petição inicial a comunhão de interesses ou a impessoalidade, deve fundamentá-la em fatos concretos, bem como deve indicar as evidências, que se provadas, confirmarão as assertivas realizadas na inicial. Com base nesses elementos, inicialmente afirmados, o magistrado poderá avaliar a viabilidade da demanda, a categoria da ação de classe a ser certificada, bem como o mecanismo processual de agregação apropriado e eventualmente

738 Fishing expedition significa autorizar a incursão probatória sem nenhuma alegação concreta, apenas uma suspeita contra a parte contrária, caracterizando abuso instrutório. A incursão deve ser proporcional aos fatos narrados, sem excessos (Cf. SUBRIN, Stephen N. Fishing expeditions allowed: the historical background of the 1938 Federal Discovery Rules. Boston College Law Review, 1998, V. 39:691-745, p. 691).

739 O trial plan (plano de julgamento) assiste o magistrado em determinar se as questões comuns são suscetíveis de tratamento agregado, bem como a extensão e a natureza do regime de agregação. Nas palavras de David Herr: "plans should address whether to try cases on a traditional case-by-case basis, on a test case basis, in a bifurcated or multifurcated organization of issue, in a consolidation or class format, or on some other basis [...] the parties should point to evidence that will prove the elements of the claims and defenses in issue. Such information enables the judge to test whether common issues support some form of aggregation and whether to limit aggregation to particular issues" (Cf. HERR, 2012, p. 609). 
superior aos demais disponíveis, podendo ser tanto a ação coletiva, como um caso-teste, a consolidação de demandas individuais, a coordenação informal de demandas ou outros.

O projeto ALI afirma, na regra $\S 2.06^{740}$, que se surgir uma controvérsia de fato ou de direito no tocante ao preenchimento dos pré-requisitos da Federal Rule 23, essa questão controvertida atinente à própria viabilidade de agregação deverá ser decidida antes da certificação da ação de classe. Esse raciocínio se aplica mesmo que a questão preliminar a respeito da viabilidade da agregação coincida com o juízo de mérito. Se a controvérsia for uma questão de fato, a Corte de Justiça deve aplicar o postulado da preponderância da evidência (preponderance of-theevidence) para decidir a questão. É possível instrução para aferição da viabilidade da agregação.

Essa questão é, todavia, muito controvertida nos Estados Unidos. Embora o projeto ALI adote esse entendimento, alguns juristas se opõem à instrução da controvérsia para fins de certificação da ação de classe, outros propõem uma investigação superficial do mérito para essa finalidade e, ainda, existem aqueles que propõe a demonstração da probabilidade de sucesso para fins de certificação. ${ }^{741}$ É preciso destacar, no entanto, que se o mérito for investigado com profundidade, apenas, para se aferir a viabilidade da agregação processual, pode se chegar a um resultado absurdo, qual seja, reunir elementos de prova suficientes que permitam concluir pela improcedência da demanda para, ao final, simplesmente não certificá-la como coletiva ${ }^{742}$

740 “[...] Legal or factual questions relevant to class-action treatment (a) if the suitability of multiple civil claims for class action treatment depends upon the resolution of an underlying question concerning the content of applicable substantive law or the factual situation presented, then the Court must decide that question as part of its determination whether to certify class action. The obligation recognized in this subsection provides no authorization for the court in the posture of a class-certification ruling to decide a question of law or fact or a mixed question of law and fact if determination of that question is not relevant to the suitability of class action treatment; (b) when deciding a question of fact pursuant to subsection (a), the court should apply a preponderance-of-theevidence standard. The court's decision on a question of fact for purposes of a class-certification ruling, however, should not be binding in subsequent proceedings in the litigation" (Cf. AMERICAN LAW INSTITUTE, 2010, p. 139).

741 Geoffrey P. Miller propõe uma investigação superficial para aferição da viabilidade da demanda coletiva e Robert G. Bone e David Evans propõem, por outro lado, uma investigação mais ampla que possa apurar a possibilidade de sucesso na demanda coletiva (likelihood of sucess) (Cf. MILLER, Geoffrey P. Review of the merits in class certification. Hofstra Law Review, 2004, V. 33:51-87p e BONE, Robert G.; EVANS, David. Class Certification and Substantive Merits. Duke Law Journal, 2002, V. 51:1251-1332p.).

742 A crítica é embasada na opinião de Elizabeth Cabraser, uma das juristas que compõe o Advisory Committee of Civil Procedure. Essa opinião foi proferida por ocasião de um encontro desse conselho para estudar novas proposições normativas. De fato, se admitida uma incursão profunda no mérito, não é difícil imaginar a chegada de um tempo em que somente ações coletivas procedentes serão certificadas no sistema jurídico estadunidense (Cf. UNITED STATES OF AMERICA. Draft Minutes. Civil Rules of Advisory Committee. March, 22-23, 2012). 
É preciso destacar que, no precedente Behrend v. Comcast Corp ${ }^{743}$, o Terceiro Circuito da Justiça Federal certificou ação coletiva, sem incursionar profundamente no mérito. Nessa medida, buscou distinguir a incursão preliminar de mérito para fins de certificação da ação de classe e a incursão exauriente de mérito para fins de julgamento. Assim, para fins de certificação, o autor coletivo deveria demonstrar apenas que (i) ele possuía condições de provar a tese jurídica alegada, (ii) os danos resultantes do evento lesivo são hábeis à mensuração na ação coletiva e (iii) isso não implicaria labiríntico cálculo dos danos individuais ${ }^{744}$.

A Suprema Corte Estadunidense, de forma bastante criticada, tem se apresentado restritiva à certificação da ação de classe nesses termos. Essa Corte, superando o entendimento firmado em Eisen, vem exigindo uma rigorosa análise de mérito para fins de certificação da ação de classe, o que inclui, até mesmo, a prova quanto à metodologia de distribuição da compensação individual pretendida pelos membros do grupo ${ }^{745}$. Enfim, a matéria é ainda muito controvertida e recente nas Cortes de Justiça, não sendo possível extrair nenhuma conclusão consolidada.

Por fim, como agregar, segundo o ALI's Project?

O principal instrumento é, sem dúvida, a ação coletiva. Segundo a regra $\$ 2.02^{746}$, a Corte deve exercer poder discricionário para autorizar o tratamento agregado de uma questão comum, pulverizada em uma multiplicidade de demandas individuais. Esse tratamento pode ser conferido mediante o manejo de uma ação coletiva, se essa dirigir-se ao núcleo comum da disputa e for superior às outras técnicas procedimentais aplicáveis. O principal escopo no tratamento agregado é a preclusão. Se a agregação, por uma ação coletiva, não facilitar a adoção de solução vinculante à controvérsia, a agregação por uma ação coletiva deve ser rejeitada.

743 UNITED STATES OF AMERICA. Court of Appeal. Third Circuit. Behrend v. Comcast Corp., 655 F.3d 182, 207 (3d Cir. 2011).

744 "[...] At the class certification stage we do not require that Plaintiffs tie each theory of antitrust impact to an exact calculation of damages, but instead that they assure us that if they can prove antitrust impact, the resulting damages are capable of measurement and will not require labyrinthine individual calculations [...]" (Ibidem). 745 No caso Behrend v. Comcast Corp, a Suprema Corte reverteu a certificação da ação de classe, sob o argumento de que o direito substancial não era passível de prova coletiva, mas, sim, individualizada (Cf. UNITED STATES OF AMERICA. Supreme Court of United States of America. Behrend v. Comcast Corp. 569 U. S. (2013)). 746 " [...](a) the Court should exercise discretion to authorize aggregate treatment of a common issue by way of class action if the Court determines that resolution of the common issue would (1) materially advance the resolution of multiple civil claims by addressing the core of the dispute in a manner superior to other realistic procedural alternatives, so as to generate significant judicial efficiencies; (2) conform to the general principles for aggregate treatment proceedings in $\$ \S 1.03-1.05$; and (3) not compromise the fairness of procedures for resolving any remaining issues presented by such claims" (Cf. AMERICAN LAW INSTITUTE, 2010, p. 82). 
Dentre as técnicas alternativas à ação de classe ${ }^{747}$, destacam-se principalmente (i) a unificação ou coordenação do procedimento probatório prévio ou da fase de saneamento do processo (coordinated discovery and pre-trial rullings); e (ii) a agregação administrativa, como reunião de ações similares, a exemplo do que ocorre na consolidação (consolidation) ou coordenação informal (informal coordination). No caso da consolidação, há a reunião formal das demandas. No caso da coordenação, os magistrados coordenam suas atividades e trabalham juntos por uma solução coerente e unitária, mas o fazem fora do âmbito de normas específicas (iii) julgamento de um caso individual ou de uma amostra de casos individuais. Trata-se de um test-case ou bellwether trial. Esse método pode ser informativo, apenas para instruir a controvérsia e analisar similaridades e diferenças nos casos ou esse método pode ser vinculante, preclusivo aos demais casos individuais. A vinculação não é, todavia, majoritariamente aceita no sistema jurídico estadunidense, a não ser quando há consentimento das partes interessadas no caso-teste.

\subsubsection{MAXIMIZANDO A VINCULAÇÃO OBRIGATÓRIA (MANDATORY)}

O American Law Institute adota, expressamente, o critério da indivisibilidade para conferir o regime processual de vinculação obrigatória (mandatory) às demandas agregadas. Conforme a regra $\$ 2.07^{748}$, se a demanda individual proposta apresentar um objeto indivisível ou paritário, a demanda será agregada segundo o regime de vinculação compulsória e os membros ausentes do grupo serão alcançados pela autoridade da coisa julgada, sem possibilidade de autoexclusão.

Na hipótese acima, a agregação será realizada, segundo o regime de vinculação obrigatória (mandatory basis). Todos os indivíduos permanecerão vinculados ao comando normativo do julgado, sendo inadmissível a autoexclusão dos membros ausentes da coletividade nesse caso.

Se o objeto for, por sua vez, divisível, há uma presunção para o exercício da autoexclusão. O projeto ALI não explicita, no entanto, os mecanismos e os critérios processuais para o exercício do direito de autoexclusão no processo coletivo. Mas, reforça que o exercício do opt out deve

747 “[...] realistic procedural alternatives under subsection (a)(1) may, in a given situation, include (1) coordinated discovery, (2) pre-trial rulings, such as on a motion for summary judgment or concerning the admissibility of evidence related to the common issue, (3) trial of an individual claimant's case or multiple individual cases, (4) an administrative aggregation within the meaning of $\S 1.02(\mathrm{~b})$; or (5) another class action already pending in another judicial system" (Cf. AMERICAN LAW INSTITUTE, 2010, p. 82)

748 “....] (c) if the Court finds that the aggregate proceeding should be mandatory in order to manage indivisible relief fairly and efficiently as to the related claims, then aggregate treatment by way of class action need not afford claimants an opportunity to avoid the preclusive effect of any determination of those claims" (Cf. AMERICAN LAW INSTITUTE, 2010, p. 148). 
ser previsto, pois o controle pessoal de uma demanda pode ser relevante no caso concreto e ele pode revelar a inadequação da representação, gerando pressão por uma melhor representação pelo advogado e também alertando o juiz para uma nova fiscalização da representatividade. ${ }^{749}$

Mas, é preciso ressaltar, de qualquer forma, que, mesmo se o objeto for divisível na prática, o direito substancial pode estabelecer situações de paridade e de impessoalidade entre os membros do grupo. Nesse caso, se houver a decisão de uma questão comum ao grupo, incide a preclusão (issue preclusion) para essa questão, obstando sua rediscussão em demandas individuais subsequentes. Exemplo disso: se a causa de pedir referir-se a uma questão comum de responsabilidade, como uma prática discriminatória não suscetível de aferição individual, e for declarada a ausência de responsabilidade em razão da inexistência da prática alegada, a existência dessa prática não poderá mais ser discutida nos processos individuais. A preclusão da questão decidida é decorrência da comunhão substancial. Nessa hipótese, a preclusão é pro et contra, tanto para a hipótese de procedência da demanda, quanto para a improcedência. ${ }^{750}$

Na realidade, isso já é bastante adotado no sistema jurídico estadunidense. Nas hipóteses de danos incidentais ou meramente econômicos, a preclusão da pretensão divisível ocorre porque ela constitui uma mera decorrência da solução da questão comum quanto à responsabilidade. Quando resolvida a questão da responsabilidade é fixada, por exemplo, uma fórmula padrão de reajuste contratual. Nesse contexto, a compensação individual torna-se impessoal, objetiva e paritária, calculada administrativamente para todos os indivíduos a partir da fórmula padrão, independentemente de aferição, caso a caso, dos atributos pessoais dos membros interessados.

Nesse ínterim, não é possível ao indivíduo pleitear, em demanda seguinte, compensação individual (maior ou menor), com fundamento na mesma causa de pedir e pedido. Isso implicaria, na prática, o afastamento da fórmula de cálculo padrão fixado na sentença genérica, bem como o afastamento da imutabilidade inerente à coisa julgada coletiva. A demanda individual somente seria possível, se o indivíduo lograsse afastar a própria imutabilidade da coisa julgada ou a eficácia preclusiva, mediante o collateral attack (impugnação incidental) ${ }^{751}$.

749 AMERICAN LAW INSTITUTE, 2010, p. 151.

750 Ibidem, p. 119.

751 Collateral attack é uma impugnação incidental à coisa julgada coletiva, realizada em uma ação autônoma, em que um indivíduo alega, preliminarmente, não ter sido alcançado (como membro ausente da classe) pela autoridade da coisa julgada coletiva. As razões elencadas para tanto são a falta de representação adequada e, modo geral, falha de justiça da decisão com respeito à particular situação jurídica daquele membro do grupo. O indivíduo alega, em 
Na realidade, a questão dos danos incidentais ou econômicos e o regime processual a eles aplicável é discussão bem antiga no sistema jurídico estadunidense. A Harvard Law Review ${ }^{752}$, em 1958, quando ainda vigente a classificação das categorias de ação de classe em true, hybrid e spurious, já propugnava por um novo regime de vinculação obrigatória ao julgado coletivo.

Esse regime deveria considerar a pendência de questões individualizadas, a serem deduzidas pessoalmente. Caso inexistissem essas questões individualizadas, sendo a matéria integralmente resolvida com fundamento na questão comum ao grupo, incidiria o efeito vinculante do julgado (binding effect) em relação aos membros ausentes da classe. Esse é o caso, por exemplo, em que há pretensão de reembolso ou de restituição, pois o cálculo da compensação individual não demanda mais cognição, prova ou quantificação individualizada. A restituição decorre de uma fórmula padrão, a qual atrai a autoridade da coisa julgada coletiva.

Por fim, é preciso destacar que um dos juristas que mais se dedicaram ao estudo da mandatory class action nos Estados Unidos foi David Rosenberg ${ }^{753}$. Embora algumas de suas ideias sejam radicais e, por isso, pouco aceitas, ele soube compreender a relação entre os critérios substanciais de agregação e a autoridade da coisa julgada (binding effect) no processo coletivo. Ele pugnava pela necessidade de obstar a duplicação de litígios de massa similares ou idênticos no sistema estadunidense, maximizando os instrumentos processuais coletivos e preclusivos.

\footnotetext{
síntese, que a ele não foram conferidas as garantias de um devido processo legal (Cf. NOTE. Collateral Attack on the binding effect of class action judgments. Harvard Law Review, 1974. V. 87:589-606p, p. 594).

752 NOTE, 1958 , p. 934.

753 David Rosenberg propôs a extinção do opt out para as demandas de massa (mass torts). Não é possível aceitar essa posição mais radical do autor. Muito embora possa ser ponderada a concessão de limites a esse direito de autoexclusão, quando inadequado ou abusivo em relação ao direito substancial, matéria que será objeto do próximo capítulo. É preciso salientar, no entanto, que a radicalidade da posição de Rosenberg, no tocante ao opt out, embora não seja aceitável, não desmerece o trabalho desse jurista, que sempre ressaltou no sistema estadunidense a necessidade de o processualista abrir os olhos para o conteúdo e para os escopos do direito material (Cf. Rosenberg, David. Avoiding duplicative litigation of similar claims: the superiority of class action vs. collateral estoppel vs. standard claims market. Harvard Law School. Discussion paper 394. 12/2002).
} 
Aliás, é interessante notar que, no Canadá, que se inspirou no sistema estadunidense, a legislação de British Columbia ${ }^{754}$ e de Ontario $^{755}$ previram expressamente que, uma vez estabelecida a responsabilidade, o montante dos danos a serem compensados podem ser apreciados por aferição estatística para todos os indivíduos. Isso é possível nas hipóteses em que, por força do direito substancial, for desnecessária a prova individual dos danos. Segue-se, assim, a resolução plena do conflito de interesses, a partir da técnica processual de agregaçãa ${ }^{756}$.

Enfim, o regime de vinculação obrigatória ao julgado, no qual inclui-se a autoridade da coisa julgada, não se refere ao tipo de demanda ou à eficácia do provimento. O regime não é vinculante (mandatory) porque a pretensão é injuntiva ou declaratória, tampouco o regime é não vinculante (non-mandatory) porque a pretensão é o ressarcimento em pecúnia. Pelo que foi visto até aqui, é possível a vinculação até mesmo das pretensões divisíveis dos indivíduos. Forçoso convir que o que importa é analisar o direito substancial, a saber, a impessoalidade e a indivisibilidade ou paridade substancial e, com isso, a identidade da situação jurídica deduzida.

Presentes essas circunstâncias do direito substancial, será possível a observância do devido processo legal, sem causar prejuízo ao indivíduo e ao direito de o próprio indivíduo narrar a sua história pessoal, que pode ser diferente ou até mesmo contrária à história coletiva do grupo. Aquilo que for pessoal, não é idêntico in re ipsa e, assim, continua a exigir cognição artesanal.

\subsubsection{MINIMIZANDO A AUTOEXCLUSÃO E A NOTIFICAÇÃO (OPT OUT AND NOTICE)}

754 “...29 (1) The court may make an order for an aggregate monetary award in respect of all or any part of a defendant's liability to class members and may give judgment accordingly if (a) monetary relief is claimed on behalf of some or all class members, (b) no questions of fact or law other than those relating to the assessment of monetary relief remain to be determined in order to establish the amount of the defendant's monetary liability, and(c) the aggregate or a part of the defendant's liability to some or all class members can reasonably be determined without proof by individual class members. [...] 30 (1) For the purposes of determining issues relating to the amount or distribution of an aggregate monetary award under this Act, the court may admit as evidence statistical information that would not otherwise be admissible as evidence, including information derived from sampling, if the information was compiled in accordance with principles that are generally accepted by experts in the field of statistics" (Cf. CANADA. British Columbia. Class Proceedings Act. British Columbia: Queen's Printer, 1996); 755 “...24 (1) The court may determine the aggregate or a part of a defendant's liability to class members and give judgment accordingly where, (a) monetary relief is claimed on behalf of some or all class members; (b) no questions of fact or law other than those relating to the assessment of monetary relief remain to be determined in order to establish the amount of the defendant's monetary liability; and (c) the aggregate or a part of the defendant's liability to some or all class members can reasonably be determined without proof by individual class members" (Cf. CANADA. Ontário. Class Proceedings Act. Ontário: Queen's Printer, 1992).

756 JONES, 2003, p. 127. 
Ao lado da maximização da vinculação ao julgado, surge, de forma correlata, a minimização do direito de autoexclusão do indivíduo. Em primeiro lugar, obsta-se o exercício desse direito nas hipóteses em que o objeto da relação substancial for indivisível e, necessariamente, unitário.

Nesse caso, a regra $\$ 2.07$ (c) do projeto ALI estabelece que, para gerenciar bem da vida indivisível, a Corte de Justiça deve determinar a agregação das demandas individuais, porventura pendentes, sob o regime de vinculação obrigatória aos membros ausentes do grupo ao julgado, não sendo possível a autoexclusão ou afastar o efeito preclusivo do julgado coletivo.

Esse entendimento aplica-se tanto para às hipóteses de indivisibilidade prática, quanto para as hipóteses de indivisibilidade normativa, isto é, aquelas hipóteses em que o direito substancial exige a concessão de tratamento impessoal e paritário, como ocorre em um fundo limitado.

Novamente, é interessante notar que o opt out ou a autoexclusão é admitida quando a controvérsia apresentar-se individualizada, pessoal ou particularizada. $\mathrm{O}$ exemplo dado pelo projeto ALI é a hipótese de a controvérsia deduzida em juízo referir-se a uma prática discriminatória aplicável com fundamento no grupo como um todo. O processamento dessa controvérsia coletiva não obsta o indivíduo de excluir-se e alegar ato discriminatório pessoal, que não coincide com a prática ou política discriminatória controvertida em relação ao grupo. ${ }^{757}$

De igual modo, há doutrina que sustenta a necessidade de o direito de autoexclusão ser exercido de forma condicionada. Apenas se demonstrada a existência de uma justa causa e se superado o burden of persuasion ou o ônus argumentativo, a exclusão pode ser admitida. O opt out frívolo não pode ser admitido. Nesse sentido, Linda Mullenix ${ }^{758}$ diz que o opt out deveria ser acompanhado de um desincentivo, cabendo ao indivíduo arcar com o burden of persuasion, isto é, arcar com o ônus de justificar a sua exclusão da ação. No mesmo sentido, defende Mark Friedman ${ }^{759}$, pugnando por uma justa causa para a exclusão do indivíduo da ação de classe.

A necessidade de o opt out ser exercido depois a indicação de uma justa causa pessoal foi, por sua vez, expressamente previsto no Canadá. Como já visto, a legislação relativa à ação de classe

757 AMERICAN LAW INSTITUTE, 2010, p. 116.

758 MULLENIX, 1986, p. 1070-1071.

759 FRIEDMAN, Mark W. Constrained individualism in group litigation: requiring class members to make a good cause showing before opting out of a federal class action. Yale Law Journal, V. 100, 1990, p. 745. 
de British Columbia ${ }^{760}$ reconhece a possibilidade de aferição agregada da compensação individual com fundamento em uma fórmula ou em um método padrão aplicável ao grupo todo.

Nesse contexto, o indivíduo pode excluir-se da aferição agregada, mas deve alegar e provar uma causa individual para o exercício desse direito. Isso porque não é admissível que o indivíduo ignore a autoridade da coisa julgada coletiva, que apurou a responsabilidade padrão ao grupo, para depois propor demanda individual idêntica, pretendendo apenas indenização superior aos demais do grupo. Para que o indivíduo alcance indenização superior, ele tem que demonstrar as peculiaridades da sua relação substancial pessoal, capaz de afastar a fórmula padrão e, assim, lograr a aferição artesanal do ressarcimento em pecúnia a ele devido no caso.

Se o exercício do opt out aproximar-se do abuso processual ou for inadequado à relação substancial deduzida, esse exercício deverá ser obstado. Não se nega o direito, apenas limita-se o seu exercício, estabelecendo, assim, um ônus argumentativo para quem pretende excluir-se do grupo. O opt out torna-se, assim, uma válvula de escape para que o indivíduo possa narrar a sua história individual e pessoal, que pode não coincidir com a história do grupo. Não se trata, assim, de um direito absoluto, de uma nova oportunidade para litigar a mesma controvérsia.

Essa técnica de argumentação deve ser ponderada, atualmente, no sistema estadunidense. Isso porque, hoje, nos Estados Unidos, ainda que um indivíduo opte por excluir-se da ação coletiva e propor a sua demanda individual, isso não quer dizer, necessariamente, que ele poderá litigar isolada ou separadamente a sua causa. Essa demanda individual pode sofrer uma consolidação, pode ser informalmente coordenada, pode ser suspensa, hipóteses nas quais não há direito algum de autoexclusão individual. E, mais, o indivíduo irá perder, ao menos em parte, o controle de sua demanda, que era exatamente o objetivo pretendido quando excluiu-se da ação. ${ }^{761}$

\footnotetext{
760 "31 [...](2) If an order is made under subsection (1), any member of the class or subclass in respect of which the order was made may, within the time specified in the order, apply to the court to be excluded from the proposed distribution and to be given the opportunity to prove that member's claim on an individual basis. (3) In deciding whether to exclude a class or subclass member from an average distribution, the court must consider (a) the extent to which the class or subclass member's individual claim varies from the average for the class or subclass, (b) the number of class or subclass members seeking to be excluded from an average distribution, and (c) whether excluding the class or subclass members referred to in paragraph (b) would unreasonably deplete the amount to be distributed on an average basis" (CANADA. British Columbia. Class Proceedings Act. British Columbia: Queen's Printer, 1996).

761 SHERMAN, MARCUS, 2004, p. 459.
} 
Enfim, o indivíduo se exclui de uma técnica de agregação, mas é novamente capturado por outra técnica de agregação do sistema. Nesse contexto, pode-se dizer, sob uma perspectiva macro, que o exercício de autoexclusão já é limitado no sistema! O indivíduo somente estará realmente excluído se a demanda apresentar o caráter da individualidade: titularidade individual do direito, objeto divisível e controvérsia pessoal, a exigir cognição artesanal em juízo.

A notificação dos membros ausentes do grupo também é condicionada aos contornos do direito substancial. A notificação individual, dirigida a cada um dos membros da classe, pode ser inviável, considerando o tamanho da classe, os custos da notificação em relação aos valores ínfimos pretendidos na demanda, a dificuldade de localização dos membros ausentes da classe.

E se o aviso de recebimento da notificação individual extraviar? E se o membro ausente mudar de residência e não receber a sua notificação individual, estará ele livre para litigar demanda idêntica, mesmo que tenha sido adequadamente representado em juízo? Se esse requisito for considerado de forma abstrata, sem correlação com o direito substancial, qualquer irregularidade no tocante à forma processual implicará consequências desastrosas na administração da justiça e na atuação do direito substancial. Por essas e outras, a notificação deve ser manejada de forma instrumental aos resultados substanciais pretendidos na demanda.

Há doutrina ${ }^{762}$ nos Estados Unidos, sustentado que uma notificação irregular pode ser superada, pela adequada representação realizada no processo coletivo. Dessa forma, essa irregularidade pode ser desconsiderada, vinculando o membro ausente do grupo que não se excluiu da ação.

Lembra-se que a forma processual existe para alcançar determinados escopos processuais e, dentre eles, o escopo jurídico, que é atuar o direito substancial. Se essa forma tornar-se desnecessária ou inidônea a alcançar os escopos e os resultados pretendidos no plano material, ela é derrotável, suscetível de ser afastada, por não mais cumprir a diretrizes constitucionais.

Se a técnica não cumpre mais a orientação constitucional de oferecer um método de resolução de conflitos acessível, efetivo, de duração razoável e que internalize os argumentos dos interessados, ela deve ser adaptada aos contornos da situação substancial concreta deduzida.

762 NOTE, 1975, p. 1403. 


\subsection{INTERESSES OU DIREITOS NO SISTEMA BRASILEIRO}

No sistema jurídico brasileiro, surgem problemas e dificuldades similares aos enfrentados no sistema jurídico estadunidense. A notícia alvissareira é que, entre nós, os critérios substanciais de agregação já foram positivados no Código de Defesa do Consumidor, estendendo-se a todo microssistema. Logo, não é difícil perceber as inerentes possibilidades de agregação colocadas pelo sistema. Aqui, com maior razão, é possível vislumbrar ações coletivas existentes de fato.

Mas, antes disso, é preciso destacar que a agregação surge como alternativa necessária, em razão da insuficiência dos mecanismos tradicionais em lidar com a litigiosidade de massa.

\subsubsection{A INSUFICIÊNCIA DOS MECANISMOS PROCESSUAIS TRADICIONAIS}

Dentre os instrumentos tradicionais, o principal a ser citado é, sem dúvida, o litisconsórcio. O litisconsórcio constitui, segundo Dinamarco ${ }^{763}$, técnica apta a conferir um esquema plurissubjetivo à relação processual, em razão de situações jurídico-materiais envolvendo uma pluralidade de pessoas cujas esferas jurídicas poderão ser atingidas pelo provimento judicial.

O objetivo da técnica é, portanto, atuar esse direito subjetivamente complexo, por vezes, rigorosamente unitário, com economia processual, eficiência e uniformidade nos provimentos jurisdicionais. O litisconsórcio é, por excelência, um instrumento de agregação processual.

Mesmo assim, não é raro encontrar casos em que a parte alega a necessidade de formação do litisconsórcio necessário em hipóteses, nas quais, se esse vier a ser formado, tornar-se-á multitudinário e, assim, impraticável de ser gerenciado no processo com economia e eficiência. A técnica que deveria ser de agregação, ao tornar-se multitudinária, incentiva à desagregação.

Nesses casos, não é possível crer em um genuíno interesse da parte pela agregação processual, mediante o recurso ao litisconsórcio. Muito pelo contrário, quando se recorre ao litisconsórcio necessário em demandas multitudinárias, o que se pretende, por vezes, é a extinção do processo sem resolução de mérito. Não se trata de buscar uma cooperação para fins de otimização dos mecanismos de tutela jurisdicional, a partir da agregação de todos os interessados e afetados.

763 DINAMARCO, 2009, p. 339. 
É perceptível, a olhos vistos, que o litisconsórcio e a participação direta em demandas multitudinárias são inidôneas e inconvenientes, no tocante à condução do processo jurisdicional, tumultuando-o. As partes podem valer-se desse instrumento não para agregar, mas exatamente para tumultuar, para extinguir o processo ou, ainda, confundir o julgador.

Quando isso ocorre no litisconsórcio facultativo, a pluralidade de partes pode e deve ser limitada. ${ }^{764} \mathrm{O}$ problema maior ocorre, nas hipóteses encartadas como litisconsórcio necessário, relativo à relação substancial incindível, pois essa limitação subjetiva não é, em tese, possível.

Nesse contexto, o mecanismo do litisconsórcio necessário torna-se, então, insuficiente para o tratamento de direitos coletivos ou, ao menos, de direitos individuais de valência coletiva ou de massa. E, por essa razão, é preciso pensar na agregação processual de larga escala, pois a estruturação subjetiva do processo não pode ficar ao encargo da estratégia das próprias partes.

A solução óbvia é, assim, o recurso a novos instrumentos, mais adequados às hipóteses em que identificado um direito coletivo ou de alcance coletivo. Nesses casos, em que o indivíduo opera como membro de um grupo, como um anônimo, a participação direta não é imprescindível para atuação do direito material, já que o objeto de cognição tende a ser os atributos do grupo.

Cândido Rangel Dinamarco ${ }^{765}$ bem assinala que, nessas hipóteses de plurissubjetividade multitudinária, típica dos direitos coletivos, "os benefícios de um só processo para a tutela de um quantidade grande de pessoas são obtidos, de maneira muito mais abrangente que mediante o litisconsórcio, nos processos voltados à tutela coletiva"766 ou, de forma geral, pela agregação.

Nesse sentido, conforme assevera Bruno Silveira e Francisco Vieira ${ }^{767}$, quanto mais complexa a crise de direito material, mais complexo e diferenciado, simetricamente, deverá ser o processo. O processo coletivo é, nesse aspecto, a adaptação da técnica processual ao contingente

764 Arruda Alvim, Thereza Alvim, Eduardo Arruda Alvim e James Marins comentam que, de uns anos para cá, delimitou-se no direito brasileiro o próprio âmbito do espectro subjetivo possível do litisconsórcio, no sentido de que demandas multitudinárias não podem utilizar-se da figura do litisconsórcio facultativo. Reconhece-se ao juiz brasileiro o poder de, com base no art. 125, I, desmembrar o processo ou mesmo inadmiti-lo em virtude de tal litisconsórcio (Cf. ARRUDA ALVIM et al. Código de Defesa do Consumidor Comentado. 2 ed. rev. amp. SÃO PAULO: Revista dos Tribunais, 1995, p. 350).

765 DINARMARCO, 2009, p. 349.

766 Ibidem, p. 349.

767 OLIVEIRA, Bruno Silveira, LIMA NETO, Francisco Vieira. Notas sobre o devido processo constitucional, o litisconsórcio e os processos coletivos. Revista de Processo. São Paulo: Revista dos Tribunais, V. 191, jan./2010. 
complexo e multitudinário. O litisconsórcio fica reservado apenas àquelas hipóteses com pouco mais de duas pessoais, em que a participação individual é, ainda, factível no processo de massa.

\subsubsection{O AVANÇO DA MOLECULARIZAÇÃO OU DA AGREGAÇÃO PROCESSUAL}

O litisconsórcio é, então, uma técnica insuficiente para lidar com o fenômeno da litigiosidade de massa. É preciso ponderar por instrumentos necessários e mais adequados a esse fenômeno.

Para essas hipóteses de conflitos multitudinários, a agregação deve ser otimizada, isto é, deve ser uma técnica necessária (com menor restrição possível) e adequada (mais idônea) aos contornos do direito substancial. É imperativo agregar a história coletiva, que diz respeito aos atributos do próprio grupo, mas reservar para a história individual as soluções atomizadas ou as técnicas tradicionais, em que a participação direta do indivíduo tende a ser infungível.

Destaca-se que a molecularização da controvérsia não é, portanto, um mero litisconsórcio multitudinário. Não é uma mera reunião de pessoas em um polo da relação processual. É mais do que isso, é uma síntese. Se não existir essa síntese ou comunhão, a relação processual, ainda que venha a nascer coletiva, poderá, em algum momento, se pulverizar em múltiplas ações ou liquidações individuais. As questões individuais vão exigir, nesse contexto, cognição artesanal, tornando-se um engodo a sentença coletiva que reconheça uma prática ilegal genérica. ${ }^{768}$

Essa noção de molecularização ou de estrutura molecular é de paternidade reconhecida no direito brasileiro. Foi Kazuo Watanabe ${ }^{769}$ quem melhor expressou a noção da tutela coletiva como tutela "molecular", como uma entidade autônoma, distinta das soluções atomizadas.

A noção de síntese é, por sua vez, anunciada por Ada Pellegrini Grinover ${ }^{770}$. Essa processualista reconheceu, argutamente, a importância da identificação da questão comum, principalmente, nos direitos individuais homogêneos. Se não existir uma questão comum relevante, capaz de avançar a resolução da controvérsia em relação à categoria, a sentença coletiva tornar-se-á falaciosa e as questões individuais ressurgirão na liquidação da sentença genérica. Desse modo, a liquidação se assemelhará, em complexidade, às verdadeiras ações individuais condenatórias.

768 Em sentido semelhante, VIGORITI, 1979, p. 25. ARAÚJO, 2000, p. 114. 
Fredie Didier e Hermes Zaneti ${ }^{771}$ salientam, nesse contexto, que não é significativa a estrutura subjetiva do processo, mas, sim, a matéria litigiosa nele discutida. A matéria litigiosa refere-se aos direitos e às formas de lesão, que tem uma estrutura comum ou arquetípica. Isso conduz à transposição de uma estrutura atômica ou fragmentada para uma estrutura molecular da lide.

O que se quer dizer, com isso, é que não basta o critério quantitativo (numerosidade de pessoas e impraticabilidade do litisconsórcio), é preciso atentar-se para o critério qualitativo, a saber, para os critérios substanciais de agregação: são elementos do direito material que informam ao intérprete "o que" e "como" agregar para o fim de ensejar uma prestação jurisdicional efetiva.

Como diz Giorgio Costantino ${ }^{772}$, a atenção do estudioso do processo civil é centrada nas tutelas das situações substanciais plurissubjetivas, com particular referência aos interesses ou direitos coletivos. Os conceitos e as técnicas processuais tradicionais são insuficientes para esse fim.

São os critérios, extraídos na relação substancial, que permitem a estruturação agregada ou molecular da controvérsia, afastando-se das soluções atomizadas. Os principais critérios adotados no sistema jurídico brasileiro foram a indivisibilidade do objeto substancial e a indeterminação dos titulares. Esses critérios dão origem à categorização tricotômica adiante.

\subsubsection{A CLASSIFICAÇÃO TRICOTÔMICA DOS DIREITOS TRANSINDIVIDUAIS}

A categorização dos direitos coletivos brasileiros consta no art. 81 do Código de Defesa do Consumidor. Essa categorização adota a classificação tricotômica. Não há consenso doutrinário, de um modo geral, nos ordenamentos jurídicos de civil law, por uma forma de classificação única. Por essa razão, abordar-se-á apenas a classificação do direito brasileiro.

Segundo Pedro Lenza ${ }^{773}$, o sistema tricotômico de classificação divide os direitos coletivos em sentido amplo em direitos difusos, coletivos stricto sensu e individuais homogêneos. Essa classificação foi eleita não apenas por força da prescrição legal, mas também pelos aspectos

771 DIDIER JR, Fredie; ZANETI JR, Hermes. Curso de Direito Processual Civil. V. 4.3 ed. rev. atual. amp. Salvador: Juspodium, 2008, p. 36.

772 COSTANTINO, Giorgio. Contributo allo studio del litisconsorzio necessario. Napoli: Editore Jovene, 1979, p. 8.

773 LENZA, Pedro. Teoria Geral da Ação Civil Pública. 3 ed. rev. atual. amp. São Paulo: Revista dos Tribunais, 2008, p. 61. 
culturais. O direito brasileiro, por razões culturais, abandonou o conceito de público como coletivo ou como povo, adotando-o apenas quando é preciso referenciar os interesses ou direitos públicos do Estado como entidade própria. Os direitos do povo são coletivos e não públicos. ${ }^{774}$ É conhecida, ainda, uma segundo classificação, agora de Barbosa Moreira ${ }^{775}$, que dividiu os interesses ou direitos em essencialmente coletivos e acidentalmente coletivos. Os direitos difusos e coletivos stricto sensu seriam direitos essencialmente coletivos, pois insuscetíveis de divisão. Os direitos individuais homogêneos seriam acidentalmente coletivos, pois divisíveis.

É preciso advertir, no entanto, como o faz o próprio Barbosa Moreira ${ }^{776}$, que entre uns e outros, existem um sem número de situações plurissubjetivas que medeiam o que é essencialmente coletivo e o que é acidentalmente coletivo. Essa escalada de coletivização já foi investigada anteriormente, é chegada a hora de aplicá-la ao direito posto no sistema jurídico brasileiro.

Na classificação legal, a seguir exposta, enfatizam-se principalmente dois critérios. O aspecto subjetivo é aquele relativo à indeterminação ou determinação dos titulares do direito. $\mathrm{O}$ aspecto objetivo é aquele relativo à indivisibilidade ou divisibilidade do objeto ou bem da vida.

O aspecto subjetivo lembra, em muito, as lições de Giannini ${ }^{777}$, já antes mencionadas. Giannini caracteriza o interesse ou direito difuso e coletivo pelo seu portador. O primeiro relaciona-se a um portador indeterminado com relação a um grupo ocasional. O segundo relaciona-se a um portador determinável com relação a um ente representativo de um grupo/classe não ocasional.

O aspecto objetivo é, majoritariamente, mencionado pela doutrina processual. O interesse ou direito coletivo e difuso é indivisível, já o individual homogêneo é marcado pela divisibilidade.

774 José Reinaldo de Lima Lopes salienta que, no Brasil, o povo não se identifica com o bem comum ou com coisa pública, que passa a ser incumbência exclusiva do Estado. O problema da pobreza, da desigualdade e qualquer outro problema social é compreendido como um problema público, do Governo e não da coletividade como povo. Situação diversa ocorre na Europa, pois lá as elites veem as questões de Estado como um problema seu (LOPES, 2003, p. 92)

775 BARBOSA MOREIRA, 1984, p. 195-197.

776 BARBOSA MOREIRA, 1977, p. 113.

777 GIANNINI, 1976, p. 23. 
Os conceitos a seguir dispostos, previstos no Código de Defesa do Consumidor, são de extrema relevância, pois são aplicáveis não apenas às relações de consumo, mas a todo microssistema processual coletivo. De igual modo, são eles a base para toda a agregação processual proposta.

\subsubsection{DIREITOS DIFUSOS}

Direitos difusos são direitos transindividuais. Pelo critério subjetivo, sua nota característica é a titularidade indeterminada, sendo os membros do grupo vinculados por circunstâncias fáticas. Pelo critério objetivo, sua nota característica é a indivisibilidade prática, insuscetível de divisão.

Isso é o que reza o art. 81, inc. I, do Código de Defesa do Consumidor: "I - interesses ou direitos difusos, assim entendidos, para efeitos deste código, os transindividuais de natureza indivisível, de que sejam titulares pessoas indeterminadas e ligadas por circunstâncias de fato". ${ }^{778}$ São exemplos de direitos difusos, costumeiramente, mencionados pela doutrina: direito à higidez ambiental, direito de o consumidor não ser alvo de publicidade enganosa e abusiva, direito às paisagens naturais, direito à preservação do patrimônio histórico e urbanístico e outros tipos.

Na tutela dos direitos difusos, todos os membros do grupo tem a mesma sorte, seja na hipótese de improcedência, seja na hipótese de procedência da ação, pois o bem é insuscetível de divisão ideal. Eventual concurso de ações, versando sobre bem indivisível, desaguaria em um inevitável conflito prático de julgados, pois os dispositivos julgados seriam contraditórios e inconsistentes.

São também notas características dos direitos difusos, segundo Rodolfo de Camargo Mancuso $^{779}$, a alta conflituosidade, a intensa litigiosidade interna, conflitos que tem como causa remota verdadeiras escolhas políticas, de alternativas ilimitadas. Nos direitos difusos, uma mesma pessoa pode ocupar os dois polos da relação processual, mas por apresentar qualidades diferentes. O empresário de uma indústria poluidora pode ser réu em uma ação para a cessação da poluição ambiental e substituído na ação coletiva proposta pelo Ministério Público, em nome de todos os moradores da cidade, para fins de preservação do meio ambiente hígido e sadio. ${ }^{780}$

778 BRASIL. Código de Defesa do Consumidor. Lei n. ${ }^{\circ}$ 8.078/1990. Brasília: Congresso Nacional, 1990. 779 MANCUSO, 2011, p. 93-121.

780 SOUZA, José Augusto Garcia. A legitimidade coletiva da defensoria pública à luz do princípio da generosidade. In: GOZZOLI, Maria Clara et al (coords.). Em defesa de um novo sistema de processos coletivos: estudos em homenagem a Ada Pellegrini Grinover. São Paulo: Saraiva, 2010, p. 300. 


\subsubsection{DIREITOS COLETIVOS STRICTO SENSU}

Direitos coletivos stricto sensu são direitos transindividuais. Pelo critério subjetivo, sua nota característica é a titularidade determinável, relativa a um ente exponencial (grupo, categoria ou classe), sendo os membros do grupo vinculados por uma relação jurídica base. Pelo critério objetivo, sua nota característica é a indivisibilidade prática, insuscetível de divisão em quotas.

Isso é o que reza o art. 81, inc. II, do Código de Defesa do Consumidor: "II - interesses ou direitos coletivos, assim entendidos, para efeitos deste código, os transindividuais, de natureza indivisível de que seja titular grupo, categoria ou classe de pessoas ligadas entre si ou com a parte contrária por uma relação jurídica base". ${ }^{781}$ São exemplos de direitos coletivos stricto sensu, costumeiramente mencionados pela doutrina: direito dos advogados, tutelado pela $\mathrm{OAB}$, a respeito de suas prerrogativas nas audiências judiciais, direitos dos pais, tutelado pela Associação de pais e mestres, pela realização de companha anti-bullying na escola dos filhos.

Aqui, à semelhança dos interesses difusos, todos os membros do grupo tem a mesma sorte, seja na hipótese de improcedência, seja de procedência da ação, pois o bem é insuscetível de divisão ideal. Eventual concurso de ações, versando sobre bem indivisível, desaguaria em um inevitável conflito prático de julgados, pois os dispositivos julgados seriam contraditórios e inconsistentes.

\subsubsection{DIREITOS INDIVIDUAIS HOMOGÊNEOS}

Por fim, a categorização tricotômica, prevista em lei, termina com os direitos individuais homogêneos. Pelo critério subjetivo, sua nota característica é a titularidade determinável. Pelo critério objetivo, sua característica é a origem comum e a homogeneidade dos interesses.

Isso é o que reza o art. 81, inc. II, do Código de Defesa do Consumidor: "III - interesses ou direitos individuais homogêneos, assim entendidos os decorrentes de origem comum" "782. São exemplos de direitos individuais homogêneos, costumeiramente mencionados pela doutrina: direito dos alunos de uma escola pela devolução de uma mensalidade-extra abusiva, direitos das diferenças relativas aos expurgos inflacionários de planos econômicos do governo etc.

781 BRASIL. Código de Defesa do Consumidor. Lei n. ${ }^{\circ}$ 8.078/1990. Brasília: Congresso Nacional, 1990. 782 Ibidem. 
Segundo Kazuo Watanabe ${ }^{783}$, origem comum e homogeneidade são requisitos distintos. Origem comum pode ser de fato ou de direito e não significa, necessariamente, uma unidade factual ou temporal. A origem pode, ainda, ser próxima ou remota. É remota, por exemplo, o caso de um dano à saúde em razão de um produto potencialmente viciado. A doença pode ter sido causada pelas condições pessoais ou pelo vício do produto. Enfim, quanto mais remota, menos homogêneo o direito, pois mais variáveis podem surgir para desequiparar os membros do grupo.

A homogeneidade, por sua vez, segundo Ada Pellegrini Grinover ${ }^{784}$, consiste no grau de coesão ou predominância da comunhão de interesses entre as partes. Assim, à semelhança das class action for damages, é necessária a predominância das questões comuns e superioridade da tutela coletiva. Ausentes esses requisitos, a demanda coletiva deverá ser julgada improcedente.

Ainda segundo Ada Pellegrini Grinover ${ }^{785}$, a predominância da questão comum e a superioridade são condições de admissibilidade da ação coletiva, equiparando-se à possibilidade jurídica do pedido e ao interesse de agir. Lembra-se, no entanto, que é aplicável, aqui, como em todo o processo, a teoria da asserção. As condições da ação são aferidas conforme as assertivas da inicial. Se essa questão for apreciada depois da instrução probatória, sendo percebida, nesse momento, a ausência da predominância ou da superioridade da ação, a questão diz respeito ao mérito, implicando a improcedência do direito individual homogêneo.

A homogeneidade do direito integra a causa de pedir, pois o direito individual homogêneo é dotado de atributos diferentes dos direitos individuais clássicos. Tanto é assim que, além da homogeneidade e origem comum, pondera-se por mais dois requisitos, qual seja, a predominância da questão comum e a superioridade da tutela coletiva. A cognição desses requisitos, segundo as assertivas da inicial, equipara-os às condições da ação, para se aferir a viabilidade da ação coletiva. A cognição desses requisitos, depois da instrução probatória, equipara-os ao mérito coletivo. Nesse sentido, vale citar as lições de Botelho de Mesquita ${ }^{786}$ :

[...] do ponto de vista processual, pode parecer que a falta de homogeneidade não diga respeito ao mérito da causa, ou seja, à relação entre o pedido e a causa de pedir, que

783 WATANABE, 2011, p. 76.

784 GRINOVER, 2000, p. 10-13

785 Ibidem, p. 10-13.

786 MESQUITA, José Ignácio Botelho. Ação civil pública. A defesa pelo Ministério Público de direitos individuais heterogêneos disponíveis e de direitos 'individuais' de entes públicos. Limites territoriais da coisa julgada. In: LOPEZ, Teresa Ancona (coord.). Ensaios e pareceres: livre-arbítrio, responsabilidade e produto de risco inerente. O paradigma do tabaco. Aspectos civis e processuais. Rio de Janeiro: Renovar, 2009, p. 264. 
consistiria na relação entre o ato ilícito e a obrigação do réu de indenizar as vítimas. Essa visão, contudo, embora seja adequada à ação individual, tendente à condenação do devedor à indenização do autor, não o é em relação à ação coletiva, que não por objeto a condenação, por assim dizer, 'individual' do devedor. Seu pedido, enquanto ação coletiva, tem por objeto a condenação genérica do devedor e, por causa de pedir, a ofensa a interesses ou direitos individuais homogêneos. A homogeneidade integra a causa de pedir e a sentença que se pronuncie sobre a relação entre ela e o objeto do pedido será necessariamente uma decisão de mérito [...]

Nada obsta, nesse último caso, que os interessados realizem a persecução de direitos individuais puros, mas, inexistindo homogeneidade no direito, deve ser improcedente a demanda coletiva.

Veja que, aqui, diferentemente do sistema estadunidense, a questão quanto à relação entre a certificação (juízo de admissibilidade da ação) e mérito foi mais bem equacionada. No sistema estadunidense, existe divergência quanto ao grau de cognição necessário para realizar o juízo de certificação da ação coletiva. Existe lá até mesmo quem defenda que a demanda coletiva somente poderia ser certificada ser houvesse probabilidade de sucesso no mérito da ação. Isso é inadmissível, pois, do contrário, somente seria certificada demandas coletivas procedentes.

Mais uma consideração se faz necessária nessa categoria de direitos individuais homogêneos. A natureza do direito individual homogêneo é matéria assaz controvertida no direito brasileiro.

Seria o direito individual homogêneo um simples direito individual, uma simples reunião de feixes individuais agregados para fins processuais apenas? Ou seria o direito homogêneo também marcado pela nota da comunhão, como se fosse uma entidade de valor autônomo?

Pelo que foi até agora exposto, já é possível antever que há uma reflexão ou uma ponderação de que os direitos individuais homogêneos constituem um categoria com atributos próprios, a exemplo do que ocorre com os direitos difusos e coletivos stricto sensu. A agregação, nesse caso, não seria mera conveniência. Essa assertiva merece, por vez, ser explicada em detalhes.

Muito bem. Em primeiro lugar, é possível reconhecer no pensamento de Ada Pellegrini Grinover $^{787}$, a partir dos conceitos de predominância e superioridade, a existência de um valor autônomo dos interesses ou direitos individuais homogêneos. Isso porque a predominância e a superioridade conferem, a esses direitos, atributos próprios típicos, que não existem nos direitos 
individuais simples ou puros, para os quais não há homogeneidade ou padronização. Enfim, essa categoria não se trata de um mero artifício legislativo, dissonante do mundo da vida.

No mesmo sentido, Marcelo Abelha Rodrigues ${ }^{788}$ salienta que, nos direitos individuais homogêneos, há uma despersonalização, que é a sua nota característica. O direito continua individual, de titularidade de uma pessoa, mas há uma indiferenciação em relação aos direitos dos demais indivíduos, vítimas da mesma situação de massa, seja um consumo, uma produção, uma propaganda. Há uma inequívoca repercussão coletiva desses interesses. Vale citar o trecho:

[...]Essa preocupação do legislador - de verter a tutela individual em tutela coletiva encontra guarida e legitimidade numa sociedade de massa, que cada vez mais despersonaliza as relações sociais. Nesse modelo de sociedade pós-capitalismo, há uma grande massa de "consumidores" e uma grande massa de serviços que são prestados de forma quase indistinta e despersonalizada. Mas, ainda que prestados e ofertados os serviços e produtos de forma massificada, o uso e fruição desses serviços é realizado de forma individual, por seres comuns, de carne e osso e com realidades e vidas diferentes uns dos outros. Enfim, os prejuízos dos produtos malfeitos e serviços mal prestados acarretam uma massa de danos individuais. Nesse diapasão, não parece haver dúvidas de que tais serviços ou produtos de consumo de massa - que possuem uma alargada dimensão social, tanto do ponto de vista quantitativo como qualitativo -, quando prestados ou ofertados de forma inadequada, ocasionarão problemas e mazelas de massa, embora sentidos por cada um dos usuários que compõe e consomem em massa. Este direito é decorrente desta lesão é um direito individual, ou não? Parece-nos que é individual, sob pena de que, se assim não fosse, estaríamos transformando indivíduos em números e ceifando sua própria dignidade. A 'despersonalização' não pode chegar a esse ponto. Todavia, por outro lado, temos que concordar, pelo menos sob a perspectiva da origem ou da dimensão da lesão, que estes 'direitos individuais' não estão na vala comum dos direitos individuais sem repercussão coletiva. Há uma diferença clara entre eles e é, justamente esta diferença que levou o legislador a tratar de forma diferenciada os interesses individuais de repercussão coletiva, permitindo que sejam tratados de forma coletiva[...] $]^{789}$

De igual modo, José Augusto Garcia de Souza ${ }^{790}$ é enfático ao defender que o solidarismo social, que como vimos é marcante no período contemporâneo, estende-se aos direitos individuais homogêneos. Há um fenômeno de dessubjetivação de vários institutos jurídicos, o que também ocorre com o direito individual homogêneo. Mesmo sendo esse último considerado acidentalmente coletivo, tem se reconhecido a sua relevância social e política objetiva.

\footnotetext{
788 RODRIGUES, Marcelo Abelha. Relações entre ações individuais e ações coletivas: anotações sobre os efeitos decorrentes da propositura e extinção das ações coletivas para defesa de direitos individuais homogêneos em relação às pretensões individuais sob a perspectiva dos arts. 35 e 38 do Projeto de Lei que altera a ação civil pública. In: GOZZOLI, Maria Clara et al (coords.). Em defesa de um novo sistema de processos coletivos: estudos em homenagem a Ada Pellegrini Grinover. São Paulo: Saraiva, 2010, p. 413-414.
}

789 ABELHA, 2010, p. 413-414.

790 SOUZA, 2010, p. 299. 
Ainda, Lionel Zaclis ${ }^{791}$ menciona que os direitos individuais homogêneos, embora divisíveis, apresentam também e, necessariamente, a mesma uniformidade (ou unitariedade, adotando os termos próprios do litisconsórcio) no que toca à questão comum, que a todos interessa.

Outra citação obrigatória é Candido Rangel Dinamarco ${ }^{792}$. Esse processualista nota as tendências solidaristas inerentes ao Estado contemporâneo, de forma que é preciso conferir à fórmula "atuação da vontade concreta" da lei uma interpretação dinâmica. A "atuação concreta" deixa de identificar-se, exclusivamente, com o individual, para admitir a tutela da coletividade.

Em sentido contrário, Elton Venturi ${ }^{793}$ ressalta que os direitos individuais homogêneos são meros artifícios legislativos, criados para o alcance de escopos processuais apenas. Inexistiriam, assim, atributos específicos que os diferenciassem dos direitos individuais. Há uma índole apenas instrumental para a tutela desses interesses ou direitos homogêneos, não há substância.

Teori Albino Zavascki ${ }^{794}$, em sentido similar, assinala que quando se fala em defesa coletiva ou em tutela coletiva não se está qualificando o direito material tutelado, mas, sim, o modo de tutelá-lo. O instrumento de defesa é coletivo, para fins de facilitação do acesso à justiça, economia processual, efetividade e uniformidade nos provimentos jurisdicionais. In verbis:

[...] a homogeneidade não compromete a essência do direito, sob o seu aspecto material que, independentemente dela, continua sendo um direito subjetivo individual. A homogeneidade decorre de uma visão do conjunto desses direitos materiais, identificando pontos de afinidade e de semelhanças entre eles e conferindo-lhes um agregado formal próprio, que permite e recomenda a defesa conjunta de todos eles $[\ldots]^{795}$

Não se nega que os direitos individuais homogêneos, tutelados coletivamente, são aptos a alcançar os escopos processuais de economia, efetividade e uniformidade dos provimentos.

Mas, se admitida for a ausência de uma qualidade intrínseca a esses direitos, surgem as seguintes questões: se não existe qualidade intrínseca nos direitos individuais homogêneos,

791 ZACLIS, Lionel. A proteção coletiva dos investidores no mercado de capitais. São Paulo: Revista dos Tribunais, 2007, p. 217.

792 DINAMARCO, Cândido Rangel. A instrumentalidade do processo. 8 ed. rev. atual. São Paulo: Malheiros, 2000, p. 217.

793 VENTURI, 2007, p. 74-75.

794 ZAVASCKI, Teori Albino. Processo coletivo: tutela de direitos coletivos e tutela coletiva de direitos. 3 ed. rev. atual. e amp. São Paulo: Revista dos Tribunais, 2008, p. 56.

795 ZAVASCKI, 2008, p. 166. 
porque esses direitos individuais ditos homogêneos são aptos a alcançar os escopos processuais supramencionados e os demais direitos individuais, se coletivizados, não seriam aptos? E, mais, se esses direitos individuais homogêneos são apenas direitos individuais, sem qualquer qualidade intrínseca, como é possível identificá-los de forma a alcançar aqueles resultados?

Respondendo a essas perguntas, não é factível imaginar que apenas a origem comum possa definir o direito individual homogêneo. Um engavetamento de 40 carros, em um engarrafamento em São Paulo, apresenta uma origem factual e jurídica comum, mas não constitui um direito individual homogêneo. É preciso analisar a relação de cada uma das colisões, o que é heterogêneo. Nesse caso, a tutela coletiva apenas tumultuaria a controvérsia.

Para identificar os direitos individuais homogêneos, não é factível também que se possa mensurar o grau de economia, de efetividade ou de uniformidade processual para fins de identificar o que é homogêneo. Esses escopos são resultados do processo coletivo, não são anteriores ao processo para permitir ao intérprete identificar o que é coletivo ou o que não é.

É preciso, pois, de um critério intrínseco de direito substancial. Esse critério é a impessoalidade, a padronização, a objetivação da controvérsia deduzida em juízo. O direito individual homogêneo, embora fruível individualmente, é deduzido em juízo não segundo a qualidade pessoal do indivíduo, ele é deduzido pelo indivíduo, na qualidade de membro de um grupo.

Nesse caso, a impessoalidade, a objetividade ou homogeneidade são orientados pelo direito substancial. Como salienta Tucci ${ }^{796}$, é preciso analisar a "situação substancial" afirmada na relação jurídica de direito processual. Percebe-se, portanto, um nexo necessário entre direito substancial e processo, mesmos nas demandas relativas à direitos individuais homogêneos.

Como bem asseverou Kazuo Watanabe ${ }^{797}$, não se trata de uma relação jurídica base preexistente entre os indivíduos. Mas, como já se disse antes, os indivíduos vinculam-se entre si, mesmo que isso não tenha sido por eles escolhido. Eles são vítimas de uma prática abusiva, de um plano econômico ilícito, de uma política pública omissiva, e, assim, inserem-se em uma narrativa

796 TUCCI, José Rogério Cruz e. A causa petendi no processo civil. 3 ed. ver. atual. São Paulo: Revista dos Tribunais, 2009, p. 134.

797 WATANABE, 2011, p. 73. 
coletiva, mesmo que esse não tenha sido o destino por elas escolhido. Trata-se do solidarismo, do entrelaçar das histórias individuais e da vinculação estreita entre os indivíduos do grupo.

Pode-se dizer que os direitos individuais homogêneos, denominados também direitos de massa ou direitos repetitivos, são decorrentes da "individualização em massa" 798 das relações jurídicas. O grupo deixa de ser o refúgio do indivíduo e a norma jurídica passa assume o lugar de abrigo.

O grupo sai de cena, mas os atributos impessoais, indiferenciados, padronizados podem permanecer na norma jurídica, que se aplica agora, diretamente, ao indivíduo isolado. Isso, em uma sociedade de massa, é até mesmo potencializado, pois o consumo é padrão, a produção é padronizada, a propaganda é padronizada, a política pública é padronizada. E, partir disso, surgem demandas clones, cognatas, similares, principalmente, na tese jurídica sustentada.

Os direitos individuais homogêneos, os direitos de massa ou direitos repetitivos são diferentes, sim, dos direitos individuais clássicos. Eles continuam sendo individuais, pela titularidade e pela fruição, mas, diferentemente dos direitos individuais clássicos, não são pessoais e não exigem cognição artesanal. Muito pelo contrário, exigem solução padronizada, racionalizada.

Conclui-se que o critério da impessoalidade é a nota característica que perpassa pelos direitos difusos, coletivos stricto sensu e também pelos direitos individuais homogêneos. Revela, com isso, os atributos próprios dos direitos coletivos amplo em sentido amplo.

O reconhecimento de um atributo intrínseco aos direitos individuais homogêneos parecer ser a conclusão que melhor se adequa ao desenvolvimento histórico da litigiosidade de massa, mormente no período moderno com a "individualização em massa". De igual modo, mantém correlação com a perspectiva comparada traçada junto ao sistema estadunidense, que também reconhece atributos substanciais às class action for damages para a tutela do direito em juízo.

\subsubsection{RESPONSABILIDADES COLETIVAS}

798 ELIAS, 1994, p. 149. 
Nem só de direitos se faz o universo coletivo. Cada vez mais se fala em responsabilidades coletivas, em contratos coletivos, em planos de saúde coletivos, em seguros coletivos e, enfim, em deveres coletivos. O solidarismo, que é a marca contemporânea do sistema jurídico, está em vários aspectos do direito substancial e, por simetria, também no direito processual.

Hoje, no direito contratual, fala-se em transposição do atomismo para o coletivismo. Segundo Thomas Wilhelmsson ${ }^{799}$, o contrato não pode ser mais visto fora da realidade na qual ele se originou. O contrato deve ser visto de acordo com a sua base de formação, bem como de acordo com as interferências que produz na realidade. Com isso, fala-se em contratos repetitivos.

Judith Martins-Costa ${ }^{800}$ comenta essa interferência do contrato na esfera de terceiros e salienta a esfera transubjetiva do contrato, que decorre, principalmente, da interdependência das relações negociais. Um contrato atinge terceiros, criando deveres de abstenção ou, até mesmo, deveres promocionais para aqueles que não figuraram na relação jurídica. Nas palavras da autora, é válido ressaltar que:

[...] Essa eficácia transubjetiva do contrato tem variadas causas. Entre outras, o fato social da interdependência mediante formas de encadeamento do ciclo produtivo típicas da sociedade de consumo pós-industrial, como a formação de "redes negociais"; a necessidade de garantir a liberdade de concorrência por meio da imposição, a terceiros, do dever de respeitar pacto de não-concorrência; a crescente consciência acerca da importância da preservação ambiental, de modo a estender a responsabilidade pela segurança e garantia ambiental a toda a cadeia contratual [...]

Lembra-se, assim, dos casos antes narrados, do contrato de reajuste do aluguel do cortiço, do contrato de plano de saúde coletivo, em que as partes pretendem operar pelo status da categoria. No caso do cortiço, por exemplo, um contrato coletivo é medida até mesmo incentivada pela Lei Moura do Estado de São Paulo ${ }^{801}$, a fim de regular, extrajudicialmente, as relações plurissubjetivas presentes no cortiço: dono do cortiço vs. cortiçado vs. vizinhos do cortiçado.

799 WILHELMESSON, Thomas. Regulação de cláusulas contratuais. Tradutor Ronaldo de Porto Macedo. Revista de Direito do Consumidor. São Paulo: Revista dos Tribunais, V. 18, abril/junho, 1996, p. 9-12. No mesmo sentido, WILHELMSSON, Thomas. Contract and equality. In. WAHLGREEN, Peter (ed.). Legal theory. V. 40. Stockholm Institute for Scandinavian Law, 2000, p. 145-165.

800MARTINS-COSTA, Judith. "Zeca Pagodinho, a razão cínica e o novo Código Civil brasileiro", Disponível no :http://www.migalhas.com.br/dePeso/16,MI4218,101048-Zeca+Pagodinho+a+razão+cínica+e+o+novo+Codigo +Civil+Brasileiro. Acesso em 4 de dezembro de 2012.

801 BRASIL. São Paulo. Lei Moura. Lei 10.928/1991. São Paulo: Câmara Municipal, 1991. 
No mesmo sentido, Giselda Hironaka ${ }^{802}$ trata, por sua vez, da objetivação dos danos ou dos critérios de apuração do prejuízo, com fundamento no risco, o que também é mencionado no sistema jurídico estadunidense. O risco é, por excelência, impessoal e paritário entre todos.

Diante dessas modificações no direito material, reconhecendo a transubjetividade, o processo deve guardar igual simetria, admitindo também um procedimento transubjetivo ou coletivo.

\subsubsection{RELAÇÃO SUBSTANCIAL PLURISSUBJETIVA}

As relações plurissubjetivas não terminam, todavia, na categorização tricotômica. Entre os direitos difusos e os direitos individuais homogêneos surgem situações substanciais plurissubjetivas e complexas, não facilmente classificáveis nos conceitos antes explicitados.

\subsubsection{DEMANDAS PSEUDOINDIVIDUAIS}

$\mathrm{Na}$ realidade, as demandas pseudoindividuais, de alcance ou de valência coletiva e os diferentes graus de vinculação entre os membros do grupo, já foram expostos em capítulo anterior da tese. Importa agora situar esse raciocínio, especificamente no sistema jurídico brasileiro, e verificar as potenciais repercussões que essa categoria coloca, hoje, na técnica processual de agregação.

Para rememorar, demanda pseudoindividual é expressão inédita cunhada por Kazuo Watanabe ${ }^{803}$. Demandas pseudoindividuais são demandas que, por força da natureza da relação substancial, são incindíveis e não admitem pretensões atomizadas, pertinentes aos indivíduos.

Foram três os principais exemplos citados por Kazuo Watanabe ${ }^{804}$ como ilustrativos das demandas pseudoindividuais, a saber, a pretensão de anulação de deliberação assemblear da sociedade anônima, de cessação da poluição ambiental e a exclusão da tarifa de assinatura telefônica. Nos três casos, existem relações substanciais que não comportam fragmentação.

802 HIRONAKA, 2005, p. 279

803 WATANABE, 2007, p. 156.

804 Ibidem, p. 156-157. 
Ainda segundo Kazuo Watanabe ${ }^{805}$, o litisconsórcio unitário lança luzes adequadas para a correta compreensão da questão. Em todas essas situações, assim como ocorre no litisconsórcio unitário, as "posições jurídicas individuais se inserem na situação global" necessariamente, uniforme, sob pena de insubsistência da situação global antecedente.

Vincenzo Vigoriti ${ }^{807}$ também usa conceito similar ao mencionar a coordenação dos interesses em prol de um escopo comum, de forma que as posições individuais confluam no coletivo. $\mathrm{O}$ caso clássico, por ele citado, é também a hipótese de anulação de deliberação assemblear da sociedade anônima, pois a posições individuais confluem na situação substancial coletiva.

O argumento pela existência de demandas pseudoindividuais é, deveras, persuasivo. Até porque, como visto, o fenômeno mencionado não se restringe ao direito brasileiro. Os nomes mudam, mas o fenômeno é o mesmo. Lembra que, no sistema jurídico estadunidense, abordamse as denominadas ações coletivas de fato (de facto class action). São aquelas hipóteses em que a relação substancial é coletiva, embora a ação não tenha sido formalmente certificada como coletiva ou, ainda, naquelas hipóteses em que existam óbices legais à coletivização da ação.

No Brasil, por exemplo, a ausência de legitimidade individual para as ações coletivas (que é limitada à ação popular) é um dos óbices ao reconhecimento formal de uma ação coletiva de fato como uma ação coletiva de direito. O indivíduo propõe a ação em nome próprio, pois alega um prejuízo em sua esfera jurídica, mas o conflito processualizado é uniforme e incindível.

Nessas situações, não é raro que se inicie um jogo de estica e puxa entre os planos individual e coletivo. O réu insiste que uma demanda individual, com alcance coletivo, é simplesmente uma demanda coletiva e deveria ser proposta por um ente exponencial. $\mathrm{O}$ autor individual alega que, mesmo que a demanda apresente alcance coletivo, não é possível negar a existência de reflexos individuais da controvérsia coletiva em sua esfera jurídica. Em função desses reflexos individuais, não é admissível a restrição do acesso à justiça individual. Com isso, segue-se a multiplicidade de demandas individuais objetivamente idênticas e a inconsistência de julgados.

805WATANABE, 2007, p. 157. 806 MOREIRA, 1972, p. 143. 807 VIGORITI, 1979, p. 107-110. 
A solução para essa questão - o que ora se pondera - não passa pela redução do acesso à justiça ao indivíduo, tampouco passa pelo impedimento de ações individuais. Impõe-se é reconhecer o conteúdo coletivo e a repercussão coletiva da lide processualizada pelo indivíduo, de forma a torná-la uma candidata à técnica de agregação processual. Não importa o nomen iuris da demanda, tampouco quem a deduz em juízo, importa, sim, o conteúdo substancial coletivo.

É verdade que, como a ação coletiva é de fato e não de direito, o sistema processual encontra dificuldades para lidar com essa categoria. Justamente por isso, os processualistas do sistema estadunidense refletem, cada vez mais, sobre as técnicas de agregação processual, até mesmo por iniciativa oficial, como fenômeno mais amplo que as ações coletivas. Com isso, pretendese realizar uma prestação jurisdicional simétrica e ótima ao real contorno da relação substancial.

Vigoriti ${ }^{808}$ também salienta que não basta recorrer a princípios gerais para resolver o problema das ações autônomas e concorrentes. É preciso uma previsão específica para canalizar e harmonizar as iniciativas processuais. Isso porque a autonomia da posição individual, se isolada e se prevalecente, funcionará como fator de desagregação ou desintegração do escopo comum.

O mesmo raciocínio é coexistente ao direito brasileiro e já é aqui abordado: a necessidade de uma agregação simétrica e ótima à relação substancial, de forma a alcançar os escopos substancias (compensação e desestimulo à conduta lesiva ou abusiva) e os escopos processuais (efetividade, eficiência, economia processual e uniformidade nos provimentos jurisdicionais)

Mas, as semelhanças entre os sistemas não param por aí. É preciso voltar aos exemplos dados por Kazuo Watanabe. Veja que, no caso da deliberação assemblear e da cessação da poluição, a eficácia do provimento é constitutiva e mandamental. A indivisibilidade é prática, isto é, a pretensão anulatória e inibitória são insuscetíveis de divisão, até mesmo em quotas ideais.

O mesmo não ocorre no caso de exclusão da tarifa básica de assinatura telefônica. A indivisibilidade, nesse caso, não é prática ou insuscetível de divisão. Muito pelo contrário, ela é suscetível de divisão prática, tanto é que mais de 30.000 demandas individuais tramitavam no Juizado Especial de São Paulo. Todas pleiteando a exclusão da tarifa apenas para si. Mas, não

808 VIGORITI, 1979, p. 128. 
é possível deixar de perceber, nesse caso, uma espécie de incindibilidade. A relação substancial é, sim, incindível, mas o fundamento é outro: a paridade ou a igualdade da posição jurídica.

A incindibilidade é, assim, normativa. Ela decorre da própria ordem substancial estabelecida pela lei, que determinou uma estrutura tarifária uniforme para todos os usuários do serviço público, regulado pela Agência de Telecomunicações - ANATEL. A incindibilidade decorre da paridade ou da igualdade, que é o cerne da própria ordem jurídica. O instituto é paritário, por excelência. Se alterada a natureza paritária, o instituto tarifário público perde a sua natureza. ${ }^{809}$

Conclusão semelhante também existe no direito estadunidense. Nas ações coletivas por fundo pecuniário limitado, o fundamento da indivisibilidade é paridade dos credores. Mais recentemente, como já mencionado, Jay Tidmarsh e David Betson ${ }^{810}$ cunharam a expressão "sameness", que significa igualdade. A agregação não se limita às hipóteses de indivisibilidade prática, mas também alcança as situações de igualdade, que autorizam uma agregação ótima.

\section{Forçoso convir que a indivisibilidade não é apenas prática, a saber, situação em que o bem é insuscetível de divisão em quotas ideias. A indivisibilidade é também normativa, a saber, situação em que natureza jurídica do bem vida é, por força normativa, incindível, pois a ordem jurídica foi constituída de forma paritária e igualitária. Os feixes de interesse individuais podem se dividir, mas andam juntos ou emparelhados.}

Ao lado da indeterminação dos titulares, da indivisibilidade, é possível mencionar, de igual modo, a paridade ou a igualdade como nota característica dos direitos coletivos ou dos direitos pseudoindividuais ou direitos de alcance coletivo. Outro critério será mencionado adiante.

\subsubsection{DEMANDAS PSEUDOCOLETIVAS}

Demanda pseudocoletiva, mencionada por Luiz Paulo da Silva Araújo ${ }^{811}$, nada mais é do que a mera soma de demandas individuais. Se a demanda coletiva de direitos individuais homogêneos

809 No mesmo sentido: YARSHELL, Flávio. Brevíssimas reflexões a propósito da legitimidade passiva nas ações civis públicas envolvendo atividades sujeitas à regulação. In: Lucon, Paulo Henrique dos Santos (Coord.). Tutela Coletiva: 20 anos da Lei da Ação Civil Pública e do Fundo de Defesa dos Direitos Difusos e 15 anos do Código de Defesa do Consumidor. São Paulo: Atlas, 2006, 110 et seq.

810 TIDMARSH, BETSON, 2011, p. 546.

811 ARAÚJO, 2000, p. 114. 
for percebida como simples soma de demandas individuais, sem qualquer atributo substancial específico, ainda que a demanda coletiva seja julgada procedente, isso não avançará a solução da controvérsia e seguir-se-á uma série de pretensões particularizadas, pessoais e singulares.

Daí a importância no reconhecimento de atributos específicos aos direitos individuais homogêneos, como a predominância da questão comum e a superioridade da tutela coletiva.

\subsubsection{POR MAIS UM CRITÉRIO: A IMPESSOALIDADE}

Há um critério que é pouco mencionado e também não conta com previsão legislativa, mas é relevante para fins de identificação das situações substanciais suscetíveis de agregação processual. Trata-se do caráter impessoal da controvérsia substancial deduzida em juízo. Nessa hipótese, o indivíduo postula não como pessoa, mas na qualidade de membro de um grupo. Deduz em juízo não os seus atributos pessoais, mas os atributos do grupo, no qual se insere.

Trata-se, nas palavras de Barbosa Moreira $^{812}$, da posição individual que se insere homogeneamente na posição global. As características ou atributos pessoais são relevantes na lide processualizada pelo indivíduo, mas, sim, os atributos do próprio grupo na qual se insere.

Esse critério é relevante à medida que revela o potencial de fungibilidade dos membros do grupo, objeto do processo capítulo. Cada indivíduo pode ser parte e figurar, formalmente, em uma demanda, mas se os indivíduos são anônimos e se todos se inserem de forma uniforme e unitária na posição global, são eles fungíveis entre si, pois, em verdade, todos processualizam uma controvérsia impessoal. A controvérsia diz respeito aos atributos do grupo. Bastaria, portanto, apenas uma demanda para influenciar o magistrado sobre a causa coletiva proposta.

O contraditório pode ser ampliado de forma coletiva. A participação direta não é imperativa, pois não é a qualidade do indivíduo, enquanto pessoa, que terá o condão de avançar a resolução da controvérsia, mas, sim, os atributos do próprio grupo. O importante é conhecer os argumentos e as alegações que digam respeito à própria ordem coletiva ou à ordem do grupo. 
Esse critério nada tem de novo, no entanto. $\mathrm{Na}$ ação popular romana, a indivisibilidade não distinguia a ação popular da ação privada. $\mathrm{O}$ que as distinguia era a qualidade do indivíduo, autor da demanda popular. Era preciso saber se o indivíduo postulava como pessoa ou na qualidade de membro da coletividade romana para realizar essa distinção. O mesmo raciocínio ocorreu, a seu turno, nas ações coletivas medievais, marcadas pela impessoalidade. O indivíduo operava pelo status de aldeão, de paroquiano, de vassalo, de cavaleiro, de senhor feudal etc.

Mais tarde, com a redescoberta dos interesses ou direitos coletivos, houve aqueles que conceituaram direitos difusos e coletivos não apenas sobre o ponto de vista quantitativo, isto é, pela indivisibilidade, mas pela pelo critério qualitativo, ou seja, da qualidade impessoal do sujeito. Segundo Postiglione ${ }^{813}$, o meio ambiente constitui interesse difuso não somente sob o ponto de vista quantitativo, mas porque toca a pessoa como núcleo da relação homem-ambiente.

Esse critério é também fundamental para distinguir os direitos individuais homogêneos dos direitos individuais. Os direitos individuais são pessoais e exigem cognição artesanal. Os direitos individuais homogêneos são impessoais e admitem cognição padronizada da questão comum, embora, ao final, possam remanescer questões individuais a serem solucionadas.

\subsubsection{IDENTIFICAÇÃO DO INTERESSE OU DIREITO COLETIVO, DE ALCANCE COLETIVO E REPETITIVO E A AMPLITUDE DA COGNIÇÃO}

A partir dos critérios substanciais de agregação, dentre eles a indivisibilidade, a paridade e a impessoalidade, como identificar os direitos difusos, coletivos e individuais homogêneos, bem como os direitos de alcance coletivo? Muito bem, a questão é ainda controvertida na doutrina.

Há quem sustente que os direitos difusos, coletivos ou individuais homogêneos são identificados pela tutela jurisdicional pretendida pelo autor coletivo ${ }^{814}$. Assim, se a tutela pretendida for um provimento condenatório ao ressarcimento em pecúnia, tratar-se-ia de direito individual homogêneo. Se a eficácia do provimento for mandamental para compelir uma empresa a adotar uma medida preventiva de segurança em favor de seus funcionários, representados pelo sindicato da categoria, tratar-se-ia de um direito coletivo stricto sensu.

813 POSTIGLIONE, 1981, p. 69.

814 NERY, Nelson. Aspectos do processo civil no Código de Defesa do Consumidor. Revista de Direito do Consumidor. São Paulo: Revista dos Tribunais, V.1, mar./1992. 
Esse raciocínio é problemático, pois não há razão plausível para distinguir o tipo de direito pelo provimento pretendido, tampouco há razão para distinguir o regime de tratamento coletivo pela eficácia do provimento: se condenatório, declaratório, constitutivo, mandamental ou executivo.

Lembra-se que a autoridade da coisa julgada, conforme a doutrina liebmaniana ${ }^{815}$, é distinta da eficácia do provimento. Assim, destaca-se, a partir das lições de Barbosa Moreira ${ }^{816}$, que a autoridade da coisa julgada incide sobre o comando normativo do julgado e não sobre a eficácia do provimento pretendido. Coisa julgada e eficácia da sentença são independentes entre si.

No aspecto coletivo, é cediço que o regime de coisa julgada é diferente entre os direitos difusos/coletivos e os direitos individuais homogêneos. Ora, se esses direitos fossem identificados apenas pela tutela pretendida, por que razão a coisa julgada se alteraria conforme a tutela pretendida ou sua eficácia? Não é possível, portanto, identificar o tipo de direito coletivo pela tutela jurisdicional, sob pena de correlacionar a autoridade da coisa julgada à eficácia do provimento. Esse raciocínio já foi, há muito, superado por Liebman, no sentido de libertar a autoridade da coisa julgada de uma imprópria vinculação com a eficácia da sentença.

No mesmo sentido, José Roberto dos Santos Bedaque ${ }^{817}$ critica esse posicionamento, pois, como já consignado, o direito substancial é anterior ao processo. O processo não poderia definir ou identificar o direito substancial, pois o direito substancial detém anterioridade lógica no sistema.

Para identificar os direitos coletivos em sentido amplo, portanto, é preciso de outro ponto referencial, que não exclusivamente a tutela jurisdicional pretendida no âmbito processual.

É bem verdade que a tutela jurisdicional pretendida pode funcionar como um indício do tipo de direito coletivo, a exemplo do sistema jurídico estadunidense, mas não o define em abstrato.

Se a tutela for declaratória e, portanto, indivisível, há indícios de que o direito seja difuso ou coletivo. Mas, é preciso investigar se essa tutela é pretendida com fundamento aplicável ao grupo como um todo ou se é pretendida por força de uma relação jurídica pessoal, como a

815 LIEBMAN, 2007, p. 50-52.

816 MOREIRA, 1971, p. 145.

817 BEDAQUE, 2007, p. 39. 
relação de vizinhança, por exemplo. Se a tutela for pretendida com fundamento no grupo como um todo, se ela for, além de indivisível, também impessoal, trata-se de um direito coletivo.

Se a tutela for ressarcitória e, portanto, divisível, há indícios de que o direito seja individual. Mas é preciso investigar se a tutela é pretendida com fundamento em uma relação pessoal ou com fundamento em uma relação substancial paritária do grupo como um todo, cujo objeto de cognição são os atributos da própria categoria que integra a parte autora. Se a relação substancial for paritária e também impessoal, o direito divisível tem um alcance coletivo.

Sob esse aspecto, como apontam Barbosa Moreira ${ }^{818}$ e Kazuo Watanabe ${ }^{819}$, o eixo de referência é a sempre a relação substancial, que foi processualizada. É preciso atentar para a forma como a controvérsia foi deduzida em juízo. E, assim, a partir da causa de pedir e do pedido, podese fixar a amplitude da demanda. Nas palavras de Watanabe 820 , "é necessário fixar com precisão os elementos objetivos da ação coletiva a ser proposta (pedido e causa de pedir). Esses dados, como é cediço, tem superlativa importância [...] na correta fixação da abrangência da demanda".

Justamente por isso, o que importa é a relação substancial (bem da vida) e o resultado prático perseguido, apurados conforme a controvérsia deduzida em juízo. São os critérios substanciais - indivisibilidade, impessoalidade e paridade - compreendidos na causa de pedir e no pedido, que identificam os direitos coletivos, tornando-os candidatos à técnica de agregação processual. Não é a tutela processual pretendida, não é o nomen iuris do direito (consumidor, contrato etc), tampouco é quem postula em juízo que identificam o direito e que autorizam o manejo das técnicas de agregação processual.

Lembra-se do caso do concurso público, que é uma relação substancial paritária e impessoal, por excelência. Se o candidato pleitear a anulação de uma questão da prova objetiva por inobservância do edital e, com isso, o prosseguimento no certame, não há dúvidas da abrangência coletiva da demanda. A cognição, relativa ao objeto indivisível, é principaliter na lide. Mas, e se o candidato aduzir a invalidade de forma incidenter tantum, apenas na causa de pedir, e depois, no pedido, pleitear os pontos dessa questão da prova apenas para si e o prosseguimento no certame, esse também seria um caso de alcance ou abrangência coletiva?

818 MOREIRA, 1972, p. 145. 
Não há dúvidas que sim, seria um caso de abrangência coletiva. O bem da vida perseguido e a o resultado prático pretendido são os mesmos nos dois casos, seja a cognição sobre a invalidade da questão principaliter, seja a cognição sobre a invalidade da questão incidenter tantum. No primeiro caso, a indivisibilidade é prática, pois todos serão alcançados pela anulação ou pela declaração de validade da questão da prova objetiva do concurso público. No segundo caso, a indivisibilidade é normativa, pois a relação substancial é paritária e impessoal. Como a concorrência no concurso público deve ser igual para todos, de acordo com o edital, ou a invalidade da questão da prova objetiva e os pontos da questão são conferidos a todos ou a nenhum candidato. Do contrário, sobreviria a desequiparação dos candidatos, esfacelando-se a própria natureza do concurso público, que é escolher o candidato mais preparado no concurso.

Não é possível permitir que a parte autora defina, estrategicamente ${ }^{821}$, a estrutura subjetiva do processo apenas pela forma como deduz o seu pedido, de forma a afastar a agregação processual. Se a parte pedir a anulação da questão, a paridade entre todos os candidatos é mantida. Se a parte pedir os pontos da questão, que é o resultado prático equivalente ao reconhecimento da invalidade da questão, a paridade é esfacelada. Ora, isso não é admissível, pois a relação substancial é a mesma, a paridade é a mesma e o resultado prático é o mesmo. Logo, não basta atentar-se para o pedido. Para identificar a amplitude da relação substancial repete-se - deve-se olhar para a causa de pedir e para o pedido e não só para a tutela pretendida.

Nesse aspecto, não é possível liminar a noção de incindibilidade ou de comunhão relativamente à lide (expressão adotada nas hipóteses de litisconsórcio) para casos de cognição principaliter.

Cândido Rangel Dinamarco ${ }^{822}$ assinala que, na hipótese de comunhão de direitos relativamente à lide, é importante que os direitos e as obrigações dos titulares estejam postos no centro da demanda para serem objeto de cognição principaliter e não incidenter tantum. Exemplo: se um contrato é colocado no centro da cognição, com pedido de anulação ou declaração de nulidade, haverá comunhão. Se a invalidade é incidental, não haveria comunhão relativamente à lide.

821 Sobre a tentativa de "camuflar" identidade jurídica, conferir: ARRUDA ALVIM, José. Ensaio sobre a litispendência no Direito Processual Civil II. São Paulo: Revista dos Tribunais, 1970.

822 DINAMARCO, 2009, p. 346. 
No processo coletivo, esse raciocínio deve ser mitigado. É preciso atentar-se também para as questões controvertidas deduzidas incidenter tantum, mas que, pela causa de pedir e pedido, permitam identificar uma relação substancial de amplitude coletiva, suscetível à agregação processual. Isso porque, repete-se, a incindibilidade, a impessoalidade e a paridade não são determinadas pela tutela pretendida, ela é resultante da própria relação substancial coletiva.

A tutela pretendida pode ser um indício a auxiliar o intérprete na identificação da substância, mas, por si só, não é suficiente. Importa é o caráter do direito substancial deduzido em juízo.

Aqui, há que se ter cuidado, ainda, com a amplitude da cognição. É preciso aferir se a cognição está centrada nos atributos do grupo ou nos atributos singulares de um indivíduo. Sob esse ângulo, um direito divisível pode ter um alcance coletivo, na hipótese em que a controvérsia deduzida em juízo incidir sobre os atributos do próprio grupo e não sobre os atributos pessoais.

A cognição, segundo Kazuo Watanabe ${ }^{823}$, é "prevalentemente um ato de inteligência, consistente em considerar, analisar e valorar as alegações e as provas produzidas pelas partes vale dizer, as questões de fato e as de direito que são deduzidas no processo e cujo resultado é o alicerce, o fundamento do iudicium, do julgamento do objeto litigioso do processo". É sobre esse alicerce cognitivo que o procedimento é desenhado e que a demanda é julgada na sentença.

Valendo desse conceito, pode-se dizer que existem situações em que o indivíduo deduz uma controvérsia relativa a um bem divisível, mas o centro de cognição em juízo não são os atributos pessoais desse sujeito, mas, sim, os atributos do próprio grupo a que ele pertence. Embora o indivíduo pudesse atuar pessoalmente, esse indivíduo opera como um anônimo, na qualidade de membro de uma categoria. Nesse contexto, o que vai ser valorado, analisado, comprovado diz respeito à situação global de um grupo, no qual o indivíduo pretende inserir-se como mero anônimo, em situação de paridade e impessoalidade aos demais interessados de um grupo.

Essas são as situações de upstream e de downstream ou de força centrípeta e força centrífuga, de que se tratou antes tanto em relação ao sistema jurídico estadunidense, quanto ao brasileiro.

823 WATANABE, 2012, p. 62. 
Nessas duas hipóteses, a vinculação entre os membros do grupo pode ser potencialmente mais forte (com força centrípeta/upstream) ou potencialmente mais fraca (com força centrífuga/ downstream), de forma que a controvérsia incide, no todo ou em parte, nos atributos do grupo.

Se essas duas categorias fossem classificadas, seriam consideradas direitos individuais homogêneos, força do conceito legal que identifica a divisibilidade como nota característica. Mas, o fato é que há um hibridismo, mormente na cognição realizada nesses casos, o que implica diferentes repercussões processuais e, por essa razão, exige um maior cuidado.

A mesma atenção com a causa de pedir e pedido deve se ter em relação às situações antes identificadas como de força centrípeta (upstream) e centrífuga (downstream). Nesse caso, não há indivisibilidade prática, tampouco a paridade é determinada clara e expressamente por uma norma jurídica, mas os contornos da relação substancial, deduzida em juízo, podem revelar uma situação potencialmente paritária e objetiva, bem como impessoal aos membros de um grupo.

No primeiro caso, de força centrípeta, a controvérsia processualizada diz respeito aos atributos do próprio grupo e a metodologia de compensação individual é paritária, proporcional ou pro rata para os membros do grupo, sendo forçoso reconhecer a amplitude coletiva da controvérsia.

Não são necessárias várias demandas individuais para discutir o reajuste de um contrato coletivo, para discutir uma prática abusiva ou uma política pública, pois essas controvérsias não dizem respeito ao indivíduo como pessoa e não exigem cognição singularizada sobre cada indivíduo. Até mesmo a quantificação pode ser padronizada e calculada administrativamente. Enfim, embora não exista indivisibilidade prática ou normativa expressa, a relação substancial deduzida em juízo pode ser objetiva, idêntica, impessoal e os indivíduos podem se inserir na controvérsia como anônimos: uma mera inserção da posição individual na situação global.

Nesse caso, o pedido é individualizado, cada um pede para si. Mas, a questão é que a cognição não é singularizada, tampouco a quantificação. São os atributos do grupo que definem a responsabilidade e, posteriormente, uma fórmula padrão permite a quantificação individual. $\mathrm{O}$ cumprimento ou a satisfação individual é mecânica, decorre da simples aplicação da fórmula.

O mesmo raciocínio se aplica no segundo caso, denominados de força centrífuga. A controvérsia processualizada diz respeito, ao menos em parte, aos atributos do próprio grupo, 
remanescendo questões individuais. Se a questão comum, relativa à responsabilidade, for cindível da questão da compensação individual, a resolução da questão comum avançará a solução da controvérsia em relação a todos os membros do grupo, sem implicar posterior rediscussão no caso individual. É importante que a questão comum seja autônoma, permanente, que não seja cambiante de acordo com as características individuais, pessoais ou singulares.

Lembra-se do caso da venda casada, antes mencionado no sistema estadunidense. Todos os indivíduos interessados alegam a existência de uma prática abusiva de venda casada, com fundamento aplicável ao grupo como um todo. Resolvida a questão comum, a respeito da existência e da responsabilidade pela venda casada, cada indivíduo poderá obter, na liquidação da sentença, o ressarcimento pelos produtos que adquiriu, sem mais rediscutir a prática ilícita. A solução da controvérsia coletiva avançou a solução individual, mantendo a estabilidade e a permanência da sentença genérica. O objeto da liquidação é apenas a quantificação do prejuízo decorrente da venda casada, seguida, da compensação individual devida aos membros do grupo.

Novamente, nesse segundo caso, não são necessárias múltiplas demandas individuais para discutir a prática abusiva, pois essa prática não diz respeito a cada indivíduo em si, mas foi realizada coletivamente. E mais, por vezes, a valência coletiva é tão forte, que até mesmo a prova é coletiva. Isso ocorre, conforme exemplo já dado, quando a prática abusiva é silenciosa.

Exemplo: a prática da venda casada não conta com previsão no contrato individual, mas todo o grupo realizou, estranhamente, um negócio jurídico antieconômico e adquiriu bens de valores superiores ao valor de mercado. Nesse caso, não há indivisibilidade, mas todos os indivíduos se reportam a uma situação unitária, uniforme e impessoal - a prática abusiva aplicada com fundamento no grupo como um todo -, para, depois, demonstrarem a situação particularizada. Nesse caso, o indivíduo coloca-se, de início, como um anônimo na controvérsia deduzida.

Por fim, nos direitos individuais homogêneos clássicos, repetitivos ou de massa, não há a valência coletiva que se comentou anteriormente. O indivíduo não precisa fazer referência ao grupo, pois ele possui todos os elementos que autorizam a judicialização da controvérsia de massa apenas para si. Mas, há uma coincidência entre os atributos do indivíduo e os atributos 
do grupo, como se fosse uma "individualização em massa" Enfim, nessa última categoria, ainda persiste a impessoalidade ou a ausência de singularidade.

As demanda clones, cognatas, repetitivas também são suscetíveis à agregação processual, mormente em razão da repetição da mesma tese jurídica, que toca a todos de forma impessoal.

Mas, de igual modo, a ação coletiva somente será adequada se a questão comum, que pode ser de fato ou de direito, avançar a resolução de cada um dos casos individuais, sem implicar a rediscussão da sentença genérica. Se houver essa rediscussão da sentença genérica nos casos individuais, a liquidação será providência tão complexa quanto à ação individual condenatória, sem avançar a resolução individual e, ainda, corre-se o risco de tumultuar a ação coletiva.

Nessa hipótese, pode ser adequada também outra técnica de agregação, como o caso-teste, em que é fixada uma tese jurídica comum, reproduzível nos casos similares. As demandas individuais continuam pulverizadas, mas a elas é dado um provimento unitário e coerente.

Para finalizar esse tópico, conclui-se que, em todas essas espécies de demandas, identifica-se um alcance coletivo ou, ao menos, uma individualização em massa da controvérsia, de forma a torná-la uma candidata à agregação processual. E, em todas, é possível uma agregação ótima.

A agregação é ótima, pois a técnica processual é necessária, isto é, menos gravosa ou restritiva aos direitos individuais. Somente serão agregadas as questões fáticas e/ou jurídicas comuns, isto é, as questões incindíveis, paritárias, objetivas e impessoais, que não exigiriam cognição artesanal ou singular em juízo. A história individual e pessoal escapa à agregação processual.

A agregação é ótima, pois também é adequada e idônea à concreção do direito substancial. A técnica de agregação será idônea para atuar o direito substancial de valência coletiva ou de massa, alcançando economia, efetividade e uniformidade nos provimentos judiciais. É imperativo ressaltar que, no juízo de adequação, o design procedimental deve-se adequar aos contornos do direito substancial e ao grau de vinculação existente entre os membros do grupo.

824 ELIAS, 1994, p. 149. 
Além das categorias difuso, coletivo e individual homogêneo, é preciso lembrar da escalada de coletivização já antes mencionada. A relação substancial pode apresentar os seguintes atributos:

(i) Indivisível e impessoal, o que é tipicamente difuso ou coletivo. São as demandas de cessação da poluição ambiental, de anulação de ato lesivo ao patrimônio público etc. O resultado tende a ser binário (0 ou 1), ou cassa ou não cessa, anula ou não anula.

(ii) Indivisível e potencialmente impessoal, o que é tipicamente difuso ou coletivo. São, principalmente, as demandas mandamentais estruturais que veiculam uma obrigação de fazer aplicável ao grupo todo. Nesse caso, a própria ordem institucional ou jurídica é objeto de reformulação. Essas demandas são, potencialmente, impessoais, pois, por vezes, cada indivíduo tem uma concepção diferente sobre como deveria ser essa nova ordem, mas isso não muda o fato de que a ordem é unitária. São exemplos a reformulação do sistema escolar, prisional ou de saúde de um Estado. Trata-se de alteração da própria prática privada ou da política pública conflituosa.

(iii) Indivisível normativamente (paritária) e impessoal, o que é tipicamente difuso ou coletivo. São demandas em que a própria ordem jurídica, por meio de um comando normativo expresso, estabelece a incindibilidade ou a paridade e a impessoalidade. São as hipóteses da massa falida, do concurso público, de uma controvérsia envolvendo a uma licitação multitudinária, da tarifação de um serviço público etc.

(iv) Potencialmente paritária e potencialmente impessoal, de forma fraca (centrífuga) ou forte (centrípeta). Em função da divisibilidade e por força do conceito legal, essas espécies podem ser enquadradas como direitos individuais homogêneos. Contudo, são situações limítrofes ou híbridas. Não há nenhuma regra ou comando normativo determinando a paridade e a impessoalidade da relação substancial existente entre os membros do grupo. Mas, os contornos da relação substancial revelam, de forma mais forte ou mais fraca, a paridade e a impessoalidade entre os membros do grupo. No sistema jurídico estadunidense, quando a potencialidade é forte e a controvérsia encontra-se à montante do grupo (upstream), sendo o ressarcimento em pecúnia meramente incidental à questão da responsabilidade, a demanda pode ser certificada como uma ação coletiva híbrida. Certifica-se na categoria 23 (b)(2) - injunctive class action or declaratory class action - e não na categoria 23(b) (3) - nas class 
action for damages ou na nossa ação coletiva para direitos individuais homogêneos. A satisfação individual é decorrente de uma fórmula uniforme aplicável ao grupo.

(v) Homogênea, repetitiva ou de massa, o que é tipicamente o direito individual homogêneo, pois o direito é divisível e apresenta uma origem comum e impessoal.

\subsubsection{O QUE AGREGAR? COMO AGREGAR?}

O que agregar? Podem ser agregadas as demandas coletivas, as demandas individuais de alcance coletivo e as demandas de massa ou repetitivas, conforme a escalada de coletivização.

O design procedimental deve se adequar aos contornos da relação substancial. Não se trata de propor uma forma livre, um processo transprocedimental, mas, sim, de adaptar o procedimento à natureza da relação substancial e ao grau de vinculação presente entre os membros do grupo. ${ }^{825}$

Quanto mais forte o vínculo, mais forte é a possibilidade em se adotar uma técnica de agregação que defina tanto à responsabilidade, quanto à metodologia de compensação individual ou, ao menos, que avance à solução da controvérsia individual, sem rediscussão da questão comum. Esse é o caso da ação coletiva ou da consolidação ou coordenação das demandas individuais para resolução unitária ou conjunta da lide. Pode-se seguir, até mesmo, a liquidação coletiva. Evita-se, com isso, até mesmo futuros processos individuais com relação à controvérsia.

Quanto menos forte o vínculo, mais forte é a necessidade de se adotar uma técnica de agregação que resolva o ponto controvertido comum, sem dispensar, porém, os processos individuais. Como o vínculo é, aqui, menos forte, pode ser que a agregação não avance essencialmente a resolução da controvérsia individual. O importante é, então, buscar construir, pela técnica de agregação, uma amostra representativa da controvérsia que, posteriormente, se reproduza nos processos individuais. A técnica de agregação, nesse caso, também pode ser a consolidação da controvérsia, bem como um caso-teste e representativo para fixação da tese normativa comum.

825 Carlos Alberto de Salles salienta a necessidade de o processualista realizar, mais do que a aplicação de normas procedimentais, mas deter a capacidade de construir arranjos ou desenhos procedimentais aptos a atender às necessidades de situações de grande especificidade. (Cf. SALLES, 2011, p. 24). 
Nesse aspecto, vale citar Ada Pellegrini Grinover ${ }^{826}$ ao mencionar que os esquemas do processo civil individual são, por vezes, usados para a tutela coletiva. Esse é a hipótese do caso-teste, que parece melhor se adequar às hipóteses dos direitos individuais homogêneos e não coletivos.

Lembra-se que, no caso-teste e na consolidação, várias demandas individuais serão ajuizadas, distribuídas e autuadas para, depois, serem suspensas ou parcialmente agrupadas para fins de resolução conjunta e unitária da controvérsia. O gasto é maior, o esforço é maior, o gerenciamento dos processos, no cartório e no gabinete do magistrado, exigem maior atenção.

Por isso, essas técnicas devem ser reservadas para as hipóteses em que realmente os processos individuais são necessários para resolver questões singulares ou pessoais. Se houver um vínculo mais forte e mais estreito entre os membros do grupo, a agregação ótima será melhor realizada pela ação coletiva. Isso porque a resolução da questão comum tenderá a avançar, integral ou substancialmente, a solução do caso individual, quiçá, até suprimindo os processos individuais.

\subsubsection{PROJETOS DE LEI E CASOS DE AGREGAÇÃO DE LEGE LATA}

A discussão doutrinária sobre os processos coletivos no sistema jurídico brasileiro é bastante farta e aprofundada. Mas, além das ações coletivas, são ainda escassos os resultados legislativos em prol de um sistema de agregação ou de molecularização das controvérsias de massa.

O sistema brasileiro foi pioneiro e um estruturou um processo coletivo inédito. Mas, o fato é que as controvérsias de massa continuam sendo deduzidas e resolvidas individualmente, mesmo que possam ser consideradas ações coletivas de fato ou demandas pseudoindividuais. Urge, há tempos, técnicas de agregação ou de molecularização que permitam o reconhecimento formal dessas controvérsias de amplitude coletiva ou massificadas no sistema processual brasileiro.

Essa busca pelo aperfeiçoamento da "molecularização" é briga antiga dos processualistas brasileiros. Várias são as propostas pela modificação do microssistema coletivo e, até mesmo, pela adoção de um Código Brasileiro de Processos Coletivos, necessário para sistematizar o processo coletivo. Essas propostas e alguns casos de coletivização serão mencionados a seguir.

826 GRINOVER, 2008, p. 236. 


\subsubsection{ANTEPROJETO DE MODIFICAÇÃO DO CÓDIGO DE PROCESSO CIVIL DE 1985}

Trata-se de anteprojeto de modificação do Código de Processo Civil apresentado, já nos idos de 1985, pela Comissão de Juristas, composta por Luís Antônio de Andrade, José Joaquim Calmon de Passos, Kazuo Watanabe, Joaquim Correa de Carvalho Júnior e Sergio Bermudes ${ }^{827}$.

Esse projeto já anunciava um "incidente de molecularização da controvérsia", sendo que a questão comum decidida seria dotada, inclusive, da imutabilidade própria da autoridade da coisa julgada coletiva. Cita-se, inicialmente, trecho da exposição de motivos dada pela Comissão de Juristas:

[...] na uniformização de jurisprudência, criou-se uma figura nova, com vistas a simplificar o julgamento de várias causas, nas quais haja identidade de autor ou de réu, quando forem afins, por versarem a mesma tese jurídica a ser decidida. A prévia fixação do entendimento da tese comum ensejará o julgamento harmonioso dos vários litígios, prevendo-se, ainda, a eficácia da coisa julgada no tocante ao ponto decidido, obstando-se à reiteração de idênticas demandas. Isso se fez, contudo, sem sacrifício da segurança da parte comum a todos os feitos, visto como se previu ação revisional, como possibilidade de reexame da matéria para casos futuros $[\ldots]^{828}$

O texto legislativo, que inclui o referido incidente de molecularização da controvérsia, assim dispõe:

[...] Art. 479-A. Quando, contra a mesma parte, estiverem em curso várias demandas que envolvam a mesma tese jurídica, qualquer juiz, ao dar o voto na turma, poderá propor se promova a reunião dos processos relacionados por afinidade, obtendo-se o pronunciamento prévio, do tribunal ou do órgão competente, sobre o ponto comum de direito.

Parágrafo único. Igual procedimento é admitido quando a parte comum às várias demandas for a parte autora.

Art. 479-B. Deferida a reunião, as partes terão o prazo comum de trinta (30) dias para o oferecimento de memoriais sobre a tese jurídica, após o que, no prazo improrrogável de dez (10) dias, será ouvido o Ministério Público, designando o presidente do Tribunal ou do órgão competente dia para o julgamento.

$\S 1 .^{\circ}$ A secretaria providenciará, com antecedência, a distribuição a todos os julgadores de cópias das peças indicadas pelo relator.

§2. ${ }^{\circ}$ A decisão, tomada pelo voto da maioria absoluta dos membros que integram o tribunal ou órgão competente, será objeto de súmula, fixando o entendimento a ser observado, pelas turmas julgadoras, em todos os processos reunidos.

827 BRASIL. Código de Processo Civil. 7 ed. Atualizador Sálvio de Figueiredo Teixeira. Rio de Janeiro: Forense, 1986 , p. 682.

828 Ibidem, p. 678. 
Art. 479-C. A parte comum a todos os processos não poderá, em casos futuros, nem como autora, nem como ré, pleitear em sentido em contrário ao que foi sumulado, salvo haja obtido, em processo revisional, a modificação do decidido.

Art. 479-D. A ação revisional será da competência originária do tribunal ou órgão competente que fixou a decisão sumulada $[\ldots]^{829}$

O projeto é de vanguarda. Recentemente, uma proposta de incidente de molecularização ou de resolução de demandas repetitivas voltou, em boa hora, a tomar força no direito brasileiro.

\subsubsection{CÓDIGO MODELO DE PROCESSOS COLETIVOS PARA ÍBERO-AMERICA}

Trata-se de um Código Modelo de Processos Coletivos para Iberoamérica, datado de 2004, elaborado pelo Instituto Ibero-americano de Direito Processual. Esse código foi inspirado, principalmente, na experiência legislativa brasileira, bem como na experiência estadunidense. ${ }^{830}$

Esse projeto foi fruto, inicialmente, do trabalho dos juristas Ada Pellegrini Grinover, Kazuo Watanabe e Antônio Gidi, no sentido de orientar os países membros nas técnicas e tendências dos processos coletivos, permitindo um intercâmbio de experiências. Trata-se, assim, de um modelo, a inspirar reformas e também adaptações às peculiaridades locais dos seus membros. ${ }^{831}$

São vários os dispositivos inovadores do código modelo. Mas, para os propósitos da presente investigação, é importante ressaltar alguns dispositivos do referido projeto em que destacam técnicas de agregação processual: o projeto reconhece (i) a necessidade de aferição da predominância das questões comuns sobre as individuais e da utilidade da tutela coletiva no caso concreto; (ii) a legitimação da pessoa física e do membro do grupo, categoria ou classe para a defesa dos interesses difusos, coletivos e individuais homogêneos de que seja titular o grupo de pessoas; (iii) a aferição judicial da representatividade adequada; (iv) em caso de inexistência do requisito da representatividade adequada, de desistência infundada ou abandono da ação pela pessoa física, a possibilidade de notificação do Ministério Público e, na medida do

829 BRASIL. Código de Processo Civil. 7 ed. Atualizador Sálvio de Figueiredo Teixeira. Rio de Janeiro: Forense, 1986, p. 691.

830 BERIZONCE, Roberto, GRINOVER, Ada Pellegrini e SOSA, Angel Landoni. Exposição de motivos do Código Modelo de Processos Coletivos para Ibero-América. In: GRINOVER, Ada Pellegrini. MENDES, Aluísio Gonçalves de Castro, WATANABE, Kazuo. Direito processual coletivo e o anteprojeto de Código Brasileiro de Processos Coletivos. São Paulo: Revista dos Tribunais, 2007, p. 422-423. No mesmo sentido: MENDES, Aluísio Gonçalves de Castro Mendes. O Código Modelo de Processos Coletivos. In: LUCON, Paulo Henrique dos Santos. Tutela Coletiva: 20 anos da Lei da Ação Civil Pública e do Fundo de Defesa de Direitos Difusos e 15 anos do Código de Defesa do Consumidor. São Paulo: Atlas, 2006, p. 33 et seq.

831 Ibidem, p. 422-423. 
possível, de outros legitimados coletivos adequados para o caso, a fim de que assumam a ação; (v) a certificação da ação como coletiva, determinando o seu prosseguimento; (vi) o cálculo do valor da indenização individual sempre que possível na própria sentença genérica da ação coletiva; (vii) quando o valor dos danos individuais for uniforme ou puder ser reduzido a uma fórmula matemática, a sentença coletiva indicará o valor ou a fórmula de cálculo da indenização individual; (viii) o membro do grupo, ao considerar ser diverso o valor da indenização individual ou da fórmula para seu cálculo, poderá propor a ação individual de liquidação; (ix) o juiz, tendo conhecimento da existência de diversos processos individuais contra o mesmo demandado, pelo mesmo fundamento, poderá notificar o Ministério Público ou, na medida do possível, outros legitimados coletivos, a fim de que, querendo, proponham ações coletivas; (x) são admitidas as provas estatísticas e por amostragem no processo coletivo. É válido, por sua vez, transcrever os dispositivos que prescrevem as providências e diligências supracitadas:

Art $2^{\circ}$. Requisitos da ação coletiva - São requisitos da demanda coletiva: I - a adequada representatividade do legitimado; II - a relevância social da tutela coletiva, caracterizada pela natureza do bem jurídico, pelas características da lesão ou pelo elevado número de pessoas atingidas. Par. $1^{\circ}$. Para a tutela dos interesses ou direitos individuais homogêneos, além dos requisitos indicados nos n. I e II deste artigo, é também necessária a aferição da predominância das questões comuns sobre as individuais e da utilidade da tutela coletiva no caso concreto [grifo nosso]

Art. $3^{\circ}$. Legitimação ativa. São legitimados concorrentemente à ação coletiva: I qualquer pessoa física, para a defesa dos interesses ou direitos difusos de que seja titular um grupo, categoria ou classe de pessoas ligadas por circunstâncias de fato; II - o membro do grupo, categoria ou classe, para a defesa dos interesses ou direitos difusos de que seja titular grupo, categoria ou classe de pessoas ligadas entre si ou com a parte contrária por uma relação jurídica base e para a defesa de interesses ou direitos individuais homogêneos; [grifo nosso]

Art. 12. Provas - São admissíveis em juízo todos os meios de prova, desde que obtidos por meios lícitos, incluindo a prova estatística ou por amostragem. [grifo nosso]

Art. 22. Sentença condenatória - Em caso de procedência do pedido, a condenação poderá ser genérica, fixando a responsabilidade do demandado pelos danos causados e o dever de indenizar. Par. $1^{\circ}$. Sempre que possível, o juiz calculará o valor da indenização individual devida a cada membro do grupo na própria ação coletiva. Par. $2^{\circ}$. Quando o valor dos danos individuais sofridos pelos membros do grupo for uniforme, prevalentemente uniforme ou puder ser reduzido a uma fórmula matemática, a sentenca coletiva indicará o valor ou a fórmula de cálculo da indenização individual. Par. $3^{\circ}$. 0 membro do grupo que considerar que o valor da indenizacão individual ou a fórmula para seu cálculo é diverso do estabelecido $\underline{\text { na sentença coletiva, poderá propor ação individual de liquidação. }}$ [grifo nosso] ${ }^{832}$ 
O projeto tem muitas inovações interessantes, mormente, para viabilizar a agregação processual. Em primeiro lugar, há o reconhecimento da legitimidade da pessoa física para os direitos difusos, coletivos e individuais homogêneos. Esse reconhecimento é fundamental para a coletivização de demandas individuais. Do contrário, se uma demanda de alcance coletivo for proposta por um indivíduo e não for possível o reconhecimento ou a certificação formal dessa ação individual como ação coletiva, o sistema processual padecerá de incoerências graves. Além da multiplicidade de processos individuais, é possível ainda o conflito prático de julgados.

O reconhecimento legislativo dos requisitos da predominância das questões comuns e da utilidade da ação coletiva permite, ainda, vislumbrar atributos próprios e autônomos à categoria dos direitos individuais homogêneos, distinguindo-a dos direitos subjetivos clássicos.

Quando o Código menciona o cálculo objetivo da indenização para os membros do grupo, em razão da uniformidade dos danos individuais ou da existência de uma fórmula matemática, há, ainda, implicitamente, o reconhecimento das situações de upstream ou de força centrípeta. A uniformidade decorre do fato de a controvérsia incidir sobre os atributos do próprio grupo e não sobre os atributos pessoais. Por essa razão, a compensação individual dispensa cognição particularizada, sendo passível de cálculo uniforme ou fórmula de cálculo padrão ou objetivo.

A admissão da prova estatística ou por amostragem reforça essa conclusão, pois esses métodos de prova permitem extrapolação estatística, isto é, inferir a posição individual a partir de uma amostra representativa da controvérsia do grupo. O indivíduo insere-se no universo coletivo.

Por fim, na hipótese de o indivíduo considerar o valor da indenização e a fórmula de cálculo insuficientes, pela diversidade do seu caso concreto, ele poderá propor ação de liquidação individual, nos termos do Código Modelo. Embora o Código não mencione, é preciso ponderar, nesse ponto, pelo cumprimento de um ônus argumentativo pelo indivíduo demonstrando a pessoalidade ou a singularidade da sua situação ou, até mesmo, uma nova dimensão da controvérsia antes deduzida. Exemplo, o indíviduo poderia argumentar que um determinado ponto da controvérsia não foi deduzido por ocasião da ação coletiva, de forma que não houve o exercício do contraditório sobre esse âmbito. Enfim, o indíviduo deve demonstrar uma singularidade ou uma nova dimensão da controvérsia, que não foi deduzida anteriormente. 
Vale salientar que, como já explicitado antes, na legislação de British Columbia, a exclusão é condicionada, cabendo ao indivíduo justificar o seu pedido de exclusão para que seja autorizado pelo magistrado. A autoexclusão condicionada também é comentada no sistema estadunidense.

Se o indivíduo limitar-se a repetir a mesma causa de pedir, o mesmo pedido, com a mesma dimensão cognitiva, não haveria razão para aplicar-lhe fórmula de cálculo diferente ou um valor indenizatório diverso dos demais membros do grupo. Afinal, se ele continua a atuar como um anônimo, subsumindo-se aos atributos do grupo, não seria admissível aplicar fórmula diversa.

O mesmo ocorre se uma ação individual for proposta paralelamente à ação coletiva, na mesma hipótese narrada anteriormente. Se a relação substancial for paritária e impessoal, de forma que a compensação individual siga fórmula padrão, não seria admissível o ajuizamento de demanda individual idêntica à demanda coletiva, apenas para lograr indenização mais vantajosa ou para lograr fórmula de cálculo mais benéfica ao indivíduo, sem que houvesse qualquer diferenciação da ação coletiva anterior. O indivíduo, ao deduzir em juízo uma demanda objetivamente idêntica à ação coletiva anterior, buscaria apenas uma segunda chance, sem qualquer argumento novo ou pessoal, apenas para lograr fórmula mais vantajosa para ele. Nessa hipótese, o indivíduo deve, igualmente, cumprir um ônus argumentativo para que sua demanda individual possa prosseguir, de forma paralela ou mesmo após do trânsito em julgado da ação coletiva.

E, mais uma consideração merece ser feita. Imagine que o indivíduo realmente proponha demanda objetivamente idêntica à ação coletiva anterior, já transitada em julgado. Imagine que esse indivíduo pretenda rediscutir a controvérsia coletiva, mas para lograr fórmula mais vantajosa apenas para ele, sem aduzir qualquer razão pessoal ou uma nova dimensão do conflito coletivo. É preciso reconhecer que, nessa hipótese fictícia, a demanda individual continuaria sendo de alcance coletivo, pois, se o indivíduo não aduzir uma nova dimensão ou uma razão pessoal, a relação substancial persiste sendo impessoal e paritária em relação aos membros do grupo. Considerando o reconhecimento da legitimidade da pessoa física e da possível conversão das demandas individuais em demandas coletivas, se o magistrado convertesse essa demanda individual em coletiva, seria forçoso reconhecer a autoridade da coisa julgada coletiva anterior, em seu efeito positivo. Essa situação-problema reforça a necessidade do cumprimento do ônus argumentativo, antes mencionado. Essas questões serão aprofundadas ainda nessa investigação. Mas, o Código-Modelo, ora analisado, oportuniza adiantar essa discussão desde logo. 
E, por fim, não é possível deixar de refletir sobre um último ponto. Para fins de conversão da ação individual em coletiva, não é fundamental a notificação do Ministério Público ou de outro legitimado coletivo para essa finalidade. O próprio indivíduo detém legitimidade reconhecida pelo Código Modelo. Logo, o magistrado poderia converter de ofício a ação individual em ação coletiva por força da legitimidade da pessoa física. O Ministério Público funcionaria, necessariamente, como custus legis. E, mais, em caso de negligência do indivíduo, o Ministério Público ou outro legitimado coletivo poderia reassumir a titularidade da ação, com a devolução do prazo para a correção de eventuais omissões ou vícios processuais. Trata-se de uma sistemática similar à ação penal subsidiária da pública, quando o órgão ministerial reassume a titularidade da ação na hipótese de inércia ou de negligência do indivíduo na sua condução.

No caso da ação penal subsidiária da pública, se o órgão ministerial omitir-se e não propuser a ação penal, inicia-se um prazo decadencial para a propositura da ação pelo indivíduo. Nesse caso, o Ministério Público funciona, necessariamente, como fiscal da lei e pode, inclusive, aditar a queixa. Se houver inércia ou negligência, agora pelo indivíduo, o Ministério Público pode retomar a titularidade da ação. Sistemática similar poderia ser aplicada, assim, para as demandas coletivas, zelando-se pela representatividade e pela atuação adequada das partes. ${ }^{833}$

O inverso também seria verdadeiro. Se a demanda coletiva for titularizada, a priori, pelo Ministério Público ou por outro legitimado coletivo e houver pessoas físicas interessadas, nada obsta a formação de um comitê popular. Esse comitê receberia informações sobre a demanda e funcionaria como monitor das providências adotadas na ação coletiva, inclusive propondo audiências públicas ao magistrado da causa para que os interessados sejam ouvidos. Em caso de inércia ou negligência do legitimado coletivo, o magistrado poderia notificar o comitê e outros legitimados coletivos a assumir a titularidade da ação. Lembra-se que equívocos processuais, como perda de prazos, não são prerrogativas da pessoa física. O Ministério Público e outros entes também são suscetíveis a equívocos, de forma que é válido o monitoramento público da ação coletiva por um comitê popular e também por outros legitimados coletivos.

833 Art. 29. Será admitida ação privada nos crimes de ação pública, se esta não for intentada no prazo legal, cabendo ao Ministério Público aditar a queixa, repudiá-la e oferecer denúncia substitutiva, intervir em todos os termos do processo, fornecer elementos de prova, interpor recurso e, a todo tempo, no caso de negligência do querelante, retomar a ação como parte principal (Cf. BRASIL. Código de Processo Penal. Brasília, DF: Senado, 1941). 
Esse comitê é extremamente importante em demandas coletivas, propostas pelo Ministério Público, como ocorre nas hipóteses de concurso público. Isso porque o indivíduo, in casu, o candidato ao concurso público, não se conforma em permanecer inerte e permitir a atuação isolada do Ministério Público. Esse indivíduo estudou anos para um concurso público e aquela concorrência é muito importante pera ele. Logo, a manutenção de uma posição de inércia é extremamente árdua. Então, ou ele vai ajuizar demanda individual idêntica à ação coletiva, e, se o sistema processual não mais permitir isso (por força da litispendência com a ação coletiva idêntica), esse indivíduo manifestará intenção de intervir, de algum modo, na ação coletiva.

Considerando a impossibilidade de um litisconsórcio multitudinário na ação coletiva, essa participação deve ser permitia por outros meios, a exemplo de um comitê popular formado pelos candidatos melhores classificados no concurso público, por audiências públicas com os candidatos, pela admissão de um amicus curiae e outras técnicas de participação factíveis.

Nesse caso, ainda que por interesses egoísticos, os maiores interessados à tutela da moralidade pública - por exemplo, o órgão que realizou o concurso público não nomeia os candidatos concursados, mas mantém parentes de vereadores contratados temporariamente - são os candidatos ao concurso público. Se o Ministério Publico lograr êxito na ação coletiva, para que os parentes sejam exonerados e os concursados nomeados, todos os indivíduos, na qualidade de candidatos concursados, se beneficiarão dessa decisão, em razão da observância da ordem de classificação no concurso público, para fins de nomeação e posse no cargo público.

Na realidade, tratando-se de demandas objetivamente idênticas, somente deve ser autorizado o processamento de uma demanda com alcance coletivo, devendo as demais serem extintas pela litispendência. Isso não é, necessariamente, algo ruim. A somatória de forças em uma mesma demanda, em um mesmo fórum de debates, que se tornará o processo coletivo, é extremamente benéfica, pois todos os argumento e meios de prova serão conhecidos por todos. De igual modo, surgiria um adequado monitoramento ou uma fiscalização do legitimado coletivo no caso.

O projeto em comento avança, substancialmente, em prol da agregação processual. As considerações, ora realizadas, constituem reflexões ou ponderações possíveis a partir do projeto em questão, de forma a contribuir com a agregação ótima das controvérsias de massa. 


\subsubsection{ANTEPROJETO DO CÓDIGO BRASILEIRO DE PROCESSOS COLETIVOS}

A elaboração do Código Modelo para Iberoamérica, segundo Ada Pellegrini Grinover ${ }^{834}$, além de servir como um repositório de princípios, inspirou reformas e o aperfeiçoamento do microssistema processual brasileiro. O Código-Modelo foi profundamente analisado nos cursos de pós-graduação da Universidade do Estado de São Paulo, sob a coordenação dos Professores Ada Pellegrini Grinover e Kazuo Watanabe na disciplina denominada de “processos coletivos”.

A partir daí, surgiu a ideia de um Código Brasileiro de Processos Coletivos. Ada Pellegrini Grinover coordenou os trabalhos em 2003, juntamente com a turma de pós-graduandos stricto sensu. Houve uma profícua colaboração dos Professores Kazuo Watanabe, Carlos Alberto Salles e Paulo Henrique dos Santos Lucon e de outros Professores da disciplina do Largo do São Francisco. Nasceu, dessa forma, em 2005, a primeira versão do Anteprojeto de Código.

Em seguida, o Instituto Brasileiro de Direito Processual sugeriu alterações para o aperfeiçoamento do texto, bem como, no segundo semestre de 2005, o texto foi analisado por um grupo de mestrandos da Universidade Estadual do Rio de Janeiro, sob a coordenação do Professor Aluísio Gonçalves de Castro Mendes, que colaboraram na redação final do projeto.

A primeira versão do Anteprojeto foi apresentada ao Ministério da Justiça no final de 2005, ocasião em que foi submetido a consulta popular, sugestões de vários órgãos públicos e instituições especializadas. A versão final do anteprojeto foi apresentada, por fim, em 2006.

São indiscutíveis os avanços dessa proposta, de forma a se falar, hoje, no Brasil não mais em processo coletivo, mas, sim, em direito processual coletivo, dotado de princípios, instrumentos e técnicas mais adequadas à situação substancial que se pretende enfrentar e concretizar. ${ }^{835}$

A revisitação da técnica processual, para efeito de agregação processual, foi essencialmente relevante em alguns aspectos: (i) a ampliação dos esquemas de legitimidade, para admitir a legitimidade da pessoa física ou do membro do grupo, classe ou categoria; (ii) a interpretação da causa de pedir e do pedido, em conformidade ao bem jurídico pretendido; (iii) análise da identidade do pedido e da causa pedir, para fins de conexão, litispendência e coisa julgada, 
considerando a identidade do bem jurídico protegido; (iii) a aferição judicial da representatividade adequada; (iv) a possibilidade de suspensão dos processos individuais, até mesmo de ofício; (v) a aferição da predominância das questões comuns e da superioridade da tutela coletiva para o direitos individuais homogêneos; (vi) a comunicação de processos repetitivos ao Ministério Público e, na medida do possível, aos outros legitimados coletivos para a propositura da ação coletiva, bem como possibilidade de comunicação ao Conselho Superior do Ministério Público para designação de órgão do Ministério Público; (vii) o gerenciamento do processo coletivo pelo juiz, com a instituição de meios alternativos de resolução de controvérsias, como a avaliação neutra de terceiro, mediação e arbitragem. ${ }^{836}$

Diferentemente do Código Modelo para Iberoamérica, o Código Brasileiro de Processos Coletivos confere especial relevância aos mecanismos alternativos de resolução de disputa. Melhor do que agregar, de forma ótima, uma controvérsia de massa, é evitar a sua judicialização, a partir da solução espontânea do conflito pelas próprias partes interessadas.

De igual modo, é de evidente interesse notar que a interpretação da causa de pedir e do pedido e a identidade desses elementos objetivos é aferida conforme o bem jurídico a ser protegido. Resta claro, portanto, que deve ser observado os contornos da relação de direito substancial para fins de identificação do direito coletivo ou de alcance coletivo no caso concreto. Vale, aqui, as considerações realizadas sobre a identificação do direito e sobre a amplitude da cognição, de forma que o cerne da cognição seja os atributos relativos à própria categoria.

Foi sentida, no entanto, a ausência de um mecanismo de conversão das demandas individuais em coletivas. Com a coletivização supracitada, frise-se, não se pretende criar ou fazer nascer uma controvérsia coletiva. O fundamento da coletivização é apenas o reconhecimento formal do alcance coletivo de uma dada controvérsia de direito substancial, já existente no mundo real.

\subsubsection{PROJETO DA NOVA LEI DA AÇÃO CIVIL PÚBLICA}

836 GRINOVER, Ada Pellegrini. Anteprojeto de Código Brasileiro de Processos Coletivos - Exposição de motivos. In: GRINOVER, Ada Pellegrini, MENDES, Aluísio Gonçalves de Castro, WATANABE, Kazuo. Direito Processual Coletivo e o anteprojeto de Código Brasileiro de Processos Coletivos. São Paulo: Revista dos Tribunais, 2007, p. 448-464. 
Esse projeto, que recebeu na Câmara dos Deputados a designação de PL nº 5.139/2099, constitui resultado profícuo de toda a discussão acadêmica e das propostas realizadas no âmbito do Anteprojeto do Código Brasileiro de Processos Coletivos. Esse projeto foi rejeitado pela Câmara dos Deputados, mas o projeto ainda aguarda a apreciação de recurso a ser julgado.

Conforme enuncia Ada Pellegrini Grinover ${ }^{837}$, no início de 2009, o Ministério da Justiça do Governo Lula retomou o Anteprojeto do Código Brasileiro de Processos Coletivos, nomeando comissão de que participaram Ada Pellegrini Grinover e outros membros do Instituto Brasileiro de Direito Processual. Decidiu-se trabalhar, nessa ocasião, com um Projeto de Lei e não Código.

Para efeito de agregação processual, esse projeto inovou em alguns pontos que merecem ser destacados: (i) a impossibilidade de extinção do processo coletivo, sem que antes seja oportunizada a supressão do vício processual ou a assunção da titularidade da ação por outro legitimado coletivo, (ii) adequação das fases procedimentais aos contornos substanciais do conflito, de forma a conferir maior efetividade ao bem jurídico protegido, admitindo-se, por exemplo, a formação de subclasses (iii) a realização de notificação a respeito da ação coletiva, autorizando a exclusão individual nos direitos individuais homogêneos, (iv) a inicial deverá ser instruída com comprovante de consulta ao Cadastro Nacional de Processos Coletivos, atestando a inexistência de ação versando sobre o mesmo bem da vida, (v) a submissão das ações coletivas a audiências públicas e a oitiva de especialistas, de forma a ensejar a mais ampla participação social e a adequada cognição judicial, (vi) sendo uniforme os danos ou a fórmula de cálculo dos danos, a sentença coletiva indicará esse valor e determinará ao réu que promova o pagamento, no prazo fixado, a cada um dos membros do grupo, (vii) o juiz poderá determinar o pagamento da compensação individual pelo réu, de ofício, independentemente da habilitação do interessado, cabendo ao réu o cumprimento da decisão sob pena da adoção de medidas indutivas, coercitivas e sub-rogatórias, (viii) para fiscalizar o cumprimento da decisão judicial, o magistrado poderá nomear pessoa qualificada, que terá acesso ao banco de dados e à documentação necessária para tanto, (ix) o membro que divergir do valor da indenização ou fórmula de cálculo, poderá propor ação de liquidação individual, (x) não serão admitidas novas demandas individuais, com relação a interesses ou direitos individuais homogêneos, quando houver julgamento de improcedência da ação coletiva em matéria exclusivamente de direito, (viii) a exclusão do membro individual ou a ausência de notificação da ação coletiva afasta a 
autoridade da coisa julgada coletiva para os direitos individuais homogêneos, (ix) proceder-seá a suspensão das ações individuais até o julgamento da demanda coletiva, (x) possível a conversão da ação individual em liquidação individual no processo coletivo, (xi) a liquidação individual é dispensada nas hipóteses em que a quantificação depender exclusivamente de prova documental, (xi) manutenção do cadastro nacional de ações coletivas, administrado pelo Conselho Nacional de Justiça, (xii) admissão de um programa extrajudicial de reparação dos danos causados aos direitos coletivos lato sensu, a ser homologado em juízo. ${ }^{838}$

Essa proposta é de valor inestimável no direito brasileiro e compreende inúmeras técnicas de agregação processual. Cumpre ressaltar que as inovações de conteúdo conferem a tônica de um verdadeiro Direito Processual Coletivo, um benfazejo instrumento para a unificação e aperfeiçoamento das ações coletivas e das técnicas processuais de agregação de um modo geral.

Em primeiro lugar, é preciso destacar a impossibilidade de extinção do processo sem a oportunidade de sanar o vício processual ou substituir o legitimado coletivo. Essa técnica enseja a verdadeira fungibilidade dos membros do grupo, permitindo avançar a resolução da controvérsia em relação a todos, não importando a estruturação subjetiva originária realizada. De igual modo, o design procedimental poderá ser alterado e adaptado aos contornos da relação substancial, de forma a realizar uma agregação ótima e simétrica aos contornos substanciais.

Em segundo lugar, chama bastante a atenção os aspectos conferidos à autoridade da coisa julgada para os direitos individuais homogêneos. O projeto admite a notificação dos membros ausentes do grupo e a autoexclusão individual. Se o indivíduo não excluir-se, ele será alcançado pela autoridade da coisa julgada coletiva da sentença de improcedência na ação coletiva para direitos individuais homogêneos, se a matéria for exclusivamente de direito. Isso é inédito.

A preclusão de uma forma geral - in casu, a preclusão máxima que é a autoridade da coisa julgada - é um instrumento de maximização da técnica de agregação processual. Isso porque ela obsta a pulverização das demandas individuais ou, ainda, a fragmentação da controvérsia. É preciso, apenas, realizar algumas ponderações. Pondera-se que o direito de autoexclusão, a exemplo do sistema jurídico estadunidense, deve ser condicionado ao ônus argumentativo.

838 BRASIL. Câmara dos Deputados. PL no 5.139/2009. Disponível em: http://www.camara.gov.br/proposicoes Web/fichadetramitacao?idProposicao=432485. Acesso em: 24 de outubro de 2013. 
A razão para isso é muito simples. O indivíduo é notificado da ação coletiva e exclui-se dessa ação. Posteriormente, a ação coletiva é julgada improcedente por matéria exclusivamente de direito. Em seguida, o indivíduo propõe uma ação individual objetivamente idêntica à ação coletiva. Se o indivíduo não aduziu nenhuma causa pessoal ou nenhuma nova dimensão à controvérsia coletiva, essa demanda deverá, ou ao menos deveria, também ser alcançada pela preclusão. Por quê? O indivíduo teve a oportunidade de aduzir novos argumentos individuais, pessoais, singulares, ou uma nova dimensão da controvérsia de massa (novas circunstâncias de fato ou de direito), mas ele não fez isso de forma concreta. Ele manteve a mesma impessoalidade e a mesma paridade com os membros do grupo, que já existia na demanda coletiva, e pretende agora apenas lograr um resultado diferente apenas para ele, qual seja, a procedência da demanda. Isso não deveria ser admitido. Mas, ainda que se admita a exclusão do indivíduo e propositura de uma demanda individual objetivamente idêntica à demanda coletiva, o indivíduo poderá ser recapturado por outra técnica de agregação ou até, mesmo, sofrer a aplicação de técnicas individuais de vinculação pelo precedente, como no julgamento pela sistemática do art. 285-A, do art. 557 do Código de Processo Civil Brasileiro.

Enfim, se a demanda individual, pendente ou posterior ao trânsito em julgado da ação coletiva, não apresentar os atributos da pessoalidade ou uma nova dimensão da controvérsia coletiva, de nada adiantará possibilitar ao indivíduo a exclusão da ação coletiva ou a propositura de uma demanda individual. Isso ocorre porque se a controvérsia deduzida pelo indivíduo permanecer com o mesmo alcance coletivo, ela poderá ser novamente agregada em juízo. A exclusão será absolutamente falaciosa, um engodo. O indivíduo exclui-se e depois é, novamente, capturado por um outra técnica de agregação processual ou, até mesmo, por um precedente.

As técnicas de vinculação pelo precedente seriam aplicáveis. É isso é até mesmo óbvio, pois, conforme explicitado no capítulo primeiro desta investigação, o precedente parte de um raciocínio analógico diferido, isto é, universaliza-se o comando normativo de um caso para um outro caso concreto similar no futuro. Esse raciocínio não é, no entanto, muito técnico nos conflitos coletivos. Isso porque a ação coletiva já engloba as posições individuais coincidentes.

Não é possível dizer que o comando normativo cunhado na ação coletiva é universalizável aos casos individuais, pois ele já foi universalizado para esses casos. Não há verdadeira analogia, pois, dada a unitariedade da relação substancial, o comando normativo do julgado coletivo se aplicaria in re ipsa, isto é, de forma presumida. O comando normativo da ação coletiva já 
considerou a posição individual (ao menos, a questão comum e coincidente) no processo de cognição e julgamento da controvérsia. O indivíduo, insere-se de forma anônima, na situação global de um grupo. Logo, se o indivíduo propuser uma demanda individual, com o mesmo alcance coletivo da demanda anteriormente julgada, isto é, se ele permanecer na qualidade de membro de um grupo, essa demanda deveria ser alcançada pela autoridade da coisa julgada.

Logo, para manter uma coerência técnica e, até mesmo, para não se ludibriar o indivíduo, a exclusão deve ser condicionada ao cumprimento de um ônus argumentativo, pois, do contrário, a promessa do acesso à justiça será vazia. O indivíduo pensa que se excluiu da demanda, mas, ao propor demanda individual com alcance coletivo, será recapturado por uma nova técnica.

De nada adiante, por exemplo, dizer que a ação coletiva, julgada improcedente, não se aplicaria ao indíviduo que exerceu o direito de autoexclusão. Isso porque, se esse indivíduo se excluiu, estrategicamente, para ajuizar demanda individual objetivamente idêntica à ação coletiva, de forma a lograr alguma vantagem (juiz mais simpatizante a causa, indenização em valor superior aos demais membros do grupo), essa demanda poder ser julgada pela sistemática do art. 285-A do Código de Processo Civil - julgamento antecipado de manifesta improcedência da ação. Logo, é melhor deixar claro que a exclusão do indivíduo é condicionada ao ônus argumentativo.

O mesmo raciocínio se aplica quando a sentença coletiva apresenta fórmula padrão ou objetiva de compensação individual. A exclusão do indivíduo, para a propositura de liquidação individual, somente pode ser admitida se apresentada uma razão pessoal ou se exposta uma nova dimensão da controvérsia coletiva, cujo ponto não foi deduzido no juízo coletivo. Se a exclusão do indivíduo for admitida, fora das hipóteses supracitadas, corre-se o risco de o indivíduo reproduzir liquidação individual com igual alcance coletivo da demanda anterior, apenas para tentar a sorte de obter vantagem maior com outro magistrado, por exemplo. $\mathrm{O}$ indivíduo, para excluir-se da liquidação agregada, deve justificar o seu pedido e aduzir razões para tanto, pois, do contrário, será alcançado inevitavelmente pela autoridade da coisa julgada coletiva. Esse raciocínio seria reforçado, se o projeto admitisse a legitimidade da pessoa física e a coletivização das demandas individuais. Se essa demanda individual, com idêntico alcance coletivo, for coletivizada, isso ensejará a aplicação do efeito positivo de coisa julgada anterior.

Outro aspecto relevante é a ampliação do contraditório coletivo, com a previsão de convocação de audiências públicas, oitivas de especialistas, divulgação do cadastro de processos coletivos. 
Por fim, importa destacar, novamente, a relevância dos meios alternativos de resolução da controvérsia, institucionalizados pelo Poder Judiciário e realizados sob a supervisão judicial.

Esses foram os principais pontos a serem comentados. O projeto avançou em prol da agregação ótima, em consonância aos critérios dados pelo direito substancial. Mas, novamente, foi sentida a ausência de um mecanismo de agregação processual, por iniciativa oficial, como é o caso da coletivização de demandas individuais ${ }^{839}$. Essa ausência é superada a seguir por novo projeto.

\subsubsection{PROJETO DE LEI SOBRE O CONTROLE JURISDICIONAL DE POLÍTICAS PÚBLICAS}

Esse projeto nasceu a partir de uma pesquisa realizada pelo Centro Brasileiro de Pesquisas e Estudos Judiciais - CEBEPEJ, em 2008, sob a coordenação de Ada Pellegrini Grinover e Kazuo Watanabe. A pesquisa iniciou-se com uma pesquisa bibliográfica e jurisprudencial realizada por pesquisadores convidados pelo CEBEPEJ. Os textos foram fichados e, posteriormente, em meados de 2009, essa pesquisa originou diversos artigos doutrinários e seminários. ${ }^{840}$

Seminários foram organizados para que os pesquisadores apresentassem os resultados das pesquisas, seguido de exposição e discussão das principais ideias. Dos debates emergiram conclusões. De igual modo, pela iniciativa dos Professores Ada Pellegrini Grinover e Kazuo Watanabe, surgiu a proposta de um processo especial de controle de políticas públicas em juízo.

Embora esse processo seja restrito às políticas públicas, o tema é um termômetro para o debate da agregação processual. Isso porque as políticas públicas tendem a ser paritárias e uniformes, aplicáveis a um grupo, classe ou categoria de pessoas. As demandas coletivas e as demandas de alcance coletivo configuram, na maior parte das vezes, apenas um incidente legal de status.

Não se discutem, muitas vezes, nesses casos, atributos pessoais de um indivíduo, mas, sim, a própria ordem ou o sistema público de saúde, escolar, prisional etc. $\mathrm{O}$ indivíduo, ao ajuizar sua

839 Constituiu um retrocesso, segundo Ada Pellegrini Grinover, com o que se concorda, a ausência de previsão da legitimidade ativa da pessoa física, com o controle judicial da representatividade adequada (Cf. GRINOVER, 2011, p. 38).

840 GRINOVER, Ada Pellegrini, WATANABE, Kazuo. Apresentação. In políticas públicas. Rio de Janeiro: Forense, 2011, p. 7-8. O controle jurisdicional de 
demanda individual, deduz, com frequência, uma controvérsia paritária e impessoal em relação aos demais membros da coletividade. Ele atua em juízo na qualidade de membro da categoria.

João sofre de artrite reumatoide. Existe o medicamento "X" previsto na rede pública de saúde, para o tratamento da moléstia que acomete João. Esse medicamento, no entanto, está defasado em relação às demais opções do mercado e sua aplicação causa um desconforto a João. Esse medicamento exige a internação de um dia no hospital e é aplicado em pequenas doses na veia, causando um desconforto e, ainda, necessitando de um acompanhamento médico para ser ministrado. À venda no mercado, todavia, tem o medicamento " $Y$ ", de custo relativamente superior ( $\mathrm{R} \$ 200,00)$, mas que basta tomar dois comprimidos por dia, sem maior desconforto.

João, ao deduzir sua demanda individual, não irá elencar nenhuma causa pessoal ou singular para pleitear o medicamento mais custoso. Ele não tem alergia ao medicamento disponível na rede de saúde, o medicamento disponível é necessário para o tratamento de sua moléstia e, também, é idôneo para o tratamento prescrito no laudo médico. Mas, João argumenta que não deveria ser obrigado a internar-se, por um dia semanalmente, sofrendo desconfortos e restrições na sua vida pessoal, apenas porque o sistema de saúde encontra-se tecnologicamente defasado. O medicamento, à venda no mercado, que constitui uma alternativa àquele disponível na rede pública, é apenas relativamente mais custoso, mas os benefícios e o conforto dado aos pacientes são muito superiores. Essa controvérsia não diz respeito, portanto, à pessoa de João, mas à própria escolha do medicamento realizada pelo administrador público, que afeta a todo o grupo de pacientes acometidos por artrite reumatoide. É um incidente legal sobre o status da categoria.

João pleiteia o medicamento para ele, mas ele faz isso na qualidade de membro de um grupo, que é afetado por uma escolha administrativa tecnologicamente defasada em termos de saúde pública. João quer o medicamento mais moderno para ele, na mesma medida que todos os demais pacientes da rede pública também querem. Isso poderá acarretar uma multiplicidade de demandas individuais objetivamente idênticas. Embora o indivíduo, que é parte, peça o medicamento apenas para ele, o centro da cognição judicial - do ato de inteligência do magistrado - não se fixa em nenhum indivíduo, mas nos atributos do próprio grupo. A amplitude da cognição sobre essa controvérsia consiste em investigar se os pacientes de artrite reumatoide fazem jus ao medicamento "Y", em saber se o direito à saúde admite essa intervenção na política pública em razão de um suposto defasamento tecnológico, e em verificar os limites do orçamento. Não se discute aspectos pessoais de João, Pedro, José ou Tamara. 
Não são necessárias múltiplas demanda individuais para essa finalidade, pois a cognição diz respeito ao status da categoria. Pode-se dizer que os indivíduos são fungíveis entre si. Basta, portanto, uma demanda individual para alcançar o escopo pretendido pelo grupo, que é, na prática, a obtenção do medicamento, mas que, de forma remota, é a alteração da política pública.

Pensando nisso foi que o Anteprojeto da Lei de Políticas Públicas admite duas técnicas de agregação: (i) a reunião de demandas individuais, versando sobre pedidos, diretos ou indiretos, de implementação ou correção de políticas públicas e (ii) a coletivização da demanda individual. Nesse sentido, cita-se os seguintes dispositivos legais previstos no anteprojeto:

Art. 19 - Quando vários processos versando sobre pedidos, diretos ou indiretos, de, implementação ou correção de políticas públicas relativas ao mesmo ente político correrem em diversos juízos, as causas serão reunidas, independentemente de conexão, para julgamento conjunto, a fim de o juiz dispor de todos os elementos necessários para uma decisão equitativa e exequível.

Parágrafo único - Aplica-se à reunião de processos a regra de prevenção do Código de Processo Civil.

Art. 21 - Quando o Tribunal receber diversos recursos em processos que objetivem o controle judicial de políticas públicas, relativamente ao mesmo ente político, e que poderão comprometer o mesmo orçamento, os processos serão reunidos para julgamento conjunto, de competência do órgão especial, com vistas a uma decisão equânime e exequível.

Art. 26 - Atendido o requisito da relevância social e ouvido o Ministério Público, o juiz poderá converter em coletiva a ação individual que:

I - tenha efeitos coletivos, em razão da tutela de bem jurídico coletivo e indivisível, cuja ofensa afete a um tempo as esferas jurídicas do indivíduo e da coletividade;

II - tenha por escopo a solução de conflitos de interesses relativos a uma mesma relação jurídica plurilateral, cuja solução, pela sua natureza ou por disposição de lei, deva ser uniforme, assegurando-se tratamento isonômico para todos os membros do grupo e padrão de conduta consistente e unitária para a parte contrária.

$\S 1^{\circ}$ - Determinada a conversão, o autor manterá a condição de legitimado para a ação, mas em litisconsórcio necessário com o Ministério Público ou outro colegitimado para a ação coletiva.

$\S 2^{\circ}$ - O Ministério Público ou outro legitimado, no prazo a ser fixado pelo juiz, poderão aditar ou emendar a petição inicial para adequá-la à tutela coletiva.

$\S 3^{\circ}$ - Se nenhum dos co-legitimados aditar ou emendar a petição inicial, o juiz encaminhará os autos ao Conselho Superior do Ministério Público para que indique um membro da instituição para fazê-lo.

$\S 4^{\circ}$ - A coisa julgada atuará erga omnes, nos termos do disposto nos arts. 103 e 104 da Lei n. 8.078, de 11 de setembro de 1990 (Código de Defesa do Consumidor).

$\S 5^{\circ}$ - Não intervindo como parte, o Ministério Público atuará como fiscal da ordem jurídica $^{841}$

841 BRASIL. CEBEPEJ. Projeto de lei que institui processo especial para o controle e intervenção em políticas públicas pelo Poder Judiciário e dá outras providências (no prelo). 
A reunião ou consolidação das demandas individuais é mais adequada, na hipótese em que houver antagonismo na categoria, isto é, nas hipóteses potencialmente impessoais. Explica-se.

Todos os indivíduos impugnam a política pública de saúde, no tocante ao tratamento conferido à moléstia artrite reumatoide e, enfim, todos se reportam à própria política pública e a ordem geral que afeta a toda a categoria. Contudo, cada pessoa tem uma concepção diferente sobre como deveria ser a correção dessa política. Em uma demanda individual, o indivíduo argumenta que o medicamento disponível na rede pública encontra-se tecnologicamente defasado. Em outra demanda individual, o indivíduo argumenta que o medicamento causa efeitos colaterais desnecessários face às demais opções do mercado. Em uma terceira demanda individual, o indivíduo alega que o procedimento de ministração do medicamento causa risco de vida, risco também desnecessário, pois existe alternativa no mercado em que basta o uso de uma pílula.

Todas essas demandas individuais têm um alcance ou uma valência coletiva, todas poderiam ser coletivizadas, pois todas impugnam uma mesma ordem unitária e paritária. Porém, a controvérsia é deduzida em juízo de forma potencialmente impessoal. Os argumentos não são pessoais ou singulares, mas são diferentes por pessoa, daí a necessidade de reunião das demandas individuais de alcance coletivo, até mesmo para a melhor instrução e resolução integral e plena da controvérsia. Nada obsta, ainda, a convocação de audiências públicas, para que sejam colhidos os argumentos contrários e favoráveis à política pública, prevenindo, assim, novos ajuizamentos de demandas individuais de alcance coletivo, a serem reunidas em juízo.

A coletivização ou a conversão de demandas individuais em ações coletivas é mais adequada nas hipóteses em que os argumentos forem impessoais e com menor grau de antagonismo entre os membros do grupo. Nessa hipótese, podem existir múltiplas demandas individuais, objetivamente idênticas, que veiculam o mesmo argumento. Nesse caso, basta a coletivização de uma demanda individual, com a suspensão das demais e, posterior, extinção ou conversão em liquidação. Mesmo que os argumentos dos indivíduos sejam os idênticos ou similares, é, igualmente, possível a convocação de audiências públicas, a formação de um comitê com outros legitimados para fins de monitoramento da demanda individual coletivizada e outras técnicas.

De qualquer forma, o projeto prevê o litisconsórcio do Ministério Público ou de outro legitimado coletivo na ação individual, objeto de coletivização. Talvez, não fosse preciso de um litisconsórcio, mas de uma atuação subsidiária do legitimado coletivo, a exemplo do que já 
ocorre na ação penal privada subsidiária da pública. A partir dessa analogia, o Ministério Público poderia aditar as peças processuais, recorrer, pleitear a produção de provas, aditar pedidos, bem como, em caso de negligência do indivíduo, retomar a titularidade da ação.

Por fim, mais uma consideração se faz necessária. As demandas tipicamente individuais, quais sejam, aquelas em que o indivíduo deduz em juízo uma controvérsia pessoal, singularizada e que requer uma cognição artesanal, não é obstada pela ação coletiva, mas poderia ser suspensa.

Exemplo, o indivíduo alega que o medicamento disponível na rede pública é inidôneo para o seu tratamento médico, pois ele é alérgico ao princípio ativo. Essa demanda requer cognição artesanal ou singularizada, mas ela poderia ser suspensa (excluindo-se, por óbvio, a tutela de urgência) para aguardar a eventual modificação da política pública na ação coletiva. Ora, se o grupo lograr êxito em alterar ou acrescentar um novo medicamento para o tratamento de artrite reumatoide, a demanda individual poderá restar prejudicada, sendo desnecessário ao indivíduo demonstrar em juízo a sua alergia. Se o indivíduo, no entanto, pretender outro medicamento, pois ele também é alérgico ao medicamento pretendido na ação coletiva, não há necessidade de suspensão da ação individual, pois a ação coletiva em nada afeta ou importa ao indivíduo.

Por fim, se a demanda coletiva for julgada improcedente, o indivíduo poderá propor uma ação individual, mas deverá cumprir o ônus argumentativo, que já se mencionou antes. Ele deverá deduzir uma causa pessoal ou uma nova dimensão da controvérsia coletiva. No caso da artrite reumatoide, o indivíduo poderá deduzir uma nova dimensão, que não foi apreciada na demanda coletiva anterior. Imagine que ele deduza em juízo o seguinte: para aqueles que sofrem de artrite reumatoide, cumulada com síndrome de Sjögren, deve ser conferido um medicamento distinto e específico para essa categoria, pois o medicamento " $\mathrm{X}$ " é um mero paliativo. A síndrome de Sjögren, que causa a artrite reumatoide e uma série de outras doenças, deve ser tratada com um coquetel medicamentoso diferente, sendo mais adequado o medicamento "Y".

Na realidade, se essa questão surgisse, por ocasião da ação coletiva anterior, o magistrado poderia estabelecer uma subclasse, formada por aqueles que também têm síndrome de Sjögren. Mas, como essa questão não foi deduzida na demanda coletiva anterior e não foi exercido o contraditório sobre ela, deve ser admitida a demanda individual proposta, pois ela detém uma nova dimensão e cumpre o ônus argumentativo. Nesse caso, se for identificada toda uma 
categoria de pessoas, em situação idêntica, gerando novamente uma multiplicidade de demandas individuais, será preciso ponderar por uma nova coletivização da ação individual.

Por fim, é importante notar que o art. 26 do projeto em questão permite a conversão de demandas individuais incidente sobre bem de natureza coletiva e indivisível, bem como a conversão de demandas individuais incidente sobre relações plúrimas uniformes e unitárias.

Por uniformidade e unitariedade, é possível inserir as relações substanciais paritárias e impessoais, por expressa disposição de lei, de que se tratou em capítulo anterior, bem como as relações substanciais potencialmente paritárias e impessoais, por força dos contornos dados pelo direito substancial, ainda que não exista dispositivo específico e expresso em lei no ponto.

Nas hipóteses potencialmente paritárias e potencialmente impessoais, é preciso atentar para duas situações. É preciso atenção para as hipóteses de potencialidade forte (força centrípeta), em que a cognição é centrada, exclusivamente, nos atributos do grupo, bem como é preciso atenção para as hipóteses de potencialidade fraca (força centrífuga), em que a cognição é centrada apenas, em parte, nos atributos do grupo e, depois, remanescem questões individuais. A segunda hipótese é mais complexa, pois deve-se aferir se há avanço da solução do conflito.

Veja, pois, quão importante é análise do direito substancial e dos critérios substanciais de agregação para determinação da agregação ótima, necessária e adequada à controvérsia. Esse projeto diz respeito à política pública, mas as técnicas de agregação nele contidas podem ser estendidas para outras hipóteses, públicas ou privadas, em que presentes os referidos critérios.

\subsubsection{ANTEPROJETO DO NOVO CÓDIGO DE PROCESSO CIVIL}

Por fim, não é possível deixar de inserir o Anteprojeto do Novo Código de Processo Civil na temática. Antes de abordar, especificamente, o aspecto da agregação processual, na forma proposta pelo Anteprojeto do Novo Código de Processo, é preciso contextualizar essa proposta. A necessidade de revisitação da técnica processual não é nova. Tanto não é nova que, em 1985, uma Comissão de Juristas já propunha no Brasil um "incidente de molecularização de demandas". Vê-se que essa tendência por reformas processuais, até mesmo, pela instituição de técnicas de processo coletivo e de agregação, apenas prossegue no sistema jurídico brasileiro. 
Várias reformas processuais foram propostas e, de fato, adotadas, com modificações sensíveis na técnica processual. Lembra-se das modificações do sistema, admitindo uma maior vinculação jurisprudencial, o processo eletrônico, as tutelas de urgência, a tutela específica da obrigação $^{842}$. A proposta de um Novo Código de Processo Civil também se insere nesse encadeamento histórico. Ela é mais uma fase, ou quiçá, até mesmo, o ápice de uma história de mudanças e de reformas processuais que se seguem, no Brasil, desde o Código Buzaid de 1973.

A iniciativa pela adoção de reformas mais amplas, profundas e mais sistemáticas, foi dada em setembro de 2009, com a nomeação de uma Comissão de Juristas, encarregados da redação das propostas, sob a presidência do Ministro Luiz Fux, à época integrando o Superior Tribunal de Justiça. A comissão foi formada, além do Ministro Luiz Fux, pela Doutora Relatora Thereza Wambier e pelos Doutores Adroaldo Furtado Fabrício, Benedito Pereira Filho, Bruno Dantas, Elpídio Donizetti Nunes, Humberto Theodoro Júnior, Jansen Almeida, José Miguel Medina, José Roberto dos Santos Bedaque, Marcus Vinicius Coelho e Paulo Cezar Pinheiro Carneiro. ${ }^{843}$

Um dos pontos destacados na exposição de motivos do Anteprojeto, que mais interessam para os propósitos ora discutidos, é reconhecimento de uma "litigiosidade desenfreada" ${ }^{844}$, com um volume irracional de ações e recursos, de lento e ineficiente processamento e julgamento. ${ }^{845}$

O Anteprojeto constituiu-se em um projeto de lei, que tramitou no Senado e, até hoje, ainda tramita na Câmara dos Deputados sob o nº 8.046/2010. Esse Anteprojeto foi objeto de grande discussão na comunidade jurídica, principalmente nos cursos de pós-graduação, na $\mathrm{OAB}$, nas Associações da Magistratura, nas Associações do Ministério Público, pelo Instituto Brasileiro de Direito Processual, bem como em dezenas de audiências públicas, realizadas por todo país.

Novas propostas foram surgindo, inclusive um Anteprojeto Substitutivo, que, em muito agregou às propostas originárias, mas com ideias inéditas. O substitutivo não veio substituir, como quer parecer o nome, mas, sim, agregar, inserir-se no debate inaugurado pela projeto

842 CALMON FILHO, Petrônio (org.). CADERNOS IBDP (série propostas legislativas) - Reforma infraconstitucional do processo civil. V. 4, set. 2005. DINAMARCO, Cândido Rangel. A execução na reforma do Código de Processo Civil. Revista da Escola Paulista da Magistratura. São Paulo: Associação Paulista de Magistrados Editora, V. 34, set./dez. de 2006.

843 BRASIL. Congresso Nacional. Senado Federal. Comissão de Juristas responsável pela elaboração de Anteprojeto de Código de Processo Civil. Código de Processo Civil: anteprojeto. Brasília: Senado Federal, Presidência, 2010.

844 Ibidem, p. 7.

845 Ibidem, p. 7. 
iniciado em 2009. A Comissão de Juristas desse projeto foi formada por Ada Pellegrini Grinover, Carlos Alberto Carmona, Cassio Scarpinella Bueno e por Paulo Henrique Lucon. ${ }^{846}$

É preciso destacar que várias e profundas são as modificações propostas. Nesta oportunidade, serão mencionadas apenas algumas, duas do Projeto Substitutivo e outra do PL nº 8.046/2010.

O Projeto Substitutivo apresenta, de forma similar ao Anteprojeto do Código Brasileiro de Processos Coletivos, no seu art. 941-A, a possibilidade de intimação dos legitimados coletivos para a propositura da ação coletiva na hipótese de múltiplas ações individuais pendentes, com o mesmo pedido ou causa de pedir ou fundamento jurídico, concentrando-se a controvérsia. De igual modo, esse projeto pondera pela suspensão das ações individuais, no seu artigo 289-A.

Proposta interessante também consta no substitutivo, proposto pelo Deputado Paulo Teixeira, que reproduz a ideia de conversão do processo individual em coletivo, prevista no projeto de Controle Jurisdicional de Políticas Públicas e, agora, aplicada no Novo Código de Processo.

O PL n ${ }^{\circ} 8.046 / 2010$, por sua vez, introduz instrumento inédito, consistente no incidente de resolução de demandas repetitivas. Esse instrumento foi inspirado, como causa mais próxima, no procedimento padrão alemão, mas, como causa remota, na antiga test claim ou caso-teste.

Segundo Aluísio Gonçalves de Castro Mendes ${ }^{847}$, são vários os ordenamentos europeus, de Civil Law ou Common Law, admitindo a resolução da controvérsia coletiva pelo recurso ao casoteste (test claim) ou, por novas versões desse mesmo recurso, como o procedimento padrão alemão (musterverfahren) e a ação de grupo inglesa (group action). Essas novas soluções são inspiradas no antigo test claim, sem prejuízo das ações coletivas que, ainda, são utilizadas.

Na realidade, o mecanismo do caso-teste ou test claim e as suas novas versões não diminuem o espectro de atuação das ações coletivas. Trata-se apenas da adoção de um procedimento especifico para os direitos individuais homogêneos, direitos repetitivos ou direitos de massa.

846 BRASIL. Anteprojeto Substitutivo do Novo Código de Processo Civil. Exposição de motivos/Comissão de Juristas. Disponível em: http://www.direitoprocessual.org.br/index.php?substitutivo-elaborado-por-adapellegrini-grinover-carlos-alberto-carmona-cassio-scarpinella-bueno-e-paulo-henrique-dos-santos-lucon.Acesso em 5 de setembro de 2013.

847 MENDES, 2012, p. 280. 
O novo instituto guarda similaridade com os artigos 543-B e 543-C do Código de Processo Civil Brasileiro vigente, que introduziu a sistemática dos recursos repetitivos no Brasil. O sistema agora proposto é aplicável não aos recursos, mas às ações individuais repetitivas. Assim, quando existir uma questão comum de direito capaz de gerar uma multiplicidade de demandas individuais repetitivas, poderá ser suscitado um incidente, cuja admissibilidade e julgamento de mérito será realizado pelos Tribunais de Justiça ou Tribunais Federais. Cita-se:

\footnotetext{
Art. 930. É admissível o incidente de demandas repetitivas sempre que identificada controvérsia com potencial de gerar relevante multiplicação de processos fundados em idêntica questão de direito e de causar lesão grave e insegurança jurídica, decorrente do risco de decisões conflitantes.

$\$ 1 .^{\circ} \mathrm{O}$ pedido de instauração do incidente será dirigido ao presidente do Tribunal: I - pelo juiz ou relator, por ofício.

II - pelas partes, pelo Ministério Público e pela Defensoria Pública, por petição.

$\S 2 .^{\circ} \mathrm{O}$ ofício ou a petição a que se refere o $\S^{\circ}$ será instruído com os documentos necessários à demonstração da necessidade de instauração do incidente.

$\$ 3$. $^{\circ}$ Se não for o requerente, o Ministério Público intervirá obrigatoriamente no incidente e poderá assumir sua titularidade em caso de desistência ou de abandono.848
}

Trata-se, na verdade, de método destinado a resolver, de forma agregada, demandas envolvendo direitos individuais homogêneos, repetitivos, de massa, decorrentes do fenômeno da “individualização em massa" 849 das relações jurídicas. Nessa categoria de direitos, há uma coincidência entre os atributos do grupo e os atributos individuais, de forma que as demandas individuais são clones ou cognatas, admitindo a resolução da questão jurídica comum. De qualquer forma, remanescem questões individuais, que não são resolvidas pelo procedimento padrão. A essas questões individuais, exige-se cognição artesanal e, assim, processo individual.

O método do incidente de demandas repetitivas não dispensa, em regra, a existência de processos individuais, em relação aos quais será aplicada a tese jurídica fixada no incidente. Muito pelo contrário, o incidente pressupõe os processos individuais. Por isso, ele deve ser restrito para a categoria dos direitos individuais homogêneos, nos quais a resolução da questão comum é complementada por procedimento voltado à resolução das questões individuais.

Nas hipóteses de direitos difusos ou coletivos stricto sensu, bem como nas hipóteses de relação substancial impessoal e paritária, pondera-se que a agregação ótima será melhor alcançada pela ação coletiva proposta por um legitimado coletivo ou pela coletivização da ação individual.

848 BRASIL. Congresso Nacional. Câmara dos Deputados. PL nº 8.046/2010. Código de Processo Civil: anteprojeto. Brasília: Câmara dos Deputados, Presidência, 2010.

849 ELIAS, 1994, p. 149. 
Diferentemente do incidente de demandas repetitivas, a ação coletiva admite a instrução probatória sobre questões fáticas plurissubjetivas e poderá dispensar as ações individuais. Lembra-se que, mesmo se o bem for divisível, existem situações nas quais os indivíduos se encontram em situação de paridade e impessoalidade até mesmo no tocante ao método de compensação individual. O indivíduo atua como membro de um grupo, fazendo remissão aos atributos do grupo e não aos seus atributos pessoais. Nesse caso, a sentença genérica coletiva já pode ser líquida e o cálculo da compensação devida ao indivíduo pode ser ministerial ou administrativo, dispensando uma complementar cognição particularizada ou artesanal pessoal.

O incidente de demandas repetitiva já pressupõe os processos individuais. Logo, não atende com igual idoneidade às situações supramencionadas, razão pela qual ele não substitui as ações coletivas, mas constitui um plus, para atender a diversidade das situações substanciais possíveis.

No tocante à controvérsia comum objeto do incidente de resolução de demandas repetitivas, é preciso destacar que a questão comum deve ser uma questão de direito autônoma, permanente, não cambiante, a qual se repete em cada caso individual e é capaz de avançar a resolução da controvérsia em relação aos membros do grupo. Essa assertiva merece explicação detalhada.

De nada adianta, por exemplo, a fixação, no incidente, de uma tese jurídica, dizendo que é lícita a cobrança pelas instituições financeiras de juros superiores a $12 \%$ ao ano nos contratos de financiamento bancário, desde que essa taxa de juros não ultrapasse a taxa média anual ${ }^{850}$. Essa tese não avança os casos individuais, pois caberá a cada magistrado nas demandas individuais investigar qual é a taxa média anual de juros praticada no período do contrato individual e, ainda, aferir se a taxa fixada no contrato é abusiva ou não, por ser muito superior à taxa média.

Essa tese jurídica comum servirá, sim, como precedente, universalizável aos casos particulares, uma vez que ela fixará os parâmetros legais a serem observados em cada caso concreto. No

850 Veja, respectivamente, a tese jurídica da súmula 282 e do precedente AgRg no REsp 889.820/RS: Súmula 282 - "A estipulação de juros remuneratórios superiores a 12\% ao ano, por si só, não indica abusividade" e "AGRAVO REGIMENTAL NO RECURSO ESPECIAL. AÇÃO REVISIONAL. CONTRATO DE FINANCIAMENTO. LIMITAÇÃO DOS JUROS REMUNERATÓRIOS EM 12\% AO ANO.IMPOSSIBILIDADE. SÚMULA N 382 DO STJ.1. A jurisprudência desta Corte é pacífica no sentido de que, nos contratos bancários, não se aplica a limitação da taxa de juros remuneratórios em $12 \%$ ao ano, e de que não se pode aferir a exorbitância da taxa de juros apenas com base na estabilidade econômica do país, sendo necessária a demonstração, no caso concreto, de que a referida taxa diverge da média de mercado. 2. Agravo regimental a que se dá provimento. (AgRg no REsp 889.820/RS, Rel. Ministra MARIA ISABEL GALLOTTI, QUARTA TURMA, julgado em 07/05/2013, DJe $14 / 05 / 2013)$ 
entanto, essa tese jurídica, fixada naqueles termos, não decidirá ou avançará a solução dos casos individuais, não "queimará etapas" da solução da controvérsia, pois em cada um dos casos individuais será preciso realizar um juízo sobre a taxa concretamente aplicada no contrato e sobre a abusividade ou não dessa taxa à luz da taxa média anual de juros. Essa tese jurídica é capaz de estabelecer coerência e consistência, pois os parâmetros legais são os mesmos. Mas, não há decisão unitária ou agregada sobre a questão comum, pois cada indivíduo continuará a propor sua demanda individual para saber se a sua taxa de juros anual é abusiva ou não.

Uma tese jurídica, como essa dada em exemplo, apresenta elementos cambiantes (data do contrato, taxa concreta, taxa média de juros e parâmetro de abusividade), de forma a ensejar a realização de distinções nos casos individuais (distinguishing), isto é, ela admite decisões casuísticas. Por essa razão, o indivíduo continuará a propor a sua demanda individual.

Por exemplo, o incidente aprecia o seguinte caso: (i) o contrato analisado foi datado de 1993, (ii) os juros aplicados forem $33 \%$ ao ano e (iii) a taxa média de juros para o ano de 1993, segundo o Banco Central, é o percentual de $23 \%$. O Tribunal entendeu abusiva a taxa aplicada ao contrato, pois foi muito superior à taxa média. Com isso, a tese jurídica extraída é "lícita a cobrança de juros acima de $12 \%$ ao ano, desde que a taxa aplicada ao contrato não seja abusiva e muito superior à taxa média anual de juros". Como aplicar essa tese nos processos individuais? Essa tese dispensa novos processos individuais ou eles continuarão sendo ajuizados? Houve decisão agregada no tocante à questão de direito, dispensando retrabalho no caso individual?

Enfim, teses jurídicas, como a mencionada no exemplo, podem orientar a solução dos casos individuais, mas não consiste em uma decisão unitária sobre a relação jurídica concreta. Isso porque, em cada demanda individual, ainda será preciso avaliar a abusividade da taxa de juros. A questão jurídica, embora repetitiva, não é autônoma, não queima etapas, apenas exige a análise da questão individual à luz da tese jurídica antes firmada, admitindo o distinguishing.

Mais interessante seria, portanto, pensar o incidente de resolução de demandas repetitivas como uma amostra representativa da controvérsia, a exemplo do ocorre com o caso-teste. Não basta olhar para um caso e replicá-lo para os demais, é preciso conhecer o universo coletivo dos casos e, a partir desse universo coletivo, identificar uma amostra representativa (um ou mais casos similares, selecionados por alguma técnica estatística) que ensejará uma decisão unitária e agregada da questão jurídica, a ser extrapolada para todos os demais casos individuais. 
Conforme explicita o Manual for Complex Litigation ${ }^{851}$, do sistema jurídico estadunidense, a prova por amostragem é aquela em que há a prova de uma universalidade de eventos, a partir da prova de apenas uma amostra. O mesmo raciocínio aparece no julgamento por amostragem ou no julgamento da amostra representativa da controvérsia, o que é realizada no caso-teste.

Por essa técnica, julga-se um ou mais casos, para depois extrapolar o resultado do julgamento para a universalidade de casos pendentes. Veja que não se trata apenas de estabelecer parâmetros normativos a serem observados no julgamento individual, como ocorre no precedente vinculante. Trata-se, sim, de julgar e de avançar, ao menos em parte, a resolução da controvérsia individual, evitando a rediscussão da questão no processo individual. $\mathrm{O}$ julgamento da amostra representativa presume que seja resolvida a controvérsia ou, ao menos, parte da controvérsia individual. O método é idôneo se forem utilizados os parâmetros estatísticos para a seleção da amostra no universo coletivo. Esse método de julgamento também denominado de "trial by statistics" ${ }^{52}$. O escopo dessa técnica é evitar a realização de um juízo subjetivo ou casuístico, por um juízo objetivo, impessoal e paritário para toda a categoria.

No sistema jurídico estadunidense, a realização do julgamento por amostragem é, de fato, um fundamento para a agregação, pois o processamento e a decisão é agregada ou unitária, reduzindo o escopo dos processos individuais e obstando a rediscussão da questão comum.

Lembra-se do caso da taxa de juros. Nesse caso, seria possível imaginar a construção de uma amostra representativa da controvérsia. Basta, para isso, conhecer o universo coletivo de casos similares individuais e, partir disso, estabelecer um parâmetro objetivo de abusividade. Exemplo: a taxa de juros do contrato é, em tese, abusiva se for superior a $30 \%$ em relação à taxa média anual de juros, definida pelo Banco Central, conforme a tabela anexa ao voto do relator. Se João possuir um contrato com taxa de juros superior a apenas $5 \%$ da taxa média de juros anual, segundo a tabela do Banco Central, a sua taxa de juros não é abusiva conforme a tese jurídica fixada no incidente. João será desestimulado a ingressar com sua ação individual.

Não se trata de um procedimento representativo, não há representante adequado, como ocorre com as ações coletivas. Mas, para se alcançar um dos escopos da agregação processual, que é 
a decisão unitária sobre a controvérsia de massa, a questão comum aos casos individuais (a amostra do universo coletivo) deve ser representativa de todos os demais casos individuais.

Como diz Consolo e Dora Rizzardo ${ }^{853}$ e, entre nós, também Antônio do Passo Cabral ${ }^{854}$, é como se fosse uma tentativa de estabelecer "algo análogo a uma class action, mas sem classe" 855.

Nesse aspecto, vão surgir situações mais simples, que são, há muito, conhecidas pelas Cortes de Justiça. São as questões jurídicas "maduras" ${ }^{856}$, que contam com jurisprudência consolidada e já são mecanicamente aplicadas nos processos individuais. Nesses casos, o universo coletivo, com as eventuais diferenças quantitativas ou qualitativas de um caso para outro, é bem conhecido pelo Judiciário, de forma que a amostra representativa é facilmente identificável.

De outro lado, podem surgir questões jurídicas comuns "não maduras", cujo universo de casos individuais é ainda pouco conhecido. Nessa hipótese, ou o incidente será inadmitido ou, por força da gravidade da repetição e de multiplicação das causas, o incidente é admitido. Mas, exigirá um maior esforço instrutório do relator para aferir a questão jurídica comum e representativa do conflito (a amostra), a partir de um universo coletivo ainda pouco esclarecido.

No tocante ao processamento do incidente, caberá ao Tribunal realizar o juízo de admissibilidade e o julgamento de mérito. São duas fases, segundo Aluísio de Castro Mendes. ${ }^{857}$

Na fase da admissibilidade, o anteprojeto prevê que relator poderá requisitar informações ao órgão em cujo juízo está o processo originário, para complementar as informações do incidente. Embora o projeto não mencione, é possível admitir também o pedido de informações a outros juízos, que também apresentem grande quantidade de processos individuais similares, nas hipóteses em que for preciso complementar as informações devidas sobre o universo coletivo.

853 CONSOLO, Claudio, RIZZARDO, Dora. Due modi di mettere le azioni collettivi alla prova: Inghilterra e Germania. Rivista Trimestrale di Diritto e Procedura Civile. Anno LX, N. 3, set. de 2006, p. 900.

854 CABRAL, Antônio do Passo. O novo procedimento modelo (mustervenfahren) alemão: uma alternativa às ações coletivas. Revista de Processo. São Paulo: Revista dos Tribunais, V. 147, 2007, p. 128.

855 CONSOLO, RIZZARDO, op. cit, p. 900. CABRAL, op. cit., p. 128.

856 No estágio maduro da controvérsia, como diz Francis McGovern, pouca ou nenhuma evidência é necessária para fins de julgamento coletivo, pois já houve ampla instrução nos casos individuais, muitos julgamentos das controvérsias individuais, inúmeros recursos, de forma que os argumentos e as estratégias judiciais das partes já foram, em muito exauridas. As demandas individuais, nesse estágio, são facilmente agregáveis (Cf. MCGOVERN, Francis E. Resolving mature mass tort litigation. Boston University Law Review. V. 69:659-694, 1989, p. 688). 857 MENDES, 2012, p. 284-285. 
Em caso de rejeição do incidente, o curso dos processos individuais será retomado. Em caso de admissibilidade, os processos individuais serão suspensos, em primeiro e segundo grau, na área de jurisdição do Tribunal e o incidente deverá ser julgado, no mérito, no prazo legal de 6 meses. O marco inicial para a fluência do prazo citado começa a partir da decisão de admissibilidade do incidente e o relator poderá prorrogar esse prazo, mediante decisão fundamentada. O projeto prevê, ainda, a possibilidade de suspensão nacional dos processos individuais pelo Tribunal Superior competente para conhecer de eventual recurso especial e recurso extraordinário.

A fase seguinte é relativa ao julgamento de mérito do incidente. Ultrapassada a fase da admissibilidade, será instaurado um contraditório coletivo comum no prazo de 15 dias, quando as pessoas interessadas poderão juntar documentos, bem como pleitear diligências para o esclarecimento da controvérsia. Em seguida, novo prazo será aberto para parecer ministerial.

Por fim, é polêmica a questão relativa à eficácia vinculante da tese jurídica fixada no incidente de demandas repetitivas. Aluísio Gonçalves de Castro Mendes ${ }^{858}$ defende que a melhor alternativa seria a extensão da coisa julgada aos titulares dos direitos dos processos individuais. A aplicação da tese aos processos individuais representa, pois, o efeito positivo da coisa julgada.

Essa conclusão, pela extensão da coisa julgada, é a que melhor se coaduna à natureza unitária da decisão sobre a questão jurídica comum. A decisão é extensiva aos demais casos individuais, pois eles pertencem ao mesmo universo coletivo, cuja amostra representativa foi objeto de julgamento. O resultado da amostra é, assim, extrapolado para os demais casos individuais.

Não se poderia tratar de um precedente, pois, como já explicitado antes ${ }^{859}$, o precedente é apenas universalizável. A analogia entre a ratio do precedente e o caso individual não é in re ipsa. E, por fim, o precedente pode ser afastado pela distinção entre os casos paradigma e o caso individual subsequente (distinguishing) ou pela superação da tese jurídica fixada (overruling).

No incidente de resolução de demanda repetitivas, a tese jurídica já foi universalizada, pois ela foi forjada em um processo sob contraditório coletivo e incide sobre a amostra representativa do grupo. A tese jurídica é, portanto, aplicada por mera derivação aos casos individuais, sendo, 
assim, menos derrotável. O seu afastamento equipara-se ao afastamento da autoridade da coisa julgada, o que é, em tese, possível, mas muito mais raro que o afastamento do precedente. ${ }^{860}$

A proposta é, ainda, muito recente, de modo que não é possível realizar um exercício de futurismo para explicitar todas as repercussões do instituto. Mas, desde já, é preciso destacar a necessidade de discussões mais aprofundadas sobre natureza desse instituto e seus escopos. Se o procedimento visa reduzir e desestimular a propositura de demandas individuais, por meio de uma decisão unitária, pode-se dizer que sua natureza é de agregação processual. Por isso, a tese jurídica comum deve abreviar o julgamento ou "queimar etapas" dos casos individuais.

Se o procedimento visa estabelecer apenas a uniformidade, a coerência ou a consistência aos provimentos judiciais, sem preocupação à variação da fattispecie, a natureza é de vinculação jurisprudencial. A tese jurídica fixaria, assim, apenas os parâmetros legais interpretativos de uma dada controvérsia repetitiva, ainda que isso não venha a avançar, substancialmente, a solução do caso individual ou a reduzir o número de demandas individuais no futuro próximo.

Além das propostas de lege ferenda, é possível encontrar alguns caso de agregação, mediante a coletivização de demandas individuais, de lege lata. Segue-se com um breve relato dos casos.

\subsubsection{CASOS DE COLETIVIZAÇÃO DE LEGE LATA}

O primeiro caso a ser mencionado é do Tribunal de Justiça do Estado do Espírito Santo. Tratase de recurso que tramitou sob a relatoria do Des. Samuel Meira Brasil Jr, com o $\mathrm{n}^{\mathbf{o}}$ $11089001348^{861}$. O caso mencionado diz respeito à tutela de urgência, reapreciada em sede de Agravo de Instrumento, em que se discutia preterição em concurso público, motivada pela contratação de servidores, sob regime excepcional de provimento de designação temporária.

860 Como diz Candido Rangel Dinamarco, a utilidade da coisa julgada é o seu efeito imunizador, de assegurar estabilidade ao julgado, impedindo que a mesma controvérsia seja novamente discutida. A coisa julgada é o grau mais elevado de estabilidade do sistema jurídico, cujo escopo é a segurança jurídica. Mas, até mesmos os rigores da coisa julgada podem ser relativizados em hipóteses excepcionais. Mas, a possibilidade de uma das partes derrotar a coisa julgada é mais rara, exigindo uma ponderação de valores atinentes ao processo. A possibilidade de afastar um precedente é autorizada, segundo determinadas técnicas processuais, antes mencionados (Cf. DINAMARCO, Cândido Rangel. Nova era do processo civil. 4 ed. São Paulo: Malheiros, 2013, p. 223-224). 861 BRASIL. Tribunal de Justiça do Estado do Espírito Santo. Agravo de Instrumento no 11089001348 . Acesso em 25 de outubro de 2013. 
Os autores, candidatos do certame, argumentavam que os servidores temporários exerciam funções típicas do cargo público, quando ainda havia candidatos aprovados no concurso público por eles realizado, o que caracterizava a preterição. O réu argumentava, no entanto, que não havia cargo público vago e que os servidores temporários atuavam em substituição aos servidores ativos, que estavam licenciados ou, de qualquer modo, afastados de sua atividade. Por essa razão, não se tratava de preterição dos candidatos aprovados em concurso público.

A acórdão salientou, no entanto, a existência de um impasse. Se, por um lado, era plausível a alegação do réu de que os servidores contratados estavam em regime de substituição de servidores efetivos, por outro lado, não era possível olvidar de que esse regime já perdurava há mais de três anos, desde 2005, data em que já havia candidatos aprovados em concurso público, que é a forma regular e constitucionalmente assegurada de provimento dos cargos públicos

Para resolver o impasse, decidiu-se, em sede de tutela de urgência, que, considerando a reiterada prática da contratação temporária pelo réu e a possível continuidade dessa prática no curso do processo judicial, os candidatos concursados deveriam adquirir preferência na contratação temporária. Diante da cognição sumária realizada nos autos, a tutela de urgência não autorizava a nomeação dos candidatos aprovados. Autorizava-se, apenas, a contratação temporária dos próprios candidatos concursados, enquanto a questão controvertida não era apreciada em sede de cognição exauriente. Nesse sentido, cita-se trecho do julgado referenciado:

[...] tendo em vista a incerteza quanto à existência de cargos vagos, em razão do grau sumário e superficial de cognição do presente recurso, tenho que as referidas contratações temporárias devem ser mantidas, eis que não é admissível a nomeação definitiva de um candidato quando não há cargo, criado por lei, a ser provido. Entrementes, ante a reiterada contratação temporária e possível continuidade dessa prática durante o desenvolver do presente processo, convenço-me que os candidatos concursados adquirem preferência nessa contratação. Vale dizer que, se as contratações temporárias são necessárias, mas existe concurso público dentro do prazo de validade, nada mais razoável que ofertar as referidas contratacões aos próprios candidatos concursados, os quais poderão ser nomeados, com caráter de definitividade, em caso de comprovada vacância ou de criação de novos cargos durante o prazo de validade do concurso. No momento, repito, ante a incerteza quanto ao número de cargos existentes e quanto à vacância dos mesmos, não é possível realizar a nomeação dos candidatos concursados. Embora existam contratações temporárias, as mesmas, ao que tudo indicam, podem não representar a vacância de cargos, mas apenas a substituição temporária de um servidor efetivo [...] Nessa linha de raciocínio enquanto não aprofundada a cognição dos autos, entendo prudente a manutenção das contratações temporárias, todavia essas contratações devem ser 
oferecidas aos candidatos concursados segundo a ordem de classificação no certame. $[\ldots]$ [grifo original] ${ }^{862}$

Por força da tutela de urgência, o réu deveria ofertar as contratações temporárias aos candidatos aprovados no concurso público, ao menos até o julgamento de mérito da ação originária em trâmite naquela Justiça Estadual ou ao menos até a vacância dos cargos públicos pretendidos.

O único problema posto, em tese, por essa decisão, é que não se tratava de uma ação coletiva, ajuizada por um dos legitimados coletivos. Muito pelo contrário, a demanda foi proposta, exclusivamente, por alguns indivíduos, que eram candidatos concursados. E, esses candidatos, autores da demanda individual, não eram sequer os melhores colocados no certame, de modo que não seria possível ofertar-lhes a contratação temporária, sem que igual oferta fosse feita, em primeiro lugar, aos melhores classificados, os quais não eram partes na demanda.

A solução encontrada pelo Relator foi assegurar a tutela jurisdicional de urgência, deferida em sede de Agravo de Instrumento, aos melhores colocados no certame, ainda que eles não tivessem sido formalmente integrados à demanda na condição de partes. A razão para isso é que, diante da concessão da tutela de urgência favorável aos candidatos do certame, não havia dúvidas quanto à adequada representação conferida pelos autores da demanda individual. A decisão da tutela de urgência poderia ser estendida também para os demais candidatos no certame, observando sempre a ordem de classificação no concurso. Nesse sentido:

[...] Essa decisão assegura uma tutela em favor dos melhores classificados no concurso público (uma vez que qualquer resultado que viole a ordem classificatória do concurso público é inconstitucional), inclusive aqueles que não se encontram formalmente na relação jurídica processual. Mas, nem por isso serão excluídos dos efeitos da decisão. Os candidatos Leonardo Colodette e José Mozart Erthal, detentores da $4^{\circ}$ (quarta) e $7^{\circ}$ (sétima) posição, terão a tutela assegurada, pois não é possível entregar a pretensão dos recorridos sem proteger o seu respectivo direito (constitucional) de acesso a cargo público por concurso. Estão, assim, substituídos pelos recorridos na eventualidade de um provimento jurisdicional favorável. Desse modo, a representatividade adequada dos agravados para obter tutela favorável aos demais aprovados no concurso público encontra-se legitimidade secundum eventum litis, pelo resultado favorável da demanda aos eventuais substituídos $[\ldots]^{863}$

Forçoso convir que essa decisão procedeu à coletivização, de lege lata, da demanda individual para os demais candidatos no certame, especificamente os melhores classificados no concurso,

862 BRASIL. Tribunal de Justiça do Estado do Espírito Santo. Agravo de Instrumento no 11089001348 . Acesso em 25 de outubro de 2013.

863 BRASIL. Tribunal de Justiça do Estado do Espírito Santo. Agravo de Instrumento nº 11089001348 . Acesso em 25 de outubro de 2013. 
os quais não eram partes na demanda. Isso porque não era possível desatender o direito dos melhores candidatos à estrita observância da ordem de classificação na concorrência pública.

Com isso, resta claro que houve o reconhecimento de um dos critérios substanciais de agregação, ora abordados nesta investigação, a saber, o critério da paridade. Embora a pretensão fosse divisível, o bem jurídico protegido - direito de concorrência em concurso público - é normativamente incindível e paritário. Desse modo, se uma prerrogativa é conferida a um candidato, com mais razão deve ser conferida aos melhores candidatos, segundo a ordem de classificação, sob pena de desequiparar as posições individuais e esfacelar o instituto do concurso público, cujo escopo é selecionar o candidato mais preparado naquele certame.

A hipótese de coletivização de lege lata não se exaure nesse caso, todavia. Novamente, no Tribunal de Justiça do Estado do Espírito Santo, é possível encontrar, ainda, uma segunda hipótese de coletivização de lege lata. Essa hipótese é muito mais complexa, exige um maior esforço de adaptação processual e impõe maior incerteza do design procedimental aplicável.

A hipótese mencionada diz respeito à Ação Civil Pública nº 19637-12.2013.8.08.0024 ${ }^{864}$. Em sua peça inicial, o Ministério Público narra a existência de 42 processos individuais tramitando na justiça capixaba com relação ao concurso público para provimento do cargo de Delegado da Polícia Civil. As demandas individuais estão pulverizadas nas Varas da Fazenda Pública Estadual de Vitória e Vila Velha. E, em todas essas demandas individuais, os autores discutem questões da prova objetiva, no tocante à elaboração e ao conteúdo da questão, supostamente em desconformidade ao edital do concurso público objeto da controvérsia deduzida em juízo.

Nessas demandas individuais, os candidatos autores não pleiteiam a anulação da questão objetiva, mas apenas os pontos da questão para sua esfera jurídica. As demandas também não são rigorosamente idênticas, pois os candidatos pedem pontos de questões diferentes. Uns candidatos pedem os pontos da questão 64 e 77, outros da questão 26 e 44 e assim por diante.

Em todas as demandas individuais, segundo o órgão ministerial, deve-se observar o princípio da isonomia e da eficiência no concurso público. O órgão ministerial argumenta que se os pontos forem deferidos, em sede tutela de urgência ou em cognição exauriente, para apenas 
alguns candidatos, autores das demandas individuais, os princípios da isonomia e da eficiência serão violados. O princípio da isonomia será violado, porque todos os candidatos devem concorrer em igualdade de condições. O princípio da eficiência será inobservado, pois os aprovados devem ser aqueles candidatos mais preparados e não aqueles que lograram receber, judicialmente, os pontos de uma questão, enquanto aos outros não tiveram a mesma sorte.

Por essa razão, o membro do Ministério Público pleiteia, na ação coletiva, a extensão dos pontos conferidos a qualquer candidato, em uma demanda individual, a todos os demais candidatos do concurso público, mantendo-se a isonomia entre todos. Assim, veja pretensão ministerial:

[...]seja concedida liminarmente a tutela pretendida no sentido de determinar aos requeridos a extensão da pontuação pertinente às questões da prova objetiva anuladas por força de decisões judiciais, liminares ou definitivas, pretéritas ou futuras, a todos os candidatos inscritos no concurso público para provimento de cargos de Delegado da Polícia Civil do Estado do Espírito Santo $[\ldots]^{865}$

A pretensão do Ministério Público é, nada menos, do que coletivizar as 42 demandas individuais existentes e qualquer outra demanda individual futura relativa a esse mesmo concurso público, no sentido de que seja mantida a igualdade dos candidatos no tocante à pontuação. Assim, quando a pontuação for conferida por força da invalidade de uma questão da prova em favor do autor individual, a mesma pontuação deve ser estendida pela ré para os demais candidatos.

E, mais, o Ministério Público do Estado do Espírito Santo encarta a sua pretensão como sendo de direito coletivo stricto sensu, isto é, indivisível e titularizado por grupo, classe ou categoria. Veja:

[...] Assim, como a presente ação civil pública tem por objeto a tutela de direitos coletivos stricto sensu lesados ou ameaçados de lesão, a sentença nela proferida fará coisa julgada ultra partes em favor do grupo de candidatos inscritos no concurso público em foco (inciso II do art. 103 da Lei n ${ }^{\circ}$ 8.078/90), garantindo-se a plena e total aplicação dos princípios que orientam os concurso públicos, mitigando-se os efeitos do citado artigo 472 do CPC $[\ldots]^{866}$

Na realidade, a controvérsia deduzida na referida ação coletiva encontra-se na mesma linha das tendências de reforma processual que foram vistas nos tópicos anteriores. Destacam-se os

865 BRASIL. Tribunal de Justiça do Estado do Espírito Santo. Ação Civil Pública no 19637-12.2013.8.08.0024. Acesso em: 25 de outubro de 2013, p. 26 do recurso.

866BRASIL. Tribunal de Justiça do Estado do Espírito Santo. Ação Civil Pública nº 19637-12.2013.8.08.0024.

Acesso em: 25 de outubro de 2013, p. 13 do recurso. 
critérios substanciais de agregação, uma vez que são os princípios do direito substancial e são os contornos da relação substancial, deduzida em juízo, a revelar a necessidade de agregação.

No caso narrado, o Ministério Público apenas narrou a necessidade de observância da isonomia e da eficiência. Mas, traduzindo isso de forma mais ampla, pode-se dizer que são os critérios da paridade e da impessoalidade, presentes no direito substancial, que exigem a agregação processual como técnica adequada e necessária à resolução dessa controvérsia de massa.

O caso narrado é de concurso público, mas poderia ser uma licitação multitudinária, poderia ser uma política pública, uma prática econômica abusiva e se, nesses casos, estivermos diante de uma situação de indivisibilidade, paridade ou impessoalidade, pondera-se pela agregação.

Ocorre que, o último caso narrado impõe maiores incertezas e dificuldades no design procedimental. O Ministério Público pretende o tratamento coletivo das demandas individuais, pois a pontuação das questões da prova objetiva, se invalidadas, devem ser dados a todos os candidatos. Ocorre que o Ministério Público não deduz a invalidade de qualquer questão da prova objetiva. A causa de pedir e o pedido ministerial não englobam a causa de pedir e os pedidos de todas as demandas individuais. Muito pelo contrário, o seu pedido é que essas demandas sejam coletivizadas e, se a invalidade de alguma questão da prova objetiva vier a ser lograda pelo autor individual, que a ordem seja estendida para todos os demais candidatos.

A partir daí, inúmeras questões relativas à técnica processual começaram a despontar. E, ainda, uma série de confusões se sucedeu. Nem todos entenderam que o pedido do Ministério Público referia-se a um direito coletivo stricto sensu. Alguns magistrados, inclusive apreciando tutela de urgência em grau recursal ${ }^{867}$, trataram as demandas individuais como se fossem demandas de direitos individuais homogêneos e, ainda, admitiram, em tese, a possibilidade de suspensão das ações individuais em razão da supracitada ação coletiva proposta pelo Ministério Público.

Vale destacar, desde logo, que a controvérsia em tela não diz respeito a direitos individuais homogêneos. Em primeiro lugar, a própria peça inicial do Ministério Público define o direito tutelado como coletivo stricto sensu. Em segundo lugar, o direito não é divisível ou homogêneo.

867 BRASIL. TRIBUNAL DE JUSTIÇA DO ESTADO DO ESPÍRITO SANTO. Agravo de Instrumento ${ }^{\circ}$ 13239-65.2013.8.08.0024. Acesso em 25 de outubro de 2013. 
Na realidade, todas as demandas individuais são "ações coletivas de fato", pois todas pretendem a pontuação de questões da prova objetiva, por inobservância do edital do certame. Se a questão for reconhecida válida ou inválida para um, deverá ser reconhecida válida ou inválida para todos, sob pena de comprometimento da paridade e da própria concorrência global no concurso.

E, de igual modo, não é possível a suspensão das ações individuais, como sói ocorrer na hipótese de direitos individuais homogêneos. A suspensão seria uma técnica processual adequada se a ação coletiva deduzisse em juízo todos os pontos controvertidos comuns às demandas individuais. Assim, a controvérsia seria integralmente resolvida na ação coletiva, aplicando-se o efeito positivo da autoridade da coisa julgada aos processos individuais.

Mas, o Ministério Público não procedeu dessa forma. Não há causa de pedir na ação coletiva, pela invalidade de uma ou de outra questão. O que o Ministério Público fez foi referir-se às ações individuais, pleiteando o mesmo resultado, eventualmente deferido para o autor individual, para todos os demais candidatos. Se essas ações individuais forem suspensas, não haverá meio processual para apreciação da controvérsia deduzida em juízo pelos autores.

Por fim, a tutela de urgência foi deferida em grau recursal, para que os pontos, eventualmente, deferidos nas demandas individuais, de alcance coletivo, sejam estendidos para todos os demais candidatos do certame. Algumas questões, ainda, no entanto, deverão ser resolvidas:

(i) Essas demandas individuais, de alcance ou valência coletiva, estão pulverizadas em três Varas da Fazenda Pública. Assim, já aconteceu de um juízo reconhecer a validade de uma questão no processo do candidato $\mathrm{X}$ e outro juízo reconhecer a invalidade dessa mesma questão na demanda do candidato $\mathrm{Y}$, estendendo o resultado para todos os demais candidatos, inclusive para o candidato $X$, que sucumbiu anteriormente. Depara-se, assim, com inúmeros conflitos práticos de julgado. Essa questão já foi alegada na resposta ofertada pela Procuradoria do Estado e pela Comissão do Concurso. Não há, ainda, solução para as questões postas, pois o processo encontra-se na fase de julgamento da tutela de urgência.

(ii) A lista de classificação no certame está precária. Segundo a Procuradoria do Estado do Espirito Santo, a lista de classificação e até a nomeação dos candidatos está à mercê das ações individuais. Isso porque o candidato ajuizou uma demanda 
individual e logrou obter a pontuação da questão, que foi considerada inválida. Essa pontuação foi estendida a todos os demais candidatos. Ocorre que o candidato, autor dessa demanda individual, reprovou na fase seguinte do certame, o que implica, em regra, a perda superveniente do interesse de agir na demanda individual. Com a extinção dessa demanda individual, não mais subsiste a decisão que deferiu a pontuação extensível a todos os demais candidatos, o que implica a modificação da lista geral de classificação. A lista de classificação ficou instável, muda ao sabor das demandas individuais e, com isso, torna-se impossível finalizar o concurso público.

Na realidade, grande parte dos argumentos alegados pela Procuradoria do Estado merece ser levados em consideração para fins de desenho do procedimento a ser adotado no caso em tela.

De fato, essas demandas individuais não poderiam tramitar de forma pulverizada, pois todas detém alcance coletivo e deveriam ser reunidas em um mesmo juízo. Com a reunião, deve ser afastado o iminente risco de conflito prático de julgados. A questão de n. 77, 66, 44 ou qualquer outra questão impugnada da prova objetiva do certame deve, pois, ser apreciada por uma decisão unitária, em um procedimento agregado, e não de forma pulverizada em cada uma das ações individuais. A pulverização das demandas individuais incentiva o abuso ou o efeito carona invertido: agora todos os candidatos do concurso têm interesse em ajuizar uma ação individual pulverizada, pois se um candidato não lograr êxito na sua pretensão, outro candidato poderá ajuizar uma demanda individual e, se lograr êxito, estender a pontuação para todos.

De igual modo, a eventual extinção de uma demanda individual ou o abandono da demanda individual não poderia prejudicar os demais candidatos, tampouco alterar a ordem de classificação. Considerando que já existe uma ação coletiva em trâmite, essa ação individual deve permanecer reunida à ação coletiva, para ser apreciada. Ainda que a demanda individual seja abandonada ou não subsista mais interesse de agir do autor individual, o processo é objetivo por força da ação coletiva em trâmite, que pretende estender a pontuação a todos os candidatos.

Essas soluções técnicas estão, no entanto, apenas no plano da cogitação para o caso narrado. Até o presente momento não há manifestação concreta sobre nenhuma dessas questões controvertidas ou sobre possíveis soluções, antes citadas para fins agregação processual. 
O design procedimental é, ainda, uma incógnita. Mas, mesmo assim, é interessante notar que as "ações coletivas de fato" já existem no direito brasileiro e são mais comuns do que se poderia imagina, sendo sentida a necessidade de soluções imediatas, segundo o direito vigente, para o processamento formal dessa controvérsia coletiva.

\subsection{SÍNTESE PARCIAL}

O reconhecimento dos critérios substanciais de agregação tem implicações tanto no sistema jurídico estadunidense, quanto no sistema jurídico brasileiro. No sistema jurídico estadunidense, destaca-se o regime processual das ações coletivas, como a maximização da vinculação obrigatória ao julgado e com a minimização da autoexclusão e a notificação, tudo em consonância ao grau de variância ou convergência substancial entre os membros do grupo.

No direito brasileiro, já existe, de igual modo, a aplicação de técnicas de agregação, de lege lata, de acordo com aquele mesmo grau de variância. Urge, no entanto, um verdadeiro sistema processual coletivo, como a ampliação das técnicas de agregação e, mais, com a possibilidade de adaptação do design procedimental e da estruturação subjetiva da lide às hipóteses exigidas pelo direito substancial: a um direito de massa deve ser conferido um processo de massa.

Em todos os casos em que há uma abrangência coletiva ou de massa, a agregação é possível. Os variáveis graus de vinculação que existe entre os planos individual e coletivo manifestamse, por sua vez, apenas na forma de tratamento ou nos instrumentos de agregação processual.

A intensidade com que as situações jurídico-substanciais de uma pluralidade de sujeitos se entrelaçam ou refletem de forma impessoal, indivisível ou paritária uns nos outros - reflexos que foram ponto a ponto explicitados e exemplificados no capítulo anterior - determinam não a agregação em si, mas o tratamento processual ou o regime processual da agregação.

Existem regimes de vinculação obrigatória, na qual não se admite a exclusão do indivíduo e será ele, eventualmente, prejudicado pelo resultado do procedimento agregado. Existem regimes de vinculação não obrigatória, na qual se admite a exclusão do indivíduo e não será ele prejudicado por eventual improcedência do resultado decisório do procedimento agregado. 
Pondera-se, apenas, que mesmo nos regimes de vinculação não obrigatória, seja admitida a instituição de um ônus argumentativo às partes, para evitar abusos ou sucessivas investidas de indivíduos ao Poder Judiciário, deduzindo uma mesma controvérsia coletiva em juízo. Esse tema será recuperado, todavia, no último capítulo, quando abordado o ônus argumentativo. 


\section{SEÇÃo III - AGREGAÇÃO, PRECLUSÃo E ARGUMENTAÇÃo}

\section{TEORIA DA REPRESENTAÇÃO E AS GARANTIAS CONSTITUCIONAIS PROCESSUAIS}

Nas seções e capítulos anteriores, foram exploradas diversas técnicas de agregação processual, bem como a necessidade de otimização dessas técnicas conforme a natureza do direito substancial controvertido. Deixou-se de abordar, naquela ocasião, propositadamente, as técnicas de preclusão processual. É chegada a hora de abordar a preclusão também como uma das técnicas de agregação processual. Este capítulo desenvolve as premissas desse raciocínio.

\subsection{APRESENTAÇÃO}

A preclusão, em geral, não constitui uma técnica direta de agregação processual, pois ela não possibilita o processamento e/ou a resolução conjunta e unitária da controvérsia. Por outro lado, pode-se dizer tratar-se de uma técnica indireta ou equivalente, pois, embora não promova a reunião ou a agregação da controvérsia, ela permite a estabilização dos resultados alcançados.

Nesse aspecto, Jay Tidmarsh e Roger Trangsrud ${ }^{868}$ salientam que nenhum sistema de agregação processual pode dispensar as técnicas de preclusão para alcançar o aperfeiçoamento e a otimização sistêmica. A agregação processual deve alcançar os membros ausentes do grupo. Do contrário, seria preciso agregar eternamente. Nenhuma técnica de agregação será completa, se, na semana que vem, um novo grupo de pessoas deduzir uma demanda sobre a mesma questão controvertida, já agregada e decidida de forma unitária em uma primeira oportunidade.

Casad e Clermont ${ }^{869}$ assinalam, ainda, que tanto a preclusão quanto a agregação aumentam a eficácia da adjudicação processual, evitando que a mesma controvérsia seja novamente litigada.

O mesmo raciocínio também é adotado pelo direito processual brasileiro. Barbosa Moreira ${ }^{870}$ já mencionou que o litisconsórcio, que é uma das técnicas de agregação processual, e a extensão 
subjetiva da coisa julgada apresentam equivalência funcional. Trata-se de dois expedientes a que recorre o legislador para evitar a quebra da homogeneidade nas relações plurissubjetivas. O resultado pretendido pela duas técnicas é o mesmo, apenas alcançado por método diverso.

Antes de Barbosa Moreira, a processualística italiana clássica já havia se debruçado sobre a questão. Chiovenda ${ }^{871}$ já salientava que, nas relações plurissubjetivas, a impugnação de um sujeito exclui a dos demais sujeitos, pois quando eles se encontram na mesma situação jurídica e diante de um mesmo bem de natureza indivisível, há que se reconhecer a identidade da qualidade jurídica entre eles. A identidade da qualidade jurídica substitui a identidade física do indivíduo, que é parte na demanda, ensejando, com isso, a vinculação de terceiros ao julgado.

Assim, o mesmo critério que autoriza, por exemplo, as hipóteses de litisconsórcio unitário, também autoriza a extensão subjetiva da coisa julgada. Eis a equivalência funcional entre as técnicas de agregação e as técnicas de preclusão. Essa equivalência ocorre porque, nas controvérsias plurissubjetivas ou de massa, os sujeitos interessados na relação de direito substancial deduzida em juízo apresentam-se na mesma posição ou qualidade jurídica. A identidade é o critério que atrai tanto as técnicas de agregação, quanto as técnicas de preclusão.

Ocorre que, uma vez admitida a preclusão como técnica equivalente ou indireta de agregação, é preciso equilibrar, balancear ou otimizar a estabilidade do comando decisório alcançado no procedimento agregado com o direito de autonomia e de defesa individual. $O$ terceiro, que não foi parte, isto é, que não figurou formalmente na demanda e que não participou pessoalmente do contraditório, deve ter oportunidade de narrar a sua história pessoal e os seus argumentos.

Camilo Zufelato ${ }^{872}$ bem assevera que, se a lei brasileira permanece fortemente atrelada ao dogma da coisa julgada e da restrição da coisa julgada apenas às partes, vários são os juristas nacionais que já reconhecem a autoridade da coisa julgada na esfera jurídica de terceiros. Para isso, é premente estabelecer um novo ponto de equilíbrio entre as técnicas de preclusão e a impossibilidade, segundo os preceitos constitucionais clássicos, de um terceiro sofrer prejuízos em sua esfera jurídica própria sem ter participado pessoal e diretamente do processo judicial.

871 CHIOVENDA, Giuseppe. Principii di Diritto Processuale Civile. Napole: Jovene, 1965, p. 915-924. Ibidem, 1998 , p. 429.

872 ZUFELATO, 2011, p. 85. 
Urge, como já dizia, Cappelletti ${ }^{873}$, um novo garantismo processual para as controvérsias plurissubjetivas ou coletivas. E, já sob essa perspectiva garantista, Proto Pisani ${ }^{874}$ salienta que a extensão subjetiva da coisa julgada não implica, necessariamente, contrariedade ao devido processo legal e seus consectários. Uma nova ponderação constitucional já é, portanto, possível.

Eis aí o campo minado a ser enfrentado. Essa é uma das questões mais difíceis e controvertidas do processo civil, da qual não é possível fugir. Mas, aqui, mais uma vez, é a natureza do direito substancial que indica o caminho a seguir, complementada pela ponderação das clássicas garantias constitucionais do processo civil: garantias do contraditório e do acesso à justiça.

\subsection{TEORIAS DA REPRESENTAÇÃO}

Como ressaltado, desde o início do presente trabalho, é a natureza do direito substancial o elemento crucial para a identificação das hipóteses e das formas de agregação processual. Antes de agregar, é preciso saber o que agregar. Vamos continuar, agora, a partir desse mesmo ponto.

Também, aqui, é a natureza do direito substancial o critério determinante para estabelecer a extensão subjetiva da coisa julgada e a aplicabilidade de outras técnicas de preclusão em relação a terceiros, membros ausentes e futuros de um grupo. A natureza do direito substancial dita as hipóteses em que o comando normativo do julgado alcança a esfera jurídica do terceiro. A imutabilidade, por sua vez, é decorrência da reinterpretação e da ponderação das garantias constitucionais processuais no plano dos direitos coletivos ou direitos de alcance coletivo. ${ }^{875}$

Inicialmente, pode-se dizer que as teorias de representação nos esclarecem os mecanismos ou as condições que autorizam a afetação de um terceiro nas controvérsias plurissubjetivas ou de massa. Esses mecanismos ou condições são variados, ora o fundamento da representação é consentimento do representado, ora o fundamento da representação é a semelhança descritiva entre representante e representado, ora o fundamento da representação é identidade dos interesses entre dois ou mais sujeitos, de forma a vinculá-los ao mesmo conteúdo normativo.

873 CAPPELLETTI, 1976, p. 207.

874 PISANI, Andrea Proto. Appunti sui rapporti tra i limiti soggettivi di efficacia della sentenza civile e la garanzia costituzionale del diritto di difesa. In: Rivista Trimestrale di Diritto e Procedura Civile, Anno XXV, 1971, p. 1240.

875 Em sentido semelhante, Camilo Zufelato ressalta a existência de um vínculo de coordenação entre a relação jurídica de um indivíduo, acobertada pela coisa julgada, e as relações jurídicas de terceiro, bem como a necessidade de equilibrar o alargamento da autoridade do julgado com as garantias constitucionais (ZUFELATO, 2011, p.106). 
Mais tarde, porém, vê-se que a representação está intimamente atrelada ao direito material. Isso pode soar estranho, mas a representação quase deixa de existir, ela se torna virtual. Não se trata mais de um sujeito agir em sua defesa e na defesa de outro, não se trata de um sujeito realizar as mesmas escolhas por outro. Trata-se, sim, de identificar as situações em que a relação de direito material cria as condições ótimas de "indivisibilidade e identidade" 876 e de "dependênciaprejudicialidade" 877 ou "coordenação" 878 para a comunicação da comando normativo do julgado cunhado em relação às partes em relação aos terceiros, estranhos ao processo originário.

Importa esclarecer, ainda, que essa representação de que se está tratando não se confunde com a representação processual, que possui um significado técnico conferido pelo direito brasileiro.

Representação, no sentido técnico e processual, significa a atuação de alguém, em juízo, em nome de outrem e no interesse de um direito de titularidade de outrem ${ }^{879}$. Representação, aqui, é utilizado no sentido das condições, dos aspectos, dos mecanismos que autorizam a afetação de um terceiro em uma controvérsia plurissubjetiva. É o consentimento do terceiro que autoriza a sua afetação? É a semelhança entre representante e representado? É a identidade de interesses?

\subsubsection{TEORIA FORMALISTA (FORMA OU RITUAL)}

Hanna Pitkin apresenta uma das obras mais completas a respeito da história do conceito de representação. Embora a obra não se dirija especificamente ao direito processual, sendo a representação abordada de forma genérica, incluindo o âmbito da política, da arte, da simbologia, os conceitos apresentados também podem ser aplicados ao direito processual.

A representação, no sentido formal, significa a forma ou ritual solene, pela qual a representação é concedida. Trata-se do ato de autorizar ou de consentir, ainda que implicitamente, conferido por um sujeito em favor de outro sujeito, para que esse último possa agir em nome e no interesse do primeiro. O fundamento da representação é a forma pela qual ela é realizada, isto é, exigese uma forma ou um ritual solene consistente na ciência, autorização ou consentimento.

876 GRINOVER, 2005, p. 6.

877 PISANI, 1971, p. 1239-140. TUCCI, 2006, p. 79.

878 ZUFELATO, 2011, p. 106.

879 Esse sentido técnico é explicitado por Cândido Rangel Dinamarco e Hugo Nigro Mazzili (Cf. DINAMARCO, 2009, p. 119; MAZZILLI, 2007, p. 62). 
Nesse sentido, segundo Pitkin ${ }^{880}$, um representante é aquele que foi autorizado a agir e o representado vincula-se às consequências da representação como se ele mesmo tivesse agido. Isso é chamado de visão formalista, pois ela é definida por uma transação que ocorreu fora e antes da atividade representativa. Os limites da representação são dados pelos limites da autorização conferida pelo representado ou pelo seu consentimento, ao menos implícito.

Esse é conceito já era marcante, por exemplo, no direito romano, na figura dos procuratores e cognitores, o que foi abordado em capítulo anterior. Reminiscências dessa visão formalista ainda vige no direito coletivo, o que ocorre nas hipóteses de opt in, isto é, o terceiro manifesta a vontade de ser incluído no processo. De igual modo, o opt out revela uma espécie de consentimento pela inércia, pois o indivíduo notificado, pode requerer a exclusão da demanda.

No tocante ao direito de autoexclusão, o aspecto do consentimento foi expressamente abordado no precedente Phillips Petroleum co. $v$. Shutts. ${ }^{881}$ Nesse precedente, restou consignado que a notificação e a possibilidade de autoexclusão dos membros ausentes da classe estabelecem uma espécie de consentimento implícito à vinculação do terceiro ao resultado da demanda coletiva.

No mesmo sentido, Yeazell ${ }^{882}$ também menciona um resquício da visão formalista de representação na categoria das class actions for damages 23(b)(3). De igual modo, esse autor ressalta o individualismo marcante na exigência de consentimento para fins de representação.

No direito brasileiro, Mafra Leal ${ }^{883}$ também assevera um resquício dessa doutrina, pois o art. 103 c/c com o artigo 104 do Código de Defesa do Consumidor preveem uma espécie de opt out para aqueles que já estão com suas ações individuais em curso. Para esses, é possível escolher entre aderir a ação coletiva, suspendendo sua ação individual, ou prosseguir com essa última.

É preciso destacar, por fim, que a representação pelo consentimento é pontual e remanescente no direito coletivo, principalmente no sistema jurídico estadunidense, porquanto a propositura, o processamento e o julgamento de uma demanda coletiva independe da concordância dos

880 PITKIN, 1972, p. 38-41.

881 UNITED STATES OF AMERICA. Supreme Court of United States. Phillips Petroleum co. v. Shutts. 472 U.S. 797 (1985).

882 YEAZELL, 1987, p. 256.

883 LEAL, 1998, p. 62. 
membros ausentes ou dos membros representados do grupo. De igual modo, até mesmo, a notificação individual e o direito de opt out são objetos de flexibilização naquele sistema.

Lembra-se que a notificação pode ser flexibilizada, sendo realizada por meios coletivos e não de forma individual. De igual modo, há sérias propostas no sentido de se exigir condições e justificativas para a realização do opt out. Mas, mesmo que admitida a exclusão do indivíduo da ação coletiva, eventual demanda individual subsequente poderá ser novamente agregada por outra técnica processual, como ocorre na consolidação das demandas individuais, que não admite qualquer exclusão. Nota-se, portanto, que a técnica de autoexclusão não é absoluta.

Essa teoria, sob o aspecto prático e de acordo com as exigências contemporâneas de justiça, é notadamente insuficiente. Como bem lembra Mafra Leal ${ }^{884}$, o consentimento dos membros representados torna a representação legítima e a extensão subjetiva da coisa julgada em harmonia com o devido processo legal. No entanto, não satisfaz as exigências contemporâneas de acesso à justiça, devido a impossibilidade fática de consulta a todos os membros ausentes da classe e devido aos custos que uma tentativa desse porte implicaria no processo civil coletivo.

Sob o aspecto exclusivamente teórico, Pitkin ${ }^{885}$ já advertia para a insuficiência dessa teoria. A teoria formalista de representação é notadamente insuficiente, até mesmo em teoria, pois, sendo a representação um ato de autorização, não é possível falar em boa representação ou má representação. A representação, sob esse aspecto, restringir-se-ia à forma, não teria conteúdo.

Enfim, seria uma fórmula vazia, não importando a performance e os resultados alcançados pelo representante, pois o representado seria vinculado necessariamente apenas porque consentiu.

Essa teoria restringe-se, em muito, às ciências humanas ${ }^{886}$, mas a representação também existe na arte, na matemática, na estatística. Logo, há de existir outro conceito de representação que não se refira à mera autorização ou ao mero consentimento estabelecido entre pessoas naturais.

\subsubsection{TEORIA DA SEMELHANÇA DESCRITIVA (TIPICIDADE OU QUALIDADE)}

884 LEAL, 1998, p. 63.

885 PITKIN, 1972, p. 46-49.

886 PITKIN, 1972, p. 48. 
A teoria anterior merece pequena reparação, pois ela é inapta a estabelecer qualquer espécie de controle ou juízo de adequação em relação ao representante. Pitkin ${ }^{887}$ salienta que era preciso agregar ao conceito de representação uma preocupação com a correspondência de ideias, uma noção de equivalência entre representante e representado, uma semelhança ou reflexo do outro.

Sob esse aspecto, o que importa é qualidade do representante e a sua correspondência com o representado ${ }^{888}$. Por essa razão, a teoria da representação por semelhança descritiva diz que é preciso estabelecer uma tipicidade, uma correspondência, uma réplica das características entre o representante e o representado. Essa noção é importante tanto nas ciências humanas, mas também na estatística, por exemplo ${ }^{889}$. Pode-se dizer que uma amostra é representativa, pois ela é uma fração correspondente ao universo que se pretende investigar. A amostra é apta a fornecer informações adequadas e precisas sobre o universo e a permitir inferências válidas sobre ele.

O noção de uma representação por semelhança descritiva é, na realidade, muito comum no sistema jurídico estadunidense. No direito medieval, como visto, o representante era escolhido pelas suas características típicas, sendo selecionado o indivíduo "mais discreto", "mais rico", "guerreiro" ${ }^{890}$. Atualmente, a tipicidade das pretensões e defesas entre o representante e os dos demais membros ausentes da classe é um dos requisitos de admissibilidade da Federal Rule 23. A tipicidade sobrepõe-se com alguns aspectos do requisito da representatividade adequada. ${ }^{891}$

De igual modo, para fins de aferição judicial da tipicidade e da representatividade adequada, exige-se que o representante seja membro da classe e que compartilhe dos mesmos atributos dos representados, de forma a ser considerado idôneo para essa finalidade. ${ }^{892} \mathrm{O}$ representante deve apresentar as mesmas qualidades do grupo, de forma a garantir uma correspondência, uma conexão ou um alinhamento de interesses, bem como de forma a evitar conflitos ou antagonismos entre o representante e os representados. Medidas de gerenciamento judicial do

887 PITKIN, 1972, p. 60-90.

888 IbIdem, p. 60-90. COFFEE JR, John C. Class action accountability: reconciling exit, voice and loyalty in representative litigation. Columbia Law Review, 2000, V. 100:370-439, p. 411.

889 PITKIN, op. cit., p. 87.

890 YEAZELL, 1987, p. 91.

891 Há, ao menos, uma sobreposição conceitual. A doutrina diverge quanto à extensão dessa sobreposição e quanto à necessidade de manutenção desse critério como requisito autônomo. MEECE, Gregory S. Class action, typicality and rule 10B-5: will the typical representative please stand up? Emory Law Journal. 1987, V. 36: 649-690, p. 651.TWINER III, Olger C. Federal Rule of Civil Procedure 23(a)(3) typicality requirement: the superfluous prerequisite to maintaining a class action. Ohio State Law Journal, 1981, V. 42:797-811, p. 811.

892 KLONOFF, 2007, p. 30. 
processo coletivo, como a intervenção obrigatória de um terceiro (mandatory intervention ${ }^{893} \mathrm{ou}$ intervenção iussu iudicis ${ }^{894}$ ) ou como a formação de subclasses, partem do princípio de que a existência de diferenças e conflitos entre os membros da classe prejudicam a representatividade.

Ainda que o autor da ação seja uma associação, a jurisprudência estadunidense afirma que a tipicidade das pretensões e das defesas é aferida, inicialmente, entre os membros ausentes do grupo. Em relação à associação, exige-se apenas a existência de um prejuízo concreto às suas finalidades, de forma a que essa associação esteja no mesmo patamar ou em situação de semelhança aos membros ausentes do grupo ${ }^{895}$ Presume-se que o interesse da associação, cuja finalidade é a proteção dos seus membros, é lesado quando os interesses dos seus membros também são lesados no âmbito protegido pelas finalidades institucionais daquela organização. ${ }^{896}$

Por vezes, exige-se - diga-se desnecessariamente - até mesmo um litisconsórcio da associação com um indivíduo, membro do grupo, para estabelecer a correspondência entre representante e representado. Isso ocorre, principalmente, nas hipóteses de pretensão à indenização pecuniária. Ganha força, hoje, todavia, a ideia de não é preciso que o representante seja necessariamente um membro do grupo, exige-se, sim, que ele seja alguém com interesse concreto no conflito. ${ }^{897}$

893 A intervenção obrigatória de terceiro foi bastante discutida após o precedente Martin v. Wilks. Nesse caso, um grupo de bombeiros brancos, que não foi parte em demanda anterior, insurgiu-se contra provimento jurisdicional, acobertado pela coisa julgada, que instituiu ação afirmativa em favor do grupo de bombeiros negros. O grupo de bombeiros brancos alegou discriminação inversa. Argumenta-se que a intervenção desse grupo (bombeiros brancos) no processo anterior obstaria a rediscussão da controvérsia em demanda subsequente, complementando a representação realizada pelo empregador na primeira demanda. Nem sempre o empregador é considerado o melhor representante dos empregados, quando há subgrupos. (FISS, Owen. Um novo processo civil: estudos norteamericanos sobre jurisdição, constituição e sociedade. Coordenação do trabalho Carlos Alberto de Salles. Tradução Daniel Porto Godinho da Silva e Melina de Medeiros Rós. São Paulo: Revista dos Tribunais, 2004, p. 216-218). No mesmo sentido, a intervenção obrigatória também é ressaltada por John C. McCoid, para fins de complementação da representação (Cf. MCCOID, John C. A single package of multiparty disputes. Stanford Law Review, 1976, V. 38:707-728p. p. 718).

894 Moacyr Lobo da Costa, no sistema brasileiro, ressalta que a intervenção obrigatória de terceiro, provocada pela iniciativa do magistrado, foi prevista no Código de Processo Civil de 1939. Esse técnica tinha por escopo integrar um terceiro que poderia ser prejudicado pela sentença, em razão do nexo presente na relação jurídica de direito substancial entre a parte e o terceiro, para que esse último fosse alcançado pela autoridade da coisa julgada (Cf. COSTA, Moacyr Lobo da. A intervenção iussu iudicis no processo civil brasileiro. São Paulo, 1961, p. 133). 895 COOPER, 1987, p. 511. GIDI, 2007, p. 126-128.

896 Por essa razão, sustenta-se a legitimidade ordinária do ente coletivo, pois quando há prejuízo concreto às finalidades institucionais desse ente, ele estará defendendo interesse próprio, pois os interesses de seus associados também são seus à medida que se propôs a defendê-los no seu ato constitutivo (Cf. WATANABE, Kazuo. Tutela jurisdicional dos interesse difusos: a legitimação para agir. In: GRINOVER, Ada Pellegrini (coord.). A tutela dos interesses difusos. A tutela dos interesses difusos. São Paulo: Max Limonad, 1984, p. 94).

897 GIDI, 2007, p. 126-128. CONTE, Alba; NEWBERG, Herbert. Newberg on class action. V. 1. 4 ed. Minneapolis: Thomsom West, 2002, p. 123. 
Ada Pellegrini Grinover ${ }^{898}$, no sistema jurídico brasileiro, também já mencionou a importância da representatividade adequada, pois constituiu garantia dos membros ausentes do grupo. $\mathrm{Na}$ hipótese de manejo de uma ação coletiva por uma associação ou pelo Ministério Público, por exemplo, não há qualquer óbice a que o magistrado realize a aferição da representatividade adequada desse ente, avaliando a credibilidade, a seriedade, a idoneidade, a pertinência temática, o alinhamento dos interesses entre o representante e a categoria representada. Ressalta-se, com isso, a especial qualidade que deve ter o representante para ser considerado adequado ao grupo, a saber, deve compartilhar dos mesmos atributos e interesses do grupo.

De igual modo, Susana Henriques ${ }^{899}$, Álvaro Mirra ${ }^{900} \mathrm{e}$ Swarai Cervone ${ }^{901}$ ressaltam a necessidade de uma especial qualidade, capacidade, compromisso e aptidão do representante para o exercício do múnus e para o fim de promoção satisfatória dos interesses da coletividade.

De igual modo, aqui, o legitimado coletivo também deve mostrar o interesse concreto na ação coletiva. Uma autarquia ambiental do Espírito Santo, para ajuizar uma ação para a defesa da paisagem natural do Amazonas, deve demonstrar um interesse direto e concreto nessa proteção. Isso porque, muito embora o direito seja difuso, não há, necessariamente, uma correspondência, uma proximidade e um maior conhecimento da realidade ambiental do Amazonas por essa autarquia, cujas atividades de proteção ambiental se restringem ao Estado do Espírito Santo.902

A ideia de semelhança descritiva, nos termos antes destacados, também está presente em outras técnicas de agregação, que não a ação coletiva. A consolidação e o caso-teste não apresentam um representante adequado, mas pode-se dizer que o magistrado deve apurar uma amostra adequada da controvérsia - um interesse sem classe - que represente o universo coletivo. ${ }^{903}$

898 GRINOVER, Ada Pellegrini. Da coisa julgada. In: GRINOVER, Ada Pellegrini, WATANABE, Kazuo e NERY JR., Nelson (coords.). Código Brasileiro de Defesa do Consumidor Comentado pelos Autores do Anteprojeto II. 10 ed. rev. atual. reform. Rio de Janeiro: Forense, 2011, p. 178.

899 COSTA, Susana Henriques da. A representatividade adequada e o litisconsórcio - o projeto de lei $\mathrm{n}^{\circ}$ 5.139/2009. In: CALMON, Petrônio et al (coords.). Em defesa de um novo sistema de processos coletivos: estudos em homenagem a Ada Pellegrini Grinover. São Paulo: Saraiva, 2010, p. 626.

900 MIRRA, Álvaro Luiz Valery. Ação Civil Pública em defesa do meio ambiente: a representatividade adequada dos entes intermediários legitimados para a causa. In: MILARÉ. Édis (coord.). A Ação Civil Pública após 20 anos: efetividade e desafios. São Paulo: RT, 2005, p. 34 e 44.

901 OLIVEIRA, Swarai Cervone. In: CALMON, Petrônio et al (coords.). Em defesa de um novo sistema de processos coletivos: estudos em homenagem a Ada Pellegrini Grinover. São Paulo: Saraiva, 2010, p. 652.

902 Em sentido semelhante, Hugo Nigro Mazzilli (Cf. MAZZILLI, 2007, p. 293).

903 FALLON, GRABILL, WYNNE, 2008, p. 2344. 
Muito embora a teoria da semelhança descritiva tenha dado um salto qualitativo ao conceito de representação adequada, essa teoria não esgota o conceito, tampouco é suficiente. A mera semelhança, a correspondência ou a equivalência entre representante e representado não implicam necessariamente uma adequada atividade representativa. A semelhança contribui apenas para assegurar e selecionar um representante idôneo, mas não exige que o representante aja de acordo com os interesses do grupo. Não há, ainda, uma instância de controle ou de limites.

Como diz Hanna Pitkin ${ }^{904}$, a semelhança descritiva é um dos aspectos da representação. Porém uma definição geral da representação baseada tão somente na semelhança seria incorreto.

\subsubsection{TEORIA DA IDENTIDADE DOS INTERESSES (SUBSTÂNCIA OU CONTEÚDO DA ATIVIDADE)}

Na visão formalista de representação, o representante não tinha deveres ou obrigações, contava apenas com uma autorização para agir. Segundo a teoria da representação pela semelhança descritiva, o representante deveria ser alguém que comungasse dos mesmos atributos, das mesmas qualidades do grupo. Agora, pela teoria da identidade dos interesses, é relevante que representante aja em favor da categoria. O marco dessa teoria é a substância ou o conteúdo da atividade representativa de um grupo. Representação é mais que qualidade, é uma atividade.

Para garantir a adequada representação como atividade, o interesse do representante deve ser, em primeiro lugar, um interesse pessoal na promoção e na defesa do seu direito Além de pessoal, o interesse do representante deve ser idêntico ao interesse do grupo. Por quê? Parte-se do princípio de que o homem somente representa, em verdade, aquilo com que ele realmente se preocupa ${ }^{905}$. Se o interesse é pessoal e também é idêntico, o representante, ao promover o seu próprio interesse, promoverá, consequentemente, o interesse dos demais membros do grupo. Trata-se, assim, de uma presunção, que parte de um senso egoístico do homem médio.

O representante somente age em favor do outro, apenas porque primeiro age em seu próprio interesse, que apenas coincide com os interesses dos demais. O link ou a conexão entre o representante e o representado é o self-interest ${ }^{906}$ ou interesse próprio que motiva o legitimado.

904 PITKIN, 1972, p. 81. 
A partir dessa teoria da identidade dos interesses, conforme assevera Pitkin ${ }^{907}$, é possível discutir as obrigações de um representante, bem como avaliar a defesa que ele realiza pela categoria.

A exigência do interesse próprio do representante visa a motivar e a garantir a vigorosa tutela dos membros do grupo, isto é, visa ao bom desenvolvimento da atividade representativa (substância ou conteúdo). Pitkin ${ }^{908}$ salienta que se uma pessoa abre mão de um interesse ou de um direito, isso pode ser compreendido como um ato de generosidade. Agora, se um representante abre mão de um interesse ou de um direito, que é dele e também de outros, isso pode ser compreendido como um ato de irresponsabilidade. $\mathrm{O}$ fato é que se espera de um representante uma defesa vigorosa dos direitos do grupo e um comportamento mais cauteloso no tocante aos riscos. O representante deve se comportar como se fosse prestar contas de sua atividade. Ele deve estar preparado para justificar suas ações, caso isso seja necessário.

Nos Estados Unidos, a noção de identidade dos interesses como fundamento da representação foi, majoritariamente, adotada e aceita como o elo de coesão entre representante e representados. Essa teoria, no entanto, subdividiu-se em duas: a teoria da comunhão de interesses (theory of community of interest) e da comunhão de direitos (common right theory). ${ }^{909}$

Segundo a teoria da comunhão de direitos, os membros do grupo devem compartilhar um mesmo direito ou apresentarem um mesmo vínculo jurídico, encontrando-se em uma situação de homogeneidade jurídica. A teoria da comunhão de interesses, por sua vez, não exige os mesmos direitos, mas exige os mesmos atributos dos membros do grupo em relação ao mesmo objeto controvertido. Enquanto a primeira teoria é qualitativa, voltada ao tipo de direito que se pretende tutelar, a segunda é quantitativa, voltada ao número (predominância) de questões comuns ao grupo. As diferenças entre as duas teorias é, no sistema estadunidense, bastante tímida hoje. Isso porque a comunhão exigida pela Rule 23, após a reforma de 1966, é de questões de fato e/ ou de direito, não houve adoção exclusiva de nenhuma das duas teorias. ${ }^{910}$

907 PITKIN, 1972, p. 186.

908 Ibidem, p. 118.

909 Sobre essas teorias, consultar: (Cf. KAMP, Allen R. Adjudicating the rights of plaintiff class: current procedural problems. Saint Louis University Law Journal, 1982, V. 36:364-399p. SIMEONE JR, Joseph J. Class suits under the Codes. Western Reserve Law Review, dezembro de 1955. LILLY, Graham C. Modeling class action: the representative suit as an analytic tool. Nebraska Law Review, 2003, V. 81:1008-1055p. PROTOS, Michael C. An epistemological approach to class certification: a classy understanding of the problems of class action. Case Western Reserve Law Review, 1992, V.42:1297-1337p).

910 PROTOS, 1992, p. 1311. 
Essa conclusão não poderia ser diferente, pois como já visto em capítulos anteriores, a certificação da ação de classe segundo a Rule 23, é prática, mas não há dispensa da análise do relação jurídica de direito substancial. O que importa não é se os indivíduos possuem o mesmo direito (o mesmo rótulo ou vínculo jurídico) ou se eles possuem o "mesmo núcleo de fatos operativos"911 na controvérsia, o que importa é que eles estejam na mesma posição ou situação no tocante à controvérsia deduzida em juízo. As duas teorias revelam o indivíduo na qualidade de membro do grupo: o que importa é que os indivíduos, membros do grupo, apresentem a mesma orientação impessoal sobre a controvérsia em juízo, para fins de sua representação. ${ }^{912}$

A orientação dos indivíduos pode ser impessoal, porque o direito substancial apresenta um vínculo jurídico entre os membros do grupo, como se o direito de um se estendesse até o outro, a exemplo das relações societárias, da sucessão de interesses etc. Os indivíduos estão na mesma posição em relação ao bem protegido pelo direito substancial, objeto da controvérsia em juízo.

A orientação dos indivíduos também pode ser impessoal, porque o direito substancial, mesmo que sem o mesmo rótulo jurídico, apresenta situações objetivas e cognatas, permitindo que os indivíduos assumam uma posição equidistante em relação ao objeto da controvérsia deduzida em juízo. O importante é a impessoalidade e a inexistência de características pessoais. ${ }^{913}$

Ainda, por força da teoria da identidade de interesses, a vigorosa tutela dos interesses do grupo pelo representante é um dos critérios práticos para aferição da representatividade adequada. Assume-se que se há essa identidade de interesses entre representante e representado, o primeiro deverá perseguir vigorosamente os interesses do grupo ao perseguir os seus próprios interesses.

911 PROTOS, 1992, p. 1317.

912 Ibidem, p. 1328

913 Em sentido semelhante, Michael Protos diferencia: "where the common right theory identifies and orients a person based on a right in relation to a common subject matter, the community of interest structure examines questions arising from a common subject matter. Using questions in relation to a common subject matter fundamentally changes the relationship of the individuals constituting the group. Most importantly, no privity exist among individuals in the community of interest theory approach. Nonetheless, the theory serves to describe a person's orientation with regard to a certain subject matter. The common question thus act as the unifying force, which binds all members of the group. [...] Similar to the common right theory, the questions in relation to the subject matter are, the bottom, a label which describes or communicates information. The characteristics contained within any particular orientation, whether a right in relation to a common subject matter or questions in relation to a common subject matter, are the building blocks of a class. People having the same orientation, by virtue of their possession of the same right in relation to a subject matter or question in relation to common subject matter, exhibit the same characteristics" (Ibidem, p. 1329 -1330). 
É preciso destacar, todavia, na hipótese de restar configurada a ausência superveniente do interesse de agir do representante, isso não necessariamente implicará a extinção da ação coletiva ou a substituição do representante. A repetição dos atos lesivos no tempo e a permanência da conduta abusiva em relação aos demais membros da classe corroboram a manutenção do interesse e, até mesmo, da representatividade do autor coletivo. No clássico precedente Roe v. Wade $e^{914}$, por exemplo, o término da gravidez da representante não impediu a análise de mérito de uma ação coletiva que questionava leis estaduais contra o aborto. Afinal, a gravidez é temporária para qualquer mulher em situação semelhante, logo o seu término não é hábil a afastar a representatividade da autora coletiva. De igual modo, a questão controversa - gravidez e lei antiaborto - é recorrente e devia ser apreciada mesmo após ao fim da gravidez.

O mesmo raciocínio está presente no precedente Sosna v. Iowa ${ }^{915}$. Nessa ocasião, foi proposta uma ação coletiva, impugnando lei estadual que exigia a residência por um ano no Estado para que a pessoa possa se divorciar. Quando a ação foi julgada pela Suprema Corte, o representante já residia no Estado há mais de um ano. Assim, ainda que o representante já pudesse se divorciar ao tempo da decisão, a Suprema Corte afastou a perda superveniente do interesse de agir no caso em tela. Assinalou que, tratando-se de uma demanda coletiva, não interessava o status pessoal do representante, mas, sim, a resolução do incidente legal respeito do status do grupo. Se o representante não pudesse prosseguisse na demanda, o ato ilícito poderia ser repetido.

Mesmo assim, nada obsta que, se após a certificação da ação de classe, surgir uma alteração peremptória do interesse do representante (como, por exemplo, um acordo com a parte adversa ou o atendimento espontâneo do seu interesse), seja esse substituído por outro membro do grupo. Se os atributos do representante do grupo vieram a ser questionados ou se o representante vier a negligenciar a condução da ação coletiva e atuar sem zelo e diligência, a substituição do representante é admissível, nessa hipótese, e é também preferível à extinção da ação coletiva. ${ }^{916}$

914 UNITED STATES OF AMERICA. Supreme Court of United States. Roe v. Wade. 410 U.S 113 (1973). EPSTEIN, Lee et al. Courts, judges and politcs: an introduction to the judicial process. 6 ed. Boston: McGrawHill, 2006, p. 278.

915 UNITED STATES OF AMERICA. Supreme Court of United States. Sosna v. Iowa. 419 U.S. 393(1975). Esse precedente foi comentado em: NOTE. Class standing and class representative. Harvard Law Review, $1981, \mathrm{~V}$. 94:1637-1659p, p. 1643.

916 NOTE, 1981, p. 1665. 
Por fim, a noção de identidade de interesses busca afastar eventuais antagonismos e conflitos entre os membros do grupo e o representante ${ }^{917}$. Nessa hipótese, é possível a formação de subclasses, com a admissão de mais um representante para cada subclasse, de forma a garantir a vigorosa tutela dos interesses antagônicos presentes dentro da mesma categoria litigante.

No direito brasileiro não é muito diferente. Cassio Scarpinella ${ }^{918}$, Ada Pellegrini Grinover ${ }^{919}$, Kazuo Watanabe ${ }^{920}$, Pedro Lenza ${ }^{921}$, Susana Henriques ${ }^{922}$, Swarai Cervone de Oliveira ${ }^{923}$ são autores que admitem a aferição da representatividade adequada no direito brasileiro, cabendo ao magistrado aferir a vigorosa tutela dos interesses dos membros da coletividade..$^{924}$

Cassio Scarpinella ${ }^{925}$ assinala, ainda, uma vez admitida a representatividade adequada no direito brasileiro, o papel de controle e fiscalização do magistrado deve ser valorizado, para evitar-se “falcatruas multitudinárias"926. O juiz deverá exigir a descrição da coletividade, poderá convocar e ouvir membros do grupo para aferir a idoneidade da pretensa representação e, ainda, verificar quais são os interesses prevalecentes no seio da coletividade, apurando a identidade.

\subsubsection{TEORIA DA REPRESENTAÇÃO VIRTUAL (PERFORMANCE OU RESULTADO)}

Como salientado, a representação, no tocante ao seu conteúdo, significa uma atividade em que o representante defende e torna presente os interesses do representado. Isso ocorre em razão da identidade dos interesses. O representante promove os seus interesses e, nessa medida, também promove responsivamente os interesses do representado com quem está alinhado. Com isso, assegura-se a ausência de conflito de interesses e a vigorosa tutela dos interesses comuns.

917 NOTE, 1981, p. 1665. FEDERAL JUDICIAL CENTER, 2004, p. 271 e 272.

918 BUENO, 1996, p. 129.

919 GRINOVER, 2011, p. 278.

920 WATANABE, 2011, p. 97.

921 LENZA, 2008, p. 188.

922 COSTA, 2010, p. 626.

923 OLIVEIRA, 2010, p. 652.

924 Em sentido contrário, Pedro da Silva Dinamarco, Arruda Alvim, Thereza Alvim, Eduardo Arruda Alvim e James Marins (Cf. DINAMARCO, Pedro da Silva. Ação Civil Pública. São Paulo: Saraiva, 2001, p. 133-138. ARRUDA ALVIM et al, 1995, p. 350-351).

925 BUENO, 1996, p. 145.

926 Ibidem, p. 142. 
Um fato merece destaque: o representante não, necessariamente, irá realizar as mesmas escolhas que o representado, não, necessariamente, adotará a mesma estratégia do representado. Não há essa coincidência. $\mathrm{O}$ representante atua em nome do representado, mas não é uma marionete, não é um instrumento ${ }^{927}$. O representante é uma pessoa com capacidade de agir e julgar, que deverá promover os interesses comuns, impessoais, indivisíveis e/ou paritários do grupo. Não há promoção - o que seria impossível em grandes grupos - de opiniões e preferências pessoais.

Assim, é possível dizer que os interesses que permitem e possibilitam a representação são objetivos. Se o representante fosse obrigado a seguir cada desejo, cada vontade, cada sentimento do representado, a representação seria impossível, seria uma das mais frágeis ficções. O representante não conseguiria dar um passo sem obter uma instrução ou fazer uma consulta aos representado. Isso já seria difícil em relação a apenas um representado, quanto mais quando a representação alcançasse um grupo ou uma categoria com inúmeros membros - larga escala.

Quando um advogado é contratado para representar os interesses de um cliente, quando o diretor de uma empresa é escolhido representante da pessoa jurídica, quando um político é eleito senador, o que o representado deseja é a promoção objetiva (no sentido de fomento ou de trabalho a favor) dos seus interesses por alguém capacitado. O cliente não diz ao advogado o que fazer a todo o momento, a cada petição, a cada recurso, ele diz qual é o seu interesse, cabendo ao advogado a capacidade de agir e pensar a melhor a estratégia de promovê-lo.

O mesmo raciocínio ocorre no processo. Os interesses comuns que ensejam a representação adequada são, como bem assevera Pitkin ${ }^{928}$, objetivos. É um interesse objetivo e impessoal, que não diz respeito a ninguém em especial, mas diz respeito ao indivíduo na qualidade de membro de um categoria. Por isso, a representação não é realizada no vácuo, não depende da mera coincidência episódica de interesses. O fundamento da representação é encontrado, em maior ou em menor grau, nos vínculos presentes no direito substancial entre os membros do grupo.

O fundamento da representação não é, por si só, o fato de que as escolhas do representante e do representado seriam coincidentes, idênticas ou semelhantes, caso o representado viesse a atuar.

927 PITKIN, 1972, p. 153.

928 Ibidem, p. 158. No mesmo sentido, Yeazell ressalta a objetividade do interesse que enseja a representação, independente da vontade individual: "interests became objective characteristics of the existing social order, not after-the-fact empirical judgment by individuals about whether a given arrangement of things had led to their increased well-being" (Cf. YEAZELL, 1987, p. 207). 
O fundamento da representação é que, por força do direito material, representante e representado encontram-se em uma mesma posição ou situação com relação à controvérsia deduzida, daí o alinhamento dos seus interesses. Trata-se de uma situação de anonimato individual ${ }^{929}$, de fungibilidade dos membros do grupo, pois, a princípio, qualquer deles é igualmente propenso a realizar a promoção dos direitos do grupo ${ }^{930}$. Não se trata de interesses pessoais, mas, sim, de interesses impessoais que impactam o indivíduo como membro do grupo.

Esse interesse é abstrato, impessoal e pode estar ligado ao membro de um grupo (João na qualidade de afrodescendente, pretendendo a sua cota no vestibular), a uma categoria (associação de afrodescendentes na defesa do direito de cotas na universidade) ou a destinatários indeterminados (pela paz mundial e pela igualdade de gênero, raça ou de classe).931

Diante disso, a atividade representativa consiste na deliberação racional dos argumentos comuns ou compartilhados no grupo, com a promoção dos seus interesses, isto é, consiste em uma performance ou no resultado desempenhado. Para que essa performance surja, a atividade representativa não pode ocorrer no vácuo. Ela somente ocorre quando o direito material, objeto da controvérsia, for deduzido de modo objetivo ou impessoal permitindo o alinhamento dos interesses entre representante e representado. Nesse caso, o papel do representante não é servir de espelho, marionete ou megafone do representado, mas, sim, deliberar racionalmente e promover os interesses comuns que o alcança na qualidade de membro de uma categoria. ${ }^{932}$

A comunicação da situação de um sujeito à situação dos demais sujeitos de um grupo decorre da natureza da relação substancial. E, nesses termos, a representação realizada é denominada de representação virtual ou representação pela performance ou pelo resultado desempenhado.

929 BONE, 1990, p. 218.

930 Robert G. Bone salienta que, a princípio, qualquer membro do grupo é apto para apresentar os argumentos de fato e de direito. Nesse sentido, cita-se que: "since all members, of the class associated with a legally defined status were identically situated with respect to litigation, any of them could be counted on to present all the relevant factual and legal arguments" (BONE, Robert G. Rethinking the "day in court" ideal and nonparty preclusion. New York University Law Review. 1992, V. 67:193-293p, p. 211). Nesse mesmo sentido, consultar Owen Fiss (Cf. FISS, 2004, p. 219).

931 Em sentido semelhante Hanna Pitkin (Cf. PITKIN, 1972, p. 156).

932 Segundo Hanna Pitkin, com fundamento na teoria de Burke, o papel do representante é a deliberação racional dos interesses. Em suas palavras: "is to find, through rational deliberations, the interest of the people, and to do so he needs do know their feelings. [...] To say a man represents a certain constituency is a formal way of saying that he represents the interest of which it is part" (Cf. PITKIN, 1972, p. 184-185). 
A representação é virtual, pois ela somente é cabível quando se está diante de interesses ou direitos coletivos ou, noutros termos, interesses objetivos, impessoais, indivisíveis e/ou paritários. Representar não é realizar as mesmas escolhas por outro indivíduo. Representar é o ato de deliberar as escolhas racionalmente possíveis no contexto em que os interesses ou direitos são objetivos do grupo, hipótese em que não existem circunstâncias pessoais a ser escolhidas. ${ }^{933}$

A representação é pela performance, isto é, ela visa ao desempenho de um resultado e se mede por esses resultados, a saber, pela deliberação racional dos interesses e direitos objetivos.

Todos as teorias, antes mencionadas, constituem apenas uma garantia para que o resultado da atividade representativa surja. A forma representativa (ciência prévia da representação, autorização ou consentimento), a especial qualidade e tipicidade do representante e o conteúdo idêntico dos interesses são garantias necessárias para assegurar o resultado, qual seja, a performance adequada do representante, como a promoção dos interesses ou direitos comuns.

Os conceitos de representação, antes mencionados, constituem um ideal ou uma garantia processual para assegurar a adequada representação, mas não necessariamente implicam um bom trabalho, não necessariamente garantem a adequada performance do representante. $\mathrm{O}$ cerne da representação - se foi adequada ou não - mede-se pela performance, pelo resultado.

E, mais, esse resultado somente poderá ser experimentado com regularidade, ele somente será real e não ficcional, se o direito substancial criar as condições propícias à essa representação.

Um direito individual, artesanal, singular pode até ser representado por meio de uma autorização ou de um consentimento individual. Mas, como assinala Pitkin ${ }^{934}$, uma teoria de representação subjetiva seria apenas formal e exigiria constantes autorizações ou consultas. Afinal, quanto mais singular e subjetivo um interesse, maior a pessoalidade desse interesse e maior é a capacidade de apenas o seu dono ou guardião defendê-lo. Nesse caso, a participação

933 PITKIN, 1972, p. 176 e 198. BONE, 1990, p. 233 e passim.

934 Hanna Pitkin ressalta a diferença entre interesse subjetivo e objetivo que "the more subjective interest is, the more it resembles the things a man can only define for himself - his opinions, his wants, his will. [...] a man can represent the common purposes or goals of an association, and thus act for a group. This is because every association "has a specific object or objects which the members have previously determined as desirable" (Cf. PITKIN, 1972, p. 207). 
pessoal tende a produzir resultados mais precisos e acurados na proteção do interesse pessoal, pois presume-se que as circunstâncias pessoais são mais conhecidas pela própria pessoa.

Nesse caso de pessoalidade, não há nenhuma razão e nenhuma garantia para se pensar que o interesse de um terceiro, representante do grupo, será coincidente com o interesse do representado, autorizando uma performance representativa adequada. Isso é, em tese, possível, mas trata-se de coincidência episódica. ${ }^{935}$ Não é possível presumir representação nesses termos.

Daí a relevância da adequada identificação do interesse ou direito controvertido. Antes de agregar, mediante a representação dos interesses, é preciso verificar o que é possível agregar. A resposta é distinguir o que é individual ou artesanal do que é coletivo, impessoal e padrão.

\subsubsection{ORIGENS E CONCEITO DE REPRESENTAÇÃO COMO PERFORMANCE OU RESULTADO}

A noção de representação pela performance ou resultado tem origem no pensamento de Burke, no início do século XIX, em uma época em que se discutiam reformas na composição dos membros da Casa Legislativa dos Comuns. Como salienta Yeazel1936, havia muita discrepância na época, pois o sistema eleitoral não contava com uma base teórica, nem com critérios claros.

Nesse contexto, Burke buscava uma critério racional para a representação política. Para Burke, os interesses a serem representados deveriam ser independentes. $\mathrm{O}$ interesse, representado politicamente, não era coincidente com a opinião ou vontade de qualquer dos representados. A representação era de interesses abstratos e objetivos e não de pessoas. Não era o interesse dos fazendeiros ou dos industriais de um condado, mas o interesse da agricultura ou da indústria. ${ }^{937}$

A atividade representativa consistia, portanto, em essência em permitir a deliberação ${ }^{938}$ ou reflexão racional sobre esses interesses. A representação é virtual, decorre da performance ou

935 Mais, uma vez é Hanna Pitkin que salienta a necessidade de que a representação incida sobre interesses objetivos, pois do contrário a representação apenas uma formalidade (seguir instruções subjetivas) "there is no reason to suppose that the representative's will is going to coincide with the will of his principal. [...]. In the same way, if one's interest is definable only subjectively, to have anyone else allegedly acting in one's interest can only be an empty formality" (Cf. PITKIN, 1972, p. 207).

936 YEAZELL, 1987, p. 201.

937 BEER, Samuel H. The representation of interests in British Government: historical background. American Political Science Review, setembro de 1957, LI, p. 615-618.

938 Ibidem, p. 615. 
do resultado, pois ela visa à deliberação racional dos argumentos do grupo, com a promoção de seus interesses, ainda que o representante não tenha sido formalmente escolhido pelo representado. É a confiabilidade dos resultados, pois houve uma performance adequada.

Trata-se de um novo standard de representação, que permite apurar a qualidade da performance e dos resultados concretos da atividade representativa. Permite, ainda, julgar a ação do representante. Esse standard, por sua vez, não suprime ou supera as teorias antes expostas.

A forma, a tipicidade e a identidade dos interesses constituem formas processuais imbuídas de garantismo, isto é, são técnicas convencionais ou predispostas consideradas, presumidamente, adequadas para alcançar um resultado. Mas, se, apesar de todas essas técnicas, o representante falhar em deliberar e em promover os interesses do grupo, as garantias supracitadas terão sido, ao final, formas vazias de significado ${ }^{939}$. Logo, o exercício da atividade representativa exige o estabelecimento de garantias como a seleção do representante mais adequado, a tipicidade, a identidade de interesses entre os membros do grupo. Trata-se, todavia, apenas de uma presunção de representação, é preciso, ao final, apreciar a performance ou o resultado desempenhado.

E, mais, o resultado, qual seja, a deliberação e a promoção dos interesses comuns ao grupo, pode ocorrer com a observância das garantias ou, até mesmo, sem a observância daquelas. Se houver, por exemplo, um descuido do advogado e do juiz em selecionar o representante mais típico ou com maior alinhamento à classe, mas, apesar disso, o interesse comum ao grupo vier a ser deliberado e promovido em concreto, pode-se dizer que houve representação adequada. ${ }^{940}$

Enfim, muito embora o representante não fosse, a priori, tão adequado assim, tão típico assim, muito embora os representados não tivessem sido cientificados ou consentido com a representação, se o interesse comum, objetivo e impessoal ao grupo foi debatido, discutido e promovido pela performance do representante, é possível dizer que houve representação.

\footnotetext{
939 Hanna Pitkin expõe "to be 'virtually' so is to be so 'in essence of effect, although not formally or actually; admitting of being called by the name so far as the effect or result is concerned'. Burke uses the term in just this way in speaking of virtual representation. He conceives that representation has a substantive content, an effect which its formal institutionalization is supposed to produce. Election of members to Parliament is intended to supply this content and bring about his effect. If it fails to do so it becomes an empty formality" (Cf. PITKIN, 1972, p. 175-176).

940 Ibidem, p. 176.
} 
Importa destacar que a representação virtual é um conceito até mais completo e mais amplo que os anteriores. A representação virtual não dispensa quaisquer dos critérios anteriores. A forma de seleção do representação, a tipicidade e a identidade de interesses constituem garantias de representatividade adequada. Acrescenta-se, apenas, o standard da representação virtual, para aferir a performance, o desempenho ou os resultados da atividade representativa realizada.

\subsubsection{A REPRESENTAÇÃO PROSPECTIVA E RETROSPECTIVA}

Um representante eleito, um representante típico, um representante autorizado não necessariamente realiza um bom trabalho. A eleição dos critérios, antes mencionados, como tipicidade, ciência ou autorização dos representados e identidade dos interesses visa apenas a assegurar ou a viabilizar uma representação adequada. É uma versão prospectiva, garantista e presumida da representação que visa alcançar o desempenho idôneo da atividade representativa.

A representação virtual é, por sua vez, concreta ou retrospectiva. É a performance concretamente realizada e o resultado desempenhado. $\mathrm{O}$ resultado consiste, por sua vez, na deliberação racional dos argumentos do grupo e na promoção - no sentido de fomentar ou trabalhar a favor - dos interesses comuns a esse grupo. É essa deliberação e fomento que vão dizer se houve ou não o exercício adequado da representação no caso concreto. De igual modo, é esse resultado concreto que comporta eventual preclusão aos membros ausentes do grupo.

Caso os interesses dos membros do grupo sejam únicos e singulares, não sendo objeto de enfrentamento e discussão, isso é uma evidência de que a representação não cumpriu o seu escopo. Trata-se de uma visão concreta e retrospectiva e não meramente especulativa. ${ }^{941}$

Como salienta Pitkin ${ }^{942}$, os resultados podem ser alcançados mesmo que tenha ocorrido vício na eleição ou na escolha do representante. Isso, todavia, não dispensa a representação como garantia, nem dispensa o esforço em selecionar o representante mais adequado à controvérsia.

A representação virtual não teria uma vida muito longa se não houvesse como substrato a representação como garantia. $\mathrm{O}$ representante deve manter um elo ou uma relação com o

941 PITKIN, 1972, p. 178.

942 Ibidem, p. 176. 
representado, de acordo com o direito substancial. E, também, o representante deve ser selecionado segundo o modo de proceder que, presumidamente, permita alcançar os resultados. Esse modo de proceder convencional e preordenado garante que a performance e os resultados não sejam episódicos, um mero acaso. A representação garantia confere vida longa à representação virtual, à performance e a possibilidade e probabilidade de alcançar resultados. ${ }^{943}$

Se um indivíduo ou um grupo tiver sido excluído e vier a sofrer prejuízos na defesa dos seus interesses - que não foram levados ao debate ou que não foram expressamente discutidos e enfrentados - não só não haverá resultado ou performance, como o exercício da representação como atividade terá sido ineficaz. A permanência da representação virtual deve, portanto, encontrar substrato na representação garantia. Muito embora, insiste-se, é possível que os vícios, episodicamente ocorridos, não venham prejudicar os resultados da atividade representativa e o escopo da representação: a deliberação e reflexão racional sobre os argumentos compartilhados pelo grupo, com a concreta promoção dos seus interesses e direitos.

A representatividade adequada, sob o aspecto da garantia, é uma forma, é um modo convencional de design procedimental. Essa forma garantia, convencional, tem por escopo alcançar um resultado ou escopo. Mas, ela não determina necessariamente o resultado da representação. A forma é só uma presunção relativa de que se o procedimento seguir determinado modo, esse resultado deverá ocorrer. Caso o resultado surja, mesmo que inobservada a forma, pode-se dizer que houve o adequado exercício da atividade representativa.

Esse sentido de representação virtual, pela performance ou resultado é encontrado no direito estadunidense. Mas, igual preocupação também pode ser encontrada no direito brasileiro.

\subsubsection{TÉCNICA PROCESSUAL: REPRESENTANTE ADEQUADO E AMOSTRA ADEQUADA}

Os dois aspectos antes mencionados da representação - garantia e resultado - são igualmente relevantes para fins de agregação processual e são velhos conhecidos da instrumentalidade.

943 Nesse sentido: "this is why virtual representation, although sometimes better than actual representation, must have a substratum in the actual in order to ensure its permanence. [...] Actual representation is no guarantee of the substance or 'virtue' in any particular case, but is the best assurance in the long run" (PITKIN, 1972, p. 180). 
No direito processual estadunidense, a fórmula da representatividade adequada constitui técnica processual intimamente vinculada ao devido processo legal. Trata-se de mecanismo que visa a assegurar aos membros ausentes e futuros do grupo o direito de ser ouvido e de ter seus argumentos considerados, influenciando a convicção do magistrado e contribuindo com a produção de provimento jurisdicional mais acurado ou correto. O processo deve-se desenvolver com respeito a esses parâmetros constitucionais, observando a representação como garantia.

Nesse sistema, a representatividade adequada é um requisito de admissibilidade da ação coletiva. Remete à especial qualidade e à capacidade do representante de atuar com seriedade, com diligência, com zelo e vigor, sem conflitos de interesses com os representados e de forma a ensejar a deliberação racional e a efetiva promoção dos interesses compartilhados pelo grupo.

Por isso, a Rule 23 estabelece os aspectos e as qualidades do representante. O objetivo é aferir a viabilidade de uma ação coletiva e possibilidade de pronunciamento de mérito sobre a lide.

Caso a representação seja exercida, de forma adequada, garantindo a efetiva deliberação sobre os interesses do grupo em juízo, a decisão surtirá efeitos erga omnes, alcançando os membros ausentes desse grupo e impedindo nova discussão sobre a controvérsia plurissubjetiva. Mas, do contrário, caso insuficiente a performance do representante e pífios os resultados, em razão da ausência de discussão dos interesses do grupo, o julgado poderá ser impugnado, para fins de rediscussão da controvérsia. Nesse caso, sem representação idônea, não há representação alguma, logo não há a formação de estabilidade sobre a controvérsia em relação aos ausentes. ${ }^{944}$

É um raciocínio instrumental, voltado para os resultados. Pode existir forma, sem a produção de resultado e, nesse caso, não há representação. Ou, pode inexistir forma (forma viciada e inválida), mas, com a produção de resultados, isto é, com a performance do representante e a deliberação dos interesse do grupo. Diante do resultado, é de se reconhecer a representação. Isso nada mais do que a relação de interdependência entre direito substancial e processo. ${ }^{945}$

944 Através de uma ação autônoma e incidental, individual ou coletiva, a representatividade adequada poderá ser reapreciada, mas, agora, em conformidade à performance e aos resultados concretos da atividade representativa (Cf. NOTE. Collateral attack on the binding effect of class action judgment. Harvard Law Review, V. 87: 589$606 \mathrm{p})$.

945 COOPER, 1987, p. 494. 
Transportando essa ideia para o direito brasileiro, a mesma conclusão é aplicável. A garantia da representatividade adequada pode ser enquadrada como condição de ação - a legitimidade para agir ${ }^{946}$-, isto é, a especial qualidade que deve apresentar o portador dos interesses em juízo.

A representatividade adequada é, nesse sentido, um filtro garantista. Nesse momento, realizase um exame superficial nos aspectos da relação de direito material coletiva, como, por exemplo, a identidade dos interesses e a inexistência de conflito. $\mathrm{O}$ objetivo disso é aferir a viabilidade da demanda e a possibilidade de sobrevir pronunciamento de mérito sobre aquela.

A ausência de representatividade adequada e, portanto, de legitimação para agir, sob uma visão prospectiva, deve implicar a extinção do processo coletivo. Isso porque não estariam presentes, prima facie, os requisitos formais que asseguram o devido processo legal, isto é, o direito dos membros ausentes do grupo de serem ouvidos e de terem seus argumentos considerados.

Não é possível afastar a ocorrência de vícios na aferição da representatividade adequada. Um vício é sempre possível. A técnica da representatividade adequada pode não ser corretamente aplicada, descuidando-se o magistrado em aferir a idoneidade do representante e a viabilidade da demanda coletiva. Mas, se mesmo assim, a representação desenvolveu-se até o fim e o representante logrou realizar uma performance adequada, promovendo a deliberação dos interesses do grupo, pode-se dizer que não houve prejuízo e o resultado da representação foi alcançado. Muito embora o representante não fosse ideal, se os argumentos dos membros ausentes do grupo foram considerados e apreciados pelo juiz, houve adequada representação.

A situação descrita é substancialmente semelhante ao esquema de invalidades processuais e à aplicabilidade do princípio da instrumentalidade das formas, vigente no direito brasileiro.

Um ato processual somente é nulo, se não houver alcançado o seu escopo. As condições da ação, por exemplo, objetivam evitar o desenvolvimento inútil do processo, quando não há

946 Aluísio Gonçalves de Castro Mendes defende que o requisito da representatividade adequada se encartaria, no direito brasileiro, como condição da ação (legitimidade par agir). De fato, o enquadramento como legitimidade para agir parecer ser mais adequado, porquanto (i) o requisito da representatividade adequada diz respeito à própria relação de direito material, o que caracteriza a natureza das condições da ação (ii) caso o representante seja inidôneo, ele não é apto a realizar a persecução jurisdicional do interesse ou direito coletivo pretendido, isto é, ele não é parte legítima (MENDES, 2012, p. 80). Em sentido contrário, José Rogério Cruz e Tucci trata a representatividade adequada como pressuposto da ação (TUCCI, José Rogério. "Class action" e mandado de segurança coletivo. São Paulo: Saraiva, 1990, p. 19-20). 
compatibilidade entre as afirmações do autor e o sistema processual. Mas, se apesar disso, o processor vier a se desenvolver, com resolução da controvérsia, não há sentido em pronunciar a invalidade. Se a parte era, a priori, ilegítima para figurar no polo passivo da demanda, o processo deveria ser extinto. Mas, se o processo prosseguiu e foi produzida prova, que afastou a responsabilidade do réu, não há mais que se pronunciar a ilegitimidade, mas, sim, a ausência de responsabilidade. A demanda proposta deve ser julgada improcedente e não inadmissível. ${ }^{947}$

Aluísio Gonçalves de Castro Mendes ${ }^{948}$ é um dos autores brasileiros que afirma, nesse aspecto, a importância da performance na causa para fins de aferição da representatividade adequada nas ações coletivas. Isso é, especialmente, relevante para evitar objeções da parte adversa.

Essa conclusão também é verdadeira fora da ação de classe. As demais técnicas de agregação processual, como a consolidação ou o caso-teste, também possuem regras relativas à seleção de uma amostra adequada, representativa do universo coletivo de demandas individuais similares.

Como bem pontua Claudio Consolo e Dora Rizzardo ${ }^{949}$, bem como Antônio do Passo Cabral ${ }^{950}$, o caso-teste nada mais é do que a seleção de um interesse coletivo sem a definição de classe. A agregação processual, valendo-se do caso-teste, decorre da identificação e da resolução da controvérsia existente com relação a esse interesse coletivo. Posteriormente, o resultado é comunicado às demais demandas individuais, pendentes no universo coletivo de casos iguais.

É possível, no entanto, que a amostragem no caso-teste tenha sido viciada. Isso ocorre, por exemplo, na hipótese de o magistrado selecionar uma demanda individual qualquer sem atenção ao universo coletivo. Mas, se apesar da inobservância da forma, isso não prejudicar a identificação da questão comum controvertida no grupo e o efetivo debate sobre ela, não houve prejuízo à representação, pois o resultado e o escopo da técnica processual foram alcançados.

\subsubsection{SUBUMBÊNCIA, PARTICIPAÇÃO E ARGUMENTAÇÃO}

947 BEDAQUE, p. 288-291.

948 MENDES, 2012, p. 78.

949 CONSOLO, RIZZARDO, 2006, p. 900

950 CABRAL, 2007, p. 128. 
Por fim, uma última questão merece ser abordada no tocante à teoria da representação virtual. Como já se disse, a representação virtual é aquela que se julga pela performance ou resultado.

O bom e o mau desempenho da atividade representativa não são medidos, todavia, pela vitória ou pelo prejuízo (sucumbência na demanda) em relação aos membros ausentes do grupo. $\mathrm{O}$ bom e o mau desempenho da atividade representativa vinculam-se, sim, à consideração e à deliberação ou não sobre os argumentos atinentes ao grupo. A representação é a técnica que introduz a argumentação no processo coletivo e nas demais técnicas de agregação processual.

A vitória do interesse representado ou a sucumbência desse mesmo interesse não constituem o escopo ou o resultado da representação. A vitória e a sucumbência são possíveis com representação ou sem representação. Ainda que o indivíduo venha a realizar a defesa direta e pessoal do seu direito, tanto a vitória, quanto a sucumbência são possíveis. A representatividade não pode ser medida, portanto, em termos de vitória ou de sucumbência, mas, sim, em termos de performance argumentativa: se atividade realizada pelo representante logrou a promoção dos interesses comuns ao grupo, com a efetiva consideração e discussão dos seus argumentos.

O que define a atividade representativa no processo é a deliberação racional, é argumentação sobre os interesses ou direitos coletivos do grupo. Esse é o cerne da representação virtual.

As informações e os argumentos do debate são dados pelo representante típico, o qual deve estar alinhado aos interesses do grupo. É possível, ainda, consulta eventual aos membros ausentes da grupo para angariar novos argumentos, novas informações, novas provas etc. Esse é o substrato formal que busca garantir o exercício da atividade representativa e seus escopos. É o modo convencional de produzir o conteúdo e, assim, produzir a representação adequada.

Mas, caso inobservada essa forma e mesmo que o representante não seja aquele ideal, o que importa é atingimento do resultado. A questão é saber se houve a apreciação dos argumentos do grupo e a discussão racional sobre os interesse ou direitos coletivos, objeto da controvérsia.

A verificação da performance argumentativa, como já se disse, é retrospectiva. Trata-se de aferir em um momento posterior, caso o resultado da representação venha a ser questionado por um dos membros ausentes do grupo, se houve a promoção dos interesses ou direitos desse 
grupo, com a oportunidade de influenciar, por argumentos, a convicção do juiz. A representação virtual é a técnica que introduz o processo de argumentação dos interesses ou direitos coletivos.

É bem verdade que a noção de performance argumentativa não foi ainda mencionada, no Brasil, como fundamento da representatividade adequada e, por conseguinte, como fundamento do devido processo constitucional aplicado às ações coletivas e às demais técnicas de agregação.

Não obstante, pode-se dizer que a própria natureza do processo consiste em um instrumento ou método de argumentação. O processo agregado, como também - passe o truísmo - é um processo, compartilha essa mesma natureza instrumental e argumentativa de que antes se tratou.

Raciocínio semelhante já é adotado no direito brasileiro. Como bem salienta Cândido Rangel Dinamarco ${ }^{951}$, o processo é instrumento à serviço do direito substancial, cuja função consiste na solução das controvérsias de direito material. É a técnica preordenada à consecução de objetivos e de escopos do sistema. José Roberto dos Santos Bedaque ${ }^{952}$, na mesma linha, assevera que o processo é o método estatal de resolução das controvérsias. É a técnica direcionada ao resultado.

Muito bem. Mas, qual é o cerne do processo? Qual é o seu elemento distintivo? O cerne do processo e o seu elemento distintivo é, segundo Samuel Meira Brasil ${ }^{953}$, o debate que ocorre em seu bojo. O processo é o método argumentativo de solução das controvérsias, pois é, pela técnica de argumentação, que se busca resolver o conflito de interesses existente entre as partes.

E, mais, é possível existir processo até mesmo sem a participação de uma das partes e mesmo que a decisão proferida não seja favorável a ela, isto é, mesmo nas hipóteses de sucumbência.

O que importa, segundo Brasil ${ }^{954}$, é verificar se foi possível o desenvolvimento da argumentação sobre a questão controvertida. Um exemplo disso é o caso de um processo que foi extinto, liminarmente, por inépcia da inicial ou pela prescrição. Nessa hipótese, o Tribunal de Justiça pode dar provimento à Apelação Cível do autor e anular a sentença, antes da citação do réu. A

951 DINARMARCO, 2000, p. 224.

952 BEDAQUE, José Roberto dos Santos. Efetividade do processo e técnica processual. 2 ed. São Paulo: Malheiros, 2007, p. 34.

953 BRASIL JR, 2007, p. 43.

954 Ibidem, p. 41-42. 
sentença terá sido, então, desfavorável a quem não participou do processo. Não é possível negar que esse processo realmente existiu pela argumentação, ainda que sem a participação do réu.

Nessa hipótese, continua Brasil ${ }^{955}$, depois da citação, o réu poderá alegar novas situações fáticas ou jurídicas que não foram deduzidas pelo autor e que não foram enfrentadas pelo magistrado.

Com isso, pode-se concluir que, mesmo no processo individual, a participação é argumentativa. A participação é o mecanismo que visa oportunizar a argumentação, "visando à correta formação do provimento jurisdicional" ${ }^{956}$. No caso acima narrado, por exemplo, o réu poderá deduzir argumentos que não foram anteriormente enfrentados, objetivando combater o provimento jurisdicional prolatado e contribuir com novos argumentos para o seu reexame.

A participação argumentativa visa à correção do provimento jurisdicional, que foi prolatado sem a participação prévia do réu. Não se trata da participação pela participação, mas a participação para uma melhor performance na promoção dos interesses ou direitos defendidos pelo membro ausente. Não se trata de repisar os mesmos argumentos, mas trata-se de trazer novas circunstâncias fáticas ou jurídicas, capazes de influenciar a convicção no magistrado.

$\mathrm{Na}$ agregação processual, a ideia não é diferente do processo individual, só mais ampla. A atividade do representante consiste em introduzir a argumentação sobre os interesses ou direitos coletivos. O performance insuficiente da atividade representativa ocorre quando os argumentos do grupo ou da categoria não são apresentados e/ou não são enfrentados no processo.

Nesse sentido, é reaberta a oportunidade de influenciar a convicção do magistrado. Veja que não se trata de reabrir a via processual para dar a uma das partes uma nova chance para ganhar ou para perder, não se trata de uma nova oportunidade para tentar a sorte, tampouco de simplesmente participar, reproduzindo todos os argumentos já enfrentados pelo magistrado.

955 BRASIL JR, 2007, p. 42.

956 BEDAQUE, José Roberto dos Santos. Elementos objetivos da demanda examinados à luz do contraditório. In: TUCCI, José Rogério Cruz e. BEDAQUE, José Roberto dos Santos. Causa de pedir e pedido no processo civil (questões polêmicas). São Paulo: RT, 2002, p. 40). 
A via processual é reaberta para que o parte (réu, membro ausente do grupo, membro futuro do grupo) possa participar argumentativamente, isto é, para que novos argumentos, fáticos, jurídicos que não foram ainda discutidos, sejam apreciados e considerados pelo magistrado.

É exatamente esse o sentido da representação virtual, aplicável às hipóteses de interesses e direitos coletivos. A atuação de um sujeito, em nome de outros sujeitos, é possível nas ações coletivas e em outras técnicas de agregação, pois os membros da classe estão, por força da relação substancial, em uma mesma posição ou situação em relação ao objeto da controvérsia. Os indivíduos, na qualidade de membros do grupo, são, igualmente, propensos a argumentar.

Considerando que todos apresentam, na controvérsia deduzida, a qualidade de membro de um grupo, todos os indivíduos são, presumidamente, anônimos e fungíveis nessa posição. A princípio, qualquer um deles é apto a apresentar os argumentos, de fato e de direito, no tocante aos interesses ou direitos coletivos. Lembra-se que os interesses ou direitos coletivos, de que se trata, são aqueles cujas notas caracterizadoras consistem na objetividade, impessoalidade, indivisibilidade e/ou paridade. Não se trata de discutir circunstâncias pessoais, mas, sim, de questões objetivas que impactam o indivíduo como membro do grupo, daí sua fungibilidade.

A representação garantia ou prospectiva visa a selecionar o representante mais idôneo, com maior capacidade de apresentar esses argumentos. A representação virtual, por sua vez, mira o resultado, isto é, apurar se os argumentos da categoria foram efetivamente enfrentados. Adverte-se, de novo, que o resultado pode surgir, ainda que inobservada a forma preordenada.

Conclui-se, portanto, que o elemento fundamental, na teoria da representação virtual, é a argumentação, isto é, a consideração e o enfrentamento dos argumentos comuns ao grupo. $\mathrm{Na}$ agregação processual, para assegurar o devido processo legal não se exige, necessariamente, a participação ou a autorização individual. O que se exige é a performance ou resultado, com a efetiva promoção dos interesses do grupo e com o enfrentamento expresso dos seus argumentos.

A questão do garantias constitucionais e do devido processo constitucional, em relação aos membros ausentes da classe, que não participaram diretamente, será retomada mais adiante. Agora, é necessário melhor situar a noção de representação virtual em cada um dos sistemas. 


\subsubsection{SISTEMA ESTADUNIDENSE}

A noção teórica de representação virtual, antes mencionada, já é corrente no sistema jurídico estadunidense. Essa teoria está presente na prática de muitos institutos do direito processual.

A ação de classe é, por exemplo, uma técnica que emprega o conceito de representação virtual. O que importa é a resultado da atividade representativa, com a consequente vinculação dos membros ausentes da classe. Nesse contexto, a notificação e a técnica da autoexclusão tem caráter instrumental. Trata-se de monitorar e incrementar a atividade de representação, propiciando a promoção dos interesses do grupo, mediante a deliberação dos seus argumentos.

Embora a notificação (notice) e a autoexclusão (opt out) já tenham sido mencionados em tópicos anteriores desta investigação, é necessário sistematizar o pensamento já exposto, agora no bojo da teoria da representação virtual e da realidade estadunidense. Com isso, pretende-se demonstrar o afirmado caráter instrumental ${ }^{957}$ dessas técnicas na ação coletiva. Senão vejamos.

A notificação dos membros ausentes do grupo é possível, mas discricionária nas categorias 23(b)(1) e 23 (b)(2). Quando realizada, devem ser adotados, preferencialmente, mecanismos coletivos de divulgação. Na categoria 23(b)(3), a notificação é exigida. Segundo o texto normativo, exige-se a melhor notificação possível. Embora as divergências na jurisprudência e na doutrina sejam efervescentes quanto ao tema, há quem defenda tratar-se de notificação individual, devida a cada membro ausente da classe que possa ser facilmente identificável..$^{958}$

A razão de ser dessa técnica processual é ampliar a atividade argumentativa dos interessados, de forma que eles possam contribuir com a defesa dos interesses do grupo, bem como monitorar a atividade representativa. Na categoria (b)(3), a ciência da ação coletiva permite, ainda, o exercício da autoexclusão. ${ }^{959}$ Indaga-se, apenas, o seguinte: é possível representatividade adequada sem a garantia da notificação, seja a do tipo discricionária, seja a tipo individualizada?

957 BRONSTEEN, FISS, 2003, p. 1436.

958 UNITED STATES. Supreme Court of United States. Eisen V. Carlisle \& Jacquelin et al. 417 U.S 156 (1974). 959 A notificação visa aferir a satisfação da classe com atividade representativa. Mesmo quando a notificação é realizado para fins de exercício da autoexclusão, ela também afere essa satisfação. Isso porque a técnica de autoexclusão é apresentada como mecanismo de voz, lealdade e, também, exclusão (Cf. COFFEE, 2000,437-439). 
A notificação nas categorias 23 (b)(1) e 23(b)(2) é discricionária. Logo, resta claro que o próprio texto normativo não exige a ciência dos membros ausentes do grupo como requisito da representatividade adequada. A notificação não é um fim em si mesma, tampouco determina inexoravelmente o resultado. Logo, é possível a representação adequada sem notificação. ${ }^{960}$

Mas, nem por isso, a notificação pode ser facilmente dispensada. Embora a notificação seja discricionária, ela pode e deve ser incentivada, sob a forma coletiva, principalmente nas hipóteses e temas mais impactantes. Nas categorias 23(b)(1) e 23(b)(2), a notificação visa, principalmente, incrementar a atividade argumentativa, dando voz aos membros ausentes e gerando informações (input) que podem contribuir com a performance da representante ${ }^{961}$

A notificação cumpre papel relevante ao cientificar as partes e ao ensejar eventual manifestação no processo coletivo, por audiências públicas e por outros instrumentos individuais ${ }^{962} \mathrm{e}$ coletivos, incrementando a deliberação sobre os interesses pertinentes à categoria. A notificação permite fiscalizar a atividade do representante, monitorando a sua lealdade aos interesses ou direitos do grupo. Como consignado antes, a notificação é uma técnica preordenada à obtenção do resultado: a promoção dos interesses ou direitos do grupo, com o enfrentamento dos seus argumentos, muito embora esse resultado possa surgir independente da observância da técnica.

A notificação na categoria 23(b)(3) exige a notificação dos membros ausentes do grupo. É providência obrigatória, que deve ser realizada da melhor maneira possível. O precedente Eisen v. Carlisle \& Jacquelin ${ }^{963}$, embora bastante criticado, seguiu a literalidade do texto normativo e exigiu a notificação individualizada de todos os membros facilmente identificáveis. A notificação, realizada nesses termos, representou, no caso Eisen, uma despesa processual superior ao proveito econômico da ação, por tratar-se de uma ação de classe por dano ínfimo.

960 A questão não é consolidada, mas a jurisprudência já salientou que a ausência de notificação não importa necessariamente em violação ao devido processo legal, na hipótese em que houver a representação adequada dos interesses (Cf. Wetzel v. Liberty Mut. Ins. Co 508 F. 2 d 239 (3rd Cir. 1975), Woodward V. Rogers 344 F. Supp. 974 (D.D.C. 1972), Northern Natural Gas Co v. Grounds 292 F. Supp. 619 (D. Kan. 1968)). No mesmo sentido, na doutrina: NOTE. Jurisdiction and notice in class actions: "playing fair" with national classes. Harvard Law Review, 1984, V. 132: 1487-1514p, p. 1502.

961 COFFEE, 2000, p. 437-439. BRONSTEEN, FISS, 2003, p. 1435. LILLY, 2003, p. 1033.

962 A técnica de autoexclusão, ao cientificar as partes, poderia converter-se em uma técnica de pesquisa e de intervenção. Houve, quem, inclusive propusesse o envio de um formulário (proof of claim forms), junto com a notificação, com o objetivo de colher informações sobre a coletividade. Essa prática, caso adequada e não dispendiosa, é recomendada pelo Manual for Complex Litigation (FEDERAL JUDICIAL CENTER, 2004, p. 302). 963 UNITED STATES. Supreme Court of United States. Eisen V. Carlisle \& Jacquelin et al. 417 U.S 156 (1974). 
Muito embora o texto normativo para a categoria 23(b)(3) estabeleça a obrigatoriedade da notificação, o mesmo raciocínio, antes realizado para as demais categorias, também se aplica aqui. A técnica da notificação é uma forma, é um modo convencional preordenado à consecução do resultado, isto é, fiscalizar a atividade representativa, desenvolver o exercício da argumentação sobre os interesses do grupo e permitir a exclusão de situações particularizadas. ${ }^{964}$

Como já se disse, a representação adequada é resultado, que pode ser alcançado inobstante a forma. Owen Fiss ${ }^{965}$ é um dos autores que pugna uma por uma abordagem mais uniforme e flexível da notificação, inclusive na categoria 23(b)(3). Embora a notificação seja recomendável e ela deva ser realizada, ela não precisaria ser, necessariamente, individualizada nessa categoria.

Isso porque a ausência de notificação de cada um dos indivíduos, membros do grupo, ou o devolução de uma das notificações por equívoco do endereço não necessariamente comprometem a performance da atividade representativa e a promoção dos interesses e direitos do grupo. Na categoria 23(b)(3), os interesses ou direitos discutidos também tendem a ser objetivos, impessoais e paritários, de forma que, na ausência de circunstâncias pessoais, um indivíduo, membro do grupo, é tão propenso quanto ao outro para realizar a defesa coletiva.966

Um interesse ou direito pode admitir divisibilidade, isto é, pode admitir compensação ou satisfação particularizada ou, em linguagem coloquial, "desligada" uma da outra. Mas, apesar disso, a controvérsia pode ser deduzida em juízo com relação, em todo ou em parte, aos atributos objetivos do grupo e não individuais. O centro da cognição e do debate judicial serão alegações objetivas ou coletivas, que impactam o indivíduo como membro do grupo. Nesse aspecto, não há tanta diferença do que acontece em relação às demais categorias da ação de classe.

A diferença pode persistir apenas no tocante à compensação individual, que pode exigir cognição pessoal. Haverá outro casos, porém, que até mesmo a compensação individual será objetiva. São os casos de upstream, em que a compensação individual segue fórmula objetiva.

964 A notificação não é garantia do devido processo legal, nem mesmo na categoria 23(b)(3). A notificação deve ser flexível e consentânea às circunstâncias do caso concreto (Cf. NOTE, 1984, p. 1502 e NOTE 1976, p. 1566). 965 FISS, 2004, p. 219

966 Ibidem, p. 219. BONE, 1992, p. 211. 
Por isso as diferenças, atualmente existentes entre as categorias da ação de classe, não tem explicação satisfatória ou solução técnica muito confortável, seja na teoria, seja na prática. ${ }^{967}$

Stephen Yeazell ${ }^{968}$ salienta que a notificação deve ser exigida na categoria 23(b)(3), porque há o risco da pessoalidade. $O$ fato da notificação ser exigível não significa, porém, que ela não possa ser adaptável às circunstâncias do caso concreto. Convém trazer à memória que o rigor dessa exigência foi, por vezes, perverso à consecução do direito material nesse sistema jurídico.

E, mais, em alguns casos é possível presumir a objetividade ou a inexistência de discrepância entre os membros do grupo. Esse é o caso, continua Yeazell ${ }^{969}$, dos danos individuais ínfimos.

De fato, certos interesses, embora essencialmente objetivos, incidentes sobre bem indivisível, podem gerar maiores antagonismos no grupo - sobre o conteúdo do interesse e sobre a forma de implementação - do que nas hipóteses de interesses divisíveis. Por exemplo, uma situação de segregação racial e a pretensão mandamental de unificar o sistema escolar entre brancos e negros é indivisível. O sistema escolar é único. Mas, cada raça pode ter uma concepção diferente sobre como fazer isso. Acabou a segregação, como mudar a realidade? Vai se investir mais em esportes ou na biblioteca? Vão ser comprados mais livros com autores negros ou vai ser de autoria aleatória? As bolsas estudantis vão para o programa esportivo de basquete ou de rúgbi? Quais os requisitos de admissão na escola? Algumas questões impactam mais a vida do indivíduo, ainda que na qualidade de membro do grupo, que a pretensão de compensação por um dano ínfimo, que é certificada na categoria 23(b)(3) e a qual exige notificação obrigatória.

$\mathrm{Na}$ realidade, é de difícil compreensão os diferentes regimes processuais de notificação, aplicável às categorias da ação de classe. A justificativa dada pela doutrina, para essa diferença, é que nas duas primeiras categorias haveria maior coesão na classe, por tratar-se, em regra, de pretensão declaratória e mandamental. E, na terceira categoria, por tratar de compensação

967 YEAZELL, 1987, p. 249-256.

968 A controvérsia deduzida e certificada na categoria 23(b)(3) deve ser objetiva e impessoal. Mas, há, em maior ou menor grau, o risco de existir questões pessoais dos membros da classe. Por isso, por força do consentimento implícito (opt out), a responsabilidade pelo resultado da adjudicação e por suas consequências no destino de cada indivíduo é colocada nas mãos do próprio interessado. É um mecanismo seguro de adjudicação. Mas, por vezes, a própria adjudicação é posta em risco, pelos rigores da forma. Por isso, o consentimento torna-se um mecanismo residual, em conformidade à "teoria substantiva" da ação de classe, que exige um juízo de adequação entre direito e processo (YEAZELL, 1987, p. 249-256. No mesmo sentido, NOTE, 1976, p. 1402-1416.).

969 YEAZELL, 1987, p. 253. 
financeira, a coesão é menor, logo a notificação individualizada é exigida. Mas, como já enfrentado antes, não é a pretensão que define ser o direito coletivo ou de alcance coletivo.

O que define o alcance coletivo do interesse ou direito pretendido é a objetividade, a impessoalidade, a indivisibilidade do bem, e/ou a paridade dos indivíduos em relação à controvérsia deduzida em juízo. É o fato de os indivíduos, membros de um grupo, apresentarem-se em uma mesma situação de impessoalidade e de equidistância do objeto. $\mathrm{O}$ caráter coletivo acima mencionado pode surgir, portanto, em qualquer das três categorias.

Por isso, pugna-se, cada vez mais no sistema estadunidense, por um sistema uniforme e flexível de notificação ${ }^{970}$, à luz da representação virtual ou da performance representativa. A notificação é recomendável para todas as categorias da ação de classe, pois ela tende a incrementar a performance da representação em qualquer das três categorias. Trata-se de uma técnica processual que garante a permanência dos resultados, com o monitoramento do representante e com incremento da atividade argumentativa, contribuindo para que os resultados não sejam episódicos. A notificação deve ser, no entanto, flexível. Ela deve ser compreendida como um instrumento dirigido ao resultado e também adaptável às circunstâncias dos casos concretos.

Igual conclusão também é aplicável para à autoexclusão. A rigor, até mesmo o opt out pode ser condicionado ou vedado, em determinados circunstâncias, na hipótese em que isso não afetar a performance da atividade representativa. A técnica da autoexclusão, assim como a notificação, também apresenta finalidade instrumental: é preordenada ao resultado, mas não o determina.

Vamos lembrar de algumas situações que já foram comentadas, quando abordada a maximização e minimização do opt out. O indivíduo que se exclui de uma técnica de agregação como a ação coletiva pode ser recapturado por outra técnica de agregação, como a consolidação que não admite o opt out. Nesse caso, o resultado é o mesmo. Diante de um direito coletivo ou de alcance coletivo, o design procedimental é modelado em favor da resolução unitária da questão comum controvertida, sem seja possível ao indivíduo escapar da agregação processual.

970 Em sentido semelhante: BONE, 1994, passim. NOTE, 1984, p. 1502. ALPERT, Richard. The uniform class actions act: some promise and some problems. Harvard Journal on Legislation. 1979, V. 16:584-667p, passim. 
Nas ações coletivas por danos ínfimos, o opt out é severamente desaconselhado. Como diz Coffee $\mathrm{Jr}^{971}$, nas ações de classe de valor negativo, além de inexistir interesse na persecução individual, os sujeitos estão em posição idêntica em relação ao interesse da categoria. A identidade decorre do escopo comum dos indivíduos em desestimular a prática abusiva e em lograr a compensação, o que não seria viável para nenhum deles, se não fosse a ação coletiva.

Nas ações coletivas ditas híbridas, em que há pedido de ressarcimento em pecúnia incidental à tutela mandamental ou declaratória, limitação ao opt out também ocorre. Nesses casos, a demanda é certificada na categoria 23(b)(2), inclusive no tocante ao ressarcimento em pecúnia, sem direito à autoexclusão. Isso ocorre, porque o ressarcimento em pecúnia é considerado uma mera restituição e, pois, infenso às características individualizadas de cada membro do grupo. ${ }^{972}$

De igual modo, não são raras as propostas para liminar o exercício abusivo do opt out. Isso porque, mesmo, o opt out não é uma exigência do devido processo legal. ${ }^{973}$ A técnica da autoexclusão pode ser condicionada ou, até mesmo, vedada diante das circunstâncias do caso.

Dentre essas propostas, exige-se, por exemplo, que o indivíduo, ao pretender excluir-se da ação coletiva, apresente uma justa causa ${ }^{974}$. O membro do grupo, que pretende a sua exclusão, deve demonstrar novas circunstâncias de fato ou de direito da controvérsia ou circunstâncias pessoais, que o diferencie da categoria. Ele deve demonstrar que não pretende simplesmente duplicar a controvérsia, aproveitando-se da instrução da ação coletiva por exemplo (free ride).

E, mais, o opt out compreende mais do a exclusão, é uma técnica processual que também confere voz e garantia de lealdade aos membros ausentes. Pelo pedido de opt out, o indivíduo pode comunicar a insatisfação com a ação coletiva deduzida ou com o representante, cientificando o juiz sobre eventual inadequação do procedimento adotado, sobre a deslealdade do representante e permitindo, quiçá, a correção dos rumos da ação coletiva em discussão.

Insiste-se, portanto, que a atividade de representação adequada diz respeito à deliberação racional dos interesses do grupo (argumentação). A representação é vinculada à performance.

971 COFFEE, 2000, 433.

972 As demandas coletivas que não forem consideradas predominantemente indenizatórias, podem ser certificadas na categoria 23(b)(2), conforme explicitado pelo próprio Conselho Consultivo na Rule 23.

973 FRIEDMAN, 1990, p. 745.

974 Ibidem, p. 745. 
Outro fundamento justifica a representação virtual no sistema estadunidense. É preciso destacar que nem mesmo a observância da técnica processual, com a notificação individualizada e com a oportunidade de autoexclusão não obstam, por si só, o exercício do collateral attack. O indivíduo pode arguir, preliminarmente, em uma ação subsequente, a ausência de representatividade adequada mesmo que observadas todas as formalidades previstas em lei. ${ }^{975}$

Nesse caso, o motivo que autoriza o collateral attack é o vício do conteúdo ou do resultado. A ausência de representatividade adequada é imputável à insuficiente performance na promoção dos interesses do grupo, muito embora toda a forma tenha sido observada com perfeição.

A jurisprudência estadunidense, por sua vez, já manifestou adesão explicita à teoria da representação virtual. No precedente Taylor v. Sturgell ${ }^{976}$, a Suprema Corte dos Estados Unidos admitiu a existência de representação virtual, com preclusão a quem não foi parte, nas seguintes hipóteses: (i) nas ações coletivas, pois a parte ausente foi adequadamente representada; (ii) quando houver consentimento das partes, como, por exemplo, em um caso-teste, na qual as partes acordam em submeter uma demanda ao julgamento, comunicando o resultado às demandas individuais pendentes; (iii) nas hipóteses em que preexistirem relações jurídicas de direito substancial entre os membros do grupo, como o sucessor e o sucedido; (iv) nas ações propostas por curadores, tutores e outros fiduciários; (v) nas demandas propostas pelo assistente (interveniente) ou por quem possuía ou assumiu, de qualquer modo, o controle da demanda, apresentando alegações e provas; e (vi) nas ações em que, por força de expressa previsão legal, a preclusão é imposta ao terceiro, como, por exemplo, ocorre nas hipóteses de falência.

Esse precedente rejeita, por sua vez, uma doutrina expansiva da representação virtual, a saber, rejeita o reconhecimento da preclusão fora das hipóteses das ações coletivas e das demais técnicas de agregação. Não é admissível a preclusão sem as garantias do devido processo legal.

No precedente citado, Greg Herrick, um entusiasta de aviões antigos e proprietário de um avião F-45, propôs uma ação em face da agência federal FAA para obter cópias dos documentos

975 Trata-se de hipótese em que a forma (notificação e opt out) foi observada, mas, não, necessariamente, implicou performance representativa idônea, com o enfrentamento dos argumentos do grupo (Cf. KLONOFF, 2007, p. 237). 976 UNITED STATES OF AMERICA. Supreme Court of United States. Taylor v. Sturgell. 128 S.CT 2161 (2008). 
atinentes ao modelo vintage do avião F-45, pois segundo o Freedom of Information Act (FOIA), toda pessoa tem direito de solicitar quaisquer registros mantidos por agência americana federal.

A ação proposta por Herrick foi julgada improcedente, pois os documentos pretendidos foram considerados sob segredo comercial. A agência mantinha esses documentos, pois eles foram apresentados pela empresa no processo de autorização para manufatura da aeronave. A publicidade desses documentos foi negada, administrativamente, pela agência. Na demanda, Herrick alegou que havia uma carta da empresa datada de 1955, autorizando a exibição dos documentos ao público para a realização de reparos na aeronave ou para a reposição de peças dos aviões produzidos. A Corte Distrital salientou, no entanto, que a carta apresentada não alterava o status confidencial dos documentos pleiteados, junto à agência federal. E, ainda, a empresa restaurou esse status ao negar o conhecimento dos documentos no momento presente.

O julgamento foi mantido pela Corte de Apelação. E, um mês após esse julgamento, Brent Taylor - amigo de Herrick, também entusiasta de aviões antigos e que pertencia à mesma associação de aviões antigos presidida por Herrick, bem como representado pelo mesmo advogado de Herrick - ajuizou demanda com idêntico conteúdo, pretendendo os mesmos documentos. Argumentou, igualmente, que havia uma carta da empresa data de 1955 que autorizava a exibição dos documentos. Argumentou, ainda, que não era mais possível restaurar o status de confidencialidade. A Corte Distrital salientou que a demanda de Taylor não poderia prosseguir, por força da preclusão inerente à coisa julgada da demanda anterior. Taylor havia sido representado virtualmente por Greg Herrick, sendo inadmissível nova investida judicial.

A Suprema Corte dos Estados Unidos, em decisão duramente criticada pela doutrina, asseverou a inaplicabilidade da doutrina da representação virtual no caso narrado e a inexistência de preclusão, razão pela qual a demanda subsequente, proposta por Taylor, deveria prosseguir.

Segundo a Suprema Corte, a aplicabilidade da doutrina da representação virtual era inadmissível, pois implicava o reconhecimento de uma ação coletiva de fato, sem que fosse previamente ofertada qualquer garantia processual, como a notificação das partes ausentes. De igual modo, a doutrina da representação virtual tinha qualidade episódica nessa hipótese. De igual modo, não havia qualquer prova nos autos de que Taylor soubesse da ação de Herrick, de que tivesse com ele relação jurídica ou que tivesse controlado a propositura da primeira ação. 
Embora teoria da representação virtual não tenha sido adotada nessa versão expansiva, a doutrina não abandonou a ideia. Muito pelo contrário, para contornar a vedação do precedente, pululam propostas de coletivização formal das "ações coletivas de fato" ${ }^{977}$. No precedente Taylor v. Sturgell, a demanda foi processada como individual e, apenas para fins de preclusão, foi reconhecido tratar-se a hipótese de um direito público ou coletivo, suscetível de agregação.

A alternativa é, então, reconhecer previamente a incidência da controvérsia sobre um direito coletivo, promovendo a agregação processual, para depois vincular os membros ausentes da classe A preclusão é, segundo o American Law Institute ${ }^{978}$, um dos escopos da agregação processual. Não há sentido em agregar se isso não abreviar a discussão, sobre a mesma questão, em outro procedimento. Por isso, primeiro agrega-se e estrutura-se, subjetivamente, o processo para a adjudicação completa e unitária do controvérsia, para depois admitir a preclusão.

Na realidade, a agregação processual é uma garantia para que o resultado da representação virtual - efetivo debate sobre os argumentos do grupo -, seja alcançado e para que o resultado não seja episódico. Isso porque à medida que há previsibilidade e ciência das partes sobre a deliberação dos interesses do grupo, ampliam-se as possibilidades de monitoramento e de incremento da performance do representante, com possível ampliação dos argumentos.

De qualquer modo, frise-se que, segundo ressalta o American Law Institute ${ }^{979}$, permanece, no direito estadunidense, uma versão residual da doutrina expansiva da representação virtual.

Mesmo sem prévia agregação, a jurisprudência ainda reconhece a representação virtual em alguns casos residuais. Dentre eles, destaca-se a hipótese em que as partes e o grupo se sobrepõe parcialmente. É o que ocorre quando alguns autores, mas não todos, que ajuizaram a segunda demanda, também participaram da primeira demanda, já acobertada pela coisa julgada. Em hipóteses como essa, a jurisprudência já reconheceu que a parte da classe, que não participou da primeira demanda, foi representada naquela ocasião pelos outros membros do grupo, que participaram. Em função disso, a segunda demanda é extinta para toda a classe da demanda subsequente e não apenas para os autores que já haviam participado da demanda originária.

977 NAGAREDA, 2010, p. 1108. 
Exemplo disso ocorre, em regra, em processos de interesse público (public law litigation), em que se pretende um novo provimento mandamental (injunction), já objeto de julgamento em um processo anterior, acobertado pela coisa julgada. Nesse caso, reproduz-se demanda individual ou coletiva, quando alguns membros do grupo já participaram na demanda anterior.

No precedente Petit et al (86 autores) v. City of Chicago ${ }^{980}$, policiais brancos impugnaram a política discriminatória de promoções na carreira da polícia de Chicago, sob o argumento de que não havia fundamento para a discriminação no tocante à promoção ao cargo de sargento. Ao apreciar a questão, a Corte Distrital ressaltou que a discriminação era, no caso, incontroversa. Na década de 70, várias ações foram propostas alegando discriminação de raça e gênero em face da polícia de Chicago, o que culminou com uma ação afirmativa e com a definição de quotas para afrodescendentes, latinos e mulheres. No precedente United States $v$. City of Chicago, a questão do exame para a promoção na carreira policial foi expressamente debatida e discutida, sendo que alguns autores da presente demanda intervieram naquela ocasião. Por isso, foi reconhecida a preclusão da segunda demanda no tocante ao método de pontuação do exame de promoção (scoring), matéria já decidida anteriormente. A preclusão foi reconhecida para quem interveio na ação anterior e para todos os demais indivíduos da classe.

Veja que não houve preclusão, apenas, para os intervenientes da demanda anterior, houve preclusão para toda a classe representada na segunda demanda (policiais brancos). A representação é virtual nesse caso, pois na demanda anterior não houve um juízo sobre a representatividade adequada do interveniente. A atuação do interveniente vinculou os membros ausentes, pois, no processo subsequente, percebeu-se a reprodução de argumento já enfrentado.

Segundo o American Law Institute ${ }^{981}$, nas ações derivadas, propostas por um acionista, também é reconhecida essa versão residual da representação virtual, bastando, para tanto, que tenha havido a adequada representação dos interesses do grupo, mesmo que sem prévia coletivização.

No precedente Nathan $v$. Rowan ${ }^{982}$, a demanda proposta por Nathan foi obstada, pois uma primeira demanda proposta por Singer, um outro acionista, já havia sido julgada prejudicada

980 UNITED STATES OF AMERICA. District Court, N. D Illinois. Petit et al v. City of Chicago. 239 F. Supp. 2d 761 (2002).

981 AMERICAN LAW INSTITUTE, 2010, p. 26.

982 UNITED STATES OF AMERICA. United States Court of Appeal, Sixth Circuit. Nathan v. Rowan. 651 F. 2 d 1223 (1984). 
em razão do transcurso do prazo prescricional. A coisa julgada da demanda anterior obstou o prosseguimento da demanda posterior, mesmo sem a prévia certificação da ação de classe. Isso porque os interesses da classe de acionistas foram adequadamente representados na ação anterior, sendo objeto de enfrentamento todas as questões relevantes. Concluiu-se que o prazo prescricional era comum e já havia transcorrido integralmente para toda a classe de acionistas. E, como essa questão já foi expressamente debatida e decidida, não era possível rediscuti-la.

Esses são os principais aspectos da teoria da representação virtual, aplicada ao sistema jurídico estadunidense. Muito embora o nome representação virtual seja alienígena ao direito processual brasileiro, pondera-se que esse fenômeno não está muito longe também desse sistema jurídico.

\subsubsection{SISTEMA BRASILEIRO}

Como já é cediço, a teoria da representação virtual nada mais é do performance do representante adequado e o resultado desempenhado, segundo o qual um representante efetivamente age na promoção dos interesses ou direitos do grupo, mediante a deliberação dos seus argumentos.

Lembra-se que essa teoria não é aplicável no vácuo, sob pena de se tornar uma ficção. Um pessoa não necessariamente realiza as mesmas escolhas, a mesma estratégia e utiliza os mesmos argumentos da outra. Muito pelo contrário, o indivíduo é o melhor guardião dos seus interesses.

O que ocorre, na realidade, é que em alguns situações substanciais, há uma objetividade do direito e não estão em jogo circunstâncias pessoais. Logo, presume-se, na ausência de indicação em contrário, que qualquer membro do grupo é apto a apresentar os argumentos de fato ou de direito do grupo como um todo. Nessa hipótese, o exercício da representação virtual, com adequada performance do representante e com o debate sobre os argumentos do grupo, autoriza a preclusão ao grupo. Mas, caso o argumento não tenha sido enfrentado, superável a preclusão.

Nome similar - representação virtual - não é comum entre nós. Mas, de qualquer modo, os elementos que compõe a teoria da representação virtual também podem ser percebidos por aqui.

Muito bem. Em primeiro lugar, como visto, a noção de representatividade adequada já é um conceito corrente no processo coletivo brasileiro, seja na doutrina, seja na jurisprudência. 
Em segundo lugar, a relação entre representação e direito material é expressamente mencionada pelos processualistas brasileiros. Ada Pellegrini Grinover ${ }^{983}$ já salientou que o esquema representativo é idôneo para assegurar, nos direitos coletivos, a melhor defesa aos interessados. Afirmou que, uma vez reconhecida a complementariedade entre o interesse individual e o interesse social, a objetividade do processo de massa é comparável ao processo constitucional.

Barbosa Moreira ${ }^{984}$ já ressaltou que o regime da disposição unitária da controvérsia é dado pela relação jurídica de direito material. A unitariedade da relação jurídica substancial enseja a vinculação dos virtuais litisconsortes pela resolução da controvérsia realizada em favor de outros legitimados. Evita-se, com isso, duas coisas julgadas inconsistentes no plano substancial.

No mesmo sentido, Camilo Zufelato ${ }^{985}$ lembra que a solução que evoca a preclusão aos membros ausentes do grupo é autorizada pelo direito material. A comunicação do resultado do julgamento ocorre porque primeiro há uma comunicação ou coordenação na relação de direito material. José Rogério Cruz e Tucci ${ }^{986}$ conclui que a própria autoridade da coisa julgada (e não os efeitos da sentença) que se estende, por vezes, aos terceiros, considerando a sua posição de subordinação (nexo de prejudicialidade e dependência) e do direito material em discussão.

Conquanto, deve-se registrar uma advertência. Ada Pellegrini Grinover ${ }^{987}$ adverte não é possível desconhecer que parte da doutrina alimenta dúvidas sobre a fórmula da representatividade adequada, pois consideram artificial a ideia de estranhos no processo se considerarem, na prática, adequadamente representados. Isso seria uma ficção. O mesmo pondera Barbosa Moreira $^{988}$ sobre o recurso ao artificial à noção de representação para a finalidade preclusiva.

Por isso mesmo, é preciso ter cuidado. Exatamente para evitar a sombra da ficção, é que a representação virtual é retrospectiva, aplicável a situações substanciais objetivas, bem como fundamentada no resultado e na efetiva deliberação dos argumentos do grupo. Não basta que o representante seja coincidente ou um espelho do grupo, importa é que os argumentos de fato ou

983 GRINOVER, 2011, p. 177.

984 MOREIRA, 1972, p. 142-145.

985 ZUFELATO, 2011, p. 126.

986 TUCCI, 2006, p. 101, 191 e 347.

987 GRINOVER, 2011, p. 177.

988 MOREIRA, op. cit., p. 34. 
de direito do grupo tenha sido enfrentados. Caso não tenham sido enfrentados, não há representação virtual, pois insuficiente a promoção ou o fomento dos interesses da categoria.

Quando se fala em performance e em resultado, também é seguro traçar uma aproximação com o direito brasileiro. $\mathrm{O}$ raciocínio presente na representação virtual no tocante à relação entre forma e resultado não só é condizente com o processo civil brasileiro, mas coincide com a última fase de desenvolvimento da doutrina processual: a instrumentalidade substancial.

Representação virtual nada mais é do que pugnar por um processo civil de resultados, aplicado às hipóteses de litigiosidade de massa e de agregação processual. Nesse ponto, Tucci ${ }^{989}$ assinala que a extensão da coisa julgada é tema envolto, ainda, de muita incerteza na doutrina, razão pela qual deve ser equacionado pelos cânones do contraditório e do processo civil de resultados.

No mesmo sentido, Aluísio Gonçalves de Castro Mendes ${ }^{990}$, ao abordar a representatividade adequada, salienta que deve ser aferida a qualidade do representante. Mas, se mesmo depois do julgamento, for levantada objeção à performance concretamente realizada pelo representante, é possível afastar a estabilização do comando normativo em relação aos membros ausentes.

O mesmo raciocínio é, segundo Pedro Dinamarco ${ }^{991}$, aplicado à ação coletiva passiva. Nesse cenário, determinando membro do grupo é nomeado representante da classe requerida. Ainda que esse representante recuse o encargo, o juiz poderá mantê-lo, pois o que importa é a performance na defesa da classe, como consequência da defesa do seu próprio interesse.

Como bem atentou Gidi'992, há uma avaliação abstrata, preliminar e prospectiva da representatividade adequada e, posteriormente, uma avaliação retrospectiva, quando possível negar a autoridade da coisa julgada ao membro ausente do grupo em razão da ausência de representatividade concreta. Essa fórmula é, também, idônea para evitar os abusos e a má-fé.

Mais à frente esse ponto será retomado. O que importa ponderar, nesse momento, é que, também no sistema jurídico brasileiro, a representação é aferida, de forma concreta, pelo

989 TUCCI, 2006, p. 104 et seq.

990 MENDES, 2012, 78.

991 DINAMARCO, 2001, p. 137.

992 GIDI, 2007, p. 99. 
resultado ou pela performance do representante em promover os interesses ou direitos do grupo, mediante a deliberação racional dos seus argumentos. É uma técnica preordenada ao resultado.

Aliás, esse entendimento já existe no direito brasileiro, até mesmo no processo individual. Como bem acentuou Samuel Meira Brasil Jr ${ }^{993}$, o elemento distintivo do processo é ser método argumentativo de resolução de controvérsia. Daí a importância das técnicas de argumentação.

Tereza Arruda Alvim ${ }^{994}$ salienta a importância do raciocínio argumentativo na ingerência do Poder Judiciário na vida das pessoas. Antônio do Passo Cabral ${ }^{995}$ ressalta que a preclusão é dinâmica e argumentativa (embora restrinja à hipótese de identidade de parte), de forma a não ser possível reavaliar questões de fato ou de direito, logicamente unidas à conclusão final.

$\mathrm{Na}$ agregação processual, seja nas ações coletivas ou demais técnicas, a técnica da argumentação assume igual relevância na resolução unitária da controvérsia. Cabe ao representante introduzir os argumentos do grupo. E, mais, a atividade representativa concreta equivale a deliberação racional dos argumentos do grupo, com a promoção de seus interesses.

Interessante aplicação desse raciocínio seria à hipótese de anulação de deliberação assemblear pelo sócio. O legitimado concorrente ou o litisconsorte virtual deve ser vinculado ao comando normativo do julgado, pois, por força da relação substancial, os membros do grupo são presumidamente fungíveis. Na ausência de indicação contrária, qualquer deles é apto a apresentar os argumentos de fato ou de direito relevante ao grupo. Caso a performance do representante seja insuficiente e caso um outro legitimado apresente uma nova dimensão da controvérsia (novas circunstâncias) ou uma questão pessoal, a estabilidade pode ser afastada.

993 BRASIL JR, 2007, p. 43.

994 Segunda Tereza Arruda Alvim Wambier, quando o Estado de Direito intervém na vida das pessoas, ele deve justificar essa intromissão: a) materialmente, pois a intromissão deve ter fundamento, e b) formalmente, pois o fundamento deve ser declarado, exposto, demonstrado (Cf. WAMBIER, Teresa Arruda Alvim. Nulidade do processo e da sentença. 5 ed. rev. atual. São Paulo: RT, 2004, p. 323).

995 CABRAL, 2013, p. 394. 
Raciocínio similar foi defendido por Proto Pisani ${ }^{996}$, Michelle Taruffo ${ }^{997}$ e, entre nós, por José Rogério Cruz e Tucci ${ }^{998}$. Sustentaram que a vinculação é possível, desde que resguardada a possibilidade de oposição posterior do terceiro em face do comando normativo decidido.

Pondera-se, apenas, que a participação do terceiro não deve ser justificada pela simples ausência de participação prévia. A participação do terceiro justifica-se quando ausente o resultado e quando insuficiente a performance, sem enfrentamento dos argumentos da categoria.

Enfim, percebe-se que, além da representação virtual, caminha-se para uma reinterpretação das garantias constitucionais nas controvérsias plurissubjetivas, na qual se encarta a litigiosidade de massa. O objetivo não é exaurir o tema, mas, apenas, enfrentá-lo sob a ótica constitucional.

\subsection{GARANTIAS CONSTITUCIONAIS PROCESSUAIS}

A questão que, aqui, se coloca é como admitir a representação e, por conseguinte, a vinculação dos membros ausentes da classe sem que seja assegurado a cada um deles o direito de acessar e de participar em contraditório, pessoal e diretamente, no procedimento objeto de agregação.

Na realidade, como consequência necessária da agregação processual, uma conclusão se impõe: a necessidade de revisitação e de reinterpretação das garantias constitucionais processuais, mormente, as garantias do acesso à justiça e do contraditório no processo. Nem sempre o acesso e a participação serão pessoais e diretos e nem sempre isso será necessário, idôneo e proporcional diante das exigências do direito material controvertido na hipótese em concreto.

Mauro Cappelletti ${ }^{999}$ já, há muito, anuncia a necessidade de um novo garantismo, que representa uma superação do garantismo individualista e tradicional. O processo deve conferir garantias suficientes não apenas ao indíviduo, mas também aos grupos. Não há solução apriorística, para tanto, a resposta jurisdicional deve apresentar uma flexibilidade em sua articulação concreta.

996 PISANI, 1971, p. 1239 -1240.

997 Na mesma ordem de ideias, Michelle Taruffo salienta: "il diritto di difesa può non essere inteso come necessità della effettiva participazione al giudizio di tutti coloro che possono subire gli effetti della sentenza, ma, piú limitatamente, come riconoscimento a tali soggetti dell'oportunità e della concreta possibilità di provedere alla própria tutela (TARUFFO, Michelle. I limiti soggettivi del giudicato e le "class action". In: Rivista di Diritto Processuale, Anno XXIV, 1969, p. 616-617). 
A propósito, Ada Pellegrini Grinover ${ }^{1000}$ já afirmou que diante da evolução dos institutos no processo coletivo, que envolve uma multiplicidade de sujeitos interessados, e diante dessa nova realidade de direito material a ser efetivada, é simples a conclusão pela necessidade de adaptação da técnica processual, mas também das garantias processuais constitucionais.

Cassio Scarpinella ${ }^{1001}$ ressalta que o direito processual tem pautado sua atuação em uma releitura dos conceitos fundamentais do direito tradicional, centrado no indivíduo e nas lides exclusivamente privadas. Nessa medida, a concepção do devido processo legal, do contraditório e da formação da coisa julgada apenas inter partes não só sofre mitigações, mas passa por uma verdadeira revolução, a partir das novas exigências criadas pela mutação do direito material.

Na realidade, as garantias processuais constitucionais são adaptáveis às circunstâncias fáticas e jurídicas, sem perder o seu escopo de proteção. Esse é o sentido da ponderação, isto é, mantémse o conteúdo mínimo de proteção ao indivíduo, mas o modo como essa proteção se realiza (técnica processual) é adaptável, varia conforme a necessidade, adequação e a proporcionalidade diante do caso concreto e das demais garantias processuais aplicáveis.

Lembra que a técnica é o modo, é a forma convencional preordenada à consecução de um resultado consistente na resolução da controvérsia de direito material. Essa forma é orientada pelas garantias processuais constitucionais, mas a forma não se confunde ou não se equivale à própria garantia. Logo, uma garantia pode ser concretizada de diferentes modos, de acordo com as diferentes peculiaridades e exigências do direitos substancial. Diferentes controvérsias de direito material podem atrair diferentes técnicas processuais, sem violação àquelas garantias.

\subsubsection{DIREITO DE PARTICIPAÇÃO PROCESSUAL}

O direito de participação no processo é suscetível de variação como técnica processual. O conteúdo mínimo da garantia do contraditório deve ser observada, mas a técnica processual é suscetível a sofrer alterações, conforme as peculiaridades do direito material. Antes de abordála, é preciso analisar as teorias de participação: orientada ao processo e orientada ao resultado.

1000 GRINOVER, 2005, p. 7.

1001 BUENO, 1996, p. 101. 
Como diz Bone ${ }^{1002}$, é comum, nos dias de hoje, distinguir duas teorias de participação. Pela teoria da participação orientada ao processo, a participação é valiosa por si mesma, independentemente do resultado. Pela teoria da participação orientada ao resultado, a participação é valiosa, à medida que permite o aperfeiçoamento dos resultados da adjudicação.

\subsubsection{TEORIA DA PARTICIPAÇÃO ORIENTADA AO PROCESSO}

Essa teoria responde por vários nomes. Robert Summers ${ }^{1003}$ a denomina de participação orientada ao processo (process value efficacy ou process-oriented), Lawrence Tribe ${ }^{1004} \mathrm{de}$ participação intrínseca (intrinsic), Richard B. Saphire ${ }^{1005}$ de participação inerente (inherent) e Bone ${ }^{1006}$ adota o mesmo sentido de Summers, qual seja, participação orientada ao processo.

Segundo essa teoria, a participação é valiosa por si mesma, independentemente do resultado, pois ela enseja confiabilidade e legitimidade ao processo como método de resolução da controvérsia. A participação, por si só, amplia a satisfação da parte e promove a sua dignidade.

Nas palavras de Saphire ${ }^{1007}$, o devido processo legal é uma garantia contra a arbitrariedade. O processo devido equivale a um processo justo e não discriminatório, que respeita a dignidade do indivíduo e sua capacidade de influenciar e reagir aos impactos adversos em sua vida. Para isso, a influência do indivíduo é relevante, pois a sua dignidade é promovida pelo fato de ser possibilitada a sua interação e a colaboração com a autoridade. Isso gera um sentimento, por si só, de que a justiça foi alcançada, pois conferido ao indivíduo a possibilidade de influenciar.

Trata-se em uma fórmula subjetiva de justiça, baseada no sentimento, no valor da autonomia pessoal e no poder de influenciar o órgão decisório, afastando os impactos adversos ao indivíduo. É a simples satisfação de participar, que gera confiança e sentimento de respeito.

1002 BONE, 1992, p. 237-269.

1003 SUMMERS, Robert S. Evaluating and improving legal process - a plea for "process values". Cornell Law Review, 1974, V. 60:1-52p, p. 6.

1004 TRIBE, Lawrence H. Constitutional choices. Cambridge: Harvard University Press, 1985, p. $222-226$. 1005 SAPHIRE, Richard B. Specifying due process values: toward a more responsive approach to procedural protection. University of Pennsylvania Law Review, 1978, V.127: 111-195p, p. 121.

1006 BONE, 1992, p. 264.

1007 SAPHIRE, op. cit., p. 119-121. 
Segundo Summers ${ }^{1008}$, há valores que, se implementados no processo, são valiosos, ainda que sem qualquer resultado e mesmo sem aperfeiçoar o resultado. O resultado pode ser negativo, mas o fato de o indivíduo ter participado lhe confere valor. Exemplo, em uma eleição, eu posso julgar um político pela sua capacidade, pela inteligência e pela experiência. Depois, quando do exercício do mandato, eu posso julgar esse político pelos resultados, pelo cumprimento das promessas de campanha, por suas ações. Assim ocorre com o processo: ele pode ser considerado bom pelas suas próprias qualidades como método, por sua forma intrínseca ou inerente. ${ }^{1009}$

Atualmente, no Brasil, há um clamor por uma maior participação antes de decisões judiciais de terceira via, isto é, baseada em uma visão jurídica estranha às alegações das partes. Embora não se negue que o magistrado possa valorizar juridicamente os fatos, sem vincular-se aos pedidos e alegações das partes, ressalta-se a importância de franquear a manifestação das partes, para evitar que sejam elas surpreendidas com uma visão jurídica que não tenham ainda percebido. ${ }^{1010}$

A participação é valorizada por si mesma, por sua qualidade de ampliar a confiança no processo e não tanto por influenciar o resultado, até porque se o magistrado intima as partes para se manifestarem sobre uma visão jurídica, é porque ele já vislumbrou, antes, esse resultado. ${ }^{1011}$

É preciso destacar que essa teoria, por si só, não é suficiente para o conceito de devido processo legal. Não é possível dizer que um estado de coisas é justo simplesmente porque observado um procedimento com a participação dos interessados. Até porque, em determinados casos, a participação pode ser amplamente franqueada sem implicar a satisfação e a confiabilidade das partes no método. O exemplo clássico disso é ação por dano ínfimo. Todos os indivíduos podem

1008 SUMMERS, op. cit., p. 12.

1009 Em contrapartida, é preciso destacar que, mesmo que o processo possa ser julgado por suas qualidades intrínsecas, ela não dispensa conexão com o direito material. Isso porque, valendo-se da metáfora de Summers, ainda que o político possa ser avaliado, previamente, segundo suas qualidades intrínsecas e antes de qualquer resultado representativo, essa qualidade deve ser necessária e adequada ao objeto pretendido. Por exemplo, ao se julgar um político pela sua inteligência ou experiência, não se refere, por exemplo, à inteligência musical ou a experiência culinária, refere-se à inteligência política ou a experiência de gestão pública. Com isso, a qualidade pode ser intrínseca, mas ela não deixa de ser preordenada aos escopos do objeto que se pretende alcançar.

1010 OLIVEIRA, Carlos Alberto Alvaro de. Garantia do contraditório. In: TUCCI, José Rogério Cruz e. Garantias constitucionais do processo civil. São Paulo: Revista dos Tribunais, 1999, p. 143.

1011 Mesmo nessa hipótese - juízos de terceira via - pondera-se que a participação continua sendo válida para aprimorar o resultado e não por razões dignitárias apenas. Por exemplo, se o magistrado acolhe uma questão de ordem pública ofício, como a intempestividade de um recurso, sem que o recorrente tenha abordado a contagem do prazo recursal em sua peça, é possível a ocorrência de erro. Nesse caso, o recorrente, se instado a se manifestar previamente, poderia apresentar alguma circunstância, que se considerada, alteraria a contagem do prazo (litisconsórcio com procuradores diferentes). Nesse caso, a participação prévia, em uma situação de dúvida, é válida para melhor esclarecer a controvérsia e não apenas para fins de prestigiar as partes. 
participar (mesmo que os custos não compensem), mas a participação de um indivíduo não teria, necessariamente, o condão de alterar a prática abusiva e desestimulá-la para o futuro.

Muitos são os casos de partes que reclamam de uma cobrança mínima, mas irregular, realizada, de tempos em tempos, em sua conta de telefone. Mas, quantos são os casos de indivíduos realmente satisfeitos com os serviços prestados após a sua participação nessa reclamação?

Assim, de acordo com as peculiaridades do direito material, a participação, ainda que valiosa em si mesma, pode ser dosada e mitigada, para adequar-se às circunstâncias fáticas ou jurídicas de uma hipótese concreta. A dosagem da participação, nesses casos, é válida, até mesmo porque pode ampliar a confiança e a satisfação das partes com o processo enquanto método.

\subsubsection{TEORIA DA PARTICIPAÇÃO ORIENTADA AO RESULTADO}

Essa teoria também responde por vários nomes. Summers ${ }^{1012}$ a denomina de participação orientada ao resultado (good result efficacy/ result-oriented), Lawrence Tribe ${ }^{1013}$ de participação instrumental (instrumental), Richard B. Saphire ${ }^{1014}$ de participação substantiva (substantive) e Bone ${ }^{1015}$ adota o mesmo sentido de Summers, a saber, participação orientada ao resultado.

Segundo essa teoria, a participação é valiosa porque - e na medida que - tende a aperfeiçoar os resultados da atividade de adjudicação do direito. A participação visa permitir as partes influenciar a convicção do juiz, permitindo uma visão dos fatos e do direito mais apurada e com menor risco de erro, de má-compreensão dos fatos e de equivocada aplicabilidade do direito. ${ }^{1016}$

Essa teoria, por sua vez, parte, segundo Bone ${ }^{1017}$, de uma teoria de adjudicação. A participação visa a adjudicação do direito, isto é, a resolução das questões de fato e de direito controvertidas, com a prestação da tutela jurisdicional às partes interessadas. A participação é avaliada segundo a qualidade dos resultados alcançados na efetivação dos direito controvertido entre as partes.

1012 SUMMERS, 1974, p. 5-6.

1013 TRIBE, 1985 , p. 222-226.

1014 SHAPIRE, 1978, 121.

1015 BONE, 1992, p. 237.

1016 Nesse sentido, Larry Alexander salienta que a preocupação com o processo, de forma apartada da substância, beira à incoerência (Cf. ALEXANDER, Larry. Relationship between procedural due process and substantive constitutional rights. U. FLA. L. REV, 1987, V. 39: 323-341p., p. 325-326).

1017 BONE, 1992, passim. BONE, Robert G. Procedure, participation and rights. Boston Law Review, 2010, V. 90:1011-1028p., passim. 
No precedente Codd v. Verger ${ }^{1018}$, o autor, um policial do Departamento de Nova York, foi demitido no estágio probatório sem prévia audiência de justificação, providência que era, em tese, exigida pelo devido processo legal. A razão para a dispensa do policial foi uma tentativa de suicídio no exercício anterior da função policial. $\mathrm{O}$ autor não disputou os fatos ou afastou a veracidade dessa informação, mas apenas alegou violação ao devido processo legal. A Suprema Corte dos Estados Unidos, apreciando a questão, asseverou que não era necessária a prévia audiência da parte, pois a ela falhou em alegar ou provar os elementos necessários do seu caso.

O propósito do direito de audiência é, continua Corte, conferir uma oportunidade para refutação das alegações da parte adversa. Assim, se não há controvérsia ou disputa quanto aos fatos, apenas o argumento de vício no devido processo legal, não há necessidade dessa audiência, pois não há interesse na refutação das alegações da parte adversa. A participação é valiosa à medida que pode maximizar a precisão dos resultados, seja pela argumentação do interessado, seja pela refutação dos argumentos da parte contrária. Se a participação em nada acrescenta ao resultado, ela não é, de per si, necessária e idônea na realização do devido processo legal na hipótese.

No precedente Mathews v. Eldridge ${ }^{1019}$, a Suprema Corte ressaltou que o devido processo legal é conformado para minimizar o risco de erro na apuração do direito substancial. A participação visa, portanto, ampliar o conhecimento dos fatos e das questões de direito, acrescentando precisão ao resultado, o que apenas corrobora o caráter instrumental dessa garantia processual.

A teoria procedimental de Dworkin ${ }^{1020}$ reforça a teoria da participação orientada ao resultado. Isso porque o processo é avaliado pela sua tendência de produzir resultados conforme o direito substancial, com a identificação e o cumprimento do direito alegado pelas partes. Nesse medida, a participação das partes é alocada ou distribuída no procedimento de acordo com a possibilidade de alcançar o resultado e pode até ser superada se o resultado vier a ser alcançado.

Bedaque $^{1021}$, por fim, salienta que a garantia do contraditório consiste em meio pelo qual as partes tem assegurada a participação, para fins de influenciar o convencimento do juiz. Com o

1018 UNITED STATES OF AMERICA. Supreme Court of United States. Codd v. Verger. 429 U.S. 624 (1977). 1019 UNITED STATES OF AMERICA. Supreme Court of United States. Mathews v. Eldridge. 424 U.S 319 (1976).

1020 DWORKIN, Ronald. A matter of principle. Oxford: Oxford University Press, 2001, p. 72-99.

1021 BEDAQUE, 2006, p. 486-487. 
contraditório, o juiz toma conhecimento das versões antagônicas. O contraditório não é, pois, fim em si mesmo, está ligado à segurança do instrumento e à adequação aos seus escopos.

\subsubsection{O CONTRADITÓRIO, AS TEORIAS DE PARTICIPAÇÃO E O DIREITO SUBSTANCIAL}

A garantia constitucional do contraditório não se resume a nenhuma das duas teorias antes mencionadas. O contraditório é um instrumento que garante tanto a legitimidade do método, quanto a possibilidade de influenciar a convicção do magistrado na resolução do direito material. Seja como for, o design procedimental deve ser modelado segundo o direito material.

A participação pode, em tese, ser limitada, sem prejuízo à legitimidade do procedimento (escopo da teoria da participação orientada ao processo), bem como sem prejuízo à consecução do resultado: atuação do direito substancial controvertido (escopo da participação orientada ao resultado). Isso ocorre porque - frise-se - nem toda a decisão afeta pessoalmente o indivíduo. ${ }^{1022}$

Na hipótese em que os interesses substanciais são compartilhados, são objetivos, impessoais, paritários ou indivisíveis, a questão controvertida não se subsume às características pessoais de um indivíduo. O indivíduos aparecem, nesse cenário, como anônimos ${ }^{1023}$, como fungíveis, como membros de um grupo e não segundo as suas características singulares, pessoas e particulares.

Nesse sentido, mesmo quando a participação é orientada ao processo, pelo seu valor intrínseco, essa participação, como técnica processual, pode ser dosada. Ela é uma técnica preordenada à consecução de um procedimento legítimo e confiável. Assim, quando os interesses são coletivos, presume-se que uma técnica como a representatividade adequada e a concessão de uma participação mais compreensiva e abrangente - e não direta e pessoal - seria suficiente para alcançar a mesma legitimidade do procedimento e a mesma confiabilidade do resultado.

É notável que a demanda pela participação pessoal e direta aumenta à medida que o tratamento judicial conferido também é direto e pessoal. Presume-se que o indivíduo é o melhor guardião dos seus próprios interesses. Essa presunção pode ser afastada e refutada, com a consequente 
adaptação da técnica processual, à medida que a controvérsia deduzida em juízo não referir-se ao indivíduo isolado, mas, sim, ao grupo ou ao indivíduo como membro do grupo.

De igual modo, a participação orientada ao resultado conduz ao mesmo raciocínio. O resultado é mais apurado quão maior for a informação e quão melhor e mais forte for a argumentação sobre o direito alegado. Mas, se os interesses são compartilhados e não demandam informações pessoais ou particularizadas, não será a informação de um indivíduo ou a concepção de um indivíduo que irá maximizar a precisão dos resultados. Os argumentos também tornam-se comuns, impessoais e objetivos. Mais uma vez, a representatividade adequada e a participação mais abrangente e compreensiva se apresenta adequada como técnica processual, sem prejuízo aos resultados. A participação é valorizada, mas não necessariamente precisa ser individual.

Aliás, nesse sentido, afirma Owen Fiss ${ }^{1024}$, ao consignar que toda pessoa tem o direito de ter seu interesse representado, mas não necessariamente tem direito à participação individual. Isso é possível em virtude dos interesses compartilhados entre um grupo de pessoas situadas na mesma classe e na mesma posição jurídica, tornando os indivíduos igualmente propensos à proteção desse interesse, na ausência de qualquer indicação especial ou singular.

O participação deixa de ser individual, sem que, com isso o procedimento seja considerado menos legítimo e com piores resultados. Muito pelo contrário, os membros do grupo são fungíveis, são anônimos, são equiparáveis em razão da identidade dos interesses, de modo que a participação coletiva é vantajosa para ampliar o debate e "assegurar que todos os interesses sejam levados em conta e que os argumentos mais fortes sejam formulados em seu favor". ${ }^{1025}$

Mas, e se existirem dimensões ou circunstâncias particularizados na controvérsia? Nessa hipótese, caso exista uma dimensão da controvérsia não debatida ou caso existam argumentos pessoais que não tenham sido expressamente enfrentados, restaura-se a participação direta. A técnica da agregação processual foi apenas um modo convencional ou uma forma presumida e preordenada em função do direito substancial coletivo e na ausência de dimensão particular.

1024 FISS, 2004, p. 219.

1025 Ibidem, p. 231. 
Caso, posteriormente, seja demonstrada uma nova dimensão da controvérsia (novas circunstâncias fáticas ou jurídicas não debatidas) ou caso o argumento pessoal do indivíduo não tenha sido expressamente enfrentado, sendo insuficiente a representação realizada em juízo, a participação direta é restaurada, muito embora de forma postergada ou postecipada. A análise da performance argumentativa, realizada pelo representante, é aferida de modo subsequente.

Novamente é Owen Fiss ${ }^{1026}$ que aborda, com precisão, essa questão. Um decisão somente é final se os interesses foram adequadamente representados, com o expresso enfrentamento dos argumentos do grupo. Se os interesses do grupo não foram promovidos, com a deliberação de seus argumentos, a decisão permanece vulnerável a uma nova impugnação. Nesse sentido:

\begin{abstract}
...nenhum indivíduo pode ser obrigado por uma decisão judicial a menos que seus interesses estejam adequadamente representados no processo. Isso significa que uma decisão estrutural pode ser final se, e somente se, todos os interesses estiverem adequadamente representados no processo. Se um dos interesses envolvidos não estiver representado de forma adequada, a decisão judicial permanece vulnerável a uma nova impugnação; se, entretanto, tal interesse foi completamente representado no processo que conduziu ao proferimento da decisão judicial, a corte poderá rejeitar liminarmente a nova impugnação, sob o fundamento de que a questão já fora analisada - não obstante o autor da impugnação não tenha participado no processo inicial.
\end{abstract}

É igualmente relevante uma segunda ponderação. Somente uma nova dimensão da controvérsia (novas dimensões de fato ou de direito) ou uma circunstância pessoal não enfrentada pode ensejar uma impugnação do membro ausente do grupo. Isso porque a possibilidade de uma nova impugnação ou de relitigar uma questão já decidida não é dada ao indivíduo, membro ausente do grupo para que ele tenha uma nova chance, para que ele possa alterar o resultado. $\mathrm{O}$ contraditório é postecipado para que o indivíduo possa influenciar a convicção do magistrado sobre uma circunstância não enfrentada e não para lograr um segundo provimento jurisdicional.

Nesse sentido, Robert G. Bone ${ }^{1027}$ ilustra essa questão com um exemplo interessante. Imagine que um julgamento seja decidido com fundamento no "cara ou coroa", isto é, lançando uma moeda para cima. A participação pessoal não é relevante nesse cenário. A moeda não precisa ser relançado apenas porque alguém não jogou pessoalmente a moeda para cima. Isso ocorre porque o resultado é fundamentado na sorte, sem interferência pessoal. Admitir um segundo lançamento, nesse caso, é admitir apenas uma nova tentativa, uma nova chance de tentar a sorte. 
O mesmo raciocínio se aplica ao caso de um argumento já enfrentado no processo judicial, com relação a um direito ou interesse compartilhado, coletivo, objetivo, impessoal, indivisível e/ou paritário. Se não há pessoalidade na controvérsia deduzida em juízo, os argumentos do grupo tendem a compartilhar uma natureza idêntica. Por isso mesmo, reproduzir um argumento já enfrentado é, nesse contexto, tentar a sorte, é tentar um juiz mais simpático, é tentar uma nova estratégia judicial, sem que isso resulte em acréscimo de precisão ao resultado. E o pior se o interesse for indivisível (todos tiverem necessariamente a mesma sorte no plano material), surge um efeito carona positivo: o segundo indivíduo do grupo que tentar a sorte beneficia o primeiro que já discutiu idêntica questão e sucumbiu. Nenhum direito de participação, seja orientado ao processo, seja orientado ao resultado, autoriza essa última espécie de participação individual.

Volta-se a se insistir, portanto, que o cerne da agregação processual - a questão de anterioridade lógica - é a identificação da relação jurídica de direito material. O direito ao contraditório deve ser mensurado (juízo de necessidade e adequação) pelo direito material em jogo na hipótese. ${ }^{1028}$

Um último aspecto merece ser destacado. A conclusão alcançada neste tópico aplica-se tanto a direitos indivisíveis quanto a direitos divisíveis, mas impessoais, paritários, idênticos ou equiparados no bojo da litigiosidade de massa. Não é a tutela pretendida que define o direito, tampouco o direito coletivo se esgota nas hipóteses de indivisibilidade do bem. O que define o direito coletivo ou de alcance coletivo é a sua identidade ou igualdade (sameness) ${ }^{1029 .}$

Isso já foi abordado antes nessa investigação, apenas reitera-se, agora, com fundamento nas lições de Owen Fiss ${ }^{1030}$, para quem o âmago da questão é o fato de que interesse individual nem sempre permanece isolado, mas pode ter a mesma sorte ou ser idêntico àquele de uma classe. O interesse compartilhado de que trata Fiss tanto pode ser implementado por uma pretensão mandamental (injunction), quanto para a pretensão condenatória idêntica (como ocorreu no caso Eisen v. Carlisle \& Jacqueline), o que deve chamar a atenção é o propósito de alcançar valores objetivos pragmáticos e a necessidade de enforcement do direito substancial alegado.

1028 Em sentido semelhante: ISSACHAROFF, Samuel. When substance mandates procedure: Martin v. Wilks and the rights of vested incumbents in civil rights consent decrees. Cornell Law Review, 1992, V. 77:189-252p. ("the opportunity to be heard must be mensurate to the rights at stake"). 
Por todo o exposto, sustenta-se, ainda, que o conteúdo mínimo da garantia constitucional do contraditório é a "participação argumentativa"1031, isto é, a participação pela argumentação.

A participação é dosada e exercida à medida que pode incrementar e fortalecer os argumentos das partes na defesa dos seus interesses ou direitos, influenciando a convicção do magistrado na resolução da controvérsia de direito material, bem como produzindo resultados legítimos e confiáveis. A participação é, ainda, avaliada segundo a performance argumentativa, isto é, pela efetiva apresentação, discussão e enfrentamento dos argumentos deduzidos em juízo.

E, mais, a participação não é, nessariamente, pessoal ou coletiva, pois nem sempre o argumento é pessoal ou coletivo. O contraditório não se confunde com a solução técnica da participação.

Frise-se que a forma ou a técnica processual - o modo presumido ou convencional de resolução de controvérsias - adota a participação mais pessoal ou menos pessoal de acordo com a especificidade do direito material. Quando o direito for individual, a exigir cognição artesanal, maior a necessidade de participação pessoal e de influência do indivíduo na precisa determinação do direito material. Quando o direito for coletivo ou de alcance coletivo, a exigir cognição padronizada, maior a necessidade de uma participação mais ampla e compreensiva na determinação do direito material. Nesse caso, os indivíduos são igualmente hábeis a defender esse direito em juízo e, de igual modo, é mais vantajoso que os argumentos mais fortes sejam apresentados em um mesmo fórum em favor de todos os indivíduos do grupo afetado. ${ }^{1032}$

\subsubsection{O ABUSO PROCESSUAL E O ÔNUS/CARGA DE ARGUMENTAÇÃO}

O contraditório é participação argumentativa ou participação pelo argumento. É importante destacar que o contraditório visa incrementar a deliberação sobre os argumentos do grupo, produzindo resultados confiáveis e legítimos, em consonância ao direito material controvertido.

O contraditório, quando oportunizado ao membro ausente do grupo, não autoriza a simples rediscussão da controvérsia. Não se trata de conferir mais uma chance de vitória a quem não foi parte, simplesmente porque não figurou formalmente no processo. A possibilidade de

1031 Essa expressão foi adotada em dissertação de mestrado, de nossa autoria, intitulada "Por um novo garantismo: acesso à justiça e contraditório na tutela jurisdicional coletiva", que não foi ainda publicada.

1032 Em sentido semelhante, AMERICAN LAW INSTITUTE, 2010, p. 156. FISS, 2004, p. 231. 
impugnar o resultado do processo, em relação ao qual não participou, decorre da necessidade aperfeiçoar o resultado pela participação pessoal. Sob essa perspectiva, pondera-se que não existe o direito de tentar a sorte, apenas para mudar o resultado do provimento jurisdicional. Essa orientação se sustenta por mais uma razão: a prestação jurisdicional não deve ser lotérica.

A regra acima mencionada constitui uma das regras de argumentação jurídica. Trata-se da regra do ônus de argumentação, que é baseado no princípio da inércia perelmaniano. Explicar-se-á. Segundo o princípio da inércia, um argumento aceito ou consolidado não pode ser mudado ou rejeitado sem que o interessado apresente uma razão suficiente para tanto. É inadmissível a dúvida universal, a rejeição frívola da tradição, o mero capricho ou a teimosia sem que uma razão seja ofertada para alteração do provimento produzido. A mudança exige justificação. Esse princípio confere, segundo Perelman ${ }^{1033}$, maior estabilidade e segurança à ciência do direito.

A conclusão acima exposta, por sua vez, fundamenta uma das regras da argumentação jurídica, a saber, a regra do ônus ou da carga de argumentação. Essa regra prescreve que uma proposição pressuposta como verdadeira ou válida na comunidade jurídica, mas ainda não expressamente discutida ou enfrentada, pode ser problematizada se indicada uma razão para essa finalidade. ${ }^{1034}$

Essa regra contribuiu cumpre não somente com a função de estabilização do direito, mas também confere maior segurança jurídica e proteção da confiança na aplicação do direito. A carga da argumentação protege a boa-fé, as expectativas legítimas do jurisdicionado e obsta, em regra, as modificações inesperadas, contraditórias ou desarrazoados no sistema jurídico.

As técnicas processuais de preclusão, dentre as quais, incluem-se a coisa julgada (claim preclusion) e a preclusão das questões decididas (issue preclusion), compartilham esse escopo.

Essas técnicas serão ainda aprofundadas. Mas, nesse momento, importa destacar que, principalmente no sistema estadunidense, a preclusão cuida não apenas de estabelecer estabilidade e definitividade à controvérsia já deduzida em juízo. Visa também evitar que uma questão já decidida, mediante o enfrentamento expresso dos argumentos, seja novamente

1033 PERELMAN, Chaim; OLBRECHT-TYTECA. Tratado de la argumentación: la nueva retórica. Tradução para o espanhol de Julia Sevilla Munoz. Madri: Gredos, 1989, p. 178.

1034 ALEXY, Robert. Teoria da argumentação jurídica: teoria do discurso racional como teoria de justificação jurídica. Tradução Zilda Hutchinson Schild Silva. São Paulo: Landy Editora, 2005, p. 196. 
reproduzida, sem uma razão suficiente. Isso se aplica, em alguns casos, até mesmo a quem não foi parte na demanda anterior, quando vexatória, frívola, desarrazoada, abusiva ou arbitrária for a tentativa de simplesmente lograr a sorte em juízo, sem acrescer ao debate ou à argumentação.

Lembra-se, com isso, das propostas de que seja demonstrada uma justa causa (burden of persuasion ou ônus de persuasão) para que o membro ausente do grupo, que não figurou formalmente como parte na demanda coletiva, possa excluir-se da ação de classe. De igual modo, por ocasião do collateral attack, deve o autor, preliminarmente, cumprir o ônus de afastar a representação adequada na ação coletiva, não bastando a mera alegação de vícios formais.

E, mais, pode-se dizer que a técnica da preclusão é uma derivação histórica da doutrina do abuso processual e, por vezes, até hoje, ainda é suplementada por essa doutrina. As técnicas de preclusão tem, por vezes, a sua aplicabilidade expandida sob a epígrafe do abuso processual. ${ }^{1035}$

Principalmente, na Inglaterra, onde as técnicas de preclusão são mais restritas que nos Estados Unidos, a ampliação da preclusão tem sido realizada sob o aspecto do abuso processual. ${ }^{1036}$

Parte-se do pressuposto que as garantias processuais constitucionais não garantem e não legitimam as práticas processuais abusivas. O esforço de relitigar questões já decididas, em violação aos princípios aplicáveis à coisa julgada é considerado, por exemplo, abusivo. Nos Estados Unidos, Hazard $\mathrm{Jr}^{1037}$ salienta que demandas repetitivas ou similares tem sido limitadas. Por exemplo, a regra da coisa julgada era aplicada de forma rigorosa, salvo nas hipótese de habeas corpus. Mas, em razão do uso abusivo e repetitivo desse writ, uma mudança de postura já foi notada nas Cortes de Justiça estadunidense, para limitar o exame das petições repetitivas.

\footnotetext{
1035 A Corte de Justiça pode valer-se dos poderes inerentes à jurisdição para prevenir a litigância que beira ao abuso processual, mesmo fora das hipóteses de coisa julgada. O uso discricionário da doutrina do abuso processual é aplicável não apenas às partes, que podem, eventualmente, adotar comportamento contraditório ao adotado em outro procedimento, mas também a terceiros, para evitar processos repetitivos (Cf. ZUCKERMAN, Adrian. Zuckerman on Civil Procedure: principles of practice. 2 ed. UK: Sweet \& Maxwell Ltd, 2006, P. 944).

1036 Linda Silberman comenta que a doutrina da preclusão, na Inglaterra, é limitada às partes, por isso a doutrina do abuso processual complementa a preclusão: "an additional doctrine - abuse of process - is used to supplement the doctrine of merger, causa of action estoppel and issue estoppel, and expands what might be viewed as relatively narrow principles of res judicata. 'Abuse of process' may be invoked to prevent a party from proceeding on a claim that could have been part of a prior proceeding, or it may be used to prevent parties other than those to the original proceedings from asserting claims or issue previously decided" (CF. SILVERMAN, Linda. Finality and preclusion. In: CHASE, Oscar, HERSHKOFF, Helen. Civil litigation in comparative context. Minneapolis: Thomson West, 2007, p. 442).

1037 HAZARD JR, Geoffrey C. Abuse of procedural rights: regional report for the United States. In: TARUFFO, Michele. Abuse of Procedural Rights: comparative standards of procedural fairness. Boston: Kluwer, 1998 , p. 46.
} 
$\mathrm{Na}$ Inglaterra, a doutrina da coisa julgada tem sido adaptada ao contexto das ações de grupo, permitindo uma aplicação mais flexível da preclusão, sob o fundamento do abuso processual. Isso porque a categoria de abuso processual não é exaustiva e novos tipos de abuso podem ser reconhecidos, embora seja recomendável o desenvolvimento contido dessa doutrina. ${ }^{1038}$

A doutrina do abuso processual também fundamenta, na Inglaterra, a possibilidade de extinção liminar de demandas abusivas, sendo assim entendidas aquelas que não se fundamentam em motivos razoáveis, que são grosseira ou obviamente infundadas e vexatórias. Novamente, essa técnica é particularmente relevante para o réu, para evitar a rediscussão de questões já decididas.

Demandas sem fundamento de fato ou de direito - objetivamente sem esperança (objectively hopeless) ${ }^{1039}$-, ainda que o autor honestamente acredite que tenha ela algum mérito, é sugestivo de abuso processual. Um demanda vazia de fundamento implica uma distorção do processo, por isso é abusiva. O abuso processual é um dado objetivo, não exige dolo ou má-fé subjetiva.

Fentiman ${ }^{1040}$ e Neil Andrews ${ }^{1041}$ ressaltam, ainda, que o exercício dessa técnica tem sido usada de modo cauteloso pelas Cortes de Justiça Inglesas. É um mecanismo considerada draconiano, por limitar a possibilidade de instrução e, por isso, deve ser aplicável apenas às hipóteses óbvias.

De igual modo, como bem salienta Taruffo ${ }^{1042}$, o raciocínio também se aplica ao acesso à justiça. O fato de ser assegurado ao indivíduo o direito de acesso à justiça, não autoriza ou não lhe confere a prerrogativa de ajuizar demanda frívolas, ou sem qualquer interesse jurídico (mero aconselhamento). Neste caso, não há exercício do acesso à justiça, mas, sim, abuso processual.

O capricho e a teimosia, sem razões ou fundamentos que justifiquem a provocação do órgão jurisdicional, também podem ser consideradas, no direito brasileiro, espécie de abuso

1038 ANDREWS, Neil. Abuse of process in English Civil Litigation. In: TARUFFO, Michele. Abuse of Procedural Rights: comparative standards of procedural fairness. Boston: Kluwer, 1998, p. 69.

1039 ANDREWS, 1998, p. 69.

1040 FENTIMAN, Richard. Abuse of procedural rights: the position of English Law. In: TARUFFO, Michele. Abuse of Procedural Rights: comparative standards of procedural fairness. Boston: Kluwer, 1998, p. 59. 1041 ANDREWS, op. cit., p. 81.

1042 TARUFFO, Michele. General Report. In: TARUFFO, Michele. Abuse of Procedural Rights: comparative standards of procedural fairness. Boston: Kluwer, 1998, p. 12-13. 
processual. O "mero capricho" era, inclusive, previsto no art. $3^{\circ}$ do Código de Processo Civil de 1939 , consistente em um estado que ia da infantilidade, da teimosia à protelação maldosa. ${ }^{1043}$

Com isso, conclui-se a importância da observância do ônus ou da carga de argumentação no direito processual. Frise-se que essa regra não se limita apenas a conferir estabilidade às decisões judiciais, mas assegura a legítima confiança do jurisdicionado no método estatal de resolução de controvérsias: uma proposição consolidada não deve ser mudada sem uma razão.

\subsubsection{DIREITO DE ACESSO À JUSTIÇA}

A mesma linha de raciocínio é aplicável à garantia constitucional do acesso à justiça. Aliás, tanto no sistema jurídico estadunidense, quanto o sistema jurídico brasileiro, o conteúdo da garantia do acesso à justiça não significa, necessariamente, direito de persecução individual da atividade jurisdicional, mas, sim, direito ao acesso e ao cumprimento da ordem jurídica justa.

No sistema brasileiro, já é consagrada o acesso à justiça como "acesso à ordem jurídica justa"1044. Como salienta Kazuo Watanabe ${ }^{1045}$, o acesso não pode ser visto nos acanhados limites do acesso aos órgãos jurisdicionais. $\mathrm{O}$ acesso implica direito ao conhecimento e à informação sobre direito substancial, direito ao método de resolução da controvérsias, bem como direito à preordenarão dos instrumentos processuais capazes de promover a efetiva tutela de direitos.

No sistema estadunidense, a orientação não é diversa. Acesso à justiça não significa direito à invocação irrestrita do Poder Judiciário ${ }^{1046}$. Significa a acessibilidade ao método de reivindicação de direitos. A restrição legítima ou ilegítima é julgada, nesse aspecto, conforme a resolução do direito material e as razões da parte em afastar o efeito vinculante da coisa julgada e acessar pessoalmente o Poder Judiciário, para a resolução da sua controvérsia. ${ }^{1047}$

1043 THEODORO JR, Humberto. Abuso de direito processual no ordenamento jurídico brasileiro. In: BARBOSA MOREIRA, José Carlos. Abuso dos Direitos Processuais. Rio de Janeiro: Forense, 2000, p. 96.

1044 WATANABE, Kazuo. Acesso à Justiça e sociedade Moderna. In: GRINOVER, Ada Pellegrini (org.) Participação e processo. São Paulo: Ed. RT, 1988, p. 128.

1045 Ibidem, p. 128.

1046 UNITED STATES OF AMERICA. Supreme Court of United States. Boddie v. Connecticut. 401 U.S 371

(1971).

1047 NOTE, 1976, p. 1408 
A técnica processual ou o modo convencional para o exercício dessa garantia pode ser realizado mediante a persecução individual ou pela persecução coletiva de um direito alegado, observado, no último caso, a necessidade de uma adequada representação. A garantia constitucional processual do acesso à justiça não se confunde, portanto, com a solução técnica. Essa garantia visa à acesso e ao enforcement da ordem jurídica justa. E, à semelhança do contraditório, a forma ou o modo convencional para alcançar esse resultado é adaptável ao direito material.

Nesse contexto, afirma-se que as técnicas de agregação processual concretizam a garantia constitucional do acesso à justiça não no sentido de conferir a cada indivíduo a possibilidade de perseguir pessoalmente o direito por ele alegado, mas, sim, porque visam a plena realização dos escopos do direito substancial coletivo, isto é, "full realization of substantive policies" 1048.

Como ressalta Cooper ${ }^{1049}$, quando os danos individuais são ínfimos, a adjudicação unitária da controvérsia, ainda que sem provocação de todos os indivíduos do grupo, enseja o enforcement do direito substancial, que do contrário não seria implementado. Quando os fundos do devedor são limitados, a adjudicação unitária enseja a divisão equitativa dos valores devidos. Se assim não o fosse, esses valores poderiam ser apropriados pelo autor mais rápido em acessar à justiça, em inobservâncias às próprias exigências do direito material. A adjudicação unitária possibilita, ainda, resultados, mais precisos no direito material, porque as técnicas de agregação processual permitem concentrar recursos, argumentos, informações e provas em favor de todos os indivíduos, ampliando a deliberação "once for all" sobre os interesses compartilhados do grupo.

Enfim, o acesso à justiça não pode ser uma promessa vazia, mas deve alcançar resultados. E, por isso, não se pode confundi-la com o seu modo de exercício. A persecução individual nas hipóteses acima narradas, de natureza coletiva, objetiva, impessoal, paritária e/ou indivisível, esvaziaria o significado e o escopo do acesso à justiça. A persecução coletiva em hipóteses pessoais ou singularizadas esvaziaria o significado e o escopo do acesso à justiça, pois o indivíduo é, em regra, o melhor guardião do seu interesse e o mais capacitado a persegui-lo.

Não é à toa que Cândido Rangel Dinamarco ${ }^{1050}$ aborda que a fórmula da jurisdição deve ser revista nos quadrantes deste século. A missão do sistema processual não pode ser a mera

1048 NOTE, 1976, 1371.

1049 COOPER, 1987, p. 504.

1050 DINARMARCO, 2000, p. 216-217. 
atuação da vontade concreta da lei, sem preocupação com a dinâmica social e com a realidade de massa. Por isso, há se de conferir a essa fórmula uma interpretação dinâmica, de forma que a atuação da vontade concreta deixa de se exaurir naquilo que é exclusivamente individual.

Por fim, mesmo a mitigação do direito de ação, com a extinção liminar de demanda frívolas ou vexatórias, também se coadunam à garantia do acesso à justiça. Isso porque o acesso é voltado à resolução da controvérsia de direito material e à promoção da ordem jurídica justa. Se esse resultado não for, prima facie, viável ou o exercício do direito de ação for manejado de forma abusiva ou dissonante do seu escopo, a extinção não compromete essa garantia processual. Muito pelo contrário, garante o direito do réu de somente ser provocado por iniciativas factíveis.

Como bem assinalou Teresa Arruda Alvim Wambier ${ }^{1051}$, o Estado de Direito caracteriza-se como o Estado que se justifica, tendo como pauta a ordem jurídica a que ele se submete. Assim, quando o Estado de Direito intervém na vida das pessoas, deve justificar essa introdução materialmente e formalmente, isto é, a intervenção deve existir por um fundamento material e esse fundamento deve ser concretamente exposto, declarado e demonstrado no processo.

Pode-se dizer que o inverso também é verdadeiro, para que o Estado de Direito seja provocado e instado a "intrometer-se" na vida das pessoas, retirando-as do estado de inércia, quem o provoca deve, igualmente, justificar-se, apontar as razões e os fundamentos pelos quais o faz.

\subsection{SÍNTESE PARCIAL}

A representação, para fins de agregação processual, consiste, em sua ultima ratio, na performance ou no resultado da atividade argumentativa: é a argumentação, com a consideração e o enfrentamento dos argumentos comuns ao grupo. Na agregação processual, para assegurar o devido processo legal não se exige, necessariamente, a participação ou a autorização individual. O que se exige é a performance ou resultado adequado, com a efetiva promoção dos interesses ou direitos do grupo e com o enfrentamento expresso dos seus argumentos em juízo.

Na realidade, como consequência necessária da agregação processual, uma conclusão se impõe: a necessidade de revisitação e de reinterpretação das garantias constitucionais processuais,

1051 WAMBIER, 2004, p. 323. 
mormente, as garantias do acesso à justiça e do contraditório no processo. Nem sempre o acesso e a participação serão pessoais e diretos e nem sempre isso será necessário, idôneo e proporcional diante das exigências do direito material controvertido na hipótese em concreto.

As garantias processuais constitucionais são adaptáveis às circunstâncias fáticas e jurídicas, sem perder o seu escopo de proteção. Esse é o sentido da ponderação, isto é, mantém-se o conteúdo mínimo de proteção ao indivíduo, mas o modo como essa proteção se realiza (técnica processual) é adaptável, varia conforme a necessidade, adequação e a proporcionalidade diante do caso concreto, das circunstâncias substanciais e das demais garantias processuais aplicáveis.

Por todo o exposto, sustenta-se, ainda, que o conteúdo mínimo da garantia constitucional do contraditório é a participação argumentativa, isto é, a participação pela argumentação.

A participação é dosada e exercida à medida que pode incrementar e fortalecer os argumentos das partes na defesa dos seus interesses ou direitos, influenciando a convicção do magistrado na resolução da controvérsia de direito material, bem como produzindo resultados legítimos e confiáveis. A participação é, ainda, avaliada segundo a performance argumentativa, isto é, pela efetiva apresentação, discussão e enfrentamento dos argumentos deduzidos em juízo.

Acesso à justiça é acesso à ordem jurídica justa. A garantia constitucional processual do acesso à justiça não se confunde, portanto, com a solução técnica: modo de persecução do direito, quer coletivo, quer individual. Essa garantia visa à acesso e ao enforcement da ordem jurídica justa. 


\section{PRECLUSÃO E ARGUMENTAÇÃO}

As premissas teóricas fundamentais para a reconhecer a possibilidade de preclusão em relação aos membros ausentes do grupo, após adjudicação unitária da controvérsia, já foram lançadas.

\subsection{APRESENTAÇÃO}

O objetivo do presente capítulo não é exaurir a temática da preclusão, mas, sim, investigar a preclusão como técnica indireta de agregação processual. Como já salientado não é possível agregar a controvérsia coletiva ou demandas individuais de alcance coletivo ad infinitum. É preciso vincular os membros ausentes do grupo - e nisso compreende-se os membros futuros-, sob pena de resolvida a controvérsia em relação a um grupo, surgir, em seguida, controvérsia idêntica ou similar em relação a outros membros do mesmo grupo, a exigir nova agregação.

A agregação processual pressupõe, portanto, técnicas de preclusão. Mas, nesse contexto, é preciso atentar para a extensão e sobre os limites da preclusão. Isso porque o preclusão não pode obstar ao indivíduo que ele venha a narrar em juízo a sua história, que pode ser diferente ou contrária à história do grupo. Essa é otimização - o ponto de equilíbrio - que se investiga.

Muito bem. Essa otimização parte, a princípio, da identificação do direito material controvertido e do representação adequada, que se guia pela performance argumentativa do representante, com a promoção dos interesse do grupo e o enfrentamento de seus argumentos.

\subsection{PRECLUSÃO: GÊNERO}

A expressão preclusão é utilizada aqui para fins comparativos apenas, pois, conforme expressa Shapiro ${ }^{1052}$, ela é gênero. É um conceito mais abrangente e compreensivo, da qual são espécies a coisa julgada (claim preclusion) e a preclusão das questões decididas (issue preclusion).

Essas duas espécies integram, nos Estados Unidos, a doutrina da decisão prévia (former adjudication $)^{1053}$, que representa o estudo dos impactos da litigância e adjudicação anterior de

1052 SHAPIRO, David L. Civil procedure: preclusion in civil actions. New York: Foundation Press, 2001, p. 818.

1053 CASAD, CLERMONT, 2001, p. 3-9. HAZARD JR, Geoffrey C. Preclusion as issues of law: the legal system's interest. Iowa Law Review, 1981, V. 40:81-94p, p. 81. 
uma controvérsia nos processos subsequentes. Para os propósitos do presente trabalho, não será objeto de investigação a doutrina do law of the case ${ }^{1054}$, isto é, a preclusão intraprocessual, que consiste na a perda da faculdade de realizar um ato dentro da mesma relação processual.

No sistema brasileiro, pode-se dizer que a preclusão também é gênero. Como salienta Dinamarco ${ }^{1055}$, a preclusão é um fenômeno processual de maior amplitude e de variedade intensa, pois significa, em maior ou menor grau, a extinção de uma faculdade ou poder no processo. A coisa julgada, sob o aspecto, formal é, inclusive, denominada de preclusão máxima, pois obsta a substituição do comando decisório como ato do processo. E, sob o aspecto material, a coisa julgada garante a definitiva ou a estabilidade do comando emergente da sentença na vida das pessoas, impedindo que um ato estatal posterior venha a negar o direito reconhecido.

A coisa julgada e as preclusões em geral (consumativa, temporal, lógica), incluem no sistema processual com o mesmo escopo de conferir estabilidade às decisões e segurança jurídica.

\subsection{CONCEITOS CLÁSSICOS DE PARTE E TERCEIRO}

Admitir a preclusão em relação aos membros ausentes do grupo não implica alteração dos conceitos tradicionais do processo civil. Aliás, essa é uma conclusão que pode ser extraída de ambos os sistemas jurídicos investigados, tanto do sistema brasileiro, quanto do estadunidense.

É preciso destacar que parte é e continua sendo - mesmo no procedimento agregado - aquele que figura formalmente na relação jurídica de direito processual. Ocorre que, em dadas circunstâncias do direito substancial, a parte pode representar terceiros que não figuraram formalmente no contencioso plurissubjetivo ou de massa. Nesse caso, por força do exercício do devido processo legal e das demais garantias constitucionais processuais, esses terceiros podem ser igualmente vinculados ao comando normativo do julgado ou à prévia questão decidida.

1054 A doutrina da law of the case consiste na inviabilidade de reconsideração de uma decisão em estágios mais avançados do procedimento. A preclusion of inconsistent positions (preclusão por posições inconsistentes) consiste, a seu turno, na perda da faculdade de realizar um ato em razão de adoção de comportamento inconsistente em momento anterior do procedimento. A diferenciação das espécies de preclusão pode ser conferida em: NOTE. Developments in the law - Res Judicata. Harvard Law Review, 1952, V. 65: 818-887.

1055 DINARMARCO, Cândido Rangel. A nova era do processo civil. 4 ed. São Paulo: Malheiros, 2000, p. 220 et seq. 
Sabe-se que o direito substancial enseja a identificação das hipóteses de pluralidade de partes ou de litigiosidade de massa (pluralidade de partes em larga escala). Mas, é o exercício do contraditório como a participação argumentativa e o acesso à ordem jurídica justa que determinam a estabilidade da decisão, vinculando os membros ausentes do grupo representado.

Nesse sentido, o American Law Institute ${ }^{1056} e$, em obra sobre a agregação processual, define parte como aquele que figurou formalmente no processo. Em regra, somente as partes são vinculadas ao resultado adjudicado. Mas, em circunstancias determinadas do direito material, terceiros também podem ser vinculados, pois representados pelas partes no processo. Esses terceiros são, em regra, denominados de sujeitos representados ou membros ausentes da classe, os quais não dispõem dos mesmas prerrogativas e responsabilidades originariamente reservadas às partes.

No direito brasileiro ${ }^{1057}$, de igual modo, parte é quem figurou formalmente no processo. Terceiro é um estranho à relação jurídica de direito processual. A comunicação da situação de um sujeito com a de outro sujeito do grupo é decorrência do direito substancial. A imutabilidade da decisão, que afeta os terceiros nessa situação, decorre da ponderação das garantias processuais.

\subsection{CONTROVÉRSIAS DE MASSA OU PLURISSUBJETIVAS: FUNGIBILIDADE DOS MEMBROS DO GRUPO E PRECLUSÃO}

A coisa julgada e a preclusão das questões decididas são tratadas em conjunto, pois ambas são exigências da segurança jurídica ou da finalidade de pôr fim ao conflito (principle of finality).

No sistema estadunidense, a coisa julgada é denominada de res judicata, mas também é possível encontrar as nomenclaturas estoppel by judgment e claim preclusion. A última terminologia é a mais popular hoje, sendo adotado originariamente por Alan Vestal ${ }^{1058}$ e atualmente adotada pelo Restatement (Second) of Jugdments, obra que disciplina importantes temas processuais.

1056 AMERICAN LAW INSTITUTE, 2010, p.

1057 LIEBMAN, Enrico Tullio. Manual de Direito Processual Civil I. Rio de Janeiro: Forense, 1984, p. 122.

BUENO, Carlos Scarpinella. Partes e terceiros no processo civil brasileiro. São Paulo: Saraiva, 2003.

1058 VESTAL, Allan D. Preclusion/res judicata variables: parties. Iowa Law Review, 1965, V. 50: 27-76p. p.

28. SHAPIRO, 2001, p. 10 
A preclusão das questões decididas é, por sua vez, denominada de collateral estoppel ou issue preclusion. De igual modo, a última terminologia é a mais popular, adotada originariamente por Alan Vestal ${ }^{1059} \mathrm{e}$, hoje, presente na maior parte das obras que comentam sobre esse tema.

No Brasil, utiliza-se, principalmente, os nome de coisa julgada e res judicata. Embora ainda não exista uma similar nacional para a preclusão das questões decididas (issue preclusion), esse instituto goza de crescente apoio dos processualistas brasileiros ${ }^{1060}$. E, mais, no Projeto do Novo Código de Processo Civil, é estatuído que a questão prejudicial será declarada por sentença, com força de coisa julgada, assegurado o contraditório, ainda que sem pedido de um das partes.

Em linhas gerais, em ambos os sistemas, a autoridade da coisa julgada impede a rediscussão posterior de uma mesma causa de pedir, do mesmo pedido (same claim) e entre as mesmas partes. Em sua função negativa, a coisa julgada obsta a realização de outro julgamento sobre a mesma controvérsia. Em sua função positiva, a coisa julgada impõe a observância de sua autoridade em outro processo, no qual alega-se uma questão prejudicial já decidida com essa força. ${ }^{1061}$ Excepcionalmente, a autoridade da coisa julgada incide sobre quem não foi parte no processo anterior, mas apresenta a mesma qualidade jurídica na controvérsia deduzida (privity).

A preclusão das questões decididas, por sua vez, veda o reexame de uma questão já decidida (issue), que fundamentou a resolução de uma controvérsia em processo anterior. Trata-se de doutrina mais abrangente e flexível ${ }^{1062}$ que a coisa julgada, pois aplica-se ainda que sem a identidade da demanda e, assim, sendo diverso o objeto do processo. No sistema estadunidense, essa técnica admite a mitigação da identidade física do indivíduo para que seja reconhecida a estabilidade da questão decidida no processo subsequente, no qual diversa uma das partes.

Na realidade, para os propósitos ora discutidos, interesse exatamente investigar a aplicabilidade das técnicas de preclusão exatamente nessas hipóteses em que a identidade física do indivíduo pode ser mitigada ou afastada. São as hipóteses de controvérsias plurissubjetivas ou de massa, em que, diante da natureza do direito material, impõe-se o reconhecimento da fungibilidade dos

1059 VESTAL, 1965, p. 28. SHAPIRO, 2001, p. 46.

1060 TUCCI, 2006, p. 141, MANCUSO, 2007, p. 231. CABRAL, 2013, p. 353.

1061 Sobre a função negativa e positiva da coisa julgada, conferir: MESQUITA, José Ignácio Botelho. A coisa julgada. Rio de Janeiro: Forense, 2006, p. 66-67.

1062 CASAD, CLERMONT, 2001, p. 43-44. 
indivíduos na qualidade de membros do grupo. O membro do grupo é fungível, pois é tão predisposto quanto ao outro a realizar a defesa dos interesses ou direitos coletivos da categoria.

Sob esse aspecto, é preciso realizar uma exposição comparada desse dois institutos (coisa julgada e preclusão de questões) no sistema jurídico estadunidense e no sistema brasileiro.

\subsection{SISTEMA JURÍDICO ESTADUNIDENSE}

\subsubsection{COISA JULGADA (CLAIM PRECLUSION)}

Coisa julgada ou claim preclusion é a qualidade vinculante que se agrega à decisão final proferida em uma demanda, obstando a sua reanálise em demandas subsequentes idênticas (same claim) e, em regra, em relação às mesmas partes. Uma especificidade do sistema jurídico estadunidense é a necessidade de concentrar o conflito de interesses em uma mesma demanda.

Em regra, todas as causas de pedir possíveis relativas à mesma controvérsia são consumidas (merged) pela coisa julgada, bem como impõe-se vedação a análise de todas as causas de pedir possíveis relativas à mesma controvérsia, não oportunamente litigadas na demanda anterior (bar). É inadmissível, assim, o fracionamento da controvérsia em várias demandas similares Trata-se da regra denominada, em inglês, de "rule against splitting a cause of action". ${ }^{1063}$

A imposição de cumulação das causas de pedir e de pedidos relativos a uma mesma transação ou evento controverso em uma mesma demanda, por si só, já favorece a agregação processual, pois obsta demandas repetitivas. O objetivo é concentrar o máximo do conflito de interesses existente entre duas pessoas em uma mesma demanda. Não se trata, todavia, de tarefa fácil.

Alcançar esse objetivo impõe problemas próprios, pois constitui matéria assaz controvertida, naquele sistema, a definição do que se compreende como causa de pedir (cause of action).

O teste hoje adotado, no sistema estadunidense, para definir o montante necessário da controvérsia que deve ser veiculada em uma demanda é denominado transactional view ${ }^{1064}$. 
Trata-se de teste funcional que evita utilizar a expressão cause of action e salienta que, com o julgamento final de uma demanda, extingue-se todas as pretensões do autor em face do réu com relação a mesma transação ou a mesma série de transações. O conjunto de fatos que constitui uma transação ou conjunto de transações deve ser determinado de forma pragmática, sendo considerado, para tanto, fatos relacionados no tempo, espaço, origem e motivação, de modo a compor uma unidade para julgamento e conformar-se às expectativas jurídicas das partes.

Tradicionalmente, esse teste é aplicável à típica demanda individual entre um autor e um réu, sendo direcionado à cumulação dos elementos objetivos da demanda. As situações de pluralidade de partes, ainda que relacionadas à mesma transação, constituem, em regra, demanda diversas para efeito de preclusão. Não há exigência, assim, de cumulação subjetiva. ${ }^{1065}$

Mesmo assim, em algumas controvérsias plurissubjetivas ou de massa pode ser reconhecida a autoridade da coisa julgada em relação a terceiros, que não figuraram como parte no processo.

Esse é fenômeno é denominado de privity. A expressão privity é usada para descrever sujeitos que não foram partes na demanda anterior, mas que, em determinadas circunstâncias, são de qualquer modo vinculados pelo mesmo comando normativo do julgado aplicável às partes. Isso ocorre em razão de uma alguma sorte de relação representacional entre a parte e o terceiro.

Trata-se do sentido de representação virtual, em que existe uma identidade ou um relacionamento jurídico entre representante e representado. Shapiro ${ }^{1066}$ lembra que a doutrina da representação virtual somente se aplica às hipóteses em que existir uma especial relação entre os interessados, que permita a performance representativa de um indivíduo em nome do outro. Não basta a coincidência de interesses, a identidade é decorrente da relação entre os sujeitos.

No mesmo sentido, é o que ensina Robert Klonoff ${ }^{1067}$, ao consignar que não basta a mera coincidência dos interesses e a oportunidade de participar na demanda prévia para estabelecer o fenômeno de privity, isto é, para estabelecer um vínculo entre representante e representado.

1065 Nesse sentido: CASAD, CLERMONT, 2001, p. 69. 
Esse relação existente entre representante e representado, que autoriza a vinculação para efeito de preclusão pode ser de natureza substantiva (substantive privity) ou processual (procedural).

\subsubsection{PRIVITY SUBSTANTIVO}

Segundo Casad e Clermont ${ }^{1068}$, privity de natureza substantiva consiste em uma relação jurídica de direito substancial que existe entre determinadas pessoas, quando essa relação cria um papel representativo. Segundo Bone ${ }^{1069}$, privity é um vínculo jurídico e uma identificação substancial intensa existente entre indivíduos. A obra Restatement (Second) of Judgment ${ }^{1070}$ dedica, por sua vez, 19 seções para o tema "relações jurídicas de direito material resultando em preclusão".

Há uma variedade de relações de direito material, que implicam preclusão a quem não foi parte. Por exemplo, esse é o caso de interesses sucessivos, como aquele que existe entre o alienante e o adquirente de um objeto litigioso. $\mathrm{O}$ adquirente, que recebeu o bem após o início da demanda (pendente lite), é considerado privity e é vinculado ou beneficiado pela adjudicação da controvérsia entre o alienante e a parte adversa. A forma de transferência é considerada irrelevante, aplicando-se à compra, à hipoteca, aos herdeiros, aos curadores e aos receptores em geral, que são vinculados pela adjudicação da controvérsia relativa aos seus predecessores. ${ }^{1071}$

Foge aos propósitos do presente trabalho exaurir todas as hipóteses de direito material, preclusivas em relação a terceiros. Mas, como assinala Casad e Clermont ${ }^{1072}$, o direito estadunidense examina uma série de relações substanciais, cada qual com suas regras especiais sobre a coisa julgada e exceções. Dentre essas relações, destacam-se relações societárias, relações securitárias, relações relativas a bem indivisível como uma pretensão injuntiva ou mandamental, relações entre membros de uma mesma família, relações de depósito e outras.

\subsubsection{PRIVITY PROCESSUAL}

Privity de natureza processual consiste na vinculação de indivíduo, por força da representação na demanda realizada por uma das partes. Esse indivíduo deve consentir com a representação

1068 CASAD, CLERMONT, 2001, P.153.

1069 BONE, 1992, p. 226.

1070 AMERICAN LAW INSTITUTE. Restatement (Second) of Judgment 2d. Minneapolis: Thomson West, 1982. 1071 WASSERMAN, Rhonda. Procedural due process: a reference guide to the United States Constitution, Connecticut: Praeger, 2004, p. 171-184.

1072 CASAD, CLERMONT, 2001, p. 155. 
ou assumir o controle da litigância, para que seja possível a sua vinculação ao resultado do julgamento. Enquadram-se, nessa categoria, a representação realizada por um agente fiduciário, como os administradores, os guardiões, os curadores ou, de modo geral, os depositários. ${ }^{1073}$

De igual modo, essa mesma noção de privity ou de vínculo de natureza processual também se aplica a relações substancias mais fluídas, mais fracas ou com menor certeza. Mesmo no privity processual, não se dispensa um vínculo substancial. Muito embora os membros ausentes do grupo e a parte não se vinculem por uma relação jurídica própria. São as características objetivas e impessoais da relação jurídica substancial que autorizam a representação adequada. ${ }^{1074}$

O privity processual exige a adequada representação. Em caso de objeção à performance do representante, realizada em demanda individual ou coletiva subsequente, a Corte de Justiça deverá aferir a idoneidade da representação antes realizada. As ações representativas de classe e as ações representativas do tipo parens patriae encartam-se nessa modalidade de privity. ${ }^{1075}$

Na realidade, frise-se, importa a performance e o resultado da atividade argumentativa realizada pelo representante, para que a vinculação dos membros ausentes do grupo possa persistir. Isso porque a racionalidade da regra é que, identificada uma relação substancial impessoal, indivisível e/ou paritária, presume-se que o representante seja capaz de aduzir todos os argumentos e todas as provas atinentes ao interesse comum e idêntico ao grupo. Caso o indivíduo, membro do grupo, venha a demonstrar a insuficiência dessa performance no caso concreto, é possível afastar a representação e, portanto, a preclusão processual nessa hipótese.

A diferença entre o privity substantivo e o privity processual é a identificação do direito substancial. No primeiro caso, a relação substancial diz respeito a uma determinada relação jurídica, como a alienação do objeto litigioso, relações de parentesco, seguro etc. No segundo caso, a relação substancial é mais fluída ou mais incerta, sua identificação se dá pelas características do direito. Não se basta a mera coincidência de interesses individuais, é preciso uma específica relação de direito material com algum grau de objetividade para essa finalidade.

1073 WASSERMAN, op. cit., p. 180.

1074 KLONOFF, 2007, p. 229.

1075 CASAD, CLERMONT, 2001, p. 159-160. WASSERMAN, 2004, p. 179-188. 
Por fim, um tema deve ser retomado. As ações coletivas, nas categorias 23(b)(1) e 23(b)(2), trata de interesses impessoais, indivisíveis e/ou paritários, em que todos tem a mesma sorte no plano material. Nesse caso, pondera-se por uma agregação compulsória de demandas individuais, caso não proposta a ação coletiva. Isso porque se o interesse é indivisível ou paritário, todos seria, de qualquer forma, alcançados pelo julgado: é uma ação coletiva de fato.

Mas, não só. A preclusão também alcançaria toda a classe, sendo a vinculação dos membros ausentes do grupo uma providência imperativa. Não é admissível, ao menos em regra, a exclusão dos membros ausentes do grupo (mandatory class action). E, não poderia ser diferente, pois sendo o objeto indivisível, a ausência de vinculação implicaria resultados inconsistentes. ${ }^{1076}$

A preclusão não se restringe a essa hipótese. Na categoria 23(b)(3), o comando normativo do julgado também é vinculante aos membros ausentes da classe que foram adequadamente representados em juízo. Para tanto, mesmo tratando-se de direitos divisíveis, é preciso aferir, em maior ou menor grau, a impessoalidade e paridade na relação entre os membros da classe. Insiste-se que não basta a mera coincidência de interesses ou direito individuais, é preciso, ao menos em parte, a existência dessa uniformidade (sameness) ${ }^{1077}$ na interesse ou direito.

Nessa segunda hipótese, pondera-se, no sistema estadunidense, pela ampliação da preclusão sobre a questão decidida, in casu, sobre a questão compartilhada pelo grupo ou classe. Nesse caso, a preclusão não alcançaria as questões individuais, mas, apenas a questão comum. ${ }^{1078}$

\subsubsection{PRECLUSÃO DAS QUESTÕES DECIDIDAS (ISSUE PRECLUSION)}

A técnica da preclusão das questões decididas (issue preclusion) impõe vedação à rediscussão de determinadas questões resolvidas em processo anterior, sem consideração sobre a identidade das partes e sobre a identidade dos elementos objetivos da demanda (causa de pedir e pedido). 
Essa técnica é considerada mais flexível e compreensiva, pois apresenta uma aplicabilidade diversa da coisa julgada. Ela pode ser invocada fora do contexto da identidade da demanda, que fundamenta a coisa julgada, integrando a doutrina da decisão prévia (former adjudication). ${ }^{1079}$

De igual modo, diferentemente da coisa julgada, não se exige, para fins de preclusão, que a questão controvertida tenha sido objeto, no processo anterior, de uma decisão final de mérito. Uma questão apreciada em sede de decisão interlocutória pode restar preclusa, basta, para tanto, que ela tenha sido decidida após prévia deliberação e não tenha sido reconsiderada. ${ }^{1080}$

Muito embora seja mais flexível e compreensiva, a técnica da preclusão das questões apresenta, ao menos de forma pontual, uma aferição mais rigorosa de um dos seus pressupostos, qual seja, o da identidade da questão. A preclusão da questão somente alcança a questão efetivamente discutida e decidida, que tenha sido essencial à resolução da controvérsia do processo anterior.

Nesse aspecto, a preclusão da questão decidida também difere da coisa julgada. A coisa julgada alcança as questões deduzidas e as deduzíveis. É um instituto mais simples e com menos exceções. A preclusão de questões, por sua vez, alcança apenas a questão deduzida e decidida, há um maior número de exceções e exige-se um maior cuidado com a identidade da questão.

Por isso, é preciso maior atenção para aferir se houve a reprodução da questão. Forçoso analisar a dimensão assumida pela questão no contexto em que foi arguida, isto é, o montante da controvérsia processualizada e a forma como essa questão foi posta para o debate. Isso porque, como diz Casad e Clermont ${ }^{1081}$, fixar uma questão jurídica para todas as finalidades, em todos os contextos e por todo o tempo pode realmente impedir a consecução do direito substancial.

\subsubsection{IDENTIDADE E DIMENSÃO DA QUESTÃO: ARGUMENTAÇÃO E EVIDÊNCIA}

1079 CASAD, CLERMONT, 2001, p. 43-44.

1080 Segundo o precedente Lummus v. Commonwealth Oil Refining Co, "finality in the context here relevant may mean little more than that the litigation of a particular issue has reached such a stage that a court sees no really good reason for permitting it to be litigated again" (Cf. UNITED STATES OF AMERICA. Lummus v. Commonwealth Oil Refining Co. 297 f. 2D 80, 89 (2d Cir. 1961).

1081 CASAD, CLERMONT, 2001, p. 114. No mesmo sentido, Allen Kamp ressalta que não há vinculação quando a questão decidida for exclusivamente de direito, mormente direito constitucional, nas hipóteses em que houver alteração da norma jurídica aplicável à hipótese. É cabível subsequente modificação na questão decidida, quando a alterado o ambiente legal (legal environment) (Cf. KAMP, 1982, p. 397). 
Por vezes, nem todas as implicações de uma questão controvertida não são conhecidas. Por vezes, os impactos da questão decidida em outros processos não são previsíveis. Por vezes, simplesmente não há interesse em se litigar todos os aspectos de uma questão para a resolução da controvérsia. Por essa e outras razões, a preclusão limita-se apenas à questão efetivamente discutida e decidida, considerada essencial à resolução da controvérsia anteriormente deduzida.

Em primeiro lugar, para fixar a extensão e os limites da preclusão da questão é preciso aferir a identidade da questão no contexto ou na dimensão em que foi decidida. Não basta a identidade abstrata da questão. Essa identidade deve ser aferida considerando a regra jurídica aplicável, as limitações de cognição do procedimento anterior, o ônus da prova ou, noutros termos, a questão deve ser passível de idêntica valoração nos dois contextos em que ela foi suscitada. ${ }^{1082}$

A preclusão da questão pressupõe a reprodução dessa questão no mesmo contexto decisório. A reprodução é, aqui, compreendida como a sobreposição das evidências sobre os fatos e dos argumentos jurídicos passíveis de serem debatidos e decididos nos dois contextos decisórios.

A comparação é pragmática e o grau de sobreposição da questão decidida nas duas demandas (originária e subsequente) deve considerar as evidências e os argumentos que permitiram avançar a resolução da controvérsia no primeiro processo e as evidências e os argumentos que são passíveis de avançar a resolução da controvérsia no processo subsequente. O escopo é apenas evitar a litigância repetitiva quando diante, essencialmente, da mesma controvérsia. ${ }^{1083}$

Por exemplo, a responsabilidade do réu por negligência pode aparecer em um contexto de responsabilidade civil, submetida a regras especificas de valoração da prova, como o convencimento pela mera preponderância da evidência (preponderance of evidence). Mas também, a mesma questão pode surgir em um contexto de reponsabilidade penal, submetido a regras de valoração da prova mais rígidas, que exige convencimento além da dúvida razoável (beyond a reasonable doubt). Nesse caso, não há reprodução da questão e litigância repetida. ${ }^{1084}$

1082 FIELD, Richard H. KAPLAN, Benjamin, CLERMONT, Kevin M. Civil Procedure. New York: The Foundation Press, 1997, p. 1156. 1083 FIELD, KAPLAN, CLERMONT, 1997, p. 1156. CASAD, CLERMONT, 2001, p. 115-116.

1084 CASAD, CLERMONT, 2001, p. 138. 
Mas, além disso, não basta a identidade da dimensão da questão e do contexto decisório, é preciso que a questão tenha sido efetivamente discutida e decidida. Quando se diz efetivamente discutida e decidida, é porque os argumentos atinentes ao ponto controvertido devem ter sido expressamente apresentados e enfrentados. Não é suficiente a oportunidade de discuti-los, importa a dedução e a decisão sobre esse ponto. Não há preclusão, por exemplo, sobre questão não contestadas, questões confessadas, questões transigidas ou omitidas e outros casos. ${ }^{1085}$

Ainda, é preciso que a apreciação da questão controvertida tenha sido essencial à resolução da controvérsia no processo anterior. Presume-se que somente o que é relevante ou essencial à resolução da controvérsia será vigorosamente discutido e decidido. Questões secundárias, marginais, não fundamentais para alcançar a conclusão, são consideradas dicta, não precluem. Esse raciocínio visa, ainda, desencorajar as partes a litigar, evitando que elas se enveredem na discussão de cada ponto marginal da controvérsia, mesmo sem relevância para a sua resolução, apenas por temer e para evitar eventual preclusão da questão decidida em outro procedimento.

Não há interesse, por exemplo, em estimular que uma das partes recorra de apenas um das questões controvertidas, considerado irrelevante para a conclusão sentencial, apenas evitar uma preclusão futura dessa mesma questão, quando a parte já logrou a procedência de sua demanda.

\subsubsection{EXCEÇÕES}

Em certas situações, o sistema estadunidense considera imprópria a aplicação da técnica de preclusão da questões decididas (issue preclusion). São exceções que se aplicam a situações que se presumem a ausência de essencialidade da questão e a ausência de efetivo debate. ${ }^{1086}$

A) Não há identidade, para efeito de preclusão, quando as circunstâncias da questão forem as mesmas, mas diferente for o parâmetro normativo. No precedente Capps v. Whitson $^{1087}$, o passageiro de um ônibus ajuizou demanda indenizatória contra uma empresa rodoviária e contra o proprietário do veículo colidente ao ônibus, por danos sofridos em acidente de trânsito. A demanda do passageiro foi julgada procedente, sendo

1085 CASAD, CLERMONT, 2001, p. 125.

1086 Para esclarecimento das exceções, abaixo explicitadas, consultar: CASAD, CLERMONT, 2001, p. 129-145. FIELD, KAPLAN, CLERMONT, 1997, p. 1162-1178. SHAPIRO, 2001, p. 56-60. HAZARD JR, 1981, p. 86. KANE, 2007, p. 241-243.

1087 UNITED STATES OF AMERICA. Supreme Court of Virginia. Capps v. Whitson. 160 S.E. 71 (Va. 1931). 
reconhecida a negligência da empresa rodoviária. Posteriormente, essa mesma empresa ajuizou demanda em face do proprietário do veículo colidente. Na sua defesa, o proprietário alegou a preclusão sobre a questão decidida, pois na ação anterior já havia sido estabelecida a negligência da empresa rodoviária. A Corte de Justiça não reconheceu a preclusão sobre a questão, pois o parâmetro legal para a aferição da negligência é diverso nos dois casos. O dever de cuidado da empresa rodoviária em relação ao passageiro do seu ônibus é superior e diverso do dever de cuidado que existe na responsabilidade civil por acidente de trânsito entre dois veículos privados.

B) Não há identidade, para efeito de preclusão, quando for o mesmo parâmetro normativo, mas diversas forem as circunstâncias. Se a Corte de Justiça considerar que a parte contratante era insana no momento de um contrato, isso não preclui a discussão quanto a um outro contrato realizado pela mesma parte em um outro período de tempo. É preciso destacar, todavia, que se argumentação daquele invoca a preclusão demonstrar a continuidade do estado de insanidade para o outro contrato, caberá a parte adversa cumprir o ônus argumentativo, afastando a identidade da questão na hipótese. ${ }^{1088}$

C) Há identidade pela inferência. Uma demanda entre A e B é julgada improcedente, pois a conduta de B não foi negligente. Posteriormente, A ajuíza uma segunda demanda em face de $\mathrm{B}$, alegando má-conduta voluntariosa de B. A decisão quanto a negligência precluiu a questão subsequente. Afirmada a ausência de simples negligência, infere-se que não há que se falar em voluntariosa má-conduta, que é pior espécie de descuido. ${ }^{1089}$

D) Não há preclusão, se a questão foi decidida, mas não debatida (contestada). Trata-se das hipóteses de acordo, confissões, consentimento, revelia, questões suscitadas mas não contestadas. Em contrapartida, questões supervenientes, não suscitadas na inicial, mas efetivamente debatidas e decididas, são suscetíveis à preclusão da questão decidida. ${ }^{1090}$

E) Não há preclusão no tocante à pura questão de direito, ou seja, quando a relação de direito material controvertida no caso concreto não está relacionada com a relação de

1088 Nesse sentido: CASAD, CLERMONT, 2001, p. 123.

1089 Ibidem, 2001, p. 123.

1090 Ibidem, p. 124-126. HAZARD JR, Geoffrey C. Revisiting the second restatement of judgments: issue preclusion and related problems. Cornell Law Review, 1981, V.66:564-592, p. 575. 
direito material controvertida no processo subsequente. ${ }^{1091} \mathrm{Na}$ questão de direito, a vinculação é admissível, apenas, por força dos doutrina do stare decisis, isto é, vinculação pela ratio decidendi do precedente vinculante. A vinculação pelo precedente exige apenas a coerência do parâmetro normativo (ratio) aplicável entre dois casos similares. A preclusão das questões decididas (issue preclusion) exige, por sua vez, a presença da objetividade, da impessoalidade, da indivisibilidade e/ou paridade, identificando as relações jurídicas concretas individuais em ambas as demandas.

F) A preclusão não se aplica também quando a questão diz respeito à incidência tributária em relação a períodos temporais diversos. No precedente Comissioner v. Sunnen, não foi admitida a preclusão em relação a períodos temporárias diversos de incidência tributária, por força da mudança do contexto legal entre o primeiro e o segundo processo. Não é possível perpetuar o tratamento tributário em relação a uma pessoa, quando, em momento posterior, diverso é o parâmetro normativo aplicável. ${ }^{1092}$

G) Não há preclusão na hipótese de a Corte de Justiça, que decidiu primeiro a questão, for de hierarquia inferior ou tratar-se de um procedimento mais informal, como, por exemplo, nos Cortes de Pequenas Causas (small-claims Courts). Isso porque não há necessidade de assistência de advogado, há limitação da competência e das provas passíveis de utilização no processo e o procedimento tende a ser mais informal. ${ }^{1093}$

H) Não há preclusão sobre a questão decidida se o ônus de convencimento (burden of persuasion) do processo subsequente for mais favorável. Por exemplo, a absolvição do réu não obsta a discussão da sua responsabilidade no âmbito civil, pois o ônus de convencimento para admitir a responsabilidade penal é mais rigoroso que a responsabilidade civil. De igual modo, não há preclusão quando essa era imprevisível ao tempo do primeiro julgamento, não assegurando a adequada discussão da questão. ${ }^{1094}$

\footnotetext{
1091 HAZARD JR, 1984, p. 88 et seq. No precedente United States v. Moser, não foi admitida a preclusão, pois as controvérsias de direito material nos dois casos eram diferentes, embora subsumíveis ao mesmo contexto normativo. Já no precedente Montana $v$. United States, a preclusão foi admitida, pois o contexto factual e legal era o mesmo nas duas demandas e a questão controvertida comum (inclusive os aspectos substantivos concretos e não meramente normativos) já havia sido decidida (Cf. FIELD, KAPLAN, CLERMONT, 1997, p. 1166-1172). 1092 Raciocínio semelhante motivou a súmula 239 do Supremo Tribunal Federal Brasileiro. Nessa súmula, foi assinalado que provimento que declara não devida a restituição de tributo em um determinado ano não é vinculativa para períodos posteriores. Isso porque a discussão foi limitada ao determinado exercício tributário (Cf. CABRAL, 2013, p. 385). 
I) Não há preclusão se a decisão foi ambígua, isto é, se várias questões são abordadas, mas não for possível compreender qual delas foi fundamental para a conclusão. Por exemplo, A ajuíza demanda em face de B, pretendendo ressarcimento por danos em seu automóvel após acidente de trânsito. B, em sua defesa, alega que não foi negligente e que A não era o proprietário do carro. A sentença julga improcedente a demanda, de forma genérica, dizendo que B não foi responsável pelo acidente de trânsito. Agora, A ajuíza nova demanda em face de B, pretendendo indenização por danos morais em razão do mesmo acidente (admitindo-se, nesse caso, o fracionamento da controvérsia). B, em sua resposta, alega preclusão, pois foi considerado não responsável na demanda anterior. Nesse caso, não há preclusão das questões decididas, pois não é possível saber o que foi conclusivo para afastar a responsabilidade de B na primeira demanda. Não se sabe se a responsabilidade foi negada, em razão da inexistência de negligência ou se a responsabilidade foi negada, pelo fato de o autor não ser o proprietário do carro, fato que seria irrelevante para o prosseguimento da demanda no tocante aos danos morais. ${ }^{1095}$

J) Há divergência no tocante à ocorrência de preclusão na hipótese de a decisão fundamentar-se em questões decididas, que constituem fundamento alternativo para a conclusão. Noutros termos, cada uma das questões é suficiente, para, sozinha, conduzir à conclusão da sentença. Nesse caso, surgem duas possibilidades. A primeira é que, como nenhuma das questões é essencial para fundamentar a conclusão, porque sempre existe a outra alternativa, não há preclusão. A segunda é que como todas as questões são hábeis a fundamentar sozinha a conclusão, todas são essenciais e suscetíveis à preclusão. A segunda corrente - pela preclusão - foi a que recebeu maior adesão. ${ }^{1096}$

\subsubsection{PRECLUSÃO E TERCEIROS}

A regra da preclusão no sistema estadunidense sempre foi a identidade de partes ou daqueles na mesma posição jurídica (privity) para fins de vinculação dos membros ausentes de um grupo.

Por força do doutrina do mutuality of estoppel - mutualidade - a preclusão somente se operava entre as mesmas partes ou entre privies. Terceiros não poderiam se beneficiar ou vincular-se à questão previamente decidida, ser ter sido parte ou ter sido representado na demanda anterior.

1095 CASAD, CLERMONT, 2001, p. 143.

1096 Ibidem, p. 145-146. 
Isso mudou. Essa doutrina foi, substancialmente, alterada no precedente Bernhard v. Bank of America National Trust de $1942^{1097}$. Nesse caso, o Sr. Charles O. Cook foi autorizado a gerir os negócios da Sra. Clara Satler. Anos mais tarde, ele realizou a retirada de uma importância da conta bancária da Sra. Satler, sendo o valor destinado ao seu uso pessoal. Posteriormente, após a morte da Sra. Satler, o Sr. Cook tornou-se o inventariante de seu espólio. Os herdeiros, descendentes da testadora, impugnaram as declarações prestadas pelo Sr. Cook, argumentando que ele deixou de informar o saque efetuado em dinheiro na conta bancária da testadora. $\mathrm{O}$ magistrado aprovou as contas e a declaração de bens apresentadas pelo inventariante, salientando que o valor em dinheiro foi uma doação da testadora, ainda em vida para o inventariante. Posteriormente, Helen Bernhard, uma dos herdeiras do inventário, ajuizou demanda em face da instituição financeira, pleiteando o ressarcimento da quantia sacada, pois não havia autorização da Sra. Satler para essa finalidade. A instituição financeira, muito embora não tivesse sido parte na demanda anterior, invocou, em sua defesa, a preclusão da questão decidida no inventário. Ao decidir sobre esse ponto, a Suprema Corte da California reconheceu a preclusão em favor da instituição financeira, pois a questão quanto à validade da doação já havia sido efetivamente discutida e decidida no inventário, vinculado os herdeiros e prejudicando o prosseguimento da demanda subsequente relativa à mesma questão controversa.

A partir desse momento, consagrou-se o uso defensivo da issue preclusion. O réu, em demanda subsequente, pode invocar a preclusão da questão decidida em face do autor da demanda anterior. Posteriormente, foi admitido também o uso ofensivo da issue preclusion. Nesse caso, um terceiro, autor de uma demanda subsequente, pode invocar a preclusão de uma questão previamente decidida em relação ao réu de uma demanda anterior, que veio a sucumbir. ${ }^{1098}$

O uso ofensivo foi admitido, no sistema federal estadunidense, a partir do precedente Parklane Hosiery Co v. Shore ${ }^{1099}$. No caso, a agência federal SEC ajuizou demanda em face da companhia Parklane por emitir falsa declaração em conexão à processo de fusão da empresa. Essa demanda que foi julgada procedente. Posteriormente, um dos acionistas ajuizou uma ação coletiva por danos, em razão da falsidade da declaração prestada pela companhia, bem como pleiteou o

1097 SHAPIRO, 2001, p. 108-109. UNITED STATES OF AMERICA. Supreme Court of California. Bernhard v. Bank of America National Trust. 122 P. 2d. 892 (CAL. 1942). 1098 SHAPIRO, 2001, p. 108-109. 1099 UNITED STATES OF AMERICA. Supreme Court of United States. Parklane Hosiery Co v. Shore. 439 U.S 322 (1979). 
julgamento parcial e antecipado da controvérsia a respeito da questão da responsabilidade, invocando a preclusão da questão decidida na demanda anterior. A Suprema Corte reconheceu a ocorrência da preclusão nesse caso concreto, dando origem ao uso ofensivo da preclusão.

A partir de então, a preclusão das questões decididas tornava-se aplicável a quem não figurou como parte na demanda anterior. Com efeito, considerando que a resolução da questão controvertida comum pode alcançar uma pluralidade de interessados, era natural a eficácia expansiva da issue preclusion. Isso implicou, assim, o abandono da doutrina da mutualidade ${ }^{1100}$

É preciso destacar, no entanto, que o abandono da doutrina da mutuality of estoppel ou da mutualidade ou reciprocidade das partes é objeto de duras críticas, no sistema estadunidense, principalmente por dar azo ao uso ofensivo da preclusão aplicado às controvérsias de massa. ${ }^{101}$

O uso ofensivo da preclusão é fortemente desencorajado, pois incentiva a propositura de demanda fragmentárias, bem como incentiva a postura do "wait and see" 1102 , isto é, uma postura passiva. O autor não arca com os ônus e com os riscos da propositura da ação e da instrução (que pode ser muito custosa), mas beneficia-se do resultado favorável da questão decidida.

De igual modo, a adoção da preclusão apenas para beneficiar a parte, seja autor ou réu, é acoimada de restaurar o "one way intervention" ${ }^{1103}$, isto é, a preclusão de mão única. Essa possibilidade é vedada, principalmente, nas ações coletivas, pois o indivíduo que se excluiu da ação de classe deve ser tratado como terceiro, sem beneficiar ou vincular-se à questão decidida.

Por essas e outras razões, é comum encontrar críticas ao abandono da doutrina da mutualidade no sistema jurídico estadunidense. A alternativa oferecida pela doutrina não seria, no entanto, restaurar essa doutrina, mas, sim, expandi-la. Casad e Clermont ${ }^{1104}$ assinalam que a preclusão das questões decididas (issue preclusion) poderia operar de forma recíproca, beneficiando ou vinculando terceiros (preclusão mão dupla ou two-way intervention). Esse raciocínio, no entanto, somente seria aplicável às hipóteses em que houver a agregação processual prévia das

1100 Nesse sentido, é o que sustenta CASAD, CLERMONT, 2001, p. 121.

1101 FURMAN, Roger. Offensive assertion of collateral estoppel by persons opting out of a class action. The Hastings Law Journal, 1980, V. 31: 1189-1214, p. 1191.

1102 SHAPIRO, 2001, p. 123.

1103 FURMAN, op. cit., p. 1191.

1104 CASAD, CLERMONT, 2001, p. 187. 
controvérsias coletivas. Essa exigência depreende-se da necessidade de segurança do instrumento, bem como da necessidade de evitar a fuga às garantias do devido processo legal.

Nessa ordem de ideias, a preclusão seria enquadrada como técnica complementar à agregação processual e seria restrita, exclusivamente, à questão comum controvertida na categoria.

A necessidade de correlação entre as técnicas de preclusão e de agregação visa apenas reforçar a defesa do membro ausente do grupo e evitar a fuga das proteções processuais inerentes a uma ação coletiva, por exemplo. Sem a prévia agregação, não seria possível aferir, previamente, a representatividade adequada, tampouco ampliar a promoção dos interesses do categoria.

A issue preclusion poderia ser aplicada, nesse aspecto, às ações individuais indenizatórias, quando a questão comum já tiver sido resolvida em uma ação coletiva. E, também, poderia ser estendida a outras técnicas de agregação como a consolidação de demandas individuais (consolidation) e como ao caso-teste (test-case), vinculando não apenas as demandas individuais pendentes em juízo, mas também os membros ausentes e futuros do grupo.

Esses membros que ainda não propuseram suas demandas individuais não são, a princípio, vinculados pela adjudicação unitária da controvérsia, que se destina às demandas pendentes. Mas, à medida que essas demandas reproduzissem a mesma questão decidida no procedimento agregado, pondera-se que a issue preclusion seria aplicável à hipótese de demandas sucessivas.

Nesse sentido, o American Law Institute ${ }^{I 105}$ já recomendou a aplicação da issue preclusion na hipótese de interesses ou direitos divisíveis, desde que reproduzida a questão decidida na hipótese de interesses ou direitos indivisíveis. Argumenta que o tratamento coletivo conferido aos interesses ou direitos indivisíveis, que admitem a vinculação compulsória dos membros ausentes de um grupo, poderia implicar a preclusão da questão comum e, por conseguinte, impedir o prosseguimento de uma ação no tocante às questões individuais correlatas.

Destaca-se a preclusão da questão decidida (issue preclusion), segundo o American Law Institute $^{1106}$, atrelar-se-ia ao efetivo debate e decisão da questão comum, que foi objeto de 
apreciação na ação coletiva mandatória Nesse cenário, a preclusão assumiria versão de "mãodupla”, tanto para a hipótese de julgamento favorável, quanto desfavorável da questão.

Por fim, é preciso destacar que a preclusão das questões decididas (issue preclusion), tanto na prática atual estadunidense, quanto na versão projetada acima exposta, somente seria aplicável se a questão tiver sido efetivamente discutida e decidida no mesmo contexto decisório da demanda anterior. Do contrário, insuficiente a performance realizada, o membro ausente do grupo poderá propor sua ação individual, para apresentar uma nova dimensão da controvérsia coletiva e, assim, novas circunstâncias fáticas ou jurídicas não apreciadas anteriormente.

De igual modo, circunstâncias pessoais não precluem ${ }^{1107}$. Por exemplo, a questão decidida diz respeito a existência de uma prática abusiva ou de um padrão discriminatório de uma empresa. Caso seja decidido pela inexistência da prática abusiva ou do padrão discriminatório, não há óbice para que o indivíduo alegue, por exemplo, em um processo subsequente, um vício de consentimento ou um ato particular de discriminação contra ele. Nesse caso, não há preclusão, pois a questão é pessoal e exige cognição artesanal. A preclusão restringir-se-ia à questão comum ao grupo, a saber, a questão quanto à existência da prática ou do padrão discriminatório.

Lembra-se que o objetivo da técnica de agregação e, por conseguinte, da preclusão a ela correlata, é apenas evitar a reprodução da questão comum ou compartilhada por membros ausentes e futuros do grupo, com a apreciação dos mesmos argumentos pelo Poder Judiciário.

Para tanto, presume-se que, nas hipóteses de interesses ou direitos coletivos ou de qualquer modo objetivo, impessoal, indivisível e/ou paritário, qualquer indivíduo, membro do grupo, é igualmente capacitado a defender os interesses do grupo e apresentação dos seus argumentos.

Mas, trata-se de uma simples presunção (aliás, toda forma é uma presunção ${ }^{1108}$ ), isto é, um modo convencional, uma técnica preordenada à consecução do resultado. Caso o resultado não seja alcançado, com a performance esperada, aquela presunção pode e deve ser afastada ou refutada. Frise-se: caso existam circunstâncias pessoais, não há preclusão. Caso exista uma nova dimensão da controvérsia coletiva, isto é, novas circunstâncias de fato ou de direito com relação 
à questão comum, que não foram deduzidas pelo representante ou sequer existiam ao tempo do julgamento, também não preclusão. Nesses casos, pode-se dizer que a presunção foi superada.

Recorda-se que a issue preclusion somente alcança a questão efetivamente discutida e enfrentada, que tenha sido essencial à resolução da controvérsia. A identidade da questão é aferida pela dimensão dessa questão (argumentos e evidências) e pelo contexto decisório.

\subsubsection{OPT OUT E O ÔNUS ARGUMENTATIVO}

O mesmo raciocínio - que ressalta a importância do ônus argumentativo - também é possível encontrar na técnica da autoexclusão ou opt out, aplicável às class actions for damages.

Linda Mullenix ${ }^{1109}$ é uma das autoras que sustenta a necessidade de o membro ausente do grupo, que pretende a autoexclusão, cumprir o burden of persuasion, isto é, apresentar uma justa causa que justifique a exclusão pretendida. De igual modo, sustenta que, em caso de opt out abusivo, deve ser exigido a assunção de todas as despesas decorrentes do procedimento em separado.

Robert G. Bone ${ }^{1110}$ ressalta a possibilidade do uso abusivo e arbitrário do opt out, principalmente em demanda por danos ínfimos. O opt out pode ser encorajada por advogados oportunistas, nesse contexto, em razão da concorrência pelos honorários advocatícios devidos na causa. $\mathrm{O}$ valor a ser compensado individualmente pode ser ínfimo, mas os honorários advocatícios não.

Na mesma linha, Mark Friedman ${ }^{1111}$ já consignou a necessidade de obstar a exclusão abusiva do membro ausente da classe, condicionando a técnica da autoexclusão à apresentação de uma justificativa (good cause showing), mormente a existência de circunstâncias de fato e de direito que não seriam apreciadas de forma adequada na ação coletiva, pelo atuação do representante.

Em proposta de reforma realizada pelo Conselho Consultivo (Advisory Committee) ${ }^{1112}$, foi sugerido estabelecer limites e condições para o exercício do opt out, os quais seriam descritos na decisão de certificação da ação de classe. A Corte de Justiça deveria determinar quando,

1109 MULLENIX, 1986, p. 1070-1071.

1110 BONE, 1994, p. 103. BRONSTEEN, FISS, 2003, p. 1443.

1111 FRIEDMAN, 1995, p. 745.

1112 BONE, op. cit, p. 109-110 
como e sob quais condições os membros putativos da classe poderiam excluir-se da demanda coletiva. Para tanto, alguns parâmetros foram ressaltados como (i) a natureza e extensão da controvérsia e o remédio pretendido, (ii) a extensão da responsabilidade e dos danos sofridos pelos membros do grupo, (iii) o potencial conflito entre os membros do grupo, (iv) o interesse da parte adversa à classe em assegurar a resolução final e consistente da controvérsia, (v) a ineficiência e impraticabilidade de procedimento separado. De igual modo, a exclusão, embora admitida, poderia ser condicionada, por exemplo, à impossibilidade de invocação da offensive issue preclusion ou a proibição de uma ação individual sobre a mesma questão controvertida.

Em todas essas hipóteses, o que se pretende evitar é que o indivíduo venha a ser excluir da ação coletiva para, em seguida, propor ação individual com questões controvertidas idênticas no grupo. Por isso, exige-se o cumprimento da carga argumentativa (ou burden of persuasion).

É preciso destacar que a demanda individual não é idêntica à demanda coletiva. Por isso, não há, em regra, coisa julgada. Mas, se o indivíduo continuar litigando a mesma questão objetiva e impessoal, de cognição padronizada, pleiteando apenas a satisfação individual do seu direito, o Poder Judiciário será levado a apreciar, mais uma vez, as mesmas circunstâncias e os mesmos argumentos atinentes ao grupo. Por isso, quando reproduzida a questão, incide a preclusão.

As propostas supracitadas são - ao menos é o que se pondera nesse momento - as mais adequadas e coerentes ao estágio de desenvolvimento da temática da agregação processual.

Sabe-se, por exemplo, que nas ações coletivas híbridas, o pedido condenatório ao ressarcimento em pecúnia é incidental e a satisfação pretendida pelo indivíduo é potencialmente paritária, segundo fórmula aplicável ao grupo como um todo. Nesse caso, mesmo sendo divisível o interesse ou direito do membro do grupo, o sistema não admite o exercício da autoexclusão.

Isso decorre, aliás, de remissão expressa da Rule 23 e é aplicável, principalmente, às hipóteses de upstream, ou seja, hipóteses em que a resolução da controvérsia independe de análise pessoal do membro do grupo. Nesse caso, a satisfação individual é mera decorrência da resolução da questão comum ao grupo. É como se a controvérsia fosse resolvida pela sentença genérica, sem necessidade de análise e quantificação particularizada para fins de reparação individual. Notase, portanto, que de acordo com a impessoalidade e a paridade presente na relação de direito substancial - ainda que divisível - é possível até mesmo negar a possibilidade de autoexclusão. 
De igual modo, o indivíduo que se exclui da ação coletiva poderá ser recapturado por outra técnica de agregação. Exemplo: persistindo a controvérsia quanto ao interesse ou direito coletivo e persistindo a existência da questão comum, a demanda individual poderá ser consolidada junto à ação coletiva ou junto às ações individuais similares, sem direito a opt out .

\subsubsection{COLLATERAL ATTACK E O ÔNUS ARGUMENTATIVO}

O mesmo raciocínio - que ressalta a relevância do ônus argumentativo - está presente no collateral attack. Collateral attack ${ }^{1113}$ nada mais é do uma ação individual ou coletiva, na qual se alega, preliminarmente, a ausência de adequada representação no processo anterior, e por essa razão, a inocorrência de preclusão a impedir o processamento da demanda subsequente.

É uma técnica cujo escopo consiste em erodir ou afastar a estabilidade e a definitividade decorrente do julgamento anterior de uma demanda ou de uma mesma questão controvertida.

No precedente Gonzales v. Cassidy ${ }^{1114}$, o collateral attack foi utilizado com bom êxito. Na hipótese, uma demanda coletiva foi proposta em favor de todos os taxistas, cujas licenças foram cassadas quando envolvidos em acidentes de trânsito sem condições de arcar com danos causados. A sentença coletiva invalidou o comando administrativo, que determinava a cassação da licença nessa hipótese. Mas, a retroatividade da sentença, com a devolução da licença cassada, foi reconhecida apenas em favor do autor. Por essa razão, um nova ação foi proposta por um dos membros ausentes da classe (Gonzales), em razão da ausência de adequada representação. O autor da demanda coletiva falhou na representação do grupo, pois, uma vez plenamente favorecido, não recorreu em favor dos demais taxistas. A Corte de Apelação do Quinto Circuito afastou a coisa julgada em relação aos membros ausentes do grupo, pois não enfrentada a questão da retroatividade, falhando o autor coletivo em não recorrer nesse ponto.

Mais, recentemente, o Segundo Circuito, no precedente Wolfert v. Transamerica Home First, Inc ${ }^{1115}$ ressaltou que o collateral attack não é admissível se o argumento deduzido pelo indivíduo, no processo subsequente, foi expressamente considerado e rejeitado pela Corte

1113 NOTE, 1974, p. 593.

1114 Ibidem, p. 593. UNITED STATES OF AMERICA. United States Court of Appeal, Fifth Circuit. Gonzales v. Cassidy. 474 F. 2 d 67 (1963).

1115 KLONOFF, 2007, p. 237. UNITED STATES OF AMERICA. United States Court of Appeal, Second Circuit. Wolfert v. Transamerica Home First, Inc. 439 F 3d. 165(2006). 
de Justica na ação coletiva anterior. O collateral attack é, por outro lado, admissível, se a Corte de Justiça apurou, apenas abstratamente, a representatividade adequada na demanda coletiva.

Nota-se, novamente, a importância do ônus argumentativo. Se o indivíduo reproduzir o mesmo argumento, já apreciado ou enfrentado em demanda anterior, não há razão para afastar a preclusão e autorizar a rediscussão da controvérsia na demanda subsequente. A rediscussão da controvérsia somente é admissível nas hipóteses em que o resultado ou a performance do representante, cuja representatividade foi apenas abstratamente apurada, for insuficiente.

\subsubsection{PRIOR ACTION PENDING}

É importante ressaltar, ainda, que, lidando com as mesmas questões relativas à coisa julgada e à preclusão de questões decididas, encontra-se a doutrina da "prior action pending"1116, similar à litispendência brasileira. O escopo dessa técnica é obstar o processamento de ações repetitivas, ainda em curso, antes do julgamento do conflito, evitando resultados inconsistentes.

Em regra, identificado o processamento de uma segunda demanda idêntica, isto é, mesmas partes ou privies e mesmo objeto litigioso (causa de pedir e pedido) de uma demanda anterior. A segundo demanda deve ser extinta sem resolução de mérito (dismissal without prejudice).

É interessante notar que a extinção é apenas uma das soluções técnicas possíveis, para a hipótese de identidade da relação jurídica de direito substancial que foi processualizada ou deduzida em juízo. É possível, por exemplo, que a primeira Corte de Justiça, na qual pende a primeira demanda, suspenda a tramitação das demandas pendentes nos demais órgãos. De igual modo, a Corte de Justiça, na qual pende a segunda demanda, pode suspender o processamento desta controvérsia em deferência à outra Corte de Justiça, a qual primeiro recebeu a demanda.

Essa segundo possibilidade - suspensão da segunda demanda pela própria Corte de Justiça em que aquela pende - é denominada de lis alibi pendens (suit elsewhere pending) ou lis pendens. ${ }^{1177}$ Trata de uma criação jurisprudencial, que decorre do poder gerencial inerente às Cortes de Justiça, de autocontrolar o seu próprio acervo (dockets), em deferência ao sistema. 
A suspensão é, especialmente, relevante na hipótese em que a controvérsia não pode ser reunida por razões de competência (sistema federal e estadual). E, de igual modo, percebe-se a importância dessa técnica na hipótese em que existem uma ou mais questões comuns a um grupo (responsabilidade, por exemplo), que é idêntica em todos os processos individuais, mas remanescem questões pessoais de cada indivíduo. Nesse caso, a resolução das questões individuais pode ser suspensa, enquanto apreciada a questão comum compartilhada pelo grupo.

De igual modo, mecanismos de agregação processual, como a consolidação e coordenação informal de demandas individuais e/ou coletivas, já analisadas anteriormente, também constituem um caminho alternativo à extinção, o que deve ser mensurado no caso concreto. ${ }^{1118}$

A reunião é, especialmente, relevante, quando é necessário fundir as causas de pedir de dois legitimados. A reunião das demandas poderia ensejar a ampliação (em um master file ou processo mestre) da causa de pedir e do pedido das demandas individuais ou coletivas, de legitimados diferentes, propiciando, assim, uma adjudicação unitária e evitando resultados inconsistentes. Por exemplo, é o caso de impugnação à prestação do serviço de escoamento de águas de uma cidade. Segundo o primeiro autor, o sistema de drenagem de águas é insuficiente, sendo necessário a dragagem dos rios próximos, para evitar as constantes enchentes em um bairros próximos. Segundo o segundo autor, há uma deficiência no próprio sistema de água e esgoto, em razão do entupimento de canos e bueiros, como constantes vazamentos de água e esgoto na rua. Diante da questão comum, consistente em investigar a origem ou causa do mau funcionamento do serviço e a solução, as demandas poderiam ser reunidas em um mesmo órgão.

O que importa, seja para a extinção, seja para a suspensão, seja para reunião de demandas coletivas e/ou individuais, é a identidade da relação substancial que foi deduzida em juízo ou, ao menos, a identidade de algumas das questões controvertidas no grupo. A extinção aplica-se apenas na hipótese de identidade do objeto litigioso. Para outros casos, sem completa identidade, concorrem outras técnicas, como a suspensão ou a reunião de demandas.

\subsection{SISTEMA JURÍDICO BRASILEIROS: DIAGNÓSTICOS E PROPOSTAS DE LEGE FERENDA}


Não há, no Brasil, a expressão privity substantivo ou privity processual (que representa, em verdade, apenas um vinculação substancial mais fluída). Não obstante, o fenômeno, qual seja, a vinculação de um terceiro à autoridade da coisa julgada, formada de um processo na qual ele não figurou formalmente na condição de parte também é, entre nós, muito conhecida.

No sistema jurídico brasileiro, a extensão subjetiva da coisa julgada não é justificada por uma representação ficcional, isto é, não basta a coincidência de interesses para que um sujeito passe automaticamente a defender os interesses ou direitos de outro sujeito no processo. Aqui, muito embora não se use essa expressão, a representação também é virtual ou pela performance.

A vinculação de um terceiro à autoridade da coisa julgada somente é possível, em razão da vinculação presente no direito substancial. A extensão subjetiva da coisa julgada decorre da extensão do direito material controvertido deduzido em juízo ${ }^{1119}$. Trata-se de interesses ou direitos, de um modo geral, objetivos, em que o indivíduo comparece, na controvérsia processualizada, como um anônimo, isto é, fungível na qualidade de membro de um grupo.

O contraditório e o acesso à justiça, compreendidos como participação argumentativa e acesso à ordem jurídica justa, não deixam de ser observados nesse contexto. Primeiro, porque presumese que todos os indivíduos nessa condição são igualmente propensos a promover os interesses ou direitos do grupo. Em segundo lugar, porque existindo uma circunstância pessoal (o indíviduo deseja litigar os seus aspectos pessoais e infungíveis) ou porque existindo novas circunstâncias de fato ou direito (uma nova dimensão da controvérsia coletiva), a participação (leia-se argumentativa) é postergada. Cumpre, apenas, a observância do ônus ou da carga da argumentação, isto é, devem ser apresentados argumentos e razões que afastem ou refutem aquela presunção. Não basta, por exemplo, repetir os mesmos argumentos, a mesma evidência.

Muito bem. Esse fenômeno, guardadas as devidas proporções, é encontrado no período antigo, medieval e, até mesmo, moderno. Scialoja ${ }^{1120}$, por exemplo, já ressaltava que tratando-se de um interesse geral, que afeta o indivíduo como membro do grupo, a identidade física do indivíduo (mutamento della persona) era irrelevante para o reconhecimento da coisa julgada.

1119 GRINOVER, 2005, p. 6. TUCCI, 2006, p. 101. ZUFELATO, 2012, p. 106. MANCUSO, 2007, p. 536.

1120 SCIALOJA, 2013 (reprint 1883), p. 8. 
No período medieval, a coisa julgada alcançava membros ausentes do grupo, pois a controvérsia deduzida era um incidente legal de status $^{1121}$. O indivíduo aparecia como servo, arrendatário, cavaleiro, religioso, senhor de terras etc. Mesmo no período moderno, cuja doutrina era uma reação ao período medieval, a preclusão foi, em certa medida, admitida, embora sob a denominação de precedente. O precedente é, todavia, doutrina mais abrangente e mais tênue, pois derrotável pelo distinguishing e pelo overruling e aplicável apenas à questões de direito.

No período moderno, quando invocou-se o suposto precedente nas ações coletivas, ele era aplicado na mesma relação jurídica de direito material ou em uma relação jurídica de direito material cognata, isto é, quando presumia-se a igualdade das circunstâncias fáticas e jurídicas. Por isso, o uso do precedente, nesse contexto, equivalia pragmaticamente à preclusão, isto é, à perda da faculdade de refutar a decisão, pois a analogia ou semelhança já era, ex ante, percebida.

Não bastasse a história, atualmente a extensão subjetiva da coisa julgada é sustentada, mormente em controvérsias plurissubjetivas, também pela doutrina ${ }^{1122}$. Não se trata de superar a doutrina da coisa julgada inter partes, mas de complementá-la para outra hipótese substancial.

Se, lá, no sistema estadunidense, o fenômeno de privity substantivo refere-se às relações de sucessão processual, de alienação de objeto litigioso, de seguro e garantia, de questões de estado, de sociedade. Aqui, o mesmo raciocínio existe em relação em relação à anulação de deliberação assemblear, à anulação de patentes, às questões de estado, à alienação do objeto litigioso, à sucessão e substituição processual, ao litisconsórcio unitário e concurso subjetivo.

E, não para por aí. A mesma conclusão foi alcançada para os direitos transindividuais (difusos, coletivos e individuais homogêneos). Nesse caso, não há identificação da específica relação jurídica, como as relações societárias ou questões de estado, por exemplo. Mas, o vínculo no plano substancial persiste, em maior ou menor grau, entre os membros de uma categoria. São as peculiaridades do interesse ou direito, na forma com a qual deduzidos em juízo, que permite a identificação da sua amplitude no caso: a impessoalidade, a indivisibilidade e/ ou paridade.

1121 BONE, 1990, p. 233.

1122 Em sentido semelhante: TUCCI, 2006, p. 101. ZUFELATO, 2011, p. 85. 
Vale repetir as palavras de Ada Pellegrini Grinover ${ }^{1123}$, pela força de seu argumento: o que dá resposta à questão da vinculação dos membros ausentes do grupo à coisa julgada é a “indivisibilidade do bem e a identidade da situação jurídica”. É a simples "natureza das coisas”.

De igual modo, essa ideia pode ser compreendida melhor com remissão à doutrina de Chiovenda, que identificou a relevância da identificação da relação jurídica de direito material.

\subsubsection{IDENTIFICAÇÃO DA DEMANDA: CONTROVÉRSIAS PLURISSUBJETIVAS OU DE MASSA}

Chiovenda ${ }^{1124}$, em doutrina processual clássica, já ressaltava a importância da qualidade ou posição jurídica do indivíduo na controvérsia deduzida em juízo, para fins de reconhecimento da identidade da relação processual e para fins de vinculação de terceiros à coisa julgada.

Para fins de identidade de uma demanda, não importa necessariamente a identidade de um sujeito, importa, sim, a qualidade com que o sujeito se apresenta na demanda. Por isso, a alteração da identidade física de um indivíduo não tem como consequência necessária o afastamento da identidade da demanda. Esse raciocínio - alteração da pessoa com a manutenção da qualidade jurídica - ocorre nos casos de solidariedade, relações societárias, direitos potestativos, impugnação de várias pessoas à ato jurídico ou à cessação de um mesmo estado.

Por qualidade ou posição jurídica, entende-se a posição da parte em relação ao objeto. A parte e o terceiro ocupam a mesma posição ou qualidade em relação ao bem jurídico protegido, objeto da demanda. Trata-se de uma espécie de equidistância. Segundo Cruz e Tucci, nessas hipóteses excepcionais, a identidade entre as ações, para fins de reconhecimento da coisa julgada, por exemplo, decorre não da identidade de fundamentos, mas da vinculação presente na relação de direito substancial. Nesse sentido, cita-se a ponderação de José Rogério Cruz e Tucci ${ }^{1125}$ :

\footnotetext{
Advirta-se, contudo, que, perante várias situações concretas, a teoria da tríplice identidade desponta, insuficiente para desempenhar o papel que lhe é reservado no confronto de duas ou mais ações. E, a despeito de sua adoção expressa pelo nosso Código, não pode restar dúvida de que a doutrina e a jurisprudência devem procurar soluções que extravasam os lindes daquela. Assim, diante de tais situações
}

1123 GRINOVER, 2005, p. 7.

1124 CHIOVENDA, 1998, p. 429.

1125 TUCCI, José Rogério Cruz e. A causa petendi no processo civil. 3 ed. rev. atual. São Paulo: Revista dos Tribunais, 2009, p. 232. 
excepcionais, que revelam a insuficiência dos tria eadem, duas regras devem ser observadas quanto à sua incidência prática: a) não constitui ela um critério absoluto, mas, sim, uma 'boa hipótese de trabalho', até porque ninguém se arriscou a apontar outra que a superasse e b) quando for inaplicável, perante uma situação concreta, deve ser relevada a segundo plano, empregando-se, em seu lugar, a teoria da identidade da relação jurídica.

Em outra ocasião, Cruz e Tucci ${ }^{1126}$ asseverou, ao abordar o tema da ação popular romana, que "para Paulo, diferentemente do ponto de vista manifestado por Nerácio, não se impunha a identidade de pessoas, mas apenas a 'mesma condição': realmente, poderia haver eadem res, mesmo se os sujeitos fossem fisicamente diversos, embora em idêntica posição jurídica."

No mesmo sentido, Leonel ${ }^{1127}$ infere a insuficiência da tríplice identidade, especialmente na tutela das controvérsias plurissubjetivas ou de massa. Para aferir a identidade, importa maior atenção ao bem jurídico protegido e à qualidade da parte na controvérsia. Para tanto, é preciso investigar os fundamentos que delimitam o pedido e a substanciação dos fatos no processo. Quanto mais indeterminada a coletividade interessada, mais genéricos e abstratos os fatos e menor a necessidade especificação dos fatos individuais. E, ao contrário, quanto menos determinada a coletividade, maior a necessidade de especificação dos fatos individuais.

De igual modo, Mancuso ${ }^{1128}$ ressalta a despersonalização do interesse no processo coletivo, situando as partes em igual condição ou com igual qualidade jurídica na controvérsia deduzida.

Pois bem. Em capítulo anterior, foi expressamente ressaltado que importa: (i) verificar as características da controvérsia de direito substancial, na forma como ela foi deduzida em juízo (a objetividade, a impessoalidade, a indivisibilidade e/ou a paridade, dados que são extraídos da relação de direito substancial) e, ainda, (ii) atentar-se para centro da cognição judicial, se centrado nos atributos do grupo ou nos atributos pessoais de um indivíduo. A partir desses elementos, é possível identificar a qualidade do indivíduo na controvérsia deduzida em juízo.

Nas demandas cujo objeto litigioso é impessoal, indivisível e/ou paritário, há maior grau de objetividade e de certeza quanto à unitariedade, pois todos os indivíduos tem a mesma sorte no plano material. A controvérsia diz respeito ao interesse ou direito que impacta o indivíduo,

1126 TUCCI, 2006, p. 45.

1127 LEONEL, Ricardo de Barros. A causa petendi nas ações coletivas. In: TUCCI, José Rogério Cruz e; BEDAQUE, José Roberto dos Santos. Causa de pedir e pedido no processo civil (questões polêmicas). São Paulo: Revista dos Tribunais, 2002, p. 145.

1128 MANCUSO, 2007, p. 220. 
como membro do grupo. Não há, em regra, questões pessoais ou particulares, que exijam cognição artesanal. Como diz Barbosa Moreira"1129, são demandas "essencialmente" coletivas.

O mesmo raciocínio também pode ser aplicável a bem divisíveis, quando a controvérsia deduzida em juízo apresentar-se, em maior ou menor grau, de forma impessoal e paritária. Por vezes, o indivíduo pode deduzir uma controvérsia, posicionando-se como membro de um grupo. Ele não pretende litigar aspectos pessoais ou particulares, mas, sim, questões que o atingem em sua esfera jurídica, na medida que afeta a esfera jurídica de todos os demais membros do grupo. Novamente, Barbosa Moreira"1130, denomina essas demandas de "acidentalmente" coletivas.

A demanda não deixa de ser coletiva, pois existem aspectos de direito substancial que indicam a impessoalidade e a objetividade. A representação pela performance somente é possível, pois já existe um vínculo - ainda que mais fluído - no direito material. Essa demanda é, por sua vez, acidentalmente coletiva, pois o aspecto coletivo é ocasional, depende da forma como a controvérsia foi deduzida em juízo e se o centro de cognição incide sobre aspectos do grupo.

Por exemplo, quando se impugna uma prática ou padrão discriminatório. Nesse último caso hipotético, o indivíduo não alega um ato de discriminação pessoal ocorrido no ambiente de trabalho. Ele alega, por exemplo, que o padrão pelo qual são concedidas as promoções pelo empregador eterniza e incentiva a discriminação racial ou de gênero na categoria de negros ou de mulheres. Nesse caso, também há uma equidistância. Os indivíduos não ocupam a mesma posição jurídica, pois todos querem a promoção para si. Mas, a posição de cada indivíduo que sofreu a discriminação está igualmente situada em relação à prática, que é uniforme para todos.

E, por vezes, somente à remissão à prática ou ao padrão é capaz de avançar a tutela individual. Por exemplo, quando a prática ou a política abusiva é implícita ou silenciosa. Nesse caso, não há evidência particular da prática, mas apenas o fato de o grupo adotar, sem explicação aparente, um determinado comportamento ou existir uma estatística de grupo (inexistência de mulheres ou negros promovidos à gerente) ${ }^{1131}$. Cada indivíduo, nesse caso, faz remissão ao

1129 MOREIRA, 1984, p. 196.

1130 Ibidem, p. 197.

1131 As ações individuais ou coletivas tem objetos diversos. Nas ações individuais, são especificados fatos pessoais ou atos de discriminação isolado cometidos contra a pessoa. Mas, provar um ato de discriminação isolado e individual não permite concluir, necessariamente, que a promoção de um indivíduo foi negada por razões de raça ou gênero, embora possa ensejar danos morais, por exemplo. A situação é diversa nas ações coletivas. Nas ações coletivas, impugna-se uma prática ou um padrão lesivo, que obsta a promoção não apenas do indivíduo, autor da 
comportamento do grupo ou do outro membro, para provar a prática abusiva que o acometeu e lograr a promoção pretendida. As circunstâncias individuais, se existentes, apenas ilustram a controvérsia ${ }^{1132}$, pois o que importa é demonstrar o padrão discriminatório geral e disseminado.

Por essa razão, a agregação é possível nos direitos divisíveis. O fato de a compensação pretendida pelo indivíduo ser divisível, não significa que ele será individual. O que deve ser analisado é a controvérsia de direito substancial deduzida (se impessoal, objetiva, paritária) e se o centro de cognição é o grupo ou o indivíduo. Não há sentido em processar 50 ações de empregados, todos alegando ter sofrido uma mesma prática ou o mesmo padrão de discriminação. A agregação, nessa hipótese, permitiria a resolução unitária da controvérsia. E, mais, com uma participação coletiva e não pessoal, maior seria a possibilidade de ampliar o debate e de reunir os mais fortes argumentos do grupo para a resolução da controvérsia.

Pela mesma razão, também é possível ponderar por uma espécie de preclusão, pois a questão controvertida não diz respeito à pessoa do indivíduo, mas, sim, a sua qualidade ou posição jurídica naquela controvérsia impessoal. Circunstâncias pessoais ou singulares não precluiriam.

\subsubsection{PARTE}

$\mathrm{Na}$ realidade, pode-se dizer que os conceitos clássicos de parte e de terceiro não se alteram. Parte continua sendo quem figurou formalmente na demanda. Mas, como, nas controvérsias plurissubjetivas ou de massa, a identidade na demanda independe da identidade da pessoa física, os terceiros poderiam ser excepcionalmente alcançados pela autoridade da coisa julgada.

Mancuso $^{1133}$, no entanto, ao conferir maior precisão ao fenômeno, salienta que o terceiro alcançado pela autoridade da coisa julgada não é propriamente um estranho. Os sucessores da parte, os substituídos, os cessionários do objeto litigioso, tais figuras de terceiros não são

demanda, mas de qualquer outro membro do grupo. Nesse caso, a cognição incide sobre a categoria e o método de prova incide sobre a alegação de uma prática uniforme e disseminada, mediante prova estatística e por amostragem. A procedência da ação coletiva é hábil a alterar essa prática, com uma ação afirmativa, conferindo maiores oportunidades de promoção. Nesse cenário, não é difícil imaginar que um ou mais indivíduos venham a juízo pleitear a sua promoção, em ações individuais, mas todos alegando a mesma prática ou padrão abusivo. Embora a ação tenha sido veiculada individualmente, a controvérsia tem alcance coletivo, pois a prática é objetiva, impessoal e paritária. Em razão desse alcance coletivo, a agregação é possível (Em sentido semelhante: GIDI, 2007, p. 97) 
estranhos, pois em verdade, seus direitos não são derivados, mas, sim, um prolongamento do direito controvertido na causa. É natural, nesse aspecto, a extensão subjetiva da coisa julgada.

\subsubsection{OBJETO LITIGIOSO: PEDIDO E CAUSA DE PEDIR}

O objeto litigioso do processo, mediante a análise de seus elementos objetivos, é matéria assaz relevante e tormentosa entre os processualistas, para fins de identificação da demanda proposta.

Adotada a tríplice identidade como hipótese de trabalho e, ainda, integrando-a à teoria da identidade da relação jurídica de direito substancial, é possível apartar-se da efervescência doutrinária quanto às diversas teorias de objeto litigioso do processo. Não importa se o objeto litigioso é definido pelo pedido ou pela causa de pedir. O que importa - e sobre esse ponto não parece haver divergência - é que a identificação da conteúdo da sentença e dos limites objetivos da coisa julgada é uma referência ao pedido, delimitado ou iluminado pela causa de pedir.

Muito bem. Nas controvérsias plurissubjetivas ou de massa, é preciso especial atenção com a amplitude da controvérsia de direito material processualizada ou deduzida em juízo, para fins de identificação do interesse ou direito transindividual: se difuso, coletivo ou homogêneo.

No pedido, importa conferir especial atenção ao pedido mediato do processo, isto é, o bem jurídico que se pretende tutelar e o resultado prático a ser alcançado ao final do processo.

Paulo Henrique dos Santos Lucon, Daniela Monteiro Gabbay, Rafael Francisco Alves e Tathyana Chaves ${ }^{1134}$ assinalam que a análise da identidade do pedido e da causa de pedir deve ter por fundamento a identidade do bem jurídico pretendido (pedido mediato) e o mesmo ou equivalente resultado prático, com a efetiva proteção do bem da vida pretendido.

Isso é importante, especialmente, para obstar tentativas de "camuflar" 1135 a identidade jurídica, evitando, com isso, as técnicas de agregação processual. Lembra-se de um exemplo: a pretensão

1134 LUCON, Paulo Henrique et al. Interpretação do pedido e da causa de pedir nas demandas coletivas (conexão, continência e litispendência). In: LUCON, Paulo Henrique dos Santos. (coord.). A tutela coletiva: 20 anos da Lei da Ação Civil Pública e do Fundo de Defesa de Direitos Difusos e 15 anos do Código de Defesa do Consumidor. São Paulo: Atlas, 2006, p. 184 et seq.

1135 ALVIM, Arruda, José Manoel. Ensaio sobre a litispendência no Direito Processual Civil II. São Paulo:

Revista dos Tribunais, 1970, p. 102. 
de candidato de um concurso em obter os pontos da questão de uma prova objetiva, alegando a invalidade da exigência dessa questão à luz do conteúdo programático do edital do certame. Esse é uma tentativa de camuflagem, para evitar o litisconsórcio. Isso porque o que se pretende tutelar é higidez da observância do edital (invalidade da questão, por inobservância do edital).

No entanto, ao se pleitear os pontos e não a invalidade da questão, o pedido imediato aparenta a inexistência de comunhão (camuflar a comunhão). A comunhão, no entanto, continua a existir, por força da relação jurídica de direito substancial e do bem da vida pretendido, pois é inadmissível a concessão de pontos para um e não para outro, sob pena de desequiparação.

O direito pretendido - higidez do edital -, cujo fundamento está apenas na causa de pedir, tem alcance coletivo, pois uma questão não pode ser válida para um candidato e inválida para o outro. A interpretação do edital e as condições para concorrer as vagas deve ser igual para todos. De igual modo, o pretensão de receber os pontos e a pretensão de declarar a invalidade da questão objetiva impugnada implicam a mesma consequência prática, qual seja, a lista de classificação do concurso será alterada. Ocorre que, no primeiro caso, a lista será alterada, favorecendo um e prejudicando outros. No segundo caso, todos terão a mesma sorte em decorrência da invalidade da questão, mantendo a paridade constitucional do concurso público.

O mesmo cuidado é preciso com a causa de pedir. Nesse aspecto, é corrente na doutrina a noção de que os limites objetivos subordinam os limites subjetivos da demanda. Mancuso ${ }^{1136}$ salienta que a decisão deve projetar-se conforme a carga eficacial no plano material, isto é, conforme as faixas do universo coletivo, atingindo a todos no âmbito da relação substancial em jogo.

E, como salienta Zufelato ${ }^{1137}$, alcançar todos os sujeitos vinculados à situação fática é condition sine qua non para a promoção da boa prestação jurisdicional. A causa de pedir remota ou fática é, portanto, de grande importância, para aferição da amplitude da controvérsia deduzida.

Novamente, Leonel ${ }^{1138}$ foi preciso em esclarecer a importância da substanciação ou da especificação dos fatos para identificação do direito controvertido. Quão maior a indeterminação da coletividade interessada, maior a abstração dos fatos e menores serão as 
situações individuais. Quão maior a determinação da coletividade interessada, maior a possibilidade de surgimento de situações individuais. É na causa de pedir remota ou fática que a substanciação ou especificação dos fatos poderá ser melhor examinada para aquele escopo.

Paulo Henrique Lucon ${ }^{1139}$ também assinala que, mesmo nos direitos individuais homogêneos, embora as causas de pedir seja tecnicamente distintas, o que importa é que a demanda individual se insira no mesmo contexto social, geográfico e temporal da causa de pedir da demanda coletiva.Trata-se de um enfoque mais amplo da identidade da relação de direito substancial.

Os fundamentos jurídicos não são menos importantes. Os fatos são abstratos, mas também são abstratos e amplos os fundamentos ou argumentos jurídicos possíveis à promoção daquele interesse ou direito coletivo. Dada a objetividade da controvérsia, é preciso assegurar que "os argumentos sejam levados em conta e que os argumentos mais fortes sejam formulados" ${ }^{1140}$. Por isso, a agregação processual tem o mérito de permitir a formação de um grande fórum para a deliberação racional dos interesses ou direitos coletivos e dos argumentos do grupo como todo.

Nesse caso, a participação não é pessoal, mas ela pode ofertada por mecanismos coletivos como audiências públicas, como a intervenção individual a exemplo do "proof of claim forms" do direitos estadunidense, como a intervenção de um amicus curiae etc. Se o interesse ou direito é objetivo, ele não deve ser definido por preferências pessoais. Os indivíduos devem poder participar, sim, mas coletivamente. A participação coletiva ensejará a reunião dos argumentos do grupo e permitirá um debate mais amplo, por permitir a formulação de um maior número de argumentos e, quiçá, de argumentos mais fortes do que se o indivíduo atuasse sozinho.

O conjunto fática e jurídico, descrito na causa de pedir e no pedido, facilitará a identificação da amplitude da controvérsia, mormente, pelas características do conflito de direito material deduzido em juízo. E, de igual modo, é sobre esse conjunto que incidirá a cognição judicial, que deverá centrar-se, ao menos em parte, na análise das características do grupo e não na análise artesanal das características individuais. Quão maior a necessidade de cognição artesanal, maior a pessoalidade da controvérsia, o que é incompatível com a agregação 
processual e, por conseguinte, também é incompatível com a adoção de técnica preclusivas. Eis a importância da "correta fixação do objeto litigioso" 1141 para as técnicas de agregação.

\subsubsection{COISA JULGADA COLETIVA SECUNDUM EVENTUM LITIS VEL PROBATIONIS, SECUNDUM PROBATIONEM E REBUS SIC STANTIBUS: DIREITOS DIFUSOS E COLETIVOS}

A essa altura, não é novidade dizer que ínsito aos direitos difusos e coletivos está a coisa julgada inter alios, com a extensão subjetiva aos membros ausentes do grupo. O fundamento é a natureza da relação de direito material e ponderação das garantias constitucionais processuais.

A solução legislativa foi conferir, na hipótese de direitos difusos e coletivos, respectivamente, a eficácia erga omnes e ultra partes, segundo as respectivas faixas do universo coletivo, como enuncia Mancuso ${ }^{1142}$. A expressão erga omnes define o âmbito de vinculatividade do comando normativo do julgado aos membros ausentes e indeterminados de um grupo circunstancial, conforme o objeto litigioso do processo. Se a questão diz respeito à cessação da poluição, que acomete os habitantes do Município de Cubatão, esse é o âmbito de vinculatividade da decisão.

A expressão ultra partes também define o âmbito de vinculatividade do julgado aos membros ausentes do grupo, classe ou categoria, os quais mantém entre si uma relação jurídica base. Os membros do grupo alcançados pela coisa julgada são aqueles que, segundo Mancuso ${ }^{1143}$, foram inseridos no âmbito do pedido e da causa de pedir (objeto litigioso) do processo coletivo.

No sistema jurídico estadunidense, mesmo na hipótese de direitos difusos e coletivos (indivisíveis), há uma preocupação com o adequada representação na controvérsia. E, mais, há igualmente a preocupação em permitir que, na hipótese de ter sido inadequada a representação, a controvérsia seja rediscutida, afastando-se, nesse caso, a estabilidade da coisa julgada.

Igual preocupação também ocorre no sistema jurídico brasileiro. Isso é percebido pelo fato de a estabilidade da coisa julgada, nos direitos difusos e coletivos, vincular-se à suficiência da prova produzida. Mancuso ${ }^{1144}$ cunhou, por essa razão, a expressão coisa julgada secundum 
eventum litis vel probationis. Noutros termos, não há formação da estabilidade, inerente à coisa julgada, na hipótese de sentença de improcedência em razão da insuficiência de provas.

Nesse caso, não é necessário impugnar, preliminarmente, a sentença de improcedência por insuficiência de provas, como ocorre no collateral attack, para que seja possível reabrir a possibilidade de rediscussão da controvérsia. A oportunidade de rediscussão da controvérsia já foi reconhecida ope legis, pois o legislador já reconheceu a importância de um suficiente grau de cognição para reconhecer como adequada a performance do representante e, por conseguinte, a estabilidade do comando decisório coletivo, com a vinculação da categoria.

Se os resultados são insatisfatórios, se a instrução foi deficiente e se a sentença foi julgada improcedente por insuficiência de provas (com o risco, até mesmo, de ter havido conluio), há elementos idôneos para afastar, prima facie, a adequação da performance do representante.

Não há necessidade de o magistrado, no entanto, consignar expressamente a insuficiência do material probatório, a fim de que a coisa julgada secundum eventum litis vel probationis seja formada. Em caso de dúvida ou de ambiguidade no conteúdo da sentença (se há ou não há suficiência probatória), a questão poderá ser apreciada em uma demanda subsequente.

Segundo Antônio Gidi ${ }^{1145}$, basta ao autor reproduzir a demanda, com o novo material probatório (prova que era passível de apresentação anterior, mas não foi apresentada pelo representante na demanda anterior), que demonstrará, com isso, ipso facto, a instrução insuficiente da demanda anterior e a improcedência por insuficiência de provas. Nesse caso, todavia, entende-se que é recomendável que o autor argumente, preliminarmente em sua petição inicial, a juntada do novo material probatório ou que pleiteie a produção de novas provas, pois do contrário o réu e o magistrado somente saberão (se houve ou não suficiência probatória e se há ou não coisa julgada) no curso da instrução. É ônus do autor argumentar sobre a existência da nova prova.

Mas, mesmo que o representante tivesse vigorosamente tutelado os interesses ou direitos coletivos, a insuficiência pode ser explicada pela imaturidade ${ }^{1146}$ da controvérsia. Isso ocorre quando a controvérsia foi deduzida, quando ainda não esclarecidos no mundo da vida (até mesmo na ciência) todos os fatos pertinentes ou todos os impactos de uma lesão a um bem 
difuso ou coletivo. Nesse caso, a demanda é julgada improcedente por insuficiência de provas, mas não isso não decorre da baixa performance do representante, mas pelo fato de ele adiantarse na propositura demanda, quando o conhecimento sobre a questão controvertida ainda não estava consolidado. Aqui, também é recomendável a repropositura da ação coletiva, para a apresentação de uma nova prova, desconhecida ou inexistente ao tempo da demanda anterior.

A mesma orientação é possível na hipótese de suficiência probatória. Em razão do desenvolvimento da tecnologia ou ciência, uma produto que não era considerado nocivo passa a ser considerado arriscado. Nesse caso, também é possível a rediscussão da controvérsia. Essa última hipótese, que diz respeito à prova superveniente, quando suficiente o conjunto probatório anterior, é denominada pela doutrina de coisa julgada secundum probationem. ${ }^{147}$

A diferença desta última situação em relação às duas anteriores é que, nas primeiras, a improcedência por insuficiência de prova afastava, prima facie, a estabilidade inerente à coisa julgada. No segundo caso, houve suficiência probatória, logo houve a formação da coisa julgada erga omnes. A autoridade da coisa julgada, no entanto, atrela-se ao conjunto probatório.

Alterado o conjunto probatório no tempo, com a apresentação de prova inexistente no momento da tramitação da ação originária, é admissível a propositura de nova ação coletiva, para rediscussão da controvérsia à luz da nova evidência. A rediscussão é, portanto, possível em qualquer resultado, seja a sentença coletiva de procedência, seja a sentença de improcedência.

Por fim, uma terceira possibilidade deve ser considerada, a saber, a coisa julgada rebus sic stantibus, admissível nas hipóteses de alteração do estado de fato ou de direito no tempo. Castro Mendes $^{1148}$ salienta que, no Anteprojeto do Código Modelo de Processos Coletivos para Iberoamérica cogita-se da possibilidade de revisão do comando normativo da sentença, com a rediscussão de relação continuativa, na hipótese de modificação no estado de fato ou de direito.

Mancuso $^{1149}$ salienta que, nessa hipótese, não há mitigação da coisa julgada, pois toda a coisa julgada está sujeita a limites temporais, de modo que ela agrega imutabilidade a uma decisão

1147 GRINOVER, 2011, p. 197. TUCCI, 2006, p. 315. 
sobre um determinado objeto litigioso nos limites em que estabilizado à época da decisão. Assim, alterada as circunstâncias fáticas ou jurídicas no tempo, há nova fattispecie e nova lide.

É interessante notar que, no sistema jurídico brasileiro, há igual preocupação com a adequada representação, bem como a possibilidade de reabrir a via processual para a rediscussão da controvérsia coletiva. Por isso, nas hipóteses de insuficiência probatória, de suficiência probatória com a superveniência de prova e de alteração das circunstâncias fáticas ou jurídicas (legal environment), cessam os efeitos da representação anterior e oportuniza-se a rediscussão.

A sentença proferida, no tocante aos direitos difusos e coletivos, acobertada pela coisa julgada, não preclui a persecução de questões individuais ou pessoais do membro do grupo. Isso porque a autoridade da coisa julgada estende-se apenas aos aspectos impessoais, indivisíveis e paritários da controvérsia. À semelhança do sistema estadunidense, não há preclusão de questões pessoais, individuais, singulares da controvérsia, que exigem cognição artesanal.

Apenas uma ponderação deve ser feita. Individual não significa aquilo que é deduzido pelo indivíduo. Individual diz respeito à característica da pessoalidade do direito substancial deduzida em juízo, que exige cognição artesanal. Assim, se um indivíduo, em uma controvérsia de massa, vier a reproduzir a mesma questão comum e objetiva, já decidida pelo Poder Judiciário, valendo-se de alguma técnica de agregação, ele deve cumprir o ônus argumentativo.

O indivíduo não pode simplesmente ignorar o provimento unitário, antes proferido, e, com isso, buscar a resolução da mesma questão controversa, sem em nada lhe acrescentar ou refutar.

\subsubsection{COISA JULGADA COLETIVA SECUNDUM EVENTUM LITIS: DIREITOS HOMOGÊNEOS E ÔNUS ARGUMENTATIVO}

Também não é nenhuma novidade dizer que a coisa julgada secundum eventum litis, isto é, a vinculação da estabilidade da coisa julgada alcança terceiro segundo o resultado do processo, é aplicável na hipótese de direitos individuais homogêneos quando procedente o provimento. 
Na realidade, como esclarece Ada Pellegrini Grinover ${ }^{1150}$, trata-se de técnica que foi emprestada à tutela coletiva. No processo individual, originariamente, essa técnica faz referência à formação ou não formação da coisa julgada em relação às partes. No processo coletivo, diz respeito - repete-se- à vinculação de terceiros à estabilidade do comando normativo do julgado. Como bem assinala Cassio Scarpinella ${ }^{1151}$, a coisa julgada, nos direitos individuais homogêneos, é "um plus" em prol do indivíduo, pois não há exclusão da possibilidade de tutela na forma individual, desde que o indivíduo não intervenha ou se associe à ação coletiva pendente.

Nesse caso, a imutabilidade da decisão forma-se na esfera coletiva, pro et contra, independentemente da suficiência ou não das $\operatorname{provas}^{1152}$. Não obstante, o comando normativo da sentença estende-se ao plano individual, com a autoridade inerente da coisa julgada, de acordo com o resultado do processo. Se procedente, beneficia os sujeitos. Se improcedente, não há impedimento a discussão da questão em uma ação individual. Não há obrigação de intervenção na ação coletiva e, caso já propostas as ações individuais, elas podem ser suspensas.

De igual modo, a autoridade da coisa julgada que agrega à sentença de procedência em relação aos direitos difusos e coletivos somente pode ser estendida ou transportada - também secundum eventum litis - ao plano individual, abreviando o procedimento para a satisfação de um direito cuja questão comum (ex. questão quanto à responsabilidade do réu) já tenha sido decidida previamente. Trata-se do transporte in utilibus da ação coletiva para as ações individuais. ${ }^{1153}$

Muito embora o tema da coisa julgada secundum eventum litis tenha levantado divergências e tormentosas questões no direito brasileiro sobre a constitucionalidade dessa técnica ${ }^{1154}$, a sistemática adotada pelo Código de Defesa do Consumidor se justifica e - pondera-se - é de grande precisão técnica. Isso porque o transporte simplista e descontextualizado da solução americana não se apresentava adequada, por razões contingenciais da realidade brasileira:

1150 GRINOVER, 2005, p. 7.

1151 BUENO, 1996, p. 133.

1152 GRINOVER, 2011, p. 180-181.

1153 GRINOVER, 2011, p. 178-181.

1154MESQUITA, José Ignácio Botelho. Na ação do consumidor, pode ser inútil a defesa do fornecedor. Revista do Advogado, V. 33, 1990, p. 81. MATTOS, Luiz Norton Baptista de. A litispendência e a coisa julgada nas ações coletivas segundo o Código de Defesa do Consumidor e os anteprojetos do Código Brasileiro de Processos Coletivos. In: GRINOVER, Ada Pellegrini; MENDES, Aluísio Gonçalves de Castro, WATANABE, Kazuo. Direito Processual Coletivo e o anteprojeto de Código Brasileiro de Processos Coletivos. São Paulo: Revista dos Tribunais, 2007, p. 206-207. 
...a deficiência da informação completa e correta, a ausência de conscientização de enorme parcela da sociedade, o desconhecimento dos canais de acesso à justiça, a distância existente entre o povo e o Poder Judiciário, tudo a constituir gravíssimos entraves à intervenção de terceiros, individualmente interessados, nos processos coletivos, e mais ainda para seu comparecimento a juízo visando a exclusão da futura coisa julgada. ${ }^{1155}$

Mas, mais do que isso, não há identidade entre uma demanda coletiva para direitos difusos e coletivos e demandas individuais homogêneas - daí a precisão técnica. Isso porque as demandas individuais homogêneas contém, em parte, pedidos individuais, logo não é possível uma perfeita identificação com o objeto litigioso difuso ou coletivo. $\mathrm{O}$ indivíduo pretende o ressarcimento ou a tutela declaratória, constitutiva ou mandamental apenas para si mesmo.

Não há possibilidade de comparação entre uma demanda coletiva relativa a direitos difusos e coletivos e uma demanda coletiva relativa a direitos individuais homogêneos, pois não há uma relação de abrangência entre os pedidos. Nesse sentido, assinala Gidi1"156, ao salientar que "não é porque o consumidor se pode beneficiar da imutabilidade do comando da sentença coletiva (extensão in utilibus da coisa julgada) que se pode dizer que o seu pedido está sendo julgado.”

Com exceção da situação de upstream, em que a cognição é centrípeta, ou seja, é atraída e exercida exclusivamente sobre os atributos do grupo e a satisfação individual decorre de fórmula uniforme aplicável a todos, as controvérsias de direitos individuais homogêneos apresentam um procedimento bifásico. O procedimento não termina com a sentença genérica coletiva, a controvérsia tende a prosseguir na liquidação, ocasião em que as questões individuais ou pessoais deverão ser resolvidas para fins de satisfação do indivíduo, membro do grupo.

Não há, portanto, identidade de causas. E também não há coisa julgada pro et contra. Não é admissível que o indivíduo seja vinculado pela autoridade da coisa julgada que se agregou a uma sentença coletiva de improcedência, que obstaria em tese o prosseguimento individual, sem que lhe seja oportunizado demonstrar a pessoalidade, da sua controvérsia ou uma nova dimensão (novas circunstâncias de fato ou de direito) da controvérsia coletiva antes litigada. 
Não há identidade da demanda, mas é possível a identidade de algumas questões controvertidas de direito substancial e dos argumentos comuns ou compartilhados pelo grupo em sua defesa.

A relação de direito individual homogêneo, embora divisível, pode ser impessoal e paritária, com argumentos comuns ou compartilhados pelo grupo, de forma que os indivíduos encontremse, ao menos em parte, em uma situação de equidistância da questão controvertida em juízo.

As situações de upstream e downstream, por exemplo, ensejam uma potencial paridade e impessoalidade aos membros do grupo, conforme a controvérsia deduzida em juízo. Os direitos individuais homogêneos, também denominados direitos de massa ou repetitivos, em que os indíviduos estão desligados ou até mesmo ignoram uns aos outros, revela a mesma impessoalidade, uma certa despersonalização na controvérsia deduzida perante o Judiciário.

Se não existisse, ao menos, essa impessoalidade na relação de direito substancial, a representação na ação coletiva seria uma mera ficção, uma mera coincidência episódica de interesses, sem qualquer previsão de que um indivíduo estaria propenso à defesa do outro. Se esse representação é possível, é porque há um vínculo - mais fluído e potencial - no direito material, que torna o representante propenso a promover o interesse ou direito do grupo.

Nesse sentido, como ressalta Leonel ${ }^{1157}$, não há identidade da demanda, mas, em certo sentido, há uma identidade da relação jurídica de direito material. Cita-se trecho dessa assertiva:

Há identidade de causas? Não, certamente. Há identidade de relação jurídica substancial? Depende da concepção adotada a respeito desse critério [...] sob o enfoque mais elástico, calcado na economia e instrumentalidade processual, fugindose do conceito meramente estrito e jurídico da relação jurídica de direito material, pode-se afirmar que, dentro da necessidade de proteção ao patrimônio ambiental, não deixa de estar presente pela identidade de circunstâncias materiais - mesmo no contexto dos atos que ocasionaram a lesão, mesmo local, mesma circunstância temporal - uma identidade de relação substancial, ou ainda a abrangência da situação substancial deduzida na ação individual pela deduzida na demanda coletiva.

Nesse contexto, pode ser comum a repetição dos mesmos argumentos, já expressamente discutidos e enfrentados, no tocante às questões controvertidas comuns ou impessoais, que alcançam o indivíduo como membro do grupo. Os mesmos argumentos, a mesma peça inicial (um modelo padrão), já enfrentada em outra ocasião, pode ser, em tese, objeto de reprodução. 
Há coisa julgada? Não. Há abuso? Talvez. É oportunizado ao indivíduo aduzir novos argumentos, para refutar e influenciar o convencimento do magistrado já consolidado em um provimento coletivo. É oportunizado ao indivíduo aduzir circunstâncias pessoais (a sentença afastou a existência de uma prática abusiva, mas é possível ao indivíduo alegar um vício de consentimento contratual particularizado). É oportunizado ao indivíduo aduzir uma nova dimensão da controvérsia (novas circunstâncias fáticas ou jurídicas) Mas, pondera-se que, a despeito de o indivíduo não ter participado pessoalmente da ação coletiva, não há direito à repetição, mais uma vez, de um argumento comum ao grupo, já enfrentado e refutado.

O direito ao contraditório é o direito de participar argumentativamente, influenciando a convicção do magistrado e oportunizando a formação ou a correção do provimento jurisdicional. Não há direito de tentar a sorte, para quem sabe, agora, lograr resultado diverso.

Reflexão semelhante já realizou Sergio Arenhart ${ }^{1158}$, ao consignar que os efeitos da sentença coletiva não pode ser simplesmente desconsiderados. Transcreve-se um trecho desse raciocínio:

\begin{abstract}
...um terceiro, no tocante a uma ação reivindicatória envolvendo dois sujeitos, não pode simplesmente desconsiderar os efeitos do provimento ali emanado; terá de tomar em conta estes efeitos se, por acaso, vier a pretender a propriedade objeto daquele demanda, pleiteando-a junto àquele que se sagrou vencedor na primeira ação (ainda que desta não tenha ele feito parte). Logicamente, estes terceiros têm - se interessados - a faculdade de "afastar" o efeito, mediante a propositura de alguma demanda judicial (o que é possível, pois não se sujeitam eles à imutabilidade da coisa julgada). Não podem, todavia, simplesmente "desconsiderar" os efeitos da decisão judicial, sob o singelo argumento de não terem participado do processo judicial. Ora, essa característica, ocorrente em ações individuais, não é diferente em relação a demandas coletivas. E o fato de o direito tutelado pela ação coletiva ser individual (de massa) não altera essa circunstância, nem permite que se discrimine a situação aqui examinada. A impossibilidade concreta de o titular do direito material desconsiderar o efeito do provimento obtido na demanda coletiva.
\end{abstract}

Pondera-se que não só os efeitos da ação coletiva não podem ser desconsiderados, mas não podem ser desconsiderados os argumentos que implicaram à improcedência da demanda coletiva. Não é admissível agir como se ação coletiva jamais tivesse existissem no mundo jurídico, apenas porque não houve participação pessoal. A regra do ônus ou da carga de argumentação deve ser aplicado no processo coletivo. Nada deve ser mudado sem uma razão.

1158 ARENHART, Sérgio Cruz. A tutela de direitos individuais homogêneos e as demandas ressarcitórias em pecúnia. In: GRINOVER, Ada Pellegrini; MENDES, Aluísio Gonçalves de Castro, WATANABE, Kazuo. Direito Processual Coletivo e o anteprojeto de Código Brasileiro de Processos Coletivos. São Paulo: Revista dos Tribunais, 2007, p. 220-221. 
Logo, se um argumento já foi enfrentado e decidido no tocante à questão comum de um grupo, quem pretender afastá-lo deverá apresentar razões ou argumentos para essa finalidade.

Trata-se, simplesmente, de aplicar ao processo coletivo brasileiro, a noção de ônus de argumentação ou burden of persuasion, obstando apenas a repetitividade dos argumentos, que não acrescentam à deliberação e à promoção do interesse ou direito individual homogêneo, repetitivo ou direito de massa. As circunstâncias pessoais e novas não precluem, mas não é admissível a reprodução de um mesmo argumento, já expressamente apreciado e decidido.

Igual raciocínio poderá ser aplicado, de forma coerente, às demais técnicas de agregação, como o caso-teste (incidente de resolução de demandas repetitivas no sistema brasileiro) e na hipótese de consolidação de demanda individuais para fins de resolução conjunta e unitária. Seria uma espécie de issue preclusion, a ser analisada nos processos individuais pendentes/subsequentes.

Por exemplo, o incidente de molecularização de demandas individuais já propunha uma espécie de preclusão da questão decidida no incidente. O Projeto da Nova Lei de Ação Civil Pública já prevê a preclusão das questões de direito decididas na ação coletiva, embora com a possibilidade de autoexclusão. O Projeto do Novo Código de Processo não indica, claramente, a preclusão da questão comum repetitiva. Mas, o modelo inspirador (musterverfahren) dessa técnica, presente no sistema jurídico alemão, adota a técnica preclusiva para essa hipótese.

No caso das ações coletivas julgadas improcedentes, o ônus argumentativo deve ser cumprido, preliminarmente, na demanda individual subsequente. Caberá ao autor individual ou indicar circunstâncias individuais ou uma nova dimensão da questão comum (novas circunstâncias fáticas ou jurídicas). Porém, será inadmissível o prosseguimento no tocante à matéria repetitiva.

Com isso, não haveria propriamente uma estabilidade da sentença coletiva de improcedência, pois é possível a propositura de demandas individuais subsequentes. Mas, a ausência de estabilidade prévia ou ex ante, não autoriza o indivíduo a ignorar os argumentos já enfrentados e decididos naquela ocasião, reproduzindo-os na demanda individual subsequente. A razão para isso é que a participação argumentativa e o acesso à ordem justa já foram exercidos na hipótese.

É preciso esclarecer que essa proposta não visa instaurar, por via transversa, uma coisa julgada pro et contra para os direitos individuais homogêneos Uma proposta como essa não lograria 
bom êxito, afinal não há identidade de demandas. E, mais, o reconhecimento, ex ante, da coisa julgada não seria uma solução pragmática. Reconhecer a autoridade da coisa julgada coletiva prot et contra para o plano individual de forma ex ante para, depois, afastá-la, transformaria a coisa julgada em "um polvo". Mas, no lugar de tentáculos, seriam várias regras e exceções. Isso desnaturaria, por certo, a natureza do instituto da coisa julgada, que se vincula ao princípio da segurança jurídica e da certeza da relações jurídicas. Esse não é o escopo da presente proposta. O que se pretende é que, por força do exercício do contraditório, entendido como participação argumentativa, uma questão comum, já enfrentada e decidida, não seja mais reproduzida.

Por isso, existe há diferença no sistema estadunidense entre coisa julgada e preclusão da questão decidida. A preclusão da questão decidida é mais ampla e flexível, aplicável exatamente nas hipóteses em que não há identidade de demandas. A issue preclusion está atrelada ao contraditório, pois a preclusão somente se estabelece nas hipóteses em que a questão foi debatida e decidida. A noção de burden of persuasion, aplicado ao opt out, e o collateral attack adotam a mesma linha: a inadmissibilidade de rediscussão de argumento enfrentado e decidido.

Forçoso convir que o reconhecimento do ônus argumentativo, ora proposto para o direito brasileiro, visa apenas situar, de forma coerente e consistente, a questão da repetição dos argumentos no contexto constitucional antes abordado. Se contraditório é a participação argumentativa e se o acesso à justiça é o acesso à ordem jurídica justa - como ora se pondera não há direito à repetição de um argumento, para simplesmente tentar a sorte, quiçá com um juiz mais simpático à causa. O exercício da jurisdição não é comparável ao ato de jogar uma moeda ao alto para lograr um resultado, é atividade argumentativa. Cabem as partes, por sua vez, conferir o input dessa atividade, isto é, aduzir os argumentos para convencer o magistrado.

O que existe é a possibilidade de influenciar e refutar, por novos argumentos, a questão decidida, justificando-se, por isso, a possibilidade de persecução individual do direito alegado. 


\section{CONCLUSÃO}

Na presente investigação, foram confrontadas várias técnicas de agregação processual, com o escopo de responder a seguinte questão: qual a extensão, necessária e adequada, da agregação processual, sem prejuízo a autonomia individual. O que é possível agregar? Como agregar?

O cerne de toda a técnica é a atenção ao direito substancial. A agregação não deve ser realizada no vácuo, ou noutros termos, não deve ser realizada sem as circunstâncias impessoais, indivisíveis ou paritárias presentes no direito substancial, sob pena violar a autonomia individual e o devido processo. São essas circunstâncias que ensejam a agregação. Pode-se dizer que a impessoalidade, a paridade e a indivisibilidade são os critérios substanciais de agregação.

O processamento e a resolução unitária de uma controvérsia de massa somente é admissível no tocante a interesses ou direitos objetivos, isto é, impessoais, paritários e/ou indivisíveis. Uma pessoa não necessariamente realiza as mesmas escolhas, a mesma estratégia e utiliza os mesmos argumentos da outra. Muito pelo contrário, o indivíduo é o melhor guardião dos seus interesses.

O que ocorre, na realidade, é que em alguns situações substanciais, há uma objetividade do direito e não estão em jogo circunstâncias pessoais. Logo, presume-se que qualquer membro do grupo é apto a apresentar os argumentos de fato e/ou de direito relevantes ao grupo como um todo. Há, por assim dizer, uma espécie de fungibilidade entre os membros do grupo.

Nessa hipótese, o exercício da representação, com a adequada performance do representante e com o debate sobre os argumentos do grupo, autoriza tanto a agregação processual compulsória de um grupo, como também a preclusão em relação aos membros ausentes. Essa representação, de que se trata, é virtual, porquanto não se trata de um sujeito realizar as mesmas escolhas do outro ou adotar a mesma estratégia de outro, mas, sim, de promover interesses ou direitos que, ao menos em parte, não dizem respeito à nenhuma pessoa especial: uma situação impessoal.

O resultado da representação não é medido pela vitória ou sucumbência, procedência ou improcedência, mas, sim, pela performance do representante em promover os interesses ou direitos do grupo, permitindo a deliberação racional dos seus argumentos. Uma vez enfrentado ou discutido um argumento, o provimento que nele se fundamenta somente deve ser afastado 
por novas razões, por novos argumentos, pois nenhum provimento consolidado na ciência do direito deve ser mudado sem que uma nova razão seja oferecida para essa mesma finalidade.

A agregação apresenta extensão, necessária e adequada, no processo civil, exatamente naquelas hipóteses de fungibilidade do membro do grupo, isto é, quando o indivíduo posiciona-se na controvérsia deduzida em juízo de forma impessoal, paritária ou com relação a bem indivisível.

Nesse contexto, não há prejuízo a autonomia individual. Isso porque a agregação processual não obsta a dedução de circunstâncias pessoais pelo indivíduo, tampouco obsta a apresentação de uma nova dimensão da controvérsia de massa (novas circunstâncias de fato ou de direito). O que deve ser obstada é a rediscussão dos mesmas questões e dos mesmos argumentos, já enfrentados pelo magistrado no procedimento anterior, que porventura vierem a ser repetidos. 


\section{REFERÊNCIAS}

ABRAHAM, Kenneth S., ROBINSON, Glen O. Aggregative valuation of mass torts claims. Law and contemporary problems Law Review. V. 53:137-157p.

ALEXANDER, Larry. Relationship between procedural due process and substantive constitutional rights. U. FLA. L. REV, 1987, V. 39: 323-341p.

ALEXY, Robert. Teoria da argumentação jurídica: teoria do discurso racional como teoria de justificação jurídica. Tradução Zilda Hutchinson Schild Silva. São Paulo: Landy Editora, 2005.

ALMEIDA, Gregório Assagra de. Direito material coletivo - superação da summa divisio direito público e direito privado por uma nova summa divisio constitucionalizada. Belo Horizonte: Del Rey, 2008.

ALPERT, Richard. The uniform class actions act: some promise and some problems. Harvard Journal on Legislation. 1979, V. 16:584-667p.

ALVES, José Carlos Moreira. Direito romano. 15. ed. Rio de Janeiro: Forense, 2012.

ALVIM, Arruda, José Manoel. Ensaio sobre a litispendência no Direito Processual Civil II. São Paulo: Revista dos Tribunais, 1970.

AMERICAN LAW INSTITUTE. Restatement (Second) of Judgment 2d. Minneapolis: Thomson West, 1982.

ANDREWS, Neil. Abuse of process in English Civil Litigation. In: TARUFFO, Michele. Abuse of Procedural Rights: comparative standards of procedural fairness. Boston: Kluwer, 1998.

ANDREWS, Neil. Multi-party proceedings in England: representative and group action. Duke Law Journal of Comparative and International Law, 2001, V. 11: 249-267p.

ANTONICCI, Peter A. Statistical sampling as a basis for extrapolating liability and/or damages. In: GREER, Marcy Hogan (org.). A practitioner's guide to class action. Chicago: ABA Publishing, 2010.

ARANGIO-RUIZ, Vincenzo. Il mandato in diritto romano: corso di lezioni svolto nell'università di Roma. Anno 1948-1949. Napoli: Casa Editrice Dott. Eugenio Jovene, 1965.

ARAÚJO, Luiz Paulo da Silva. Ações Coletivas: a tutela jurisdicional dos direitos individuais homogêneos. Rio de Janeiro: Forense, 2000.

ARENHART, Sérgio Cruz. A tutela de direitos individuais homogêneos e as demandas ressarcitórias em pecúnia. In: GRINOVER, Ada Pellegrini; MENDES, Aluísio Gonçalves de Castro, WATANABE, Kazuo. Direito Processual Coletivo e o anteprojeto de Código Brasileiro de Processos Coletivos. São Paulo: Revista dos Tribunais, 2007.

A tutela inibitória da vida privada. São Paulo: Revista dos Tribunais, 2000.

Perfis da tutela inibitória coletiva. São Paulo: Revista dos Tribunais, 2003, p. 140 (Coleção Temas Atuais de Direito Processual Civil V6.

ARRUDA ALVIM et al. Código de Defesa do Consumidor Comentado. 2 ed. rev. amp. SÃO PAULO: Revista dos Tribunais, 1995.

ASSIS, Araken. Cumulação de ações. 4. ed. rev. atual. São Paulo: Revista dos Tribunais, 2002.

BACKHAUS, Jürgen G., CASSONE,Alberto and RAMELLO, Giovanni B. (editors). The law and economics of class actions in Europe: lessons from America. Massachusetts: Edward Elgar Publishing Limited, 2012. 
BARTON, R. Joseph. Utilizing statistics and bellwether trial in mass torts: what do the Constitution and Federal Rules of Civil Procedure permit? William \& Mary Bill of Rights Journal, 1999, V. 8: 199-240p.

BASSETT, Debra Lyn. Adequacy of class representation. Georgia Law Review, 2004, V. 38:927-989p.

BEDAQUE, José Roberto dos Santos. Direito e Processo. 4 ed. rev. amp. São Paulo: Malheiros, 2006.

Efetividade do processo e técnica processual. 2 ed. São Paulo: Malheiros, 2007.

Elementos objetivos da demanda examinados à luz do contraditório. In: TUCCI, José Rogério Cruz e. BEDAQUE, José Roberto dos Santos. Causa de pedir e pedido no processo civil (questões polêmicas). São Paulo: RT, 2002.

Legitimidade processual e legitimidade política. In: SALLES, Carlos Alberto de. Processo civil e interesse público: o processo como instrumento de defesa social. São Paulo: Revista dos Tribunais, 2003.

BEER, Samuel H. The representation of interests in British Government: historical background. American Political Science Review, setembro de 1957, LI.

BENN, Stanley, "Rights," Encyclopedia of Philosophy, ed. Paul Edwards, New York: Macmillan, 1967.

BEN-SHAHAR, Omri. Causation and multiple tortfeasors. In: FAURE, Michael (org.). Tort law and economics. V. 1. 2 ed. Massachussetts: Edward Elgar Publishing Limited, 2009.

BERIZONCE, Roberto, GRINOVER, Ada Pellegrini e SOSA, Angel Landoni. Exposição de motivos do Código Modelo de Processos Coletivos para Ibero-América. In: GRINOVER, Ada Pellegrini. MENDES, Aluísio Gonçalves de Castro, WATANABE, Kazuo. Direito processual coletivo e o anteprojeto de Código Brasileiro de Processos Coletivos. São Paulo: Revista dos Tribunais, 2007.

BOGART, W. A. Questioning litigation role's: courts and class action in Canada. Indiana Law Journal, $1987, \mathrm{~V}$. 62:665-700p.

BONE, Robert G. Personal and impersonal litigative forms: reconceiving the history of adjudicative representation. Boston University Law Review, 1990, V. 70:213-307p.

Procedure, participation and rights. Boston Law Review, 2010, V. 90:1011-1028p.

Rethinking the "day in court" ideal and nonparty preclusion. New York University Law Review. 1992, V. 67:193-293p.

Rule 23 redux: Empowering the federal class action. The Review of litigation, 1994, V. 14: 79-112p.

Securing the normative foundations. Boston University Law Review, 2006, V. 86:1155-1170p.

BONE, Robert G.; EVANS, David. Class Certification and Substantive Merits. Duke Law Journal, 2002 , V. 51:1251-1332p.

BONÍCIO, Marcelo José Magalhães. Proporcionalidade e processo: a garantia constitucional da proporcionalidade, a legitimação do processo civil e o controle das decisões judiciais. São Paulo: Atlas, 2006.

BRASIL JR, Samuel Meira. Justiça, Direito e Processo: a argumentação e o direito processual de resultados justos. São Paulo: Atlas, 2007. 2010. Precedentes vinculantes e jurisprudência dominante na solução das controvérsias. Tese. São Paulo: USP,

BRASIL. Anteprojeto Substitutivo do Novo Código de Processo Civil. Exposição de motivos/Comissão de Juristas. Disponível em: http://www.direitoprocessual.org.br/index.php?substitutivo-elaborado-por-adapellegrini- 
grinover-carlos-alberto-carmona-cassio-scarpinella-bueno-e-paulo-henrique-dos-santos-lucon. Acessoem 5 de setembro de 2013.

BRASIL. Anteprojeto Substitutivo do Novo Código de Processo Civil. Exposição de motivos/Comissão de Juristas. Disponível em: http://www.direitoprocessual.org.br/index.php?substitutivo-elaborado-por-adapellegrini-grinover-carlos-alberto-carmona-cassio-scarpinella-bueno-e-paulo-henrique-dos-santos-lucon.Acesso em 5 de setembro de 2013.

BRASIL. Câmara dos Deputados. PL no 5.139/2009. Disponível em: http://www.camara.gov.br/proposicoes Web/fichadetramitacao?idProposicao=432485. Acesso em: 24 de outubro de 2013.

BRASIL. CEBEPEJ. Projeto de lei que institui processo especial para o controle e intervenção em políticas públicas pelo Poder Judiciário e dá outras providências (no prelo).

BRASIL. Código de Defesa do Consumidor. Lei n. ${ }^{\circ}$ 8.078/1990. Brasília: Congresso Nacional, 1990.

BRASIL. Código de Processo Civil. 7 ed. Atualizador Sálvio de Figueiredo Teixeira. Rio de Janeiro: Forense, 1986.

BRASIL. Congresso Nacional. Câmara dos Deputados. PL no. 8.046/2010. Código de Processo Civil. Brasília: Câmara dos Deputados, Presidência, 2010.

BRASIL. Congresso Nacional. Senado Federal. Comissão de Juristas responsável pela elaboração de Anteprojeto de Código de Processo Civil. Código de Processo Civil: anteprojeto. Brasília: Senado Federal, Presidência, 2010.

BRASIL. INNOVARE. Projeto Poupança. Disponível: www.premioinnovare.com.br/praticas/projetopoupanca2208/. Acesso em: 21 de agosto de 2013.

BRASIL. Ministério da Justiça. $O$ desenho de sistema de resolução alternativa de disputas para conflitos de interesse público. Série Pensando o Direito 038/2010. São Paulo, 2010.

BRASIL. Ministério da Justiça. Secretária de Assuntos Legislativos. Série Pensando Direito n $38 / 2010$. O desenho de sistemas de resolução alternativa de disputas para conflitos de interesse público. GABBAY, Daniela Monteiro, CUNHA, Luciana Gross (coords.). Fundação Getúlio Vargas - FGV, 2010.

BRAZIL, Wayne D. Special masters in the pre-trial development of big cases: potential and problems. In: BRAZIL, Wayne D., HAZARD JR., Geoffrey C., RICE, Paul R. Managing Complex Litigation: A practical guide to the use of special master. Chicago: American Bar Foundation Press, 1983.

BRENNAN, Troyen A. Causal chains and statistical links: the role of scientific uncertainty in hazardous substance litigation. Cornell Law Review, 1998, V. 73:469-533p.

BRIGUGLIO, Felippo. Studi sul procurator: l'acquisto del possesso e dela proprietà. Milano: Dott. A. Giuffrè Editore, 2007.

BRONSTEEN, John, FISS, Owen M. The class action rule. Notre Dame Law Review, 2003, V. 78: 1419-1454p.

BRUNS, Carl Georg. Le azioni popolari romane per Carlo Giorgio Bruns. Traduzione di Vittorio Scialoja, com prefazione e note del traduttore, in Studio Giuridici I, Roma, 1933.

BUENO, Carlos Scarpinella. Partes e terceiros no processo civil brasileiro. São Paulo: Saraiva, 2003.

As class actions norte-americanas e as ações coletivas brasileiras: pontos para uma reflexão conjunta. Revista de Processo. São Paulo: Revista dos Tribunais, V. 82, abr./jun. De 1996.

BURCH, Elisabeth Chamblee. Aggregation, community, and the line between. Kansas Law Review, 2010, V.58:889-916p. 
Group Consensus, Individual Consent. The George Washington Law Review, V. 79: 506-541.

CABRAL, Antônio do Passo. O novo procedimento modelo (mustervenfahren) alemão: uma alternativa às ações coletivas. Revista de Processo. São Paulo: Revista dos Tribunais, V. 147, 2007.

Coisa julgada e preclusões dinâmicas: entre continuidade, mudança e transição de posições processuais estáveis. Salvador: Editora Juspodium, 2013.

CALMON FILHO, Petrônio (org.). CADERNOS IBDP (série propostas legislativas) - Reforma infraconstitucional do processo civil. V. 4, set. 2005. DINAMARCO, Cândido Rangel. A execução na reforma do Código de Processo Civil. Revista da Escola Paulista da Magistratura. São Paulo: Associação Paulista de Magistrados Editora, V. 34, set./dez. de 2006.

CALVERT, Frederic. A treatise upon the law respecting parties to suits in equity. New York: John S. Littell, 1837.

CAM, Helen Maud. England before Elizabeth. London: Hutchinson House University Library, 1950.

Liberties and Communities in Medieval England: collected studies in local administration and topography. Cambridge: University Press, 1944.

CANADA. British Columbia. Class Proceedings Act. British Columbia: Queen's Printer, 1996.

CANADA. Ontário. Class Proceedings Act. Ontário: Queen's Printer, 1992.

CAPPELLETTI, Mauro. Appunti sulla tutela giurisdizionale di interessi collettivi o diffusi. Le azioni a tutela di interessi collettivi: atti del Convengo di studio (Pavia, 11-12 giugno 1974) Padova, CEDAM, 1976.

Cass. Civ. sez. un, 8 maggio 1978, n.2207. POSTIGLIONE, Amedeo. Il rapporto diritto-ambiente nel quadro della tutela degli interessi diffusi e collettivi, il ruolo della Corte di Cassazione. In: Strumenti per la tutela degli interessi diffusi della collettività. Atti del convegno nacionale promosso dalla Sezione di Bologna di Italia Nostra (Bologna, 5 dicembre 1981). Bologna: Palazzo Pepoli, 1981.

CEBEPEJ. A Tutela dos interesses metaindividuais - ações coletivas. Ministério da Justiça - Secretária de Reforma do Judiciário. Brasília, 2007.

CHAFEE, Zechariah. Some Problems of Equity. Ann Harbor: University of Michigan Press, 1950.

CHAYES, Abram. The role of the judge in public law litigation. 1976. V. 89:1281-1316p.

CHIOVENDA, Giuseppe. Instituições de Direito Processual Civil. V.1. Tradutor Paolo Capitanio. Anotações de Enrico Tullio Liebman. São Paulo: Bookseller, 1998.

Istituzioni di diritto processuale civile. V. 1. 2. ed. Napole: Jovene, 1960.

Principii di Diritto Processuale Civile. Napole: Jovene, 1965, p. 915-924. Ibidem, 1998.

CINTRA, Antônio Carlos de Araújo, GRINOVER, Ada Pellegrini e DINAMARCO, Cândido Rangel. Teoria Geral do Processo. 25 ed. rev. atual. São Paulo: Malheiros, 2009.

CITADINO, Gisele. Pluralismo, direito e justiça distributiva: elementos da filosofia constitucional contemporânea. 3. ed. Rio de Janeiro, Lúmen Juris, 2004.

COFFEE JR, John C. Class action accountability: reconciling exit, voice and loyalty in representative litigation. Columbia Law Review, 2000, V. 100:370-439.

COMMANDUCCI, Paollo. Justice and rights: a conceptual analysis. In: PECZENIK, Aleksander; KARLSSON, Mikael (eds.) Law, justice and state I: essays on justice and rights. Stuttgart: Steiner,1995. 
CONSOLO, Claudio, RIZZARDO, Dora. Due modi di mettere le azioni collettivi alla prova: Inghilterra e Germania. Rivista Trimestrale di Diritto e Procedura Civile. Anno LX, N. 3, set. de 2006.

CONTE, Alba; NEWBERG, Herbert. Newberg on class action. V. 1. 4 ed. Minneapolis: Thomsom West, 2002. COOPER, Edward H. Mass and repetitive litigation in the Federal Courts. South Carolina Law Review, V. 38:490-533.

COSTA, Moacyr Lobo da. A intervenção iussu iudicis no processo civil brasileiro. São Paulo, 1961.

COSTA, Susana Henriques da. A representatividade adequada e litisconsórcio - o projeto de Lei n. 5.139/2009. In: In: GOZZOLI, Maria Clara et al (coords.) Em defesa de um novo sistema de processos coletivos: estudos em homenagem a Ada Pellegrini Grinover. São Paulo: Saraiva, 2010.

COSTANTINO, Giorgio. Brevi note sulla tutela giurisdizionale degli interessi collettivi davanti al giudice civile. Le azioni a tutela di interessi collettivi: atti del Convengo di studio (Pavia, 11-12 giugno 1974) Padua, CEDAM, 1976.

Contributo allo studio del litisconsorzio necessario. Napoli: Editore Jovene, 1979.

COVER, Robert M. For James Mm Moore: some reflections on a reading of the rules. Yale Law Review, 1975, V. 84: 718-740p.

CRISAFULLI, Vezio. Verbete “Azione popolare”, in Nuovo Digesto Italiano II. Torino: Unione Tipografico, 1937.

DAMAŠKA, Mirjan R. The faces of justice and state authority: a comparative approach to the legal process. New Haven: Yale University Press, 1986.

DEGNAN, Ronan E. Supreme Court of California 1970-1971 - foreword: adequacy of representation in class action. California Law Review, 1972, V. 60: 705-719p.

DENTI, Vittorio. La giustizia civile. Bologna: Società Editrice il Mulino, 1989.

DENTI, Vittorio. Relazione Introduttiva. Le azioni a tutela di interessi collettivi: atti del convengo di studio (Pavia, 11-12 giugno 1974) Padova, CEDAM, 1976.

DIDIER, Fredie e ZANETTI JR, Hermes. Curso de Direito Processual Civil: processo coletivo. 3 ed. rev. atual. amp. Bahia: Juspodium, 2008.

DINAMARCO, Cândido Rangel. A instrumentalidade do processo. 8 ed. rev. atual. São Paulo: Malheiros, 2000.

Fundamentos do Processo Civil Moderno I. 6 ed. São Paulo: Malheiros, 2010.

Instituições de Direito Processual Civil II. 6. ed. rev. atual. São Paulo: Malheiros, 2009.

Nova era do processo civil. 4 ed. São Paulo: Malheiros, 2013.

. Verbete "Direitos transindividuais, difusos, coletivos e individuais homogêneos - tutela coletiva". Vocabulário do processo civil. São Paulo: Malheiros, 2009.

DINAMARCO, Pedro da Silva. Ação Civil Pública. São Paulo: Saraiva, 2001.

Competência, conexão e prevenção nas ações coletivas. In: Milaré, Edis (coord.) A ação civil pública após 20 anos: efetividade e desafios, São Paulo: RT, 2005.

DWORKIN, Ronald. A matter of principle. Oxford: Oxford University Press, 2001. 
Levando os direitos a sério. São Paulo: Martins Fontes, 2007.

ELIAS, Norbert. A Sociedade dos Indivíduos. Tradução Vera Ribeiro. Revisão e notas Renato Janine Ribeiro.

ERBSEN, Allan. From "predominance" to "resolvability": a new approach to regulating class action. Vanderbilt Law Review, 2005, V. 58:995-1081p.

ERICHSON, Howard M. A typology of aggregate settlements. Notre Dame Law Review, 2005, V. 80: 1784-1792p.

Informal aggregation: procedural and ethical implications of coordination among counsel in related lawsuits. Duke Law Journal, 2000, V. 50: 381-471p.

ESTELITA, Guilherme. Do litisconsórcio no direito brasileiro. Rio de Janeiro: Universidade do Brasil, 1954.

FADDA, Carlo. L'azione popolare: studio di diritto romano ed attuale. Edição reproduzida (1894). Roma: L'erma, 1972 (Studia Juridica XXVI).

FAGUNDES, Miguel Seabra. Da ação popular. Revista de Direito Administrativo. Rio de Janeiro, 1946, V. VI.

FALLON, Eldon, GRABILL, Jeremy T., WYNNE, Robert Pitard. Bellwether trials in multidistrict litigation. Tulane Law Review, V. 82: 2323-2367p.

FARGNOLI, Iole. Studi sulla legittimazione ativa all'interdetto quod vi aut clam. Milano: Giuffrè, 1998.

FARIA, José Eduardo. A definição do interesse público. In: SALLES, Carlos Alberto de (org.) Processo Civil e Interesse Público: o processo com o instrumento de defesa social. São Paulo: Revista dos Tribunais, 2003.

FEDERAL JUDICIAL CENTER. Manual for Complex Litigation. 4 ed. Washington: Federal Judicial Center, 2004.

FENTIMAN, Richard. Abuse of procedural rights: the position of English Law. In: TARUFFO, Michele. Abuse of Procedural Rights: comparative standards of procedural fairness. Boston: Kluwer, 1998.

FENTON, Richard L, HARTMAN, Kendra. Parens Patriae actions and the limits of State sovereignty. In: GREER, Marcy Hogan (editor). A practitioner's guide to class action. Illinois: ABA Publishing, 2010.

FIELD, Richard H. KAPLAN, Benjamin, CLERMONT, Kevin M. Civil Procedure. New York: The Foundation Press, 1997.

FINNIS, John. Natural law and natural rights. 2. ed. New York: Oxford University Press, 2011.

FISCH, William B. European analogues of class action: group action in France and Germany. The American Journal of Comparative Law, 1979, V.27: 51-79p.

FISS, Owen M. The civil rights injunction. Bloomington: Indiana University Press, 1978.

FISS, Owen. Um novo processo civil: estudos norte-americanos sobre jurisdição, constituição e sociedade. Coordenação do trabalho Carlos Alberto de Salles. Tradução Daniel Porto Godinho da Silva e Melina de Medeiros Rós. São Paulo: Revista dos Tribunais, 2004.

FRIEDMAN, Mark W. Constrained individualism in group litigation: requiring class members to make a good cause showing before opting out of a federal class action. Yale Law Journal, V. 100, 1990.

FURMAN, Roger. Offensive assertion of collateral estoppel by persons opting out of a class action. The Hastings Law Journal, 1980, V. 31: 1189-1214. 
GASSET, José Ortega y. A rebelião das massas. Tradução Herrera Filho. Rio de Janeiro: Ridendo Castigat Mores (www.jahr.org), 1959.

GERKEN, Heather. K. Understanding the right to an undiluted vote. Harvard Law Review, 2001, V. 114: 1665$1743 p$.

GIDI, Antônio. A class action como instrumento de tutela coletiva dos direitos: as ações coletivas sob uma perspectiva comparada. São Paulo: Revista dos Tribunais, 2007.

GIDI, Antônio. Coisa julgada e litispendência em ações coletivas: mandado de segurança coletivo, ação coletiva de consumo, ação coletiva ambiental, ação civil pública e ação popular. São Paulo: Saraiva, 1995.

GIDI, Antônio. MAC-GREGOR, Eduardo Ferrer (coords.). La tutela de los derechos difusos, colectivos e individuales homogéneos: hacia un código modelo para iberoamérica. Presentación Roberto O. Berizonce. Introducción Ada Pellegrini Grinover. 2 ed. Argentina: Editorial Porrúa, 2004.

GIUSSANI, Andrea. Studi sulle class actions. Padova: CEDAM, 1996.

GOLD, Steve. Causation in toxic tort: burdens of proof, standards of persuasion and statistical evidence. The Yale Law Journal, 1986, V. 96: 376-402p.

GRANTHAM, Jeffrey M, BODDEN, C. Patrick. The special role of 23(b)(2) classes. In: GREER, Marcy Hogan (org.) A practitioner's guide to class action. Chicago: ABA Publishing, 2010.

GREER, Marcy Hogan, FISCHER, Madeleine. Medical monitoring classes. In: GREER, Marcy Hogan (org.). A practitioner's guide to class action. Chicago: ABA Publishing, 2010.

GRINOVER, Ada Pellegrini e CALMON, Petrônio. Direito Processual Comparado XIII - World Congress of Procedural Law. Rio de Janeiro: Forense, 2008.

GRINOVER, Ada Pellegrini, MENDES, Aluísio Gonçalves de Castro e WATANABE, Kazuo (coords.). Direito Processual Coletivo e o anteprojeto de Código Brasileiro de Processos Coletivos. São Paulo: Revista dos Tribunais, 2007.

GRINOVER, Ada Pellegrini, WATANABE, Kazuo. Apresentação. In públicas. Rio de Janeiro: Forense, 2011. O controle jurisdicional de políticas

GRINOVER, Ada Pellegrini. A tutela jurisdicional dos interesses difusos. Revista de Processo, V. 14-15, São Paulo: Revista dos Tribunais, abr./set. De 1979.

A tutela jurisdicional dos interesses difusos no sistema brasileiro. In: GRINOVER, Ada Pellegrini (coord.). A tutela dos interesses difusos. São Paulo: Max Limonad, 1984, p. 177-178 (Série Estudos Jurídicos N. $1)$.

Ações coletivas iberoamericanas: novas questões sobre a legitimidade e a coisa julgada. Revista Forense, V. 361, mai./jun. 2002.

Anteprojeto de Código Brasileiro de Processos Coletivos - Exposição de motivos. In: GRINOVER, Ada Pellegrini, MENDES, Aluísio Gonçalves de Castro, WATANABE, Kazuo. Direito Processual Coletivo e o anteprojeto de Código Brasileiro de Processos Coletivos. São Paulo: Revista dos Tribunais, 2007.

Coisa julgada erga omnes, secundum eventum litis e secundum probationem. Revista Forense, V. 380, jul./ago. De 2005.

Da class action for damages à ação de classe brasileira: os requisitos de admissibilidade. Revista Forense, V. 352, out./nov./dez. De 2000.

Da coisa julgada. In: GRINOVER, Ada Pellegrini, WATANABE, Kazuo e NERY JR., Nelson (coords.). 
Código Brasileiro de Defesa do Consumidor Comentado pelos Autores do Anteprojeto II. 10 ed. rev. atual. reform. Rio de Janeiro: Forense, 2011.

Direito Processual Coletivo. In: GRINOVER, Ada Pellegrini, MENDES, Aluísio Gonçalves de Castro e WATANABE, Kazuo (coords.). Direito Processual Coletivo e o Anteprojeto de Código Brasileiro de Processos Coletivos. São Paulo: Revista dos Tribunais, 2007.

. Os fundamentos da justiça conciliativa. In: GRINOVER, Ada Pellegrini, WATANABE, Kazuo e LAGRASTA NETO, Caetano. Mediação e gerenciamento do processo: revolução na prestação jurisdicional. São Paulo: Atlas, 2007.

Relatório Geral - Civil Law: os Processos Coletivos nos países de Civil Law. In: GRINOVER, Ada Pellegrini, Watanabe, Kazuo e MULLENIX, Linda (coords). Os Processos Coletivos nos Países de Civil Law e Common Law: uma análise de direito comparado (XIII Congresso Mundial de Direito Processual Salvador- Bahia, 16 a 22 de setembro de 2007 - Tema n. 5 - Novas Tendências em matéria de legitimação e coisa julgada nas ações coletivas). São Paulo: Revista dos Tribunais, 2008.

HAZARD JR, Geoffrey C. Abuse of procedural rights: regional report for the United States. In: TARUFFO, Michele. Abuse of Procedural Rights: comparative standards of procedural fairness. Boston: Kluwer, 1998, p. 46.

61: 1254-1289.

Indispensable party: the historical origin of a procedural phantom. Columbia Law Review, 1961, V.

Preclusion as issues of law: the legal system's interest. Iowa Law Review, 1981, V. 40:81-94p.

Revisiting the second restatement of judgments: issue preclusion and related problems. Cornell Law Review, 1981, V.66:564-592.

Discovery vices and trans-substantive virtues in the Federal Rules of Civil Procedure. University of Pennsylvania Law Review. 1989, V. 137: 2237-2247p.

HAZARD JR, Geoffrey C.et al. An historical analysis of the binding effect of class suits. University of Pennsylvania Law Review, 1998, V. 146: 1849-1948.

HEINSZ, Timothy J. Grieve it again: of stare decisis, res judicata and collateral estoppel in labor arbitration. Boston College Law Review. V. 38: 275-300.

HERR, David. Annotated Manual for Complex Litigation. 4. ed. Minneapolis: West, 2012.

HEYBURN II, John G. A view from the panel: part of solution. Tulane Law Review, 2008, V. 82: 2225-2244p.

HEYBURN II, John G. Reflexions on the panel's work. ABA Section of Litigation Joint Committee's CLE Seminar, 2012.

HIRONAKA, Giselda Maria F. Novaes. Responsabilidade pressuposta. Belo Horizonte: Del Rey, 2005.

HODGES, Christopher. The reform of class and representative actions in European Legal Systems. A new framework for collective redress for Europe. Oregon: Hart Publishing, 2008.

HUTCHINSON, Diane Wood. Class action: representation or joinder? The Supreme Court Review, 1983.

ISSACHAROFF, Samuel. Class action conflicts. University California Davis Law Review, 1997, V. 30:805-833p.

ISSACHAROFF, Samuel. Preclusion, due process and the right to opt out of class action. Notre Dame Law Review, 2002, V.77: 1057-1082p. Private claims, aggregate rights. New York University Public Law and Legal Theory Working Papers. 
Paper 93, 2008, p. 2. Disponível em http://lsr.nellco.org/nyu_plltwp/93. Acesso em 13 de junho de 2013.

When substance mandates procedure: Martin v. Wilks and the rights of vested incumbents in civil rights consent decrees. Cornell Law Review, 1992, V. 77:189-252p.

JONES, Craig. Theory of class action. Toronto: Irwin Law, 2003.

JONES, Peter. Human rights, group rights, and people rights. Human Rights Quarterly, 1999, V. 21.1: 80-107p.

KALVEN JR, Harry, ROSENFIELD, Maurice. The contemporary function of the class suit. The University of Chicago Law Review, 1941, V. 8: 684-721p.

KAMP, Allen R. Adjudicating the rights of plaintiff class: current procedural problems. Saint Louis University Law Journal, 1982, V. 36:364-399p.

KANE, Mary Kay. Civil Procedure. 6 ed. Minneapolis: Thomson West, 2007.

KAPLAN, Benjamin. Comment on Carrington. University of Pennsylvania Law Review, 1989, V. 137: 2125$2127 \mathrm{p}$.

KAPLAN, Benjamin. Continuing work of civil committee: 1966 amendments of Federal Rules of Civil Procedure. Harvard Law Review, 1968, V. 81:356-416p.

KIM, Susanna M. Conflicting ideologies of group litigation: who may challenge settlements in class actions and derivative suits. Tennesse Law Review, 1998, V. 66:88-135p.

KLONOFF, Robert H. Class actions and other multi-party litigation. Minneapolis: Thomson West, 2007.

KOCH, Harald. Non-class group litigation under EU and German Law. Duke Journal of Comparative and International Law, 2001, V.11: 355-368p.

KOSELLECK, Reinhart. Los extratos de tiempo. Estudios sobre la história. Barcelona: Paidós Ibérica, 2001.

LAHAV, Alexandra D. Bellwether Trials. The George Washington Law Review, 2008, V. 76: 576-638p.

LANDERS, Jonathan M. Of legalized blackmail and legalized theft: consumer class actions and the substanceprocedure dilemma southern. California Law Review, 1974, V. 47:842-900p.

LEAL, Márcio Flávio Mafra. Ações coletivas: história, teoria e prática. Porto Alegre: Sergio Antonio Fabris Editor, 1998.

LEITE, José Rubens Morato. Dano extrapatrimonial ou moral ambiental e sua perspectiva no direito brasileiro. In: MILARE, Edis (coord.). Ação Civil Pública - Lei no 7.347/1984 - 15 anos. 2 ed. rev. atual. São Paulo: Revista dos Tribunais, 2002.

LEMOS, Margaret H. Aggregate litigation goes public: representative suits by state attorneys general. Harvard Law Review, 2012, V. 26: 486-549p.

LENZA, Pedro. Teoria Geral da Ação Civil Pública. 3 ed. rev. atual. amp. São Paulo: Revista dos Tribunais, 2008.

LEONEL, Ricardo de Barros. A causa petendi nas ações coletivas. In: TUCCI, José Rogério Cruz e; BEDAQUE, José Roberto dos Santos. Causa de pedir e pedido no processo civil (questões polêmicas). São Paulo: Revista dos Tribunais, 2002.

Manual do processo coletivo. São Paulo: Revista dos Tribunais, 2012.

LESAR, Hiram H. Class suits and the federal rule. Minnesota Law Review, 1938, V. 22: 34-59p. 
LIEBMAN, Enrico Tullio. Eficácia e autoridade da sentença e outros escritos sobre a coisa julgada. Tradução de Alfredo Buzaid e Benvindo Aires. Tradução dos textos posteriores à edição de 1945 de Ada Pellegrini Grinover. Notas de Ada Pellegrini Grinover. 4 ed. Rio de Janeiro: Forense, 2007.

Manual de Direito Processual Civil I. Rio de Janeiro: Forense, 1984.

LILLY, Graham C. Modeling class action: the representative suit as an analytic tool. Nebraska Law Review, 2003, V. 81: 1008-1055p.

LOPES, José Reinaldo de Lima Lopes. O aspecto distributivo do direito do consumidor. Revista de Direito Mercantil, Industrial, Econômico e Financeiro. Ano XL. V. 123. Malheiros: São Paulo, jul./set. 2001.

Crise da norma jurídica e a reforma do Poder Judiciário. In: FARIA, José Eduardo (org.). Direitos humanos, direitos sociais e justiça. São Paulo: Malheiros, 2005.

A definição do interesse público. In: SALLES, Carlos Alberto de (org.). Processo civil e interesse público: o processo como instrumento de defesa social. São Paulo: RT, 2003.

LOZANO Y CORBI, Enrique: La legitimación popular em el proceso romano clássico. Barcelona: Bosch, Casa Editorial, 1982.

MAIA, Diogo Campos Medina. Ação coletiva passiva. Rio de Janeiro: Lumen Juris, 2009.

MAITLAND, Frederic W. Township and borough. Volume II. London: Routledge/Thoemmes Press, 1997.

MANCUSO, Rodolfo de Camargo. Ação Popular: proteção do erário, do patrimônio público, da moralidade administrativa e do meio ambiente. 7. ed. rev. atual. São Paulo: Revista dos Tribunais, 2011.

2007.

Divergência jurisprudencial e súmula vinculante. 3 ed. rev. atual. São Paulo: Revista dos Tribunais,

Interesses difusos: conceito e legitimação para agir. 7 ed. rev. atual. amp. São Paulo: Revista dos Tribunais, 2011.

Jurisdição coletiva e coisa julgada: teoria geral das ações coletivas. 2. ed. rev. atual. amp. São Paulo: Revista dos Tribunais, 2007.

MARCIN, Raymond B. Searching for the Origin of Class Action. Catholic University Law Review, 1973-1974.

MARCUS, Richard L. Confronting the consolidation conundrum. Brigham Young University Law Review, 1995, p. 880-924. $557-592 \mathrm{p}$.

Still confronting the confronting the consolidation conundrum. Notre Dame Law Review, 2012, V. 88:

MARCUS, Richard L., SHERMAN, Edward F., ERICHSON, Howard M. Complex litigation: cases and materials on advanced civil procedure. 5 ed. St. Paul: Thomson West, 2010.

MARINONI, Luiz Guilherme. Técnica processual e tutela dos direitos. 3 ed. rev. Atual. São Paulo: Revista dos Tribunais, 2010.

MARK, Richard W., STRAUCH WEISS. Exposure torts. In: GREER, Marcy Hogan (org). A practitioner's guide to class action. Chicago: ABA Publishing, 2010.

MARTINS-COSTA, Judith. "Zeca Pagodinho, a razão cínica e o novo Código Civil brasileiro", Disponível no :http://www.migalhas.com.br/dePeso/16,MI4218,101048-Zeca+Pagodinho+a+razão+cínica+e+o+novo+Codigo +Civil+Brasileiro. Acesso em 4 de dezembro de 2012. 
MATTOS, Luiz Norton Baptista de. A litispendência e a coisa julgada nas ações coletivas segundo o Código de Defesa do Consumidor e os anteprojetos do Código Brasileiro de Processos Coletivos. In: GRINOVER, Ada Pellegrini; MENDES, Aluísio Gonçalves de Castro, WATANABE, Kazuo. Direito Processual Coletivo e o anteprojeto de Código Brasileiro de Processos Coletivos. São Paulo: Revista dos Tribunais, 2007.

MAZZILI, Hugo Nigro. A Defesa dos Interesses Difusos em Juízo: meio ambiente, consumidor, patrimônio cultural, patrimônio público e outros interesses. 20 ed. rev. amp. atual. São Paulo: Saraiva, 2007.

MCCOID, John C. A single package of multiparty disputes. Stanford Law Review, 1976, V. 38:707-728p.

MCGOVERN, Francis E. Resolving mature mass tort litigation. Boston University Law Review. V. 69:659-694, 1989.

MCGOVERN, Francis F. Rethinking coooperation among judges in mass tort litigation. UCLA Law Review, 1997, V. 44: 1851-1870p.

MEADOR, Daniel J. Inherent judicial authority in the conduct of civil litigation. Texas Law Review, 1995, V. 73 : $1805-1817 \mathrm{p}$.

MEECE, Gregory S. Class action, typicality and rule 10B-5: will the typical representative please stand up? Emory Law Journal. 1987, V. 36: 649-690.

MELLO, Celso Antônio Bandeira de. Conteúdo jurídico do princípio da igualdade. 3 ed. São Paulo: Malheiros, 2007.

MENDES, Aluísio de Castro. Ações Coletivas e Meios de Resolução Coletiva de Conflitos no Direito Comparado e Nacional. 3 ed. rev. atual. amp. São Paulo: Revista dos Tribunais, 2012, p. 51 (Temais Atuais de Direito Processual Civil, V. 4).

O Código Modelo de Processos Coletivos. In: LUCON, Paulo Henrique dos Santos. Tutela Coletiva: 20 anos da Lei da Ação Civil Pública e do Fundo de Defesa de Direitos Difusos e 15 anos do Código de Defesa do Consumidor. São Paulo: Atlas, 2006.

MESQUITA, José Ignácio Botelho. A coisa julgada. Rio de Janeiro: Forense, 2006.

Ação civil pública. A defesa pelo Ministério Público de direitos individuais heterogêneos disponíveis e de direitos 'individuais' de entes públicos. Limites territoriais da coisa julgada. In: LOPEZ, Teresa Ancona (coord.). Ensaios e pareceres: livre-arbítrio, responsabilidade e produto de risco inerente. O paradigma do tabaco. Aspectos civis e processuais. Rio de Janeiro: Renovar, 2009.

Na ação do consumidor, pode ser inútil a defesa do fornecedor. Revista do Advogado, V. 33, 1990.

MILARÉ, Edis. A ação civil pública por dano ao meio ambiente. In: MILARE, Edis (coord.). Ação Civil Pública - Lei $n^{o}$ 7.347/1984 - 15 anos. 2 ed. rev. atual. São Paulo: Revista dos Tribunais, 2002.

MILLER, Arthur R. Of Frankenstein Monsters and shining knights: myth, reality and "the class action problem". Harvard Law Review, 1979, V. 92:664-694p.

MILLER, Geoffrey P. Overlapping class action. New York University Law Review, 1996, V. 71:514-546p.

Review of the merits in class certification. Hofstra Law Review, 2004, V. 33:51-87p.

MIRRA, Álvaro Luiz Valery. Ação Civil Pública em defesa do meio ambiente: a representatividade adequada dos entes intermediários legitimados para a causa. In: MILARÉ. Édis (coord.). A Ação Civil Pública após 20 anos: efetividade e desafios. São Paulo: RT, 2005.

Ação Civil Pública ambiental e as tutelas jurisdicionais da prevenção e precaução. In: MILARÉ, Edis (coord.). Ação Civil Pública Ambiental após 25 anos. São Paulo: Revista dos Tribunais, 2010. 
MOORE, James Wm. Federal Rules of Civil Procedure: some problems raised by the preliminary draft. Georgetown Law Review, 1937, V. 25: 551-576p.

MOORE, James Wm; COHN, Marcus. Federal class action. Illinois Law Review, 1938, V. 32: 307-325p.

MOREIRA, José Carlos Barbosa. A ação popular no direito brasileiro como instrumento de tutela jurisdicional dos chamados "interesses difusos". Temas de Direito Processual. São Paulo: Saraiva, 1977.

1971.

Ainda e sempre a coisa julgada. Direito Processual Civil (ensaios e pareceres). Borsói: Rio de Janeiro, 1971.

Direito Processual Civil (ensaios e pareceres): ainda e sempre a coisa julgada. Rio de Janeiro: Borsói,

La iniciativa em la defensa de los intereses difusos y colectivos (un aspecto de la experiência brasileña). Temas de Direito Processual Civil - Quinta Série. São Paulo: Saraiva, 1994, p. 164-165. LEONEL, 2013.

Litisconsórcio unitário. Rio de Janeiro: Forense, 1972.

Temas de direito processual civil. $3^{\text {a }}$ Série. São Paulo: Saraiva, 1984.

MULHERON, Rachael. The class action: in a common law legal systems - a comparative perspective. Oregon: Hart Publishing, 2006.

MULLENIX, Linda S. Class resolution of the mass tort case: a proposed federal procedure act. Texas Law Review, 1986, V. 64: 1039-1099p.

. Aggregate litigation and the death of democratic dispute resolution. Northwestern University Law Review, 2013, V. 107: 511-564p.

Aggregate litigation and the death of democratic dispute resolution. Northwestern University Law Review, 2013, V. 107:511-564p.

General Report - common law. In: GRINOVER, Ada Pellegrini. WATANABE, Kazuo e MULLENIX, Linda. Os processos coletivos nos países de civil law e common law: uma análise de direito comparado. São Paulo: Revista dos Tribunais, 2008.

MARCUS, Richard L., SHERMAN, Edward F. And ERICHSON, Howard M. Complex litigation: cases and materials on advanced civil procedure. 5 ed. St. Paul: Thomson West, 2010.

NAGAREDA, Richard A. Mass torts in a world of settlements. Chicago: The University of Chicago Press, 2007.

The law of class action and other aggregate litigation. New York: Foundation Press, 2009.

Embededd aggregation in civil litigation. Cornell Law Review, 2010, V. 95: 1105- 1119p.

$242 \mathrm{p}$.

The preexistence principle and the structure of class action. Columbia Law Review, 2003, V. 103: 149-

NERY, Nelson. Aspectos do processo civil no Código de Defesa do Consumidor. Revista de Direito do Consumidor. São Paulo: Revista dos Tribunais, V.1, mar./1992.

NEWMAN, Dwight. Community and collective rights: a theoretical framework for rights held by groups. Oxford: Hart Publishing, 2011.

NORDH, Roberth. Group actions in Sweden: reflections on the purpose civil litigation, the need for reforms, and 
a forthcoming proposal. Duke Law Journal of Comparative and International Law, 2001, V. 11: 381-404p.

NOTE. Collateral Attack on the binding effect of class action judgments. Harvard Law Review, 1974. V. 87:589606p.

NOTE. Collateral attack on the binding effect of class action judgment. Harvard Law Review, V. 87: 589-606p.

NOTE. Developments in the law - multiparty litigation in the Federal Courts. Harvard Law Review, 1958 V. 71:874-998p.

NOTE. Developments in the law - Res Judicata. Harvard Law Review, 1952, V. 65: 818-887.

NOTE. Developments in the law: class action. Harvard Law Review, 1976, V. 89: 1319-1517p.

NOTE. Developments in the law: multiparty litigation. Havard Law Review, 1958, V. 71: 874-998p.

NOTE. Developments in the law: multiparty litigation. Havard Law Review, 1958, V. 71: 874-998p.

NOTE. Jurisdiction and notice in class actions: "playing fair" with national classes. Harvard Law Review, 1984, V. 132: $1487-1514 \mathrm{p}$.

OLIVEIRA JR, Waldemar Mariz de. Tutela jurisdicional dos interesses coletivos. In: GRINOVER, Ada Pellegrini (coord.). A tutela dos interesses difusos. São Paulo: Max Limonad, 1984 (Série estudos jurídicos n. 1).

OLIVEIRA, Bruno Silveira, LIMA NETO, Francisco Vieira. Notas sobre o devido processo constitucional, o litisconsórcio e os processos coletivos. Revista de Processo. São Paulo: Revista dos Tribunais, V. 191, jan./2010.

OLIVEIRA, Carlos Alberto Alvaro de. Garantia do contraditório. In: TUCCI, José Rogério Cruz e. Garantias constitucionais do processo civil. São Paulo: Revista dos Tribunais, 1999.

. Do formalismo no processo civil: proposta de um formalismo-valorativo. 3 ed. São Paulo: Saraiva, 2009.

OLIVEIRA, Swarai Cervone. In: CALMON, Petrônio et al (coords.). Em defesa de um novo sistema de processos coletivos: estudos em homenagem a Ada Pellegrini Grinover. São Paulo: Saraiva, 2010.

OLSON, Mancur. The logic of collective action: public goods and the theory of group. 12 ed. Massachusetts: Harvard University Press, 2002.

PACE, Nicholas M. Group and aggregate litigation in the United States. The ANNALS of the American Academy of Political and Social Science, 2009, V. 622: 32-40p.

PALADIN, Livio. Verbete "Azione popolare”, in Novissimo Digesto Italiano II, Torino: Unione Tipografico, 1957.

PARDOLESE, Roberto. Il problema degli interessi collettivi e i problemi dei giuristi. Le azioni a tutela di interessi collettivi: atti del Convengo di studio (Pavia, 11-12 giugno 1974) Padua, CEDAM, 1976.

PECZENIK, Aleksander. On law and reason. Lund (Sweden): Springer, 2009.

The basis of legal justification. Lund: Infotryck AB. Distributed by Aleksander Peczenik, 1983.

PERELMAN, Chaim; OLBRECHT-TYTECA. Tratado de la argumentación: la nueva retórica. Tradução para o espanhol de Julia Sevilla Munoz. Madri: Gredos, 1989.

PISANI, Andrea Proto. Appunti preliminari per uno studio sulla tutela giurisdizionale degli interessi collettivi (o più esattamente: superindividuali) innanzi al giudice civile ordinario. Le azioni a tutela di interessi collettivi: atti del convengo di studio (Pavia, 11- 12 giugno 1974) Padova, CEDAM, 1976. 
Appunti sui rapporti tra i limiti soggettivi di efficacia della sentenza civile e la garanzia costituzionale del diritto di difesa. Rivista Trimestrale di Diritto e Procedura Civile, ano XXV, 1971.

PITKIN, Hanna Fenichel. The concept of representation. California: University of California Press, 1972.

POCOCK, John Greville Agard. The Ancient Constitution and the Feudal Law: a Study of English Historical Thought in the Seventeenth Century. Cambridge: Cambridge University Press, 1987.

POUND, Roscoe. The causes of popular dissatisfaction with the administration of justice. Presented at the annual convention of American Bar Association in 1906.

PROTOS, Michael C. An epistemological approach to class certification: a classy understanding of the problems of class action. Case Western Reserve Law Review, 1992, V.42:1297-1337p.

RAZ, Joseph. Morality of freedom. New York: Oxford University Press, 1988.

Rights and politcs. Indiana Law Journal, 1995, V. 71: 27-44p.

REDISH, Martin H. Wholesale justice: constitucional democracy and the problem of the class action lawsuit. Stanford: Stanford University Press, 2009.

REED, John W. Compulsory joinder of parties in civil actions. Michigan Law Review, 1957, V. 55: 327-538p.

RENDLEMAN, Doug. Complex litigation: injunctions, structural remedies and contempt. New York: Thomson Reuters, 2010.

RESNIK, Judith. Compared to what? ALI Aggregation and the shifting contours of due process and of lawyer's powers. The George Washington Law Review, 2011, V. 79: 628-699p.

From "cases" to "litigation". Law and contemporary problems. 1991, V. 54: 6-67p.

RODOTÀ, Stefano. Le azioni civilistiche. Le azioni a tutela di interessi collettivi: atti del Convengo di studio (Pavia, 11-12 giugno 1974) Padua, CEDAM, 1976.

RODRIGUES, Marcelo Abelha. Relações entre ações individuais e ações coletivas: anotações sobre os efeitos decorrentes da propositura e extinção das ações coletivas para defesa de direitos individuais homogêneos em relação às pretensões individuais sob a perspectiva dos arts. 35 e 38 do Projeto de Lei que altera a ação civil pública. In: GOZZOLI, Maria Clara et al (coords.). Em defesa de um novo sistema de processos coletivos: estudos em homenagem a Ada Pellegrini Grinover. São Paulo: Saraiva, 2010.

RODRIGUES, Ruy Zoch. Ações repetitivas: casos de antecipação da tutela sem o requisite de urgência. São Paulo: Revista dos Tribunais, 2010.

SAKS, Michael J., BLANCK, Peter David. Justice improved: the unrecognized benefit of aggregation and sampling in the trial of mass torts. Stanford Law Review, 1992, V. 44:815-849p.

SALLES, Carlos Alberto de. Arbitragem em contratos administrativos. Rio de Janeiro: Forense, 2011.

Entre eficiência e a equidade: bases conceituais para um Direito Processual Coletivo. In: FIGUEIREDO, Guilherme José Purvin e RODRIGUES, Marcelo Abelha (coords.). O Novo Processo Civil Coletivo. Rio de Janeiro: Lumen Juris, 2009.

Execução judicial em matéria ambiental. São Paulo: Revista dos Tribunais, 1998.

Processo civil de interesse público. In: SALLES, Carlos Alberto de (org.). Processo civil e interesse público: o processo como instrumento de defesa social. São Paulo: Revista dos Tribunais, 2003.

SANDEL, Michael. Liberalism and limits of justice. 2 ed. Cambridge: Cambridge University Press, 1998. 
SAPHIRE, Richard B. Specifying due process values: toward a more responsive approach to procedural protection. University of Pennsylvania Law Review, 1978, V.127: 111-195p.

SAVAGE, Zachary B. Scaling up: implementing issue preclusion in mass tort litigation through bellwether trials. New York University Law Review, 2013, V. 88: 439- 475p.

SCHAUER, Frederick. Formalism. Yale Law Review, 1988, V.97: 509-548p.

SCHUCK, Peter. Mass torts: an institutional evolutionist perspective. Cornell Law Review, 1995, V. 80: 941989p.

SCHWARZER, William W. Judicial federalism: a proposal to amend the multidistrict litigation statute to permit Discovery coordination of large-scale litigation pending in state and federal courts. Texas Law Review, $1995, \mathrm{~V}$. 73: $1529-1568 \mathrm{p}$.

SCHWARZER, William W. WEISS, Nancy E., HIRSH, Alan. Judicial federalism in action: coordination of litigation in state and federal courts. Virginia Law Review, 1992, V. 78: 1689-1751p.

SCIALOJA, Vittorio. Procedimiento civil romano: ejercicio y defesa de los derechos. Traducción de Santiago Sentis Melendo y Marino Ayerra Redin. Buenos Aires: Ejea, 1954.

SERENKA JR, Robert L. Annotation: propriety of allowing class member to opt out in class action certified under subsections $(b)(1)$ and $(b)(2)$ of Rule 23 of Federal Rules of Civil Procedure. American Law Reports Federal, 563 (2009).

CASAD, Robert C. e CLERMONT, Kevin M. Res judicata: a handbook on its theory, doctrine, and practice. Durham: Carolina Academic Press, 2001.

SHAPIRO, David L. Civil procedure: preclusion in civil actions. New York: Foundation Press, 2001.

Class action: the class as party and client. Notre Dame Law Review, 1997-1998, V. 73:913-961p.

SHERMAN, Edward F. Aggregate disposition of related cases: the policy issue. Review of Litigation, $1991, \mathrm{~V}$. 231:237-254p.

Class actions and duplicative litigation. Indiana Law Journal, 1987, V. 62:507-559p.

The MDL model for resolving complex litigation if a class action is not possible. Tulane Law Review, 2008, V. 82: 1-29p.

SILVA, José Afonso da. Ação popular constitucional: doutrina e processo. 2. ed. rev. amp. São Paulo: Malheiros, 2007.

SILVER, Charles. Comparing class action and consolidations. The Review of Litigation, 1991, V. 10: 495-520p.

SILBERMAN, Linda. Finality and preclusion. In: CHASE, Oscar, HERSHKOFF, Helen. Civil litigation in comparative context. Minneapolis: Thomson West, 2007.

SIMEONE JR, Joseph J. Class suits under the Codes. Western Reserve Law Review, dezembro de 1955.

SOUZA, José Augusto Garcia. A legitimidade coletiva da defensoria pública à luz do princípio da generosidade. In: GOZZOLI, Maria Clara et al (coords.). Em defesa de um novo sistema de processos coletivos: estudos em homenagem a Ada Pellegrini Grinover. São Paulo: Saraiva, 2010.

STUNDTNER, Elizabeth A. Proving causation in toxic tort cases: T-cell studies and as epidemiological and particularistic evidence. Environmental Affairs, 1993, V. 20:335-370. 
SUBRIN, Stephen N. Fishing expeditions allowed: the historical background of the 1938 Federal Discovery Rules. Boston College Law Review, 1998, V. 39:691-745.

. How equity conquered common law: the federal rules of civil procedure in historical perspective, 1987, V. 135:909-1002p.

SULLIVAN, E. Thomas et al. Complex litigation. California: LexisNexis, 2009.

SUMMERS, Robert S. Evaluating and improving legal process - a plea for "process values". Cornell Law Review, 1974, V. 60:1-52p.

TARUFFO, Michele. General Report. In: TARUFFO, Michele. Abuse of Procedural Rights: comparative standards of procedural fairness. Boston: Kluwer, 1998.

. I limiti soggettivi del giudicato e le "class actions". Rivista di Diritto Processuale, Padova: CEDAM, volume XXIV (serie II), anno 1969.

Some remarks on group litigation in comparative perspective. Duke Law Journal of Comparative and International Law, 2001, V.11: 405-421p.

__. I limiti soggettivi del giudicato e le "class action". In: Rivista di Diritto Processuale, Anno XXIV, 1969. 2011.

Precedente e jurisprudência. Revista de Processo. V. 36. N. 199. São Paulo: Revista dos Tribunais, set.

TEIXEIRA, Sálvio de Figueiredo. Apreciações sobre o Código de Processo Civil Anotado. 7 ed. Rio de Janeiro: Forense, 1986, 675-713p.

TIDMARSH, Jay, BETSON, David. Optimal class size, opt-out rights and 'indivisible' remedies. The George Washington Law Review, 2011, V. 79: 542-576p.

TIDMARSH, Jay, TRANGSRUD, Roger H. Complex litigation: problems in advanced civil procedure. New York: Foundation Press, 2002.

TRANGSRUD, Roger H. Aggregate litigation: critical perspectives. George Washington University Law School, 2011, V. 79:293-305p.

TRIBE, Lawrence H. Constitutional choices. Cambridge: Harvard University Press, 1985.

TROCKER, Nicolò. Gli interessi diffusi nell'opera della giurisprudenza. Rivista trimestrale di diritto e procedura civile. Ano XLI, N. 4, Milano: Dott. A. Giuffrè, dicembre 1987.

AZEVEDO, Luiz Carlos de. O direito de ser citado: perfil histórico. São Paulo: Resenha Universitária - Fundação Instituto de Ensino para Osasco, 1980.

TUCCI, José Rogério Cruz e AZEVEDO, Luiz Carlos de. Lições da história do processo civil romano. 1. ed. 2. tir. São Paulo: Revista dos Tribunais, 2001.

TUCCI, José Rogério Cruz e. A causa petendi no processo civil. 3 ed. rev. atual. São Paulo: Revista dos Tribunais, 2009.

. Limites subjetivos da eficácia da sentença e da coisa julgada civil. São Paulo: Revista dos Tribunais, 2006.

Precedente judicial como fonte do direito. São Paulo: Revista dos Tribunais, 2004.

Limites subjetivos da eficácia da sentença e coisa julgada civil. São Paulo: Revista dos Tribunais, 2006. 
. "Class action” e mandado de segurança coletivo. São Paulo: Saraiva, 1990.

TWINER III, Olger C. Federal Rule of Civil Procedure 23(a)(3) typicality requirement: the superfluous prerequisite to maintaining a class action. Ohio State Law Journal, 1981, V. 42:797-811.

UNITAD STATES OF AMERICA. Federal Rules of Civil Procedure. Washington: US Government Printing Office, 2010.

UNITED STATES OF AMERICA. Draft Minutes. Civil Rules of Advisory Committee. March, 22-23, 2012.

UNITED STATES OF AMERICA. Rule 23. Federal Rules of Civil Procedure. Washington: US Government Printing Office, 2010.

VAIRO, Georgene. Why me? The role of private individuals in complex claims resolution. Stanford Law Review, 2005, V. 57: 1391-1428p.

VENTURI, Elton. Processo Civil Coletivo: a tutela jurisdicional dos direitos difusos, coletivos e individuais homogêneos no Brasil. Perspectivas de um Código Brasileiro de Processos Coletivos. São Paulo: Malheiros, 2007.

VESTAL, Allan D. Preclusion/res judicata variables: parties. Iowa Law Review, 1965, V. 50: 27-76p.

VIGLIAR, José Marcelo Menezes. A Lei $n^{\circ}$ 9.494, de 10 de setembro de 1997, e a nova disciplina da coisa julgada nas ações coletivas: inconstitucionalidade. Revista dos Tribunais, Ano 86, V. 745, nov. de 1997.

Litigiosidade contida (e o contingenciamento da litigiosidade). In: SALLES, Carlos Alberto de. As grandes transformações do processo civil brasileiro: homenagem ao Professor Kazuo Watanabe. São Paulo: Quartier Latin do Brasil, 2009.

VIGORITI, Vincenzo. Interessi collettivi e processo: la legittimazione ad agire. Milano: Dott. A Giuffrè Editore, 1979.

VINOGRADOFF, Sir Paulo. Villainage in England: essays in english mediaeval history. Oxford: Clarendon Press, 1892.

Vol. 23:515-524p.

WALTER, Gerhard. Livre Apreciación de la Prueba. Bogotá: Temis, 1985.

Mass tort litigation in Germany and Switzerland. Duke Law Journal of Comparative and International Law, 2001, V. 11: 369-379p.

WAMBIER, Teresa Arruda Alvim. Nulidade do processo e da sentença. 5 ed. rev. atual. São Paulo: RT, 2004.

Casos problemáticos: partes ou terceiros (análise de algumas situações complexas de direito material). In: WAMBIER, Teresa Arruda Alvim; WANBIER, Luiz Rodrigues. In: Aspectos polêmicos e atuais sobre terceiros no processo civil e assuntos afins. São Paulo: Revista dos Tribunais, 2004.

WASSERMAN, Rhonda. Procedural due process: a reference guide to the United States Constitution, Connecticut: Praeger, 2004.

WATANABE, Kazuo. A cognição no processo civil. São Paulo: Malheiros, 2012.

Acesso à Justiça e sociedade Moderna. In: GRINOVER, Ada Pellegrini (org.) Participação e processo. São Paulo: Ed. RT, 1988.

Da defesa do consumidor em juízo. In: GRINOVER, Ada Pellegrini, WATANABE, Kazuo e NERY JR., Nelson (coords.). Código Brasileiro de Defesa do Consumidor Comentado pelos Autores do Anteprojeto II. 10 ed. Rev. atual. reform. Rio de Janeiro: Forense, 2011. 
Demandas coletivas e os problemas emergentes da práxis forense. Revista de Processo, v. 67, São Paulo: Revista dos Tribunais, jul./set. De 1992.

Do objeto litigioso das ações coletivas: cuidados necessários para sua correta fixação. In: MILARÉ, Edis (coord.). Ação Civil Pública Ambiental após 25 anos. São Paulo: Revista dos Tribunais, 2010.

Do processo individual de defesa do consumidor. In: GRINOVER, Ada Pellegrini, WATANABE, Kazuo e NERY JR., Nelson (coords.). Código Brasileiro de Defesa do Consumidor Comentado pelos Autores do Anteprojeto II. 10 ed. rev. atual. reform. Rio de Janeiro: Forense, 2011.

Relação entre demanda coletiva e demandas individuais. In: GRINOVER, Ada Pellegrini, MENDES, Aluísio Gonçalves de Castro e WATANABE, Kazuo (coords.). Direito Processual Coletivo e o anteprojeto de Código Brasileiro de Processos Coletivos. São Paulo: Revista dos Tribunais, 2007.

Tutela jurisdicional dos interesse difusos: a legitimação para agir. In: GRINOVER, Ada Pellegrini (coord.). A tutela dos interesses difusos. A tutela dos interesses difusos. São Paulo: Max Limonad, 1984.

Tutela jurisdicional dos interesses difusos: a legitimação para agir. In: GRINOVER, Ada Pellegrini (coord.). A tutela dos interesses difusos. São Paulo: Max Limonad, 1984.

WEINSTEIN, Andrew S. Avoiding the race to res judicata: federal anti-suit injunctions of competing state class actions. New York University Law Review, 2000, V. 75: 1085-1120p.

WEINSTEIN, Jack B. Individual justice in mass tort litigation. Illinois: Northwestern University Press, 1995.

WILHELMESSON, Thomas. Regulação de cláusulas contratuais. Tradutor Ronaldo de Porto Macedo. Revista de Direito do Consumidor. São Paulo: Revista dos Tribunais, V. 18, abril/junho, 1996, p. 9-12.

Contract and equality. In. WAHLGREEN, Peter (ed.). Legal theory. V. 40. Stockholm Institute for Scandinavian Law, 2000.

WILTON, Timothy. The class action in social reform litigation: In whose interest? Boston University Law Review, 1983, V. 63:597-641p.

WOOD, Diane P. Adjudicatory jurisdiction and class action. Indiana Law Review, 1987, V. 62:597-624.

WORLD HEALTH ORGANIZATION. IARC Monographs on the evaluation of carcinogenic risks to human. V. 84. France, Lyon: IARC Press, 2004.

YARSHELL, Flávio. Brevíssimas reflexões a propósito da legitimidade passiva nas ações civis públicas envolvendo atividades sujeitas à regulação. In: Lucon, Paulo Henrique dos Santos (Coord.). Tutela Coletiva: 20 anos da Lei da Ação Civil Pública e do Fundo de Defesa dos Direitos Difusos e 15 anos do Código de Defesa do Consumidor. São Paulo: Atlas, 2006.

YEAZELL, Stephen C. From medieval group litigation to the modern class action. New Haven: Yale, 1987.

ZACLIS, Lionel. A proteção coletiva dos investidores no mercado de capitais. São Paulo: Revista dos Tribunais, 2007.

ZAVASCKI, Teori Albino. Processo coletivo: tutela de direitos coletivos e tutela coletiva de direitos. 3 . ed. rev. atual. amp. São Paulo: 2008.

ZUCKERMAN, Adrian. Zuckerman on Civil Procedure: principles of practice. 2 ed. UK: Sweet \& Maxwell Ltd, 2006.

ZUFELATO, Camilo. Ação coletiva passiva no direito brasileiro: necessidade de regulamentação legal. In: GOZZOLI, Maria Clara et al (coords.) Em defesa de um novo sistema de processos coletivos: estudos em homenagem a Ada Pellegrini Grinover. São Paulo: Saraiva, 2010. 
Coisa julgada Coletiva. São Paulo: Saraiva, 2011. 